\title{
E-Commerce and Sales Management in Agribusiness
}

\section{Dissertation}

to attain the doctoral degree (Dr. sc. agr.) of the Faculty of Agricultural Sciences

Georg-August-University of Goettingen

submitted by

Dorothee Hedwig Schulze Schwering born in Coesfeld

Goettingen, August 2021 
1. Referee: Prof. Dr. Achim Spiller

2. Referee: $\quad$ Prof. Dr. Michael Clasen

3. Referee: $\quad$ Prof. Dr. Bernhard Brümmer

Date of oral examination: November $5^{\text {th }}, 2021$ 


\section{Summary}

The digitization trend is changing processes in the agricultural sector and affects all players in the agricultural value chain equally. At present, especially the digital development of agricultural trade is being driven forward at full speed by a wide range of providers. In this context, questions about changes of the agricultural purchasing behavior and the implications for agricultural trade structures are currently much in the spotlight. This dissertation therefore considers the role of e-commerce and sales management within the agricultural input industry as a significant part of agribusiness. In addition to online the sales channel, personal selling, as an offline sales channel, is also examined.

The articles presented here demonstrate that e-commerce as a procurement channel for agricultural inputs is well-accepted overall but to different degrees, and that regular online purchasing is limited to only certain, well-standardized, inputs. A fundamental interest of the agricultural sector in e-commerce can be confirmed and suggests that e-commerce in agriculture enjoys significant potential which has not yet been utilized.

Online purchasing is strongly influenced by the perceived benefits associated with e-commerce, which, however, vary significantly among farmers. On the other hand, distrust of online commerce as well as relationships and loyalty to local retailers have a negative effect on farmers' e-commerce adoption. The results also illustrate that there are different groups of farmers, who differ in terms of their e-commerce attitudes and shopping behaviors. A significant portion of agricultural customers appears to be mentally not ready for online retailing, while another part is already particularly open-minded towards digital distribution channels. As common in B2B, farmers' attitudes toward e-commerce are strongly influenced by cognitive factors, although affective components should not be dismissed, either. Accordingly, companies in the agricultural input industry are called upon to tailor their sales and marketing strategies to the needs of their individual customer groups. Even though stationary trade has emerged as the benchmark of e-commerce within this dissertation, particularly due to personal contact opportunities, companies should adapt their business models and integrate digital sales channels as part of a multi-, to omnichannel strategy in order to be able to satisfactorily serve their digital customers of tomorrow.

However, from the company's point of view, factors such as product characteristics and traditionally personal sector and company structures as well as a lack of financial resources and human capital act as digitalization brakes. The agricultural sales force in particular is affected 
by both structural change and digital transformation and is under enormous pressure to adapt. Overall, farmers rate the performance of the agricultural sales force as only satisfactory. Professional competence alone is not enough to convince farmers. Rather, it is the personality and social competence of the sales force that contributes to their long-term reputation with the customer. The results demonstrate that the agricultural sales force often lacks customer centricity, which needs to be optimized. This might be done by placing a stronger focus on the sales-oriented personality and social skills of new sales employees as early as the recruitment stage. However, it is precisely the acquisition of new sales specialists that is proving difficult. For example, a position in sales enjoys only moderate popularity among students of agricultural sciences. Likewise, the subject of sales is not dealt with satisfactorily in agricultural studies. The "hard-selling" image negatively attached to sales deters many graduates. The attractiveness of a sales position for students of agricultural sciences can be increased by pointing out career options and creating options to get in contact with sales. Thus, there is still a need for action both at the vocational school or university side and on the company side to motivate agricultural trainees to work in sales.

In addition to the digital transformation and structural change in agriculture, society's predominantly negative or critical attitude toward agriculture is exerting additional pressure on the already strained agricultural input industry. Strategic communications management of input companies, especially of their sales and marketing departments, is therefore crucial not only to optimize customer centricity, but also to ensure that public concerns are taken seriously and addressed thematically.

This dissertation suggests that the topic of e-commerce and sales management in agribusiness, especially in the agricultural input industry, remains a highly exciting topic both for research and for the agricultural sector as a whole, in which further structural changes can be expected in the coming years. 


\section{Table of Contents}

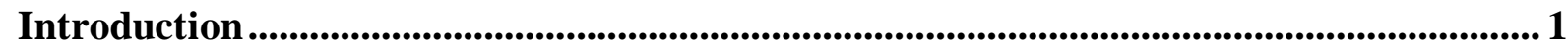

Chapter I - E-Commerce in Agribusiness .............................................................21

I.1 Das Online-Einkaufsverhalten von LandwirtInnen im Bereich landwirtschaftlicher

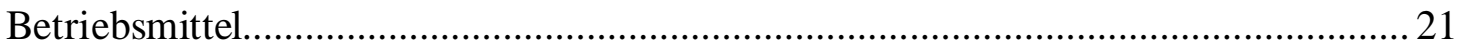

I.2 Agricultural E-Commerce Attitude Segmentation of Farmers..................................59

I.3 Zukunftsperspektiven von Online-Shops in der landwirtschaftlichen Vorleistungsindustrie eine Analyse aus der Perspektive von LandwirtInnen .............. 88

I.4 Crop Protection Market Segmentation: Relationship Between Buyer Segments and the Use of Digital Sales Channels.

I.5 Agricultural Input Trade: Farmers' Expectations Towards E-Commerce Websites - Shopping Convenience is Key

I.6 Barrieren des Onlinehandels von Futtermitteln................................................... 153

Chapter II - Sales Management in Agribusiness

II.1 Die Wahrnehmung des Außendienstes in der landwirtschaftlichen

Vorleistungsindustrie - Eine empirische Studie aus Sicht deutscher LandwirtInnen 195

II.2 Identifizierung von Verkäufertypen in der landwirtschaftlichen

Vorleistungsindustrie aus Sicht der landwirtschaftlichen KundInnen 208

II.3 Einflussfaktoren auf die Attraktivität einer Tätigkeit im Vertrieb bei Studierenden der Agrarwissenschaften

Chapter III - Excursus: Seed Industry Reputation

III.1 Ever New Topics Damage the Reputation - The Public and the Publicized Issues of the Seed Industry 265

General Discussion, Implications, and Outlook 291

General Discussion and Summary. 291

Implications and Outlook 305 


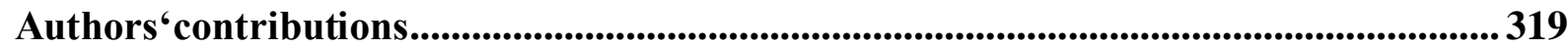

Formal declarations / Eidesstattliche Erklärung ….....................................................323

Acknowledgement / Danksagung......................................................................................3325 


\title{
Introduction
}

\author{
In the next few years, digital business models will revolutionize \\ the agricultural and food industry.
}

- Prof. Dr. Karin Schnitker in 2017 .

\section{To be competitive in the future, companies should adapt their business models today to the customers of the digital tomorrow.}

- German Federal Ministry forEconomic Affairs and Energy in 2017 -

Digitalization is described as one of the new megatrends in agriculture and agribusiness, affecting all actors in agricultural value chains (Gandorfer et al., 2017). The trend of increasing integration of digital marketplaces into the information technology systems of trading partners will continue, and more and more sub-steps of a trading transaction will be automated (Clasen, 2018). In 2017 alone, a lot has happened in the agricultural input industry. For example, one of the leading agricultural cooperatives in Germany, the AGRAVIS Raiffeisen AG, presented its digital platform "myfarmvis", which aims at a professional digital dialogue and exchange of goods with cooperative partners and farmers as a supplement to stationary trade (GWS, 2020). In the same year, the online shop myAGRAR, the online trading subsidiary of the longestablished ATR Landhandels Gruppe, was introduced, through which a variety of farm inputs can be ordered online (myAGRAR, 2021). Also in 2017, the Munich-based start-up Agrando entered the market as a digital agricultural trading platform for farm inputs and has since been on an expansion course (Agrando, 2021). The examples given underline the trend and, as predicted in the opening quote by Prof. Dr. Karin Schnitker (Deter, 2017), prove the rapid digital transformation process in agricultural input trade as an important part of the agribusiness. Agribusiness occupies a significant economic position in Germany. It includes all actors involved both directly and/or indirectly in the production and sales of agricultural products and food. This includes the upstream sector of agriculture (i.e., agricultural input industry), agriculture itself, and the downstream sector (i.e., food processing), (Strecker et al., 2010). After vehicle manufacturing and mechanical engineering, it is the third-largest sector within manufacturing and contributes around 238 billion EUR (12\%) to its total turnover (Janze et al., 2021). With a total of around 700.000 businesses, agribusiness employs about 10\% of all employed persons in Germany (Pascher et al., 2020). The sector is largely characterized by small and medium-sized enterprises, enjoys a reputation for being grounded, and agribusiness companies are predominantly located in rural areas (Janze et al., 2017). 
The agricultural input industry, which supplies agricultural enterprises with goods and services, e.g., animal feed, machinery, and chemicals, belongs to the important subsectors of agribusiness (Janze et al., 2017). Sales in the agricultural input sector have remained relatively constant in recent years, and are thus not affected by the lasting agricultural structural change (Hemmerling et al., 2016; Pascher et al., 2020). With annual production-related expenditures of more than 45 billion EUR by German agriculture and in view of the necessary increase in agricultural production, the agricultural input industry is therefore regarded as one of the most promising industries (Pascher et al., 2020; Proplanta, 2011).

The products of the agricultural input industry are predominantly distributed via intermediate trade stages, which are traditionally organized through private or cooperative agricultural trade. Accordingly, German agribusiness has long been characterized by indirect distribution channels (Gollisch and Theuvsen, 2015; Strecker et al., 2010). Within such bilateral connections, the relationships between the parties involved are much more private and personal than in, e.g., electronic marketplaces (Hartmann, 2019). Relationships between stationary agricultural trade and farmers have been able to grow over decades and are in many cases still very close (Gollisch and Theuvsen, 2015). On average, farmers' relationships with key business partners have already lasted for around 17 years (Schulze, 2012), and the communication is mainly personal (Fecke et al., 2018b). Input companies have adapted to the value that farmers place on face-to-face contact and personal relationships with a sales force which performs not only a sales function but also an advisory function (Rüther and Maier, 2007).

Even if the sales strategies described here suggest that agricultural input trade is a very traditional and specialized sector, it is a major economic factor and cannot ignore the trends, i.e., the digital transformation that is currently taking place in all sectors. A key component of this digital transformation is the emergence of a platform economy (Kenney and Zysman, 2016). Digital platform refers to a set of digital frameworks whose algorithms are used to organize and structure economic, marketplace, and social interactions (e.g., purchase, lending or renting of goods and services) between two or more different actors (Kenney and Zysman, 2016; Kilhoffer et al., 2017). Within these platform economies, advantages arise primarily from the interactions of the users, due to so-called network effects. Accordingly, the benefit for all participants increases the more players are active on the platform (Gregory et al., 2020).

These platform economies, or the business model of network effects, are also increasingly found in the agricultural sector, both through start-ups and long-established agricultural retailers or cooperatives. As shown in the initial examples, various online shops and online 
marketplaces for agricultural inputs have recently emerged in Germany (Bickert, 2020; Huchtemann, 2020). However, the types and ownership status of digital business models, and particularly of platform models, are diverse. If we look at the e-commerce business models that are particularly relevant for this work, we can single out two upper models, i.e., the classical online shop and the online marketplace.

In the context of a business-to-business (B2B) online store, a single company offers its products to several business customers (Hartmann, 2019). Examples are the online store myAGRAR, as a subsidiary of the ATR Landhandels Gruppe, the BayWa online store for agriculture, or ag.supply, an online store initiated as a start-up. Myfarmvis is a customer portal developed by AGRAVIS Raiffeisen AG that offers not only e-commerce but also other functions that are important for farm management, such as documentation and digital forecasting tools, and thus stands out somewhat from the previous models. Three of the four listed online stores were founded in 2017 and 2018. In contrast, the business model of online marketplaces, which are currently booming in several sectors, functions quite differently. Within four years, about 20 new digital marketplaces operated by start-ups have been founded (Huchtemann, 2020). The goal is to bring buyers and sellers together, thus opening up new marketing channels. About $15 \%$ of the newly founded marketplaces specialize in the marketing of agricultural inputs (e.g., Agrando), while others also trade agricultural commodities in addition to farm inputs (e.g., Agrarconnect, Agrar2b), (Bickert, 2020; Huchtemann, 2020). Marketplaces such as Unamera, Agrora, Agrimand, CropSpot, or the NextMarktplatz from FarmFacts, where farmers can obtain product offers and enter purchase and supply contracts directly from the farm management system, are part of the latest agricultural platform generation (Bickert, 2020; NextFarming, 2021). Advantages of this platform economy for users are, among others, that prices and products can be compared more quickly and easily (Bösel, 2021; Jakosuo, 2019). Online trade also means that farmers have more product and purchasing options than ever before. However, these increasing price and product comparisons lead to increased market transparency and rising pressure on margins (Munz and Doluschitz, 2021, 2020; Schulze, 2012).

The increased emergence of digital business models coupled with the lasting structural change in agriculture and the consolidation process of cooperatives and private trade is creating increasing competitive constraints (Munz and Doluschitz, 2021; Schulze, 2012). Furthermore, scenarios are being discussed in the sector about the impact of the entry of digital marketplaces by operators from outside the industry (e.g., Amazon Business, Google). Google is already making its way into the agricultural business and in 2017 invested in a U.S. online marketplace 
to purchase farm inputs and to market agricultural products (Lehmann, 2017). Such entries increase the pressure on the business models of the established players. In addition to the changes brought about by digital marketplaces, other digital technologies such as blockchain, augmented reality, and the use of artificial intelligence will lead to further innovations in distribution (Clasen, 2018; Wallmüller, 2017).

In agricultural trade, digitalization is perceived as a pressure to change. For example, in terms of supporting and relieving the workload of employees, as well as in terms of combining digital sales channels with personal consulting, which is considered a unique selling point of local agricultural trade (Deutsch et al., 2020). The risks of disintermediation (Zentes and Morschett, 2007) and digital disruption are increasing for companies (Bösel, 2021; Deloitte, 2012). The platform economy in particular has great potential for disruptive change (Jakosuo, 2019; Kenney and Zysman, 2016). It is therefore exciting to observe what is happening in agribusiness and whether there will be a disruption as well. In this context, the network effects, interlinked with platform economics, are already being critically discussed as, if any of the competing platforms gains a certain lead in membership and thus becomes the gatekeeper platform, many others will be pushed out of the market (Phillips et al., 2019). According to Deloitte's (2012) digital disruption map, agriculture is one of the so-called "long fuse, big bang" industries. According to this, significant changes due to digital disruption will occur in about 4 to 10 years and cause a 15 to $50 \%$ change within the industry, whereby agriculture is placed in the midfield here. In comparison, the map predicts a short fuse of about one year for the retail trade or ICT and media, but a big bang with an impact of over $40 \%$ change in business. Accommodation and food services are cited as a counterexample with a short fuse (about 1 year) and a small bang (10\% impact), (Deloitte, 2012).

Prominent questions concerning the agricultural trade business are therefore: How will agricultural trade, in particular input trade, develop in the future? Will (new) digital marketplaces displace (traditional) agricultural trade? It is obvious that the agricultural trade will have to adapt to the new establishing circumstances and requires clear positioning and the development of strategic competitive advantages (Schulze, 2012).

The digital business developments show that the digitalization of distribution is essential to generate competitive advantages in the future (Lässig et al., 2015). About $60 \%$ of the companies assume that the relevance of platforms in business-to-business (B2B) sales will be high in the future and forecast growing shifts in sales in online distribution over the next few years due to large platforms as gatekeepers. The latest developments in the platform economy in particular 
show that there is no getting around it for companies if they want to be successful (Krah, 2020). The expansion of rural internet infrastructure as part of the European Digital Agenda (European Commission, 2021) is creating additional pressure on manufacturers, retailers, and farmers to participate in the digital transformation. Otherwise, there is a risk of being left behind and ultimately being forced out of the market.

Decisive for the success of new, digital distribution systems is, on the one hand, the readiness of customers, i.e., the farmers, and, on the other hand, the digital maturity of the company (Binckebanck and Elste, 2016). Digital maturity seems to be slower among medium-sized enterprises, which characterize agribusiness. Compared to large companies or corporations of agricultural trade, small and medium-sized companies (SMEs) often lack the financial resources and the necessary digital know-how to implement those technical complex digital platform and consulting solutions (Deutsch et al., 2020; Schwartz, 2017). Furthermore, the medium-sized structure of the sector, in which businesses are more dependent on individual employees (Gollisch and Theuvsen, 2015), makes it even more difficult for companies to digitize, particularly in accordance with the sales department, which is still a "people's business". Farmers basically want to have a single personal contact person at agricultural retail and usually maintain these relationships over many years (Schulze, 2012). Digitizing sales structures therefore primarily means a high level of organizational effort, in that departments have to be turned upside down and employee roles redefined. Factors such as employees' reluctance to embrace innovation or their fear of being replaced by artificial intelligence in other words, a lack of employee commitment - inhibit the transformation process (Merhar et al., 2019; Schmieder, 2019). If the described digital innovations, e.g., digital platforms, result in the preservation of large companies or corporations of agricultural trade, this could also increase the risk of a growing oligopoly in agricultural supply and sales channels, with possible negative effects on product selection and pricing for farmers (Deutsch et al., 2020; Ma et al., 2019). On the one hand, this is true but, on the other hand, if farmers prefer to have a direct (offline) contact anyway, this can remain precisely the strength of small private companies and retailers if they manage to strategically incorporate this into their distribution structures. However, as indicated in the opening quote, companies must align their business models with their increasingly digital customers in order to remain competitive (BMWi, 2017). When considering farmers' digital readiness, terms such as farming 4.0, smart farming, or precision farming are omnipresent. The central element is usually the intelligent networking of production processes in order to improve production sequences, increase yields, and save 
resources (Gandorfer et al., 2017; Klerkx et al., 2019). According to Ackermann et al. (2018) and Gartzke (2016), around $75 \%$ and $99 \%$ of farmers use the internet on a daily or weekly basis, respectively, and already eight out of ten farmers rely on digital technologies today (Bitkom, 2020). According to a recent survey by Gabriel et al. (2021), about 36\% of farms in Germany already have a high level of digitization. From this perspective, the technical prerequisites, i.e., their technical digital readiness, for the electronic commerce for farm input purchase seem to be in place on farms. Nevertheless, the majority of farmers still do their documentation by hand or with Excel (Battermann et al., 2008; Harms et al., 2018; top farmplan, 2019). They are therefore still far away from a networked way of working. At the same time, manufacturers of agricultural technology, for example, are producing increasingly intelligent and networked machines that often encounter non-digital users.

However, and particularly against the background of the traditional, personal sales structures of the agricultural input industry, the question arises if farmers are also "mentally ready" for digital input purchasing. While it can be assumed that the use of some digital technologies (e.g., weather forecast, documentation) has already become part of farms' daily business, only little is known about the farmers' attitudes and usage of e-commerce. This opens up exciting fields of research. For example, what currently determines farmers' (digital) purchasing behavior? Or are farmers perhaps still being left behind by factors such as digital oversupply, lack of clarity, lack of user-friendliness, or the fear of becoming too transparent? And does the current e-commerce offering match what the farmers expect, how are the offers structured, and above all, what do farmers need and want?

In the course of this, a research landscape on agricultural e-commerce is building up. A first wave of research already took place at the time of the internet boom in the early 2000s, when a large number of digital markets for agricultural trade were established (Clasen, 2018). At that time, studies were often designed on American markets (Akridge, 2003; Batte, 2006; Henderson et al., 2006) and sometimes also on European markets (Clasen, 2005; Stricker et al., 2001). Being just under 20 years old, they are already quite outdated.

Current studies have investigated the extent to which farmers use digital sales channels for the procurement of farm inputs today (Ackermann et al., 2018; Gartzke, 2016). These studies also investigated which sociodemographic and farm-related characteristics influence e-commerce usage and if there is a willingness to switch from stationary to digital suppliers (Fecke et al., 2018a). According to these studies, farmers are generally interested in e-commerce. However, e-commerce penetration rates are relatively low and product-dependent 
(Ackermann et al., 2018; Ardrey et al., 2020; Gartzke, 2016). Only 13\% of European farmers made an online purchase of agricultural inputs in 2019 (Ardrey et al., 2020). While standardized search goods (spare parts, stable supplies, office materials) are more likely to be purchased online, farmers are less likely to use e-commerce for experience goods such as fertilizers, pesticides, or seeds and feeds (Ackermann et al., 2018; Ardrey et al., 2020; Gartzke, 2016). Farmers still continue to use cooperative and traditional private agricultural trade as their main source of supply (Ackermann et al., 2018). Even if most farm managers have already bought some farm inputs online or have had private e-commerce experience, e-commerce on farms has not really taken off yet. The results confirm the complexity of digital agricultural input marketing and farmers' product category-related and non-homogeneous purchasing behaviors. However, research on the topic of agricultural e-commerce behavior is still in its infancy and, especially considering the rapid dynamics of digitalization, there is a great need for further research.

In view of the described distribution structures in the agricultural input industry, it does not seem surprising that, despite the increasing emergence of e-commerce, service and customer orientation are still seen by farmers as important reasons to remain loyal to local, stationary agricultural trade (Fecke et al., 2018a; Gartzke, 2016; Munz and Doluschitz, 2021). The personal conversation with the farm input supplier, which is highly valued by farmers, is crucial here, because farmers fear that the accessibility, frequency, and intensity of personal conversations will decrease with the increasing e-commerce offer. At the same, time data security is being led and concerns are being raised about too much personal transparency through the transfer of sensitive data to a seemingly unknown entity (Gabriel et al., 2021). Lack of personal advice and good local dealer networks are therefore considered a reason for farm-related e-commerce rejection (Ardrey et al., 2020; Fecke et al., 2018b; Gartzke, 2016).

This simultaneous high demand for personal touchpoints paired with the rapid development of digital distribution channels highlights the importance of a strategic sales management for every agricultural input company, regardless of whether it is a start-up, a medium-sized company, or a large corporation, as the sales department is considered an important link between the company and the customer (Albers and Krafft, 2013; Puspitasari and Harjanti, 2017; Schmitz and Wieseke, 2015). Within that, the sales force, which has close customer contact and includes the tasks of personal sales, often functions as a personal touchpoint for customers and thus is a decisive sales element (Fredebeul-Krein, 2012). Particularly in the market for farm inputs, which is characterized by indirect sales and complex products that are used by customers 
in a very farm-specific way (Rüther and Maier, 2007), the manufacturing companies and distributors employ a personnel-intensive sales force for the support and advice of their products (Barnard et al., 2016; Maier, 2013; Voss, 2008). For more than $75 \%$ of manufacturers, regular customer visits by sales representatives are the most frequently used communication channel to their agricultural customers (Voss, 2008).

While sales in the farm input industry are not affected by the ongoing structural change, it is evident that the demands of farmers towards input suppliers have changed in the course of digitalization and structural change of agriculture, representing a significant challenge for the sales activities of manufacturers and retailers in the industry. In Germany, the number of largescale farms is increasing, while the number of small-scale farms is decreasing. $5 \%$ of the largest farms already manage more than $40 \%$ of agricultural land (Junge, 2021; Statistisches Bundesamt, 2019). Agricultural customers that persist in structural change are increasingly professionalizing and specializing, resulting in larger procurement volumes and countervailing market power (Hill and Doluschitz, 2015; Pionke, 2018). In addition, the educational level of farmers is also continuously increasing (Demel and Wolf, 2018). The agricultural sales force must therefore face up to these bundles of changes to ensure a competent and farmer-oriented sales service. Existing scientific literature lists professional competence, personality, and social competence as factors that sales representatives should possess to remain successful (Churchill et al., 1985; Homburg et al., 2016).

Research on how the sales force is perceived by farmers and what they expect from a customer-oriented salesperson or consultant is not yet available. It has also not yet been scientifically investigated how the expressions of the three success determinants are fulfilled by sales representatives in the agricultural input industry, and how they are perceived by farmers. However, especially in times of increasing digital transformation, the service and customer orientation of farmers enable local, stationary agricultural retail with its sales force to position itself positively against online trade (Munz and Doluschitz, 2021). For this purpose, sales force competencies must be developed, but new scientific research is required for the strategic development of these competencies. In this context, it should also be investigated how the noticeable shortage of skilled workers and managers can be counteracted, which is one of the major obstacles for agribusiness companies in Germany. According to a forecast, the demand for skilled workers in the agricultural sector will increase by around $10 \%$ over the next ten years (VDL, 2018). The marketing of complex agricultural production inputs and the associated customer-related service and advisory functions represent a demanding task that 
requires certain personal and professional skills from sales representatives (Schmitz and Wieseke, 2015). Filling open sales positions could therefore become problematic for companies in the sector. Sales management is thus exposed to a field of tension arising from the rapidly advancing digital transformation, the structural changes in German agriculture, the associated consolidation processes in agricultural trade, and a growing shortage of specialists and managers in all areas of the industry. These factors will lead to significant changes in the sales management of companies along the agricultural value chain in Germany. Thus, companies in the agricultural input industry are obliged to align their marketing and sales processes in such a way that they are consistently oriented towards the various target groups (Voss, 2008).

Against the background of the described situation in the German agricultural input trade, this dissertation first examines the purchasing behavior of German farmers, with a special focus on the use of digital sales channels. This approach serves to gain comprehensive insights into and a better understanding of the only sparsely studied online shopping behavior of farmers. Furthermore, the results will help to gain a better understanding of the resulting agricultural demands in input purchasing and provide starting points for future scientific research. In order to better classify farmers' needs for digital distribution channels and to also gain an understanding of the supplier side, the perceived corporate barriers to digital commerce are investigated. With these two perspectives, chapter I aims to provide a comprehensive picture of the implementation of digital sales channels within the agricultural input industry.

In addition, the dissertation examines how the agricultural sales force, as a personal point of customer contact, is perceived and evaluated by farmers. This aims to gain a better understanding of the reputation and role of the agricultural sales force and its resulting competence requirements. At the same time, it is also examined whether a job in agricultural sales is interesting for students of agricultural sciences. The objective is to get an impression of where the perceived shortage of skilled personnel in agricultural sales comes from and how this can be countered through university education and the industry (chapter II). In the last chapter (chapter III), an excursion into another research perspective - the reputation of the seed industry from the consumer's point of view - is made. 
The objective of this dissertation is to provide comprehensive insights into the currently well-discussed area of agricultural distribution channels: the e-commerce and selected aspects of sales management in agribusiness, the so far hardly considered area of the agricultural sales force. This should help to propose recommendations for action within the (digital) transformation processes in the agricultural input industry and thus contributes to a competitive, future-oriented, and farmer-focused input trade. The structure of this dissertation is outlined in Figure 1.

\section{Introduction}

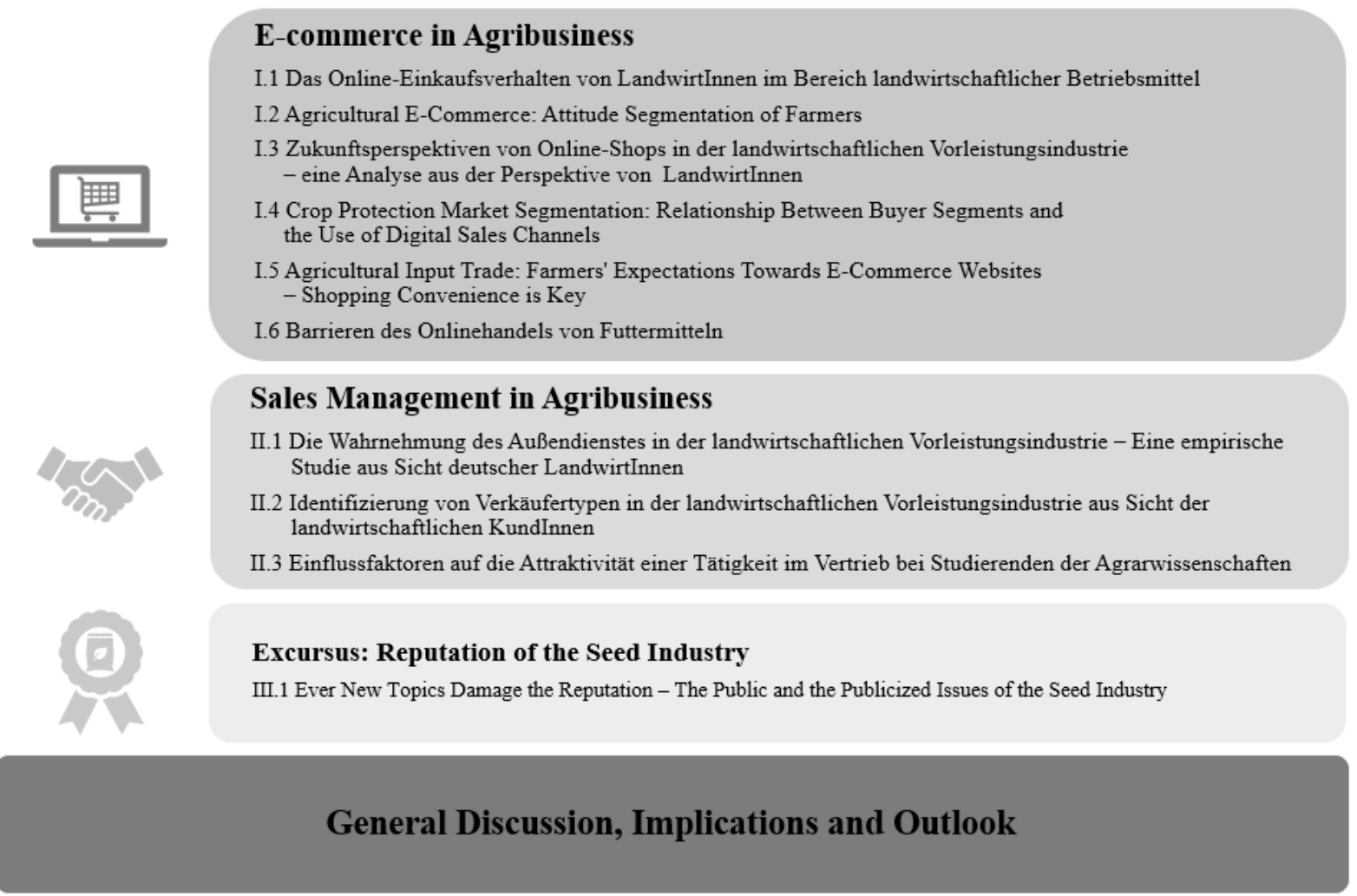

Figure 1: Structure of the dissertation 


\section{Chapter 1: E-commerce in Agribusiness}

The increasing share of e-commerce offers in agricultural trade and farmers' so far hesitant behavior towards e-commerce stimulate significant interest in understanding the purchasing behavior and decision-making processes of farmers. Based on a quantitative online survey of 371 German farmers, the first three articles of this dissertation contribute to this topic. A scientific consideration of e-commerce in agribusiness requires an understanding of the recent penetration rate, which is given in the first article "Das Online-Einkaufsverhalten von LandwirtInnen im Bereich landwirtschaftlicher Betriebsmittel". The aim of this article is to clarify the extent to which e-commerce is used and to better understand the online purchasing behavior of German farmers for agricultural inputs, based on Kool's (1994) model of farmers' buying behavior. With this, the extent to which product characteristics as well as personal and farm characteristics influence online purchasing decisions is investigated.

Among the array of factors that have been examined in previous research as potential determinants of online shopping, attitude has been shown to have a significant influence on online buying behavior (Chang et al., 2005; Javadi et al., 2012). Here, most studies use attitude as a single-factor concept and focus mainly on emotional or cognitive aspects (Hasan, 2010), although attitude is a multidimensional variable with cognitive, affective, and behavioral components (ABC model), (Fishbein and Ajzen, 1975). While general studies on online shopping attitudes are widely available in the literature, there are only few studies on farmers' online shopping attitudes. Therefore, the second article "Agricultural E-Commerce: Attitude Segmentation of Farmers" aims to extend the existing knowledge by analyzing farmers' online shopping attitudes based on a multidimensional concept, which also includes soft factors like emotions.

"Why should I use something that I do not think will catch on?". For the success of an innovation, such as e-commerce, customer perceptions and evaluations of the innovation are considered as crucial factors (Tomczak et al., 2016). However, according to this line of thought, which many farmers might have, there are hardly any studies that examine the potential of e-commerce in the agricultural industry from the farmer's point of view. For this reason, the article "Zukunftsperspektiven von Online-Shops in der landwirtschaftlichen Vorleistungsindustrie - eine Analyse aus der Perspektive von LandwirtInnen" examines whether farmers consider e-commerce in the agricultural sector to have a promising future and what position stationary trade occupies for them. 
Scientific studies have shown that the extent of e-commerce varies depending on the product category. According to these studies, well-standardized search goods such as care products and materials for everyday use are purchased online more frequently, while individualized experience goods such as animal feed, fertilizers, and pesticides are purchased less frequently (Ackermann et al., 2018; Gartzke, 2016). The fourth to sixth articles of this chapter therefore exemplarily address the purchasing behavior and online trade barriers of crop protection products and agricultural animal feed, as the two products lag behind in e-commerce. In terms of methodology, the fourth article draws on segmentation approaches which are common in the literature, and which are seen as a standard approach to studying agricultural purchasing behavior (Alexander et al., 2005; Borchers et al., 2012; Gloy and Akridge, 1999). The fourth article "Crop Protection Market Segmentation: Relationship Between Buyer Segments and the Use of Digital Sales Channels" aims, on the one hand, to clarify whether these long-established segmentation approaches are still valid today and, on the other hand, if they are valid for a specific market like German crop protection trade. Moreover, the literature lacks consideration of how the identified segments differ in their attitudes towards digital sales channels. For this reason, the third research question addresses the relationship between crop protection market segments and the purchase-related usage of digital sales channels.

E-commerce is characterized by a high speed of change which is additionally driven by the platform economy, making e-commerce websites increasingly intelligent and convenient for customers. Huang et al. (2019) speak of a next-generation e-commerce platform. However, what expectations farmers have of a particular e-commerce website and how these influence their shopping experience has not yet been studied. The fifth article in this chapter "Agricultural Input Trade: Farmers' Expectations of an E-Commerce Website - Shopping Convenience is Key" is devoted to precisely this question. Using the qualitative approach with the thinking aloud method (Konrad, 2020), the paper allows to capture unfiltered perceptions and expectations of farmers regarding the e-commerce website and thus provides approaches for the design of agricultural e-commerce offers to improve the customer experience and to create long-term customer added value of digital offers.

The sixth and final article "Barrieren des Onlinehandels von Futtermitteln" changes the perspective from the farmer to the feed supplier and investigates the online trade barriers for feed products. Using the qualitative approach of expert interviews (Gläser and Laudel, 2010), the paper allows to capture the perception of e-commerce barriers from the supplier side and 
thus to penetrate acceptance and implementation difficulties. With this change of perspective, the last article contributes to a more comprehensive view of agricultural e-commerce.

\section{Chapter 2: Sales Management in Agribusiness}

Despite the digital developments in agricultural input sales described at the beginning of this introduction and examined in chapter I, there is still a strong demand for personal contact with the dealer from the farmer's point of view (Fecke et al., 2018b; Schulze, 2012). Therefore, the second chapter of the dissertation deals with sales management in agribusiness and in three individual articles particularly addresses the agricultural personal sales force. The first article "Die Wahrnehmung des Außendienstes in der landwirtschaftlichen Vorleistungsindustrie Eine empirische Studie aus Sicht deutscher LandwirtInnen" outlines, on the basis of an online survey with 238 German farmers, the perceptions and evaluation of sales force competencies in the various subsectors of the agricultural input industry (like seeds, crop protection, fertilizers, agricultural technology, and agricultural trade).

The second article "Identifizierung von Verkäufertypen in der landwirtschaftlichen Vorleistungsindustrie aus Sicht der landwirtschaftlichen KundInnen" revisits these skills and uses a cluster analysis for the identification of different salesperson typologies. The formation of salesperson typologies is based on their professional and social skills and the personality of sales representatives. These two articles for the first time scientifically take up the topic of the agricultural sales force, contribute to gaining a better understanding of the agricultural field service, and give first recommendations for action for a sales force optimization towards more customer centricity.

Since a noticeable shortage of skilled workers and managers is perceived as one of the major obstacles for agribusiness companies (Schmitz and Wieseke, 2015; VDL, 2018), the third paper "Einflussfaktoren auf die Attraktivität einer Tätigkeit im Vertrieb bei Studierenden der Agrarwissenschaften" addresses the attitudes of 299 agricultural students toward a job in agricultural sales. The focus is on identifying factors that can increase the attractiveness of this job from the students' point of view. 


\section{Chapter 3: Excursus: Seed Sector Reputation}

In addition to the challenges described above, the input industry also has to contend with the general social acceptance problem of agriculture. In the course of this, the controversy over genetic modification (GM) can be mentioned as just one example, which has increased public interest in the seed sector (Schurmann, 2004). Against this background, the last research article of this dissertation investigates, based on 753 consumer responses, consumers' topics of concern and the relationship with the sector's reputation. These insights help the industry's issue management to prioritize topics of concern and to identify critical consumer groups to encourage a discourse with them. All in all, the last article also contributes to a gain in knowledge for sales management in agribusiness, i.e., the agricultural input industry. The increasing social pressure on agriculture obligates the sales and marketing of companies not only to convince the farmers, but also to follow a certain license to operate in order to remain competitive and not to further fuel the pressure (Gistri et al., 2019). 


\section{References}

Ackermann, S., Adams, I., Gindele, N. and Doluschitz, R. (2018). The role of e-commerce in the purchase of agricultural input materials. Landtechnik 73(1): 10-19. doi: 10.15150/lt.2018.3177

Agrando (2021). Agrando Agrarbedarf online suchen und regional finden. Agrando. https://agrando.com/de-de. (24.07.2021).

Akridge, J.T. (2003). E-Business in the Agricultural Input Industries. Applied Economic Perspectives and Policy 25(1): 3-13. doi: 10.1111/1467-9353.00041

Albers, S. and Krafft, M. (2013). Vertriebsmanagement. Organisation, Planung, Controlling, Support. Springer Gabler, Wiesbaden. doi: 10.1007/978-3-8349-3663-9

Alexander, C.E., Wilson, C.A. and Foley, D.H. (2005). Agricultural Input Market Segments: Who Is Buying What? Journal of Agribusiness 23(2): 113-132. doi: 10.22004/ag.econ.59673

Ardrey, J., Denis, N., Magnin, C. and Revellat, J. (2020). Unlocking the online retail opportunity with European farmers. McKinsey \& Company. https://mck.co/2Rt1EhS. (07.03.2021).

Barnard, F.L., Akridge, J.T., Dooley, F.J., Foltz, J.C. and Yeager, E.A. (2016). Agribusiness management. Routledge, London.

Batte, M.T. (2006). Shopping at the Farm Office: What Is the Future of Farm E-commerce? Journal of the American Society of Farm Managers and Rural Appraisers 2006(387-2016-22853): 100105. doi: 10.22004/ag.econ.190698

Battermann, H.W., Steinmann, H.-H. and Theuvsen, L. (2008). Einzelbetrieblicher Umgang mit Dokumentationspflichten im Pflanzenschutz: Eine empirische Erhebung. Agrarwirtschaft 57(6): 287-298. doi: 10.22004/ag.econ.97699

Bickert, C. (2020). Online trading Agriculture 4.0 - or only hot air? Beiträge DLG Wintertagung 2020. https://www.dlg.org/en/agriculture/topics/dlg-agrifuture-magazine/knowledge-skills/onlinetrading-agriculture-40-or-only-hot-air. (30.06.2021).

Binckebanck, L. and Elste, R. (2016). Digitalisierung im Vertrieb. Strategien zum Einsatz neuer Technologien in Vertriebsorganisationen. Springer Gabler, Wiesbaden. doi: 10.1007/978-3-658-05054-2

Bitkom, 2020). Schon 8 von 10 Landwirten setzen auf digitale Technologien. Bitkom e.V. https://bit.ly/3aWVgXl. (21.04.2021).

BMWi (2017). Digitale Geschäftsmodelle. Themenheft Mittelstand-Digital. Bundes-Ministerium für Wirtschaft und Energie, Berlin.

Borchers, B., Roucan-Kane, M., Alexander, C. E., Boehlje, M., Downey, W. S. and Gray, A. W. (2012). How Large Commercial Producers Choose Input Suppliers: Expendable Products from Seed to Animal Health. International Food and Agribusiness Management Review 15(2): 1-20. doi: 10.22004/ag.econ.127281

Bösel, B. (2021). Plattformen verändern die Agrarbranche. f3.de. https://f3.de/farm/plattformenverandern-die-agrarbranche-452.html. (28.07.2021).

Chang, M.K., Cheung, W. and Lai, V. S. (2005). Literature derived reference models for the adoption of online shopping. Information \& management 42(4): 543-559. doi: 10.1016/j.im.2004.02.006

Churchill, G.A., Ford, N. M., Hartley, S. W. and Walker Jr, O. C. (1985). The determinants of salesperson performance: A meta-analysis. Journal of marketing research 22(2): 103-118. doi: $10.1177 / 002224378502200201$

Clasen, M. (2018.). Die Rolle Digitaler Marktplätze in einer vollständig selbstgesteuerten Landwirtschaft. In: Ruckelshausen, A., Meyer-Aurich, A., Borchard, K., Hofacker, C., Loy, J.P., Schwerdtfeger, R., Sundermeier, H.-H. F. and Theuvsen, B. (eds.). 38. GIL-Jahrestagung, 
Digitale Marktplätze und Plattformen in Kiel. Lecture Notes in Informatics. Gesellschaft für Informatik e.V, Bonn 17-22. doi: 10.25968/OPUS-1889

Clasen, M. (2005). Erfolgsfaktoren digitaler Marktplätze in der Agrar- und Ernährungsindustrie. Dissertation. Deutscher Universitätsverlag, Wiesbaden.

Deloitte (2012). Digital disruption - Short fuse, big bang? Building the Lucky Country. Business imperatives for a prosperous Australia No. 2, Australia.

Demel, J. and Wolf, R. (2018). Aus- und Weiterbildung in landwirtschaftlichen Berufen. Statistisches Monatsheft Baden-Württemberg. Statistische Landesamt Baden-Württemberg. https://www.statistik-bw.de/Service/Veroeff/Monatshefte/PDF/Beitrag18_09_01.pdf.

Deter, A. (2017). Digitalisierung - eine Chance für die Landwirtschaft. top agrar online. https://www.topagrar.com/management-und-politik/news/digitalisierung-eine-chance-fuer-dielandwirtschaft-9449744.html. (23.07.2021).

Deutsch, M., Otte, L. and Otter, V. (2020). Digital first? Auswirkungen der Digitalisierung auf Vertriebsstrukturen im deutschen Agrarhandel. Austrian Journal of Agricultural Economics and Rural Studies 29(4): 23-30. doi: 10.15203/OEGA_29.4

European Commission (2021). EU Member States join forces on digitalisation for European agriculture and rural areas | Shaping Europe's digital future. https://digitalstrategy.ec.europa.eu/en/news/eu-member-states-join-forces-digitalisation-europeanagriculture-and-rural-areas. (22.06.2021).

Fecke, W., Danne, M. and Musshoff, O. (2018a). E-commerce in agriculture-The case of crop protection product purchases in a discrete choice experiment. Computers and electronics in agriculture 151(2018): 126-135. doi: 10.1016/j.compag.2018.05.032

Fecke, W., Michels, M., Hobe, C.-F. von and Mußhoff, O. (2018b). Wie kommunizieren Landwirte in Zeiten der Digitalisierung? Berichte über Landwirtschaft - Zeitschrift für Agrarpolitik und Landwirtschaft 96(2): 1-17. doi: 10.12767/buel.v96i2.194

Fishbein, M.A. and Ajzen, I. (1975). Belief, attitude, intention and behaviour: An introduction to theory and research. Addison-Wesley, Boston, US.

Fredebeul-Krein, T. (2012). Koordinierter Einsatz von Direktmarketing und Verkaufsaußendienst im B2B-Kontext. Kundenmanagement \& Electronic Commerce. Gabler Verlag, Wiesbaden. doi: 10.1007/978-3-8349-3940-1

Gabriel, A., Gandorfer, M. and Spykman, O. (2021). Nutzung und Hemmnisse digitaler Technologien in der Landwirtschaft. Berichte über Landwirtschaft - Zeitschrift für Agrarpolitik und Landwirtschaft 99(1): 1-27. doi: 10.12767/buel.v99i1.328

Gandorfer, M., Schleicher, S., Heuser, S., Pfeiffer, J. and Demmel, M. (2017). Landwirtschaft 4.0Digitalisierung und ihre Herausforderungen. Ackerbau-technische Lösungen für die Zukunft Bayerische Landesanstalt für Landwirtschaft (LfL), Freising (9): 9-20.

Gartzke, S. (2016). Kleffmann Group Global New Media Tracker - Our international Study Kleffmann Group. In: Farwick, C. (eds.). Kleffmann Group. Agri Experts Around the World. Newsletter, $18-21$.

Gistri, G., Corciolani, M. and Pace, S. (2019). Does the perception of incongruence hurt more? Customers' responses to CSR crises affecting the main reputation dimension of a company. Journal of Marketing Management 35(7-8): 605-633. doi: 10.1080/0267257X.2019.1580761

Gläser, J. and Laudel, G. (2010). Experteninterviews und qualitative Inhaltsanalyse als Instrumente rekonstruierender Untersuchungen. VS Verlag für Sozialwissenschaften, Springer, Wiesbaden.

Gloy, B.A. and Akridge, J. T. (1999). Segmenting the commercial producer marketplace for agricultural inputs. The International Food and Agribusiness Management Review 2(2): 145-163. doi: $10.1016 /$ S1096-7508(00)00023-9 
Gollisch, S. and Theuvsen, L. (2015). Risikomanagement im Landhandel: Charakteristika, Herausforderungen, Implikationen. Berichte über Landwirtschaft - Zeitschrift für Agrarpolitik und Landwirtschaft 93(1): 1-16. doi: 10.12767/buel.v93i1.72

Gregory, R.W., Henfridsson, O., Kaganer, E. and Kyriakou, H. (2020). The role of artificial intelligence and data network effects for creating user value. Academy of Management Review 46(3): 534551. doi: 10.5465/amr.2019.0178

GWS (2020). Raiffeisen Portal GmbH gegründet. Gesellschaft für Warenwirtschaftssysteme mbH. https://www.pressebox.de/pressemitteilung/gws-gesellschaft-fuer-waren wirtschafts-systeme$\mathrm{mbh} /$ Raiffeisen-Portal-GmbH-gegruendet/boxid/1018432. (24.07.2021).

Harms, J., Jakob, M., Sonnewald-Daum, T., Weizenhöfer, T. and für Landwirtschaft, B. L. (2018.2018). Selektives Trockenstellen-eine Maßnahme zur Reduzierung des Antibiotikaeinsatzes in der Milchviehhaltung. In: Wendl, G. (eds.). Milchviehhaltung - Lösungen für die Zukunft Landtechnisch-bauliche Jahrestagung 2018. Schriftenreihe. Bayerische Landesanstalt für Landwirtschaft (LfL), Freising 97-110.

Hartmann, E. (2019). Ein Überblick der E-Marktplätze im B2B-Bereich Handbuch Digitale Wirtschaft. In: Kollmann, T. (eds.). Handbuch Digitale Wirtschaft. Springer Gabler, Wiesbaden, 603-629. doi: 10.1007/978-3-658-17291-6_45

Hasan, B. (2010). Exploring gender differences in online shopping attitude. Computers in Human Behavior 26(4): 597-601. doi: 10.1016/j.chb.2009.12.012

Hemmerling, U., Pascher, P. and S. Naß (2016). Situationsbericht 2016/17 Trends und Fakten zur Landwirtschaft. Deutscher Bauernverband, Berlin.

Henderson, J.R., Akridge, J. T. and Dooley, F. J. (2006). Internet and e-commerce use by agribusiness firms: 2004. Journal of Agribusiness 24(1): 17-39. doi: 10.22004/ag.econ.57697

Hill, S. and Doluschitz, R. (2015). Ländliche Genossenschaften in Deutschland. In:Hill, S. (eds.). Die Bedeutung von Werten in Genossenschaften und deren Umsetzung: eine empirische Analyse Disseration. Fakultät Agrarwissenschaften, Universität Hohenheim, 72-75.

Homburg, C., Schäfer, H. and Schneider, J. (2016). Sales Excellence. Vertriebsmanagement mit System. Springer Gabler, Wiesbaden.

Huang, Y., Chai, Y., Liu, Y. and Shen, J. (2019). Architecture of next-generation e-commerce platform. Tsinghua Science \& Technology 24(1): 18-29. doi: 10.26599/TST.2018.9010067

Huchtemann, J.-P. (2020). Entrepreneurship und Vertriebsmanagement im Agribusiness. Dissertation. Cuvillier Verlag, Göttingen.

Jakosuo, K. (2019). Digitalisation And Platform Economy - Disruption In Service Sector. The European Proceedings of Social \& Behavioural Sciences 75-85. doi: 10.15405/epsbs.2019.01.02.7

Janze, C., Theuvsen, L., Schmidt, C. and J. Meyer (2017). Konjunkturbarometer Agribusiness in Deutschland 2017. Ernst \& Young GmbH. https://expydoc.com/doc/11684749/konjunkturbarometer-agribusiness-in-deutschland-2017. (24.07.2021).

Janze, C., Weinrich, R., Schmidt, C., Schukat, S., Langer, G., Robinsion, D.M. and C. Winkel (2021). Konjunkturbarometer Agribusiness in Deutschland 2021. Ernst \& Young GmbH. https://assets.ey.com/content/dam/ey-sites/ey-com/de_de/news/2021/01/ey-studieagribusiness-2021.pdf.

Javadi, M.H.M., Dolatabadi, H. R., Nourbakhsh, M., Poursaeedi, A. and Asadollahi, A. R. (2012). An analysis of factors affecting on online shopping behavior of consumers. International Journal of Marketing Studies 4(5): 81-98. doi: 10.5539/ijms.v4n5p81

Junge, S. (2021). Wachsen oder Weichen - Deutsche Landwirtschaft im Strukturwandel. Bundeszentrale für politische Bildung. https://bit.ly/2SuUPNx. (24.03.2021). 
Kenney, M. and Zysman, J. (2016). The rise of the platform economy. Issues in science and technology 32(3): 61-69.

Kilhoffer, Z., Lenaerts, K. and Beblavý, M. (2017). The Platform Economy and Industrial Relations: Applying the Old Framework to the New Reality. CEPS Research Report 2017(12): 1-53.

Klerkx, L., Jakku, E. and Labarthe, P. (2019). A review of social science on digital agriculture, smart farming and agriculture 4.0: New contributions and a future research agenda. Wageningen Journal of Life Sciences 90-91 100315. doi: 10.1016/j.njas.2019.100315

Konrad, K. (2020). Lautes Denken Designs und Verfahren. In: Mey, G. and Mruck, K. (eds.). Designs und Verfahren. Springer, Wiesbaden, 373-393.

Kool, M. (1994). Buying behavior of farmers. Kool, Wageningen.

Krah, E. (2020). B2B-Vertrieb auf Handelsplattformen wächst. springerprofessional.de. https://www.springerprofessional.de/handel/vertriebskanaele/b2b-vertrieb-aufhandelsplattformen-waechst/17763730. (28.07.2021).

Lässig, R., Leutiger, P., Fex, A., Hentschel, S., Tornier, S. and F. Hirt (2015). Die digitale Zukunft des B2B-Vertriebs. Warum Industriegüterunternehmen sich auf veränderte Anforderungen ihrer Kunden einstellen müssen. Roland Berger GmbH, München.

Lehmann, N. (2017). Google investiert in die Landwirtschaft. agrarheute. https://www.agrarheute.com/management/agribusiness/google-investiert-landwirtschaft538455. (26.07.2021).

Ma, L., Nuetah, A. and Wang, X. (2019). Market power and returns to scale in farm-value share determination: An extension of the Muth-Gardner approach. China Agricultural Economic Review 11(1): 70-78. doi: 10.1108/CAER-01-2018-0003

Maier, P. (2013). Entwicklung der landwirtschaftlichen Beratung in der Bundesrepublik Deutschland unter dem Aspekt der Beratungsqualität. Problemy Nauk Stosowanych 1(1): 189-196.

Merhar, L., Höllthaler, G. and Berger, C. (2019). Digitale Assistenzsysteme für die Produktion: Von der Zielfindung bis zur Einbindung gemeinsam mit den Mitarbeitern Arbeit 4.0 im Mittelstand. In: Bosse, C.K. and Zink, K.J. (eds.). Arbeit 4.0 im Mittelstand. Chancen und Herausforderungen des digitalen Wandels für KMU. Springer Gabler, Berlin Heidelberg, 279-302. doi: 10.1007/978-3-662-59474-2_17

Munz, J. and Doluschitz, R. (2021). Status quo der Adoption digitaler Technologien im genossenschaftlichen Agrarhandel- Möglichkeiten einer digitalen Differenzierungsstrategie. Berichte über Landwirtschaft - Zeitschrift für Agrarpolitik und Landwirtschaft 99(2): 1-32. doi: 10.12767/buel.v99i2.335

Munz, J. and Doluschitz, R. (2020). Determinanten zur Akzeptanz der Einführung digitaler Technologien im genossenschaftlichen Agrarhandel. Zeitschrift für das gesamte Genossenschaftswesen 70(4): 283-307. doi: 10.1515/zfgg-2020-0020

myAGRAR (2021). myAGRAR Onlineshop Ihr starker Hoflieferant. https://www.myagrar.de/. (24.07.2021).

NextFarming (2021). Unser gemeinsamer Marktplatz - eine Allianz für bessere Geschäfte. https://www.nextfarming.de/landwirt/marktplatz/. (29.07.2021).

Pascher, P., Hemmerling, U., Naß, S. and Stork, S. (2020). Situationsbericht 2018/19 Trends und Fakten zur Landwirtschaft. Deutscher Bauern verband e.V., Berlin.

Phillips, P.W., Relf-Eckstein, J.-A., Jobe, G. and Wixted, B. (2019). Configuring the new digital landscape in western Canadian agriculture. NJAS - Wageningen Journal of Life Sciences 9091(2019): 100295. doi: 10.1016/j.njas.2019.04.001

Pionke, S. (2018). Fitness-check agrarhandel Unbequeme Sandwich-Position. agrarzeitung. https://www.agrarzeitung.de/news/media/4/Fitness-Check-Agrarhandel-37180.pdf. 
Proplanta (2011). Die Agrar- und Ernährungswirtschaft als Zukunftsbranche mit Wachstumspotential. Proplanta Das Informationszentrum für die Landwirtschaft. https://www.proplanta.de/agrarnachrichten/agrarwirtschaft/die-agrar-und-ernaehrungswirtschaft-als-zukunftsbranche-mitwachstumspotential_article1294400436.html. (24.07.2021).

Puspitasari, E. and Harjanti, W. (2017). Meaningful Experience Of Motivation To Power Seller With Orientation On Consumer Satisfaction For Identification Of Employee Benefits In The Textile Sales In South Surabaya. International Journal Of Entrepreneurship And Business Development 1(1): 1-22. doi: 10.29138/ijebd.v1i1.341

Rüther, C. and Maier, P. (2007). Wie beurteilen LandwirtInnen Beratungsleistungen? Qualität landwirtschaftlicher Fachberatung. Fachzeitschrift B\&B Agrar 60(2): 54-56.

Schmieder, V.C. (2019). Künstliche Intelligenz als Substitut menschlicher Arbeit. Die Zukunft mittelständischer Verwaltungsprozesse im Kontext der Digitalisierung. Springer Gabler, Wiesbaden.

Schmitz, C. and Wieseke, J. (2015). Herausforderungen und Potenziale im Vertrieb. Marketing Review St. Gallen 32(6): 12-21. doi: 10.1007/s11621-015-0596-3

Schulze, B. (2012). Herausforderungen des Landhandels unter veränderten Marktbedingungen: Theoretische Überlegungen und empirische Evidenz. Annual Conference, Stuttgart. German Association of Agricultural Economists (GEWISOLA) 52(133053): doi: 10.22004/ag.econ.133053

Schurmann, R. (2004). Fighting "Frankenfoods": Industry Opportunity Structures and the Efficacy of the Anti-Biotech Movement in Western Europe. Social Problems 51(2): 243-268. doi: 10.1525/sp.2004.51.2.243

Schwartz, M. (2017). E-Commerce steckt im Mittelstand noch in den Kinderschuhen. KfW Research Fokus Volkswirtschaft. 161(12): 1-16 https://www.kfw.de/PDF/DownloadCenter/Konzernthemen/Research/PDF-Dokumente-Fokus-Volkswirtschaft/Fokus-2017/FokusNr.-161-Februar-2017-E-Commerce.pdf. (20.03.2020).

Statistisches Bundesamt (2019). Betriebsgrößenstruktur landwirtschaftlicher Betriebe nach Bundesländern. https://bit.ly/2RpSpz0. (24.03.2021).

Strecker, O., Strecker, O.A., Elles, A., Weschke, H.-D., Kliebisch, C. and Enneking, U. (2010). Marketing für Lebensmittel und Agrarprodukte. DLG-Verlag, Frankfurt am Main.

Stricker, S., Sundermeier, H. H. and Müller, R. A. (2001). Landwirte im Internet: Stand der Nutzung und Verwendungsabsichten. In: Kögl, H., Spilke, J. und Birkne, U. (eds.). Referate der 22. GILJahrestagung, Information und Kommunikation im Dienst der ländlichen Entwicklung, in Rostock. Gesellschaft für Informatik e.V, Bonn, 138-142.

Tomczak, T., Vogt, D. and Frischeisen, J. (2016). Wie Konsumenten Innovationen wahrnehmen Neuartigkeit und Sinnhaftigkeit als zentrale Determinanten Business Innovation: Das St. Galler Modell. In: Hoffmann, C.P., Lennerts, S., Schmitz, C., Stölzle, W. und Uebernickel, F. (eds.). Business Innovation: Das St. Galler Modell. Springer Fachmedien Wiesbaden, Wiesbaden, 187-209. doi: 10.1007/978-3-658-07167-7_12

top farmplan (2019). Das Agrar-Büro durch Ackerschlagkartei \& Co digitalisieren. f3.de. https://f3.de/anzeige/das-agrar-buro-durch-ackerschlagkartei-co-digitalisieren-336.html. (03.08.2021).

VDL (2018). Bachelor und Master - Was kommt nach dem Studienabschluss? Absolventenbefragung im Agrarbereich 2018. VDL- Berufsverband Agrar, Ernährung, Umwelt, Berlin. https://www.vdl.de/beruf-karriere/broschueren-film/. (20.05.2020).

Voss, J. (2008). Customer-Relationship-Management im Agribusiness. Dissertation. Sierke, Göttingen.

Wallmüller, E. (2017). Praxiswissen Digitale Transformation. Den Wandel verstehen, Lösungen entwickeln, Wertschöpfung steigern. Hanser, München. 
Zentes, J. and Morschett, D. (2007). Disintermediation in Wertschöpfungsketten - eine transaktionskostentheoretische Analyse der Ausschaltungsgefahr für den Großhandel Theoretische Fundierung und praktische Relevanz der Handelsforschung. In: Schuckel, M. und Toporowski, W. (eds.). Theoretische Fundierung und praktische Relevanz der Handelsforschung. Deutscher Universitäts-Verlag, Wiesbaden, 507-528. doi: 10.1007/978-38350-9535-9_24 
Chapter I - E-Commerce in Agribusiness

\section{I.1 Das Online-Einkaufsverhalten von LandwirtInnen im Bereich landwirtschaftlicher Betriebsmittel}

Authors: Dorothee Schulze Schwering \& Achim Spiller

This article was published in similar form as Discussion paper No. 1805, (2018), Georg-AugustUniversität Göttingen, Department für Agrarökonomie und Rurale Entwicklung (DARE), Göttingen, ISSN 1865-2697. 


\section{I.1 Das Online-Einkaufsverhalten von LandwirtInnen im Bereich landwirtschaftlicher Betriebsmittel}

\section{Zusammenfassung}

Heute ist die Digitalisierung unter dem Begriff Industrie 4.0 in allen Wirtschaftsbranchen allgegenwärtig. Auch die digitale Ausstattung der landwirtschaftlichen Vorleistungsunternehmen und ihrer Kundschaft steigt daher stetig an. Deshalb müssen Unternehmen der landwirtschaftlichen Vorleistungsindustrie die Digitalisierung ihrer Vertriebs-, Informations- und Servicefunktionen optimieren und setzen vermehrt auf den elektronsischen Handel (E-Commerce). Ziel der Studie war es daher, dass OnlineEinkaufsverhalten deutscher LandwirtInnen in Bezug auf Betriebsmittel zu untersuchen. Anhand einer Online-Umfrage der Georg-August-Universität Göttingen unter 371 deutschen LandwirtInnen wurde festgestellt, dass knapp 90\% der LandwirtInnen das Internet häufig bis sehr häufig für betriebliche Zwecke nutzen, aber nur 18,3\% von ihnen dieses regelmäßig für betriebliche Einkäufe nutzen. Das Online-Einkaufsverhalten der LandwirtInnen hängt, ähnlich wie das allgemeine Einkaufsverhalten, von Produkt- und Marktmerkmalen, individuellen und betrieblichen Eigenschaften sowie von der Beziehung und Loyalität zum Handel vor Ort ab. So beeinflussen die wahrgenommenen Vorteile, das Online-Einkaufsvergnügen und die persönliche Erfahrung mit dem Online-Handel die E-Commerce-Nutzung positiv. Im Internet werden vorzugsweise hoch standardisierte und bekannte Betriebsmittel erworben. Die Analyse der Nutzerstruktur der online-einkaufenden LandwirtInnen ergab eine sowohl weitestgehend soziodemografische Unabhängigkeit als auch eine Unabhängigkeit hinsichtlich betriebsbezogener Eigenschaften. Misstrauen und die Beziehung/Loyalität zum Landhandel korrelieren hingegen negativ mit dem Nutzungsverhalten des betrieblichen E-Commerce. Die Studie zeigt in Ansätzen, dass die Mehrheit der LandwirtInnen dem Online-Einkauf positiv gegenüber eingestellt ist. Es wird außerdem deutlich, dass eine enge Beziehung zum Landhandel heute noch von tragender Bedeutung ist und der strategische Vertrieb daher die Optimierung von "Multichannel-Systemen" zentralisieren sollte. 


\section{$1 \quad$ Einleitung}

Der E-Commerce-Markt wächst stetig und ist eines der wichtigsten Instrumente der Weltwirtschaft (El Gawady, 2005). Für viele Menschen ist das Internet für Einkäufe bereits ein etablierter und zunehmend relevanter Kanal. Allein in Deutschland gibt es etwa 53 Millionen digitale KäuferInnen, das entspricht ca. 98\% aller Internetnutzenden (GTAI, 2017). Deutschland weist damit innerhalb Europas das größte E-Commerce-Kundenpotential auf (Späth, 2014). Gerade der business-to-business (B2B) E-Commerce hat enormes Potenzial, jedoch steckt er in Deutschland noch häufig in den Anfängen. Fachleute sind sich aber einig, dass geschäftliche Ein- und Verkäufe in den kommenden fünf Jahren verstärkt über Onlineshops und Online-Marktplätze getätigt werden. Der derzeit noch geringe Anteil des Online-Kanals am B2B-Umsatz (2 to 3\%) lässt eine starke Wachstumsdynamik erwarten. Laut Prognosen wird der Online-B2B-Markt im Jahre 2020 ein Volumen von 6.700 Milliarden Dollar generieren und damit mehr als die doppelte Größe des Online business to consumer (B2C) Marktes einnehmen (Vidyasekar, 2014). Auch für kleine und mittelständische Unternehmen ergeben sich hieraus neue Potentiale, indem neue Kundengruppen erschlossen werden können, die Markenreichweite ausgeweitet werden kann und sich vielfältige Möglichkeiten ergeben den wandelnden Kundenanforderungen gerecht zu werden. Im Jahr 2015 wurden etwa 4\% des Umsatzes kleiner und mittlerer Unternehmen bereits über OnlineVertriebskanäle erzielt (Schwartz, 2017).

Allgemein lässt sich eine branchenübergreifende Digitalisierung der Geschäftsprozesse beobachten. Vor diesem Hintergrund und dem im Rahmen der digitalen Agenda geplanten Ausbau der Internet-Infrastruktur ländlicher Räume (Bundesregierung, 2014) steigt die digitale Ausstattung der landwirtschaftlichen Vorleistungsunternehmen und ihrer KundInnen stetig an. Da Landwirtschaft Betreibende zunehmend digital vernetzt und ausgestattet sind, überarbeiten Unternehmen die Digitalisierungsstrategien ihrer Vertriebs-, Informations- und Servicefunktionen und setzen dabei vermehrt auf E-Commerce. Frühere Studien aus den USA (Akridge, 2003; Batte und Ernst, 2007; Henderson et al., 2006; Henderson et al., 2004) und der EU (Canavari et al., 2003; Manouselis et al., 2009; Strzębicki, 2015) zeigen, dass der OnlineHandel für Unternehmen der Vorleistungsindustrie einen vielversprechenden Absatzweg darstellt. Obwohl der Anteil des E-Commerce am Markt für landwirtschaftliche Betriebsmittel derzeit sehr gering ist, kommt ihm eine zukünftig stärkere Bedeutung zu. Den derzeitigen Herausforderungen im Betriebsmittelmarkt, wie zum Beispiel die geografische Isolierung, die 
Ineffizienz in den Lieferketten und die Nachfrage nach einzigartigen und spezialisierten Betriebsmitteln könnten die Entwicklung von E-Commerce forcieren (Batte und Ernst, 2007). So sind heute bereits viele Betriebsmittel und Ersatzteile in einer Vielzahl von Onlineshops und Online-Marktplätzen verfügbar. Neben den Online-Pure-Playern erweitern zunehmend auch Betriebsmittelhersteller ihre klassischen Vertriebswege um den Kanal Onlineshop, um wettbewerbsfähig zu bleiben und ihre Kundschaft nicht an Online-Pure-Player zu verlieren (Ehmke et al., 2001; Henderson et al., 2000). Diese Ausweitung der klassischen Vertriebskanäle führt dazu, dass viele unterschiedliche Vertriebskanäle bedient werden müssen, was auch als "Multichannel-Management" bezeichnet wird (Barnes-Vieyra und Claycomb, 2001).

AktuelleZahlen deutscher Studien verdeutlichen, dass landwirtschaftliche Betriebe das Internet zunehmend in ihren Betriebsalltag integrieren (Ackermann et al., 2018; Gartzke, 2016). So waren 2016 75\% der LandwirtInnen täglich online (Gartzke, 2016) und fast jeder fünfte Betrieb verfügt bereits über digitalisierte Produktionstechniken (Hemmerling et al., 2016). Trotz dieser steigenden Durchdringung des Internets in der Agrarwirtschaft belegen Studien, dass landwirtschaftliche Betriebe Onlineshops bisher nur zögerlich für den Einkauf nutzen (Gartzke, 2016; Stricker et al., 2001). In einer Untersuchung zum Online-Kaufverhalten im B2B-E-Commerce wurde herausgestellt, dass allgemein etwa $28 \%$ der Unternehmen ihre Einkäufe wöchentlich über Onlineshops tätigen, 19\% sogar täglich (Wittmann und Listl, 2017), während nur 1,6\% der LandwirtInnen täglich und 7,1\% von ihnen wöchentlich Betriebsmittel über das Internet einkaufen (Stricker et al., 2001). Gartzke (2016) zeigte, dass auf den Landwirtschaftlichen Betrieben etwa 19 Online-Bestellungen im Durchschnitt eines Jahres getätigt werden.

Hohes Vertrauen zum lokalen Handel und fehlende persönliche Beratung beim Internetkauf seien für LandwirtInnen Hauptgründe, sich gegen den Internetkauf $\mathrm{zu}$ entscheiden (Gartzke, 2016). Vor 15 Jahren etwa schienen der persönliche Kontakt sowie die persönlichen Geschäftsbeziehungen zwischen LandwirtInnen und dem lokalen Handel so eng zu sein, dass Preisvorteile im Onlineshop sie nicht zum Online-Kauf motivieren konnten (Clasen, 2005; Clasen et al., 2003). Allerdings gibt es bislang kaum aktuelle Studie, die das heutige Verhalten der LandwirtInnen beim Online-Einkauf von Betriebsmitteln empirisch untersucht. Dabei ermöglichen Kenntnisse über die Einkaufspräferenzen und -einstellungen der LandwirtInnen, den Hersteller,- und Handelsunternehmen, Produkte grundsätzlich so zu vermarkten, wie es von ihrer Kundschaft bevorzugt wird (Borchers et al., 2012). Insgesamt fehlen den Unternehmen 
im Agribusiness jedoch grundlegende Erkenntnisse und Empfehlungen über LandwirtInnen als Online-KundInnen. Der vorliegende Aufsatz greift diese Forschungslücke auf.

Vor diesem Hintergrund stellt sich die Frage, welche landwirtschaftlichen Betriebe bereits Betriebsmittel online beziehen und welche Produkte vorzugsweise online gekauft werden. Des Weiteren wird beleuchtet, inwiefern Produkteigenschaften sowie persönliche und betriebliche Eigenschaften das Einkaufsverhalten beeinflussen. Diese Fragestellungen sollen anhand einer empirischen Erhebung (als Datengrundlage dient eine Befragung unter 371 deutschen LandwirtInnen) beleuchtet werden.

Zunächst werden aus der vorgestellten Literatur Forschungsfragen abgeleitet. Darauf folgt die Beschreibung der Datenerhebung. Im anschließenden Abschnitt werden die Ergebnisse dargestellt und diskutiert. Der Beitrag endet mit einem Fazit und den Limitationen der Studie.

\section{Hypothesengenerierung}

Im Folgenden wird zunächst das Modell des landwirtschaftlichen Einkaufsverhaltens von Kool (1994) vorgestellt und beschrieben. Daran anschließend werden die einzelnen Modellelemente erläutert und in den E-Commerce-Kontext gesetzt. Hieraus werden Hypothesen zum Einfluss der Modellelemente auf das betriebliche E-Commerce-Nutzungsverhalten abgeleitet.

\subsection{Beschreibung des Modells des landwirtschaftlichen Einkaufsverhaltens}

Für ihre landwirtschaftlichen Betriebe beziehen LandwirtInnen Betriebsmitteln. Dabei handelt es sich um Produktionsfaktoren, die im Leistungserstellungsprozess der landwirtschaftlichen Betriebe eingesetzt werden. Zu den landwirtschaftlichen Betriebsmitteln zählen beispielsweise Futtermittel, Düngemittel, Saat- und Pflanzgut und Pflanzenschutzprodukte. Betriebsmittel sind demnach Investitionsgüter, die von landwirtschaftlichen Unternehmen beschafft werden, um weitere Leistungen zu erstellen (Strecker et al., 2010; Voss, 2008). Somit, im Gegensatz zu privaten KonsumentInnen, beziehen LandwirtInnen Betriebsmittel unter Berücksichtigung von unter anderem wirtschaftlichen Gesichtspunkten. Allein im Jahr 2015 lagen die produktionsbedingten Ausgaben der deutschen Landwirtschaft bei 44,1 Mrd. € (Hemmerling et al., 2016). Mit 36\% haben Futtermittel gefolgt von Landmaschinen, Dünger und Pflanzenschutz den bedeutendsten Anteil. Bereits im Jahr 1994 erklärte Kool, dass LandwirtInnen mindestens Zweidrittel ihrer Einnahmen für landwirtschaftliche Betriebsmittel von externen Zulieferern aufbringen. Die hohen Aufwendungen sind ein Grund, warum LandwirtInnen oft an bestehenden Strukturen beim Einkauf festhalten. 
Das Kaufverhalten der Landwirtschaft Betreibenden hat Ähnlichkeiten und Unterschiede sowohl zum industriellen Kaufverhalten als auch zum Konsumentenkaufverhalten (Kool, 1994). Deshalb ist die Erklärung und Analysen des Einkaufsprozesses von LandwirtInnen oftmals schwierig, da das landwirtschaftliche Kaufverhalten an der Grenze vom Kapital- und Konsumgütermarketing klassifiziert werden kann (Clasen und Mueller, 2006; Kool, 1994; Rosskopf und Wagner, 2006; Zimmermann, 2003). Rein rechtlich gesehen sind LandwirtInnen unternehmerisch tätig und würden, entsprechend der vier Bereiche des OnlineMarketings, zum B2B-E-Commerce gehören. Aber die herkömmliche Unterscheidung zwischen B2B und B2C-Märkten ist im Agrargeschäft oft nicht eindeutig differenzierbar (Clasen und Mueller, 2006). Dies erschwert es Unternehmen der Vorleistungsindustrie ihre KundInnen $\mathrm{zu}$ verstehen und sie auf effiziente Weise anzusprechen und $\mathrm{zu}$ bedienen (Gunderson et al., 2005). Auf der einen Seite kaufen LandwirtInnen Produktionsfaktoren, die für die Produktion von landwirtschaftlichen Outputs eingesetzt werden und unterliegen daher dem industriellen Kaufverhalten. Sie verhalten sich problemlösungsorientiert, d.h. sie sind rational motiviert. Wirtschaftliche Anreize und das Streben nach präzisen Einkommenszielen prägen den Einkaufsprozess der LandwirtInnen (Akridge, 2003; Babb, 1988; Kool, 1994).

Auf der anderen Seite sind das Handeln bzw. die Entscheidungen von LandwirtInnen teilweise auch emotional gesteuert. Gerade heute können LandwirtInnen zwischen vielen Einkaufskanälen wählen und haben spezifische Kriterien, auf denen ihre Kaufentscheidung basiert. Laut Kool (1994) werden besonders in Situation mit vielen Alternativen emotionale und soziale Kriterien entscheidend. Es ist daher erforderlich zu verstehen, warum und wie LandwirtInnen einen bestimmten Einkaufskanal und ein spezifisches Produkt auswählen. Kool (1994) untersuchte die Komplexität des Einkaufsprozesses von LandwirtInnen von Investitions- und Konsumgütern und befragte 2.241 niederländische Landwirtschaft Betreibende. Zunächst entwickelte er jedoch einen Ansatz zur Erklärung des landwirtschaftlichen Einkaufsverhaltens. Demnach kann die Einkaufsentscheidung landwirtschaftlicher UnternehmerInnen als ein durch eine Problemstellung ausgelöster Prozess beschrieben werden. In Abhängigkeit von der spezifischen Situation kann dieser Problemlösungsprozess sowohl routiniert als auch komplex ablaufen. Die spezifische Einkaufssituation kann dabei durch zwei wesentliche Einflussgrößen, zum einen die Art des spezifischen Beschaffungsvorgangs und zum anderen durch individuelle Eigenschaften der Landwirtin oder des Landwirts, erklärt werden (Abb. 1). 


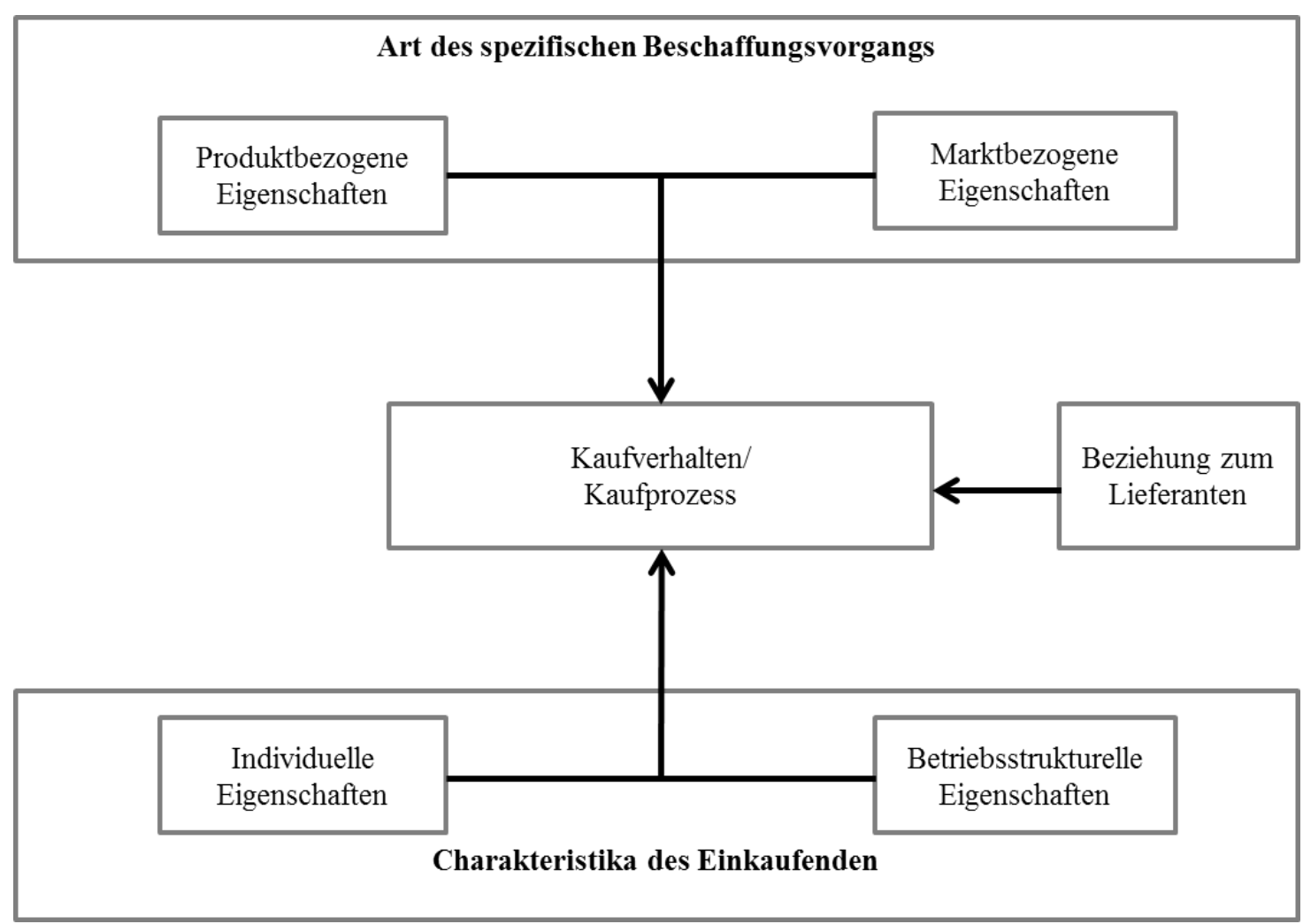

Abbildung 1: Modell des landwirtschaftlichen Einkaufsverhaltens

Quelle: Eigene Darstellung nach Kool (1994)

Die Art des spezifischen Beschaffungsvorgangs enthält Produkteigenschaften (z.B. Produktart, Marktdurchdringung, Bedeutung des Produktes im Betriebsalltag) und die Marktmerkmale (z.B. die Anzahl der Anbieter, Angebot, Marktstruktur). Die individuellen Charakteristika der Landwirtin oder des Landwirts lassen sich unterteilen in betriebsbezogene Merkmale (z.B. Betriebsgröße, Bewirtschaftungsform) und Persönlichkeitsmerkmale der Einkaufenden (z.B. Alter, Ausbildung, Erfahrung, Preisbewusstsein). Beeinflusst wird die Kaufentscheidung auch durch die Beziehung und Loyalität der LandwirtInnen zu ihren Lieferanten. Abbildung 1 gibt einen Überblick über das Modell des landwirtschaftlichen Einkaufsverhaltens nach Kool (1994). Aus diesem Ansatz wird ersichtlich, dass eine eindeutige Zuordnung des landwirtschaftlichen Einkaufsverhaltens $\mathrm{zu}$ den konzeptionellen Grundlagen der organisationalen Beschaffung oder zu denen der Konsumentenforschung nicht möglich ist (Voss, 2008). BetriebsleiterInnen verfügen mit ihren spezifischen Motiven und Präferenzen zumeist über das gesamte Einkaufsbudget. Die individuellen Einkaufsentscheidungen dürfen aber nicht vorwiegend den Motiven und Präferenzen untergeordnet sein, sondern müssen dem eigentlichen Zweck, der landwirtschaftlichen Unternehmung mit dessen ökonomischen Zielen, dienen (Voss, 2008). 


\subsection{Produktbezogene Eigenschaften und deren Bedeutung für den Online-Handel}

Laut Kool (1994) hat die Art des Produktes sowie dessen Wichtigkeit und Bedeutung im Betriebsalltag einen Einfluss auf das Einkaufsverhalten landwirtschaftlicher UnternehmerInnen. So ist der Einkaufsprozess umfangreicher für Produkte, die nicht regelmäßig beschafft werden (z.B. Maschinen). Das bedeutet, für diese Produkte werden mehr Informationen und Beschaffungsalternativen geprüft. LandwirtInnen vereinfachen ihre Kaufentscheidungsprozesse mit Voranschreiten des Produktes im Produktlebenszyklus. Das bedeutet, je bekannter ein Produkt ist, desto schneller entscheidet sich eine Landwirtin/ ein Landwirt, ein bestimmtes Produkt zu kaufen. Daher verläuft der Beschaffungsvorgang für Verbrauchsgüter meist sehr routiniert, d.h. unter Zurückgreifen auf gleiche Lieferanten ohne vorherige Bewertung von Beschaffungsalternativen. Die Zuordnung des Produktes als Verbrauchsgut (Saatgut, Futtermittel etc.) oder Investitionsgut (Maschinen) hat noch einen weiteren Effekt. So können Verbrauchsgüter beispielweise saisonabhängig sein oder müssen speziell auf die Gegebenheiten des Betriebes zugeschnitten werden. Bei Investitionsgütern sinkt die Komplexität der Kaufentscheidung erst mit zunehmender Erfahrung. Bei neuen und innovativen Produkten entscheiden LandwirtInnen nur langsam und berücksichtigen viele verschiedene Informationsquellen. Diejenigen, die gut über Produkte informiert sind (hohes Produktinvolvement), zeigen oft einen größeren Einsatzim Kaufprozess (Kool, 1994).

Wie auch Kool (1994) stellten E-Commerce Studien die Bedeutung von Produktmerkmalen im Entscheidungsprozess von LandwirteInnen heraus (Batte und Ernst, 2007; Clasen, 2005). Laut der allgemeinen Konsumentenforschung kaufen KundInnen sehr differenziert im Internet ein und bevorzugen das Internet nur für bestimmte Produktgruppen (Monsuwé et al., 2004; Vijayasarathy, 2003). So ist sich auch die agrarökonomische Literatur einig, dass der E-Commerce zwar Einzug in die Landwirtschaft erhalten hat, jedoch gilt dies nicht gleichmäßig über alle landwirtschaftlichen Produktbereiche hinweg (Ackermann et al., 2018; Gartzke, 2016). Wheatley et al. (2001) stellten fest, dass die fehlende Einheitlichkeit der Produkte eine besondere Herausforderung für ein erfolgreiches E-Commerce in der Landwirtschaft ist. Onlineshopping, bei dem die Überprüfung der physischen Produkteigenschaften und der direkte Kontakt zwischen den Transaktionspartnern nicht möglich ist, wurde daher oft als zu anonym für den Agrarsektor angesehen (Fritz, 2007). Daher eignen sich laut Batte und Ernst (2007) standardisierte Produkte am besten für digitale Marktplätze. Auch Fellnhofer und Hinterhuber (2011) kamen zu dem Ergebnis, dass bei LandwirtInnenen generell eine Bereitschaft zur Nutzung des Internets für standardisierte Aktivitäten wie der Informationsbeschaffung, 
der Verständigung mit Behörden, der Abwicklung von Bankgeschäften und dem Einkauf von gut standardisierten Produkten vorhanden ist. Landmaschinen und Ersatzteile, Arbeitskleidung und Büroausstattung werden daher von deutschen LandwirteInnen am häufigsten online gekauft (Gartzke, 2016). Andere Betriebsmittel wie Futtermittel und Düngemittel werden ebenfalls über das Internet verkauft, allerdings auf sehr niedrigem Niveau, da es deutliche Vorbehalte aufgrund fehlender persönlicher Beratung und gesetzlicher Regelungen gibt (Ackermann et al., 2018; Clasen, 2005; Gartzke, 2016).

Die schwierige Bereitstellung komplexer Information über das Internet stellt ein Hindernis des E-Commerce dar (Henderson et al., 2000). Eine Besonderheit der Landwirtschaft ist, dass es oft Situationen gibt in denen Produkte schnell benötigt werden. Einkäufe dieser "Akutprodukte" können nicht geplant werden, während die Verwendung von "Wartungsprodukten" besser im Voraus vorbereitet werden kann (Akridge, 2003). Auch Produktpreise wirken sich stark auf den Entscheidungsprozess von LandwirteInnen aus, da diese betriebswirtschaftlich denken und Preise vergleichen. Die Tatsache, dass LandwirtInnen generell das Internet mit niedrigeren Produktpreisen verbinden, unterstützt die Einführung von Onlineshops in der Agrarbranche (Henderson et al., 2006). Jedoch würden viele LandwirtInnen Betriebsmittel eher von lokalen Händlern kaufen, selbst wenn die Preise höher sind als im Internet (Batte, 2006). Anhand der aufgeführten Aspekte lassen sich zum Einflussfaktor "Produkteigenschaften" folgende Hypothesen ableiten:

Hypothese 1a: LandwirtInnen nutzen das Internet als Beschaffungskanal produktgruppenspezifisch.

> Hypothese 1b: Je bekannter/standardisierter ein Produkt ist, desto höher ist die Online-Kaufbereitschaft der LandwirtInnen für das jeweilige Produkt.

- Hypothese 1c: Wahrgenommene Preisvorteile des Mediums Internet erhöhen die Nutzungsabsicht.

\subsection{Marktbezogene Eigenschaften und deren Bedeutung für den Online-Handel}

Zu den marktbezogenen Eigenschaften zählt Kool (1994) die Anzahl und Größenverteilung von Verkäufern und Käufern in einem Markt sowie mögliche Eintrittsbarrieren und Produktdifferenzierungen. Diese Eigenschaften sind für ein gutes Verständnis der KäuferVerkäufer-Beziehung von großer Bedeutung. Aber auch die Marktdynamik und Transparenz sind entscheidend, da sie den Grad der Marktunsicherheiten bestimmen. Während die Markttransparenz vom Grad und der Klarheit der Unterschiede zwischen den jeweiligen 
anbietenden Unternehmen im Markt abhängt (Heterogenität), bezieht sich die Marktdynamik darauf, wie sich diese Unterschiede mit der Zeit verändern (Håkansson, 1982; Kool, 1994). Die Position einelner landwirtschaftlicher Betriebe im Betriebsmittelhandel hängt von der Marktstruktur ab. In den vergangenen Jahrzehnten haben sich sowohl die Struktur der landwirtschaftlichen Betriebe als auch die Landhandelsstrukturen in Deutschland stark verändert. Dies macht sich in einer kontinuierlichen Abnahme der Anzahl landwirtschaftlicher Betriebe bemerkbar (Hemmerling et al., 2016). Gleichzeitig führen die rückläufigen Betriebszahlen bei konstantem Flächen- und Produktionsumfang zu größer strukturierten und spezialisierten landwirtschaftlichen Betrieben, die höhere Einkaufsbudgets vorweisen und damit eine deutlich stärkere Kaufkraft haben (Voss, 2008). Für den Agrarhandel resultiert daraus, dass die einzelnen Betriebe durch ihre Verhandlungsmacht unabhängiger von den örtlichen Landhändlern werden und immer öfter direkt mit Betriebsmittelherstellern in Kontakt treten. Auf der Angebotsseite ist eine zunehmende Anzahl an Wettbewerbern und die Homogenisierung von Produkten und Dienstleistungen erkennbar (Voss, 2008). Auch der traditionelle Agrarhandel erfuhr in den vergangenen Jahren einen Konsolidierungsprozess. So werden zukünftig Kooperationen, Fusionen und Übernahmen nicht nur den genossenschaftlichen, sondern auch den privaten Landhandel weiter prägen (Voss, 2008). Da sich der Einfluss von Marktcharakteristika in einer empirischen Befragung nur schwer prüfen lässt, wurde in der vorliegenden Studie nur auf zwei, aus Kundensicht, gut prüfbare Faktoren zurückgegriffen, zum einen die Zufriedenheit mit dem derzeitigen Onlineangebot sowie der empfundene Wettbewerbsdruck innerhalb des Berufsstandes.

\subsection{Betriebsbezogene Eigenschaften und deren Bedeutung für den Online-Handel}

Zu den Merkmalen des Betriebes zählen die Betriebsform, Betriebsgröße, Ortsansässigkeit und Art der Landwirtschaft (Ackerbau/Viehhaltung/Mischbetriebe). Dabei bestimmt die Art der Landwirtschaft die saisonale Arbeitsbelastung und die für die Kaufentscheidung zur Verfügung stehende Zeit. Je stärker die Arbeitsbelastung, desto weniger Zeit können LandwirtInnen für den Einkauf aufwenden. In Zeiten hoher Arbeitsbelastung werden weder die Eignung von Lieferanten überdacht, noch werden Investitionsgüter (bspw. Traktoren) angeschafft. Laut Kool (1994) ist der Einkaufsprozess von Ackerbauern und Milchviehhaltern beispielsweise umfangreicher als der von Schweinehaltern. Als weiterer Einflussfaktor auf die Komplexität des Kaufprozesses gilt die Betriebsgröße, wobei größere Unternehmen umfassendere Informationen nachfragen (Kool, 1994). Nach Babb (1988) beeinflusst die Betriebsgröße unter anderem aufgrund von Skaleneffekten das Kaufverhalten der LandwirtInnen. 
Obwohl die Betriebsgröße als wichtiger Einflussfaktor für die Internet- und Computeradoption angesehen wird, scheint sie aber kein bedeutender Faktor für die Einführung des elektronischen Handels zu sein (Batte, 2006; Mishra und Williams, 2006; Taragola und van Lierde, 2010). (Ackermann et al., 2018) bestätigen ebenfalls, dass kein signifikanter Zusammenhang zwischen Betriebsgröße und der Nutzung von E-Commerce in der Landwirtschaft vorherrscht. Für größere Betriebe scheinen jedoch die Vorteile des elektronischen Handels offensichtlicher zu sein, u.a. auf Grund von Skaleneffekten. Darüber hinaus fordern laut Akridge (2003) größere Betriebe eine qualitativ bessere Leistung von ihren zuliefernden Unternehmen. Neben der Betriebsgröße haben auch die Ortsansässigkeit, Betriebsform und dessen Diversifizierung einen Einfluss auf die Internetnutzung und damit die Anwendung von Onlineshopping (Park und Mishra, 2003). Dabei kann die früher ungleiche Internetnutzung von West- und Ostdeutschland heute nicht mehr bestätigt werden und hat somit keinen signifikanten Einfluss mehr auf die Nutzung von Internet und E-Commerce (Ackermann et al., 2018).

Hypothese 2a: Die tatsächliche Nutzung von Onlineshops ist unabhängig von den jeweiligen Betriebsmerkmalen (Betriebs-Form, Typ, Größe, Herkunft).

Hypothese 2b: Zwischen den jeweiligen Betriebsmerkmalen und der E-Commerce Nutzungsabsicht besteht kein Zusammenhang (Betriebs-Form, Typ, Größe, Herkunft).

\subsection{Individuelle Eigenschaften und deren Bedeutung für den Online-Handel}

Die individuellen Eigenschaften können in sozioökonomische Eigenschaften und Managereigenschaften unterteilt werden. Sozioökonomische Eigenschaften umfassen Alter, Geschlecht und Ausbildung. Studien belegen einen negativen Einfluss des Alters auf die Internetnutzung, wobei ältere BetriebsleiterInnen das Internet mit geringerer Wahrscheinlichkeit in ihre tägliche Betriebsführung integrieren (Batte, 2006; Mishra und Williams, 2006; Taragola und van Lierde, 2010). Ackermann et al. (2018) konnten bei deutschen LandwirtInnen keinen signifikanten Zusammenhang zwischen dem Alter und der Häufigkeit des Online-Bezugs von Betriebsmitteln feststellen. Sie konnten hingegen einen Einfluss des Bildungsniveaus auf die E-Commerce-Nutzung bestätigen. Es ist bekannt, dass ein höheres Bildungsniveau positiv mit der Nutzung des E-Commerce korreliert, was auch durch frühere Studien bestätigt werden konnte. Demnach steigt mit höherem Bildungsabschluss die Nutzung von E-Commerce (Ackermann et al., 2018). Ernst und Tucker (2001) geben an, dass Männer mit höherer Wahrscheinlichkeit das Internet und dessen Anwendungen nutzen. 
Neben den demografischen Faktoren können auch Charaktereigenschaften und Managementeigenschaften das Online-Verhalten von LandwirtInnen beeinflussen. Managercharakteristika sind Variablen wie Kauferfahrung, Risikoaversion und Qualitätsbewusstsein der ManagerInnen in Bezug auf Produkte und Dienstleistungen. Aber auch die Bequemlichkeit der LandwirtInnen, die empfundene Benutzerfreundlichkeit, Nützlichkeit und frühere Online-Einkaufserfahrungen lassen sich zu den individuellen Eigenschaften zuordnen. Laut Kool (1994) beeinflusst die Einkaufserfahrung die Entscheidungsfindung, da mit zunehmender Erfahrung in Bezug auf ein bestimmtes Produkt die Entscheidungsfindung speziell für dieses vereinfacht wird.

Aus der allgemeinen E-Commerce-Forschung ist bekannt, dass das wahrgenommene Risiko bzw. die Angst, die Internet-Nutzung und die online Abbruchrate beeinflusst (Cho, 2004; Mathew, 2016). Als große Inhibitoren von Onlineshopping gelten Datenschutzbedenken und Angst vor unsicheren Transaktionen (Joines et al., 2003). So wird ein risikoaverser Mensch mit geringer Wahrscheinlichkeit E-Commerce-Anwendungen nutzen (Taragola und van Lierde, 2010). Neben Angst prägt aber vor allem der Spaßfaktor die Internetnutzung und damit auch den Online-Einkauf. Konsumenten, welche das Internet regelmäßig nutzen, haben Spaß und tun es zu ihrer Freude (Mathew, 2016). Beeinflusst werden Emotionen durch die Wahrnehmung von Vorteilen des Onlineshoppings. Auch das Vertrauen beeinflusst die Internetnutzung, denn je höher der Vertrauensgrad ist, umso höher ist die Onlineshop-Zufriedenheit (Mathew, 2016; Rose et al., 2012). Einer digitalen Renaissance des Agrarhandels scheinen aus Sicht der LandwirtInnen demanch mangelndes Vertrauen sowie Datenschutz- und Sicherheitsbedenken gegenüberzustehen (Fellnhofer und Hinterhuber, 2011; Henderson et al., 2006). Im Kaufentscheidungsprozess der LandwirtInnen hat das Vertrauens- und Sicherheitsgefühl eine besondere Bedeutung (Batte, 2006). In einer Studie von Batte und Ernst (2007) gab die Mehrheit der Befragten (77\%) an, dass sie nur bei Online-Unternehmen kaufen würden, die sie kennen und denen sie vertrauen. Nicht nur das Misstrauen gegenüber Onlineshops, sondern auch das Vertrauen der LandwirtInnen $\mathrm{zu}$ ihren Lieferanten ist entscheidend in ihrem Einkaufsprozess. Hauptgründe, warum LandwirtInnen sich gegen den Internetkauf entscheiden, sind hohes Vertrauen zum lokalen Handel, fehlende persönliche Beratung beim Internetkauf und allgemeines Misstrauen gegenüber dem Internet (Gartzke, 2016). LandwirtInnen verlangen einen zunehmend hohen Service, sodass der fehlende direkte Kundendienst von Onlineshops als ein limitierender Faktor von E-Commerce identifiziert werden kann (Akridge, 2003; Briggeman und Whitacre, 2010; Gartzke, 2016; Henderson et al., 2000). 
Auch die Vertrautheit der LandwirtInnen mit dem Online-Kauf beeinflusst ihr generelles Online-Kaufverhalten (Henderson et al., 2000). Diejenigen, die mit einer Technologie vertraut sind, neigen dazu, sie mehr zu nutzen als diejenigen, die es nicht sind. Laut Smith et al. (2004) hat die Erfahrung mit der Computernutzung allgemein positive Auswirkungen auf die geschäftliche Internetnutzung. Mit zunehmender Internetnutzung steigt auch der wahrgenommene Nutzen von Onlineshops und damit deren tatsächliche Nutzung (Allred et al., 2006; Fusilier und Durlabhji, 2005; Koufaris, 2002; Mathew, 2016; Monsuwé et al., 2004; Rose et al., 2012; Shih, 2004; van der Heijden et al., 2001). Empfundene Vorteile wie Zeitersparnis, Bequemlichkeit und Einfachheit werden von LandwirtInnen anerkannt und führen zu einer positiven Online-Kaufabsicht (Akridge, 2003; Batte, 2006). Ackermann et al. (2018) stellten heraus, dass entgegen älteren Studien nicht die Kostenvorteile (Clasen, 2005), sondern vielmehr die Zeitvorteile für die Nutzung von Onlineshops sprechen. Tabelle 1 fasst die aus der Literatur abgeleiteten Hypothesen über den Einfluss individueller Eigenschaften zusammen.

Tabelle 1: Hypothesenübersicht für den Einfluss individueller Eigenschaften auf die betriebliche E-Commerce-Nutzung

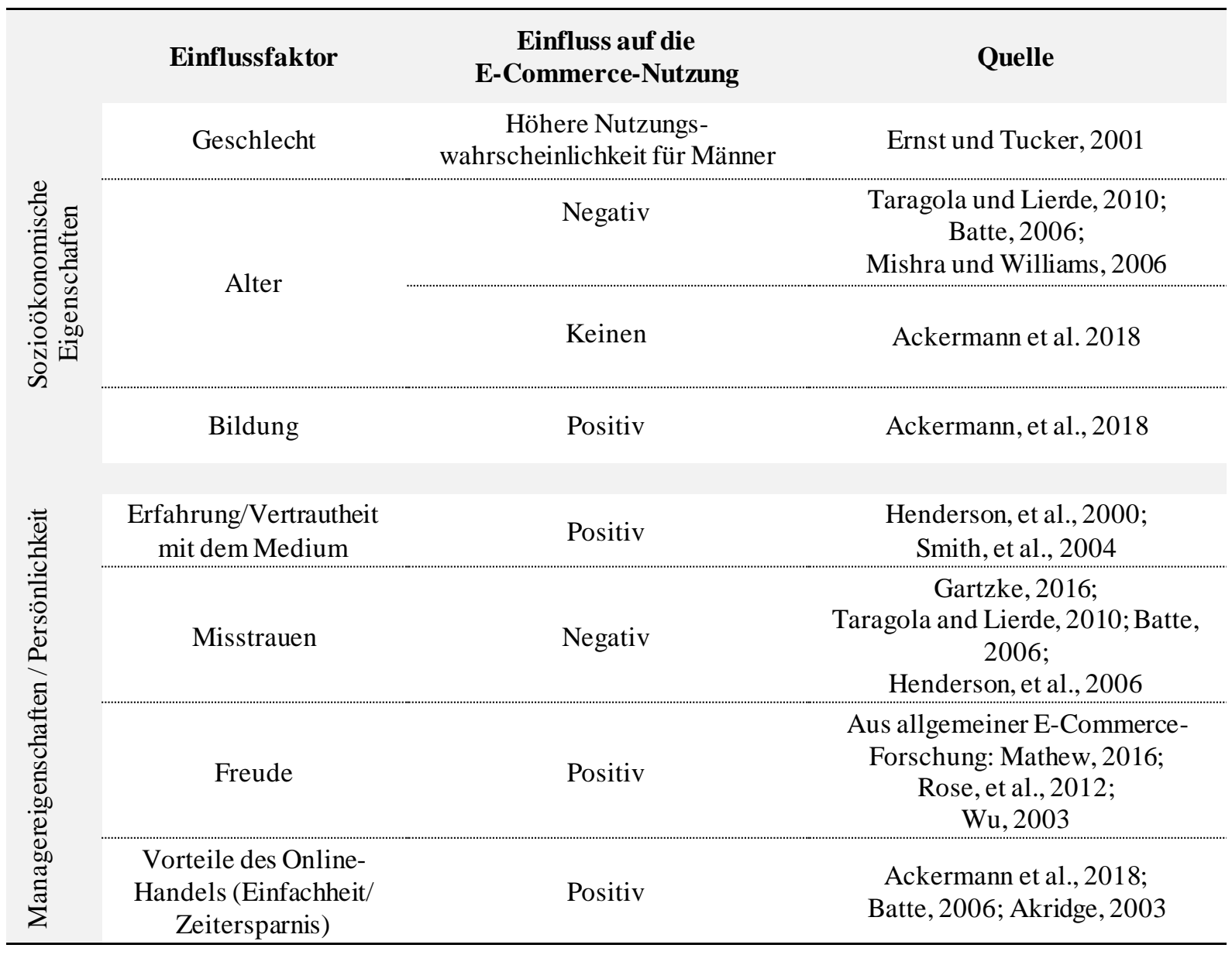

Quelle: Eigene Darstellung 
Zusammenfassend lassen sich aus der Literatur folgende Hypothesen ableiten:

> Hypothese 3a: Es besteht kein Zusammenhang zwischen den sozioökonomischen Eigenschaften (Geschlecht, Alter, Bildung) der LandwirtInnen und ihrer betrieblichen E-Commerce-Nutzung.

$>$ Hypothese 3b: Es besteht ein Zusammenhang zwischen den Managereigenschaften (Erfahrung, Risikoaversion, Begeisterung, Qualitäts- und Preisbewusstsein) der LandwirtInnen und seiner betrieblichen E-Commerce-Nutzung.

\subsection{Beziehung zum Handel vor Ort und deren Bedeutung für den Online-Handel}

Der fünfte von Kool (1994) identifizierte Einflussfaktor auf den landwirtschaftlichen Einkaufsprozess ist die Beziehung zu Lieferunternehmen. Die Loyalität und eine gute persönliche Beziehung der LandwirtInnen zu ihren örtlichen Betriebsmittelhandel reduzieren die Komplexität des Einkaufsprozesses. LandwirtInnen suchen bei bestehenden guten Geschäftsbeziehungen seltener nach alternativen Beschaffungsquellen (Kool, 1994). Zudem ist die regionale Versorgung durch den örtlichen Landhandel nach wie vor sehr gut und kann somit als ein Hemmfaktor für den E-Commerce angeführt werden (Ackermann et al., 2018). Ein weiterer Grund ist der gute und persönliche Kontakt sowie die persönlichen Geschäftsbeziehungen zwischen LandwirtInnen und dem lokalen Handel, die so eng sind, dass Preisvorteile über die E-Commerce Angebote sie nicht zum Online-Kauf motivieren können (Clasen, 2005). Gollisch und Theuvsen (2015) bestätigen die enge Beziehung zwischen Landwirtschaft und Agrarhandel. Sie sehen jedoch auch einen Rückgang der traditionellen Beziehungen und eine zunehmende Preisfokussierung der LandwirtInnen. Jüngste empirische Befunde weisen jedoch auf die hohe Bedeutung von Service und Kundenorientierung im Agrarhandel hin (Gartzke, 2016). Henderson et al. (2000) befragten AgrarmanagerInnen hinsichtlich der Hemmnisse des E-Commerce innerhalb der Landwirtschaft. Die Führungkräfte der Agribusiness-Firmen stimmten darin überein, dass Landwirtschaft Betreibende Kundenservice und persönliche Beziehungen wünschen. Laut Kool (1994) legen LandwirtInnen generell bei hoch standardisierten und regelmäßig eingesetzten Gütern weniger Wert auf persönliche Informationsquellen als bei Investitionsgütern.

Hypothese 4a: Preisvorteile im Internet führen dazu, dass LandwirtInnen zukünftig mehr Betriebsmittel online erwerben werden.

> Hypothese 4b: Bewerten LandwirtInnen ihre Beziehung zum Landhandel als eng, ist ihre aktuelle und zukünftige Bereitschaft für eine betriebliche E-Commerce-Nutzung geringer. 


\section{$3 \quad$ Empirische Studie}

\subsection{Studiendesign und Datenerhebung}

Das Ziel dieser Umfrage bestand darin, dass Online-Kaufverhalten deutscher LandwirtInnen, bezogen auf den Einkauf von Betriebsmitteln, zu identifizieren. Die Umfrage richtetesich somit an diejenigen, die bereits Onlineshopping-Erfahrung haben. Um jene zu erreichen, die bereits online aktiv sind, wurde die Umfrage online durchgeführt.

Der auf Basis einer Literaturanalyse entwickelte Fragebogen gliedert sich inhaltlich sowie formal in vier Abschnitte. Zu Beginn wurde eine Filterfrage gestellt, in welcher die teilnehmenden Personen gefragt wurden, ob sie jemals etwas online für ihren Betrieb eingekauft haben. Nur wenn die Teilnehmenden diese Frage bejaht haben, konnten sie mit dem Fragebogen fortfahren. Nach der Filterfrage wurden einleitende Fragen zur Internetnutzung und zum persönlichen Beratungsbedarf beim Betriebsmittelkauf gestellt. Anschließend wurde die Einstellung der LandwirtInnen zum Online-Einkauf von Betriebsmitteln abgefragt. Die Fragen wurden unter Verwendung des Strukturmodells der Einstellung nach Rosenberg et al. (1961) zusammengestellt, welches auch unter dem Begriff des ABC-Modells der Einstellung bekannt ist und drei Komponenten, eine kognitive, affektive und verhaltensbezogene Komponente beinhaltet. Die ABC-Variablen wurden aus vorherigen Studien der E-Commerce-Forschung abgeleitet. Ein Teil der Bewertungselemente wurde sprachlich modifiziert, um dem Kontext dieser Studie zu entsprechen. Im Gegensatz zu Mathew (2016) nahm diese Studie die tatsächliche Nutzung von Onlineshops als zusätzlichen Faktor und nicht als Verhaltenskomponente der Einstellung. Aussagen über die Verhaltensintention wurden nach Ostrom (1969) der Verhaltenskomponente zugeordnet. Der letzte Abschnitt bestand aus soziodemografischen Fragen. Alle Variablen mit Ausnahme der demografischen Fragen und der Fragen zur Internetnutzung wurden anhand einer Fünf-Punkte-Likert-Skala bewertet, die von $1=$,stimme voll zu“ bis 5=,,stimme überhaupt nicht zu“ reichte. Die Bearbeitung des Fragebogens nahm etwa 15 Minuten in Anspruch.

Im Mai 2017 wurden ca. 4.000 anerkannte landwirtschaftliche Ausbildungsbetriebe in Deutschland per E-Mail kontaktiert. Darüber hinaus unterstützten mehrere landwirtschaftliche Verbände und Zeitschriften die Verbreitung der Umfrage per E-Mail, auf ihren jeweiligen Internetseiten und über ihre Social-Media-Kanäle. 894 LandwirtInnen beantworteten die Filterfrage zu Beginn der Umfrage. 56\% ( $\mathrm{n}=501)$ von ihnen tätigten bereits einen betrieblichen Online-Kauf und verfügen somit über entsprechende Erfahrungen. 
Eine im Anschluss an die Datenerhebung durchgeführte Datenbereinigung filterte unbrauchbare Datensätze aus. Dabei wurden Datensätze mit mehr als drei fehlenden Angaben innerhalb der demografischen Angaben entfernt. Die Statement-Batterien wurden auf ungewöhnliche Fälle hin überprüft, d.h. Datensätze mit immer wiederkehrenden bzw. gleichen Antwortmustern wurden identifiziert und eliminiert. Auch Teilnehmende mit einer auffallend niedrigen Antwortzeit (unter sechs Minuten) wurden nicht in der statistischen Analyse berücksichtigt, da die mittlere Bearbeitungszeit 15 Minuten betrug. Nach sorgfältiger Datenbereinigung enthält der Datensatz für diese Studie valide Daten von 371 deutschen LandwirtInnen. Die statistische Datenanalyse erfolgte mittels quantitativer Analysemethoden mit der Statistiksoftware IBM SPSS Statistics 23. Unter Verwendung einer quantitativexplorativen Vorgehensweise wurde versucht mit Hilfe statistischer Verfahren, wie der Korrelations-, und Faktorenanalyse, einflussreiche Variablen zu identifizieren.

\subsection{Charakteristik der Stichprobe}

Die deskriptive Auswertung der demografischen Variablen ist in Tabelle 2 zusammengefasst. Die meisten Befragten kommen aus Westdeutschland (37,2\%), (Hessen, Nordrhein-Westfalen, Rheinland-Pfalz, Saarland) und Süddeutschland (35,5\%), (Bayern, Baden-Württemberg). Dies lässt sich anhand dessen erklären, dass rund 1.700 Bauern aus dem Süden und 1.110 Bauern aus Westdeutschland per E-Mail kontaktiert wurden. Darüber hinaus sind West- und Süddeutschland als die Regionen mit den meisten landwirtschaftlichen Betrieben in Deutschland bekannt. Die durchschnittliche Betriebsgröße liegt mit etwa 260 Hektar deutlich über dem nationalen Durchschnitt von knapp 60 Hektar (Hemmerling et al., 2016). Mit 46,6\% ist der Betriebszweig der Tierhaltung am häufigsten vertreten, gefolgt von Mischbetrieben $(30,5 \%)$ und Ackerbaubetrieben (16,4\%). Damit liegt der Anteil tierhaltender Betriebe und Ackerbaubetriebe unter dem bundesweiten Durchschnitt mit etwa 50,2\% und 28,3\% (Statistisches Bundesamt, 2014). Mit knapp 90\% ( $n=321)$ dominiert die konventionelle Bewirtschaftung. Etwa 10\% der Befragten gaben an $(n=36)$ ökologische Landwirtschaft zu betreiben (14 Personen machten keine Angabe). Der Anteil der ökologischen Betriebe weicht damit nur leicht vom deutschen Durchschnitt (9\%) ab (Hemmerling et al., 2016). 
Tabelle 2: Stichprobenbeschreibung

\begin{tabular}{|c|c|c|}
\hline Demografische Angaben & Anzahl & Anteil am Gesamtsample (\%) \\
\hline \multicolumn{3}{|l|}{ Alter (Jahren), $(n=335) \phi 37,3$ Jahre } \\
\hline bis 24 & 57 & 17.0 \\
\hline $25-34$ & 104 & 31.0 \\
\hline $35-44$ & 61 & 18.2 \\
\hline $45-54$ & 75 & 22.4 \\
\hline $55-64$ & 37 & 11.0 \\
\hline älter als 65 & 1 & 00.3 \\
\hline \multicolumn{3}{|l|}{ Herkunft $(n=371)$} \\
\hline Norddeutschland & 80 & 21.6 \\
\hline Ostdeutschland & 22 & 5.9 \\
\hline Süddeutschland & 131 & 35.3 \\
\hline Westdeutschland & 138 & 37.2 \\
\hline \multicolumn{3}{|l|}{ Betriebsgröße (Hektar), $(n=371) \varnothing 257,7$ ha } \\
\hline bis 10 & 11 & 03.0 \\
\hline $10-19$ & 18 & 04.9 \\
\hline $20-49$ & 33 & 08.9 \\
\hline $50-99$ & 114 & 30.8 \\
\hline $100-199$ & 100 & 27.0 \\
\hline $200-499$ & 60 & 16.2 \\
\hline mehr als 500 & 34 & 09.2 \\
\hline \multicolumn{3}{|l|}{ Landwirtschaftliche Bildung $(n=371)$} \\
\hline Keine landwirtschaftliche Bildung & 55 & 14.8 \\
\hline Landwirtschaftliche Ausbildung & 33 & 08.9 \\
\hline Landw. Meister-/in, staatl. Geprüfte-/r Landwirt-/in & 163 & 43.9 \\
\hline Landwirtschaftliches Studium & 104 & 28.0 \\
\hline Noch in landwirtschaftlicher Ausbildung & 16 & 04.3 \\
\hline \multicolumn{3}{|l|}{ Position im Betrieb } \\
\hline Betriebsleiter-/in & 255 & 68,8 \\
\hline Angestellter-/in & 23 & 6,2 \\
\hline Auszubildender-/in & 5 & 1,3 \\
\hline Mithelfendes Familienmitglied & 71 & 19,1 \\
\hline Gesellschafter & 17 & 4,6 \\
\hline
\end{tabular}

Quelle: Eigene Erhebung.

Der Anteil männlicher Teilnehmer liegt bei 83\%. Das Durchschnittsalter beträgt 37 Jahre. Das Alter liegt damit unter dem nationalen Durchschnitt, indem nur $26 \%$ aller BetriebsleiterInnen jünger als 45 Jahre sind (Hemmerling et al., 2016). Die Berufsausbildung ist ebenfalls überdurchschnittlich, da $28 \%$ der Befragten über einen Hochschulabschluss verfügen und der Bundesdurchschnitt für LandwirtInnen bei $11 \%$ liegt (Hemmerling et al., 2016). Der hohe Anteil an Befragten ohne landwirtschaftliche Ausbildung hängt vermutlich mit dem etwa äquivalenten Anteil mithelfender Familienangehöriger zusammen. Es wird daher angenommen, dass mithelfende Familienmitglieder, die diesen Fragebogen beantwortet haben, nicht zwingend eine landwirtschaftliche Ausbildung absolviert haben. 
Ein Generationswechsel steht bei 45,6\% $(\mathrm{n}=169)$ in den nächsten Jahren nicht an. 53,4\% ( $n=198)$ der Betriebe planen in den nächsten Jahren die Übergabe des Hofes. Die Nachfolge ist dabei bei 39,1\% ( $n=145)$ bereits geklärt. Die meisten Betriebe $(42,6 \%)$ planen innerhalb der nächsten 10 Jahre ihren derzeitigen Stand zu halten, während 39,6\% der Betriebe auf Wachstum setzen, $13,7 \%$ eine betriebliche Umstrukturierung planen, 3,5\% den Betrieb aufgeben und 0,5\% sich verkleinern wollen.

Damit ist diese Studie bezogen auf die soziodemografischen und zum Teil auch auf die betrieblichen Eigenschaften nicht vollständig repräsentativ und kann daher eher als richtungsweisend interpretiert werden.

\section{$4 \quad$ Ergebnisse und Diskussion}

Nach einer deskriptiven Darstellung der Präferenzen von LandwirtInnen beim Online-Einkauf landwirtschaftlicher Betriebsmittel, folgt die Analyse der Eiflussfaktoren auf das Einkaufsverhalten. Hierzu wird in einem ersten Schritt eine Faktorenanalyse durchgeführt. Dies führt zur Reduktion der möglichen Einflussvariablen, wodurch die wesentlichen Einflussgrößen sowie die tatsächliche und zukünftige Nutzung abgebildet werden können. Mittels Korrelations- und Regressionsanalysen werden dann die Zusammenhänge und Einflüsse der identifizierten Faktoren auf die E-Commerce-Nutzung ermittelt.

\subsection{Präferenzen beim Online-Einkauf landwirtschaftlicher Betriebsmittel}

Die anfänglich gestellte Filterfrage zeigt, dass bereits 56\% $(n=501)$ der LandwirtInnen einen betrieblichen Online-Einkauf getätigt haben. Damit verfügt die Mehrheit der Befragten bereits über entsprechende Kenntnisse. Zufrieden mit dem derzeitigen Onlineangebot für landwirtschaftliche Betriebsmittel sind 44,3\% ( $n=160)$ während 13,8\% ( $n=50)$ unzufrieden bis sehr unzufrieden mit dem Angebot sind. In der vorliegenden Studie gaben 88,7\% ( $\mathrm{n}=329)$ der Befragten an, das Internet häufig bis sehr häufig für betriebliche Zwecke zu nutzen. Dabei empfinden 35,6\% ( $n=132)$ das Internet als schnell, 25,6\% ( $n=94)$ hingegen empfinden es als langsam. Es kann daher vorausgesetzt werden, dass die Internetinfrastruktur auf den landwirtschaftlichen Betrieben die Nutzung von E-Commerce überwiegend zulässt. Die Zahlen belegen außerdem, dass LandwirtInnen mit der Nutzung von Computern und Internetanwendungen vertraut sind. Wie Abbildung 2 verdeutlicht, wird für einen betrieblichen Online-Einkauf vorzugsweise der Computer bzw. der Laptop verwendet. Das Tablet wird von der Mehrheit $(57,1 \%)$ der Befragten selten bis nie für den Online-Einkauf genutzt. Smartphones werden mit 40,5\% bereits recht häufig für den Einkauf verwendet. 


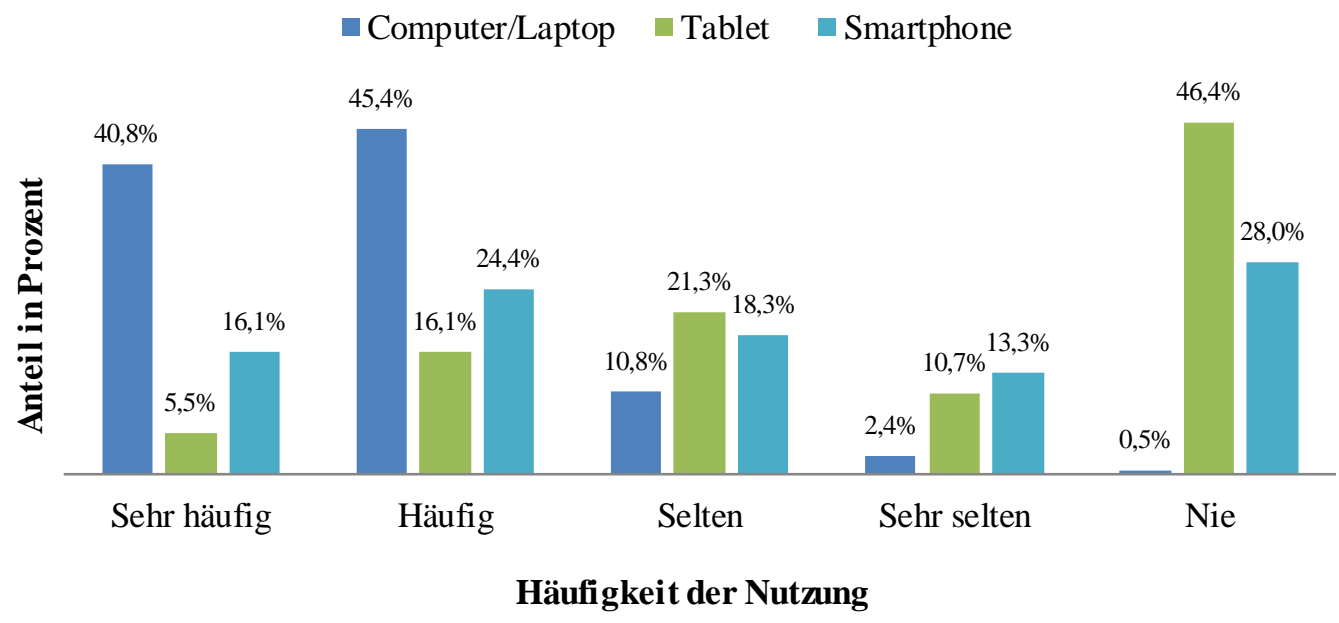

Abbildung 2: Für den Online-Kauf verwendete Geräte $(\mathrm{n}=\varnothing 359)$

Quelle: Eigene Erhebung.

Abbildung 3 stellt dar, welche Bezugsquellen LandwirtInnen für die jeweiligen Betriebsmittel bevorzugen. Dabei sind unter Instandhaltungsmaterialien solche Materialien zu verstehen, die für die Instandhaltung von Maschinen und Gebäuden eingesetzt werden (z.B. Ersatzteile, Öle, Dichtungsmaterialien etc.). Materialien des täglichen Bedarfs umfassen Produkte, die regelmäßig im Betrieb eingesetzt werden (bspw. Arbeitskleidung, Besen etc.). Die Grafik verdeutlicht, dass der Handel vor Ort für die Beschaffung von Betriebsmitteln die Hauptbezugsquelle ist. Über nahezu alle Produktgruppen hinweg ist der Handel vor Ort die bevorzugte Bezugsquelle, lediglich Materialien des täglichen Bedarfs werden vorzugsweise online erworben. Es zeigt sich, dass typische Verbrauchsgüter bzw. Erfahrungsgüter (Futtermittel, Düngemittel, Saatgut und Pflanzenschutzmittel) nur von 2 bis 5\% der Befragten bevorzugt online gekauft werden.

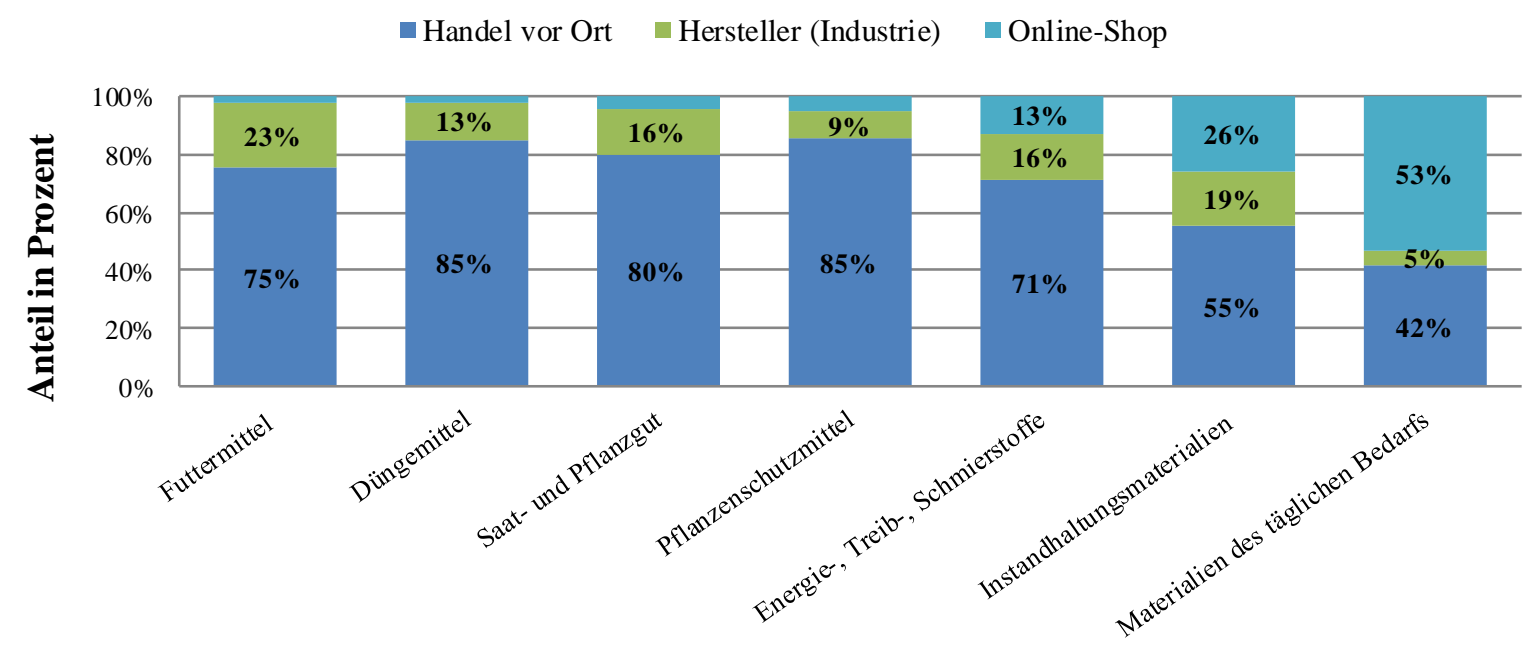

Betriebsmittelkategorie

Abbildung 3: Bevorzugte Bezugsquelle für Betriebsmittel $(n=\varnothing 353)$

Quelle: Eigene Erhebung. 
Obwohl der Handel vor Ort sich als bevorzugte Bezugsquelle herausstellt, lässt sich aus Abbildung 3 ablesen, dass einige LandwirtInnen durchaus das Internet für ihren Betriebsmitteleinkauf nutzen. Die Häufigkeit, mit der die jeweiligen Betriebsmittel von den LandwirtInnen online bezogen werden, ist in den Abbildungen 4 und 5 dargestellt. Mithilfe einer fünfstufigen Likert-Skala von 1=,,sehr häufig“ bis 5=,,nie“ wurde gefragt, wie häufig die jeweiligen Betriebsmittel online erworben werden. Allgemein (Produktgruppen unabhängig) nutzen nur 18,3\% der Befragten das Internet häufig für den Betriebsmitteleinkauf (Abb. 4). Die Mittelwerte in Abbildung 5 zeigen, dass nur Materialien des täglichen Bedarfs regelmäßig im Internet gekauft werden (Mittelwert 2,42). Individualprodukte, das heißt Produkte, die auf die Gegebenheiten der jeweiligen Betriebe angepasst und abgestimmt werden müssen, werden sehr selten online bezogen. Besonders selten werden Pflanzenschutzprodukte und Düngemittel im Internet gekauft.

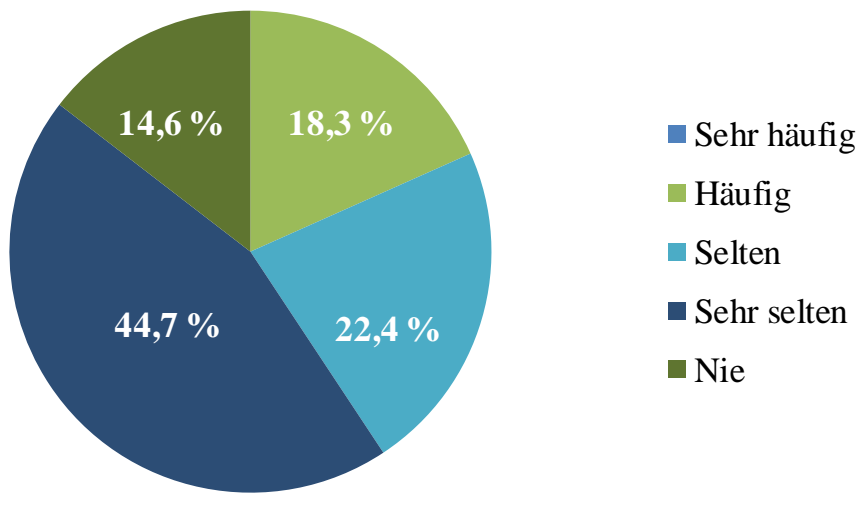

Abbildung 4: Regelmäßigkeit des Online-Bezugs von Betriebsmitteln in \% $(\mathrm{n}=\varnothing 369)$ (unabhängig von der Produktgruppe) Quelle: Eigene Erhebung

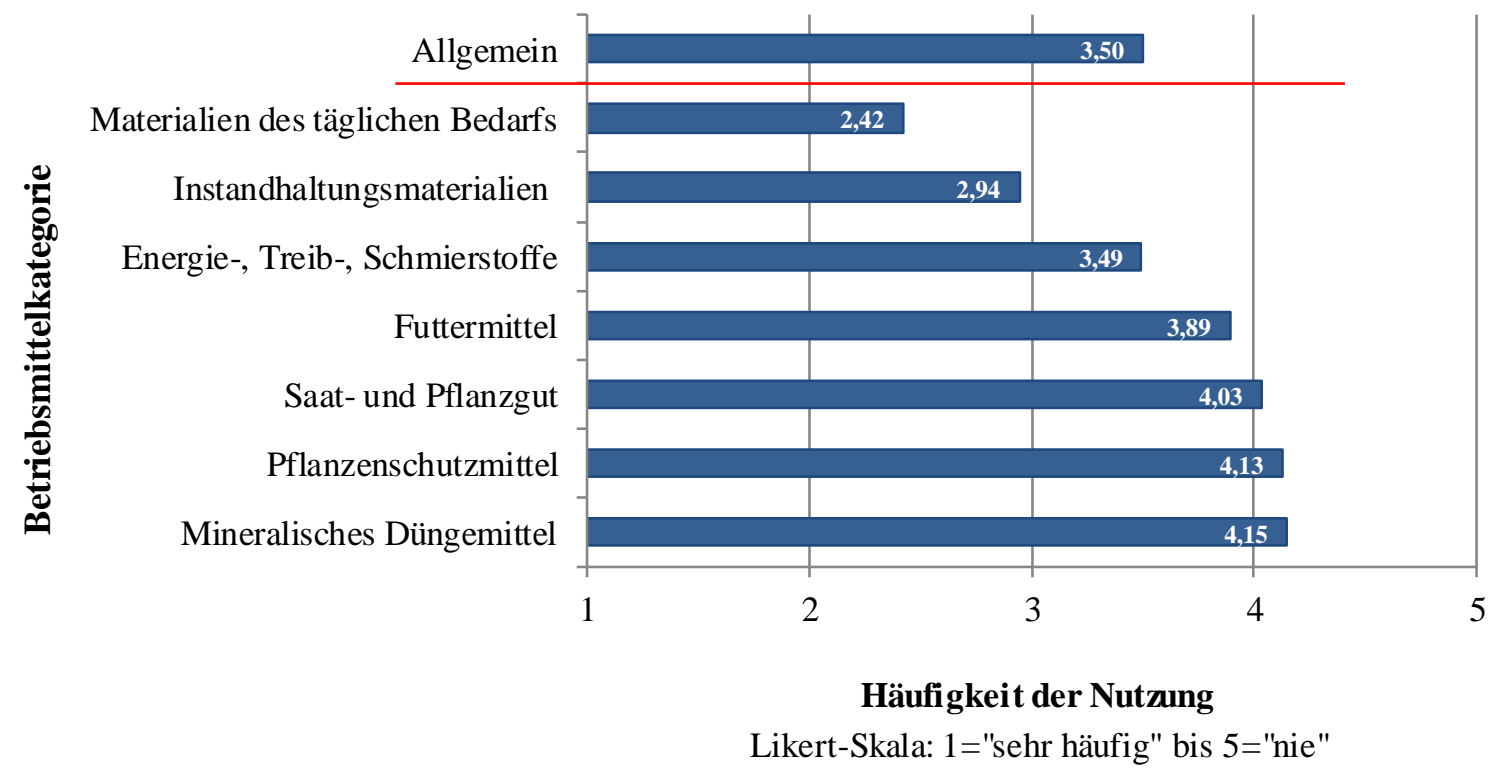

Abbildung 5: Mittlere Häufigkeit des Online-Bezugs nach Betriebsmittelkategorie ( $\mathrm{n}=\varnothing$ 369) Quelle: Eigene Erhebung 


\subsection{Faktorenanalyse}

Mit der Faktorenanalyse werden Statements zusammengefasst, die zu einem ähnlichem Antwortverhalten geführt haben (Backhaus et al., 2016). Besteht eine hohe Korrelation zwischen den einzelnen Fragen, wird davon ausgegangen, dass die Variablen auf einen gemeinsamen Faktor laden (Brosius, 1998). Vor Beginn der Faktorenanalyse wurden die Ausgangsdaten mittels Kaiser-Meyer-Olkin-Kriterium (KMO), variablenspezifischem Measure of sampling adequacy (MSA) und Bartlett-Test auf ihre Eignung für die Faktorenanalyse geprüft. Der KMO-Wert und die MSA-Werte geben an, ob ein nennenswerter Zusammenhang zwischen den Variablen besteht, und geben somit Aufschluss darüber, ob die Daten für eine Faktorenanalyse geeignet sind. Der MSA-Index entspricht dem KMO-Index, nur wird der KMO-Wert für die gesamte Matrix ausgegeben, während die MSA-Werte für einzelne Variablen auf Grundlage der Anti-Image-Matrix berechnet werden. Je größer diese Werte, desto stärker die Zusammengehörigkeit der Variablen. Die Werte können zwischen 0 und 1 liegen, wobei ein KMO-Wert größer 0,5 für die Auswertung herangezogen werden sollte (Kaiser und Rice, 1974). Die Faktorladung ist das Maß für die Zuordnung einer Variablen zu einem Faktor und gibt die Stärke und die Richtung der Korrelationen zwischen dem Faktor und der Variablen an (Backhaus et al., 2016). Ein Eigenwert größer 1 wurde als Abgrenzung der Faktorenanzahl herangezogen. Die einzelnen Faktoren wurden anhand des Cronbach's Alpha $(\mathrm{C} \alpha)$ auf ihre Reliabilität und anhand der erklärten Gesamtvarianz auf ihre Validität geprüft. Der Wertebereich von $\mathrm{C} \alpha$ liegt zwischen 0 und 1, wobei ein $\mathrm{C} \alpha$ größer als 0,7 auf eine reliable Abbildung hindeutet (Hair et al., 2009). Ein exakter Grenzwert für die erklärte Gesamtvarianz liegt nicht vor, in der Literatur werden aber Werte von 50\% - 60\% als hinnehmbar diskutiert (Hair et al., 2009; Watson, 2017).

In einem ersten Schritt wurde eine konfirmatorische Faktoranalyse durchgeführt, welche die E-Commerce Nutzungsabsicht zu einem Faktor verdichtet (Tabelle 3). Durch die Bildung des Faktors wird ein KMO Wert von 0,642 (akzeptabel) erreicht und $\mathrm{C} \alpha$ deutet mit 0,744 auf eine hohe Reliabilität hin. Die aktuelle Nutzungsrate wird durch einen errechneten Status Quo angegeben. Zur Abbildung des Status Quo wurde ein Index erstellt, der die tatsächliche E-Commerce-Nutzung des Landwirts angibt und sich aus den Angaben zum Einsatz und zur Regelmäßigkeit von Onlineshops im Einkaufsprozess aller Betriebsmittelkategorien errechnet (je höher der Index desto stärker die tatsächliche Nutzung). 
Tabelle 3: Faktoranalyse: Faktor Nutzungsabsicht E-Commerce

\begin{tabular}{lc}
\hline Variablen & Faktorladung \\
\hline In Zukunft werde ich auch Betriebsmittel von hohem Wert online kaufen. & 0,862 \\
In Zukunft werde ich auch komplexere Betriebsmittel online kaufen. & 0,857 \\
In Zukunft werde ich mehr Betriebsmittel online kaufen. & 0,712 \\
\hline $\begin{array}{l}\text { Faktorenanalyse: KMO: 0,642; Ca: 0,744; Erklärte Gesamtvarianz: 66,148\% } \\
\text { Likert-Skala: } 1=, \text { Stimme voll und ganz zu“ bis 5=,,lehne voll und ganz ab“ }\end{array}$ & \\
\hline Quelle: Eigene Erhebung &
\end{tabular}

Bevor die Einflussgrößen auf die tatsächliche Nutzung und die Nutzungsabsicht bestimmt werden können, muss eine zweite Faktorenanalyse durchgeführt werden, um die übrigen Variablen zu einigen wenigen Faktoren zu verdichten. Durch eine theoriegestützte Selektion der als geeignet erscheinenden Variablen konnten aus 14 Statements vier Faktoren gebildet werden. Diese vier Faktoren erklären insgesamt 59,4\% der Gesamtvarianz, der KMO-Wert beträgt 0,785 und deutet auf die gute Eignung der Variablen für eine Faktorenanalyse hin. Tabelle 4 bildet die Cronbach’s Alpha Werte $(\mathrm{Ca})$ ab. Diese sind mit der Ausnahme von zwei Faktoren, oberhalb von 0,7 und damit zufriedenstellend.

Der Faktor "Vorteile" des Online-Einkaufs setzt sich aus vier Items zusammen, welche Interneteinkäufe als einfach, bequem, zeitsparend und den Alltag erleichternd definieren. Der Faktor "Produktmerkmale" bildet sich ebenfalls aus vier Items und geht davon aus, dass bekannte, standardisierte und günstigere Produkte besser für den Online-Handel geeignet sind. Das Vergnügen, die Glücksgefühle und die Vorfreude beim Onlineshopping sind dem Faktor "Freude" zugeordnet. Datenschutzbedenken, Risikoempfinden und Sicherheitsprobleme des Internets bilden den Faktor "Misstrauen".

Tabelle 4: Reliabilität der extrahierten Faktoren

\begin{tabular}{lc}
\hline Faktoren & $\mathbf{C \alpha}$ \\
\hline Vorzüge des Online-Einkaufs & 0,766 \\
Online-Handel begünstigende Produktmerkmale & 0,714 \\
Freude am Online-Einkauf & 0,683 \\
Misstrauen gegenüber dem Online-Einkauf & 0,639 \\
\hline Faktorenanalyse: KMO: 0,785; Erklärte Gesamtvarianz: 59,4\% & \\
Likert-Skala: 1=,Stimme voll und ganz zu“ bis 5=,,lehne voll und ganz ab“ &
\end{tabular}




\title{
4.3 Die Bedeutung von produktbezogenen Eigenschaften
}

Die vorangestellten Ergebnisse zeigen, dass LandwirtInnen sehr differenziert im Internet einkaufen und dieses nur für bestimmte Betriebsmittelkategorien in Erwägung ziehen (H1). Bereits an dieser Stelle kann der Einfluss von Produktmerkmalen auf den Einkaufsprozess von LandwirtInnen bestätigt werden. Dennoch gilt zu prüfen, von welchen Merkmalen die Entscheidung für oder gegen den Online-Kauf abhängt. Die Literatur führt hierzu die Bekanntheit bzw. den Grad der Standardisierung an. Die bereits angeführten Ergebnisse können diese Annahmen bestätigen. So werden standardisierte Produkte wie Materialien des täglichen Bedarfs oder Instandhaltungsprodukte häufiger online gekauft als Individualprodukte (Abb. 5). Abbildung 6 verdeutlicht, dass LandwirtInnen standardisierte Produkte als für den Onlineshop geeigneter ansehen und diese auch eher online kaufen würden. Auch die Bekanntheit wirkt sich positiv auf die Kaufbereitschaft aus. So würden die Befragten vorzugsweise ihnen bereits bekannte Produkte im Internet kaufen.

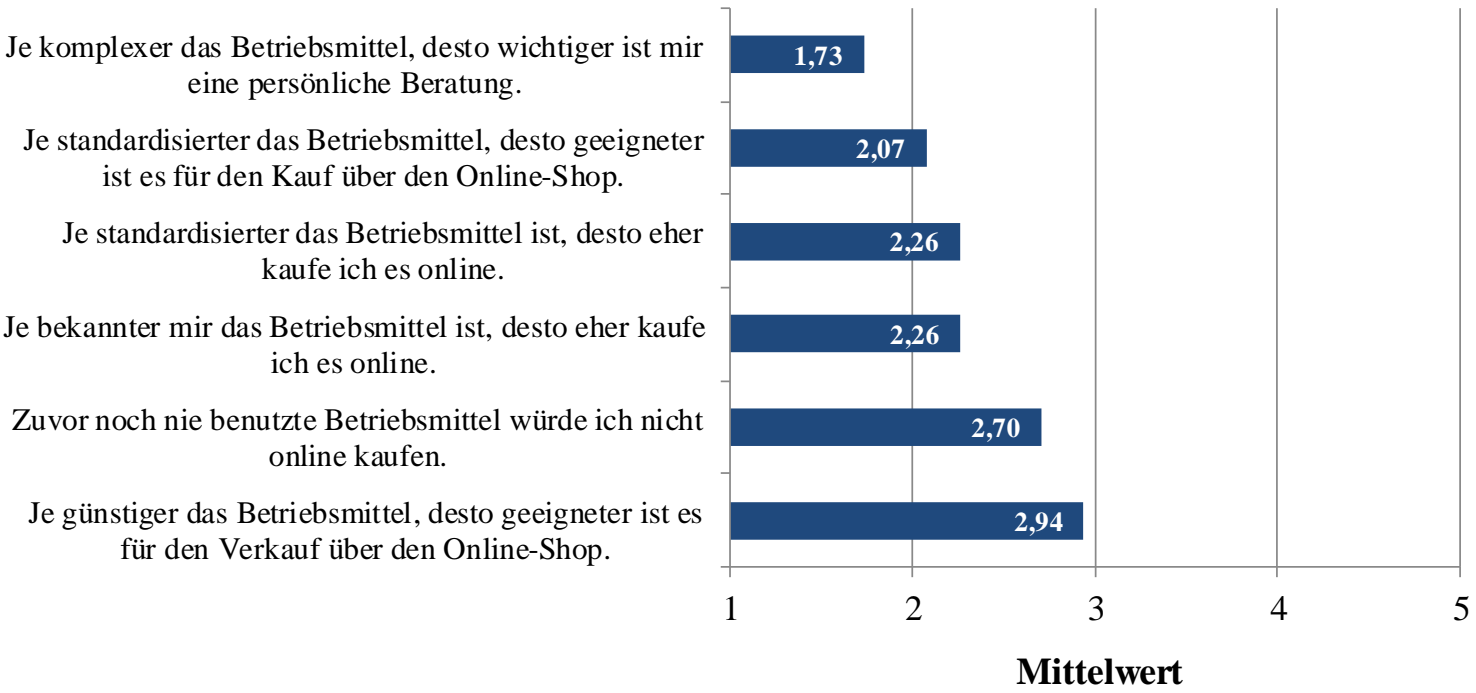

Likert-Skala: $1=$ "stimme voll und ganz zu" bis $5=$ "lehne voll ung ganz ab"

\begin{abstract}
Abbildung 6: Mittelwerte für ausgewählte Statements zu Produktmerkmalen ( $\mathrm{n}=371)$ Quelle: Eigene Erhebung
\end{abstract}

Abbildung 6 stellt auch dar, dass für komplexere Produkte eine persönliche Beratung von großer Wichtigkeit ist. Hinsichtlich der Onlineshop-Eignung günstiger Produkte sind sich die LandwirtInnen eher uneinig. Mit einem Mittelwert von 2,94 stimmen sie dieser Aussage nur zum Teil zu. Die Häufigkeitsverteilung zeigt, dass 24,6\% nicht der Meinung sind, dass günstigere Produkte sich besser für den Online-Verkauf eignen. 27,7\% stimmen dieser Aussage hingegen zu und 47,7\% wählten die Antwortmöglichkeit teils/teils. Darüber hinaus stimmen nur weniger als die Hälfte aller Befragten (42,9\%) zu, in Zukunft mehr Betriebsmittel online zu 
kaufen, wenn der Onlineshop günstiger ist als der Handel vor Ort. Hieraus lässt sich schließen, dass der Produktpreis ein wesentlicher Einflussfaktor ist, er jedoch für die meisten LandwirtInnen nicht das einzige Entscheidungskriterium für einen Online-Einkauf ist und vermutlicht nicht sein wird.

Durchgeführte Regressionsanalysen (Tabellen 5 und 6) bestätigen einen starken Einfluss der Produktmerkmale (Bekanntheit, Grad der Standardisierung und Preisgünstigkeit) sowohl auf die derzeitige Nutzungsintensität als auch auf die Online-Kaufabsicht. Die Hypothese „Je bekannter/standardisierter ein Produkt ist, desto höher ist die Online-Kaufbereitschaft der LandwirtInnen für das jeweilige Produkt" kann bestätigt werden. Es kann angenommen werden, dass die Online-Kaufbereitschaft der LandwirtInnen für das jeweilige Produkt umso höher ist, je geeigneter ein Produkt für den Online-Handel zu sein scheint. Dies macht deutlich, dass der Preis nicht das alleinige Entscheidungskriterium für oder gegen einen Online-Einkauf ist. In Verbindung damit steht die Hypothese, dass ein Zusammenhang zwischen der Wahrnehmung von Preisvorteilen im Internet und dem Nutzungsverhalten besteht.

Mittels einer Korrelationsanalyse wurde auch überprüft welchen Einfluss die Annahme von Preisvorteilen im Internet auf die Nutzungsabsicht hat. Die bivariate Korrelationsanalyse nach Spearman hat eine signifikante Korrelation ( $r=0,274 ; p \leq 0,01)$ zwischen der Annahme, dass das Internet niedrigere Preise als der Handel vor Ort bietet, und dem zukünftig häufigeren Einkauf von Betriebsmitteln über das Internet ergeben. Das bedeutet, dass angenommen werden kann, dass jene LandwirtInnen, die Preisvorteile des Internets wahrnehmen, auch eher bereit sind in Zukunft verstärkt im Internet einzukaufen. Eine Korrelation lässt sich auch hinsichtlich der aktuellen Nutzung erkennen. Die Korrelation nach Kendall Tau bestätigt eine negative Korrelation $(\mathrm{r}=-0,169 ; \mathrm{p}=0,00)$. Dies deutet darauf hin, dass die tatsächliche Nutzung des Internets umso höher ist, je stärker LandwirtInnen die Meinung vertreten, dass das Internet niedrigere Preise als der Handel vor Ort bietet. Die Hypothese, dass „Produktpreise im Onlineshop einen Einfluss auf die betriebliche E-Commerce-Nutzung haben “ kann bestätigt werden. Aktuelle Studien belegen, dass LandwirtInnen generell für den Wechsel zu einem Online-Händler einen Preisrabatt einfordern (Fecke et al., 2018). In der Literatur wird zum einen der Standpunkt vertreten, dass der Preis ein wesentlicher Einflussfaktor ist (Clasen, 2005; Fecke et al., 2018), zum anderen fanden Ackermann et al. (2018) heraus, dass vor allem der Zeitfaktor entscheidend ist. 
Ein zentrales Ergebnis dieser Arbeit ist, dass sich der Online-Einkauf von LandwirtInnen auf ganz bestimmte Produktgruppen beschränkt. Damit beweist sich, dass Produktmerkmale einen Einfluss auf den Einkaufsprozess haben. Abbildung 3 zeigt, welche Produktgruppen bevorzugt über das Internet gekauft werden, diese Grafik deckt sich im Wesentlichen mit den Ergebnissen aus den Studien von Gartzke (2016) und Ackermann et al. (2018). Clasen und Mueller (2006) haben untersucht, dass komplexe und neue Produkte nicht für den landwirtschaftlichen OnlineVertrieb geeignet sind, was die Ergebnisse dieser Studie ebenfalls implizieren. Etablierte Produkte, die regelmäßig genutzt werden und keinen gesetzlichen Anforderungen unterliegen, haben ein höheres E-Commerce-Potenzial (Clasen und Mueller, 2006; Gartzke, 2016). Diese Studie belegt, dass Produkte, die weniger standardisiert sind und individuell an den Betrieb angepasst werden müssen oder eine intensivere Beratung benötigen, seltener online gekauft werden.

\subsection{Die Bedeutung von marktbezogenen Eigenschaften}

In der vorliegenden Studie wurden, bezogen auf die Marktmerkmale, die Zufriedenheit mit dem Onlineangebot sowie der empfundene Wettbewerbsdruck der LandwirtInnen abgefragt. Dabei geben 44,3\% ( $\mathrm{n}=160)$ der Antwortenden an, mit dem derzeitigen Onlineangebot für landwirtschaftliche Betriebsmittel zufrieden zu sein, während 13,8\% ( $\mathrm{n}=50)$ unzufrieden bis sehr unzufrieden mit dem Angebot sind. Eine nach Pearson signifikante Korrelation konnte zwischen der Zufriedenheit mit dem Onlineangebot und der aktuellen Nutzung festgestellt werden $(\mathrm{r}=-0,144 ; \mathrm{p}=0,006)$. Dies lässt vermuten, dass LandwirtInnen das Internet als Beschaffungskanal umso stärker nutzen, je zufriedener sie mit dem Onlineangebot sind. 44,5\% ( $n=165)$ sind der Meinung, dass das Internet eine bessere Auswahl bietet als der Handel vor Ort. So kann davon ausgegangen werden, dass die Anzahl an Online-Anbietern und deren Angebot für die Landwirtschaft als recht zufriedenstellend empfunden wird.

Innerhalb des Berufsstandes empfinden die LandwirtInnen keinen Wettbewerbsdruck. So lehnen sie die Aussagen „Ich kaufe online, weil es meine Berufskollegen auch tun.“ Mit einem Mittelwert von 4,15 und „Ich muss Betriebsmittel online kaufen, um konkurrenzfähig zu bleiben“ mit einem Mittelwert von 3,68 eindeutig ab (Likert-Skala von 1=,,stimme voll und ganz zu“; 5=,,lehne voll und ganz ab“). 


\subsection{Die Bedeutung der betriebsbezogenen Eigenschaften}

Aus der Literatur ergab sich die Hypothese, dass kein Zusammenhang zwischen den jeweiligen Betriebsmerkmalen (Betriebs-Form, Typ, Größe, Herkunft) und der betrieblichen E-Commerce-Nutzung in der Landwirtschaft besteht. Für die vorliegende Stichprobe lässt sich dies bestätigen. So konnten keine signifikanten Korrelationen zwischen den jeweiligen Betriebsmerkmalen und der tatsächlichen Nutzung sowie der Nutzungsabsicht festgestellt werden. Das bedeutet, dass sich, bezogen auf die Stichprobe, die Nutzung von Onlineshops für den Einkauf von Betriebsmitteln als unabhängig von der Betriebsform, Betriebsgröße und der Ortsansässigkeit erweist.

Die Betriebsgröße hat keinen signifikanten Einfluss auf die E-Commerce-Nutzung, somit kann an dieser Stelle früheren Studien nicht voll zugestimmt werden (Akridge, 2003; Mishra und Williams, 2006; Taragola und van Lierde, 2010). Der ausbleibende Einfluss der Betriebsgröße kann jedoch damit erklärt werden, dass die durchschnittliche Betriebsgröße der Betriebe in dieser Studie mit etwa 260 Hektar deutlich über dem Durchschnitt von knapp 60 Hektar liegt. Das die Betriebsform keinen Einfluss auf die E-Commerce-Nutzung hat, könnte daran liegen, dass das Internet (und damit die Möglichkeit zur E-Commerce-Nutzung) heute auf allen Betrieben unabhängig von deren (Betriebs-) Form eingesetzt wird und eingesetzt werden muss. Die Ergebnisse dieser und anderer Studien (Ackermann et al., 2018; Gartzke, 2016) zeigen, dass nahezu alle landwirtschaftlichen Betriebe das Internet in ihren Betriebsalltag integrieren und damit die Voraussetzungen über alle Betriebsformen hinweg gegeben sind. Kool (1994) führte zudem an, dass je nach Betriebsform und entsprechender Saison, die für den Betriebsmittelkauf zur Verfügung stehende Zeit variiert. Landwirtschaft Betreibende aller Betriebsformen verbringen heute jedoch zunehmend mehr Zeit im Büro (Deter, 2018; Pellens, 2018), was für eine Betriebsform übergreifende E-Commerce-Nutzung spricht.

\subsection{Die Bedeutung individueller Eigenschaften}

\section{Bedeutung sozioökonomischer Eigenschaften}

$\mathrm{Zu}$ den sozioökonomischen Eigenschaften zählen Geschlecht, Alter und Bildungsniveau der LandwirtInnen. Innerhalb der vorliegenden Stichprobe ist sowohl die tatsächliche Nutzung als auch die Nutzungsabsicht im Wesentlichen unabhängig von den sozioökonomischen Eigenschaften der LandwirtInnen. Es konnte lediglich eine geringe, negative Korrelation zwischen der tatsächlichen Nutzung und dem Alter identifiziert werden $(r=-0,88 ; p=0,02)$. Daraus lässt sich schließen, dass ältere LandwirtInnen das Internet derzeit weniger stark nutzen. 
Dieser Effekt zeigt sich jedoch nicht für die Nutzungsabsicht. Daraus kann geschlussfolgert werden, dass die Nutzungsabsicht unabhängig vom Geschlecht, Alter und dem allgemeinen sowie dem landwirtschaftlichen Bildungsniveau ist.

Dies widerspricht früheren Studien (Batte, 2006; Taragola und van Lierde, 2010) die feststellten, dass demographische Faktoren das Ausmaß der E-Commerce-Nutzung erklären, da LandwirtInnen, die jünger und besser ausgebildet sind und einen Hofnachfolger haben, Onlineshops eher nutzen. Der Unterschied in der Altersvariable sowie die Bedeutung des Unterschiedes zwischen der vorliegenden Studie und den vorherigen Studien (Batte, 2006; Mishra und Williams, 2006; Taragola und van Lierde, 2010) könnte sich aus der Tatsache ergeben, dass jüngere LandwirtInnen in dieser Studie überrepräsentiert sind. Zu ähnlichen Ergebnissen wie die vorliegende Studie kommen auch Ackermann et al. (2018). Auch sie konnten in der deutschen Landwirtschft keinen signifikanten Zusammenhang zwischen dem Alter und der Häufigkeit des Online-Bezugs von Betriebsmitteln feststellen. Hingegen hat bei ihnen die hohe Ausbildung einen signifikanten positiven Einfluss. Mit höherem Bildungsabschluss steigt demnach die Nutzung von E-Commerce Ackermann et al. (2018), welches durch die vorliegende Studie so nicht bestätigt werden konnte. Dies könnte dem ohnehin schon überdurchschnittlichen Bildungsniveau der Stichprobe geschuldet sein.

Ernst und Tucker (2001) geben an, dass Männer mit höherer Wahrscheinlichkeit das Internet und dessen Anwendungen nutzen. Das Geschlechterverhältnis dieser Studie liegt bei Männer 87\% ( $\mathrm{n}=308)$ und 17\% Frauen ( $=63)$. Im Bundesdurchschnitt wurden 2016 weniger als 10\% der landwirtschaftlichen Betriebe von Frauen geführt (Pascher et al., 2018). Mit 17\% Frauenanteil liegt die vorliegende Stichprobe somit über dem Bundesdurchschnitt. Dadurch lässt sich vermutlich auch die signifikante Korrelation nach Kendall-Taub zwischen Geschlecht und Nutzungsabsicht $(r=-0,88 ; p \leq 0,05)$ erklären, die darauf hindeutet, dass Frauen eine höhere Nutzungsabsicht geäußert haben. Dies könnte darauf zurückgeführt werden, dass der Anteil der Frauen in der Landwirtschaft wächst (DBV, 2012) und gleichzeitig sind ihre Entscheidungsbefugnis bzw. ihre Mitbestimmungsrechte oft sehr hoch. Eine in NordrheinWestfalen durchgeführte Studie über Frauen in der Landwirtschaft ergab, dass lediglich 4\% der Frauen nicht an Entscheidungsfindungen beteiligt sind (Kuhlmann et al., 2016). Somit kann sowohl Männern als auch Frauen die Aufgabe des Betriebsmitteleinkaufs zugeteilt werden. 


\section{Bedeutung der Managereigenschaften}

Um die unterschiedlichen Einflussgrößen auf die aktuelle Nutzung und die Nutzungsabsicht bestimmen zu können, werden im Folgenden zwei Regressionsanalysen gerechnet. In der ersten linearen Regressionsanalyse wird die Index-Variable "aktuelle Nutzung" als abhängige Größe definiert, in der darauffolgenden der Faktor "Nutzungsabsicht". Neben den vier gebildeten Faktoren werden auch die standardisierten Einzelstatements „Ich bin sehr erfahren im Umgang mit Onlineshopping“, „Ich stehe im engen Kontakt zum Handel vor Ort“ und „Ich kaufe immer beim gleichen Händler“ als unabhängige Variablen eingesetzt.

Die Ergebnisse zeigen, dass nicht nur die ermittelten Faktoren erklärend sind, sondern auch einzelne Items, die keinen Eingang in die Faktoranalyse fanden, einen Beitrag zur Erklärung der tatsächlichen Nutzung leisten (Tabelle 5). Es kann festgestellt werden, dass $23,9 \%\left(\mathrm{r}^{2}\right)$ der Varianz der tatsächlichen Nutzung durch die abgebildeten Faktoren und Items erklärt werden kann. Gemessen am Beta-Wert haben "Vorteile", "Produktmerkmale" und der Faktor "Erfahrung" einen großen positiven und zudem stark signifikanten Einfluss auf die tatsächliche Nutzungsrate. Während die Faktoren "Misstrauen" sowie die "Beziehung zum Handel vor Ort" einen stark negativen Einfluss besitzen, haben Freude und Loyalität zum Landhandel nur einen schwachen Einfluss auf die tatsächliche Nutzung.

Tabelle 5: Lineares Regressionsmodell zur Erklärung der tatsächlichen Nutzungsintensität

\begin{tabular}{|c|c|c|c|}
\hline Unabhängige Variablen & Effektgröße & $\begin{array}{c}\text { Standard- } \\
\text { fehler }\end{array}$ & T-Wert \\
\hline Vorteile des Online-Einkaufs & 0,223 & 0,052 & $4,293 * * *$ \\
\hline Online-Handel begünstigende Produktmerkmale & 0,133 & 0,047 & $2,831 * *$ \\
\hline Freude am Online-Einkauf & 0,104 & 0,048 & $2,155^{*}$ \\
\hline Misstrauen gegenüber dem Online-Einkauf & $-0,136$ & 0,047 & $-2,918 * *$ \\
\hline Erfahrung (Einzel Statement) ${ }^{1}$ & 0,199 & 0,054 & $3,637 * * *$ \\
\hline Beziehung zum Landhandel (Einzel Statement) ${ }^{1}$ & $-0,120$ & 0,048 & $-2,478 *$ \\
\hline Loyalität zum Landhandel (Einzel Statement) ${ }^{1}$ & $-0,080$ & 0,048 & $-1,684$ \\
\hline
\end{tabular}

In einer zweiten Regressionsanalyse werden die Einflussgrößen auf die Nutzungsabsicht analysiert (Tabelle 6). Hier wird festgestellt, dass 19,3\% der Varianz der Online-Kaufabsicht durch die Faktoren und Items erklärt werden kann. 
Tabelle 6: Lineares Regressionsmodell zur Erklärung der Nutzungsabsicht

\begin{tabular}{|c|c|c|c|}
\hline Unabhängige Variablen & Effektgröße & $\begin{array}{c}\begin{array}{c}\text { Standard- } \\
\text { fehler }\end{array} \\
\end{array}$ & T-Wert \\
\hline Vorzüge des Online-Einkaufs & 0,267 & 0,054 & $4,997 * * *$ \\
\hline Online-Handel begünstigende Produktmerkmale & 0,120 & 0,049 & $2,473^{*}$ \\
\hline Freude am Online-Einkauf & 0,151 & 0,050 & $3,015^{* * *}$ \\
\hline Misstrauen gegenüber dem Online-Einkauf & $-0,203$ & 0,049 & $-4,213 * * *$ \\
\hline Erfahrung (Einzel Statement) ${ }^{1}$ & 0,006 & 0,056 & 0,113 \\
\hline Beziehung zum Landhandel (Einzel Statement) ${ }^{1}$ & $-0,109$ & 0,051 & $-2,176^{*}$ \\
\hline Loyalität zum Landhandel (Einzel Statement) ${ }^{1}$ & $-0,122$ & 0,049 & $-2,491 *$ \\
\hline
\end{tabular}

Die Beta-Werte verdeutlichen, dass Vorteile und Freude einen positiven und gleichzeitig stark signifikanten Einfluss auf die Nutzungsabsicht haben. Online-Handel begünstigende Produktmerkmale üben einen leicht geringeren, aber ebenfalls signifikanten, Einfluss auf die Nutzungsabsicht aus. Ähnlich wie bei der tatsächlichen Nutzung hat Misstrauen gegenüber dem Online-Einkauf den stärksten negativen Einfluss auf die Nutzungsabsicht. Während zuvor die Loyalität keinen Einfluss zeigte, hat sie nun einen deutlich stärkeren und signifikant negativen Einfluss auf die Nutzungsabsicht. Keinen signifikanten Einfluss hat hingegen die Onlineshopping-Erfahrung.

In beiden Analysen konnte eine große Bedeutung der wahrgenommenen Vorteile sowie der Produktmerkmale festgestellt werden. Bei einem Vergleich der wichtigsten Einflussgrößen auf die tatsächliche Nutzung und die Nutzungsabsicht lässt sich erkennen, dass das Misstrauen besonders wichtig für die Nutzungsabsicht und die Erfahrung entscheidend für die tatsächliche Nutzung ist.

Freude am Onlineshoppen hat nach den Vorteilen den stärksten positiven Einfluss auf die Nutzungsabsicht. Die vorliegende Arbeit bestätigt, dass der affektive Status (Gefühle= Freude und Misstrauen) einen starken Einfluss auf das Nutzungsverhalten hat. Dies deckt sich mit den Erkenntnissen aus der allgemeinen E-Commerce-Forschung (Rose et al., 2012). Empfundene Vorteile wie Zeitersparnis, Bequemlichkeit, Erleichterung und Einfachheit werden von LandwirtInnen anerkannt und resultieren in einer positiven Nutzungsabsicht (Akridge, 2003; Batte, 2006). Die Ergebnisse der Regressionsanalyse in Tabelle 5 und 6 bestätigen diese Annahme. Es kann davon ausgegangen werden, dass sowohl die aktuelle als auch die zukünftige betriebliche E-Commerce-Nutzung der LandwirtInnen umso stärker ist, je mehr sie 
die Vorteile des Online-Handels wahrnehmen. Die Vorteilhaftigkeit könnte durch die neue Ära mobiler Geräte wie Tablets und Smartphones weiter angetrieben werden und so den E-Commerce-Einsatz von LandwirtInnen zukünftig ankurbeln. Internetfähige Endgeräte mit ihren Apps und Diensten machen den Internetzugang einfacher und rentabler (Akroush und AlDebei, 2015). Dies führt zu einem enormen E-Commerce-Wachstum. Wie auch Hoffmann et al. (2014) bestätigt diese Studie den allgemeinen Trend und zeigt, dass landiwrtschaftliche Betriebe zunehmend mit mobilen Endgeräten ausgestattet sind. Sie beobachteten auch eine Tendenz $\mathrm{zu}$ einer in Zukunft stärkeren Nutzung mobiler Anwendungen, da die LandwirtInnen in erster Linie darauf abzielen ihre begrenzte und daher wertvolle Zeit effizienter zu nutzen (Hoffmann et al., 2014).

Fühlen sich LandwirtInnen im Umgang mit dem Online-Einkauf erfahren, ist deren aktuelle betriebliche E-Commerce-Nutzung größer, wobei sich dieser Effekt in der vorliegenden Stichprobe nicht für die Nutzungsabsicht identifizieren ließ. Es wird vermutet, dass die Erfahrung einen eher indirekten Einfluss hat, da diese mit jeder Nutzung steigt und eine signifikante positive Korrelation $(r=0,353 ; p=0,00)$ zwischen der tatsächlichen Nutzung und der Nutzungsabsicht vorliegt. Das deutet darauf hin, dass je höher die aktuelle Nutzungsrate (und die damit implizierte Erfahrung) ist, desto höher ist auch die Nutzungsabsicht.

Aus der allgemeinen E-Commerce-Forschung ist bekannt, dass das wahrgenommene Risiko und die Angst die Internetnutzung und dessen Abbruchrate beeinflusst (Cho, 2004; Mathew, 2016). Als große Inhibitoren von Onlineshopping gelten Datenschutzbedenken und Angst vor unsicheren Transaktionen (Joines et al., 2003). Es konnte mit dieser Studie ebenfalls belegt werden, dass das Misstrauen gegenüber dem Online-Handel das Nutzungsverhalten negativ beeinflusst. So ist die aktuelle und zukünftige Bereitschaft für eine betriebliche E-Commerce-Nutzung geringer, je misstrauischer LandwirtInnen dem Online-Handel gegenüberstehen. Der recht geringe Koeffizient liegt vermutlich darin begründet, dass die LandwirtInnen dieser Stichprobe bereits sehr erfahren im Umgang mit dem Internet und OnlineHandel sind und ihr Misstrauen daher an Bedeutung verloren hat.

\subsection{Bedeutung der Beziehung zum Handel vor Ort}

Die Ergebnisse bestätigen, dass die Beziehung und Loyalität zum Landahndel die landwirtschaftliche E-Commerce-Nutzung beeinflusst. LandwirtInnen suchen bei bestehenden guten Geschäftsbeziehungen seltener nach alternativen Beschaffungsquellen (Kool, 1994). Zudem ist die regionale Versorgung durch den örtlichen Landhandel nach wie vor sehr gut und kann somit als ein Hemmfaktor für E-Commerce angeführt werden (Ackermann et al., 2018). 
Tabelle 6 zeigt, dass die Loyalität zum Landhandel stärker (negativ) mit der Nutzungsabsicht korreliert als sie mit der tatsächlichen Nutzungsrate korreliert (Tabelle 5). Umgekehrt ist es bei der Beziehung zum Landhandel, deren Regressionskoeffizient größer ist in Bezug auf die tatsächliche Nutzung als auf die Nutzungsabsicht. Das bedeutet, dass sich sowohl die Loyalität als auch die Stärke der persönlichen Beziehung zwischen Landwirt und Lieferant negativ auf die E-Commerce-Nutzung auswirken. Je stärker also die Loyalität bzw. Beziehung zum Lieferanten desto geringer die Nutzungsabsicht. Die gute und enge persönliche Beziehung zwischen Landwirt und Landhandel bzw. dem Lieferanten scheint somit LandwirtInnen vom Online-Einkauf abzuhalten. Es ist demnach nicht verwunderlich, dass Gartzke (2016) als Hauptgrund für die Ablehnung von Onlineshops, das enge Vertrauensverhältnis zwischen LandwirtInnen und dem Landhandel anführt. Das große Vertrauen zum lokalen Handel spiegelt sich auch in der Betrachtung der Beschaffungskanäle wider, wo der lokale Handel allgemein an erster Stelle liegt. Neben dem Vertrauen zum Landhandel konnte auch das Misstrauen gegenüber dem Online-Handel als Hemmfaktor bestätigt werden, allerdings scheint der Einfluss des Misstrauens, anders als bei (Gartzke, 2016), größer zu sein als die Vertrauenskomponente. Dies könnte darin begründet liegen, dass tendenziell ein Rückgang der traditionellen Beziehungen zwischen Landhandel und Landwirt vermutet wird (Gollisch und Theuvsen, 2015). Andere Forscher betonen die hohe Bedeutung von Service und Kundenorientierung im Agrarhandel (Gartzke, 2016; Henderson et al., 2000), was auch mit dieser Studie belegt werden konnte. Fecke et al. (2018) konnten durch ein Discrete-ChoiceExperiment belegen, dass die von LandwirtInnen sehr geschätzte Vor-Ort-Beratung von den Online-Händlern nur schwer umgesetzt werden kann bzw. dass eine gute Vor-Ort-Beratung die Akzeptanz von Onlineshops reduziert.

\section{$5 \quad$ Limitationen}

Insgesamt stellt die vorliegende Studie eine erste Bewertung der deutschen LandwirtInnen als (B2B) Online-Kunden für landwirtschaftlichen Betriebsmitteln dar. Die Limitationen dieser Studie sollten jedoch bei der Interpretation der Ergebnisse berücksichtigt werden. Die fehlende Repräsentativität der verwendeten Stichprobe hinsichtlich Alter, Betriebsgröße, Bildung sowie Herkunft ist ein erster kritischer Faktor und schränkt die Interpretation der Ergebnisse ein. Zukünftige Studien sollten daher Wert auf eine repräsentative Stichprobe legen um die Ergebnisse entsprechend bestätigen zu können. Auch die Methodik (Online-Umfrage) ist mit gewissen Limitationen behaftet, da nur die LandwirtInnen erreicht wurden, die bereits online sind. LandwirtInnen, die möglicherweise nicht erreicht wurden, z.B. ältere (>65 Jahre), könnten 
weitere wichtige Erkenntnisse beitragen. Zukünftig wäre es spannend zu erfahren, wie andere Teile der Wertschöpfungskette wie beispielsweise Betriebsmittelhersteller, Einzelhändler und private Landhändler die Nutzung einschätzen. Diese Studie kann jedoch als wichtige PilotStudie interpretiert werden, da sie für Agribusiness-Unternehmen mit einem E-Commerce Vorhaben wichtige Informationen bereitstellt und dadurch helfen kann verschiedene Kommunikationsstrategien für verschiedene Onlineshopping-Segmente zu entwickeln.

\section{$6 \quad$ Fazit}

Die Intention der Studie war es auf Grundlage der gewonnenen Informationen tiefere Einblicke in das Online-Kaufverhalten der LandwirtInnen zu ermöglichen, um die Zielgruppen für den landwirtschaftlichen E-Commerce besser definieren zu können. Die Studie verdeutlicht das Potenzial von E-Commerce in der Landwirtschaft und zeigt auf, dass deutsche LandwirtInnen eine vielversprechende Zielgruppe darstellen. Insgesamt sind mehr als die Hälfte der LandwirtInnen mit dem Online-Handel vertraut und 18,3\% nutzen das Internet häufig für den betrieblichen Einkauf. Dabei spielen Produktmerkmale, d.h. die Typisierung und Merkmale der Produkte, eine entscheidende Rolle. LandwirtInnen kaufen produktgruppendifferenziert im Internet ein. Zudem ist ihre Entscheidung für oder gegen das Internet als Beschaffungskanal weitestgehend unabhängig von sowohl soziodemografischen Faktoten als auch von ihrern betriebsbezogenen Eigenschaften. Managereigenschaften und die bekannten Vorteile (Zeitersparnis, Einfachheit) des Internets haben hingegen größeren Einfluss auf das Nutzungsverhalten. So wollen LandwirtInnen ihre knappe Zeit effizient nutzen, was die Nutzung von E-Commerce positiv beeinflusst. Die Ergebnisse zeigen, dass Agribusiness Unternehmen differenzierte und gut durchdachte Digitalisierungsstrategien entwickeln und implementieren müssen, um die Nutzung ihrer Onlineshops zu steigern. Im Allgemeinen zeigt die Studie, dass Onlineshopping in der Landwirtschaft immer mehr an Bedeutung gewinnt und E-Commerce damit zu einem unverzichtbaren Thema wird. Trotzdem weisen die Ergebnisse darauf hin, dass der lokale Landhandel nach wie vor eine bedeutende Rolle im landwirtschaftlichen Einkaufsprozess einnimmt und kein/-e LandwirtIn davon ausgeht, dass Onlineshops den stationären Handel verdrängen werden. Es wird deutlich, dass der persönlichen Beratung eine bedeutende Rolle zukommt. Bei steigender Internet- und E-Commerce-Aktivität der LandwirtInnen ist es für Agribusiness Firmen wie dem privaten als auch genossenschaftlichen Agrarhandel daher eine zentrale Herausforderung den richtigen Grad zwischen physischer und digitaler Kundennähe $\mathrm{zu}$ finden. Dabei müssen E-Commerce-Anbieter gezielt ihre Service- und Beratungsfunktionen auf die Bedürfnisse ihrer 
Zielkunden ausrichten und optimieren. Frecke et al. (2018) schlagen hierfür bspw. die Option von Echtzeit-Feedback oder Videotelefonie zur schnellen und persönlichen Kundenbedienung vor. Auf der anderen Seite sind Unternehmen der landwirtschaftlichen Vorleistungsindustrie aufgefordert, Multichannel-Strategien zu implementieren. Dabei müssen sie ihren Kunden sowohl persönlich und fachlich kompetent zur Seite stehen, als auch digitale Lösungen bereitstellen und gezielte Teile ihres Produktsortiments über digitale Beschaffungskanäle zur Verfügung stellen. 


\section{Literatur}

Ackermann, S., Adams, I., Gindele, N. und Doluschitz, R. (2018). Die Nutzung von E-Commerce bei der Beschaffung landwirtschaftlicher Betriebsmittel. Landtechnik 73(1): 10-19. doi: 10.15150/LT.2018.3177

Akridge, J.T. (2003). E-Business in the Agricultural Input Industries. Applied Economic Perspectives and Policy 25(1): 3-13. doi: 10.1111/1467-9353.00041

Akroush, M. N. und Al-Debei, M. M. (2015). An integrated model of factors affecting consumer attitudes towards online shopping. Business Process Management Journal 21(6): 1353-1376. doi: 10.1108/BPMJ-02-2015-0022

Allred, C. R., Smith, S. M. und Swinyard, W. R. (2006). E-shopping lovers and fearful conservatives: a market segmentation analysis. International Journal of Retail \& Distribution Management 34(4/5): 308-333. doi: 10.1108/09590550610660251

Babb, E. M. (1988). Farmers' Buying and Selling Patterns lmpllcations for Cooperatives. Agricultural Cooperative Service (ACS) Research Report 73: 1-15. doi: 10.22004/ag.econ.279803

Backhaus, K., Erichson, B., Plinke, W. und Weiber, R. (2016). Multivariate Analysemethoden. Eine anwendungsorientierte Einführung. Springer Gabler, Berlin, Heidelberg. doi: 10.1007/978-3-662-46076-4

Barnes-Vieyra, P. und Claycomb, C. (2001). Business-to-business E-commerce: models and managerial decisions. Business Horizons 44(3): 13-20. doi: 10.1016/S0007-6813(01)80030-6

Batte, M.T. (2006). Shopping at the Farm Office: What Is the Future of Farm E-commerce? Journal of the American Society of Farm Managers and Rural Appraisers 2006(387-2016-22853): 100 105. doi: 10.22004/ag.econ. 190698

Batte, M. T. und Ernst, S. (2007). Net Gains from 'Net Purchases? Farmers' Preferences for Online and Local Input Purchases. Agricultural and Resource Economics Review 36(1): 84-94. doi: 10.1017/S1068280500009461 doi: 10.22004/ag.econ.127281

Borchers, B., Roucan-Kaneb, M., Alexander, C., Boehlje, Michael, D., Downeye, W., Scott und Gray, Allan, W. (2012). How Large Commercial Producers Choose Input Suppliers: Expendable Products from Seed to Animal Health. International Food and Agribusiness Management Review 15(2): 1-20.

Briggeman, B. C. und Whitacre, B. E. (2010). Farming and the Internet: Reasons for Non-Use. Agricultural and Resource Economics Review 39(3): 571-584. doi: $10.1017 / \mathrm{S} 1068280500007528$

Brosius, F. (1998). SPSS 8.0: professionelle Statistik unter Windows. Mitp-Verlag, Bonn.

Bundesregierung (2014). Digitale Agenda 2014 - 2017 Digitaler Zugang für ländliche Gebiete. https://bit.ly/3j5xRpX. (25.02.21).

Canavari, M., Miniucchi, D., Nocella, G. und Viaggi, D. (2003). Electronic commerce in agriculture and agribusiness: The case of Emilia-Romagna (Italy). 4th Conference of the European Federation of Information Technology in Agriculture, Food and Environment EFITA, Debrecen, Hungary.

Cho, J. (2004). Likelihood to abort an online transaction: influences from cognitive evaluations, attitudes, and behavioral variables. Information \& Management 41(7): 827-838. doi: 10.1016/j.im.2003.08.013

Clasen, M. (2005). Erfolgsfaktoren digitaler Marktplätze in der Agrar- und Ernährungsindustrie. Dissertation. Deutscher Universitätsverlag, Wiesbaden.

Clasen, M. und Mueller, R. A. E. (2006). Success factors of agribusiness digital marketplaces. Electronic Markets 16(4): 349-360. doi: 10.1080/10196780600999809 
Clasen, M., Müller, Rolf, A. E. und Abdul Madjied (2003). Digitale Marktplätze in der LandwirtschaftTotal virtuell? Zeitschrift für Agrarinformatik 1(3): 8-15.

DBV (2012). Frauen in der Landwirtschaft stark vertreten. Deutscher Bauernverband. https://www.lifepr.de/inaktiv/deutscher-bauernverband-ev-berlin/Frauen-in-derLandwirtschaft-stark-vertreten/boxid/282698. (01.07.18).

Deter, A. (2018). Landwirte müssen immer mehr Zeit für Bürokratie aufwenden. Top agrar online. https://www.topagrar.com/management-und-politik/news/landwirte-muessen-immer-mehrzeit-fuer-buerokratie-aufwenden-9605281.html. (25.02.21).

Ehmke, C., Ernst, S., Hopkins, J. und Tweeten, L. (2001). The Market for E-commerce Services in Agriculture. Select Paper for Agricultural and Applied Economics Association (AAEA) Annual Meetings, Chicago, Illinois 1-16.

El Gawady, Z. M. (2005). The Impact of E-commerce on Developed and Developing Countries Case Study: Egypt and United States. International conference of Globalization. Technology and Sustainable Development, United Arab Emirates University.

Ernst, S. und Tucker, M. (2001). Perceptions and adoption of information technologies: implications for Ohio's produce industry in the new economy. The Ohio State University, Division of Agricultural, Environmental, and Development Economics, Working Paper Series: AEDE-WP0016-01.

Fecke, W., Danne, M. und O. Mußhoff (2018). E-commerce in agriculture: The case of crop protection product purchases in a discrete choice experiment. (DARE) Diskussionsbeitrag Nr. 1803. Georg-August-Universität, Göttingen.

Fellnhofer, K. und Hinterhuber, H. (2011). Vertrauen in die (digitale) Zukunft Digitale Marktplätze fördern die Landwirtschaft. Ländlicher Raum Online-Fachzeitschrift des Bundesministeriums für Land- und Forst wirtschaft, Umwelt und Wasserwirtschaft 02(11): 1-7.

Fritz, M. (2007). New approaches in electronic commerce and marketing in the agri-food sector. In: Theuvsen, L., Spiller, A., Peupert, M. und Jahn, G. (Hrsg.) Quality management in food chains. Wageningen Academic Publishers, Wageningen, 463-474.

Fusilier, M. und Durlabhji, S. (2005). An exploration of student internet use in India: the technology acceptance model and the theory of planned behaviour. Campus-Wide Information Systems 22(4): 233-246. doi: 10.1108/10650740510617539

Gartzke, S. (2016). Kleffmann Group Global New Media Tracker - Our international Study. In: Farwick, C. (ed) Kleffmann Group. Agri Experts Around the World. Newsletter, 18-21.

Gollisch, S. und Theuvsen, L. (2015). Risikomanagement im Landhandel: Charakteristika, Herausforderungen, Implikationen. Berichte über Landwirtschaft Zeitschrift für Agrarpolitik und Landwirtschaft 93(1): 1-16. doi: 10.12767/buel.v93il.72

GTAI (2017). Zahlungsmethoden im Onlinehandel sind in Deutschland stark produktabhängig. Germany Trade and Invest https://www.gtai.de/gtai-de/trade/specials/zahlungsmethoden-imonlinehandel-sind-in-deutschland-stark-55382.pdf. (25.02.21).

Gunderson, M.A., Boehlje, Michael, D. und Gray, Allan, W. (2005). Segmenting Agribusiness Customers on their Capital Expenditures. Paper to be presented at the 2005 International Food \& Agribusiness Management Association World Food and Agribusiness Symposium. Purdue University.

Hair, J.F., Black, W.C., Babin, B.J. und Anderson, R.E. (2009). Multivariate data analysis. A Global Perspective. Pearson Prentice Hall, Upper Saddle River.

Håkansson, H. (1982). International marketing and purchasing of industrial goods: An interaction approach. John Wiley \& Sons, New York.

Hemmerling, U., Pascher, P. und S. Naß (2016). Situationsbericht 2016/17: Trends und Fakten zur Landwirtschaft. Deutscher Bauernverband, Berlin. 
Henderson, J., Dooley, F. und Akridge, J. (2004). Internet and E-Commerce Adoption by Agricultural Input Firms. Review of Agricultural Economics 26(4): 505-520. doi: 10.2307/3700794

Henderson, J. R., Akridge, J. T. und Dooley, F. J. (2006). Internet and e-Commerce Use by Agribusiness Firms: 2004. Journal of Agribusiness 24(345-2016-15133): 17-39. doi: 10.22004/ag.econ.57697

Henderson, J. R., Dooley, F. J. und Akridge, J. T. (2000). Adoption of E-Commerce strategies for agribusiness firms. Selected Paper at the American Agricultural Economics Association Annual Meeting. doi: 10.22004/ag.econ.21771

Hoffmann, C., Al-Askari, A., Hoang, K. und Doluschitz, R. (2014). Development trends in agricultural apps-an interim review. Landtechnik 69(5): 250-255.

Joines, J. L., Scherer, C. W. und Scheufele, D. A. (2003). Exploring motivations for consumer Web use and their implications for e-commerce. Journal of Consumer Marketing 20(2): 90-108. doi: 10.1108/07363760310464578

Kaiser, H. F. und Rice, J. (1974). Little jiffy, mark IV. Educational and psychological measurement 34(1): 111-117.

Kool, M. (1994). Buying behavior of farmers. Kool, Wageningen.

Koufaris, M. (2002). Applying the Technology Acceptance Model and Flow Theory to Online Consumer Behavior. Information systems research 13(2): 205-223. doi: $10.1287 /$ isre.13.2.205.83

Kuhlmann, H., Quinckhardt, K. und Miethe, R. (2016). Frauen in der Landwirtschaft in Nordrhein Westfalen. https://www.rheinische-landfrauen.de/fileadmin/user_upload/Landesverband/Aktuelles/Download_BBF_2016_kpl.pdf. (10.06.18).

Manou selis, N., Konstantas, A., Palavitsinis, N., Costopoulou, C. und Sideridis, A., B. (2009). A Survey of Greek Agricultural E-Markets. Agricultural Economics Review 10(1): 97-112. doi: 10.22004/ag.econ.58282

Mathew, P. M. (2016). Attitude segmentation of Indian online buyers. Journal of Enterprise Information Management 29(3): 359-373. doi: 10.1108/JEIM-08-2014-0078

Mishra, A. K. und Williams, R. P. (2006). Internet access and use by farm households. Paper for presentation at the 2006 American Agricultural Economics Association annual meeting. (3792016-22000). doi: 10.22004/ag.econ.21106

Monsuwé, T. P., Dellaert, B. G. C. und Ruyter, K. de (2004). What drives consumers to shop online? A literature review. International Journal of Service Industry Management 15(1): 102-121. doi: $10.1108 / 09564230410523358$

Ostrom, T. M. (1969). The relationship between the affective, behavioral, and cognitive components of attitude. Journal of experimental social psychology 5(1): 12-30. doi: 10.1016/0022-1031(69)90003-1

Park, T. and Mishra, A. (2003). Internet Usage by Farmers: Evidence from a National Survey. American Agricultural Economics Association Annual meeting, Montreal, Canada, 27-30. doi: 10.22004/ag.econ. 21940

Pascher, P., Hemmerling, U. und S. Naß (2018). Situationsbericht 2018_2019 Trends und Fakten zur Landwirtschaft. Deutscher Bauernverband e.V., Berlin.

Pellens, V. (2018). Landwirtschaft 2018 im Kleverland: Mehr im Büro als im Stall. RP ONLINE. https://rp-online.de/nrw/staedte/56mmerich/landwirtschaft-2018-im-kleverland-mehr-imbuero-als-im-stall_aid-23623029. (25.02.21).

Rose, S., Clark, M., Samouel, P. und Hair, N. (2012). Online Customer Experience in e-Retailing: An empirical model of Antecedents and Outcomes. Journal of Retailing 88(2): 308-322. doi: $10.1016 /$ j.jretai.2012.03.001 
Rosenberg, M. J., Hovland, C. I., McGuire, W. J., Abelson, R. P. und Brehm, J. W. (1961). Attitude Organization and Change: An Analysis of Consistency Among Attitude Components. Revue Française de Sociologie 24(4): 333. doi: 10.2307/3319768

Rosskopf, K. und Wagner, P. (2006). Vom Daten- zum Wissensmanagement: Wofür verwenden Landwirte einen Computer. In: Wenkel, K.O., Wagner, P., Morgenstern, M., Luzi, K. und Eisermann, P. (Hrsg.) Land- und Ernährungswirtschaft im Wandel: Aufgaben und Herausforderungen für die Agrar- und Umweltinformatik, Referate der 26. GIL Jahrestagung, 6.-8. März 2006, Potsdam, Germany LNI, P-78. Gesellschaft für Informatik e.V., Bonn, 225228.

Schwartz, M. (2017). E-Commerce steckt im Mittelstand noch in den Kinderschuhen. KfW Research Fokus Volkswirtschaft 161(12): 1-6. https://www.kfw.de/PDF/DownloadCenter/Konzernthemen/Research/PDF-Dokumente-Fokus-Volkswirtschaft/Fokus-2017/FokusNr.-161-Februar-2017-E-Commerce.pdf? (20.03.2020)

Shih, H.-P. (2004). An empirical study on predicting user acceptance of e-shopping on the Web. Information \& Management 41(3): 351-368. doi: 10.1016/S0378-7206(03)00079-X

Smith, A., Goe, W. R., Kenney, M. und Paul, C. J. M. (2004). Computer and Internet Use by Great Plains farmers. Journal of Agricultural and Resource Economics 29(3): 481-500. doi: 10.22004/ag.econ.30918

Späth, N. (2014). The E-Commerce Market in Germany. Germany Trade and Invest - Gesellschaft für Außen wirtschaft und Standortmarketing mbH, Berlin.

Statistisches Bundesamt (2014). Land- und Forstwirtschaft, Fischerei Betriebswirtschaftliche Ausrichtung und Standard out put Agrarstrukturerhebung. Fachserie 3 Reihe 2.1.4. https://bit.ly/3fd3DA4. (01.07.18).

Strecker, O., Strecker, O.A., Elles, A., Weschke, H.-D., Kliebisch, C. und Enneking, U. (2010). Marketing für Lebensmittel und Agrarprodukte. DLG-Verlag, Frankfurt a. Main.

Stricker, S., Sundermeier, H. H. und Müller, R. A. (2001). Landwirte im Internet: Stand der Nutzung und Verwendungsabsichten. In: Kögl, H., Spilke, J. und Birkner, U. (Hrsg.) Dynamische Simulation und nachhaltiges Grundwassermanagement in Syrien. Referate der 22. GILJahrestagung, Rostock, 138-142.

Strzębicki, D. (2015). The Development of Electronic Commerce in Agribusiness - The Polish Example. Procedia Economics and Finance 23(2015): 1314-1320. doi: 10.1016/S2212-5671(15)00573-0

Taragola, N. M. und van Lierde, D. F. (2010). Factors affecting the Internet behaviour of horticultural growers in Flanders, Belgium. Computers and electronics in agriculture 70(2): 369-379. doi: 10.1016/j.compag.2009.09.004

van der Heijden, H., T. Verhagen und M. Creemers (2001). Predicting online purchase behavior: replications and tests of competing models. Proceedings of the 34th Annual Hawaii International Conference on System Sciences, Hawaii.

Vidyasekar, A.D. (2014). Future of B2B online retailing. Fost \& Sullivan. https://store.frost.com/futureof-b2b-online-retailing.html. (02.07.18).

Vijayasarathy, L. R. (2003). Shopping orientations, product types and internet shopping intentions. Electronic Markets 13(1): 67-79. doi: 10.1080/1019678032000039903

Voss, J. (2008). Customer-Relationship-Management im Agribusiness. Dissertation. Sierke Verlag, Göttingen.

Watson, J. C. (2017). Establishing evidence for internal structure using exploratory factor analysis. Measurement and Evaluation in Counseling and Development 50(4): 232-238. doi: $10.1080 / 07481756.2017 .1336931$ 
Wheatley, W.P., Buhr, B.L. und D. DiPietre (2001). E-Commerce in agriculture: development, strategy, and market implications. Staff Papers 13938. University of Minnesota, Department of Applied Economics, Minnesota.

Wittmann, G. und Listl, C. (2017). Online-Kaufverhalten im B2B-E-Commerce 2017. Ergebnisse einer Expertenbefragung von ibi research an der Universität Regensburg, Creditreform und SIX Payment Services. Ibi research an der Universität Regensburg GmbH, Regensburg.

Zimmermann, M. (2003). Das Kaufverhalten von Landwirten im Bereich landwirtschaftlicher Investitionsgüter. Dissertation. Cuvillier Verlag, Göttingen. 


\section{I.2 Agricultural E-Commerce Attitude Segmentation of Farmers}

Authors: Dorothee Schulze Schwering, Winnie Isabel Sonntag \& Sarah Kühl

This article was submitted in a similar form for review at Computers and Electronics in Agriculture. 


\title{
I.2 Agricultural E-Commerce: Attitude Segmentation of Farmer
}

\begin{abstract}
E-commerce in agricultural trade is a growing market segment. Therefore, knowledge about the online purchasing behavior of farm managers is increasing important for several stakeholders. The purpose of this study is to explore agricultural online buying behavior from a multidimensional perspective. By means of an online survey among 371 German farmers, the attitudinal segmentation of online farmers is investigated using the tripartite model of attitudes. Four clusters were identified: business professionals, loyal offliners, online fans, and online hesitators. Results show that the advantageousness (convenience) was rated the highest and has the greatest separating power, while affective attributes are less important to farmers. Loyal offliners demonstrate that a positive emotional and cognitive evaluation does not necessarily increase the intention to use. In addition, the cluster of business professionals express that a lack of enjoyment does not automatically lead to a lower use of e-commerce. They manage large farms and are driven by the tangible advantages of the internet. The segmentation shows that there are different farmer groups needing an individual communication strategy and individual product features when buying agricultural inputs online. This can help to make online offers more attractive and increase farmers' usage intentions.
\end{abstract}

Keywords: Online shopping, ABC model, purchase behavior, B2B, input purchasing, agribusiness 


\section{$1 \quad$ Introduction}

E-commerce is gaining importance in agribusiness. Driven by the expansion of the internet infrastructure in rural areas as part of the digital agenda (European Commission, 2021), agriculture is experiencing a digital upheaval, opening new possibilities for documentation, precision production, and procurement of information and farm inputs. Today, about eight out of ten farmers already use digital technologies (Bitkom, 2020). From these technological advances, e-commerce has emerged as a new form of retail and a potential strategic tool for agricultural businesses to become more successful in a digital economy, because more information and markets become available to buyers (Negrão, 2018). Globally, the number of online marketplaces and online stores for agri cultural inputs has rapidly increased by both startups and long-established traders or manufacturers in recent years (Deutsch et al., 2020; Huchtemann and Theuvsen, 2018; Munz and Doluschitz, 2020). In Germany, for example, around 20 new marketplaces have entered the market within four years, $15 \%$ of which exclusively market farm input materials (Bickert, 2020; Huchtemann and Theuvsen, 2018). However, studies show that farmers are somewhat reluctant toward online purchasing of farm inputs. Inputs are preferably bought locally, and e-commerce penetration rates are correspondingly low for most input categories (Ackermann et al., 2018; Ardrey et al., 2020). Although the online offer is increasing, only $13 \%$ of European farmers made an online purchase of farm inputs in 2019 (Ardrey et al., 2020).

The increasing share of e-commerce offers in agricultural trade and the so far hesitant behavior of farmers stimulate significant interest in understanding what impacts a farmer's decision to engage in or refrain from online purchasing for farm inputs. Among the array of factors that have been examined in previous research as potential determinants of general online shopping, attitude has shown a significant influence on online shopping behavior (Chang et al., 2005; Javadi et al., 2012). While general studies on online shopping attitudes are widely available in the literature, there are only few studies of farmers' online shopping attitudes. The existing studies showed that convenience, time and cost savings, and flexibility positively influence an online purchase for agricultural inputs (Ackermann et al., 2018; Fecke et al., 2018; Gartzke, 2016; Henderson et al., 2006). In addition, mistrust, security concerns, lack of personal contact, and farmers' sense of loyalty negatively influence operational online shopping (Batte and Ernst, 2007; Batte, 2006; Gartzke, 2016; Henderson et al., 2006). Within these studies, emotions have been largely neglected, which may have contributed to mixed and inconsistent results (Dittmar et al., 2004; Hasan, 2010). Thus, there is a need to better understand the attitude of 
farmers towards e-commerce, as it is crucial for the implementation and design of online stores and online marketplaces to attract and retain customers (Hasan, 2010). Furthermore, most studies use attitude as a single-factor concept and focus mainly on its affective or cognitive aspect (Hasan, 2010), although attitude is a multidimensional variable with affective, behavioral and cognitive components (ABC model), (Fishbein and Ajzen, 1975).

The aim of this paper is therefore to expand on the existing knowledge base by analyzing farmers' online shopping attitudes based on a multidimensional concept. It is crucial to explore attitude formation because behavioral changes towards online shopping can be adjusted or at least influenced if e-commerce providers know how to improve new attitudes among their customers (Mathew, 2016). To the authors' knowledge, this is the first segmentation study on agricultural e-commerce. An online survey of the online buying behavior of 371 German farmers for agricultural inputs serves as the data basis. The paper analyzes data using principal component analysis (PCA) and cluster analysis. The results can help to make online offers more attractive to farmers, as e-commerce providers know which attributes form farmers' online attitudes and satisfaction and hence willingness to use.

The following is an overview of the current state of research on the two research areas, attitudes toward e-commerce and agricultural e-commerce. Subsequently, the applied data collection and evaluation methods are presented, followed by the results. Finally, in the discussion part, the results are critically examined and interpreted based on the presented theory.

\section{Research background}

\subsection{Attitude measurement in e-commerce research}

The concept of attitude and its formation is common in consumer studies and is a critical element of many consumer models (Mathew, 2016). Attitude is part of the theory of reasoned action (TRA) by Ajzen and Fishbein (1980) and describes a learned predisposition to respond to an object in a consistently evaluative manner (Fishbein and Ajzen, 1975). Accordingly, the attitude evolves over time as people gain experience with or knowledge about the object. The formed attitude then stimulates the behavior or actions towards the object. The structural, multidimensional model of attitude goes back to Rosenberg et al. (1960) and comprises three components: the affective (A), behavioral (B), and cognitive (C) component - the ABC model of attitude (Fig. 1). The affective component serves statements that represent (dis-)like, favors, feelings, or emotions toward an object (Ostrom, 1969). Statements of personal actions tendencies belong to the behavioral component and cover past action, future intentions, 
or predicted behavior. The cognitive component includes perceptual responses and statements of values and attributes assigned to the object. This could incorporate beliefs about or characteristics of the object which are not on the emotional continuum (Ostrom, 1969).

Attitude is receiving much attention in research and plays an essential role in other online applications, such as mobile advertising (Martínez-Ruiz et al., 2017), e-banking (Ayo et al., 2016), or smartphone apps (Maghnati and Ling, 2013). Among e-commerce studies, attitude shows a positive relationship with e-purchase decisions and intention (Theo and Liu, 2007; Um, 2019; Zendehdel et al., 2015). However, the studies often differ regarding the degree of influence of attitude on online shopping. Different definitions and conceptualizations of attitude explain this. Usually, the cognitive component, i.e., the perceived advantages and disadvantages of online shopping, or the affective component, i.e., positive feelings about online shopping, is considered (Hasan, 2010).

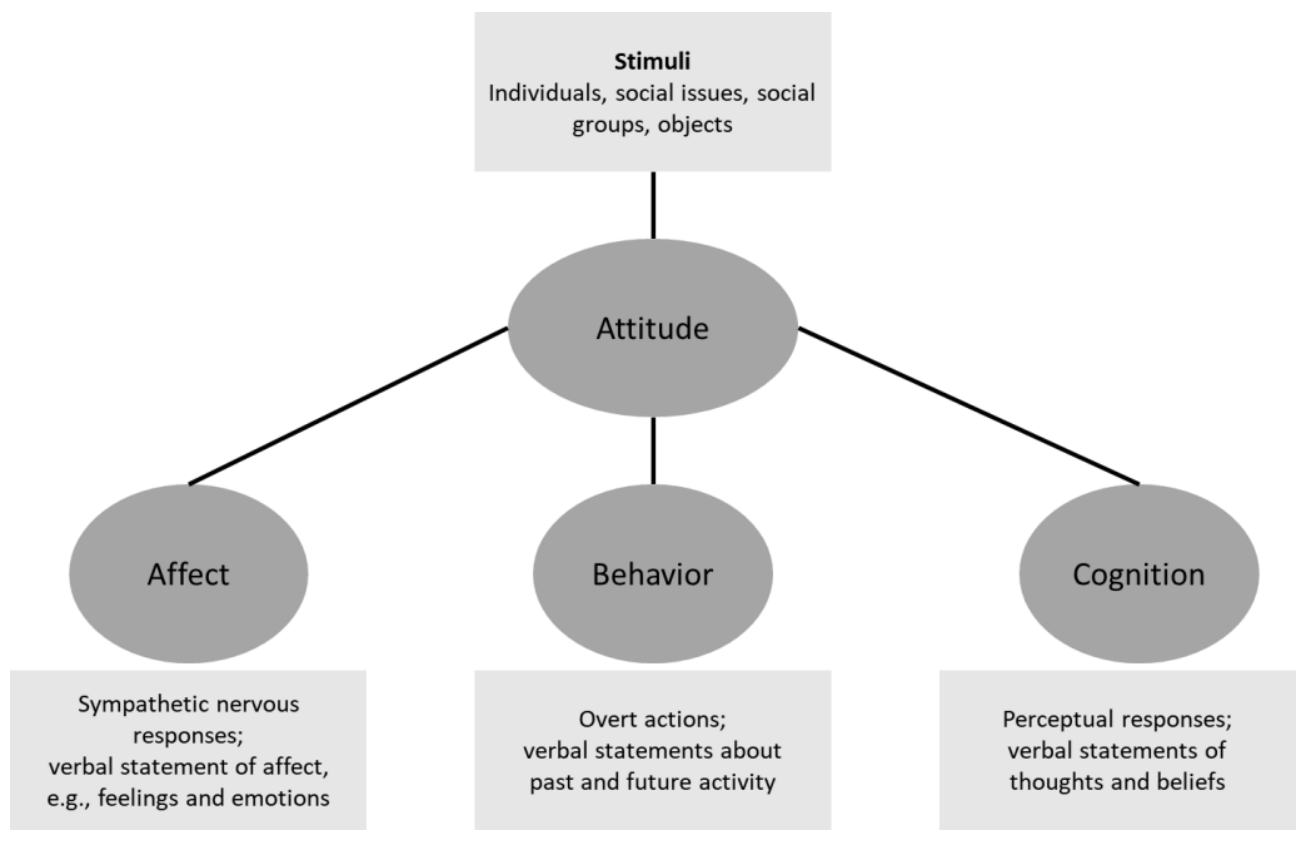

Figure 1: Tripartite model of attitude structure

Source: Own elaboration according to Rosenberg et al., (1960)

Some studies concede that attitude toward online shopping is a trifactorial construct (Hasan, 2010; Mathew, 2016; Moon et al., 2017). By analyzing the shopping behavior and attitudes towards online shoe shopping, Hasan (2010) was able to show that the behavior for men and women is influenced differently by all three attitude components. It is especially interesting that men's cognitive, affective, and behavioral attitudes are stronger than those of women, with the difference being greatest for cognition. The surprising lower affective attitude of women could be explained by their tendency to prefer conventional shopping over online shopping, as they value the emotional and psychological experience of shopping (e.g., emotional, social, 
and interpersonal interactions), while men tend to value functionality and convenience (Dittmar et al., 2004; Hasan, 2010). Moreover, online shopping cognition (higher in men) is known to be a strong antecedent to affective online shopping attitude. Thus, the results clearly show that all three components of attitude measurement are important.

Mathew (2016) performed a segmentation of Indian online buyers according to their internet usage and identified the attitude of each segment. Respondents were divided into four segments based on their e-usage. The segment with the lowest e-usage (less than 2 hours per day) enjoyed online shopping and appreciated its benefits, but their high perceived risk kept them from online shopping. On the other hand, the segment with the highest e-usage (more than eight hours per day), showed the highest online shopping enjoyment, a high degree of perceived online shopping risks, and a high importance of website attributes like information quality or product range. To explain attitude formation per segment, the hierarchy-of-effects model was adapted. It resulted in a different importance arrangement of the three attitude components forming three new segments, indicating that attitudinal segmentation is an appropriate segmentation method for online shoppers. Similar to Hasan's (2010), two clusters in Mathew's (2016) segmentation showed an attitude formation with cognition influencing affect, which then influences online shopping behavior and intention.

Moon et al. (2017) applied a structural equation modeling (SEM) and found that both consumers' cognitive and affective attitudes influence the online purchase intention towards apparel brands. The cognitive attitude here assumes that online shopping is necessary, functional, effective, helpful, and practical. The affective attitude includes positive feelings towards online shopping as being fun, exciting, delightful, thrilling, and joyful. Their results showed that cognitive and affective attitudes are important predictors of online shopping intentions, with cognitive attitude being a more robust predictor.

The literature shows that there are conflicting results about what has the stronger influence on online behavior or intention - with a propensity that cognition have greater influence. Further empirical results revealed that hedonic performance (enjoyment: fun, joy, interest, excitement, entertainment) contributes more to consumers' online buying intensity or purchase intention than perceived usefulness and perceived ease of use (Cheema et al., 2013; Liu and Forsythe, 2011) and strengthens the desire to stay at an online store website (Kim et al., 2007). Besides positive emotions, Gao and Koufaris (2006) also investigated perceived irritation (frustration, irritation, anger) as a result of visiting a website for nonperishable goods (e.g., furniture, camera). This is negatively associated with attitudes towards a website and thus impacts the 
intention to return. Emotions are present at several points in an e-commerce relationship, ranging from purchase intention to post-purchase behavior (Lievonen, 2017). Studies suggest that positive emotional appeals are evaluated depending on the product involvement. Emotional appeals work better at lower product category involvement (e.g., candy bar), and informational appeals work better at high product involvement (e.g., laptop), (Dens and Pelsmacker, 2010).

To the authors knowledge, studies on business-to-business (B2B) attitude formation using the ABC model are not available. However, it has been shown that the cognitive perceptions of e-commerce benefits (e.g., reducing transaction costs, improving work performance) and hassles (e.g., technological and organizational readiness) are key factors in determining its use (Chaudhary et al., 2018; Hamad et al., 2018). It is further known that emotions also play a role in B2B e-commerce decision making, although it differs from the business to consumer (B2C) market (Pandey and Mookerjee, 2018; Thakur and AlSaleh, 2020). Perceived enjoyment and excitement of websites used to purchase products and services influences managers' attitudes towards the website and increases the intention to use them accordingly (Thakur and AlSaleh, 2020). Pandey and Mookerjee (2018) interviewed managers involved in the vendor choice process and found that in $\mathrm{B} 2 \mathrm{~B}$ transactions, affective factors, such as power of relationships, empathy, and emotional bonds between vendor and the customer, play an important role. This is similar to results of Saprikis and Vlachopoulou (2012) who found that external factors, such as perceived business partner pressure, influence the use of B2B marketplaces, even if the characteristics of the applied e-marketplace (services, ownership status, operational rules) show a stronger influence.

However, studies on attitude formation in accordance with the $\mathrm{ABC}$ model are not available in B2B e-commerce literature. Similar to B2C e-commerce research, attitude in most B2B e-commerce studies is investigated as a single factor construct and more reflected by the perception of cognitive rational factors.

\subsection{Agricultural e-commerce}

In line with attitude-related B2B e-commerce research, studies on agricultural e-commerce adoption show a very strong cognitive approach focusing primarily on the drivers and barriers of e-commerce. Table 1 provides a literature overview of factors influencing e-commerce acceptance by farmers, sorted by barriers and drivers.

According to these studies, the acceptance of e-commerce applications increases with the degree to which they offer advantages over stationary retail (Batte and Ernst, 2007; 
Fecke et al., 2018). These include price advantages (Batte and Ernst, 2007; Henderson et al., 2006; Kalaitzandonakes et al., 2003), time savings (Ackermann et al., 2018; Batte and Ernst, 2007), simplified information retrieval (Henderson et al., 2006; Henderson et al., 2004), and increased flexibility, mobility, accessibility, and spontaneity (Gartzke, 2016; Hoffmann and Grethler, 2013). Positive e-commerce experiences also reinforce trust in this form of purchasing (Fecke et al., 2018). According to Henderson et al. (2006) and Gartzke (2016), the focus on a high degree of convenience promotes the acceptance of e-commerce offers by farmers.

Table 1: Factors influencing agricultural e-commerce

\begin{tabular}{ll}
\hline Factor & Literature \\
\hline Drivers & \\
\hline Time-savings & Ackermann et al., 2018; Batte and Ernst, 2007 \\
\hline Convenience & Gartzke, 2016; Henderson et al., 2006 \\
\hline Ordering flexibility & Gartzke, 2016 \\
\hline Mobility and spontaneity & Hoffmann and Grethler, 2013 \\
\hline Product range & Henderson et al., 2006; Henderson et al., 2004 \\
\hline Cost-savings & Batte and Ernst, 2007; Clasen, 2005; Fecke et al., 2018; \\
\hline Simplified information retrieval & Henderson et al., 2006 \\
\hline Easier product comparisons & Henderson et al., 2006; Henderson et al., 2004 \\
\hline Barriers & Henderson et al., 2006 \\
\hline Mistrust & \\
\hline Privacy/security concerns & Gartzke, 2016; Henderson et al., 2006 \\
\hline Risk aversion & Briggeman and Whitacre, 2010; Henderson et al., 2006 \\
\hline Regional supply system & Fecke et al., 2018; Taragola and van Lierde, 2010 \\
\hline Loyalty and trust to local trade & Ackermann et al., 2018 \\
\hline Lack of personal contact & Batte and Ernst, 2007; Gartzke, 2016 \\
\hline Lack of after-sales service & Ardrey et al., 2020; Briggeman and Whitacre, 2010; Gartzke, \\
\hline Anonymous online character & 2016 \\
\hline Confusion/irritation & Ardrey et al., 2020; Briggeman and Whitacre, 2010 \\
\hline
\end{tabular}

Source: Own elaboration.

Factors such as trust (Batte and Ernst, 2007; Gartzke, 2016), privacy and security concerns (Briggeman and Whitacre, 2010), trader relationships (Ackermann et al., 2018; Gartzke, 2016), internet anonymity (Fritz et al., 2007), and risk aversion (Fecke et al., 2018; Taragola and van Lierde, 2010) act as inhibitors to online purchasing of agricultural inputs. Here trust and the relationship with local traders are key factors. On the one hand, trust is related to trust toward the e-commerce provider, where known providers are always preferred to new providers (Batte and Ernst, 2007) and, on the other hand, to the strong commitment and long-term relationship with local retailers (Ackermann et al., 2018; Gartzke, 2016). Ackermann et al. (2018) indicate 
that a good regional supply system through local rural dealerships is a decisive e-commerce barrier. In addition, farmers appreciate personal contact with suppliers and the after-sales service when buying locally, which they do not expect to get from online stores (Ardrey et al., 2020; Gartzke, 2016). Along with this, farmers complain about the anonymous nature of internet shopping (Fritz et al., 2007) and confusing or irritating price and product information (Ardrey et al., 2020).

As current usage rates already suggest, e-commerce usage depends on product features. In this context, standardized experience goods (spare parts, daily equipment), products with brand names, and original packaging are particularly well-suited for online commerce (Ackermann et al., 2018; Batte and Ernst, 2007; Batte, 2006; Leroux et al., 2001).

A consideration of the emotional level of farmers in connection with online purchasing, which is certainly present in rationally oriented purchasing processes, has not been available so far. As Table 1 shows, agricultural economics research has mainly examined influencing factors assigned to the cognitive attitude component, i.e., that address statements or responses of values or attributes assigned to online shopping which are not on an emotional level (Ostrom, 1969). Cognitive attributes often refer to utilitarian traits like perceived ease of use or perceived usefulness. In the context of attitude formation, however, it is important to know which emotions arise during online shopping and how they affect attitude formation. Knowing the formation of customer attitudes helps to positively influence attitudes in a targeted manner, to increase the customer e-commerce experience, and thus to contribute to an increased e-commerce usage rate.

\section{$3 \quad$ Materials and Methods}

\subsection{Data collection and questionnaire design}

In this study, 371 German farmers were interviewed about their attitudes toward farm-related online purchasing using an online questionnaire. The online survey took place from April to May 2017. The distribution of the survey link was e-mailed throughout Germany to about 4.000 farm enterprises. In addition, several agricultural associations and magazines supported the distribution of the survey via e-mail, internet pages, and social media channels. A total of 894 farmers started the survey. The data set was first subjected to a quality check. As a result, $44 \%$ $(n=400)$ of the participants answered the filter question positively, i.e., whether they have initial experience with farm-related online shopping, and responded to the questionnaire in full. In a second step, respondents with a completion time below 6 minutes, less than $1 / 3$ of the 
average completion time, were removed $(\mathrm{n}=17)$. Also, participants that revealed inconsistent or conspicuous answering patterns were removed from the data set $(\mathrm{n}=12)$. After careful data clearing, the sample for this study contained valid data sets from 371 German farmers.

In the first part of the survey, farmers were asked about their internet usage behavior and use of e-commerce for purchasing various inputs. The central part of the questionnaire was structured according to the $\mathrm{ABC}$ model. The statements for investigating affective, cognitive, and behavioral attitudes are based on Ostrom's (1969) basic definitions and are oriented towards the statements of previous e-commerce studies, such as by Moon et al. (2017), Hasan (2010), or Goldsmith and Goldsmith (2002), (see below). These statements were assessed using a five-point Likert scale ranging from $1=$ "fully agree" to $5=$ "fully disagree". The last section of the questionnaire collected the sociodemographic and farmographic data of each participant.

\subsection{Data analysis}

The data analysis was carried out using the statistics software IBM SPSS Statistics 26. At first, descriptive statistics were conducted to describe the demographic characteristics of the sample. The usage intensity of e-commerce was identified based on three variables, which recorded a) the general frequency of use per order channel (telephone, fax, e-mail, online shop, on-site retailer), b) the preferred purchase channel (on-site retailer, manufacturer, online shop) per product group, and c) the online buying frequency per product group (feed, fertilizer, plant protection, seeds and planting material, maintenance materials for buildings and machines, energy and fuel, materials for daily use). The frequencies were presented on a five-point Likert scale ranging from $1=$ "very often" to $5=$ "never". Based on the three variables, an e-commerce usage index ranging from 1 (frequent use for $\geq$ four product groups) to 5 (non-use for any product group) was created.

Factor analysis and cluster analysis are used to explore the dataset regarding the research question. Since too many variables are a general problem of cluster analyses and can lead to problems such as multicollinearity (Fraiman et al., 2008), it makes sense to use only few feature variables. This can lead to better clustering models with easier interpretation and/or to a better partitioning of the data into clusters that are closer to the actual underlying group structure (Marbac and Sedki, 2017; Raftery and Dean, 2006). Therefore, the cluster analysis was based on selected clustering variables in accordance with the existing literature. Statements with a positive emotional expression were used for the affective component, as these have a positive influence on usage intention and online purchasing behavior (Ashraf and Pérez-Vega, 2015; Goldsmith and Goldsmith, 2002; Hasan, 2010; Mathew, 2016; Moon et al., 2017). 
For the cognitive component, variables on e-commerce advantages, including the perceived usability, were used (Goldsmith and Goldsmith, 2002; Gupta et al., 2019; Kim et al., 2009; Moon et al., 2017). The behavioral component included statements on the participants' behavioral intention to use online shopping for purchasing agricultural inputs in the future (Hasan, 2010; Moon et al., 2017).

A principal component analysis (PCA) with varimax rotation was conducted to reduce the number of items and to capture the central dimensions contributing to farmers' attitudes towards online purchasing. Before beginning the PCA, the initial data was tested for suitability for PCA using the Kaiser-Meyer-Olkin criterion (KMO), variable-specific measure of sampling adequacy (MSA), and Bartlett's test (Backhaus et al., 2016). This tests whether correlations exist between the variables (Bartlett's) and whether there is an appreciable relationship between the variables (MSA and KMO). Larger MSA or KMO values indicate that the variables are firmly related, and according to Kaiser and Rice (1974), a value below 0.5 is considered inappropriate for a PCA. Also, items with factor loadings below 0.5 were removed, according to Norris et al. (2014). The extracted factors then serve as the basis for the cluster analysis (Backhaus et al., 2016) to obtain homogeneous subgroups based on the identified attitude components.

The cluster analysis is carried out in several stages: Single-linkage clustering is first used to identify outliers, which are not considered in further calculations. Subsequently, the hierarchical cluster analysis using the proven Ward method and the squared Euclidean distance identifies the various possibilities for the number of clusters. The number of clusters is determined after a systematic comparison of the cluster possibilities using the dendrogram and the agglomeration table using the elbow criterion. The determined cluster number was additionally checked for its interpretability in terms of content. The cluster centroids are then used as a starting point for a final partitioning cluster method (K-means), which improves the homogeneity of the groups (Backhaus et al., 2016). Finally, the classification accuracy of the analysis is assessed using discriminant analysis. To assess the heterogeneity of the identified clusters, the F-values and the significances of the results were used. 


\section{$4 \quad$ Results}

\subsection{Description of the sample}

Table 2 provides an overview of the main sociodemographic and farmographic characteristics of the sample. $37 \%$ of study participants come from western Germany (Hesse, North RhineWestphalia, Saarland, and Rhineland-Palatinate) and southern Germany (35\%), (Bavaria, Baden-Wurttemberg). Only 6\% are from eastern Germany. The study consists of $83 \%$ male participants. The average age is 37 years, and the average farm size is 258 hectares. $84 \%$ of respondents' main occupation is farming. Around $16 \%$ of the surveyed farmers state that they are exclusively engaged in arable farming, and $47 \%$ are in pure animal husbandry, e.g., dairy, pig, or poultry farming. $31 \%$ indicate that they have a mixed-farm focus. Around $40 \%$ are focusing on farm growth, while $43 \%$ want to maintain the status quo, and $14 \%$ are planning to restructure - the remaining $4 \%$ plan to downsize or give up the business.

Table 2: Characteristics of the sample $(n=371)$

\begin{tabular}{lll}
\hline Attribute & & Percentage of the sample \\
\hline \multirow{4}{*}{ Regional distribution } & North & $22 \%$ \\
& East & $6 \%$ \\
& South & $35 \%$ \\
& West & $37 \%$ \\
\hline \multirow{5}{*}{ Age structure } & $<34$ years & $38 \%$ \\
& $35-44$ years & $18 \%$ \\
& $45-54$ years & $22 \%$ \\
\multirow{2}{*}{ Education } & $\geq 55-64$ years & $12 \%$ \\
\hline \multirow{5}{*}{ Farm size } & University degree & $36 \%$ \\
& $<20$ hectares & $8 \%$ \\
& $20-99$ hectares & $40 \%$ \\
& $100-199$ hectares & $27 \%$ \\
& $200-499$ hectares & $16 \%$ \\
& $\geq 500$ hectares & $9 \%$ \\
\hline \multirow{5}{*}{ Farm type } & Arable farming & $16 \%$ \\
& Animal husbandry & $47 \%$ \\
& Mixed farms & $31 \%$ \\
& Other & $6 \%$ \\
\hline \multirow{3}{*}{ Future farm perspective } & Growth & $40 \%$ \\
& Keep status quo & $43 \%$ \\
& Restructuring & $14 \%$ \\
\hline
\end{tabular}

Source: Own elaboration.

An online shopping index of 3.2 indicates a generally moderate or infrequent e-commerce use for an average of two farm input categories. The frequency analysis per input category shows that well-standardized search goods, such as maintenance materials and materials for daily use, 
are purchased online more frequently. On a Likert scale from 1="very frequently" to 5="never", the analyses showed mean values ranging from 2.4 to 3.1. Less standardized, partly individualized experience goods, on the other hand, are purchased online less frequently, with mean from 3.8 to 4.2. These include feed, fertilizers, crop protection, and seeds and seedlings, where fertilizer reveals the lowest online purchase frequency.

\subsection{Principal component analysis of clustering variables}

The results of the principal component analysis are presented in Table 3. Three factors could be formed with a total of nine items and an eigenvalue greater than one. The appropriate statements are rated as good, with a KMO value of 0.758 (Kaiser and Rice, 1974). Together they explain $65.53 \%$ of the variance of all variables. The internal consistency of the factors was tested using Cronbach's alpha $(\mathrm{C} \alpha)$, with all factors having a $\mathrm{C} \alpha$ greater than 0.68 , and are therefore acceptable. The first factor describes the affective attitude component and includes three statements on positive emotions evoked by online shopping, such as happiness, fun, anticipation. The second factor represents the cognitive attitude component containing three statements on the perceived usefulness and ease of use of online shopping. The third factor includes statements on respondents' behavioral intention to shop online.

Table 3: Results of the principal component analysis $(\mathrm{n}=366)$

\begin{tabular}{|c|c|c|c|c|}
\hline Factor & Statement & $\begin{array}{l}\text { Factor } \\
\text { loading }\end{array}$ & $\begin{array}{l}\text { Mean } \\
\text { value }\end{array}$ & $\begin{array}{l}\text { Standard } \\
\text { deviation }\end{array}$ \\
\hline \multirow{3}{*}{$\begin{array}{l}\text { Enjoyment } \\
\text { (Affective) } \\
\mathrm{C} \alpha: 0.74\end{array}$} & I enjoy buying things on the internet. & 0.616 & 2.95 & 0.86 \\
\hline & $\begin{array}{l}\text { I am happy when I've bought } \\
\text { something online. }\end{array}$ & 0.851 & 3.47 & 0.86 \\
\hline & $\begin{array}{l}\text { I am full of anticipation for the } \\
\text { product after buying online. }\end{array}$ & 0.854 & 3.14 & 0.92 \\
\hline \multirow{3}{*}{$\begin{array}{l}\text { Advantageousness } \\
\text { (Cognitive) } \\
\mathrm{C} \alpha: 0.73\end{array}$} & $\begin{array}{l}\text { Shopping on the internet is } \\
\text { convenient. }\end{array}$ & 0.845 & 2.00 & 0.76 \\
\hline & Shopping on the internet is easy. & 0.811 & 2.23 & 0.76 \\
\hline & Shopping on the internet saves time. & 0.662 & 2.24 & 0.88 \\
\hline \multirow{3}{*}{$\begin{array}{l}\text { Behavioral Intention } \\
\text { (Behavior) } \\
\mathrm{C} \alpha: 0.68\end{array}$} & $\begin{array}{l}\text { In the future, I will buy farm inputs } \\
\text { online when the price is lower than at } \\
\text { the local retailer. }\end{array}$ & 0.797 & 2.61 & 0.83 \\
\hline & $\begin{array}{l}\text { In the future, I will buy more farm } \\
\text { inputs online. }\end{array}$ & 0.849 & 2.83 & 0.79 \\
\hline & $\begin{array}{l}\text { In the future, I will also buy products } \\
\text { of high value online. }\end{array}$ & 0.650 & 3.49 & 0.95 \\
\hline
\end{tabular}

$\mathrm{KMO}=0.758$; total variance $=65.53 \%$; eigenvalue $>1$; item Likert-scales: $1=$ "fully agree" to $5=$ "fully disagree" Source: Own elaboration.

Table 3 shows that the items have mean values ranging from 2.0 to 3.5 on a five-point Likert scale from $1=$ "fully agree" to 5="fully disagree". Based on the mean values, it becomes clear 
that positive emotions triggered by online shopping, such as fun/enjoyment, are perceived somewhat less strongly compared to the benefits of online shopping with mean values slightly below 2.0 (agreement). With mean values between 2.6 and 3.5, the intention to buy online appears to be relatively restrained.

\subsection{Cluster analysis and cluster description}

Based on the three extracted factors, a cluster analysis was performed. Table 4 gives an overview of the characteristics of the clusters and the quality criteria of the cluster analysis. Using single-linkage clustering, five outliers could be identified, which are not considered in the following calculations (new $n=366$ ). The standard deviations within the clusters are lower than the general standard deviations, indicating the homogeneity of the clusters.

Table 4: Mean comparison of cluster building variables between the four clusters using ANOVA $(n=366)$

\begin{tabular}{|c|c|c|c|c|c|}
\hline & $\begin{array}{c}\text { Cluster I } \\
\text { Business } \\
\text { professionals }\end{array}$ & $\begin{array}{l}\text { Cluster II } \\
\text { Loyal } \\
\text { offliners }\end{array}$ & $\begin{array}{l}\text { Cluster III } \\
\text { Online } \\
\text { fans }\end{array}$ & $\begin{array}{l}\text { Cluster IV } \\
\text { Online } \\
\text { hesitators }\end{array}$ & Total \\
\hline $\begin{array}{l}\text { Cluster size }(\mathrm{n}) \\
(\%)\end{array}$ & $\begin{array}{c}99 \\
(27 \%)\end{array}$ & $\begin{array}{c}87 \\
(24 \%) \\
\end{array}$ & $\begin{array}{c}102 \\
(28 \%)\end{array}$ & $\begin{array}{c}78 \\
(21 \%)\end{array}$ & $\begin{array}{c}366 \\
(100 \%)\end{array}$ \\
\hline $\begin{array}{l}\text { Advantageousness } \\
\text { (Cognition) }\end{array}$ & $\begin{array}{l}-0.42^{\mathrm{bc}} \\
(0.73)\end{array}$ & $\begin{array}{l}-0.50^{\mathrm{a}} \\
(0.69)\end{array}$ & $\begin{array}{l}-0.2^{\mathrm{a}} \\
(0.69)\end{array}$ & $\begin{array}{l}1.36 \\
(0.69)\end{array}$ & \\
\hline F-value:128.36*** & 1.96 & 1.96 & 1.85 & 3.01 & 2.15 \\
\hline $\begin{array}{l}{ }^{1} \text { Shopping on the internet is } \\
\text { convenient. }\end{array}$ & $\begin{array}{l}1.80^{\mathrm{bc}} \\
(0.55)\end{array}$ & $\begin{array}{l}1.67 \mathrm{ac} \\
(0.55)\end{array}$ & $\begin{array}{l}1.76^{\mathrm{ab}} \\
(0.55)\end{array}$ & $\begin{array}{c}2.91 \\
(0.71)\end{array}$ & $\begin{array}{l}1.99 \\
(0.76)\end{array}$ \\
\hline${ }^{1}$ Shopping on the internet is easy. & $\begin{array}{l}2.04 \mathrm{bc} \\
(0.62)\end{array}$ & $\begin{array}{l}2.03 \mathrm{ac} \\
(0.64)\end{array}$ & $\begin{array}{l}1.93 \mathrm{ab} \\
(0.57)\end{array}$ & $\begin{array}{l}3.06 \\
(0.69)\end{array}$ & $\begin{array}{l}2.23 \\
(0.76)\end{array}$ \\
\hline $\begin{array}{l}{ }^{1} \text { Shopping on the internet saves } \\
\text { time. }\end{array}$ & $\begin{array}{l}2.05^{\mathrm{bc}} \\
(0.80)\end{array}$ & $\begin{array}{l}2.18^{\mathrm{a}} \\
(0.82) \\
\end{array}$ & $\begin{array}{r}1.84^{\mathrm{a}} \\
(0.67) \\
\end{array}$ & $\begin{array}{l}3.05 \\
(0.79)\end{array}$ & $\begin{array}{c}2.24 \\
(0.88)\end{array}$ \\
\hline $\begin{array}{ll}\begin{array}{l}\text { Enjoyment } \\
\text { (Affective) }\end{array} & \text { FMV }\end{array}$ & $\begin{array}{c}1.02 \\
(0.65)\end{array}$ & $\begin{array}{l}-0.28 \\
(0.89)\end{array}$ & $\begin{array}{l}-0.80 \\
(0.65)\end{array}$ & $\begin{array}{c}0.07 \\
(0.70)\end{array}$ & \\
\hline F-value: $111.26^{* * *}$ & 3.78 & 2.98 & 2.55 & 3.47 & 3.20 \\
\hline $\begin{array}{l}{ }^{1} \text { I enjoy buying things on the } \\
\text { internet. } \\
{ }^{1} \text { I am happy when I've bought } \\
\text { something online. } \\
{ }^{1} \text { I am full of anticipation for the } \\
\text { product after buying online. }\end{array}$ & $\begin{array}{l}3.27^{\mathrm{d}} \\
(0.79) \\
4.18 \\
(0.63) \\
3.88 \\
(0.67)\end{array}$ & $\begin{array}{l}2.76 \\
(0.78) \\
3.33 \\
(0.83) \\
2.85 \\
(0.82)\end{array}$ & $\begin{array}{l}2.38 \\
(0.73) \\
2.76 \\
(0.60) \\
2.50 \\
(0.73)\end{array}$ & $\begin{array}{l}3.44^{\mathrm{a}} \\
(0.66) \\
3.65 \\
(0.66) \\
3.32 \\
(0.78)\end{array}$ & $\begin{array}{l}2.94 \\
(0.85) \\
3.47 \\
(0.86) \\
3.13 \\
(0.91)\end{array}$ \\
\hline \multirow{2}{*}{$\begin{array}{l}\text { Behavioral intention } \\
\text { F-value: } 102.7 * * *\end{array}$} & $\begin{array}{l}-0.31 \\
(0.80)\end{array}$ & $\begin{array}{c}1.12 \\
(0.60)\end{array}$ & $\begin{array}{l}-0.69 \\
(0.74)\end{array}$ & $\begin{array}{c}0.04 \\
(0.79)\end{array}$ & \\
\hline & 2.79 & 3.63 & 2.48 & 3.18 & 2.99 \\
\hline $\begin{array}{l}{ }^{1} \text { In the future, I will buy farm } \\
\text { inputs online when the price is } \\
\text { lower than at the local retailer. }\end{array}$ & $\begin{array}{l}2.34^{c} \\
(0.69)\end{array}$ & $\begin{array}{c}3.32 \\
(0.67)\end{array}$ & $\begin{array}{l}2.14^{\mathrm{a}} \\
(0.69)\end{array}$ & $\begin{array}{l}2.79 \\
(0.71)\end{array}$ & $\begin{array}{c}2.61 \\
(0.83)\end{array}$ \\
\hline $\begin{array}{l}{ }^{1} \text { In the future, I will buy more } \\
\text { farm inputs online. }\end{array}$ & $\begin{array}{c}2.62 \\
(0.68)\end{array}$ & $\begin{array}{c}3.51 \\
(0.61)\end{array}$ & $\begin{array}{l}2.31 \\
(0.66)\end{array}$ & $\begin{array}{l}3.10 \\
(0.59)\end{array}$ & $\begin{array}{c}2.84 \\
(0.78)\end{array}$ \\
\hline $\begin{array}{l}{ }^{1} \text { In the future, I will also buy } \\
\text { products of high value online. }\end{array}$ & $\begin{array}{l}3.41^{\mathrm{d}} \\
(0.83)\end{array}$ & $\begin{array}{l}4.10 \\
(0.87)\end{array}$ & $\begin{array}{c}3.0 \\
(0.88)\end{array}$ & $\begin{array}{l}3.64^{\mathrm{a}} \\
(0.81)\end{array}$ & $\begin{array}{c}3.50 \\
(0.93)\end{array}$ \\
\hline
\end{tabular}

Factor mean values $(\mathrm{FMV})=$ negative values $(<0)$ are to be understood as agreement and positive values $(>0)$ as disagreement. 1= Mean value on a scale of $1=$ "fully agree" to 5="fully disagree"; standard deviations in brackets. ***ANOVA, highly significant $(\mathrm{p}<0.001) ; \mathrm{a}-\mathrm{d}=$ according to Scheffé's post hoc test, this cluster does not differ significantly $(\mathrm{p} \leq 0.05)$ from mentioned clusters I-IV; $1=$ variables were bundled in the factor for building the clusters.

Source: Own elaboration. 
The F-test results are significant, indicating that the values between the clusters are heterogeneous, and thus the cluster analysis can be evaluated as successful overall. The factor advantageousness (Cognition) has the strongest separating power (F-value 128.4), followed by enjoyment (Affective) and behavioral intention. Post-hoc tests were performed to test the significance between clusters. Since statement agreement was coded as 1 , negative values $(<0)$ are to be understood as agreement and positive values $(>0)$ as disagreement. The results show that all clusters differ significantly from each other in terms of perceived enjoyment and behavioral intention. Regarding the advantageousness of online shopping, cluster I does not differ significantly from clusters II and III.

When comparing the sociodemographic data (age, education) and the farmographic data (region, farm size, farm focus), there are hardly any significant cluster differences (Table 5). An examination of further cluster-describing variables (Table 6) reveals clues for a deeper understanding of cluster characteristics. Thus, we attempted to derive reasons for attitude formation. Satisfaction with the online offer does not differ and is on average 2.7 in the sample, which speaks for a partial satisfaction.

Table 5: Sociodemographics, farmographics, and e-commerce data per cluster $(n=366)$

\begin{tabular}{|c|c|c|c|c|c|c|}
\hline & & $\begin{array}{l}\text { Cluster I } \\
\text { Business } \\
\text { professionals }\end{array}$ & $\begin{array}{l}\text { Cluster II } \\
\text { Loyal } \\
\text { offliners }\end{array}$ & $\begin{array}{l}\text { Cluster III } \\
\text { Online } \\
\text { fans }\end{array}$ & $\begin{array}{l}\text { Cluster IV } \\
\text { Online } \\
\text { hesitators }\end{array}$ & Total \\
\hline \multirow{2}{*}{\multicolumn{2}{|c|}{$\begin{array}{l}\emptyset \text {-Age (Years)* } \\
\varnothing \text {-farm size (hectare) }\end{array}$}} & 39 & 34 & 35 & 40 & 37 \\
\hline & & 346 & 286 & 206 & 187 & 259 \\
\hline Education (\%) & $\begin{array}{l}\text { University } \\
\text { degree }\end{array}$ & 40 & 37 & 38 & 30 & 37 \\
\hline \multirow{4}{*}{$\operatorname{Region}^{1}(\%)$} & North & 18 & 19.5 & 30.5 & 14.5 & 21 \\
\hline & East & 10 & 9 & 2 & 2.5 & 6 \\
\hline & South & 35.5 & 34.5 & 27.5 & 47 & 35.5 \\
\hline & West & 36.5 & 37 & 40 & 36 & 37.5 \\
\hline \multirow{3}{*}{ Farm type (\%) } & Arable farming & 20 & 8 & 20 & 18 & 17 \\
\hline & Animal keeping & 47 & 46 & 44 & 46 & 46 \\
\hline & Mixed farms & 30 & 37 & 26.5 & 29.5 & 30 \\
\hline \multirow{4}{*}{$\begin{array}{l}\text { Order channel } \\
\text { rate }^{2}\end{array}$} & Telephone & 1.79 & 1.76 & 1.83 & 1.69 & 1.77 \\
\hline & Local retailer* & $2.15^{\mathrm{cd}}$ & $1.76^{\mathrm{cd}}$ & $1.9^{\mathrm{abd}}$ & $1.87^{\mathrm{abc}}$ & 1.93 \\
\hline & Online ${ }^{* * *}$ & $2.74^{\text {bd }}$ & $2.78^{\mathrm{ad}}$ & 2.34 & $3.10^{\mathrm{abc}}$ & 2.71 \\
\hline & E-Mail*** & $2.92^{\mathrm{cd}}$ & $3.45^{\mathrm{d}}$ & $2.80^{\mathrm{ad}}$ & $3.14^{\mathrm{abc}}$ & 3.06 \\
\hline \multicolumn{2}{|c|}{ Online shopping index $* * * 3$} & $3.2^{\mathrm{b}}$ & $3.4^{\mathrm{ad}}$ & 2.7 & $3.6^{\mathrm{b}}$ & 3.2 \\
\hline \multicolumn{7}{|c|}{$\begin{array}{l}* \text { Differences between clusters are highly significant according to ANOVA (F-values) } * \mathrm{p} \leq 0.05 ; * * \mathrm{p} \leq 0.005 ; \\
* * * \mathrm{p} \leq 0.001 ; 1=\chi^{2} \text {-test }(\mathrm{p} \leq 0.05) ; 2=\text { Likert scale from } 1=\text { "very often" to } 5=\text { "never"; } 3=\text { index ranging from } 1 \text { (frequent } \\
\text { use for } \geq \text { four product groups) to } 5 \text { (non-use); } \mathrm{a}-\mathrm{d}=\text { according to Scheffé's post hoc test, this cluster does not differ } \\
\text { significantly ( } \mathrm{p} \leq 0.05 \text { ) from marked cluster }\end{array}$} \\
\hline
\end{tabular}

Source: Own elaboration. 
Table 6: Comparison of clusters with regard to further descriptive statements using ANOVA ( $\mathrm{n}=366)$

\begin{tabular}{|c|c|c|c|c|c|c|}
\hline & Statement & $\begin{array}{c}\text { Cluster } \\
\text { I } \\
\text { Business } \\
\text { professionals }\end{array}$ & $\begin{array}{l}\text { Cluster } \\
\text { II } \\
\text { Loyal } \\
\text { offliners }\end{array}$ & $\begin{array}{l}\text { Cluster } \\
\text { III } \\
\text { Online } \\
\text { fans }\end{array}$ & $\begin{array}{l}\text { Cluster } \\
\text { IV } \\
\text { Online } \\
\text { hesitators }\end{array}$ & Total \\
\hline \multirow{2}{*}{ 氧 } & I always buy from the same dealer.** & $\begin{array}{l}2.88^{\mathrm{bcd}} \\
(0.92)\end{array}$ & $\begin{array}{l}2.54^{\mathrm{a}} \\
(0.90)\end{array}$ & $\begin{array}{l}2.92^{\text {ad }} \\
(0.94)\end{array}$ & $\begin{array}{l}3.01^{\mathrm{abc}} \\
(0.95)\end{array}$ & $\begin{array}{c}2.84 \\
(0.94)\end{array}$ \\
\hline & I buy it where it is cheapest.*** & $\begin{array}{l}2.43^{\text {cd }} \\
(0.84)\end{array}$ & $\begin{array}{l}2.84^{\mathrm{d}} \\
(0.78)\end{array}$ & $\begin{array}{l}2.40^{\text {ad }} \\
(0.81)\end{array}$ & $\begin{array}{l}2.71^{\mathrm{abc}} \\
(0.76)\end{array}$ & $\begin{array}{c}2.58 \\
(0.82)\end{array}$ \\
\hline 矛 & $\begin{array}{l}\text { In the future, online stores will } \\
\text { displace local retailers.*** } \\
\text { The farmer of tomorrow is an online } \\
\text { shopper.*** }\end{array}$ & $\begin{array}{l}3.14^{\mathrm{cd}} \\
(0.80) \\
2.76^{\mathrm{c}} \\
(0.64) \\
\end{array}$ & $\begin{array}{l}3.70^{\mathrm{d}} \\
(0.84) \\
3.06^{\mathrm{d}} \\
(0.58) \\
\end{array}$ & $\begin{array}{c}3.06^{\mathrm{a}} \\
(0.79) \\
2.55^{\mathrm{a}} \\
(0.70) \\
\end{array}$ & $\begin{array}{l}3.38^{\mathrm{abc}} \\
(0.83) \\
3.12^{\mathrm{b}} \\
(0.64) \\
\end{array}$ & $\begin{array}{c}3.30 \\
(0.85) \\
2.85 \\
(0.68) \\
\end{array}$ \\
\hline :0 & $\begin{array}{l}\text { So far, I have had only good } \\
\text { experiences with online shopping.*** } \\
\text { I am very experienced in online } \\
\text { shopping.*** }\end{array}$ & $\begin{array}{l}2.45^{\mathrm{bc}} \\
(0.66) \\
2.67^{\mathrm{b}} \\
(0.83)\end{array}$ & $\begin{array}{l}2.74^{\mathrm{ad}} \\
(0.75) \\
2.43^{\mathrm{ac}} \\
(0.82)\end{array}$ & $\begin{array}{c}2.38^{\mathrm{a}} \\
(0.86) \\
2.17^{\mathrm{b}} \\
(0.89) \\
\end{array}$ & $\begin{array}{c}2.94^{\mathrm{b}} \\
(0.78) \\
3.12 \\
(0.79)\end{array}$ & $\begin{array}{c}2.60 \\
(0.79) \\
2.57 \\
(0.90)\end{array}$ \\
\hline 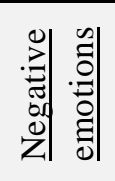 & $\begin{array}{l}\text { I feel stressed when shopping } \\
\text { online.*** } \\
\text { Online shopping frustrates me.*** }\end{array}$ & $\begin{array}{l}3.89^{\mathrm{bc}} \\
(0.79) \\
3.97^{\mathrm{bc}} \\
(0.74)\end{array}$ & $\begin{array}{l}3.87^{\mathrm{ac}} \\
(0.80) \\
3.90^{\mathrm{ac}} \\
(0.67)\end{array}$ & $\begin{array}{l}3.93^{\mathrm{ab}} \\
(0.76) \\
4.03^{\mathrm{ab}} \\
(0.65)\end{array}$ & $\begin{array}{c}3.38 \\
(0.78) \\
3.33 \\
(0.70)\end{array}$ & $\begin{array}{c}3.79 \\
(0.81) \\
3.83 \\
(0.73)\end{array}$ \\
\hline 吝| & $\begin{array}{l}\text { Importance of personal product } \\
\text { consultation.*** } \\
\text { Online product information can } \\
\text { replace a personal consultation.*** }\end{array}$ & $\begin{array}{l}2.92^{\mathrm{c}} \\
(0.70) \\
3.35^{\mathrm{cd}} \\
(0.77)\end{array}$ & $\begin{array}{l}2.44^{\mathrm{d}} \\
(0.65) \\
3.84^{\mathrm{d}} \\
(0.85)\end{array}$ & $\begin{array}{c}2.80^{\text {ad }} \\
(0.86) \\
3.19^{\mathrm{a}} \\
(0.81)\end{array}$ & $\begin{array}{l}2.52^{\mathrm{bc}} \\
(0.64) \\
3.68^{\mathrm{ab}} \\
(0.81)\end{array}$ & $\begin{array}{c}2.69 \\
(0.75) \\
3.49 \\
(0.85)\end{array}$ \\
\hline$\underset{:}{\stackrel{0}{0}}$ & Online shopping is not secure.* & $\begin{array}{l}3.49^{\mathrm{bcd}} \\
(0.79) \\
3.76^{\mathrm{bc}} \\
(0.69)\end{array}$ & $\begin{array}{l}3.32^{\mathrm{ac}} \\
(0.80) \\
3.66^{\mathrm{ac}} \\
(0.71)\end{array}$ & $\begin{array}{l}3.54^{\mathrm{ab}} \\
(0.77) \\
3.85^{\mathrm{ab}} \\
(0.72) \\
\end{array}$ & $\begin{array}{c}3.21^{\mathrm{ab}} \\
(0.75) \\
3.26 \\
(0.80)\end{array}$ & $\begin{array}{c}3.40 \\
(0.78) \\
3.65 \\
(0.76) \\
\end{array}$ \\
\hline \multirow[t]{3}{*}{ 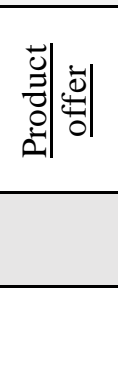 } & $\begin{array}{l}\text { The internet offers a better selection } \\
\text { than local trade.*** } \\
\text { The internet offers lower prices than } \\
\text { local trade.*** }\end{array}$ & $\begin{array}{l}2.54^{\mathrm{bcd}} \\
(0.84) \\
2.64^{\mathrm{bc}} \\
(0.80)\end{array}$ & $\begin{array}{l}2.78^{\mathrm{ad}} \\
(0.86) \\
2.78^{\mathrm{ac}} \\
(0.64)\end{array}$ & $\begin{array}{l}2.30^{\mathrm{a}} \\
(0.77) \\
2.55^{\mathrm{ab}} \\
(0.75)\end{array}$ & $\begin{array}{c}2.85^{\mathrm{ab}} \\
(0.79) \\
3.10 \\
(0.70)\end{array}$ & $\begin{array}{c}2.60 \\
(0.84) \\
2.75 \\
(0.75)\end{array}$ \\
\hline & $\begin{array}{l}\text { I have to buy farm inputs online to } \\
\text { stay competitive.*** }\end{array}$ & $\begin{array}{l}3.57^{\text {bcd }} \\
(0.87)\end{array}$ & $\begin{array}{l}3.86^{\text {ad }} \\
(0.75)\end{array}$ & $\begin{array}{l}3.30^{\mathrm{a}} \\
(0.93)\end{array}$ & $\begin{array}{l}3.85^{\mathrm{ab}} \\
(0.72)\end{array}$ & $\begin{array}{c}3.63 \\
(0.86) \\
\end{array}$ \\
\hline & $\begin{array}{l}\text { It is a relief to purchase products } \\
\text { online.*** }\end{array}$ & $\begin{array}{l}2.28^{\mathrm{b}} \\
(0.80)\end{array}$ & $\begin{array}{r}2.45^{\mathrm{a}} \\
(0.66) \\
\end{array}$ & $\begin{array}{c}1.91 \\
(0.66)\end{array}$ & $\begin{array}{c}2.83 \\
(0.78)\end{array}$ & $\begin{array}{c}2.34 \\
(0.79)\end{array}$ \\
\hline
\end{tabular}

Displayed are means and standard deviations in brackets. Scale: $1=$ "strongly agree" to $5=$ "totally disagree" Differences between clusters are significant according to ANOVA ***p $\leq 0.000, * * p \leq 0.005$, *p $\leq 0.05$; $\mathrm{a}-\mathrm{d}$ : according to Scheffé's post hoc test, this cluster does not differ significantly $(\mathrm{p} \leq 0.05)$ from marked cluster

Source: Own elaboration.

\section{Cluster I-Business professionals}

The first cluster comprises $27 \%$ of the study participants. It is characterized by the highest aversion to the affective component, i.e., enjoyment. While farmers of this cluster hardly feel any pleasure when shopping online, they see its advantageousness. Their future online buying intention for farm inputs is, in a cluster comparison, second most likely. Their online shopping index is moderate, indicating that online shopping is on average rarely done (Table 5). 
In a cluster comparison, the general frequency of ordering locally at retailers is lowest in this cluster. These farmers are characterized by the highest percentage of university degrees as well as the largest farm size. Like cluster II, they manage more farms in eastern Germany (around $10 \%$ ) compared to cluster III and cluster IV. Farmers in this cluster rate their experience in dealing with online stores weaker than the clusters II and III. On the other hand, they have had better online shopping experiences than those farmers who do not intend to use online shopping (cluster II \& IV). It is also evident that this cluster is more price-conscious and prefers to buy where prices are lowest (Table 6). Accordingly, this cluster is characterized by a strong urge to generate an advantage when buying farm inputs and can thus be described as "business professionals".

\section{Cluster II - Loyal offliners}

$24 \%$ of the participants can be assigned to the second cluster. It shows agreement on the affective and cognitive components. The advantages of online shopping, especially convenience, are recognized. In the cluster comparison, joy is perceived second most strongly. Outstanding is their above-average disagreement to practice online shopping for farm inputs in the future. Their current business-related online shopping index is the second weakest, while they most often order farm inputs on site. The second cluster is significantly younger than cluster I and IV but operates the second largest farms. Unlike in cluster III and IV, about $9 \%$ of the farms are managed in eastern Germany. The second cluster, which stands out primarily due to its lowest usage intention, shows a stronger attachment to stationary retail than other clusters. Accordingly, it has the highest rate of stationary orders (Table 5), agrees most strongly to always buy from the same dealer, and rejects a supplier change for price reasons more strong ly than the other clusters (Table 6). Security, trust, and risk concerns are perceived the second strongest. Furthermore, it predicts no future for e-commerce in the agricultural sector. For these reasons, the second cluster can be called the "loyal offliners".

\section{Cluster III - Online fans}

The third cluster is the largest (28\%) and shows the strongest agreement across all cluster-forming variables. The benefits are perceived most strongly by this cluster, and individuals in this segment also feel the most pleasure in using e-commerce. Their intention to use is significantly higher than that of the other clusters. Their online shopping index is the lowest, indicating the most frequent usage. In comparison, it is one point better than that of cluster IV. Across all product groups, it shows a more frequent online ordering rate (Fig. 2). Furthermore, $40 \%$ of this cluster run a farm in western Germany. 
Compared to the other clusters, this cluster tends to be young with small farms but is well educated (Table 5). Descriptive variables show that the third cluster is most likely to feel pressured to use online shopping to stay competitive (Table 6). However, at the same time, individuals in this cluster see online shopping as a relief and expect that e-commerce will be part of agricultural trade in the future. Due to their high perceived enjoyment and overall, very positive attitude, this cluster's individuals can be titled "online fans".

\section{$\underline{\text { Cluster IV - Online hesitators }}$}

The smallest cluster (21\%) is represented by cluster IV. In contrast to cluster III, it shows the least agreement on the cluster-forming variables. Farmers of this cluster perceive the advantages of online shopping comparatively weakly and feel hardly any pleasure in using it. They also seem to agree more strongly that they are frustrated and stressed by online shopping. It also shows the greatest security, trust, and risk concerns (Table 6). In a cluster comparison, the intention to use is low but significantly higher than the intention of CLII. The farm-related online shopping index of cluster IV is the weakest. While this cluster is significantly older than cluster II and III, it manages less agricultural land and has the least share of university graduates. Cluster IV also stands out with the highest share of farmers in southern Germany (47\%). This cluster's previous online shopping experience and competence in dealing with online shopping are rated the weakest. In line with their usage intentions, the farmers in this cluster see hardly any future for e-commerce in agricultural trade and can therefore be called "online hesitators".

\section{Discussion}

In the past, there have been several studies about farmers' online buying behavior. Most of the studies have been done based on a rather one-dimensional cognitive consideration of agricultural e-commerce and have highlighted drivers and inhibitors. To understand the online purchasing behavior of farmers from a multidimensional perspective, this study focused on farmers' attitudinal segmentation and applied the ABC model of attitude formation. Accordingly, farmers could be divided into four segments based on their affective, cognitive, and behavioral attitudes towards agricultural e-commerce. Hence, the suitability of the ABC model of attitudes as a segmentation basis for farmers' online shopping behavior can be confirmed in principle (Mathew, 2016). The results further confirm existing literat ure by showing that cognition serves as a dominant factor among the e-commerce attitude formation (Hasan, 2010; Moon et al., 2017), as this factor has a significantly better expression than affect and behavior. 
In the following, the online purchasing behavior of the clusters based on their attitude formation, and the findings that can be derived from it are discussed. At this point, it should be noted that the following only refers to farmers who already have agricultural online purchasing experience, so this is not representative of all farmers.

A closer look at the clusters implies that the B2B purchasing behavior is particularly obvious in the cluster of business professionals (Pandey and Mookerjee, 2018; Rèklaitis and Pilelienè, 2019). Business professionals manage larger farms, which are mainly found in western and eastern Germany. It can therefore be assumed that their degree of professionalization is correspondingly high (Vogel et al., 2018), which results in their more rational and economic and less emotionally driven purchasing decisions. In the cluster comparison, business professionals show a slightly lower dealer loyalty, higher aversion to personal consultation, strong price sensitivity, and the second-best perception of the online product offer, which underlines their strong efficiency-oriented behavior. In addition to the benefits that can be generated by online trade, good e-commerce future visions and good previous experiences seem to have a positive effect on these individuals' intention to use e-commerce. However, their self-perceived competence in dealing with e-commerce is low compared to loyal offliners or online fans. This might be an additional explanation for their low level of online enjoyment, as less knowledgeable shoppers can hardly generate any benefits (Abdeldayem, 2010), which may also apply to the emergence of online enjoyment. Otherwise, the comparatively high educational level speaks for a more critical view, which could indicate an underestimation of one's own competence. As the willingness to pay for training on digitalization increases with farm size (Michels et al., 2019), the perceived competence gap of business professionals could be counteracted with training offers, which might in turn positively influence affect. In order to convince individuals in this group and win them over as online shoppers, factual arguments and economic advantages are needed.

Loyal offliners are characterized by the lowest e-commerce usage intention while they also preserve positive expressions of affective and cognitive attitude towards it. However, they are most loyal to local retailers and place the highest importance on personal consultations, which might prevent them from buying online. Surprisingly, loyal offliners are the youngest cluster of this study with the highest share of mixed farms. This contradicts prior research by Kool (1994) who found that young farmers show fewer personal relationships with their local dealers and seek more alternatives. In addition, a study of Gerpott et al. (2013b) indicated that younger adults are more interested in digital technologies. Even interesting as loyal offliners show, 
as well as the group of online fans, a comparatively high competence score, which supports results by Gerpott et al. (2013a) and Michels et al. (2019) that younger farmers have already acquired knowledge about digital technologies. Nevertheless, farmers in the cluster of loyal offliners prefer local trade and demand personal advice, which might be explained by their weaker business experience, higher insecurity, and by their perhaps more susceptible to take loans (Feng et al., 2011). According to Feng et al. (2011), cooperatives, and perhaps private agricultural trade as well, represent support for younger farmers, which they strongly want to preserve, also due to valuable tying transactions. A further reason could be that the younger farmers continue the business relationships established by their parents. However, the low e-commerce preference by at least some young and rather digitally affine farmers is a new finding and should be further studied.

In contrast to the loyal offliners, the online fans agree with the assumptions by Kool (1994) and Gerpott et al. (2013b) that young farmers are less tied to local retailers, are looking for alternatives, and are more interested in digital technologies. They show the most positive expressions of all three attitude determinants and at the same time the highest current e-commerce usage rate. The purchase of farm inputs via the internet is perceived as a facilitation, and its advantages in terms of product range and time and cost savings are most appreciated. In addition, these individuals agree less that personal product consultation is important to them. Rather, they most agree that product information on the internet can replace it and at the same time show the strongest agreement to the statement that they have only had positive experiences with e-commerce. This might indicate that the farmers' own assessment of the need for personal advice is influenced by their prior experience with the product information and service in e-commerce. In addition, these positive experiences influence their intention to use e-commerce (Fecke et al., 2018; Pandey and Mookerjee, 2018). However, online fans tend to feel more pressure to use e-commerce to remain competitive. The influence of competitive pressure can also be confirmed in B2B e-commerce (Pandey and Mookerjee, 2018). Reasons for the higher perception of pressure to use e-commerce cannot be derived from this study and offers room for further research. The influence of the region should also be investigated in further studies, due to the fact that online fans often come from western and northern Germany, where the dealer network is still "relatively" good, compared to the loyal offliners, where a comparatively large share lives in the eastern regions with a weaker dealer network. A cautious and vague explanation for the higher e-commerce usage of this cluster could be that online fans may not be satisfied with the offers of stationary retail. 
Online hesitators are the opposite group to online fans. Their evaluation of cognition, affect, and behavior is significantly more negative than those of other clusters, especially of the online fans. They stand out with the highest stress and frustration levels during online shopping and the lowest trust towards online shopping, which keeps them away from e-commerce activities. According to Román and Riquelme (2014), a high perception of online shopping frustration and stress can be explained by lower internet expertise (i.e., self-perception of competence), higher age, and a lower educational level. Also, other studies have pointed out age as an influencing variable, where farmers of advanced age tend to have acquired less knowledge regarding digital technologies (Gerpott et al., 2013a; Michels et al., 2019). In addition, the hesitant e-commerce behavior of online hesitators could also be explained by farm size and the regional distribution. For example, almost half (47\%) of the comparably small farms of online hesitators are in southern Germany, which is known for its slight lag in digitalization, and it seems to still have a well-established local retailer structure (Gandorfer et al., 2017).

When looking at general sociodemo- and farmographics, our results demonstrate that although age differs significantly, younger participants are not necessarily more online-savvy. This is similar to findings by Ackermann et al. (2018), who could not identify a significant influence of age, farm size, and region on agricultural e-commerce use. While they revealed an influence of education, this study did not find significant results for this variable. Although there is a tendency, in accordance with Ackermann et al. (2018), that the use of e-commerce for farm inputs also increases with an increasing level of education, it should be noted that this is generally very high in our study. The farm size is also almost irrelevant in e-commerce usage (Ackermann et al., 2018), but larger farms are found more frequently in western and eastern Germany, and the region of the farms significantly differs between the clusters. In addition, it should also be considered at this point that only farmers who had already purchased farm inputs online participated in the study, while non-users were excluded. Thus, no conclusive statement can be made at this point about the influence of socidemo- and farmographics on usage.

From these cluster comparisons, some insights regarding the $\mathrm{ABC}$ model can be derived, which are discussed in the following.

The described findings suggest that prior online shopping experiences and perceived competence moderate attitude formation. Fecke et al. (2018) also showed that farmers' positive prior experiences with online shopping have a positive effect on the willingness to accept an online vendor. Further studies have also investigated that internet expertise, i.e., familiarity and expertise in using internet/computers, influences customer satisfaction, which might be 
explained by the ability to derive greater benefit from the facilities offered by web shops (Abdeldayem, 2010). Moreover, it seems that enjoyment may be influenced more by self-perceived competence, as especially the clusters with a high fun level (loyal offliners and online fans) also agree the most that they are very experienced in online shopping.

The results further indicate that farmers' online buying behavior might differ from consumers' online buying behavior and that the presented results partly contradict the structural $\mathrm{ABC}$ model established in consumer research.

While emotions, especially enjoyment, are known to be a strong predictor of $\mathrm{B} 2 \mathrm{C}$ online shopping intensity and intention (Fiore et al., 2005; Kim et al., 2007; Liu and Forsythe, 2011), online shopping enjoyment is less important for farmers in our study. This is reflected: a) in weaker mean values for affect compared to cognition, b) in significantly lower intention to use among loyal offliners, who perceive the second highest online enjoyment, and c) in the second highest usage intentions among business professionals for which perceived enjoyment is the lowest. This also shows that in this study, contrary to the assumptions of Cheema et al. (2013), the hedonic performance (affect) contributes less to online purchase intensity and intention than online shopping advantages (cognition). Furthermore, some previous studies presented cognition as a strong antecedent of affect (Hasan, 2010; Mathew, 2016). However, a linear correlation between cognition and affect could not be confirmed in this study since business professionals and online hesitators show opposite expressions. The group of loyal offliners contradicts Fishbein and Ajzen's (1975) assumption that consumers' liking (affect), together with their utility beliefs (cognition) influences their behavioral intention in the same direction.

Weaker relevance and lower mean values of positive emotions within farmers' e-commerce attitude formation can presumably be attributed to the high product involvement. Accordingly, positive emotional appeals work less when product involvement is high (Dens and Pelsmacker, 2010). Hill et al. (2013) found that farmers are using more information sources for high involvement products, which are expensive, novel, or risky to purchase, like machinery, some livestock, and consumables. It can therefore be assumed that due to their high product involvement, farmers react less to emotional appeals and are instead strongly influenced by informational and cognitive appeals (Dens and Pelsmacker, 2010). Our results show that farmers prefer to buy very standardized search goods via the internet which are evaluated based on easily available information or stimuli and can therefore be regarded as low-involvement products (Dens and Pelsmacker, 2010). More individualized experience goods, on the other hand, can be classified as high-involvement products and are less frequently purchased online 
by farmers, as they require more cognitive effort to evaluate the product/information (Ackermann et al., 2018; Dens and Pelsmacker, 2010). It would therefore be interesting in future studies to examine the purchasing behavior for high and low involvement inputs separately and to compare the respective behavior.

The low emotional level in agricultural online purchasing could also be a result of the farmers showing a very strong $\mathrm{B} 2 \mathrm{~B}$-oriented behavior and thus stand out from $\mathrm{B} 2 \mathrm{C}$. The $\mathrm{B} 2 \mathrm{C}$ phenomenon of impulse online buying can be cited as an underlining example. About $50 \%$ of Germans (Statista, 2020) and 60\% of Americans are online impulse buyers, whose rational purchase decision is replaced by the irrational moment of self-satisfaction, which means that these purchases appeal more to the emotional level of the buyer (Lim et al., 2017). However, emotions are also relevant in the B2B purchasing context (Pandey and Mookerjee, 2018; Thakur and AlSaleh, 2020), but B2B purchasing follows a more rationally driven choice process with profit incentives (Rèklaitis and Pilelienė, 2019). Thus, in addition to enjoyment and excitement associated with visiting a website (Thakur and AlSaleh, 2020), affective attributes, such as the strength of relationships, empathy, emotional ties, and the perceived competitive pressure, play a more decisive role in how intensively B2B e-commerce is used (Pandey and Mookerjee, 2018). The fact that in this study emotions (enjoyment) are less pronounced and do not show a linear relationship with behavior intention, as would be expected from the ABC model, could therefore be due to the selection of the statements. Accordingly, in subsequent studies, affect should focus more on the relationship level between farmers and their suppliers while taking e-commerce enjoyment as a more descriptive variable. Nevertheless, the result that enjoyment is of less importance to farmers' e-commerce usage intention is a valuable insight. Although farmers also tend to need user-friendly online shops, the majority of them focus on cognitive and thus economic advantages such as lower prices, product availability, and competitive advantages. Nevertheless, the reasons for buying agricultural inputs online differ between the segments.

\section{Limitations and implications for further research}

Overall, the present study represents a first evaluation of German farmers regarding their multidimensional attitude towards an online purchase of farm inputs. Nevertheless, the limits of this study should be considered when interpreting the results. The representativeness of the sample might limit the results interpretation, as the respondents are younger, better educated, and have larger farms than the national average. However, this group of farmers has been indicated as a (future) target group within other studies (Briggeman and Whitacre, 2010; Mishra 
and Williams, 2006), which should make these results of particular interest. To confirm the findings of this study, future agricultural e-commerce research should use a more representative sample. The age of the database (2017) might also limit the results interpretation. Since 2017, there have been many changes to online shops/e-commerce offers that have certainly resulted in an improvement of more user-friendly designs for farmers. It can therefore be assumed that perceptions/attitudes would be more positive today. Nevertheless, this study can be interpreted as a powerful exploratory study, as the trends and influencing factors of the attitude formation highlighted here can be interpreted in the long term, since it is known that attitudes remain mainly stable over time; also, they might reach another level (Olson and Zanna, 1993). The results may especially continue to apply to high-involvement goods, while they have probably become more positive for low-involvement goods. In addition, only the attitude of farmers according to the tripartite model were considered here, thereby neglecting other stimuli which have been shown to influence farmers' purchasing process. Our findings indicate the multitude of factors that influence the formation of the attitude, e.g., the assumption about the future of an innovation and the self-perception of competence, which should be included into models such as technology acceptance model (TAM) or theory of planned behavior (TPB). In addition, non-users of e-commerce were excluded from this study, but it may be of additional value to analyze their attitudes to get a more comprehensive view. Thus, they should be considered in future studies.

Finally, this study can be interpreted as a meaningful exploratory survey, as the findings of the study provide a deeper and multidimensional understanding, in terms of attitude formation, of farmers' online buying behavior for agricultural inputs. This information can help to make online offers more attractive to farmers and, with the knowledge of attitude formation, provide starting points to increase their purchase experience and purchase intention. 


\section{References}

Abdeldayem, M.M. (2010). A study of customer satisfaction with online shopping: evidence from the UAE. International Journal of Advanced Media and Communication 4(3): 235-257. doi: 10.1504/IJAMC.2010.034659

Ackermann, S., Adams, I., Gindele, N. and Doluschitz, R. (2018). The role of e-commerce in the purchase of agricultural input materials. Landtechnik 73(1): 10-19. doi: 10.15150/lt.2018.3177

Ajzen, I. and Fishbein, M. (1980). Understanding attitudes and predicting social behavior. Prentice-Hall, Englewood Cliffs, N.J.

Ardrey, J., Denis, N., Magnin, C. and Revellat, J. (2020). Unlocking the online retail opportunity with European farmers. McKinsey \& Company. https://mck.co/2Rt1EhS. (07.03.21).

Ashraf, S. and R. Pérez-Vega (2015). Insight into Dubai's Generation Y Online Shopping Behaviour: Exploring the Limitations of the Technology Acceptance Model with the Digital Natives. International Conference on Organization and Management 2015. Abu Dhabi.

Ayo, C.K., Oni, A. A., Adewoye, O. J. and Eweoya, I. O. (2016). E-banking users' behaviour: e-service quality, attitude, and customer satisfaction. International Journal of Bank Marketing 34(3): 347 367. doi: 10.1108/IJBM-12-2014-0175

Backhaus, K., Erichson, B., Plinke, W. and Weiber, R. (2016). Multivariate Analysemethoden. Eine anwendungsorientierte Einführung. Springer Gabler, Berlin, Heidelberg. doi: 10.1007/978-3662-46076-4

Batte, M.T. (2006). Shopping at the Farm Office: What Is the Future of Farm E-commerce? Journal of the American Society of Farm Managers and Rural Appraisers 2006(387-2016-22853): 100105. doi: 10.22004/ag.econ.190698

Batte, M.T. and Ernst, S. C. (2007). Net gains from'net purchases? Farmers' preferences for online and local input purchases. Agricultural and Resource Economics Review 36(1): 84-94. doi: $10.1017 / \mathrm{S} 1068280500009461$

Bickert, C. (2020). Online trading Agriculture 4.0 - or only hot air? Beiträge DLG Wintertagung 2020. https://www.dlg.org/en/agriculture/topics/dlg-agrifuture-magazine/knowledge-skills/onlinetrading-agriculture-40-or-only-hot-air. (30.06.21).

Bitkom, (2020). Schon 8 von 10 Landwirten setzen auf digitale Technologien. Bitkom e.V. https://bit.ly/3aWVgXl. (21.04.21).

Briggeman, B.C. and Whitacre, B. E. (2010). Farming and the internet: Reasons for non-use. Agricultural and Resource Economics Review 39(3): 571-584. doi: $10.1017 / \mathrm{S} 1068280500007528$

Chang, M.K., Cheung, W. and Lai, V. S. (2005). Literature derived reference models for the adoption of online shopping. Information \& management 42(4): 543-559. doi: 10.1016/j.im.2004.02.006

Chaudhary, Sanjay, Suri and P.K. (2018). Adoption of B2B E-Commerce in India: A Theoretical Framework. Journal of Management and Research 3(2): 55-63. doi: 10.5958/2455-3298.2018.00008.9

Cheema, U., Rizwan, M., Jalal, R., Durrani, F. and Sohail, N. (2013). The trend of online shopping in 21st century: Impact of enjoyment in TAM Model. Asian Journal of Empirical Research 3(2): 131-141.

Clasen, M. (2005). Erfolgsfaktoren digitaler Marktplätze in der Agrar- und Ernährungsindustrie. Dissertation. Deutscher Universitätsverlag, Wiesbaden. 
Dens, N. and Pelsmacker, P. de (2010). Consumer response to different advertising appeals for new products: The moderating influence of branding strategy and product category involvement. Journal of Brand Management 18(1): 50-65. doi: 10.1057/bm.2010.22

Deutsch, M., Otte, L. and Otter, V. (2020). Digital first? Auswirkungen der Digitalisierung auf Vertriebsstrukturen im deutschen Agrarhandel. Austrian Journal of Agricultural Economics and Rural Studies 29 23-30. doi: 10.15203/OEGA_29.4

Dittmar, H., Long, K. and Meek, R. (2004). Buying on the Internet: Gender differences in on -line and conventional buying motivations. Sex roles 50(5): 423-444. doi: 10.1023/B:SERS.0000018896.35251.c7

European Commission (2021). EU Member States join forces on digitalisation for European agriculture and rural areas | Shaping Europe's digital future. https://digitalstrategy.ec.europa.eu/en/news/eu-member-states-join-forces-digitalisation-europeanagriculture-and-rural-areas. (22.06.21).

Fecke, W., Danne, M. and Musshoff, O. (2018). E-commerce in agriculture-The case of crop protection product purchases in a discrete choice experiment. Computers and electronics in agriculture 151, 126-135. doi: 10.1016/j.compag.2018.05.032

Feng, L., Nilsson, J., Ollila, P. and Karantininis, K. (2011). The human values behind farmers' loyalty to their cooperatives. 5th international conference on economics and management of networks, Limassol, Cyprus.

Fiore, A.M., Jin, H.-J. and Kim, J. (2005). For fun and profit: Hedonic value from image interactivity and responses toward an online store. Psychology \& Marketing 22(8): 669-694. doi: 10.1002/mar.20079

Fishbein, M.A. and Ajzen, I. (1975). Belief, attitude, intention and behaviour: An introduction to theory and research. Addison-Wesley Publishing Company, Philippines.

Fraiman, R., Justel, A. and Svarc, M. (2008). Selection of Variables for Cluster Analysis and Classification Rules. Journal of the American Statistical Association 103(483): 1294-1303. doi: $10.2307 / 27640162$

Fritz, M., Hausen, T., Schiefer, G. and Canavari, M. (2007). Trust and e-commerce in the agrifood industry: Configuration of a trust environment for e-commerce activities Quality management in food chains. In: Theuvsen, L., Spiller, A., Peupert, M. und Jahn, G. (Hrsg.). Quality management in food chains. Wageningen Academic Publishers, Wageningen, 463-474.

Gandorfer, M., Schleicher, S., Heuser, S., Pfeiffer, J. and Demmel, M. (2017.). Landwirtschaft 4.0Digitalisierung und ihre Herausforderungen. In: Wendl, G. (eds.). Ackerbau - technische Lösungen für die Zukunft. Bayerische Landesanstalt für Landwirtschaft (LfL), Freising. 9-20.

Gao, Y. and Koufaris, M. (2006). Perceptual antecedents of u ser attitude in electronic commerce. ACM SIGMIS Database: the DATABASE for Advances in Information Systems 37(2-3): 42-50. doi: $10.1145 / 1161345.1161353$

Gartzke, S. (2016.). Kleffmann Group Global New Media Tracker - Our international Study Kleffmann Group. In: Farwick, C. (eds.). Kleffmann Group. Agri Experts Around the World. Newsletter, $18-21$.

Gerpott, T.J., Thomas, S. and Weichert, M. (2013a). Characteristics and mobile Internet use intensity of consumers with different types of advanced handsets: An exploratory empirical study of iPhone, Android and other web-enabled mobile users in Germany. Telecommunications Policy 37(4-5): 357-371. doi: 10.1016/j.telpol.2012.04.009

Gerpott, T.J., Thomas, S. and Weichert, M. (2013b). Personal characteristics and mobile Internet use intensity of consumers with computer-centric communication devices: An exploratory empirical study of iPad and laptop users in Germany. Telematics and Informatics 30(2): 87-99. doi: $10.1016 /$ j.tele.2012.03.008 
Goldsmith, R.E. and Goldsmith, E. B. (2002). Buying apparel over the Internet. Journal of Product \& Brand Management 11(2): 89-102. doi: 10.1108/10610420210423464

Gupta, M., Srivastava, J. N. and Kumar, S. (2019). Consumer Attitude towards Online Buying-An Empirical Study on Internet Shoppers in Bareilly. Invertis Journal of Management 11(2): 43-58.

Hamad, H., Elbeltagi, I. and El-Gohary, H. (2018). An empirical investigation of business-to-business e-commerce adoption and its impact on SMEs competitive advantage: The case of Egyptian manufacturing SMEs. Strategic Change 27(3): 209-229. doi: 10.1002/jsc.2196

Hasan, B. (2010). Exploring gender differences in online shopping attitude. Computers in Human Behavior 26(4): 597-601. doi: 10.1016/j.chb.2009.12.012

Henderson, J., Dooley, F. and Akridge, J. (2004). Internet and e-commerce adoption by agricultural input firms. Review of Agricultural Economics 26(4): 505-520. doi: 10.2307/3700794

Henderson, J.R., Akridge, J. T. and Dooley, F. J. (2006). Internet and e-commerce use by agribusiness firms: 2004. Journal of Agribusiness 24(345-2016-15133): 17-39. doi: 10.22004/ag.econ.57697

Hill, M., Kaine, G. and Ashburner, R. (2013). Where farmers' seek information when making purchasing decisions, implications for extension. Extension Farming Systems Journal 9(1): 43-51.

Hoffmann, C. and Grethler, D. (2013.2013). Bedarf nach Mobile Business in einer landwirtschaftlichen Produktion unter dynamischen Rahmenbedingungen Informatik 2013 - Informatik angepasst an Mensch, Organisation und Umwelt. In: Horbach, M. (eds.). Informatik 2013 - Informatik angepasst an Mensch, Organisation und Umwelt. Tagung vom 16. - 20. September 2013 in Koblenz, Germany. Gesellschaft für Informatik, Bonn.

Huchtemann, J.-P. and Theuvsen, L. (2018.). Startups im Agribusiness - Marktplätze als Geschäftsmodell und deren Anwendung in der deutschen Landwirtschaft. In: Ruckelshausen, A., Meyer-Aurich, A., Borchard, K., H., C., Loy, J.-P., Schwerdtfeger, R., Sundermeier, H.-H., Floto, H. and Theuvsen, B. (eds.). 38. GIL-Jahrestagung in Kiel, Germany, Digitale Marktplätze und Plattformen. Gesellschaft für Informatik e.V., Bonn 119-122.

Javadi, M.H.M., Dolatabadi, H. R., Nourbakhsh, M., Poursaeedi, A. and Asadollahi, A. R. (2012). An analysis of factors affecting on online shopping behavior of consumers. International Journal of Marketing Studies 4(5): 81-98. doi: 10.5539/ijms.v4n5p81

Kaiser, H.F. and Rice, J. (1974). Little jiffy, mark IV. Educational and psychological measurement 34(1): 111-117.

Kalaitzandonakes, N., Kaufman, J. and Wang, X. (2003). Firm entry through e-commerce in the US agricultural input distribution industry. Journal on Chain and Network Science 3(2): 123-133. doi: 10.3920/JCNS2003.x035

Kim, D.J., Ferrin, D. L. and Rao, H. R. (2009). Trust and Satisfaction, Two Stepping Stones for Successful E-Commerce Relationships: A Longitudinal Exploration. Information systems research 20(2): 237-257. doi: 10.1287/isre.1080.0188

Kim, J., Fiore, A. M. and Lee, H.-H. (2007). Influences of online store perception, shopping enjoyment, and shopping involvement on consumer patronage behavior towards an online retailer. Journal of Retailing and Consumer Services 14(2): 95-107. doi: 10.1016/j.jretconser.2006.05.001

Kool, M. (1994). Vendor loyalty of farmers: Characterisation, description and analysis. European Review of Agricultural Economics 21(2): 287-307. doi: 10.1093/erae/21.2.287

Leroux, N., Wortman Jr, M. S. and Mathias, E. D. (2001). Dominant factors impacting the development of business-to-business (B2B) e-commerce in agriculture. The International Food and Agribusiness Management Review 4(2): 205-218. doi: 10.22004/ag.econ.34473 
Lievonen, M. (2017). Consumer emotions and e-commerce: A literature review. In: Pucihar, A., Borštnar, M.-L., Kittl, C., Ravesteijn, P., Clarke, R. and Bons, R. (eds.). Bled 2017 : Proceedings of the 30th Bled eConference. Digital Transormation: Form Connecting Things to Transforming Our Lives. University of Maribor Press, Maribor 385-402. doi: 10.18690/978-961-286-043-1

Lim, S.H., Lee, S. and Kim, D. J. (2017). Is Online Consumers' Impulsive Buying Beneficial for ECommerce Companies? An Empirical Investigation of Online Consumers' Past Impulsive Buying Behaviors. Information Systems Management 34(1): 85-100. doi: $10.1080 / 10580530.2017 .1254458$

Liu, C. and Forsythe, S. (2011). Examining drivers of online purchase intensity: Moderating role of adoption duration in sustaining post-adoption online shopping. Journal of Retailing and Consumer Services 18(1): 101-109. doi: 10.1016/j.jretconser.2010.10.004

Maghnati, F. and Ling, K. C. (2013). Exploring the relationship between experiential value and usage attitude towards mobile apps among the smartphone users. International Journal of Business and Management 8(4): 1. doi: 10.5539/ijbm.v8n4p1

Marbac, M. and Sedki, M. (2017). Variable selection for model-based clustering using the integrated complete-data likelihood. Statistics and Computing 27(4): 1049-1063. doi: $10.1007 / \mathrm{s} 11222-016-9670-1$

Martínez-Ruiz, M.P., Izquierdo-Yusta, A., Olarte-Pascual, C. and Reinares-Lara, E. (2017). Do affective variables make a difference in consumers behavior toward mobile advertising? Frontiers in psychology 7 2018. doi: 10.3389/fpsyg.2016.02018

Mathew, P.M. (2016). Attitude segmentation of Indian online buyers. Journal of Enterprise Information Management 29(3): 359-373. doi: 10.1108/JEIM-08-2014-0078

Michels, M., Fecke, W., Weller Von Ahlefeld, Paul Johann, Mußhoff, O., Heckmann, A. and Beneke, F. (2019). Sind Landwirte bereit für eine Schulung zur Digitalisierung zu bezahlen? Berichte über Landwirtschaft - Zeitschrift für Agrarpolitik und Landwirtschaft 97(1): 1-19. doi: 10.12767/buel.v97i1.204

Mishra, A. K. and Williams, R. P. (2006). Internet access and use by farm households. Paper for presentation at the 2006 American Agricultural Economics Association annual meeting. (3792016-22000). doi: 10.22004/ag.econ.21106

Moon, M.A., Khalid, M. J., Awan, H. M., Attiq, S., Rasool, H. and Kiran, M. (2017). Consumer's perceptions of website's utilitarian and hedonic attributes and online purchase intentions: A cognitive-affective attitude approach. Spanish Journal of Marketing - ESIC 21(2): 73-88. doi: 10.1016/j.sjme.2017.07.001

Munz, J. and Doluschitz, R. (2020). Determinanten zur Akzeptanz der Einführung digitaler Technologien im genossenschaftlichen Agrarhandel. Zeitschrift für das gesamte Genossenschaftswesen 70(4): 283-307. doi: 10.1515/zfgg-2020-0020

Negrão, C.S.V. (2018). Impact of E-Commerce on Agricultural Business Success Improving Business Performance Through Effective Managerial Training Initiatives. In: Improving Business Performance Through Effective Managerial Training Initiatives. IGI Global, 223-253.

Olson, J.M. and Zanna, M. P. (1993). Attitudes and attitude change. Annual review of psychology 44(1): 117-154. doi: 10.1146/annurev.ps.44.020193.001001

Ostrom, T.M. (1969). The relationship between the affective, behavioral, and cognitive components of attitude. Journal of experimental social psychology 5(1): 12-30. doi: 10.1016/0022-1031(69)90003-1

Pandey, S.K. and Mookerjee, A. (2018). Assessing the role of emotions in B2B decision making: an exploratory study. Journal of Indian Business Research 10(2): 170-192. doi: 10.1108/JIBR-10-2017-0171 
Raftery, A.E. and Dean, N. (2006). Variable Selection for Model-Based Clustering. Journal of the American Statistical Association 101(473): 168-178. doi: 10.1198/016214506000000113

Rèklaitis, K. and Pilelienè, L. (2019). Principle Differences between B2B and B2C Marketing Communication Processes. Management of Organizations: Systematic Research 81(1): 73-86. doi: 10.1515/mosr-2019-0005

Román, S. and Riquelme, I. P. (2014). Personal determinants of online shopping frustration and its influence on consumers' positive word of mouth. Journal of Electronic Commerce Research 15(2): 87.

Rosenberg, M.J., Hovland, C.I., McGuire, W.J., Abelson, R.P. and J. W. Brehm (1960). Attitude organization and change: An analysis of consistency among at titude components. (Yales studies in attitude and communication.), Vol. III. Yale University Press, New Haven.

Saprikis, V. and Vlachopoulou, M. (2012). Determinants of suppliers' level of use of B2B emarketplaces. Industr Mngmnt \& Data Systems 112(4): 619-643. doi: $10.1108 / 02635571211225512$

Statista (2020). Verhalten im Online-Shopping - Bestellung von Waren ohne Kaufabsicht. https://bit.ly/37w5prI. (10.07.21).

Taragola, N.M. and van Lierde, D. F. (2010). Factors affecting the Internet behaviour of horticultural growers in Flanders, Belgium. Computers and electronics in agriculture 70(2): 369-379. doi: 10.1016/j.compag.2009.09.004

Thakur, R. and AlSaleh, D. (2020). Drivers of managers' affect (emotions) and corporate website usage: a comparative analysis between a developed and developing country. Journal of Business \& Industrial Marketing 36(6): 962-976. doi: 10.1108/JBIM-02-2020-0118

Theo, T. and Liu, J. (2007). Consumer trust in e-commerce in the United States, Singapore and China. Omega 35(1): 22-38. doi: 10.1016/j.omega.2005.02.001

Um, N.-H. (2019). Antecedents and Consequences of Consumers' Attitude toward Social Commerce Sites. Journal of Promotion Management 25(4): 500-519. doi: 10.1080/10496491.2018.1448324

Vogel, S., Engelhart, R. and Larcher, M. (2018). Ehrenamtliches Engagement, Einstellungen zu Beruf und betrieblicher Entwicklung sowie Hofnachfolge als Faktoren landwirtschaftlicher Professionalisierung-eine empirische Analyse. Austrian Journal of Agricultural Economics and Rural Studies 27(22): 175-185. doi: 10.15203/OEGA_27.1

Zendehdel, M., Paim, L. H. and Osman, S. B. (2015). Students' online purchasing behavior in Malaysia: Understanding online shopping attitude. Cogent Business \& Management 2(1): 1078428. doi: $10.1080 / 23311975.2015 .1078428$ 


\section{I.3 Zukunftsperspektiven von Online-Shops in der landwirtschaftlichen Vorleistungsindustrie eine Analyse aus der Perspektive von LandwirtInnen}

Authors: Dorothee Schulze Schwering \& Achim Spiller

This article was published in similar form in: Meyer-Aurich, A., Gandorfer, M., Barta, N., Gronauer, A., Kantelhardt, J. \& Floto, H. (eds.), (2019). 39. GIL-Jahrestagung, Digitalisierung für landwirtschaftliche Betriebe in kleinstrukturierten Regionen - ein Widerspruch in sich? Bonn: Lecture Notes in Informatics (LNI) Gesellschaft für Informatike.V., 227-232. 


\section{I.3 Zukunftsperspektiven von Online-Shops in der landwirtschaftlichen Vorleistungsindustrie eine Analyse aus der Perspektive von Landwirt Innen}

\section{Zusammenfassung}

Zunehmend digitalisieren LandwirtInnen ihre Betriebsabläufe, doch beim Einkauf landwirtschaftlicher Betriebsmittel vertrauen sie meist auf einen lokalen stationären Handel. Dabei wird dem Ein- und Verkauf über das Internet seit etwa 20 Jahren ein rasantes Wachstum vorhergesagt. Bisher liegen allerdings kaum Studien vor, die das Potenzial von Online-Shops in der Agrarbranche aus Sicht der Landwirtschaft untersuchen. Aus diesem Grunde prüft die vorliegende Studie, ob LandwirtInnen eine Zukunft für Online-Shops in der Agrarbranche sehen, und untersucht gleichzeitig, welche Stellung der stationäre Handel bei den LandwirtInnen besitzt. Als Datengrundlage dient eine Befragung von 371 deutschen LandwirtInnen. Die Befragten gehen von einer zunehmenden Bedeutung von Online-Shops innerhalb der Agrarbranche aus, wodurch der stationäre Handel zwar unter Druck gerät, aber nicht durch Online-Shops verdrängt werden wird.

Schlüsselwörter: Online-Shop, Landwirtschaft, Betriebsmittel, Regressionsanalyse, Digitalisierung 


\section{$1 \quad$ Einleitung}

Die digitale Ausstattung der landwirtschaftlichen Vorleistungsunternehmen und ihrer Kundschaft steigt stetig an. 2016 nutzten bereits $75 \%$ der deutschen Landwirt Innen täglich das Internet für betriebliche Zwecke (Gartzke, 2016). Gleichzeitig erweitern Hersteller, Handelsunternehmen und Zulieferbetriebe von Betriebsmitteln ihre klassischen Vertriebswege um den Kanal Online-Shop. Frühere Studien aus den USA (Batte und Ernst, 2007; Henderson et al., 2004) und der EU (Strzębicki, 2015) bestätigen, dass der Onlinehandel für Unternehmen der landwirtschaftlichen Vorleistungsindustrie einen vielversprechenden Absatzweg darstellt. Zudem zeigen LandwirtInnen insgesamt eine hohe Zufriedenheit beim digitalen Handel und integrieren neben Online-Shops auch digitale Marktplätze in ihren Einkaufsprozess (Clasen, 2005). Heute gilt E-Commerce von Unternehmen zu Unternehmen (B2B-E-Commerce) als eines der Wachstumssegmente der deutschen Internetwirtschaft. Dieses Wachstum ist zum einen darauf zurückzuführen, dass auch traditionelle Unternehmen verstärkt den Direktvertrieb via Internet nutzen, und zum anderen auf den allgemein wachsenden Trend zum E-Procurement sowie zum Internet-basierten Absatz (Little, 2017). Der landwirtschaftliche Betriebsmittelmarkt weist allerdings die Besonderheit auf, dass der Handel vor Ort bis heute eine elementare Stellung hat. Hohes Vertrauen zum lokalen Handel und fehlende persönliche Beratung beim Online-Handel sind für LandwirtInnen bisher die Hauptgründe, sich gegen den Internetkauf zu entscheiden (Gartzke, 2016). Doch im Zuge des allgemein prognostizierten Wachstums des B2B-E-Commerce und der digitalen Bemühungen der Vorleistungsunternehmen stellt sich die Frage, ob sich die Stellung des stationären Handels zugunsten des Online-Handels verändern wird. Ziel dieser Studie ist es daher vor dem beschriebenen Hintergrund herauszufinden, welche Bedeutung LandwirtInnen den OnlineShops in der Landwirtschaft beimessen und ob sie den traditionellen stationären Landhandel durch die Existenz von Online-Shops bedroht sehen. Diese Fragestellungen werden anhand einer empirischen Erhebung beleuchtet.

\section{Material und Methoden}

\subsection{Datenerhebung und Auswertung}

Im Mai 2017 wurde eine Online-Befragung unter LandwirtInnen in Deutschland durchgeführt. Das Sampling erfolgte mittels Schneeballverfahren, indem der Link über persönliche Kontakte, per E-Mail und über soziale Netzwerke weitergeleitet wurde. Zielgruppe der Befragung waren 
Landwirtschaft Betreibende mit betrieblicher Online-Einkaufserfahrung. $\mathrm{Zu}$ Beginn der Umfrage wurde entsprechend eine Filterfrage gestellt, die 894 LandwirtInnen beantworteten. $56 \%(\mathrm{n}=501)$ von ihnen tätigten bereits einen betrieblichen Online-Kauf und verfügen somit über, wenn auch z. T. geringe, Online-Shop-Erfahrungen. Nach einer sorgfältigen Datenbereinigung verblieben für die weiteren Analysen 371 vollständige und valide Datensätze. Es wurden überwiegend 5-Punkt-Likert-Skalen von 1=,,stimme voll und ganz zu“ bis 5=,lehne voll und ganz ab“ eingesetzt, auf denen die Befragten ihre Einstellungen zur zukünftigen Bedeutung von Online-Shops, ihrer Beziehung zum Handel vor Ort sowie weiteren ausgewählten Statements abgeben konnten. Mittels einer Rating-Skala von „sehr wichtig“ bis „unwichtig“wurde abgefragt, wie wichtig den Teilnehmenden eine persönliche Beratung für die jeweiligen Betriebsmittelgruppen ist. Aus diesen Angaben wurde ein Index gebildet, welcher den Faktor "Wichtigkeit der persönlichen Beratung" beschreibt. Die Datenanalyse erfolgte mit der Statistiksoftware SPSS 25 mittels uni-, bi- und multivariater Analysemethoden.

Zunächst wurde die Vielzahl der Items anhand einer Faktorenanalyse (Hauptkomponentenanalyse) zu einem Faktor verdichtet (Bühl, 2014). Im Anschluss wurde mit einer linearen Regression ein Modell, das die Einflussfaktoren auf die Einschätzung der Zukunftsperspektiven von Online-Shops abbildet, geschätzt.

\subsection{Stichprobenbeschreibung}

Aufgrund der Filterfrage haben alle Befragten bereits erste Erfahrungen mit dem OnlineEinkauf gesammelt. Während 48,1\% der Befragten angeben, Online-Shops häufig für Betriebsmittelbestellungen zu nutzten, geben 46,4\% an, nur selten und 5,5\% gar nicht mehr über den Online-Shop zu bestellen. Informationen zu bestellten Mengen bzw. Preisvolumen liegen nicht vor. Im Vergleich zum bundesweiten Durchschnitt in der Landwirtschaft ist die vorliegende Stichprobe nicht repräsentativ, da die Teilnehmer mit einem Durchschnittsalter von 37 Jahren deutlich jünger sowie besser ausgebildet (28\% mit Hochschulabschluss) sind. Zudem bewirtschaften die TeilnehmerInnen im Vergleich zum Bundesdurchschnitt größere Betriebe. Diese Verzerrung könnte der Filterfrage geschuldet sein, da durch sie nur LandwirtInnen mit Online-Erfahrung und damit potenziell jüngere TeilnehmerInnen für die weitere Befragung zugelassen wurden. Jedoch lässt sich argumentieren, dass gerade jüngere LandwirtInnen die zukünftige Zielgruppe für Online-Shops darstellen, womit ihre Einschätzung der Zukunftsperspektiven von besonderer Relevanz ist. Die Begrenzung der Stichprobe auf LandwirtInnen mit online-Erfahrung ist daher bei der folgenden Ergebnisbeschreibung zu berücksichtigen. 


\section{$3 \quad$ Ergebnisse}

Die Ergebnisse zeigen, dass LandwirtInnen mit dem derzeitigen Online-Angebot für landwirtschaftliche Betriebsmittel nur mäßig zufrieden sind. So sind weniger als die Hälfte der der Befragten (44,2\%) derzeit zufrieden mit dem Angebot, während 42\% nur zum Teil zufrieden und 13,8\% der Befragten unzufrieden sind. Etwa $46 \%$ haben bisher gute Erfahrungen mit dem Einkauf im Internet gemacht, rund $10 \%$ hingegen nicht. Ein Mittelwertvergleich zeigt, dass LandwirtInnen nicht vollkommen abgeneigt sind, zukünftig mehr Betriebsmittel online zu kaufen $(\mathrm{MW}=2,83)$.

Tabelle 1: Faktor Zukunftsperspektive von Online-Shops

\begin{tabular}{lcc}
\hline Statement a & Faktorladung & Mittelwert \\
\hline $\begin{array}{l}\text { Die Bedeutung von Online-Shops für die Landwirtschaft } \\
\text { wird zunehmen. }\end{array}$ & 0,813 & 2,03 \\
$\begin{array}{l}\text { Online-Shops werden den Handel vor Ort in Zukunft } \\
\text { verdrängen. }\end{array}$ & 0,649 & 3,30 \\
$\begin{array}{l}\text { Online-Shops haben keine Zukunft in der Agrarbranche. } \\
\text { a5er Likert-Skala: } 1=, \text {,stimme voll und ganz zu“ bis 5=,,lehne voll und ganz ab“; KMO=0,608; }\end{array}$ & $-0,785$ \\
$\begin{array}{l}\text { Erklärte Gesamtvarianz=56,642\%; Cronbach's Alpha=0,598 } \\
\text { Quelle: Eigene Erhebung. }\end{array}$
\end{tabular}

Tabelle 1 zeigt das Ergebnis der Faktorenanalyse, in welcher die drei Statements zur Einschätzung der Zukunftsperspektiven von Online-Shops in der Agrarbranche zu einem Faktor verdichtet werden konnten. Insgesamt gehen die LandwirtInnen davon aus, dass die Bedeutung von Online-Shops für die Landwirtschaft zunehmen wird und diese eine Zukunft in der Agrarbranche haben (Tabelle 1). 15,4\% der befragten LandwirtInnen gehen sogar davon aus, dass der Online-Shop den Handel vor Ort in Zukunft verdrängen wird, und 21,3\% stimmten dem Statement „Der Landwirt von morgen ist ein Online-Shopper“ zu. Rund 70\% $(\mathrm{n}=256)$ waren sich eher uneinig darüber, ob der/die LandwirtIn zu einem Online-Shopper wird. 41,4\% der Befragten lehnten zudem ab, dass der Handel vor Ort durch den Online-Shop verdrängt werden könnte. Mit einem Mittelwert von 1,51 stimmten LandwirtInnen zu, in engem Kontakt zum Handel vor Ort zu stehen.

Empirische Befunde belegen, dass die Zufriedenheit und das Vertrauen der Kundschaft zum stationären Handel die Einstellung der/des Kunden-/innen zum Online-Einkauf beeinflusst (Gartzke, 2016; Lingenfelder, 2004). Abgeleitet davon soll geprüft werden, ob die enge Beziehung eines Landwirts zum lokalen Handel und die Einschätzung der Zukunftsperspektiven von Online-Shops in der Agrarbranche in einem Zusammenhang stehen. 
Ebenso soll erklärt werden, welchen Einfluss die Online-Shop-Nutzungsrate auf die Einschätzung der Zukunftsperspektiven hat. Die beschriebenen Zusammenhänge werden mit Hilfe einer Regressionsanalyse untersucht. Diese empfiehlt sich, wenn wie hier von einer Ursache-Wirkungsbeziehung ausgegangen werden kann (Rönz und Förster, 2013). Die Ergebnisse zeigen, dass $30 \%\left(\mathrm{R}^{2}\right)$ der Varianz der eingeschätzten Zukunftsperspektiven durch die sieben Items erklärt werden können (Tabelle 2).

Tabelle 2: Regressionsanalyse Zukunftsperspektive und Landwirt-Händler-Beziehung

\begin{tabular}{|c|c|c|}
\hline Unabhängige Variablen & Beta-Wert $(\beta)$ & T-Wert \\
\hline Häufigkeit des Einkaufs vor Ort. ${ }^{a}$ & 0,029 & 0,612 \\
\hline Häufigkeit des Online-Einkaufs. ${ }^{a}$ & $0,205 * * *$ & 4,253 \\
\hline Wichtigkeit der persönlichen Beratung. & $-0,158 * * *$ & $-3,231$ \\
\hline Ich kaufe immer beim gleichen Händler. & $-0,152 * * *$ & $-3,242$ \\
\hline Ich stehe in engem Kontakt zum Handel vor Ort. & 0,031 & 0,652 \\
\hline Ich habe kein Vertrauen in Online-Shops. & $-0,121 * *$ & $-2,504$ \\
\hline In Zukunft werde ich mehr Betriebsmittel online kaufen. & $0,299 * * *$ & 5,880 \\
\hline
\end{tabular}

Gemessen am Beta-Wert wird die Einschätzung der Zukunftsperspektiven am stärksten durch die zukünftige Nutzungsabsicht der LandwirtInnen $(\beta=0,299 * * *)$ und deren bisherige Nutzung von Online-Shops $\left(\beta=0,205^{* * *}\right)$ beeinflusst. LandwirtInnen, denen eine persönliche Beratung wichtig ist, bewerten die Zukunftsperspektiven von Online-Shops hingegen signifikant schlechter $\left(\beta=-0,158^{* *}\right)$. Sind LandwirtInnen bei der Einschätzung der Zukunftsperspektiven zurückhaltend, weisen sie eine stärkere Händlerloyalität $\left(\beta=-0,152^{* * *}\right)$ und ein geringes Vertrauen gegenüber Online-Shops $\left(\beta=-0,121^{* *}\right)$ auf. Keinen signifikanten Einfluss hat hingegen die tatsächliche vor Ort-Einkaufsrate, das heißt die Häufigkeit, mit der Betriebsmittel im stationären Handel erworben werden $(\beta=0,029)$. Ebenfalls keinen Einfluss auf die Beurteilung der Zukunftsperspektiven hat die Intensität des Kontakts zwischen Landwirt und Handel $(\beta=0,031)$. Mittels weiterer Regressions- und Korrelationsanalysen wurde zudem geprüft, ob soziodemografische und betriebsbezogene Faktoren (Alter, Bildungsniveau, Betriebsform- und -größe) die Beurteilung beeinflussen. Hier konnte interessanterweise kein signifikanter Zusammenhang identifiziert werden. 


\section{$4 \quad$ Diskussion und Schlussfolgerung}

Diese Studie liefert erste Erkenntnisse zu den Zukunftsperspektiven von Online-Shops und der Bedeutung des stationären Handels in der Landwirtschaft. Die Ergebnisse helfen, die Potenziale landwirtschaftlicher Online-Shops nicht nur von den allgemeinen Trends innerhalb des B2BE-Commerce-Segments abzuleiten, sondern auch von den Einschätzungen ihrer tatsächlichen Nutzer, den LandwirteInnen.

Generell stehen LandwirtInnen Online-Shops bereits positiv gegenüber. Viele von ihnen haben gute Erfahrungen mit dem Online-Einkauf von Betriebsmitteln gemacht. Allerdings kann das bisherige Online-Angebot Landwirtschaft Betreibende nur bedingt zufriedenstellen. Insgesamt wird den Online-Shops in der Landwirtschaft seitens der LandwirtInnen eine wachsende Bedeutung beigemessen. So gehen sie davon aus, dass Online-Shops in der Agrarbranche zukünftig eine zunehmende Rolle spielen werden und durchaus Zukunftspotenziale besitzen. Dem Bedeutungswachstum von Online-Shops werden jedoch deutliche Grenzen gesetzt. Die meisten LandwirtInnen gehen nicht davon aus, dass Online-Shops den stationären Handel in Zukunft verdrängen können. Das bedeutet, dass LandwirtInnen den traditionellen stationären Landhandel durch die Existenz von Online-Shops nicht konkret bedroht sehen. Zu bedenken ist jedoch, dass immerhin 15,4\% der Befragten eine Verdrängung des stationären Handels durch den wachsenden Online-Markt vermuten. Interessant ist zudem, dass 21,3\% der Teilnehmer prognostizieren, dass LandwirtInnen in Zukunft zu aktiven Online-Shoppern werden.

Auch die Unsicherheit hinsichtlich dieser Aussage von rund 70\% der Befragten (Antwort teils/teils) belegt, dass ein Bedeutungszuwachs innerhalb der Landwirtschaft erwartet wird. Daraus lässt sich ableiten, dass die stationären physischen Märkte durchaus mit dem Internet (Ecommerce) um den Status des von LandwirtInnen bevorzugten Einkaufskanals konkurrieren, wenn auch auf einem noch sehr geringen Level. Die Ergebnisse zeigen, dass die Bewertung der Zukunftsperspektiven stark davon abhängig ist, wie intensiv LandwirtInnen bereits für den Betrieb online einkaufen oder dies in Zukunft planen. Ebenfalls entscheidend ist aber, wie ausgeprägt die Loyalität des Landwirts zum lokalen Handel und wie stark dessen Nachfrage nach persönlicher Beratung ist. Die Ergebnisse weisen darauf hin, dass die Chancen für OnlineShops bzw. E-Commerce in der landwirtschaftlichen Vorleistungsindustrie umso besser sind, je schwächer die Bindung zwischen diesen beiden Akteuren ist und je größer das Vertrauen in Online-Shops ist. 
Aktuell ist die Beziehung zwischen LandwirtInnen und ihren Betriebsmittelzulieferern noch sehr stark. Gründe für die starke Bindung zum Landhandel sind u. a. Standortvorteile des Landhandels und die damit verbundene Möglichkeit der schnellen Beschaffung sowie das Vorhandensein von AnsprechpartnerInnen (Gollisch und Theuvsen, 2015). Jedoch zeigt diese Studie, dass der enge Kontakt der LandwirtInnen zum Handel vor Ort die Beurteilung der Zukunftsperspektiven nicht, wie anzunehmen wäre, negativ beeinflusst, welches auf einen Bedeutungsverlust der Landwirt-Händler-Beziehung hinweisen könnte. Andere Studien weisen bereits auf einen Rückgang der Intensität traditioneller und meist emotionaler Beziehungen zwischen LandwirtIn und Agrarhandel hin, unter anderem begründet durch die zunehmende Preisfokussierung der LandwirtInnen (Gollisch und Theuvsen, 2015).

Abschließend lässt sich festhalten, dass der E-Commerce mit einem Rückgang der Intensität traditioneller Landwirt-Händler-Beziehungen eine stärkere Rolle im Einkaufsprozess der LandwirtInnen einnehmen wird. Ein gezieltes Multichannel Management, welches die landwirtschaftliche Kundschaft sowohl offline als auch online bedienen kann, wird daher zukünftig umso wichtiger. 


\section{Literatur}

Batte, M. T. und Ernst, S. (2007). Net Gains from 'Net Purchases? Farmers' Preferences for Online and Local Input Purchases. Agricultural and Resource Economics Review 36(1): 84-94. doi: $10.1017 / \mathrm{S} 1068280500009461$

Bühl, A. (2014). SPSS 22. Einführung in die moderne Datenanalyse. ST, Scientific Tools. Pearson, Hallbergmoos.

Clasen, M. (2005). Erfolgsfaktoren digitaler Marktplätze in der Agrar-und Ernährungsindustrie. Deutscher Universitäts-Verlag, Wiesbaden.

Gartzke, S. (2016). Kleffmann Group Global New Media Tracker - Our international Study. In: Farwick, C. (Hrsg.) Kleffmann Group. Agri Experts Around the World. Newsletter, 18-21.

Gollisch, S. und Theuvsen, L. (2015). Risikomanagement im Landhandel: Charakteristika, Herausforderungen, Implikationen. Berichte über Landwirtschaft Zeitschrift für Agrarpolitik und Landwirtschaft 93(1): 1-16. Doi: 10.12767/buel.v93i1.72

Henderson, J., Dooley, F. und Akridge, J. (2004). Internet and E-Commerce Adoption by Agricultural Input Firms. Review of Agricultural Economics 26(4): 505-520. Doi: 10.2307/3700794

Lingenfelder, M. (2004). Die Identifikation und Bearbeitung von Online-Käufersegmenten-Ergebnisse einer empirischen Untersuchung. In: Fritz, W. (Hrsg.) Internet-Marketing und Electronic Commerce. Grundlagen-Rahmenbedingungen-Instrumente. Gabler Verlag, Wiesbaden, 373-398.

Little, A. (2017). Wachstumstreiber B2B-E-Commerce. Handelsjournal Das Wirtschaftsmagazin für den Handel. https://www.handelsjournal.de/handel/e-commerce/wachstumstreiber-b2b-ecommerce.html. (28.08.18).

Rönz, B. und Förster, E. (2013). Regressions-und Korrelationsanalyse: Grundlagen-MethodenBeispiele. Gabler Verlag, Wiesbaden.

Strzębicki, D. (2015). The development of electronic commerce in agribusiness-The polish example. Procedia economics and finance 23(2015): 1314-1320. Doi: 10.1016/S2212-5671(15)00573-0 


\section{I.4 Crop Protection Market Segmentation: Relationship Between Buyer Segments and the Use of Digital Sales Channels}

Authors: Dorothee Schulze Schwering, Anna Hollenbeck, Saskia Krone, Achim Spiller \& Dominic Lemken

This article was submitted in a similar form for review at International Food and Agribusiness Management Association (IFAMR). 


\title{
I.4 Crop Protection Market Segmentation: Relationship Between Buyer Segments and the Use of Digital Sales Channels
}

\begin{abstract}
Digital technologies are revolutionizing agricultural trade, enabling farm input suppliers to reach customers through multiple channels. The aim of this study was to segment farmers based on their purchasing behavior for crop protection products and to examine segment-specific characteristics in the digital environment. A cluster analysis of 590 German farm managers was used to identify five distinctive buyer segments: relationship, independent, balance, persistent, and comfortable service buyers, indicating that this well-established segmentation approach is basically replicable for the German crop protection market. Independent buyers are neither dealer- nor brand-oriented, while persistent buyers prefer to buy locally and place the least value to services. Relationship buyers demand intensive personal contact, while comfortable service buyers focus on dealer and service availability but decide autonomously. However, this typology is less suitable for drawing detailed conclusions about digital behavior, as digital search and information behavior differs only little between the clusters. Regarding e-commerce, independent buyers are significantly more willing to engage in online shopping. The perception of e-commerce advantages and lack of personal contact differentiates the clusters the most. The results contribute to a better understanding of farmers' information seeking and purchasing behavior and its scientific approach.
\end{abstract}

Key Words: Farm inputs, agri-chemical, cluster analysis, purchasing behavior, omni-channel 


\section{$1 \quad$ Introduction}

Agricultural input markets for products such as animal feed, seeds, crop protection, and fertilizers are essential market segments in global agribusiness. They are characterized by ongoing transformation processes, such as lasting agricultural structural change on the customer side and mergers and consolidations on the supplier side (Munz and Doluschitz, 2021). Added to this, the "megatrend" of digitalization affects all players in agricultural value chains and drives many change processes (Gandorfer et al., 2017). Simple and for all market participants transparent and quickly available information on prices and offers for agricultural inputs, induced by digitalization, represent a core challenge for the agricultural input industry. The emergence and increasing spread of online trade (e-commerce), especially by the massive push of digital marketplaces by start-ups, has led to increasing competition (Munz and Doluschitz, 2020). Established companies therefore feel increasing pressure to change or adapt their business models (Deutsch et al., 2020). In Germany, cooperatives and the agricultural trade are adapting to market changes by mergers and the implementation of own e-commerce activities. Large cooperatives like Agravis and Baywa or long-standing agricultural retailers like ATR have already expanded their digital sales channels to attract and retain customers (Bickert, 2020; Deutsch et al., 2020; Huchtemann, 2020).

The transformation processes described can be seen particularly well in the German crop protection sector. In Germany, fertilizers and pesticides are the third-largest cost item for producing agriculture (Pascher et al., 2018). However, the German crop protection market faces a downward trend. Prices for crop protection products have tended to decline or grow only weakly in recent years, and the volume of active ingredients sold and sales in the direct business have declined (Agropages, 2020; Nishimoto, 2019). At the same time, the global crop protection market has developed into an oligopoly market (Bonny, 2017; Nishimoto, 2019; Sparks and Bryant, 2021). Through mergers and acquisitions (Schweizer, 2017), the four leading crop protection manufacturers Bayer CropScience/Monsanto, BASF, Syngenta, and DowDuPont currently hold a market share of more than 70\% (Fröndhoff, 2018). In addition, the number of farms is declining in favor of large farms, with $5 \%$ of the largest farms already managing more than $40 \%$ of agricultural land (Junge, 2021). The industry is thus confronted with a growing countervailing power of the ever-expanding farms and the changing requirement profiles of trading partners and agricultural customers (Hill, 2015). 
To create competitive advantages, agri-chemical companies are increasingly turning to digital business models. Ongoing digital upheaval in agriculture supports this. Digital progress in agriculture creates new possibilities for documentation, precision farming, and procurement of information and resources. Today, farmers are seeking out mobile applications, like pest control apps, and e-commerce options for their farms. $9 \%$ of German farmers buy crop protection products online, although the penetration rate for other product groups is higher (Gartzke, 2016). In global comparison, $11 \%$ of U.S. farmers and $8 \%$ of European farmers buy crop inputs online (Ardrey et al., 2020; Eckelkamp, 2019). The low e-commerce penetration rate for crop protection products suggests that consultation and purchase take place locally, and the local trade relationship is solid, making e-commerce adoption unattractive to farmers to date (Ardrey et al., 2020). Nevertheless, there is an increasing willingness of farmers to conduct e-commerce. But how does the farmers' reluctance to buy crop protection online, i.e., the preference for more traditional buying, and the push for digital solutions on the supplier side, fit together? Studies indicate the high degree of heterogeneity among farmers in their use of new information media (Fecke et al., 2018b; Kassem et al., 2021) as well as e-commerce (Ackermann et al., 2018; Ardrey et al., 2020; Fecke et al., 2018a; Schulze Schwering and Spiller, 2018).

The challenge for companies is to target farmers' needs based on their willingness to use digital tools by developing customer typologies that set out the most promising customer group. Nevertheless, current research has only meagerly addressed this topic. To close this gap, a market segmentation is particularly suitable. Segmentation has been an important marketing tool since the 1970s (Bernecker, 2019). Also in agricultural research, segmentation has become a standard approach to studying agricultural purchasing behavior and has been helping to develop customer-oriented marketing strategies. Seminal studies from the U.S. established a segmentation approach based on factors that are decisive when selecting a supplier (Alexander et al., 2005; Gloy and Akridge, 1999). At that time, the focus on building long-term customer relationships among input suppliers increased, which raised the question of which customers should a company attempt to build such relationships with (Gloy et al., 1997). Therefore, studies segmenting commercial farms to identify market segments for agricultural suppliers in order to optimize marketing efforts, were perceived as novel (Gloy et al., 2000; Gloy and Akridge, 1999).

However, these studies date back several years, and only a few studies investigated farmers' buying behavior for a specific product category. European agricultural segmentation studies are particularly rare. With agricultural structures and trade undergoing changes, it is therefore 
interesting for agribusinesses to obtain more recent data. Therefore, the first two research questions aim to clarify whether these long-established segmentation approaches are still valid and whether they are also valid for a specific market like German crop protection. Moreover, the literature lacks consideration of how the identified segments differ in their attitudes toward digital sales channels. For this reason, the third research question addresses the relationship between crop protection market segmentation and the purchase-related usage of digital sales channels. A survey of the purchase of crop protection products among German farmers serves as the data foundation. Principal component and cluster analysis were used to answer the research question. The market segmentation of this study helps to identify factors that are important in crop protection purchasing and helps to evaluate the common segmentation approach in terms of its current replicability. It also provides further insights into the extent to which digital media are already part of the purchasing process and whether these segmentation approaches can be used to identify typologies of digital behaviors in the purchasing process.

The following provides an overview of the current state of research on agricultural purchasing behavior. Subsequently, the data collection and evaluation methods used are presented, followed by the presentation of the results. In the discussion part, the results are critically examined and interpreted based on the presented theory.

\section{Market Segmentation in Agricultural Trade}

There have been several studies on segmentation in agricultural procurement markets. These studies refer primarily to the U.S. and both to agricultural investment goods (like machines) and expendable goods (such as seed, fertilizer, chemicals). Segmentation was mainly based on the importance of six factors that farmers assess when selecting a supplier: convenience/location, customer service/information (e.g., responsiveness, advice), personal factors (e.g., trust, work relationships), price, product performance (e.g., durability, yield), and support service (e.g., repair, delivery), (Fig. 1). These factors identified four main market segments: balance, price, performance, and convenience (Borchers et al., 2012; Feeney and Berardi, 2013; Gloy and Akridge, 1999; Roucan-Kane et al., 2011), where balance buyers weight all factors relatively equally. Few studies have also identified a service or relationshiporiented segment (Alexander et al., 2005; Burgert, 2011; Gundersson et al., 2005).

Besides the knowledge of U.S. studies, European studies have applied different segmentation variables. According to Dutch results of Kool (1994), the local dealer has a unique position in agricultural procurement. According to the degree of vendor loyalty and commitment, 
he identified three farmer segments: spurious dealer loyalty, true dealer loyalty, and behavioral dealer loyalty. Zimmermann (2003) investigated German farmers' purchasing behavior for agricultural capital goods (tractors, automatic feeders) and identified market segments built on attitude-based factors: brand loyalty, dealer loyalty, willingness to innovate, pre-sales marketing of the trade, and variety-seeking/prestige consumption and experience. For tractors, dealer- and brand-oriented shoppers as well as smart shoppers and objective loaners were identified. Smart shoppers are innovation-driven and price-conscious, while objective loners are autonomous decision-makers, conservative, and skeptical. For automatic feeders four different clusters evoked: pragmatist, prestige-oriented dealer loyal, knowledge thirsty and price-conscious conservative. While the pragmatists balance all variables fairly equally, the group prestige-oriented dealer loyalty is characterized by dealer and brand loyalty and the influenceability by their social environment (Zimmermann, 2003).

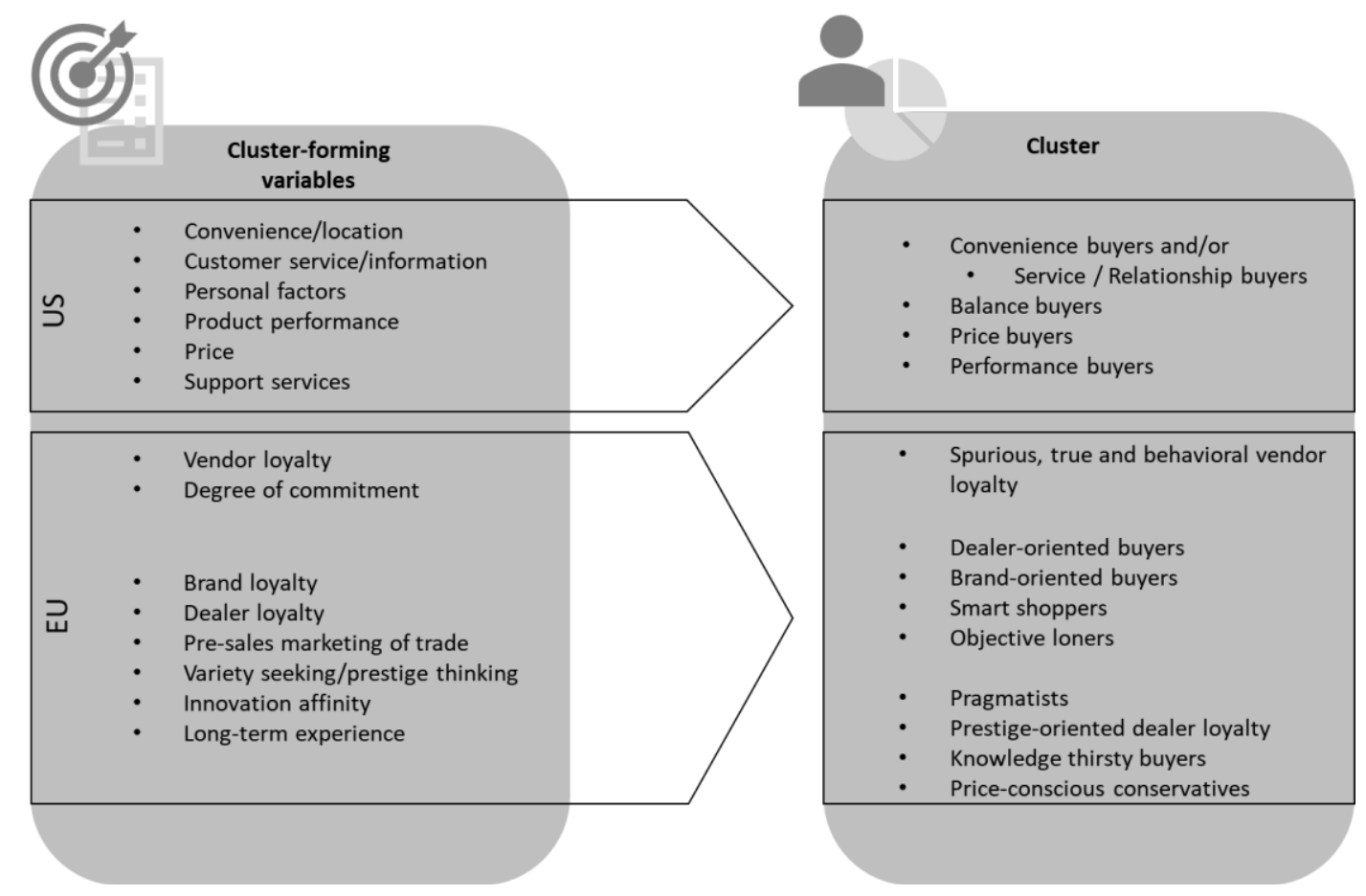

Figure 1: Overview of agricultural market segmentation approaches Source: Own elaboration.

Borchers et al. (2012) conducted a separate cluster analysis according to the type of farm input (seeds, crop protection, animal health, and feed) using five factors established by Gloy and Akridge (1999). The data, based on a U.S. survey conducted in 2008 with 980 responding crop producers, identified four segments: balance (57\%), price (18\%), performance $(14.4 \%)$, and convenience $(10.6 \%)$. Views on brands varied significantly, with price buyers being less brand loyal and more favorable towards generic products. Approximately $39 \%$ of the balance and convenience segments considered themselves brand loyal. The convenience segment was 
particularly loyal to its local agricultural trader (71\%), whereas the price segment was the least loyal farmer group. Moreover, convenience and price shoppers tended to make their decisions more independently. Due to its size, the balancing segment was desirable to crop protection sellers, and a distinctive feature of these individuals was that they still emphasized support services. Borchers et al. (2012) state that the four market segments are relatively consistent across several products, but that purchasing decisions for expendable goods depend on whether they are plant-related (seeds, crop protection) or animal-related (animal health, animal feed).

All in all, the results in the U.S. and the EU are quite similar, for example, there are similarities between: Retailer orientation and the convenience segment, brand orientation and performance buyers or between objective loaners and price buyers.

The formation of buyer typologies is still important because the results illustrated the complexity of marketing to commercial agricultural producers and their product category dependent and heterogeneous buying preferences (Borchers et al., 2012; Gloy and Akridge, 1999). Manufacturers and agricultural retailers must therefore "focus on the unique buying preferences of individual segments" (Gloy and Akridge, 1999).

\section{Digitization and Changing Buying Behavior in Agricultural Trade}

Even though dealer loyalty is high and personal relationships are critical, agricultural trade pushes for digital solutions and online sales (Bennett, 2018; Bickert, 2020). Agriculture is undergoing a digital transformation. Technology is already part of a farmer's business, and the management of upcoming data is a core resource of future business. Figures show a general increase in penetration of digital technologies and e-commerce on the farm, with about onethird using digital technologies like automatic steering systems or GPS technology (Gabriel et al., 2021). In the next few years, the primary sensors, actuators, and devices in agriculture will be connected via the internet with the fundamental goal of interaction, control, and decisionmaking (Khanna and Kaur, 2019). Significantly, the latest developments in smartphone technology enable new decision support tools to be integrated into everyday work (Bonke et al., 2018; Michels et al., 2020). According to Michels et al. (2020), 95\% of surveyed German farmers use smartphones and $71 \%$ use a crop protection smartphone app for gathering information about pest scouting, weather, and infestations forecasts. Those results illustrate that procurement of information on operating resources or production methods is increasingly shifting to the digital format. Looking at the stages of the customer decision journey, most European farmers prefer non-digital options, while initial product research is preferred to be 
conducted online by $87 \%$. Evaluation of suppliers and the use of servicing products are favored online by nearly half of the European farmers (Ardrey et al., 2020).

With this high digital level on the farms, the essential prerequisite for e-commerce is given. However, so far, digital procurement options have been adopted only slowly by European farmers. Only $13 \%$ have made an online purchase of agricultural inputs, while $33 \%$ state that they want to buy agricultural products online (Ardrey et al., 2020). Results from Germany show that agricultural inputs are mainly purchased from stationery retailers. E-commerce is used relatively rarely and only for specific product categories. Agricultural expendable goods, such as seeds, fertilizers, and pesticides, have only seldomly been bought online (Ackermann et al., 2018; Gartzke, 2016; Schulze Schwering and Spiller, 2018). Even with increasing digitization, the main factors that farmers assess when selecting a supplier remain relatively constant. Considering purchasing crop inputs, farmers emphasize price, availability of products and brands, ease of purchasing, and availability of consultants (Bennett, 2018; Eckelkamp, 2019). Fecke et al. (2018a) show that farmers demand a significantly higher annual price advantage for switching to an online retailer than switching to another regional retailer. However, short delivery times and initial experience with online shopping may favor the choice of an online store for the purchase of crop protection products (Fecke et al., 2018a). It becomes apparent that agricultural trade is undergoing a massive transformation process, leading to changing buyer expectations. Therefore, companies have to adapt business models, and farmers must be guided through the complexity and mass of information (Eckelkamp, 2018). To retain in this competitive market, manufacturers and retailers should develop new sales strategies by incorporating digital solutions. As the literature shows, while farmers favor local, personal shopping on the one hand, they are increasingly opening up to digital sales channels such as the internet, mobile apps, or e-commerce on the other hand.

For the players in agribusiness, current research is important, as it is important to know whether there is a relationship between the basic purchasing behavior for crop protection products and the usage behavior of digital sales channels. Since previous segmentation studies have mainly focused on U.S. markets for general inputs and are several years old (Alexander et al., 2005; Gloy and Akridge, 1999), the first step is to examine whether these common segmentation approaches are still valid today and whether they can be transferred to the German crop protection market. Moreover, previous segmentation studies have largely neglected the use of digital media in the purchasing process. Against this background, this study analyzes the segment-specific relevance of digital sales channels. At the same time, this will provide 
information on the extent to which existing segmentation approaches can be applied to the analysis of digital behavior in the agricultural purchasing process. New research is necessary to understand customers and to derive recommendations for manufacturers as well as for offline and online merchants to remain competitive in this challenging crop protection market. Because German farmers stand out in a European comparison for their openness to digital applications, it is particularly interesting to take a closer look at their purchasing behavior. In addition, studies have highlighted the need for targeted behavioral and digital marketing strategies to increase customer satisfaction (Ardrey et al., 2020; Borchers et al., 2012).

\section{$4 \quad$ Materials and Methods}

\subsection{Data collection and questionnaire design}

In this study, 590 farmers were interviewed digitally and by telephone by the agricultural market research service provider Kleffmann Group. The study was quoted in terms of region and farm size (Statistisches Bundesamt, 2017). Farms with less than 20 ha of agricultural land were excluded. A quota system was used because an unwanted imbalance could have arisen due to the online recruitment process, making it difficult to transfer the results to the general population of farmers. The survey was only open to farmers involved in the procurement process and who used crop protection in 2017. The questionnaire consisted of four parts: an attitude-based item battery, identification of information sources focusing on digital media, sources of supply, and farm data. The selection of items was based on proven measurement concepts from empirical studies by Kool (1994), Gloy and Akridge (1999), Zimmermann (2003), Alexander et al. (2005), Roucan-Kane et al. (2011), and Borchers et al. (2012). It covered five main areas: convenience, customer service, price, product performance, and support service. Closed questions with a five-level Likert scale from one, "does not describe me at all", to five, "describes me very well", were used for the attitude-based items. The question sequence of the individual items of the sections rotated between respondents to avoid order effects.

\subsection{Data preparation by multiple imputations with chain equation}

For further data analysis, the data set was first subjected to a quality check and adjusted accordingly. Subjects with too fast or stereotypical responses and outliers were eliminated. After data cleaning, a data set with data from 590 farmers remained for further analysis. However, parts of the questionnaire were not answered thoroughly by all respondents. 
Missing values concerned many observations (18.3\%), while only a tiny percentage of the values among the relevant variables was missing (1.2\%). Incomplete data may occur since participants were not forced to develop an opinion on all variables. In this case, 108 valid observations showed at least one missing value that otherwise would have been dropped. Missing values are problematic for principal component analyses as they lead to serious distortion and incongruous of obtained results with the relationships inherent in the data (Mackelprang, 1970). Several methods have been developed to overcome the drawbacks produced by missing values (Luengo et al., 2012; Schlomer et al., 2010). Schlomer et al. (2010) urge researchers to provide more details on how missing data has been dealt with, even if deletion has been carried out on a case-by-case basis, i.e., incomplete cases disappear. Imputations based on mean values are rejected in the literature as poorly functioning or distorted methods (Schlomer et al., 2010). A state-of-the-art approach is multiple imputations with chained equation (MICE), (Zhang, 2016). If, in detail, no a priori information indicates why responses are lacking, the responses to similar attitudes can be used to predict the response to a missing attitude. Predicting a missing value is characteristic of MICE to improve the prediction of a different missing value for each subject. The optimized prediction is used to improve the previous prediction (Zhang, 2016). Five sets of MICE imputations are performed using ordinal regressions for the prediction functions since the preference variables' ordinal nature is given. The five imputations' median is selected as the imputation value to complete the responses to an attitude. Now, all calculations can use the complete set of 590 observations. The statistical program Stata was used for data management and model execution.

\subsection{Data analysis}

After data preparation, a principal component analysis (PCA) with varimax rotation was carried out in order to condense the variables and to operationalize clustering variables following Gloy and Akridge (1999). For this purpose, the initial data were first tested for their suitability for principal component analysis using the Kaiser-Meyer-Olkin criterion (KMO) and the variablespecific measure of sampling adequacy (MSA). The former shows the extent to which the initial variables belong together based on the anti-image correlation matrix and serves as a suitability indicator. According to Kaiser and Rice (1974), the value should be at least 0.5. MSA provides an indication of which individual variables are unsuitable for the principal component analysis. This value should be greater than 0.6. Thus, three statements had to be excluded. In the second step, a dimension reduction was carried out with an explorative principal component analysis. The information on attitudes and behaviors described as necessary to purchasing was strongly 
summarized (Assael, 1984; Backhaus et al., 2016). From 31 applicable statements, all factors with an eigenvalue more significant than one were extracted using the Kaiser criterion (Backhaus et al., 2016). Five factors could be identified. The individual factors were judged as satisfactory based on reliability using Cronbach's alpha $(\mathrm{C} \alpha)$ and validity, the explained total variance. The $\mathrm{C} \alpha$ value should be at least 0.5 (Peterson, 1994) and the total variance at least $50 \%$. In the next step, the extracted standardized factors scores based on PCA were subjected to cluster analysis. Cluster analysis serves to classify the content of groups with homogeneous characteristics that simultaneously exhibit heterogeneity among themselves (Backhaus et al., 2016). The process of cluster analysis is based on the two-stage process following Gloy and Akridge (1999), Alexander et al. (2005), Roucan-Kane et al. (2011), and Borchers et al. (2012). A hierarchical cluster analysis was performed to identify the different possibilities of cluster numbers, by applying the Ward method with the squared Euclidean distance. After a systematic comparison of the cluster possibilities, content considerations, and interpretability, the decision was made in favor of a 5-cluster solution. The solution was then used as the starting value for the iteratively partitioning k-means algorithm, which generated the results. With the help of discriminant analysis, the classification accuracy could be determined. Finally, the clusters were described in more detail, focusing on their sociodemographic and business-related data, digital information, and purchasing behavior. The data was evaluated using IBM SPSS Statistics 25 .

\section{$5 \quad$ Results}

First, a sample description is given before the results of the principal component and cluster analysis are presented. This is followed by a description of the segments based on sociodemographic and farm-related data and the attitude towards digital sales channels.

\subsection{Sample description}

The sample includes 590 interviews generated from $38 \%$ online interviews and $62 \%$ computerassisted telephone interviews (CATI). The average age of the respondents is 51.7 years. The farms have an average of 148.3 hectares of agricultural area. On German average, farms with 20 hectares and more manage 104 hectares of farmland (Statistisches Bundesamt, 2017). Compared to this average, the represented farm size is relatively large. The gender distribution comprises $97 \%$ male and 3\% female respondents, thus women are slightly underrepresented. In Germany, less than ten percent of farms are run by women (Pascher et al., 2018). 40\% of the 
interviewees manage farms in southern Germany, 26\% in northern Germany, 25\% in western Germany, and $9 \%$ in eastern Germany. The distribution of farms by federal state resembles the agricultural structure in Germany (Hübbers, 2018). The sample consists of 9\% livestock farms (swine, poultry), 20\% feed-producing farms, 34\% cash crop farms (business segments generated $75 \%$ of the revenue), and $34 \%$ of the farms are mixed farms, i.e., farms with several management branches, whereby no branch accounts for more than $75 \%$ of the farm revenue (BMEL, 2019). This breakdown differs from the overall statistics and represents significantly more mixed farms. $77 \%$ of respondents have completed a vocational training, $19 \%$ hold a university degree, and the remaining $4 \%$ do not provide any information. The level of education is approximately in line with the official statistics, with $12 \%$ university graduates (Pascher et al., 2018). For $37 \%$ of the respondents, cereals are the most important crop on the farm and $28 \%$ maize.

\subsection{Principal component analysis of clustering variables}

According to Kaiser and Rice (1974), the statements with a KMO value of 0.78 could be described as meritorious (Table 1). The limit value of the explained total variance was exceeded. Five factors could be identified from the full statements. The internal cons istency of the factors was tested using Cronbach's alpha $(\mathrm{C} \alpha)$, whereby all factors could be accepted based on $\mathrm{C} \alpha$ values above 0.5 .

The identified factors deviate slightly from the five primary item batteries in the questionnaire: convenience, customer service, price, product performance, and support service in accordance with Gloy and Akridge (1999), Alexander et al. (2005), Roucan-Kane et al. (2011), and Borchers et al. (2012). The first factor can be compared most closely with the convenience/location factor in the literature because it refers to the convenience, presence, and location of local suppliers. However, elements of the categories customer service/information and personal factors are included here, which makes the factor more dealer-oriented. According to product performance (product quality and durability) in literature, farmers distinguish between branded products and non-branded products, described by the factor brand affinity. The autonomous decision-making factor contains the attitude towards customer service, and it is based on the factor customer service/information in literature. The factor service orientation addresses delivery and return services and equals the support service in literature. The price factor consists of only one item and describes the importance of price. 
Table 1: Results of the principal component analysis

\begin{tabular}{|c|c|c|c|c|}
\hline Factor & Items & FL & Mean & SD \\
\hline \multirow{6}{*}{$\begin{array}{l}\text { Dealer } \\
\text { orientation } \\
\mathrm{C} \alpha=0.82\end{array}$} & \multirow{2}{*}{$\begin{array}{l}\text { I always buy from the same dealer; that's the easiest thing for me. } \\
\text { I prefer a fixed contact person where I buy all crop protection } \\
\text { products. }\end{array}$} & 0.80 & 3.40 & 1.39 \\
\hline & & 0.75 & 3.60 & 1.30 \\
\hline & Even if the price is slightly higher, I buy from the retailer I trust. & 0.74 & 3.81 & 1.15 \\
\hline & $\begin{array}{l}\text { If the retailer does not have my favorite product, I will buy } \\
\text { something similar from him. I will not change the dealer. }\end{array}$ & 0.75 & 3.43 & 1.33 \\
\hline & I prefer to buy crop protection products locally. & 0.66 & 4.07 & 1.07 \\
\hline & I only buy products where I get good advice. & 0.59 & 3.66 & 1.31 \\
\hline \multirow{5}{*}{$\begin{array}{l}\text { Brand affinity } \\
\mathrm{C} \alpha=0.78\end{array}$} & I prefer branded products. & 0.77 & 3.08 & 1.29 \\
\hline & For standard products, I prefer branded products. & 0.77 & 3.20 & 1.31 \\
\hline & $\begin{array}{l}\text { It is worth spending more money on a product from a well-known } \\
\text { company. }\end{array}$ & 0.74 & 2.68 & 1.17 \\
\hline & Imported products and branded products are of the same quality. & -0.63 & 2.85 & 1.20 \\
\hline & Generics and branded products are of the same quality. & -0.71 & 3.26 & 1.10 \\
\hline \multirow{3}{*}{$\begin{array}{l}\text { Autonomous } \\
\text { decision- } \\
\text { making } \\
\mathrm{C} \alpha=0.51\end{array}$} & For standard products, I do not need advice. & 0.71 & 3.15 & 1.22 \\
\hline & I decide on the product choice entirely on my own. & 0.66 & 3.13 & 1.39 \\
\hline & $\begin{array}{l}\text { I obtain factual information before the purchase and do not need any } \\
\text { further advice afterwards. }\end{array}$ & 0.67 & 3.14 & 1.17 \\
\hline \multirow{2}{*}{$\begin{array}{l}\text { Service } \\
\text { orientation } \\
\mathrm{C} \alpha=0.68\end{array}$} & $\begin{array}{l}\text { I always choose the retailer with the best service, such as returns and } \\
\text { delivery. }\end{array}$ & 0.84 & 3.30 & 1.26 \\
\hline & $\begin{array}{l}\text { The most important thing when buying crop protection products is } \\
\text { the ability to return them. }\end{array}$ & 0.86 & 2.85 & 1.35 \\
\hline $\begin{array}{l}\text { Price affinity } \\
\mathrm{C} \alpha=1.0\end{array}$ & Costs are the most important factor in product selection. & 0.94 & 2.66 & 1.12 \\
\hline
\end{tabular}

Explained total variance: $60.013 \% \mathrm{KMO}=0.786$ Mean value on a Likert scale from $1=$ "describes me not at all" to $5=$ "describe me very well”; standard deviation (SD); $\mathrm{C} \alpha=$ Cronbach's alpha

Source: Own elaboration.

\subsection{Cluster Analysis and Description of Clusters}

Based on the standardized factor scores obtained from PCA, the hierarchical cluster analysis (Ward method) identified a 5-cluster solution. A cluster center analysis (k-means) led to the final mean values of the cluster-forming variables. The F-values and the significance of the results were used to assess the homogeneity of the identified clusters. Since all variables have high F-values and low significance values, the cluster analysis was assessed as successful (Table 2). Discriminant analysis was used to determine a satisfactory classification accuracy of $94 \%$ for the cluster analysis. Table 2 illustrates the cluster-forming variables and the resulting mean values.

The clusters are quite homogeneous in size so that neither particularly small nor large clu sters are represented. The factor service orientation separates the clusters most strongly $(\mathrm{F}$-value $=153.802 * * *)$, followed by dealer orientation and the autonomous factor decisionmaking. In terms of service orientation, all clusters differ significantly from each other. In dealer orientation, clusters I and III and clusters IV and V do not differ significantly from each other. Regarding price affinity, clusters I and IV do not vary. Most clusters have a similar brand 
affinity, except cluster II, which is only comparable to cluster IV. Cluster I and cluster III differ from all other clusters with respect to autonomous decision-making.

Table 2: Mean values of the cluster-forming variables

\begin{tabular}{|c|c|c|c|c|c|c|c|}
\hline & & $\begin{array}{c}\text { Cluster I } \\
\text { Relationship }\end{array}$ & $\begin{array}{c}\text { Cluster II } \\
\text { Independent }\end{array}$ & $\begin{array}{l}\text { Cluster III } \\
\text { Balance }\end{array}$ & $\begin{array}{l}\text { Cluster IV } \\
\text { Persistent }\end{array}$ & $\begin{array}{c}\text { Cluster V } \\
\text { Service } \\
\text { comfortable }\end{array}$ & \\
\hline \multicolumn{2}{|l|}{ Sample size (\#) } & $\begin{array}{l}118 \\
20 \%\end{array}$ & $\begin{array}{c}99 \\
17 \%\end{array}$ & $\begin{array}{l}126 \\
21 \%\end{array}$ & $\begin{array}{l}111 \\
19 \%\end{array}$ & $\begin{array}{l}136 \\
23 \%\end{array}$ & \\
\hline \multicolumn{7}{|c|}{ Factor mean values (FMV) and mean values (MV) of the cluster-forming variables. } & $\begin{array}{c}\text { F- } \\
\text { value }\end{array}$ \\
\hline \multirow{3}{*}{$\begin{array}{l}\text { Dealer } \\
\text { orientation }\end{array}$} & FMV & $0.127^{\mathrm{III}}$ & -1.477 & $0.026^{\mathrm{I}}$ & $0.534^{\mathrm{V}}$ & $0.506^{\mathrm{IV}}$ & $\begin{array}{c}136.66 \\
* * *\end{array}$ \\
\hline & SD & 0.77 & 0.67 & 0.83 & 0.74 & 0.59 & \\
\hline & $\mathrm{MV}^{\mathrm{b}}$ & 3.93 & 2.28 & 3.69 & 3.94 & 4.18 & \\
\hline \multirow{3}{*}{$\begin{array}{l}\text { Brand } \\
\text { affinity }\end{array}$} & FMV & $0.033^{\mathrm{III}-\mathrm{V}}$ & $-0.384^{\mathrm{IV}}$ & $0.170^{\mathrm{I}, \mathrm{IV}, \mathrm{V}}$ & $-0.020^{\mathrm{I}-\mathrm{V}}$ & $0.110^{\mathrm{I}, \mathrm{III}, \mathrm{IV}}$ & $\begin{array}{l}5.15 \\
* * *\end{array}$ \\
\hline & $\mathrm{SD}$ & 1.03 & 1.10 & 0.95 & 0.94 & 0.93 & \\
\hline & $\mathrm{MV}^{\mathrm{b}}$ & 2.96 & 2.55 & 3.10 & 2.98 & 3.16 & \\
\hline \multirow{3}{*}{$\begin{array}{l}\text { Autonomous } \\
\text { decision- } \\
\text { making }\end{array}$} & FMV & -1.059 & $0.337^{\mathrm{IV}, \mathrm{V}}$ & -0.478 & $0.632^{\mathrm{II}, \mathrm{V}}$ & $0.600^{\mathrm{IIIVV}}$ & $\begin{array}{c}120.09 \\
* * *\end{array}$ \\
\hline & $\mathrm{SD}$ & 0.68 & 0.73 & 0.77 & 0.81 & 0.72 & \\
\hline & $\mathrm{MV}^{\mathrm{b}}$ & 2.20 & 3.59 & 2.77 & 3.57 & 3.62 & \\
\hline \multirow{3}{*}{$\begin{array}{l}\text { Service } \\
\text { orientation }\end{array}$} & FMV & 0.410 & 0.051 & -0.593 & -0.995 & 0.969 & $\begin{array}{c}153.80 \\
* * *\end{array}$ \\
\hline & SD & 0.76 & 0.83 & 0.67 & 0.73 & 0.52 & \\
\hline & $\mathrm{MV}^{\mathrm{b}}$ & 3.56 & 2.81 & 2.43 & 2.07 & 4.27 & \\
\hline \multirow{3}{*}{ Price affinity } & FMV & $0.654^{\mathrm{IV}}$ & 0.208 & -0.972 & $0.547^{\mathrm{I}}$ & -0.265 & $\begin{array}{c}85.08 \\
* * *\end{array}$ \\
\hline & $\mathrm{SD}$ & 0.84 & 1.00 & 0.59 & 0.80 & 0.76 & \\
\hline & $\mathrm{MV}^{\mathrm{b}}$ & 3.38 & 3.01 & 1.70 & 3.14 & 2.31 & \\
\hline
\end{tabular}

FMV = factor mean value, where positive (negative) values indicate that the variable is overrepresented (underrepresented) in the cluster compared to the survey population (B ACKHAUS et al., 2016). SD = standard deviation; Fvalues on ANOVA significance level: $* * * p \leq 0.001 ; b=$ mean values on a Likert scale from $1=$ "does not describe me at all" to $5=$ ="describes me very well"; I-V: According to the post hoc test, the clusters did not differ significantly (p < 0.05$)$ from marked clusters.

Source: Own elaboration.

Demographic and general farm characteristic data such as age, education, farm size, and location are used to describe the individual clusters (Table 3). Single factor variance analysis (ANOVA) was used to show mean differences and significance for age and farm size. The significance and percentage distribution of other characteristics was derived from the $\mathrm{x}^{2}$ statistic of the cross-tabulation. The results show relatively high significant differences between the clusters. The investigation of the sources of supply shows that the local dealer or cooperative serves as the main source of supply. Buying centers, field sales representatives, and contractors are partly used. E-commerce plays a subordinate role in purchasing crop protection products in this sample. Before buying crop protection products, the clusters request significantly different numbers of quotations (Table 3). 
Table 3: Demographic and farm characteristics

\begin{tabular}{|c|c|c|c|c|c|c|}
\hline & & $\begin{array}{c}\text { Cluster I } \\
\text { Relationship }\end{array}$ & $\begin{array}{c}\text { Cluster II } \\
\text { Independent }\end{array}$ & $\begin{array}{l}\text { Cluster III } \\
\text { Balance }\end{array}$ & $\begin{array}{l}\text { Cluster IV } \\
\text { Persistent }\end{array}$ & $\begin{array}{c}\text { Cluster V } \\
\text { Service } \\
\text { comfortable }\end{array}$ \\
\hline \multirow{2}{*}{\multicolumn{2}{|c|}{$\begin{array}{l}\emptyset \text {-Age }(\text { years })^{1} \\
\text {-farm size }\left(\text { hectares }^{1}\right.\end{array}$}} & 50.7 & 50.1 & 50.6 & 51.2 & 54.8 \\
\hline & & $142^{\mathrm{II}}$ & $302^{\mathrm{I}-\mathrm{V}}$ & $90^{\mathrm{II}}$ & $87^{\text {II }}$ & $145^{\mathrm{II}}$ \\
\hline $\begin{array}{l}{ }^{2} \text { Education } \\
(\%)\end{array}$ & $\begin{array}{l}\text { University } \\
\text { degree }\end{array}$ & 11.0 & 35.3 & 16.7 & 18.9 & 15.4 \\
\hline \multirow{4}{*}{${ }^{2} \operatorname{Region}(\%)$} & North & 29 & 28 & 30 & 23 & 21 \\
\hline & East & 9 & 19 & 2 & 5 & 10 \\
\hline & South & 35 & 32 & 41 & 52 & 40 \\
\hline & West & 27 & 20 & 26 & 21 & 29 \\
\hline \multicolumn{2}{|c|}{ Number of requested quotes ${ }^{1}$} & 1.6 & 2.6 & 1.7 & 1.4 & 1.5 \\
\hline \multirow{3}{*}{$\begin{array}{l}{ }^{2} \text { Source of } \\
\text { supply } \\
\text { locally }(\%)\end{array}$} & $100 \%$ & 51 & 24 & 48 & 66 & 57 \\
\hline & $\geq 50 \%<100 \%$ & 4 & 12 & 8 & 10 & 4 \\
\hline & $<50 \%$ & 5 & 5 & 4 & 3 & 2 \\
\hline
\end{tabular}

Source: Own elaboration.

Relationship. Cluster I comprise $20 \%$ of participants and is dealer- and service-oriented. About $51 \%$ buy $100 \%$ at local dealers or cooperatives. The cluster comparisons show that buyers in the relationship segment want to be actively advised and accompanied in their decision-making and purchasing process. They tend to focus more on the additional services and support provided by the supplier. They are less sensitive to brands but value product prices. Even when prices are closely scrutinized, ties to local dealers would weigh more heavily. Buyers in the relationship segment cultivate an average of 142 hectares, which is in the middle range in a cluster comparison. A characteristic feature of this segment is the comparatively lower level of education, with $11 \%$ having a university degree.

Independent. Cluster II is the smallest cluster, with $17 \%$ of the participants. Farmers in this segment are very autonomous decision-makers and buyers. They are identified as free spirits, neither dealer- nor brand-oriented. Regarding the source of supply, only $24 \%$ of this segment purchase $100 \%$ of their crop protection products at local trade or cooperatives. They ask for the most quotes before buying, which indicates that they do not feel tied to a particular supplier. Service and prices are not of great importance to them, either. Information is obtained and weighed up independently, thus a consultation is unnecessary for them. Services such as return options and delivery are only partly crucial to them. Independent buyers farm significantly more agricultural land and tend to be younger farmers with high education levels. The second cluster has the largest share of farms in eastern Germany. 
Balance. Cluster III represents the second-largest segment with 126 members (21\%). Compared to the other clusters, a low cost-orientation is the feature of this cluster that stand out, indicating that prices are not the most crucial buying criterion. Balance buyers weight other factors relatively equally, without further serious expressions. Their dealer orientation is the weakest after independent buyers. However, it can be assumed that they want to maintain their dealer relationships. Dealer orientation is weighted higher than product prices. The balance segment farms an average of 90 hectares and consists mainly of farmers from southern and northern Germany. In a cluster comparison, the balancing segment is in the middle range regarding age, education, and supply source.

Persistent. With 19\%, the segment of persistent buyers forms the second-smallest cluster. It is characterized by its dealer orientation, which is just as high as that of the relationship buyers. Though, this cluster does not attach particular importance to consultations and prefers to make decisions autonomously. Service is not given huge importance, either. This is even the lowest service orientation in comparison. Products brand and price play only a moderate role in the purchasing process. Their behavior seems to be guided by known situational circumstances by relying on tried-and-true, well-functioning purchases at local dealers or cooperatives. $66 \%$ buy $100 \%$ of their inputs at local dealers or cooperatives, and farmers request the least number of quotes. More than half of the fourth cluster is from southern Germany, and they cultivate the smallest area in comparison. However, with $19 \%$ holding a university degree, the fourth cluster has the second-highest educational level.

Service comfortable. Cluster V is the largest cluster with $23 \%(\mathrm{n}=136)$. This cluster stands out by the highest dealer and service orientation, coupled with a strong need for autonomous decision-making. It attaches only moderate importance to branded products. Respondents belonging to this cluster are second-most price-averse and reject price as the most important buying criterion in the cluster comparison. Return options and delivery conditions are decisive purchasing criteria. Local dealers are preferred over price and product benefits and are evaluated based on their service offerings. The segment is largely made up of farmers from western and southern Germany. This segment has the highest average age (55 years) and the second-largest average farm size (145 ha) in this sample. Local dealers or cooperatives are the only sources of crop protection supply for $57 \%$ of service comfortable farmers. 


\subsubsection{Differences in the use of digital media as a source of information}

Respondents were asked which sources of information they use and how important these are to them when purchasing crop inputs. Twenty sources of information were given, and multiple answers were possible. For further analysis, each source is assigned to a media category: personal, print, digital. Personal media includes colleagues, private/public consultants, working groups, sales representatives, and events. Print media covers regional and national agricultural journals, books, experimental results of traders or the chambers of agriculture, and company brochures. Digital sources include newsletters or websites of newspapers/journals, a newsletter of the industry, social networks, social media, and the internet. Results show that $52 \%$ use newsletters, social media, or the internet in general, and $25 \%$ of respondents use new digital media (apps, WhatsApp groups, forums) as a source of information or advice. In general, $36 \%$ of all respondents reject an app for crop protection advice, and 36\% express their interest. The importance of those media categories is illustrated in Figure 2 by taking the mean values per category on a Likert scale of $1=$ "unimportant" to 5="very important". Personal information sources are more important than print media and digital sources.

In the following, the clusters will be analyzed with respect to their current and future use of digital media. The data in Table 4 and Table 5 were generated using a cross table and were tested for significance $\left(\mathrm{x}^{2}\right)$. Even if only small significances were found, the information can provide an idea of cluster trends.

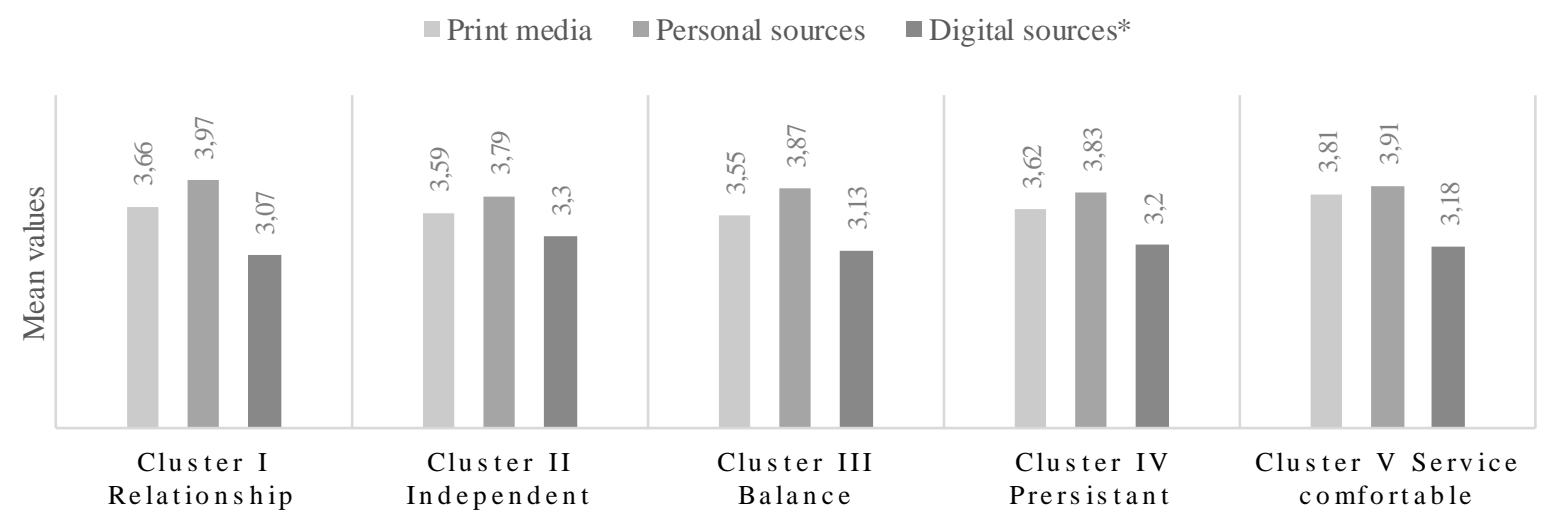

Figure 2: Importance of information sources

Mean values according to print media = magazines, technical books, brochures, test results $(n=539)$, personal sources = colleagues, private/public consultants, events $(n=576)$, digital sources $=$ newsletter, social media, internet ( $\mathrm{n}=302)$; Likert Sacle: $1=$ "unimportant" - 5="very important"; *significance level p $\leq 0.10$ by ANOVA.

Source: Own elaboration. 
Table 4: Cluster characterization concerning information seeking

\begin{tabular}{|c|c|c|c|c|c|c|}
\hline Description criteria (\%) & & $\begin{array}{c}\text { Cluster I } \\
\text { Relationship }\end{array}$ & $\begin{array}{c}\text { Cluster II } \\
\text { Independent }\end{array}$ & $\begin{array}{l}\text { Cluster III } \\
\text { Balance }\end{array}$ & $\begin{array}{l}\text { Cluster IV } \\
\text { Persistent }\end{array}$ & $\begin{array}{c}\text { Cluster V } \\
\text { Service } \\
\text { comfortable }\end{array}$ \\
\hline $\begin{array}{l}\text { Do you use } \\
\text { newsletter/websites of } \\
\text { magazines, industry }\end{array}$ & yes & 47.5 & 44 & 53 & 55 & 57 \\
\hline $\begin{array}{l}\text { newsletters, social } \\
\text { networks/media, internet? }\end{array}$ & n.a. & 52.5 & 56 & 47 & 45 & 43 \\
\hline $\begin{array}{l}\text { *How important is the } \\
\text { internet to you when } \\
\text { deciding to buy crop } \\
\text { protection products? } \\
(\mathrm{n}=248)\end{array}$ & Important & 16 & 16 & 16 & 26 & 20 \\
\hline $\begin{array}{l}\text { Do you use digital media } \\
\text { (apps, WhatsApp groups, } \\
\text { forums) to look for }\end{array}$ & Yes & 25 & 31 & 22 & 27 & 22 \\
\hline $\begin{array}{l}\text { information or advice when } \\
\text { choosing plant protection } \\
\text { products? }\end{array}$ & No & 75 & 68 & 77 & 72 & 77 \\
\hline \multirow{3}{*}{$\begin{array}{l}\text { The industry is currently } \\
\text { increasingly developing } \\
\text { apps for crop protection } \\
\text { advice. Can you imagine } \\
\text { using them? }\end{array}$} & Yes & 40 & 35 & 41 & 27 & 41 \\
\hline & Partly & 29 & 17 & 19 & 25 & 15 \\
\hline & No & 30 & 37 & 30 & 44 & 35 \\
\hline \multirow{4}{*}{$\begin{array}{l}\text { How should the } \\
\text { information or advice of } \\
\text { the apps look like for you } \\
\text { to use it? }\end{array}$} & Independent & 13 & 23 & 13 & 19 & 13 \\
\hline & Fast/up to date & 20 & 24 & 14 & 20 & 18 \\
\hline & Easy to use & 15 & 20 & 14 & 18 & 16 \\
\hline & Not annoying & 13 & 16 & 10 & 16 & 11 \\
\hline
\end{tabular}

*Differences between clusters were significant according to $\chi^{2}$-test $(\mathrm{p} \leq 0.05)$

Source: Own elaboration.

Information sources such as newsletters, social networks/media, or the internet are in most cases of moderate importance. $57 \%$ of the service comfortable segment and $55 \%$ of the persistent segment use at least one of these digital information sources when purchasing crop protection products. A differentiated analysis shows that the persistent cluster and the service comfortable cluster rate the internet to be more critical than other clusters (Table 4). In the service- and consulting-averse cluster of the persistent segment, comparatively few want to use an app for consulting purposes. They are still undecided (25\%) or refuse to use crop protection apps in the future (44\%). Of farmers in the service comfortable segment, $56 \%$ are willing to use or at least interested in apps to gather the professional support they desire. The relationship and balance segments show a low digital media penetration. Even if some of them are using digital sources, they do not attach great importance to them. However, as advice is important to balance buyers, they have one of the highest shares of farmers who are willing to use apps for crop protection advice $(41 \%)$. While digital media does not play a significant role in the purchasing process for relationship buyers to date, $40 \%$ can imagine using an app in the future. The independent 
segment is open to digital media. Individuals in this segment seem to favor mobile information sources like WhatsApp groups or general apps. Specific apps for crop protection advice are viewed more cautiously. More than one-fifth of the independent segment want apps to be more independent, fast, and up to date. In summary, however, the results are not significant regarding digital information behavior and are therefore only indicative.

\subsubsection{Attitude towards e-commerce for crop protection purchase}

E-commerce plays a minor role in the procurement of crop protection products of farmers, which is true for all clusters. Also, the proportion of farmers who is aware of e-commerce advantages is small. But regarding the future use of e-commerce, the clusters differ significantly (Table 5).

Table 5: E-commerce attitude per cluster

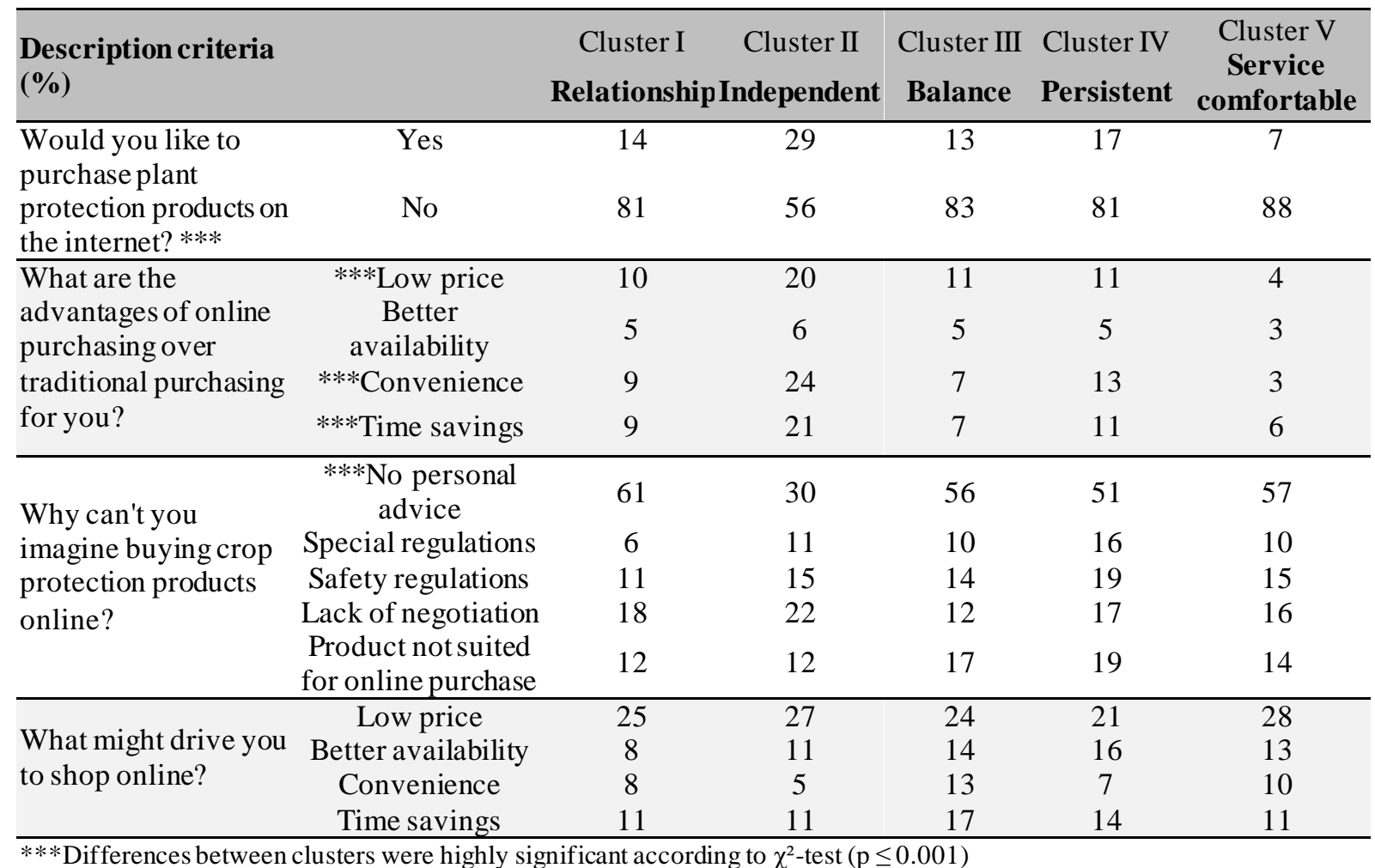

Source: Own elaboration.

E-commerce seems most likely to be an option for the independent segment. $29 \%$ would like to purchase plant protection products online, while more than $80 \%$ of farmers belonging to other segments refuse to buy pesticides on the internet. E-commerce advantages, such as time savings, convenience, and cost reduction, are seen more strongly by this segment. In contrast, one of the main disadvantages of agricultural e commerce, the lack of personal contact with dealers/consultants, is perceived by only about $30 \%$ of the independent buyers. 
Other perceived disadvantages are the lack of negotiation options (22\%) or safety regulations $(15 \%)$. More than one-fourth of the independent segment would buy online if prices were lower (27\%) on the internet. Service comfortables, the largest cluster, show the least online buying interest at only about $7 \%$. They expect to be able to generate neither convenience nor price or time advantages when buying online.

Missing personal advice is the main reason for e-commerce rejection among all clusters but especially for the relationship segment, with $61 \%$ refusing to buy online for this reason. For about one fifth of the clusters, the lack of negotiation possibilities is another important obstacle to e-commerce, except for balance buyers, with only about $12 \% .20 \%$ of persistent buyers also mention safety requirements and product suitability as a disadvantage. With the exception of independent buyers, the advantages of better accessibility, convenience, and time and cost savings are perceived by less than $10 \%$ of the farmers of the remaining segments. Only convenience and time savings are perceived slightly more by balanced buyers, with $13 \%$ and $11 \%$, respectively. Lower prices are most likely to persuade farmers to buy online (21-28\%), followed by time savings (11-17\%) and better availability (8-16\%).

It can be noted that the clusters differ not only in their stated e-commerce usage intentions but also in their e-commerce attitudes. The advantages, i.e., convenience, price, and cost savings of e-commerce, are perceived significantly differently by the clusters. Independent buyers attach significantly less importance to the perceived e-commerce barriers, e.g., of lack of face-to-face counselling, and perceive advantages significantly stronger than other clusters. The results finally show that the independent cluster stands out from the other clusters in terms of e-commerce use, while the remaining four clusters demonstrate several common and restrained features.

\section{Discussion and conclusion}

This study conducted a segmentation of German farms regarding the purchase of crop protection products and identified five different market segments. Compared to the presented literature, the identified segments show similarities to the four segments described in previous studies: balance, convenience, performance, and price by Gloy and Akridge (1999), Alexander et al. (2005), Roucan-Kane et al. (2011), and Borchers et al. (2012). Accordingly, it can be assumed that the presented segmentation approaches can still be replicated today, including for the German crop protection market. 
The first cluster can mainly be compared with the relationship segment of Gundersson et al. (2005). The relationship buyers want to be personally supported in decision-making by third parties. With 20\%, they are a relatively large group of buyers who manage comparatively large businesses, making them an important target group for manufacturers and retailers. The first cluster is not very open-minded towards digital media as an information or procurement medium. Nevertheless, due to their strong demand for advice, $40 \%$ of the farmers in the first cluster can imagine using an app for crop protection advice. However, their digital interest is limited to an advice function. The lack of personal contact on the internet deters them from buying plant protection products online. Therefore, for this cluster, digital media appeals should only be used for obtaining a specific piece of information or advice. An interaction hybrid model might be promising, where suppliers actively approach farmers and offer them support while also providing digital information and advice via newsletters, social media, and plant protection apps.

This would also be a suitable marketing strategy for the service comfortable segment. The service comfortable cluster characteristics correspond to the convenience segment of Borchers et al. (2012). It also combines the service and convenience cluster of Gloy and Akridge (1999). Farmers in this segment are very dealer-and service-oriented and thus more loyal to their suppliers and specific brands. The influence of third parties on their purchasing decisions is low, as they prefer to decide without the considerable input of others (Borchers et al., 2012). In the previous study, they represented the largest market segment with comparable large farms. According to Gloy and Akridge (1999), the convenience segment members tend to be older farmers, which also holds true for the service comfortable segment in this study. It is interesting to note that this segment of service and convenience seekers is quite open to digital media as an information source, contrary to what can be assumed from literature (Alexander et al., 2005; Feeney and Berardi, 2013). Furthermore, it appears that although the service cluster obviously uses the internet to obtain information, it does not want to buy any farm inputs online (Alexander et al., 2005). The e-commerce disinterest might be attributed to the fact that they do not associate convenience or any time or cost benefits with internet shopping. However, farmers in this cluster ask less for advice than the relationship segment, thus it is hardly surprising that the willingness to use an app for crop protection advice is very low. But, except for active consulting offers, the marketing strategy could be similar to the relationship segment. Sales days or information events organized by local dealers can be used to retain customer satisfaction and loyalty, while supplementing information can be prepared in a digital format. 
Balance buyers can be roughly compared to balance segments of the literature. Similar to the balance cluster of Feeney and Berardi (2013), this cluster disagrees the most with the statement that cost is the most important factor in product selection. Therefore, it can be characterized as price-autonomous. Dealer orientation and moderate usage of digital information sources by balance farmers can be supported by former studies (Feeney and Berardi, 2013). Crop protection product manufacturers and distributors should consider developing a marketing program targeted at this segment. For example, this could be like the persistent buyers segment's marketing program. This segment approximates Zimmermann's (2003) cluster of pragmatists. They are independent, and their decisions are neither conspicuously brand- nor dealer-oriented. Farmers who tend to be older and manage small farms are more often found in that persistent cluster. Their education tends to be higher. Zimmermann (2003) presented a positive correlation between the pragmatists and the internet; this can also be confirmed in the present study, as for persistent buyers, the internet is the more important information source compared to other segments. They are less open to apps with consulting purposes, presumably because they see digital media purely as an information medium and generally demand less consulting. For both segments, service plays a subordinate role. Due to their comparatively moderate dealer and service orientation, these cluster, especially the balance cluster, could represent potential future e-commerce segments. Accordingly, these segments should be considered when advertising e-commerce offers and emphasize time, cost, and accessibility advantages. Customer uncertainties regarding product suitability should be clarified beforehand.

The second cluster of independent buyers does not exist within former studies of Gloy and Akridge (1999), Alexander et al. (2005), Roucan-Kane et al. (2011), and Borchers et al. (2012). However, the second cluster can be compared with the price segment of these studies. It is well educated, significantly younger, brand- and advice-averse, and less interested in service offers (Alexander et al., 2005; Borchers et al., 2012). Unlike the price segment described in the literature (Borchers et al., 2012; Feeney and Berardi, 2013), the present independent segment is the smallest, but it is relatively large in farm size and with less importance placed on prices. Zimmermann (2003) identified the objective loners, who also make their decisions independently of their environment, but the other cluster characteristics do not correspond to the independent buyers of this study. As a result, independent buyers are a newly identified group that requires detailed analysis. Their low dealer orientation and loyalty might explain their high willingness to buy crop protection products on the internet. The sales potential of 
apps for crop protection is high for this segment and gives the industry reason to expand and further develop mobile apps. For independent buyers, a multi-channel strategy is suggested to meet the various requirements. The interest of independent buyers in e-commerce for crop protection products is a good prerequisite for direct online sales. Online platforms offer large companies a quick way of comparing prices and the pesticide industry an uncomplicated way of doing business. Overall, digital media and e-commerce offer exciting opportunities for this segment, and e-commerce should be a central component of future marketing strategies for this segment. It is essential to highlight and communicate factors such as convenience and time savings of e-commerce applications.

The described similarities between clusters in the literature and the clusters of this study support the replicability of the presented segmentation approaches for the current German crop protection market. However, the identified segments do not perfectly fit the segments found in former studies. This can be justified by clustering variables that differ slightly from those described in the literature. The cluster-forming factors include statements of other studies (Borchers et al., 2012; Gloy and Akridge, 1999; Roucan-Kane et al., 2011), which, however, were condensed into different factors by the principal component analysis. But, in general, the influencing factors described among several segmentation approaches, and their associated statements, can still be used for meaningful segmentation today. In addition, differences also occur since most of these segmentation studies are based on the American region, where different agricultural structures prevail compared to Europe, e.g., Germany. An overarching review of the results also highlights the neglecting role of the long-term dominant priceperformance concept in favor of a more service-oriented concept. The cluster analysis shows that service orientation is particularly well-suited for segmenting farmers, while brand affinity is hardly suitable for segmentation. Future studies should critically consider whether to include this factor, as a general shift of companies from selling products to offering more services (Vidickiene and Gedminaite-Raudone, 2018) is observable, with service that is typically based on face-to-face interactions and serves as a differentiator in service offerings (Kindström, 2010). The results show a promising role of advice via apps, but at the same time, manufacturers and retailers should also have a physical presence. Expanding the service area will contribute to long-term customer loyalty, as crop management requires a bundle of decisions that force face-to-face interactions, which cannot be met entirely by e-commerce (Bennett, 2018). Newer segmentation approaches could therefore integrate the relationship and service level even more. 
Regarding the use of digital sales channels, there are no significant differences between the clusters in terms of digital information/search behavior, so that only tendencies could be depicted in the cluster description. This shows that the farmer typology is not a particularly good predictor of farmers' digital behavior in input purchasing. But at least the results allow a more precise derivation of e-commerce behavior for one specific cluster. While the independent cluster stands out from all other clusters in terms of attitude and use of digital sales channels, the remaining four clusters hardly differ from each other. Accordingly, specific typologies based on attitudes toward the online business would probably be more useful here. Studies on e-commerce or digital media segmentation are already available and segmented based on use behavior, attitude-based, or psychographic characteristics (Mathew, 2016; Nakano and Kondo, 2018). For the agricultural sector, e-commerce studies may face the problem of low agricultural e-commerce penetration (Ackermann et al., 2018; Ardrey et al., 2020), which might result in low sample sizes or e-commerce user shares and less meaningful results. Therefore, such segmentation studies should be primarily built on attitude-based rather than usage-based factors. They should also include aspects of channel switching propensity, as shown by Fecke et al. (2018a), to identify promising agricultural user groups of digital sales channels. Presented customer profiles must be analyzed more extensively and compared with existing customer data.

The causal factors for purchasing behavior should also be examined here since previous segmentation studies have not investigated why customers have a specific purchasing behavior. Exciting results are promised by analyzing information behavior, digital usage, course of purchasing behavior, and company-specific ties to develop detailed marketing strategies. Other studies show that belonging to a market segment is relatively consistent across all consumables, suggesting that manufacturers and retailers should develop purchase-based marketing strategies rather than product-specific marketing strategies (Borchers et al., 2012). Whether this also applies to the usage of digital sales channels should be examined in followup studies, as some studies have already pointed to the product-group-specific use of e-commerce (Ackermann et al., 2018; Gartzke, 2016; Schulze Schwering and Spiller, 2018). However, Borchers et al. (2012) found a strong correlation between cluster memberships for crop protection products and seeds. It can be assumed that digital media in the purchasing process of crop protection products can also be transferred to the purchase of seeds. 
Finally, this article provides two main contributions: First, the identification and characterization of five different farmer segments for crop protection markets in Germany and thus the confirmation of the replicability of common segmentation approaches. Although the market segments are fundamentally similarin structure, there is a significant difference in terms of price perception and dealer orientation. Second, the only moderate explanatory power of this segmentation approach to explain the digital behavior of farmers within the purchasing process of agricultural inputs is remarkable. However, the results provide first initial indications of attitudes toward digital sales channels. While digital search behavior differs only slightly between the clusters, the independent cluster shows a particular affinity for e-commerce. The large service convenience cluster, on the other hand, uses the internet only for information purposes but not for shopping. The greatest differences between the clusters can be seen in the perception of e-commerce benefits and the assessment of the lack of personal contact. From the present study, crop protection manufacturers and retailers can derive initial correlations between the internationally most common form of customer segmentation and farmers' online behavior. However, online shopping should be surveyed more specifically in further studies. 


\section{References}

Ackermann, S., Adams, I., Gindele, N. and Doluschitz, R. (2018). The role of e-commerce in the purchase of agricultural input materials. Landtechnik 73(1): 10-19. doi: 10.15150/lt.2018.3177

Agropages (2020). German crop protection market down $7.4 \%$ in 2018. https://bit.ly/3xhdYBL. (24.03.21).

Alexander, C.E., Wilson, C.A. and Foley, D.H. (2005). Agricultural Input Market Segments: Who Is Buying What? Journal of Agribusiness 23(2): 113-132. doi: 10.22004/ag.econ.59673

Ardrey, J., Denis, N., Magnin, C. and Revellat, J. (2020). Unlocking the online retail opportunity with European farmers. McKinsey \& Company. https://mck.co/2Rt1EhS. (07.03.21).

Assael, H. (1984). Consumer behavior and marketing action. Kent Pubblishing Company, Boston, Massachusetts, U.S.

Backhaus, K., Erichson, B., Plinke, W. and Weiber, R. (2016). Multivariate Analysemethoden. Eine anwendungsorientierte Einführung. Springer Gabler, Berlin, Heidelberg. doi: 10.1007/978-3-662-46076-4

Bennett, C. (2018). Ag Retail Scrambles for Online Sales. The Scoop. https://bit.ly/2QSgsa5. (07.03.21).

Bernecker, M. (2019). Marktsegmentierung durch Online-Profiling Handbuch Digitale Wirtschaft. In: Kollmann, T. (eds.). Springer Gabler, Wiesbaden, Germany, 1-20. doi: 10.1007/978-3-65817345-6_19-1

Bickert, C. (2020). Online trading Agriculture 4.0 - or only hot air? Deutsche Landwirtschafts Gesellschaft (DLG) Wintertagung 2020. https://bit.ly/3i8qpLn. (30.06.21).

BMEL (2019). Klassifizierungssystem der EU für landwirtschaftliche Betriebe in Deutschland. Bundesministerium für Ernährung und Landwirtschaft (BMEL). https://bit.ly/2QW9YHh. (23.04.21).

Bonke, V., Fecke, W., Michels, M. and Musshoff, O. (2018). Willingness to pay for smartphone apps facilitating sustainable crop protection. Agronomy for Sustainable Development 38(5): 1-10. doi: 10.1007/s13593-018-0532-4

Bonny, S. (2017). Corporate Concentration and Technological Change in the Global Seed Industry. Sustainability 9(9): 1632. doi: 10.3390/su9091632

Borchers, B., Roucan-Kane, M., Alexander, C. E., Boehlje, M., Downey, W. S. and Gray, A. W. (2012). How Large Commercial Producers Choose Input Suppliers: Expendable Products from Seed to Animal Health. International Food and Agribusiness Management Review 15(2): 1-20. doi: 10.22004/ag.econ.127281

Burgert, G.W. (2011). Agricultural large commercial producers in Argentina and the United States of America: A comparative study. Purdue University, Lafayette, Indiana, U.S.

Deutsch, M., Otte, L. and Otter, V. (2020). Digital first? Auswirkungen der Digitalisierung auf Vertriebsstrukturen im deutschen Agrarhandel. Austrian Journal of Agricultural Economics and Rural Studies 29(4): 23-30. doi: 10.15203/OEGA_29.4

Eckelkamp, M. (2019). More Farmers Go Online For Crop Inputs. The Scoop. https://bit.ly/33ifvdS. (07.03.21).

Eckelkamp, M. (2018). Key Trends In How Farmers Are Using E-Commerce For Inputs. The Scoop. https://bit.ly/3xKoMJA. (28.03.21).

Fecke, W., Danne, M. and Musshoff, O. (2018a). E-commerce in agriculture-The case of crop protection product purchases in a discrete choice experiment. Computers and electronics in agriculture 151(2018): 126-135. doi: 10.1016/j.compag.2018.05.032 
Fecke, W., Michels, M., Hobe, C.-F. von and Mußhoff, O. (2018b). Wie kommunizieren Landwirte in Zeiten der Digitalisierung? Berichte über Landwirtschaft - Zeitschrift für Agrarpolitik und Landwirtschaft 96(2): 1-17. doi: 10.12767/buel.v96i2.194

Feeney, R. and Berardi, V. (2013). Seed market segmentation: how do Argentine farmers buy their expendable inputs? International Food and Agribusiness Management Review 16(1): 17-40. doi: 10.22004/ag.econ.144516

Fröndhoff, B. (2018). Nach Bayer-Monsanto Fusion: Diese 4 Unternehmen haben künftig die Macht auf dem Acker. Handelsblatt. https://bit.ly/3vFZ6Mf. (02.03.21).

Gabriel, A., Gandorfer, M. and Spykman, O. (2021). Nutzung und Hemmnisse digitaler Technologien in der Landwirtschaft. Berichte über Landwirtschaft - Zeitschrift für Agrarpolitik und Landwirtschaft 99(1): 1-27. doi: 10.12767/buel.v99i1.328

Gandorfer, M., Schleicher, S., Heuser, S., Pfeiffer, J. and Demmel, M. (2017.). Landwirtschaft 4.0Digitalisierung und ihre Herausforderungen. In: Ackerbau - technische Lösungen für die Zukunft, 9-20. Bayerische Landesanstalt für Landwirtschaft (LfL), Freising, Germany

Gartzke, S. (2016.). Kleffmann Group Global New Media Tracker - Our international Study Kleffmann Group. In: Farwick, C. (Hrsg.). Agri Experts Around the World. Newsletter, 18-21.

Gloy, B.A. and Akridge, J. T. (1999). Segmenting the commercial producer marketplace for agricultural inputs. The International Food and Agribusiness Management Review 2(2): 145-163. doi: 10.1016/S1096-7508(00)00023-9

Gloy, B.A., Akridge, J. T. and Preckel, P. V. (1997). Customer lifetime value: An application in the rural petroleum market. Agribusiness: An International Journal 13(3): 335-347. doi: 10.1002/(SICI)1520-6297(199705/06)13:3<335::AID-AGR7>3.0.CO;2-1

Gloy, B.A., Akridge, J. T. and Whipker, L. D. (2000). Sources of information for commercial farms: usefulness of media and personal sources. The International Food and Agribusiness Management Review 3(2): 245-260. doi: 10.1016/S1096-7508(01)00046-5

Gundersson, M.A., Boehle, M.D. and Gray, A.W. (2005). Segmenting Agribusiness Customers on their Capital Expenditures. Paper to be presented at the International Food \& Agribusiness Management Association World Food and Agribusiness Symposium.

Hill, S. (2015). Die Bedeutung von Werten in Genossenschaften und deren Umsetzung: eine empirische Analyse. PhD thesis. Fakultät Agrarwissenschaften, Universität Hohenheim, Germany.

Hübbers, B. (2018). Die Landwirtschaft 2017. Statistische Bände No. 410. Statistisches Landesamt Rheinland-Pfalz, Germany.

Huchtemann, J.-P. (2020). Entrepreneurship und Vertriebsmanagement im Agribusiness. PhD thesis. Cuvillier Verlag, Göttingen, Germany.

Junge, S. (2021). Wachsen oder Weichen - Deutsche Landwirtschaft im Strukturwandel. Bundeszentrale für politische Bildung. https://bit.ly/2SuUPNx. (24.03.21).

Kaiser, H.F. and Rice, J. (1974). Little jiffy, mark IV. Educational and psychological measurement 34(1): 111-117.

Kassem, H.S., Alotaibi, B. A., Aldosri, F. O. and Muddassir, M. (2021). Exploring the Relationship between Information-Seeking Behavior and Adoption of Biofertilizers among Onion Farmers. Agronomy 11(6): 1258. doi: 10.3390/agronomy11061258

Khanna, A. and Kaur, S. (2019). Evolution of Internet of Things (IoT) and its significant impact in the field of Precision Agriculture. Computers and electronics in agriculture 157(2019): 218-231. doi: 10.1016/j.compag.2018.12.039

Kindström, D. (2010). Towards a service-based business model - Key aspects for future competitive advantage. European Management Journal 28(6): 479-490. doi: 10.1016/j.emj.2010.07.002 
Kool, M. (1994). Vendor loyalty of farmers: Characterisation, description and analysis. European Review of Agricultural Economics 21(2): 287-307. doi: 10.1093/erae/21.2.287

Luengo, J., García, S. and Herrera, F. (2012). On the choice of the best imputation methods for missing values considering three groups of classification methods. Knowledge and information systems 32(1): 77-108. doi: 10.1007/s10115-011-0424-2

Mackelprang, A.J. (1970). Missing data in factor analysis and multiple regression. Midwest journal of political science 14(3): 493-505.

Mathew, P.M. (2016). Attitude segmentation of Indian online buyers. Journal of Enterprise Information Management 29(3): 359-373. doi: 10.1108/JEIM-08-2014-0078

Michels, M., Bonke, V. and Musshoff, O. (2020). Understanding the adoption of smartphone apps in crop protection. Precision Agriculture 21(6): 1209-1226.

Munz, J. and Doluschitz, R. (2021). Status quo der Adoption digitaler Technologien im genossenschaftlichen Agrarhandel- Möglichkeiten einer digitalen Differenzierungsstrategie. Berichte über Landwirtschaft - Zeitschrift für Agrarpolitik und Landwirtschaft 99(2): 1-32. doi: 10.12767/buel.v99i2.335

Munz, J. and Doluschitz, R. (2020). Determinanten zur Akzeptanz der Einführung digitaler Technologien im genossenschaftlichen Agrarhandel. Zeitschrift für das gesamte Genossenschaftswesen 70(4): 283-307. doi: 10.1515/zfgg-2020-0020

Nakano, S. and Kondo, F. N. (2018). Customer segmentation with purchase channels and media touchpoints using single source panel data. Journal of Retailing and consumer services 41(2018): 142-152.

Nishimoto, R. (2019). Global trends in the crop protection industry. Journal of pesticide science 44(3): 141-147. doi: 10.1584/jpestics.D19-101

Pascher, P., Hemmerling, U. und S. Naß (2018). Situationsbericht 2018/19 Trends und Fakten zur Landwirtschaft. Deutscher Bauernverband e.V., Berlin, Germany.

Peterson, R.A. (1994). A meta-analysis of Cronbach's coefficient alpha. Journal of consumer research 21(2): 381-391.

Roucan-Kane, M., Alexander, C. E., Boehlje, M., Downey, W. S. and Gray, A. W. (2011). Large commercial producer market segments for agricultural capital equipment. International Food and Agribusiness Management Review 14(4): 127-143.

Schlomer, G.L., Bauman, S. and Card, N. A. (2010). Best practices for missing data management in counseling psychology. Journal of Counseling psychology 57(1): 1-10. doi: 10.1037/a0018082

Schulze Schwering, D. and Spiller, A. (2018). Das Online-Einkaufsverhalten von Landwirten im Bereich landwirtschaftlicher Betriebsmittel. Diskussionsbeitrag No. 1805, Georg-AugustUniversity. Göttingen.

Schweizer, L. (2017). Übernahmerisiken: Bayer-Monsanto - eine neue Nr. 1 in der Agrarchemie? Nachrichten aus der Chemie 65(1): 31-32. doi: 10.1002/nadc.20174057493

Sparks, T.C. and Bryant, R. J. (2021). Crop protection compounds-trends and perspective. Pest Management Science 77(8): 1-9. doi: 10.1002/ps.6293

Statistisches Bundesamt (2017). Betriebsgrößenstruktur landwirtschaftlicher Betriebe nach Bundesländern. https://bit.ly/2POIP8w. (22.04.21).

Vidickiene, D. and Gedminaite-Raudone, Z. (2018). Challenges for Agricultural Poilicy in the ServiceDriven Economic System. Economics of Agriculture 65(4): 1545-1555. doi: 10.5937/ekoPolj1804545V

Zhang, Z. (2016). Multiple imputation with multivariate imputation by chained equation (MICE) package. Annals of translational medicine 4(2): 30. doi: 10.3978/j.issn.2305-5839.2015.12.63 
Zimmermann, M. (2003). Das Kaufverhalten von Landwirten im Bereich landwirtschaftlicher Investitionsgüter. PhD thesis. Cuvillier Verlag, Göttingen, Germany. 


\section{I.5 Agricultural Input Trade: Farmers' Expectations Towards E-Commerce Websites - Shopping Convenience is Key}

Authors: Lena Pleus, Dorothee Schulze Schwering \& Achim Spiller

This article was submitted in a similar form for review at German Journal of Agricultural Economics. 


\title{
I.5 Agricultural Input Trade: Farmers' Expectations Towards E-Commerce Websites - Shopping Convenience is Key
}

\begin{abstract}
To provide value to customers online, it is critical for agribusiness companies to understand what farmers expect from e-commerce websites and how those expectations relate to their online shopping experience. These questions were answered by means of a qualitative study using the "thinking aloud" method. The results show that farmers expect a measurable advantage when using e-commerce. The store design should be clear, reasonable, and illustrated with photos. One key finding of the study is that for farmers, stationary retail serves as a benchmark for e-commerce information seeking. If perceived differences between offline and online are too big, e-commerce providers lose confidence. Often, the telephone serves as a convenience benchmark, setting the bar high in terms of both the response time and personal level. The results emphasize the importance of good cross-departmental coordination in multichannel management and the improvement of customer centricity, e.g., by personal contact and convenience, among all e-commerce players in agribusiness.
\end{abstract}

Key Words: Online shopping, farm inputs, digital distribution, agricultural trade, multichannel-management 


\section{Zusammenfassung}

Um den KundInnen online Mehrwerte bieten $\mathrm{zu}$ können, ist es für Unternehmen des Agribusiness entscheidend $\mathrm{zu}$ verstehen, was LandwirtInnen von E-commerce-Websites erwarten und wie sich dies auf ihr Online-Einkaufserlebnis auswirkt. Mittels einer qualitativen Studie unter Verwendung der Methode des "lauten Denkens" soll diese Frage beantwortet werden. Die Ergebnisse zeigen, dass LandwirtInnen einen messbaren Vorteil bei der Nutzung von E-commerce erwarten. Das Design des Online-Shops sollte übersichtlich, sinnvoll und mit Fotos versehen sein. Ein zentrales Ergebnis der Studie ist, dass für Landwirt Innen der stationäre Handel als Benchmark für das Suchverhalten im E-Commerce dient. Sind die wahrgenommenen Unterschiede zwischen Online und Offline zu groß, verlieren E-CommerceAnbieter Vertrauen. Häufig dient das Telefon als Convenience-Benchmark und legt damit die Latte hoch, sowohl hinsichtlich der Responsetime als auch hinsichtlich der persönlichen Ebene. Die Ergebnisse unterstreichen die Bedeutung einer guten abteilungsübergreifenden Koordination im Multichannel-Management und die Verbesserung der Kundenzentrierung, z.B. durch persönlichen Kontakt und Convenience, bei allen E-Commerce-Akteuren im Agribusiness.

Schlüsselwörter: Online-Shopping, landwirtschaftliche Betriebsmittel, digitaler Vertrieb, Agrarhandel, Multichannel-management 


\section{$1 \quad$ Introduction}

With digitalization, farmers have more products and purchasing options available than ever before, simplifying price and product comparisons. In addition to established agricultural trading companies that offer online sales channels (in Germany e.g. Agromais GmbH, myfarmvis, myAGRAR), newly founded start-up companies (ag.supply) are also entering the market with independent online stores. However, the latter dominate primarily in online marketplaces like Agrando, agrar2b, or agrarconnect (Deutsch et al., 2020; Huchtemann and Theuvsen, 2018). In Germany, around 20 new marketplaces, initiated by startups, showed up in agriculture within four years, $15 \%$ of which explicitly market farm inputs (Huchtemann and Theuvsen, 2018). Nevertheless, studies show a comparatively low penetration rate of digital procurement transactions by farmers, which applies in particular to the input categories of crop protection and seed (Ackermann et al., 2018; Gartzke, 2016). This indicates that farmers are not satisfied with the current electronic commerce (e-commerce) offers and / or do not find it attractive (Ardrey et al., 2020). At the same time, e-commerce is characterized by a high speed of change. It has become progressively smarter and more convenient for the customer. Huang et al. (2018) speak of a next-generation e-commerce platform. The prerequisites for e-commerce success are customer-oriented business processes and maximum customer centricity (Heinemann, 2020, 2016; Morys, 2018). If, as in stationary agricultural trade, intensive advisory contacts already exist, an online store cannot close any gaps in supply but must offer real added value (Heinemann, 2020).

Within supply chain management research in agribusiness, the adoption of e-commerce is underrepresented (Luo et al., 2018). To the authors' knowledge, there are no studies on farmers' expectations of an e-commerce website and their related online shopping experience. This is, however, important to reach maximum customer centricity to generate added value and to ensure customer satisfaction and loyalty. The present study addresses this gap and examines the expectations that farmers have about an online store for agricultural inputs. For this purpose, in semi-structured in-depth interviews, participants were given two realistic tasks about online purchasing of crop protection products and corn seed. In the interview, the method of "thinking aloud" (Konrad, 2020) was used to determine how the participants engaged with the given task, which expectations were met or not met, and whether they were persuaded or not persuaded by the e-commerce website. The contribution of the research is further highlighted by the fact that this is the first study which investigates farmers' expectations of e-commerce by following the farmer during an active online shopping situation. The obtained results provide approaches for 
the design of agricultural online stores to improve customer experience and to create customer added value of digital offers in the long term.

In the following, factors of offline and online customer satisfaction as well as the factors influencing agricultural e-commerce behavior are presented in the theoretical background. This is followed by the presentation of the data collection and evaluation methods used. In the next section, the results are presented and finally discussed.

\section{Theoretical Background}

\subsection{Factors of offline and online customer satisfaction}

According to Loupiac and Goudey (2019), there is a strong link between web-based and physical retail. From an omni-channel perspective, this means that website or shop design impacts the expectations towards the physical store regarding aspects like atmosphere, merchandising, location, or degree of overcrowding (Loupiac and Goudey, 2019). On the other hand, the habit of users in the offline channel influences the use of the new technology in the online context (Lu et al., 2011). Hammerschmidt et al. (2016) found that consumers focus on channel attributes that are equal in offline and online channels. They discovered that customer satisfaction can be determined based on five attributes ( $5 \mathrm{C}$ model): confidence, choice, charge, convenience, and care (Fig. 1). The 5C model was developed and empirically tested in the retail industry. Confidence includes the feeling that the interactions and transactions are safe and trustworthy. Choice implies a sufficient number and variety of products (Hammerschmidt et al., 2016). Other studies define it as the extent to which the available range of products and offers appeals to the customer, or as the ease with which all desired products can be found (Fassnacht and Koese, 2006). Affordable products and fair price levels belong to the attribute of charge (Hammerschmidt et al., 2016). "The extent to which the purchasing process is efficient and effortless" is called convenience (Hammerschmidt et al., 2016, p. 90). Care describes the extent to which a retailer ensures that all items perform as promised after purchase. Fassnacht and Koese (2006) define it as the degree to which the business partner keeps its service promise or fulfils the intended purpose or the expected feelings.

Customer experience is also related to customer satisfaction and serves as an important pillar for companies' self-positioning in competition (Gehrckens and Boersma, 2013). According to Bilgihan et al. (2016), the online experience already begins with the "shop search". The success of e-commerce for the supplier and the shopping experience for the customer depend on how 
easily customers can find the desired e-commerce website on the internet. After finding the web page, online customer experience is largely determined by the store design (Gehrckens and Boersma, 2013; Hasan, 2016). There, according to Gehrckens and Boersma (2013) and relating to the two Cs, Convenience and Care, a distinction between the sub-areas of usability and service can be made, respectively.

The usability of an online store is characterized by five sub-aspects: product access, presentation, ordering process, customer integration, and consultation (Gehrckens and Boersma, 2013), which are also included in the website's design features, visual, navigation, and information design according to Hasan (2016). Product access means orientation in the web shop. It includes aspects such as navigation, product lists and filters, or search options. Fassnacht and Koese (2006) call this clarity of layout, which indicates the degree to which the design structure helps the user to find his way. The preparation of the shop in terms of colors, images, additional features, or article texts and details is summarized as presentation. Fassnacht and Koese (2006) differentiate between graphic quality, which describes how well the user interface is visually presented, and information quality, the degree to which information is provided to the customer in a complete, accurate, and up-to-date manner. The order process is composed of parameters regarding the shopping cart, checkout, payment options, or customer account, which are also presented within the e-commerce success model of Sharma and Aggarwal (2019). According to Gehrckens and Boersma (2013), customer integration is determined by customer interaction, product ratings, social media/newsletters, and personalization. Personalization and interaction allow customers to rate products and processes on which relies the service and recommendation policy of the website. Also, the opportunity of a customer's own shopping carts can refer to personalization (Sharma and Aggarwal, 2019). Product recommendations, advice functions, and product comparisons are assigned to the consultation attribute (Gehrckens and Boersma, 2013).

The service sub-section consists of delivery and return attributes, which include aspects such as convenience, speed, costs, and transparency about deliveries and returns (Gehrckens and Boersma, 2013). Fassnacht and Koese (2006, p. 22) call this outcome quality and describe it as "what the customer is left with after service delivery".

Because the online customer experience, which is largely determined by the shop design, is linked to customer satisfaction, the models of Hammerschmidt et al. (2016) and Gehrckens and Boersma (2013) have been summarized in Figure 1 as a benchmark for offline and online customer satisfaction. The usability dimension of Gehrckens and Boersma (2013) corresponds 
to the convenience dimension of Hammerschmidt et al. (2016), as both dimensions aim for an efficient, easily accessible, and effortless process. The service and care dimensions of the models were also combined, as they both address the post-purchasing process and therefore belong to the "out-of-store" subsection.

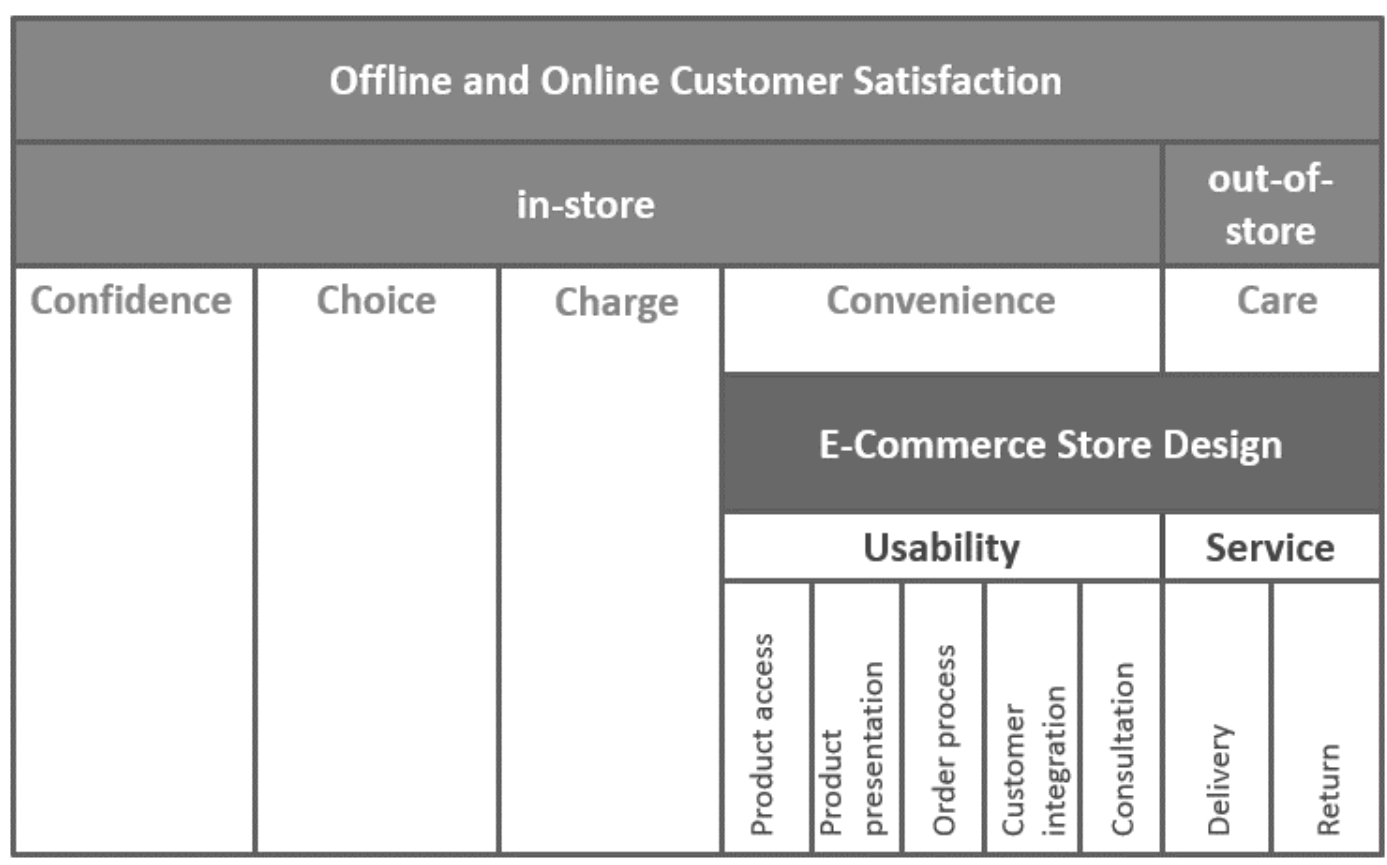

Figure 1: Benchmark factors of offline and online customer satisfaction

Own elaboration adapted from Hammerschmidt et al. (2016) and Gehrckens and Boersma (2013)

\subsection{Factors influencing agricultural e-commerce activities}

There are already several studies in the literature that have investigated the use of e-commerce by farmers and have highlighted both opportunities and barriers of agricultural online trade. These can be roughly assigned to the criteria of the developed model shown in Figure 1. Secure transaction and payment methods that consider shoppers' privacy and security concerns are the basis of confidence (Hammerschmidt et al., 2016; Henderson et al., 2006). However, distrust towards e-commerce is a main barrier of e-commerce in agricultural retail (Gartzke, 2016). Farmers prefer to buy online at known and trusted retailers rather than at unknown new suppliers (Batte and Ernst, 2007). As it is well-known that the farmer-trader relationship is very close (Batte and Ernst, 2007; Schulze Schwering and Spiller, 2018) and that the salesman is considered as the most important trust-building part in a buyer-supplier relationship (Doney and Cannon, 1997), the lack of personal contact in e-commerce decreases the confidence of farmers (Ardrey et al., 2020; Gartzke, 2016). Positive e-commerce experiences and seals of quality also strengthen trust in online shopping (Ardrey et al., 2020; Fecke et al., 2018a). 
The use of e-commerce for the purchase of farm inputs is only attractive for farmers if it provides advantages (Briggeman and Whitacre, 2010; Zeng et al., 2017). These include price advantages (Batte and Ernst, 2007; Henderson et al., 2006), time savings (Ackermann et al., 2018; Batte and Ernst, 2007), simplified information retrieval (Henderson et al., 2006; Henderson et al., 2004), as well as increased flexibility, mobility, accessibility, and spontaneity (Ardrey et al., 2020; Gartzke, 2016; Hoffmann and Grethler, 2013). Time advantages are often associated with online shopping and can outweigh the cost advantage (Ackermann et al., 2018; Batte and Ernst, 2007). According to Hammerschmidt et al. (2016), the criterion convenience has the highest influence on customer satisfaction of all five criteria. It aims to minimize the shopper's use of time and resources. Therefore, a focus on a high degree of convenience promotes farmers' acceptance of e-commerce (Gartzke, 2016; Henderson et al., 2006). Convenience can be achieved by creating a pleasant shopping atmosphere with fast and competent service as well as a practical and attractive shopping process (Hammerschmidt et al., 2016).

Farmers appreciate the increased choice and simplified product comparison of e-commerce (Henderson et al., 2006; Henderson et al., 2004). In 2017, 45\% of the questioned farmers believed that the internet offers a better choice than local shops (Schulze Schwering and Spiller, 2018). However, the huge selection of products and providers on the internet can also lead to uncertainty and the feeling of being overwhelmed (Eckelkamp, 2018).

E-commerce acceptance grows when it provides price advantages compared to stationary retail (Batte and Ernst, 2007; Fecke et al., 2018a). How high a promotional price differential must be depends on whether the product is time-sensitive or time-insensitive (Akridge, 2003; Henderson et al., 2004). For crop protection, a price advantage of 9\% (Fecke et al., 2018a), for herbicides of $10 \%$ (Batte and Ernst, 2007), proves to be conducive to switching from local retailers to e-commerce providers. Another study has implied that online price advantages increase online shopping intention by farmers (Schulze Schwering and Spiller, 2018). Nevertheless, price does not serve as the sole driving factor for switching from a local retailer to an online retailer. A cross-sector comparison shows that among selection criteria for suppliers, price takes third place behind quality and delivery (Ho et al., 2010).

Service quality is also an important criterion in retailer selection (Ho et al., 2010) and especially within platform selection in e-commerce (Zeng et al., 2017). This also applies to farmers (Yu and Zhao, 2014). In agricultural retail, the intensity of the customer relationship has a decisive influence on the evaluation of service quality (Kolesar and Wayne Galbraith, 2000). 
The evaluation of the customer relationship is in turn strongly influenced by the assessment of the quality and intensity of communication between farmer and supplier (Schulze, 2012).

Farmers prefer face-to-face meetings to communicate with retailers $(88 \%)$ and will continue to do so in the future (64\%), as it seems to be the most efficient approach for them $(73 \%)$ (Fecke et al., 2018b). Farmers associate a decrease in face-to-face conversations and in the quality of communication and customer relations with the increase of e-commerce activities (Briggeman and Whitacre, 2010; Fecke et al., 2018b; Gartzke, 2016). But farmers place high value on trusting customer relationships (Gartzke, 2016; Schulze Schwering and Spiller, 2018). If an online store offers a $20 \%$ discount compared to stationary retail, $41 \%$ would switch if the service offers were identical. Only $20 \%$ would switch to online offers if the service level were to decrease with the online discount (Kalaitzandonakes et al., 2003).

Out-of-store, the customer experience is shaped by care or service. Poor out-of-store service is cited by farmers as a core barrier to e-commerce use (Henderson et al., 2006; Henderson et al., 2004; Kalaitzandonakes et al., 2003). After-sales services include return and delivery management. After quality, delivery is the second-most important criterion for supplier selection (Ho et al., 2010) and also plays a decisive role in e-commerce for agricultural inputs (Fecke et al., 2018a). Delivery conditions that result in farmers having better access to products favor farmers' use of e-commerce (Batte and Ernst, 2007). Contrary, delivery delays for timesensitive products (e.g., crop protection) can lead to a rejection of online shopping (Briggeman and Whitacre, 2010). Fecke et al. (2018a) recommend an overnight delivery service for online shops with agricultural (time-sensitive) inputs.

The literature shows that there are already a variety of factors that can explain agricultural e-commerce behavior. These studies mostly refer to the general drivers and barriers, i.e., what motivates or hinders a farmer to choose the internet for purchasing inputs. However, how these and other factors are perceived and evaluated during the actual online purchasing process has not been researched. Studies on sub-items of the shop design important to farmers during their online shopping experience are not available. Clasen and Mueller(2006) only pointed out that successful online marketplaces in agricultural machinery trade are characterized by sufficient liquidity and no frills. Against this lack of research, our study therefore investigates how the 5C factors (Confidence, Choice, Charge, Convenience, Care) are recognized and evaluated by farmers within the online shopping process, and how they an e-commerce website should be designed to meet farmers' expectations, regarding the $5 \mathrm{Cs}$, and to influence farmers' online 
shopping experience. Knowledge on this can help to achieve better customer centricity in the internet business to generate added value that is reflected in customer satisfaction and loyalty.

\section{$3 \quad$ Materials and methods}

Farmers' perceptions of e-commerce offers and reactions to different shop attributes are largely unexplored. Qualitative research methods are particularly suitable for gaining insights into an area that has not yet been investigated. Within the qualitative methods, it was decided to use the "thinking aloud" method, in which the respondents are asked to verbalize their thoughts, perceptions, and feelings (Konrad, 2020). The aim is to gain insights into the cognitive processes involved in learning, thinking, problem solving, and decision-making (Rigby et al., 2020). The field of application of "thinking aloud" includes decision research in areas like marketing or consumer research. In user-based studies on the usability of internet offers, it is the most frequently used method (Yom et al., 2009) and is used to observe search behavior on websites to optimize the design of the websites towards more effectiveness (Gider and Hamm, 2019). Against this background, the method of "thinking aloud" was selected for the comparative analysis of different e-commerce offers in agricultural input trade.

The method is applied in the context of an in-depth case study. For data collection, eight participants were given realistic tasks and asked to speak aloud, either simultaneously or afterwards, about all thoughts, feelings, and intentions that arose during task processing (Buber, 2009; Konrad, 2020; Rigby et al., 2020). The interviewees' speech component was small and aimed to remind the respondent to say all thoughts aloud (Rigby et al., 2020). Each interview started with an instruction and a warm-up exercise for the respondents (Buber, 2009). As a warm-up, respondents were first asked to check their e-mails on a freely selected device. Afterwards, the interviewees were given two different tasks. First, they were asked to purchase a pesticide and a maize seed online using a personal, freely selectable device. The aim was to determine farmers' intuitive starting process when shopping online. The second task asked the interviewees to again purchase the above-mentioned products online, but now both the websites and the end device were specified. The websites to be tested were a) myfarmvis demo shop founded in 2017 by Agragivs Raiffeisen AG, one of the leading agricultural cooperatives in Germany. b) myAGRAR - also founded in 2017 by ATR Landhandels Gruppe, a leading agricultural trading company in Germany, Denmark and Poland. c) ag.supply - founded in 2018 by a startup. d) Agromais web shop - opened by Agromais, which was founded in 2000 and is known for its seed distribution. 
Since the demo version of the myfarmvis shop is only accessible via Agravis's own end devices, a laptop was provided. Where necessary, user accounts were created for all participants beforehand so that registration did not become part of the study. The interviews were recorded and transcribed. For evaluation of the transcripts the content of the data was structured, coded, and analyzed. This was done by following the standards of Mayring (2014). Here, the development of a category system perceived as a central instrument of content analysis (Mayring, 2014). The deductive category framework was derived from the established model (Fig. 1). In the subsequent inductive editing process, the category system was further developed and adapted to ensure comprehensive penetration of the data material. The transcripts were coded using the program MAXQDA Analytics Pro 2020. The socio-demographic and farmrelated data were collected by means of a standardized short questionnaire.

The selection of interviewees was based on location (Lower Saxony, North Rhine-Westphalia), age $(</>40$ years), education (university/technical college degree), and farm type (livestock/crop farming). The respective characteristics of the four selection criteria should be approximately equally distributed to obtain a sample that is as heterogeneous as possible. A total of eight farmers were interviewed. Due to the COVID-19 pandemic, no additional farmers could be interviewed. The interviews were held in German. They took place on the respondents' farms, were carried out from January to March 2020, and lasted on average about 60-90 minutes. The verbatim quotations in the results section have been translated analogously into English.

\section{$4 \quad$ Results}

First, the sample is described. This is followed by the presentation of the survey results. The intuitive start is followed by the results presentation according to the criteria of the established model.

\subsection{Sample description}

All respondents were farm managers and were running the farm conventionally as their main occupation. Regarding the age distribution, Table 1 shows that five participants were younger than 40 years. All respondents were male. Half of the respondents had completed a university degree in agriculture. In addition to arable farming, five farms also kept livestock. The area farmed by the respondents ranged from 93 to 811 ha. 
Local retailer was the preferred place of procurement for crop protection and seeds at the time of the study (Table 2). An exception was the purchase of seeds for special crops (e.g., vegetables, sugar beet) via marketers. The two largest farms put their requirements out to tender but differed strongly in the chosen distance radius of the suppliers ( $25 \mathrm{~km}$ vs. $200 \mathrm{~km})$.

Only one respondent had experience with e-commerce in the context of agricultural input procurement. Earlier availability of prices during the season and the simplified possibility of procuring sugar beet seed were reasons for him to use e-commerce. With one exception, the interviewees described their relationship with the stationary retailer as characterized by longevity and loyalty. "After all, this is our cooperative, they act for us." (R3); "In the region, for the region" (R5).

Table 1: Sociodemographic and farm-related data

\begin{tabular}{|c|c|c|c|c|c|c|c|c|c|c|}
\hline \multirow{2}{*}{ Respondent } & \multicolumn{2}{|c|}{ Age (years) } & \multicolumn{2}{|c|}{$\begin{array}{c}\text { University/ } \\
\text { Collage degree }\end{array}$} & \multicolumn{2}{|c|}{ Federal state } & \multicolumn{2}{|c|}{$\begin{array}{c}\text { Livestock } \\
\text { farming }\end{array}$} & \multicolumn{2}{|c|}{ Farm size (ha) } \\
\hline & $<40$ & $\geq 40$ & Yes & No & NDS & NRW & Yes & No & $\begin{array}{c}\text { Arable } \\
\text { land }\end{array}$ & $\begin{array}{c}\text { Grass- } \\
\text { land }\end{array}$ \\
\hline R1 & $\mathrm{X}$ & & $\mathrm{x}$ & & $\mathrm{x}$ & & $\mathrm{x}$ & & 275 & 0 \\
\hline $\mathrm{R} 2$ & $\mathrm{x}$ & & $\mathrm{x}$ & & & $\mathrm{x}$ & & $\mathrm{x}$ & 160 & 30 \\
\hline R3 & & $\mathrm{X}$ & & $\mathrm{x}$ & & $\mathrm{x}$ & $\mathrm{x}$ & & 90 & 3 \\
\hline $\mathrm{R} 4$ & $\mathrm{x}$ & & $\mathrm{x}$ & & $\mathrm{x}$ & & $\mathrm{x}$ & & 163 & 3 \\
\hline R5 & $\mathrm{x}$ & & & $\mathrm{x}$ & & $\mathrm{x}$ & & $\mathrm{x}$ & 680 & 21 \\
\hline R6 & $\mathrm{X}$ & & & $\mathrm{X}$ & $\mathrm{x}$ & & & $\mathrm{x}$ & 143 & 13 \\
\hline R7 & & $\mathrm{X}$ & $\mathrm{x}$ & & $\mathrm{x}$ & & & $\mathrm{x}$ & 810 & 1 \\
\hline $\mathrm{R} 8$ & & $\mathrm{x}$ & & $\mathrm{x}$ & & $\mathrm{x}$ & & $\mathrm{x}$ & 75 & 25 \\
\hline Total & 5 & 3 & 4 & 4 & 4 & 4 & 3 & 5 & & \\
\hline
\end{tabular}

Source: Own elaboration. NDS=Lower Saxony; NRW= North Rhine Westphalia

Table 2: Current procurement channels for crop protection and seeds

\begin{tabular}{llcc}
\hline Respondent & Current procurement channel & Distance (km) & $\begin{array}{c}\text { Agr. e-commerce } \\
\text { experience }\end{array}$ \\
\hline R1 & Agricultural land trade / Cooperative & $3-20$ & No \\
R2 & Cooperative / Marketer for special crops & 3 & No \\
R3 & Cooperative / Marketer for special crops & 5 & No \\
R4 & Agricultural land trade / Cooperative & 3 & No \\
R5 & Agricultural land trade / Cooperative & $10-25$ & No \\
R6 & Cooperative & 6 & No \\
R7 & 3-4 trading partners, call for tender & 200 & Yes \\
R8 & 2 cooperatives & 4 & No \\
\hline
\end{tabular}

Source: Own elaboration. 


\subsection{Intuitive starting process}

Most respondents preferred to use a computer or laptop rather than a mobile device to shop online for business purposes. The intuitive online purchase process was started by all respondents with an entry on Google. Individuals searched specifically in Google's "Shopping" section. Input terms on Google were "plant protection/ maize seed" as generic terms or specific product names, supplemented by "purchase / shopping". Only one participant chose the name of his local retailer as a search term. None of the respondents considered searching on Amazon.

“[...] and I don't think I need to look at Amazon. That is not where I would instinctively buy plant protection products." (R4)

\subsection{Factors of offline and online customer satisfaction}

Tables 3-5 show the verbatim quotations of the interviewees, translated according to meaning and sorted by model attributes. For simplified reference in the text, an abbreviation was assigned to each quotation listed in the tables. Table 3 summarizes the attributes confidence, choice, and charge.

Table 3: Quotes regarding Confidence, Choice, and Charge of e-commerce offers

\begin{tabular}{|c|c|c|c|}
\hline Category & & Quote & Respondent \\
\hline \multirow{3}{*}{ Confidence } & Cf1 & $\begin{array}{l}\text { When you know that there is a cooperative behind it, it is already } \\
\text { trustworthy, I'd say }[\ldots . .] \text { then you feel safe right away. }\end{array}$ & R6 \\
\hline & Cf2 & $\begin{array}{l}\text { I can't use the local retailer only for the things I spontaneously need, and } \\
\text { for everything else I bypass him and buy it somewhere else. I don't think } \\
\text { that would be fair. }\end{array}$ & $\mathrm{R} 2$ \\
\hline & $\mathrm{Cf} 3$ & $\begin{array}{l}\text { If it's a shop that I don't know, then I wouldn't immediately make the } \\
\text { wholesale purchase. }\end{array}$ & R4 \\
\hline \multirow[b]{2}{*}{ Choice } & Co1 & I can dismiss that one right away because it does not have what I want. & $\mathrm{R} 4$ \\
\hline & $\mathrm{Co} 2$ & $\begin{array}{l}\text { If I have to call up five apps to get my order together, I don't think I } \\
\text { would place it. }\end{array}$ & $\mathrm{R} 1$ \\
\hline \multirow{3}{*}{ Charge } & $\mathrm{Ca} 1$ & $\begin{array}{l}\text { That's where I see the advantage of signing up right away: that you also } \\
\text { get your specific price. }\end{array}$ & $\mathrm{R} 1$ \\
\hline & $\mathrm{Ca} 2$ & $\begin{array}{l}\text { The goods on site and the advice cost money, and all of this has to be } \\
\text { financed, and then you are willing to pay a little more for it. }\end{array}$ & $\mathrm{R} 3$ \\
\hline & $\mathrm{Ca} 3$ & $\begin{array}{l}\text { If you decide to use the agent on short notice [...]. Then, in most cases, } \\
\text { if it must be done very quickly, the price does not necessarily play a role. } \\
\text { Then availability is the important factor. }\end{array}$ & $\mathrm{R} 1$ \\
\hline
\end{tabular}

Source: Own elaboration.

Confidence: Confidence-related aspects were not actively addressed or expressed by the respondents, indicating that respondents did not harbor any general unease or distrust about the visited online stores. DLG certificates and the provider's image, e.g., known and wellestablished, had a positive effect on respondents' confidence. According to the interviewees, 
e-commerce offers from their current stationary retailer would receive the benefit of the doubt (Cf1) as they feel loyal (Cf2) and would combine the benefits of e-commerce with those of local retailing (R6). Caution was shown by the fact that initial orders would only include a limited product quantity or shopping cart size (Cf3). Skepticism about the expertise of individual online shops arose among respondents due to incomplete, contradictory, or irritating information, or even unusual structuring of the portfolio. The online product arrangement was compared with the product arrangement of respondents' local, well-known shops. Too much deviation led to a loss of confidence, while a certain level of equality (structure, e.g., product categories) led to the belief that "they have a little more experience" (R1).

Choice: E-commerce is generally associated with bigger product portfolios and simplified product and offer comparisons. To the surprise of the respondents, compared with local retailers, the product choice of the investigated e-commerce sites was smaller and not convincing, especially for corn seed. Availability of the desired product was critical to respondents' choice of retailer (Co1). The respondents would have liked to see a bigger or at least the same number of product offerings of stationary agricultural retailers or cooperatives reflected in e-commerce ( $\mathrm{Co} 2)$. It became clear here that respondents usually knew in advance what they wanted to buy and therefore searched for products in a targeted manner (Table 4 A7).

Charge: Most respondents expected a price advantage of an online store compared to offline stores. This was justified by the fact that e-commerce providers, compared to offline retailers, only supply the product and no further services, e.g., consultations or on-site warehousing (Ca2). Online, cost benefits were expected from leaner processes in which users wanted to participate. Respondents also expected the indication of the non-negotiable, customer-specific final price, especially when a customer log-in was necessary to see product prices (Ca1). This binding nature of the price information was, in the view of the interviewees, imperative to ensure the advantages of e-commerce. For effective online shopping, some respondents recommended knowing prices in advance. Price comparisons were made by respondents online and at physical retailers - based on the sum of product price and delivery costs. The availability of discount sales was controversial. On the one hand, it was seen as an opportunity to optimize order quantities and, on the other hand, some respondents simply wanted to see the unit price, in which possible discounts had already been considered automatically. A lower price as a purchasing motive was found to lose its function if the product was time-sensitive, and the duration between purchase and implementation of the product was a decisive success factor $(\mathrm{Ca} 3)$. 
Convenience/Usability: Table 4 presents respondents' quotes on convenience attributes. In general, respondents found it convenient that e-commerce allows orders to be placed directly and regardless of time and place. Another advantage is that the "shopping list" can be sent immediately and the order is not lost in the everyday stress (C3). The surveyed farmers considered using e-commerce if it resulted in an advantage in terms of time and/or cost savings. Ordering by phone or on-site functions were used as a reference here $(\mathrm{C} 1 ; \mathrm{C} 2)$.

Table 4: Quotes regarding Convenience / Usability of e-commerce offers

\begin{tabular}{|c|c|c|c|}
\hline Category & & Quote & Respondent \\
\hline \multirow{3}{*}{ Convenience } & $\mathrm{C} 1$ & 'Faster, cheaper' is always what you think first. & R4 \\
\hline & $\mathrm{C} 2$ & $\begin{array}{l}{[\ldots] \text { because then the online store is of no use to me, and then I can }} \\
\text { also just call directly. }\end{array}$ & R1 \\
\hline & $\mathrm{C} 3$ & $\begin{array}{l}\text { You can choose the products and send them off immediately and then it is } \\
\text { done. You don't have to worry about it again. That is very positive about it. }\end{array}$ & $\mathrm{R} 1$ \\
\hline \multirow{3}{*}{$\begin{array}{l}\text { Product } \\
\text { access }\end{array}$} & $\mathrm{Pa} 1$ & $\begin{array}{l}\text { From } \mathrm{A} \text { to } \mathrm{Z}[\ldots], \text { but if we have a letter somewhere in the middle, } \\
\text { you have to scroll down all the way. [...] Publication date: no idea - } \\
\text { I would never know. }\end{array}$ & $\mathrm{R} 1$ \\
\hline & $\mathrm{Pa} 2$ & $\begin{array}{l}\text { If you have a program that you work with a lot, of course it would be } \\
\text { even faster with an app. }\end{array}$ & $\mathrm{R} 2$ \\
\hline & $\mathrm{Pa} 3$ & Of course, if you are fixated on an app, you don't look anywhere else. & R4 \\
\hline \multirow{4}{*}{$\begin{array}{l}\text { Product } \\
\text { presentation }\end{array}$} & Pp1 & $\begin{array}{l}\text { It would be nice if there was a photo, }[. . .] \text { because with the photo I'm } \\
\text { faster, otherwise I have to read first. }\end{array}$ & R7 \\
\hline & Pp2 & It is much easier with photos. & $\mathrm{R} 3$ \\
\hline & Pp3 & $\begin{array}{l}\text { Regarding pictures: Then you're a little more confident about what } \\
\text { you're ordering. }\end{array}$ & R5 \\
\hline & Pp4 & $\begin{array}{l}\text { I want to order seed or crop protection. If the first thing I see is the } \\
\text { spare part number, the first thing I think is that I'm in the wrong store. }\end{array}$ & $\mathrm{R} 4$ \\
\hline \multirow{4}{*}{$\begin{array}{l}\text { Order } \\
\text { process }\end{array}$} & Op1 & $\begin{array}{l}\text { You know it from other homepages, I'd say. If it continues like this, } \\
\text { then you know "where" you stand. }\end{array}$ & R6 \\
\hline & Op2 & {$[\ldots]$ An invoice would be the only option. } & R3 \\
\hline & Op3 & An invoice is always more convenient. & R6 \\
\hline & Op4 & Three, four pages - that has to suffice. & R5 \\
\hline \multirow{2}{*}{$\begin{array}{l}\text { Customer } \\
\text { integration }\end{array}$} & Ci1 & $\begin{array}{l}\text { But an e-mail, then I would have to open my e-mail program again } \\
\text { and write an e-mail and, no, that would be too much effort right now. }\end{array}$ & $\mathrm{R} 4$ \\
\hline & $\mathrm{Ci} 2$ & $\begin{array}{l}\text { Then I would be quicker to pick up the phone and call. Because most } \\
\text { of the time you are working, and you can quickly put a headset in } \\
\text { your ear. }\end{array}$ & $\mathrm{R} 1$ \\
\hline \multirow{7}{*}{$\begin{array}{l}\text { Consultation/ } \\
\text { Advice }\end{array}$} & A1 & It is faster when something is suggested. & R2 \\
\hline & A2 & $\begin{array}{l}\text { Regarding recommendations: This might be quite a good advertising } \\
\text { tool for personal use, but in the plant protection area, it is rather } \\
\text { superfluous. }\end{array}$ & $\mathrm{R} 1$ \\
\hline & A3 & $\begin{array}{l}\text { Now I already feellike being on Amazon or Ebay [...] It makes you } \\
\text { uncertain. }\end{array}$ & R6 \\
\hline & A4 & $\begin{array}{l}\text { I also think "similar articles" are nonsense now. [...] "Product of the } \\
\text { day" I find - without looking at it - garbage. }\end{array}$ & R7 \\
\hline & A5 & $\begin{array}{l}\text { I have to be convinced that he will give me good advice. [...] Then, it } \\
\text { is the foot in the door for me, also for the purchase. }\end{array}$ & $\mathrm{R} 8$ \\
\hline & A6 & $\begin{array}{l}\text { I would still say where the consultation would be. I would already } \\
\text { combine it there. I think that's only fair. }\end{array}$ & $\mathrm{R} 1$ \\
\hline & A7 & $\begin{array}{l}\text { When shopping online, I no longer need any advice. } \\
\text { I have taken it before, and then I know what I want to buy, and then I } \\
\text { go to the online store and order it. }\end{array}$ & $\mathrm{R} 4$ \\
\hline
\end{tabular}


Regarding product access, respondents attached great importance to the clarity of the user interface or start page. For platforms with many areas of activity, the prominent positioning of the store button was expected. Sorting and filtering functions should be well thought out and functional. The decisive factor was a meaningful selected filter criterion depending on the product group or oriented at the sorting in stationary retail $(\mathrm{Pa} 1)$. This increased respondents perception of confidence and simplified product access. For the examined product groups, sorting by publication date or price were rated as not useful, whereas for seed products, a filtering by maturation segment (medium-late) was favored instead of an exact maturation number (R1, R6). Attention should be paid to the limitation of the required data volume. All respondents agreed that long loading times were annoying and a reason for abandonment. Compared to the browser application, the apps were associated with speed and convenience $(\mathrm{Pa} 2 ; \mathrm{Pa} 3)$.

The respondents favored a clear and accessible layout of product or article pages, i.e., product presentation. The required information ideally had to be recognizable at first glance, complete, correct, unambiguous, and reduced to the essentials. Photos were desired to speed up, simplify, and secure the selection process (Pp1-Pp3). The color selection, font size, and use of photos were also perceived as orientation support. If several product groups were offered, care should be taken that they were presented and highlighted in the same way. Ambiguities in the presentation of the article/product page were considered to harbor the risk of making a wrong purchase and would trigger purchase abandonment (Pp4). Additional information should be available through targeted requests for additional windows, PDF documents, or links, but should not overload the product presentation as such.

All respondents had prior, private e-commerce experience. Therefore, the experiences from the B2C sector serve as a benchmark to evaluate the order process (Op1). The timing of the customer login was the subject of a controversial debate: Which benefit weighs more heavily that of the non-binding price comparison or that of the immediate display of the individual product price? There was no general rejection of either variant. A watch list and the automatic buffering of the shopping cart, e.g., due to a loss of internet connection, were perceived as useful. For all respondents, the invoice was the only attractive payment method (Op2, Op3). Credit limits and maximum order values on an invoice basis should be adapted to the specific customer to allow the ordering of greater amounts (R7). The online purchasing process also had to be fast, with a low-click-to-completion rate (Op4). 
In terms of customer integration, communication between the farmer and the retailer was a key factor, and expectations depended on who initiated the contact and for which purpose. The respondents expected an e-commerce provider to integrate various media channels. If the online store wanted to inform them about delivery conditions, the respondents would expect a written communication via e-mail. When customers are requested to submit information, e.g., the plant protection certificate or a request for quotation, the respondents preferred upload options or predefined input screens rather than writing an e-mail (Ci1). However, if the respondents had specific queries, e.g., about the product function, they would like the e-commerce provider to be available by phone. In this context, waiting for answers by mail or chat was rejected by the majority (Ci2). Personal telephone calls are therefore still perceived as the most convenient and fastest way to clarify questions or other concerns.

The expectation of a consultation or advisory option depended on the respondent's particular consultation status. If consultation was provided by the local retailer at the time of the search, the respondents also expected the online store provider to offer consultation services (A5). Analogous to the business with the local retailer, the respondents also felt loyal towards the provider of consulting services. At the provider where the respondent would receive the consultation, the products for the fulfillment of the consultation contents would also be bought (A6). The interviewees recognized that this consulting service incurs costs, which are reflected proportionately in the product prices. If the farmer obtained advice from a private consultant independent of a known retailer at the time of purchase, respondents did not expect any advice from the e-commerce provider and accordingly did not feel obliged to purchase via the consultant. In this case, the online store was merely another potential trading partner(A7). The respondents also attached importance to a perfectly functioning search function that provides suggestions. Suggestions were perceived to speed up the process (A1). But the majority rejected algorithmic product recommendations typical in B2C e-commerce in the sense of "other customers also bought ... similar articles" or the "product of the day" (A2-A4).

Care/Service: Transparency was the decisive criterion for all delivery- and return-related issues. Table 5 gives an overview of care-related responses. Lack of clarity about delivery costs or time was found to lead to the abandonment of the purchase (D1). For respondents who got orders delivered from stationary retailers, on-site pickup was not an option when buying online. For the remaining respondents, the combination of online shopping and on-site pickup provided an option (D2). The level of delivery costs was evaluated in terms of their reasonableness compared to the costs of using one's own transport. However, the cost per kilometer that 
respondents associated with their own transportation varied (D3; D4). For most, 1 to 3 days' delivery time from Monday to Friday were fine. Here, the current conditions of the stationary retail were again the benchmark. For crop protection products, the respondents would have liked to see an express option or overnight service. Return conditions were only marginally addressed. The respondents did not expect pure online players to be able to return goods, which was seen differently if the local stationary retailer operated an online store (R5). Only for one respondent did return exclusion lead to an online refusal (R8). If an online shop did not have a return option, either the retailer was preferred (Rt1), or the option "return on site" was desired (Rt2).

Table 5: Quotes regarding Care of e-commerce offers by delivery (D) and return (Rt)

\begin{tabular}{|c|c|c|}
\hline & Quote & Respondent \\
\hline D1 & The transparency (about availability/delivery duration) is, after all, absolutely critical. & $\mathrm{R} 3$ \\
\hline D2 & $\begin{array}{l}\text { I think I would prefer to pick it up. Then you still have a bit of human contact. And you } \\
\text { get to hear one or two other things, or you get another recommendation or a bit of advice } \\
\text { in the process. }\end{array}$ & $\mathrm{R} 4$ \\
\hline D3 & Generally, you can't make the drive for $12 €$ or $13 €$. & $\mathrm{R} 2$ \\
\hline D4 & $\begin{array}{l}\text { I would have to pay } 14.99 € \text { for an express delivery. Then I would also consider driving } \\
\text { another three kilometers to my local dealer. }\end{array}$ & R4 \\
\hline Rt1 & I would probably go through the local retailer because they usually have to take it back. & R5 \\
\hline Rt2 & But it would be practical if it said: "returns possible on site". & R6 \\
\hline
\end{tabular}

Source: Own elaboration.

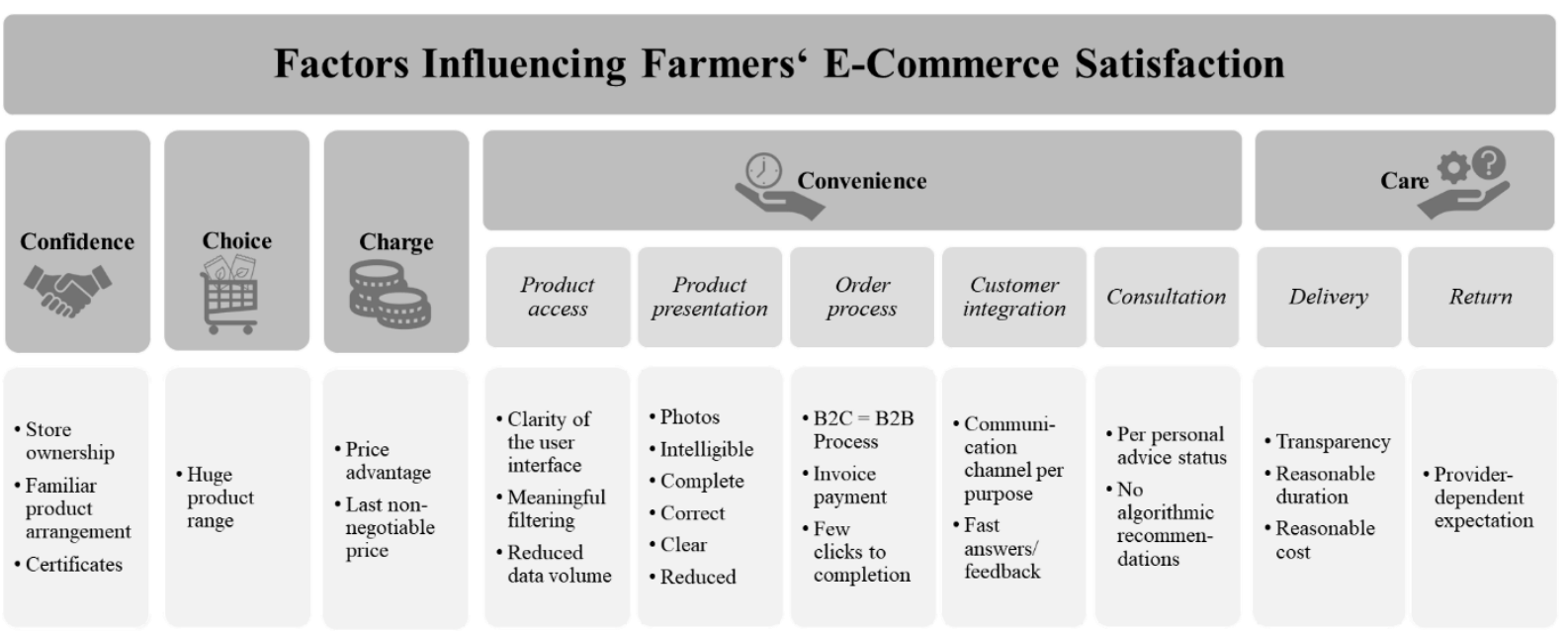

Figure 2: Revealed main factors of farmers' e-commerce satisfaction Source: Own elaboration.

The results show that the respondents' expectations of an online store for agricultural inputs depended very much on the conditions in the local retail. E-commerce vendors or those planning to build an e-commerce offering for agriculture can use the results to optimize their 
store design. Although there are other aspects of store design and customer satisfaction, the results summarized in Figure 2 allow initial recommendations for action.

\section{Discussion}

A main result of this study is that the expectations towards the website design, in terms of better serving the five presented success dimensions, are based on the conditions in stationary retail. Accordingly, e-commerce must perform better than stationary retail in all five comparative attributes to attract and retain customers. That means that local, stationary retail represents the benchmark for "everything" and still plays a fundamental role in farmers' information and purchasing process. The systematic comparison of the online offer with the offer of the stationary retail identified in this study supports the mental maps theory (Groeppel-Klein and Bartmann, 2007; Niklas, 2014) and a habitual buying behavior (Foscht et al., 2017). Lu et al. (2011) showed that the habit of users in the offline channel negatively influences the use of new technology in the online context, which was also observed among the respondents here. According to the mental maps theory, consumers form unconscious ideas/expectations of the shop design before visiting a shop, which are depicted in so-called mental maps (Niklas, 2014). While in B2C, customers derive expectations towards the local shop from their digital experiences of that supplier's web presence (Loupiac and Goudey, 2019) or expectations toward an e-commerce website from the comparison of different websites (Kollmann, 2019), farmers currently form their e-commerce mental map based on experiences from stationary retail. If the websites do not correspond to these mental maps, it can lead to problematic use, dissatisfaction, or even the abandonment of a purchase (Niklas, 2014). Concurring with this, and since learning processes are the basis of habitual purchasing processes (Foscht et al., 2017), embedding spatial information (e.g., knowledge about the placement of products) in the shopper's mind is a crucial factor for retail success (Groeppel-Klein and Bartmann, 2007). Similar structuring of the online and offline product assortment and of the joint presentation of goods is linked to positive purchasing experiences and builds trust. The mistake that some agricultural startups or companies are currently making could be that they equate farmers with "normal" consumers, which might be one reason for the low online purchase penetration in agricultural trade. Perhaps it is precisely the small but subtle differences, in this case the familiar attributes from stationary retail which should also be found in some form in the online store, which decide whether an online store in agricultural trade will be successful or not. 
In the following, this will be briefly discussed for the 5Cs:

Confidence: Farmers' strong sense of loyalty to stationary retail and mistrust are known to be major barriers to e-commerce adoption (Gartzke, 2016). The present study shows that farmers do not have a general distrust of e-commerce; rather, it develops toward the e-commerce provider and less toward security aspects, which might be reduced due to positive experiences from B2C online shopping (Fecke et al., 2018a; Fellnhofer and Hinterhuber, 2011). On the other hand, local retail is still the main source of supply, and personal contact is valued by farmers. It scores with expertise, fast availability of relevant products due to short distances, and long-standing, loyal customer relationships. Therefore, e-commerce from known suppliers gets the benefit of the doubt over unknown suppliers (Batte and Ernst, 2007). As mentioned above, the shop design, e.g., product arrangement, also contributes to farmers' confidence.

Choice: Farmers associate e-commerce offers with a larger product range and simplified product comparison (Henderson et al., 2006; Henderson et al., 2004). Respondents of this study at least expected the same product range online as offline, which was not fulfilled by the four shops investigated and served as a showstopper. Hammerschmidt et al. (2016) showed that choice (number and variety of offers) has a moderate but slightly greater impact on online satisfaction than on offline satisfaction. Their results also revealed that the mean value of choice is significantly lower online, suggesting an unused satisfaction potential, which was similar to the findings of this study.

Charge: Farmers expect the final, non-negotiable, customer-specific product price on the internet. Ardrey et al. (2020) found that prices on the internet are sometimes perceived by farmers as confusing or not up to date. Therefore, the aim should be for transparent, uniform prices across all channels and could be made possible online via customer logins, e.g., by having the system automatically calculate prices for individual customers according to specific criteria. This is already possible with the help of ERP (enterprise resource planning) systems (Okanga and Groenewald, 2019), but requires defined pricing criteria and extensive customer data. The results confirm that cost savings are one main driver of agricultural e-commerce (Batte and Ernst, 2007; Fecke et al., 2018a). However, the indirect economic benefit of reducing the opportunity costs of time and the risk of forgetting to place an order or of urgently needing a product was shown to have a higher weighting than the actual (direct) cost savings (Ackermann et al., 2018). This is in line with the findings of this study, but also with the cross-industry literature, according to which the criterion of price/cost ranks third in the selection of suppliers, after the criteria of quality and delivery (Ho et al., 2010). The competitive advantage of 
stationary retail in terms of product availability and willingness to pay for ad-hoc products could be used to increase margins on time-critical products.

Convenience/Usability: E-commerce offers should be designed in such a way that the customer's use of time and resources is minimized and with particular focus on convenience/usability (Hammerschmidt et al., 2016). It should result in measurable benefits, as these are a prerequisite for the acceptance and use of e-commerce in agricultural input markets (Gartzke, 2016; Schulze Schwering and Spiller, 2018). A shopping experience is attractive when it is clear, quick to use, and reduced to the essentials. The number of clicks to completion should be kept as low as possible to avoid annoying the customer (Süss, 2016). As already mentioned, the web shop should be sensible and strongly oriented towards the shop design of the stationary retail. Therefore, when designing the online store, it is recommended to subordinate marketing interests of the provider to the demands of farmers. Respondents also agreed that photos are an essential element to simplify and clarify an e-commerce website. Di et al. (2014) confirm that images can increase the attention, trust, and the conversion rate of the buyer, i.e., online sales. Hasan (2016) also stated that the visual design (with images) of a website is crucial for assessing website quality, where good images can increase the quality perception of the product and website (Di et al., 2014).

Care/Consultation: The respondents appreciated a personal customer service by retailers. Farmers expected an information provision geared toward a low time commitment for them. If queries related to an (online) order occur, personal telephone calls were preferred. The importance of the personal conversation is also confirmed by Fecke et al. (2018b). One fear among farmers is therefore that with increasing e-commerce offers, the frequency and intensity of face-to-face conversation will decrease (Briggeman and Whitacre, 2010; Fecke et al., 2018a; Gartzke, 2016). Against this background, it is recommended not to underestimate the strategic importance, also regarding its social function as a part of networking, of the faceto-face conversation. Even when providing or developing a multi- to omni-channel strategy, local retailers should cultivate existing customer relationships by maintaining personal conversations through, e.g., consulting services or field days. The prominence of on-site consulting services is also documented in the literature (Fecke et al., 2018a; Fecke et al., 2018b; Gartzke, 2016). Farmers who are averse to advice do not expect any advice in e-commerce, but they expect a price advantage. For out-of-store service in the form of delivery and returns, it is evident that delivery transparency is more important than the speed of delivery, thus the implementation of seamless shipment tracking is recommended. For time-sensitive products 
(crop protection) an express option or overnight delivery should be offered (Fecke et al., 2018a). A return option is required for e-commerce offers from local retailers, while it is not necessarily expected from pure online players. Furthermore, it should be noted that most farmers live very close to stationary retail and therefore have little need for online shopping or prefer "click and collect" to maintain personal contacts on site, which underlines the relevance of personal customer contact.

Managerial implications: The fact that farmers expect a similar offer and design offline and online as well as the demand for final non-negotiable prices, requires multi-channel companies to coordinate the online and offline store design very well and to always keep it comparable. For this, all company departments, i.e., especially offline sales management and online marketing, must work closely together to generate and maintain added customer value across channels. Supporting that, factors like transparent pricing and cross-channel store design are decisive components of successful multi- to omni-channel management in agricultural e-commerce. In this context, mobile applications (apps) should also be integrated, as these stand for leaner and simplified processes and show great future potential.

Since the link between consulting services and product purchases is currently based on the farmer's sense of loyalty, in the face of increasing market transparency due to e-commerce offers, an area of tension arises. This also speaks in favor of closer cooperation between the different departments in multi-channel companies. To secure the competitiveness of stationary retail, e.g., with taking personal orders and on-site consultation, and to become independent of the "good will" of the buyer, the commercialization of these services is necessary. A performance-based pricing model linked with e-commerce might be one solution. The traded products would be categorized according to their need for advice (intensive, low, or flexible) based on a percentage gradation relying on customer relationship management (CRM) data. A pricing example might be: The online price for consulting-intensive products would correspond to the price to be paid on site, including consulting. Also, the additional return service or ad hoc service could be charged by stationary retailers as part of performance-based pricing. This performance-based pricing model would be analogous to the current practice in banks, where, for example, price advantages are granted for online banking compared to the handwritten transfer slip (Neuhaus, 2016).

If, on the other hand, pure offline retailers implement a multi- to omni-channel strategy by carefully considering the desired "comparability" of the different channels, they can use their competitive advantage by giving farmers the time and cost benefits generated online without 
jeopardizing retailer loyalty. At the same time, the processes in stationary retail can be successively streamlined. For purely online retailers, the main task is to constantly optimize customer centricity, especially in the areas of convenience/usability (images, fast, and easy design) and care (personal after-sales service).

Limitations: The chosen method, "thinking aloud", was suitable to answer the research question, as deep insights into the decision-making processes and motivations of the farmers could be obtained. However, it is possible that information processing and the decision-making process are influenced by the articulation of thoughts (Buber, 2009; Rigby et al., 2020). Due to the unconscious cognitions that are not verbalized or differences in respondents' verbalization ability, the collected data might be incomplete (Buber, 2009). The methodologically conditioned small sample and the consideration of only two product groups limits the generalizability. Therefore, it is recommended to use the present findings as a basis for further quantitative research to be able to create attractive e-commerce offers that serve both farmers and retailers. For even more precise and detailed information on store design, eye-tracking could be used.

Final remark: Farmers are willing to use e-commerce if the expected measurable advantages can be generated. In the 5C model assessment, stationary retail serves as a benchmark for e-commerce. Farmers expect personal contact, and a similar product offer and store design online and offline, which positively impacts their shopping experience. This highlights the relevance of good departmental coordination within multi-channel management and the relevance of customer centricity, e.g., personal contact and convenience, among all e-commerce players in agricultural trade. 


\section{References}

Ackermann, S., Adams, I., Gindele, N. and Doluschitz, R. (2018). The role of e-commerce in the purchase of agricultural in put materials. Landtechnik 73(1): 10-19. doi: 10.15150/lt.2018.3177

Akridge, J.T. (2003). E-business in the agricultural input industries. Review of Agricultural Economics 25(1): 3-13. doi: $10.2307 / 1349859$

Ardrey, J., Denis, N., Magnin, C. and Revellat, J. (2020). Unlocking the online retail opportunity with European farmers. McKinsey \& Company. https://mck.co/2Rt1EhS. (07.03.21).

Batte, M.T. and Ernst, S. C. (2007). Net Gains from 'Net Purchases? Farmers' Preferences for Online and Local Input Purchases. Agricultural and Resource Economics Review 36(1): 84-94. doi: $10.1017 /$ S1068280500009461

Bilgihan, A., Kandampully, J. and Zhang, T. C. (2016). Towards a unified customer experience in online shopping environments. International Journal of Quality and Service Sciences 8(1): 102-119. doi: 10.1108/IJQSS-07-2015-0054

Briggeman, B.C. and Whitacre, B. E. (2010). Farming and the Internet: Reasons for Non-Use. Agricultural and Resource Economics Review 39(1203-2016-95437): 571-584. doi: $10.1017 / \mathrm{S} 1068280500007528$

Buber, R. (2009.). Denke-Laut-Protokolle. In: Buber, R. und Holzmüller, H.H. (eds.). Qualitative Marktforschung Gabler-Lehrbuch. Gabler, Wiesbaden, 555-568. doi: 10.1007/978-3-83499441-7_35

Clasen, M. and Mueller, R. A. E. (2006). Success Factors of Agribusiness Digital Marketplaces. Electronic Markets 16(4): 349-360. doi: 10.1080/10196780600999809

Deutsch, M., Otte, L. and Otter, V. (2020). Digital first? Auswirkungen der Digitalisierung auf Vertriebsstrukturen im deutschen Agrarhandel. Austrian Journal of Agricultural Economics and Rural Studies 29(4): 23-30. doi: 10.15203/OEGA_29.4

Di, W., Sundaresan, N., Piramuthu, R. and Bhardwaj, A. (2014.). Is a Picture Really Worth a Thousand Words?- On the Role of Images in E-commerce. In: Carterette, B. (eds.). Proceedings of the 7th ACM International Conference on Web Search and Data Mining. ACM, New York 633-642. doi: $10.1145 / 2556195.2556226$

Doney, P.M. and Cannon, J. P. (1997). An Examination of the Nature of Trust in Buyer-Seller Relationships. Journal of marketing 61(2): 35-51. doi: 10.2307/1251829

Eckelkamp, M. (2018). Key Trends In How Farmers Are Using E-Commerce For Inputs. The Scoop. https://bit.ly/3xKoMJA. (28.03.21).

Fassnacht, M. and Koese, I. (2006). Quality of Electronic Services: Conceptualizing and Testing a Hierarchical Model. Journal of Service Research 9(1): 19-37. doi: 10.1177/1094670506289531

Fecke, W., Danne, M. and Musshoff, O. (2018a). E-commerce in agriculture-The case of crop protection product purchases in a discrete choice experiment. Computers and electronics in agriculture 151, 126-135. doi: 10.1016/j.compag.2018.05.032

Fecke, W., Michels, M., Hobe, C.-F. von and Mußhoff, O. (2018b). Wie kommunizieren Landwirte in Zeiten der Digitalisierung? Berichte über Landwirtschaft-Zeitschrift für Agrarpolitik und Landwirtschaft 96(2): 1-17. doi: 10.12767/buel.v96i2.194

Fellnhofer, K. and Hinterhuber, H. (2011). Vertrauen in die (digitale) Zukunft Digitale Marktplätze fördern die Landwirtschaft. Ländlicher Raum: Online-Fachzeitung des Bundesministeriums für Land- und Forstwirtschaft, Umwelt und Wasserwirtschaft, (02): 1-17. 
Foscht, T., Swoboda, B. and Schramm-Klein, H. (2017.). Typen von Kaufentscheidungen. In: Foscht, T., Swoboda, B. und Schramm-Klein, H. (eds.). Käuferverhalten. Gabler Verlag, Wiesbaden, 167-182. doi: 10.1007/978-3-658-17465-1_10

Gartzke, S. (2016.). Kleffmann Group Global New Media Tracker - Our international Study Kleffmann Group. In: Farwick, C. (eds.). Kleffmann Group. Agri Experts Around the World. Newsletter, $18-21$.

Gehrckens, M. and Boersma, T. (2013.). Zukunftsvision Retail - Hat der Handel eine Daseinsberechtigung? Digitalisierung des Handels mit ePace. In: Heinemann, G., Haug, K. und Gehrckens, M. (eds.). Digitalisierung des Handels mit ePace. Innovative E-CommerceGeschäftsmodelle und digitale Zeitvorteile. Springer Gabler, Wiesbaden, 51-74. doi: 10.1007/978-3-658-01300-4_3

Gider, D. and Hamm, U. (2019). How do consumers search for and process corporate social responsibility information on food companies' websites? International Food and Agribusiness Management Review 22(2): 229-246. doi: 10.22434/IFAMR2018.0062

Groeppel-Klein, A. and Bartmann, B. (2007). Anti-clockwise or clockwise? The impact of store layout on the process of orientation in a discount store E - European Advances in Consumer Research Vol. 8. In: Borghini, S., McGrath, M.A. und Otnes, C. (eds.). E - European Advances in Consumer Research Vol. 8. Association for Consumer Research, Duluth, MN, 415-416.

Hammerschmidt, M., Falk, T. and Weijters, B. (2016). Channels in the Mirror: An Alignable Model for Assessing Customer Satisfaction in Concurrent Channel Systems. Journal of Service Research 19(1): 88-101. doi: 10.1177/1094670515589084

Hasan, B. (2016). Perceived irritation in online shopping: The impact of website design characteristics. Computers in Human Behavior 54 224-230. doi: 10.1016/j.chb.2015.07.056

Heinemann, G. (2020). Der neue Online-Handel. Geschäftsmodelle, Geschäftssysteme und Benchmarks im E-Commerce. Springer Gabler, Wiesbaden. doi: 10.1007/978-3-658-20354-2

Heinemann, G. (2016). Die Mythologie der Digitalisierung-Plädoyer für eine disruptive Transformation Digitale Transformation oder digitale Disruption im Handel. In: Heinemann, G., Gehrckens, M. und Wolters, Uly, J. (eds.). Digitale Transformation oder digitale Disruption im Handel. Springer Fachmedien, Wiesbaden, 3-28. doi: 10.1007/978-3-658-13504-1_1

Henderson, J., Dooley, F. and Akridge, J. (2004). Internet and E-Commerce Adoption by Agricultural Input Firms. Review of Agricultural Economics 26(4): 505-520. doi: 10.2307/3700794

Henderson, J.R., Akridge, J. T. and Dooley, F. J. (2006). Internet and e-Commerce Use by Agribusiness Firms: 2004. Journal of Agribusiness 24(345-2016-15133): 17-39. doi: 10.22004/ag.econ.57697

Ho, W., Xu, X. and Dey, P. K. (2010). Multi-criteria decision making approaches for supplier evaluation and selection: A literature review. European Journal of operational research 202(1): 16-24. doi: 10.1016/j.ejor.2009.05.009

Hoffmann, C. and Grethler, D. (2013). Bedarf nach Mobile Business in einer landwirtschaftlichen Produktion unter dynamischen Rahmenbedingungen. In: Horbach, M. (eds.). Informatik 2013 Informatik angepasst an Mensch, Organisation und Umwelt. Gesellschaft für Informatik e.V., Bonn. 1739-1746.

Huang, Y., Chai, Y., Liu, Y. and Shen, J. (2018). Architecture of Next-Generation E-Commerce Platform. Tsinghua Science and Technology 24(1): 18-29. doi: 10.26599/TST.2018.9010067

Huchtemann, J.-P. and Theuvsen, L. (2018.). Startups im Agribusiness - Marktplätze als Geschäftsmodell und deren Anwendung in der deutschen Landwirtschaft. In: Ruckelshausen, A., Meyer-Aurich, A., Borchard, K., H., C., Loy, J.-P., Schwerdtfeger, R., Sundermeier, H.-H., Floto, H. and Theuvsen, B. (eds.). 38. GIL-Jahrestagung in Kiel, Germany, Digitale Marktplätze und Plattformen. Gesellschaft für Informatik e.V., Bonn 119-122. 
Kalaitzandonakes, N., Kaufman, J. and Wang, X. (2003). Firm entry through e-commerce in the US agricultural input distribution industry. Journal on Chain and Network Science 3(2): 123-133. doi: $10.3920 / J C N S 2003 . x 035$

Kolesar, M.B. and Wayne Galbraith, R. (2000). A services-marketing perspective on e-retailing: implications for e-retailers and directions for further research. Internet Research 10(5): 424438. doi: 10.1108/10662240010349444

Kollmann, T. (2019.). Die Grundlagen des E-Shop. In: Kollmann, T. (eds.). E-Business Lehrbuch. Springer Gabler, Wiesbaden, 259-494. doi: 10.1007/978-3-658-26143-6_3

Konrad, K. (2020.). Lautes Denken Designs und Verfahren. In: Mey, G. und Mruck, K. (eds.). Designs und Verfahren. Springer, Wiesbaden, 373-393.

Loupiac, P. and Goudey, A. (2019). How website browsing impacts expectations of store features. International Journal of Retail \& Distribution Management 48(1): 92-108. doi: 10.1108/IJRDM-07-2018-0146

Lu, Y., Cao, Y., Wang, B. and Yang, S. (2011). A study on factors that affect users' behavioral intention to transfer usage from the offline to the online channel. Computers in Human Behavior 27(1): 355-364. doi: 10.1016/j.chb.2010.08.013

Luo, J., Ji, C., Qiu, C. and Jia, F. (2018). Agri-food supply chain management: Bibliometric and content analyses. Sustainability 10(5): 1573. doi: 10.3390/su 10051573

Mayring, P. (2014). Qualitative content analysis - theoretical foundation, basic procedures and software solution. https://bit.ly/3eR6oXZ. (16.05.21).

Morys, A. (2018.). Das Leben, wie es wirklich ist - und wie es sein sollte Die digitale Wachstumsstrategie. In: Morys, A. (eds.). Die digitale Wachstumsstrategie. 10 Prinzipien für ein profitables Online-Geschäft. Springer Gabler, Wiesbaden, 5-38.

Neuhaus, C. (2016). Überweisungen per Papier-Vordruck kosten Geld - Wie Banken bei den Gebühren tricksen. Der Tagesspiegel. https://www.tagesspiegel.de/wirtschaft/girokonto-ueberweisungenper-papier-vordruck-kosten-geld/14450392-5.html. (24.06.21).

Niklas, S. (2014). Mental Maps von Onlineshops-Kulturelle Unterschiede in der Informationsarchitektur. UP14-Vorträge. German UPA, Stuttgart.

Okanga, B. and Groenewald, D. (2019). Optimising enterprise resource planning system to leverage a firm's absorptive and adaptive capabilities. South African Journal of Information Management 21(1): 1-15. doi: 10.4102/sajim.v21i1.962

Rigby, D., Vass, C. and Payne, K. (2020). Opening the 'Black Box': an overview of methods to investigate the decision-making process in choice-based surveys. The Patient-Patient-Centered Outcomes Research 13(1): 31-41. doi: 10.1007/s40271-019-00385-8

Schulze, B. (2012). Herausforderungen des Landhandels unter veränderten Marktbedingungen: Theoretische Überlegungen und empirische Evidenz. Annual Conference, Stuttgart. German Association of Agricultural Economists (GEWISOLA) 52(133053): doi: 10.22004/ag.econ.133053

Schulze Schwering, D. and Spiller, A. (2018). Das Online-Einkaufsverhalten von Landwirten im Bereich landwirtschaftlicher Betriebsmittel. Diskussionsbeitrag No. 1805, Georg-AugustUniversity. Göttingen.

Sharma, H. and Aggarwal, A. G. (2019). Finding determinants of e-commerce success: a PLS-SEM approach. Journal of Advances in Management Research 16(4): 453-471. doi: 10.1108/JAMR08-2018-0074

Süss, Y. (2016.). Usability als wichtiger Faktor für den Erfolg von Onlineshops E-Commerce für kleinund mittelständische Unternehmen. In: Süss, Y. (eds.). E-Commerce für klein-und 
mittelständische Unternehmen. Springer Vieweg, Wiesbaden, 25-36. doi: 10.1007/978-3-65814452-4_4

Yom, M., Wilhelm, T. H. and Gauert, S. (2009.). Protokolle lauten Denkens und Site Covering. In: Buber, R. und Holzmüller, H.H. (eds.). Qualitative Marktforschung Gabler-Lehrbuch. Gabler, Wiesbaden, 635-652.

Yu, P. and Zhao, D. (2014.). Effect of Website Quality Factors on the Success of Agricultural Products B2C E-commerce. In: Li, D. und Chen, Y. (eds.). Computer and computing technologies in agriculture VII. CCTA 2013. IFIP Advances in Information and Communication Technology, vol 420. Springer. Berlin, Heidelberg, 98-113. doi: 10.1007/978-3-642-54341-8_11

Zeng, Y., Jia, F., Wan, L. and Guo, H. (2017). E-commerce in agri-food sector: a systematic literature review. International Food and Agribusiness Management Review 20(4): 439-459. doi: 10.22434/IFAMR2016.0156 


\section{I.6 Barrieren des Onlinehandels von Futtermitteln}

Authors: Dorothee Schulze Schwering \& Wiebke Kunz

This article was published in similar form in: Berichte über Landwirtschaft: Zeitschrift für Agrarpolitik und Landwirtschaft, 202098 (3).

Doi: 10.12767/buel.v98i3.305 


\section{I.6 Barrieren des Onlinehandels von Futtermitteln Barriers}

\section{Summary}

Digitisation and e-commerce are becoming increasingly important in the agricultural upstream industry. Online purchases of farm inputs are becoming more and more popular among farmers, although there are differences between product groups. Typical consumer goods such as animal feed are rarely purchased online. Therefore, the aim of the present study was to examine the current state of digitisation in the feed sector, the current range of online ordering systems among them, as well as barriers to the online distribution of feed from the manufacturers' point of view. For this purpose, an internet research of 40 websites of German and Dutch feed manufacturers and seven guideline-oriented expert interviews with employees of German feed companies were conducted. The interviews were conducted between July and August 2019 and were evaluated after transcription using a qualitative content analysis.

The results show that, so far, companies in the feed sector have been digitised to a limited extent only, and that there are short comings particularly in distribution. Online shops and ordering systems are rarely offered. Sector, company, product and customer-specific factors have an influence on a company's digital development. These include the traditional structures of the industry and its employees as well as the established organisation of the sales departments. A personal relationship between supplier and customer is still very important regarding customer loyalty, confidence building, product selection and price negotiations. In the animal feed sector, the price and product transparency associated with online sales is proving particularly difficult. This is due to product and customer-specific factors in pricing and product composition. Strong competition and price wars further complicate the situation and hinder the emergence of online shops for animal feed. The biggest barrier within the company is the lack of resources such as financial means and know-how. Due to the low demand and the delayed return on investment, digital sales channels are usually not a primary target for company investments.

With the growing online affinity of young farmers, a positive development is expected in the future. Online shops are particularly suitable for standardised products. Online contract release systems, e.g., as an app or via a customer portal, offer suitable alternatives for customer-specific feed products/mixtures. It is important to respond in a timely manner in order to remain competitive, since, according to the experts, the companies in the sector are already feeling economic pressure. A targeted omnichannel management, which can serve agricultural 
customers transparently and barrier free both offline and online, will therefore become even more important in the future. For the development of further recommendations for action it is advisable to conduct an in-depth quantitative study based on the available results.

\section{Zusammenfassung}

Die Digitalisierung und der E-Commerce gewinnen in der landwirtschaftlichen Vorleistungsindustrie zunehmend an Bedeutung. Auch der Online-Einkauf von Betriebsmitteln wird bei LandwirtInnen immer beliebter, jedoch gibt es Unterschiede zwischen den Produktgruppen. Typische Gebrauchsgüter wie Futtermittel werden bislang nur selten online erworben. Daher war Ziel der vorliegenden Untersuchung, den aktuellen Stand der Digitalisierung im Futtermittelsektor und das derzeitige Angebot an Online-Bestellsystemen zu ermitteln, sowie die Barrieren des Online-Vertriebs aus Sicht der Futtermittelhersteller zu untersuchen. Dazu wurden eine Internetrecherche der Webseiten 40 deutscher und niederländischer Futtermittelhersteller und sieben leitfadenorientierte Experteninterviews mit MitarbeiterInnen deutscher Futtermittelunternehmen durchgeführt. Die Interviews wurden zwischen Juli und August 2019 durchgeführt und nach Transkription mit Hilfe einer qualitativen Inhaltsanalyse ausgewertet.

Die Ergebnisse zeigen, dass die Unternehmen des Futtermittelsektors bislang nur wenig digitalisiert sind, Mängel gibt es insbesondere im Vertrieb. Auch Onlineshops und Bestellsysteme werden eher selten angeboten. Einen Einfluss auf die digitale Entwicklung haben unternehmens-, sektor-, produkt,- und kundenspezifischen Faktoren. Dazu gehören die traditionell geprägten Strukturen der Branche und seiner Mitarbeiter sowie die Organisation des Vertriebs. Eine persönliche Beziehung zur Kundschaft hat für die Kundenbindung, Vertrauensbildung, Produktauswahl und Preisverhandlungen noch immer eine hohe Bedeutung. Die mit dem Online-Vertrieb einhergehende Preis- und Produkttransparenz gestaltet sich im Sektor, aufgrund von produkt- und kundenspezifischen Faktoren bei der Preisbildung und Produktzusammensetzung schwierig. Der starke Wettbewerb und der Preiskampf erschweren die Situation zusätzlich und verhindern die Entstehung von Onlineshops für Futtermittel. Als größte Barriere im Unternehmen wirken mangelnde Ressourcen wie finanzielle Mittel und Know-how. Wegen der bislang geringen Nachfrage und des verzögerten Return on Investment sind digitale Vertriebskanäle meist kein primäres Ziel für Investitionen. 
Zukünftig wird aufgrund der wachsenden Onlineaffinität junger Landwirte mit einer positiven Entwicklung gerechnet. Onlineshops eignen sich vor allem für standardisierte Produkte. Für betriebsindividuelle Mischungen bieten digitale Kontraktabrufsysteme z.B. als App oder über ein Kundenportal eine geeignete Alternative. Dabei ist es wichtig, rechtzeitig zu reagieren, um wettbewerbsfähig zu bleiben, denn einen wirtschaftlichen Druck verspüren die Unternehmen des Sektors den Experten zufolge bereits jetzt. Ein gezieltes OmnichannelManagement, welches die landwirtschaftlichen KundInnen sowohl offline als auch online transparent und barrierefrei bedienen kann, wird daher zukünftig umso wichtiger. Für die Ausarbeitung weiterer Handlungsempfehlungen empfiehlt sich eine vertiefende quantitative Untersuchung auf der Grundlage der vorliegenden Ergebnisse. 


\section{$1 \quad$ Einleitung}

94\% aller deutschen Unternehmen wickeln Geschäfts- und Produktionsprozesse inzwischen mit Hilfe von Computern ab und bei vielen spielt das Internet für Kunden- und Geschäftsbeziehungen bereits eine große Rolle (Nds. MW, 2018). Auch der E-Commerce, also die geschäftliche Transaktion über das Internet, gewinnt an Bedeutung (Biesel und Hame, 2018; Böing, 2001; Meier und Stormer, 2012; Verhoef et al., 2015) und betrifft zunehmend auch das Business-to-Business Geschäft (B2B), (Hosoi, 2000; Wittmann und Listl, 2017). Im Jahr 2018 wurden knapp 1,3 Billionen Euro im elektronischen B2B-Geschäft erwirtschaftet. Die jährliche Wachstumsrate liegt bei etwa 6\%, wobei ein weiteres Wachstum prognostiziert wird (IFH Köln, 2019). Die möglichen Vorteile von E-Commerce-Anwendungen sind vielfältig. So können sie den Direktvertrieb erleichtern (Hosoi, 2000; Köllinger, 2004; Porter, 2001; Weihofen, 2004; Zeng et al., 2017), das Erschließen neuer Markt- und Kundensegmente vereinfachen (Henderson et al., 2006; Schwartz, 2017; Strzębicki, 2015), Transaktionskosten senken (BMEL, 2020; Clasen et al., 2003; Doluschitz et al., 2004) und Geschäftsprozesse optimieren, da Informationen schneller, fehlerarm und automatisiert fließen (Strzębicki, 2015).

Dass das E-Business auch in der landwirtschaftlichen Vorleistungsindustrie an Bedeutung gewinnt, wird in der Literatur bereits seit mehr als zehn Jahren diskutiert (Batte und Ernst, 2007; Henderson et al., 2004; Pape und Doluschitz, 2001; Voss, 2008), auch wenn diese "erste Generation" von Geschäftsmodellen nur begrenzt erfolgreich war. Neuere Studien (Schulze Schwering und Spiller, 2019, 2018; Strzębicki, 2015) und das vermehrte Aufkommen von Online-Bestellplattformen und -marktplätzen wie Agrando, myAgrar oder Agrar2b bestätigen die zunehmende Relevanz des Onlinehandels von Betriebsmitteln. Dabei bietet neben etablierten Betriebsmittelherstellern und Landhändlern auch eine zweite Generation von Startups verstärkt digitale Bestell- und Handelsplattformen für LandwirtInnen an (Bongardt, 2018; Huchtemann und Theuvsen, 2018; Koch, 2019).

Bislang gibt es im Online-Betriebsmittelhandel jedoch starke Unterschiede zwischen den verschiedenen Produktgruppen (Ackermann et al., 2018; Gartzke, 2016; Schulze Schwering und Spiller, 2018). Die Unterschiede beziehen sich zum einen auf die Nachfrage nach digitalen Bestellmöglichkeiten und zum anderen auf das Onlineangebot. Betriebsmittel wie Ersatzteile, Arbeitskleidung oder Büromaterialien sind online bereits über viele verschiedene Anbieter beziehbar und werden heute schon regelmäßig von LandwirtInnen online erworben. Typische Gebrauchs- und Erfahrungsgüter wie Dünge-, Pflanzenschutz- und Futtermittel werden 
hingegen deutlich seltener online gekauft (Ackermann et al., 2018; Gartzke, 2016; Schulze Schwering und Spiller, 2018). Während das Onlineangebot von Düngemittel und Pflanzenschutzmittel unter anderem durch neue Anbieter wie myAGRAR und ag.supply ausgeweitet wurde, entwickelt sich der Online-Futtermittelhandel verhaltener. Zwar bieten einige Hersteller bereits Onlinekäufe z.B. in Form von Bestell-Apps (IQ-Feed von Agravis AG, Bröring Bestell-App) an, doch andere Unternehmen entscheiden sich offenbar bewusst gegen diesen Schritt. Die ATR Landhandel GmbH \& Co. KG, welche zu den 10 stärksten Mischfutterherstellern in Deutschland zählt, hat mit ihrem Tochterunternehmen myAGRAR einen Onlineshop etabliert, worüber keine Futtermittel bezogen werden können (AgrarOnline $\mathrm{GmbH}, 2020$ ). Dabei bilden Futtermittel mit 42\% die wichtigste Kostenart in tierhaltenden Betrieben (BMEL, 2020). Umso erstaunlicher ist es auf den ersten Blick, dass der Anteil des Futtermittelsektors am landwirtschaftlichen Onlinehandel noch so gering ist.

Vor diesem Hintergrund stellt sich die Frage, warum sich der Onlinehandel von Futtermitteln nur zögerlich entwickelt und welche Faktoren als Barriere für den digitalen Vertrieb wirken. Während bereits verschiedene Studien grundsätzliche Barrieren der Digitalisierung und des E-Commerce im Agribusiness thematisiert haben (Doluschitz et al., 2004; Ehmke et al., 2001; Hooker et al., 2001; Mueller, 2001), beleuchten die meisten neueren Studien zum Betriebsmitteleinkauf im Internet die Thematik nur aus Sicht der LandwirtInnen (Ackermann et al., 2018; Fecke et al., 2018a; Gartzke, 2016; Schulze Schwering und Spiller, 2018). Zudem gibt es nach Kenntnis der Autorinnen bislang keine Forschungsarbeit mit alleinigem Fokus auf den E-commerce im Futtermittelsektor. Der vorliegende Beitrag greift diese Forschungslücke auf und untersucht, basierend auf einer intensiven Internetrecherche und sieben qualitativen Experteninterviews mit VertreterInnen verschiedener Futtermittelunternehmen, den StatusQuo und die Barrieren des Onlinehandels von Futtermitteln. Die Ergebnisse liefern Ansätze für neue digitale Vertriebsstrategien. Es wird untersucht, ob und wie digitale Kanäle in bestehende Vertriebsstrukturen eingebunden werden können, um langfristig die Kundenbindung zu verbessern.

Bevor die Einflussfaktoren auf die E-commerce Entwicklung eines Unternehmens dargestellt werden, folgen zunächst eine Beschreibung des Futtermittelsektors und des online Betriebsmittelhandels. Daran anschließend werden die Methodik und die Ergebnisse vorgestellt. Der Beitrag schließt mit einer Diskussion der Ergebnisse, der Ableitung einiger Handlungsempfehlungen und einem kurzen Fazit. 


\section{Situation des Futtermittelsektors und des Futtermittel Onlinehandels}

Futtermittel bilden mit etwa $42 \%$ einen der größten Kostenpunkte an Vorleistungen in tierhaltenden Betrieben (BMEL, 2020). Die Ausgaben betrugen im Jahr 2017 ca. 14,2 Mrd. Euro (Pascher et al., 2018), und allein in Deutschland wurden im Wirtschaftsjahr (WJ) 2017/2018 23,9 Mio. Tonnen Mischfutter produziert (BMEL, 2018). Die Futtermittelbranche beschäftigt etwa 10.000 Arbeitnehmer und besteht zum größten Teil aus mittelständischen Unternehmen (DVT, 2019, 2018). Im WJ 2017/18 waren 299 Betriebe in Deutschland gemeldet. Die Zahl ist in den letzten Jahren rückläufig (BMEL, 2018). Insgesamt weist die Branche einen eher geringen Konzentrationsgrad auf, und es herrscht ein starker Wettbewerb. $60 \%$ der Marktanteile werden von den zehn größten Mischfutterherstellern gehalten (DVT, 2019, 2018). Gleichzeitig haben Mischfuttermittel aus Sicht der LandwirtInnen, innerhalb einer Produktkategorie, einen hohen Grad an Substituierbarkeit und werden häufig als "homogene Massengüter" gesehen (Zimmermann, 2003).

Charakteristisch für den landwirtschaftlichen Warenhandel ist eine Kombination aus vergleichsweise hoher Kapitalintensität und niedrigen Margen (Gollisch und Theuvsen, 2015). In Kombination mit den heutzutage häufig unter Preisdruck leidenden LandwirtInnen führt dies dazu, dass sie eher bereit sind, aus Preisgründen den Anbieter zu wechseln. Die Kundenbindung ist daher in den letzten Jahren rückläufig (BMEL, 2018; DVT, 2018; Zimmermann, 2003). Eine Reaktion darauf ist eine Produktentwicklung der Hersteller, weg von Standardprodukten hin zu individualisierten Mischungen, die auf die Bedürfnisse der einzelnen Betriebe zugeschnitten sind (BLE, 2018). Der Vertrieb erfolgt meist regional, direkt über den Hersteller oder indirekt über Landhandel, Genossenschaften und selbstständige Futtermittelhändler (Zimmermann, 2003). Der Landhandel und die Genossenschaften fungieren meist sowohl als Lieferunternehmen für Futtermittel, als auch als Abnehmende landwirtschaftlicher Erzeugnisse wie Getreide. Ein persönlicher Kontakt zum Vertriebsaußen und -innendienst ist beim Verkauf von Futtermitteln üblich (BLE, 2018; Zimmermann, 2003).

Bereits zu Beginn der 2000er Jahre existierten erste E-Commerce-Angebote in der Agrar- und Ernährungswirtschaft. Der Erfolg blieb jedoch größtenteils aus, sodass viele der damalig anbietenden Unternehmen zeitnah wieder vom Markt verschwunden sind (Clasen, 2018; Clasen et al., 2013; Clasen, 2005; Clasen et al., 2003). Mit der in den letzten Jahren stark wachsenden Digitalisierung innerhalb des gesamten Agrarsektors ist auch das Interesse am OnlineBetriebsmittelhandel wieder stark angestiegen. Heute sind landwirtschaftliche Betriebsmittel 
bereits über eine Vielzahl digitaler Kanäle verfügbar (Bongardt, 2018). Unterschieden werden kann dabei zwischen Angeboten bereits etablierter Unternehmen und den Angeboten von Start-ups. Letztere treten insbesondere mit neuen Markplätzen oder Handelsplattformen (agrando, agrar2b, agrarconnect, Agrora etc.) und seltener mit Onlineshops (ag.supply) in den Markt ein (Huchtemann und Theuvsen, 2018). Etablierte Unternehmen dominieren im Bereich des direkten Vertriebs hingegen mit Onlineshops (myAGRAR von ATR Landhandel, BayWaShop), digitalen Kundenportalen (myfarmvis der Agrarvis) oder Bestell-Apps (IQFeed der Agrarvis). Diese Entwicklungen bestätigen die zunehmende Relevanz des Onlinehandels von Betriebsmitteln.

Doch der Online-Betriebsmittelhandel entwickelt sich in Abhängigkeit von der Produktgruppe sehr unterschiedlich (Ackermann et al., 2018; Schulze Schwering und Spiller, 2018). Vorzugsweise werden Suchgüter, deren Qualität durch die Informationssuche bereits vor dem Kauf beurteilt werden kann, online gehandelt. Zu den Suchgütern gehören Materialien des täglichen Bedarfs, Energie- und Schmierstoffe, Bürobedarf oder Ersatzteile. Komplexe und beratungsintensive Erfahrungsgüter wie Saatgut, Pflanzenschutz- Dünge- und Futtermittel werden hingegen seltener online gekauft (Ackermann et al., 2018; Gartzke, 2016; Schulze Schwering und Spiller, 2018). Während das Onlineangebot für Saatgut, Dünge- und Pflanzenschutzmittel unter anderem durch die Verfügbarkeit bei neuen Anbietern wie myAGRAR, ag.supply gestiegen ist, wächst das Onlineangebot von Futtermitteln langsamer. $\mathrm{Zu}$ den etwas häufiger online gehandelten Futtermitteln zählen Mineralfutter, Milchaustauscher, Starterfutter und Geflügelalleinfutter. Das Futtermittelangebot bei Internetanbietern ist hingegen oft sehr gering (BayWa-Shop, Agrando) oder nicht vorhanden (ag.supply, myAgrar). Laut Jörg Semmelroch (Vertriebsund Verkaufsleiter von Bergophor) müssen sich LandwirtInnen ,auf dem in Teilen unüberschaubaren Futtermittelmarkt in einer unglaublichen Produktvielfalt zurechtfinden“(Lutilsky, 2020).

Der Onlinehandel mit Futtermitteln steckt noch in der Entwicklung, kann aber hinsichtlich der Markt- und Produktübersicht neue und kundenfreundliche Lösungen ermöglichen. So stellen automatisierte Bestellprozesse z.B. in Form von Onlineshops oder Kundenportalen eine Möglichkeit für eine kundenorientierte Geschäftsprozessoptimierung dar. Zudem entfallen beim E-Commerce generell die bei manuell erfassten Bestellungen häufig auftretenden Probleme wie Medienbrüche, Wechsel von Bearbeitern, die dadurch entstehende Doppelarbeit sowie mögliche Fehler bei der Datenweitergabe. Durch eine Verbindung aller Prozesse vom Wareneingang, der Bestellannahme und Produktionsplanung bis hin zur Auslieferung können 
Arbeitsabläufe zeit- und kosteneffizienter abgewickelt werden (Weihofen, 2004). Dies kommt Kunden und Anbietern gleichermaßen zugute.

In Anbetracht der Relevanz von Futtermitteln innerhalb der Vorleistungsindustrie und der vorgestellten Entwicklungen im Onlinehandel von Futtermitteln stellt sich die Frage, welche Faktoren die digitale Entwicklung von Futtermittelunternehmen beeinflussen und worin die größten Barrieren aus Sicht der herstellenden Unternehmen bestehen. Im Folgenden werden daher die Einflussfaktoren auf die digitale Entwicklung in Unternehmen systematisch untersucht und mit Erkenntnissen aus der agrarökonomischen Forschung ergänzt, bevor sie im Anschluss empirisch überprüft werden.

\section{Einflussfaktoren auf die E-Commerce-Entwicklung eines Unternehmens}

Die digitale Entwicklung im Unternehmen und das Angebot von Onlineshops ist von verschiedenen Faktoren abhängig. Diese können, neben den Eigenschaften des Sektors und des Unternehmens selbst, auch die angebotenen Produkte und das Kundensegment betreffen. In der Literatur wird eine Vielzahl von Einflussfaktoren beschrieben, die in Tabelle 1 zusammengefasst und nachfolgend genauer erläutert werden.

Tabelle 1: Einflussfaktoren auf die digitale Entwicklung und den E-Commerce im Agribusiness

\begin{tabular}{|c|c|c|}
\hline Sektor/Unternehmen & Produkte & KundInnen \\
\hline $\begin{array}{l}\text { - } \text { Eigenschaften des Sektors } \\
\text { - } \text { Management/Mitarbeiter } \\
\text { - } \text { Vertriebsorganisation } \\
\text { - Ressourcen } \\
\text { - Logistik } \\
\text { - Unternehmensgröße } \\
\text { - Produkt- und } \\
\quad \text { Preistransparenz }\end{array}$ & $\begin{array}{ll}\text { - } & \text { Grad der } \\
& \text { Standardisierung } \\
\text { - } & \text { Beratungsintensität } \\
\text { - } & \text { Transportfähigkeit } \\
\text { - } & \text { Darstellungsfähigkeit } \\
\text { - } & \text { Preisbildung } \\
\text { - } & \text { Produkt-/Warenwert }\end{array}$ & $\begin{array}{l}\text { - } \text { Soziodemografische Faktoren } \\
\text { - Persönlicher Kontakt } \\
\text { o Beratung } \\
\text { o Preisverhandlungen } \\
\text { - Loyalität zum Handel vor Ort } \\
\text { - } \text { Vertrauen } \\
\text { - Zeitfaktor } \\
\text { - Anwenderfreundlichkeit } \\
\text { - Anreize }\end{array}$ \\
\hline
\end{tabular}

Quelle: Eigene Darstellung

\subsection{Sektor- und unternehmensspezifische Einflussfaktoren}

Die Implementierung von digitalen Technologien und E-Commerce-Angeboten im Unternehmen wird beeinflusst durch sektor- und unternehmensbezogene Faktoren. Einer Studie von Hooker et al. (2001) zufolge, die sich mit den Besonderheiten des elektronischen Agribusiness beschäftigt, spielen die Eigenschaften des landwirtschaftlichen Sektors und seiner TeilnehmerInnen eine bedeutende Rolle. Diese sind geprägt von langen Traditionen und einem 
Widerstand dagegen, bewährte Geschäftsprozesse zu verändern. Die traditionellen Strukturen der Landwirtschaft stehen daher den dynamischen und sich schnell verändernden Eigenschaften neuer E-Business-Technologien entgegen (Hooker et al., 2001). Herdon et al. (2006) bestätigen, dass die Unternehmen selbst, der Sektor und gesellschaftliche Faktoren die Einführung des E-Business im Agribusiness beeinflussen. Auch Leroux et al. (2001) nennen die Industriestrukturen als Ursache für eine geringe Adaptationsgeschwindigkeit. Akteuren der Vorleistungsindustrie fällt es oftmals schwer, ihre Vertriebsprozesse zu überdenken und nur selten wird eine klar definierte E-Commerce-Strategie verfolgt, was sich in einer mangelnden Kundenorientierung der Angebote widerspiegelt (Voss, 2008). Darüber hinaus ist ein hohes Maß an persönlichen Kontakten bei geschäftlichen Transaktionen in der landwirtschaftlichen Vorleistungsindustrie üblich und hat noch immer einen hohen Stellenwert (Henderson et al., 2006; Ivanic et al., 2001; Leroux et al., 2001; Mueller, 2001). Der erschwerte Aufbau von persönlichen Beziehungen über das Internet, insbesondere, weil diese mit Unsicherheiten über die Identität der GeschäftspartnerInnen einhergehen, kann daher als weiteres Hemmnis für die Einführung von online Absatzwegen gesehen werden (Henderson et al., 2006; Ivanic et al., 2001).

Auf der Unternehmensseite wird die digitale Entwicklung durch die Einstellung des Managements und der MitarbeiterInnen gegenüber der Implementierung neuer digitaler Technologien beeinflusst (Böing, 2001; Elste, 2016; Fitzgerald et al., 2014; Henderson et al., 2000). Ist das Management der Thematik gegenüber nicht aufgeschlossen und sind die MitarbeiterInnen nicht bereit ihre Arbeitsabläufe zu verändern, wird der digitale Fortschritt im Unternehmen gebremst. Um eine Veränderung zu erreichen, müssen MitarbeiterInnen und das Management zunächst von den Vorteilen digitaler Neuerungen überzeugt werden (Bandow und Holzmüller, 2010; Niehaus und Emrich, 2016).

Die allgemeine Organisation des Vertriebs und die Geschäftsstrukturen im Unternehmen spielen ebenfalls eine Rolle (Akridge, 2003; Hooker et al., 2001). Dies betrifft neben den genutzten Vertriebskanälen auch die Handelsregion (Akridge, 2003; Doluschitz und Pape, 2002). Bei der Einführung eines neuen Vertriebskanals kommtes regelmäßig zur Verlagerung von Kapazitäten aus den ursprünglichen Vertriebswegen, d. h. zu Kannibalisierungseffekten (Böing, 2001; Niehaus und Emrich, 2016). Diese können insbesondere bei einem indirekten Vertrieb über Zwischenhändler leicht zu Konflikten mit Händlern und Zulieferern führen, da eine direkte Konkurrenzsituation für sie entsteht (Akridge, 2003). Die Handelsregion ist von Bedeutung, da in Regionen mit einem hohen regionalen Angebot vor Ort, 
E-Commerce-Angebote seltener genutzt werden. Produkte, die nicht in der Umgebung verfügbar sind, werden hingegen eher über einen Onlinekanal erworben (Keisidou et al., 2011). Die physischen Märkte stellen also eine Konkurrenz zum E-Commerce dar (Ackermann et al., 2018). Zudem unterscheiden sich oftmals die Kundenstrukturen der verschiedenen Handelsregionen, bspw. sind im Osten Deutschlands die landwirtschaftlichen Betriebe größer als in Bayern (Pascher et al., 2018).

Auch die Ressourcen im Unternehmen sind für die E-Commerce-Entwicklung entscheidend. Dies gilt besonders für technische und finanzielle Ressourcen, Humankapital und ITKenntnisse (Doluschitzet al., 2004; Doluschitz und Pape, 2002; Ehmke et al., 2001; Hooker et al., 2001; Mueller, 2001). Fehlendes Know-how und ein Mangel an finanziellen Mitteln zählen auch außerhalb des landwirtschaftlichen Sektors zu den bekannten Hindernissen für die Digitalisierung im Unternehmen. Insbesondere sind hier die Kosten und ein Mangel an Zeit als führende Gründe gegen die Einführung eines Onlineshops zu nennen (Wittmann und Listl, 2017). Eine weitere, durch die Ressourcen beeinflusste Herausforderung stellt die Logistik dar. Diese wirkt laut Henderson et al. (2004) und Henderson et al. (2006) limitierend auf den Aufbau von E-Commerce-Aktivitäten im Unternehmen. Ein Grund hierfür ist, dass die durch den Online-Vertrieb ermöglichte Ausweitung des Vertriebsgebiets längere Transportwege und damit neue logistische Herausforderungen hervorruft (Biesel und Hame, 2018; Henderson et al., 2006). Dies kann sich vor allem in der Vorleistungsindustrie, in der es oft um den Transport großer Mengen geht, schwierig gestalten.

Die unternehmensinternen Ressourcen verursachen des Weiteren Unterschiede zwischen Klein- und Großbetrieben, vor allem in Bezug auf den Onlinehandel von Waren und die Homepagegestaltung (Doluschitz und Pape, 2002). Den Einfluss der Unternehmensgröße auf die digitale Entwicklung von Agribusinessunternehmen bestätigen Studien von Akridge (2003), Henderson et al. (2006) und Ivanic et al. (2001), in denen größere Unternehmen mit umfangreichen Produktlinien im E-Commerce weiterentwickelt und besser aufgestellt waren als kleinere Unternehmen. Auch außerhalb der Agrarbranche stellte Schwartz (2017) fest, dass insbesondere mittelständische Unternehmen im Bereich des E-Commerce noch „in den Kinderschuhen“"stecken.

Ein für den Kunden positiver Effekt des E-Commerce ist die Produkt- und Preistransparenz. Durch die im Internet herrschende hohe Anbieterverfügbarkeit können Produkte und Preise direkt gegenübergestellt und verglichen werden (Doluschitz und Pape, 2002; Henderson et al., 2006; Hosoi, 2000; Porter, 2001; Wittmann und Listl, 2017). Dies wirkt für die 
Herstellerunternehmen nachteilig, da es den Konkurrenzdruck erhöht und somit den Wettbewerb verstärkt (Akridge, 2003; Hosoi, 2000; Weihofen, 2004).

\subsection{Produktspezifische Einflussfaktoren}

Die Literatur bestätigt, dass auch die vertriebenen Produkte selbst einen Einfluss auf den Online-Vertrieb haben. Laut Doluschitz (2002) spielen bei der Vermarktung von Agrarprodukten über das Internet vor allem die Art und der Wert der Produkte sowie deren Transport- und Lagerfähigkeit eine Rolle. Futtermittel werden aufgrund der hohen Mengen seltener über das mit dem Online-Handel verbundene und wachsende Paketgeschäft (Ackermann et al., 2018; Zanker, 2018), sondern vorzugsweise über Speditionen bezogen. Die mit Futtermitteln einhergehenden hohen Anforderungen an die Logistik können daher die Bereitschaft für den internetbasierten Ein- und Verkauf senken.

Zudem gilt die begrenzte Verifizierbarkeit bei Erfahrungsgütern, wie Futtermitteln, als Hürde für den Verkauf über das Internet (Ackermann et al., 2018). Demnach eignen sich besonders weitestgehend standardisierte Produkte, deren Qualität leicht objektiv feststellbar ist, die gut lagerfähig und leicht zu versenden sind, für den Online-Vertrieb. Dies bestätigen auch Batte und Ernst (2007) sowie Schulze Schwering und Spiller (2018). Komplexe, individualisierte oder spezialisierte Produkte wie Futtermittel, benötigen oftmals eine spezifische Beratung, welche über Onlinekanäle schwer bereitzustellen ist und die Vermarktungschancen über das Internet negativ beeinflusst (Voss, 2008). Die Darstellungsfähigkeit von Agrarprodukten im Internet stellt eine weitere Herausforderung dar (Wheatley et al., 2001). Die Produkte weisen meist eine hohe Heterogenität auf, diese ist online schwer darstellbar, da physische Produkteigenschaften, wie Textur, Geruch und Qualität online nicht übermittelt werden können.

Leroux et al. (2001) nannten in ihrer Studie zu den Einflussfaktoren auf die Entwicklung des B2B-ECommerce in der Landwirtschaft unter anderem die Komplexität der Transaktionen als einen weiteren Einflussfaktor. Dies betrifft vor allem die Preissetzung. Demnach fällt es bei Agrarprodukten häufig schwer, Preise für einen Online-Vertrieb festzulegen, da diese von Faktoren wie Produktstandort, Zeitpunkt der Bestellung, Rohstoffpreis, Qualität und Menge abhängig sind und dementsprechend stark variieren können. Eine automatisierte Anpassung wurde von den Autoren auf Grund der benötigten aufwändigen Datenbank als nicht umsetzbar eingestuft (Leroux et al., 2001). Es ist daher davon auszugehen, dass auch Futtermittel nur schwer online dargestellt und bepreist werden können. 
Neben der Preisbildung ist auch der Warenwert wichtig für die Entscheidung für oder gegen einen Onlineshop. Sicherheiten, Garantien oder die physische Betrachtung können notwendig sein, damit der Online-Handel mit großen und teuren Produkten florieren kann (Batte, 2006).

Laut Fecke et al. (2018a, 2018b) fordern LandwirtInnen einen Preisrabatt, wenn sie vom stationären Handel zum Onlinehandel wechseln. Dabei sollten die Logistikkosten die Kostenvorteile durch den Onlinehandel nicht aufheben (Ackermann et al., 2018).

\subsection{Kundenspezifische Einflussfaktoren}

Ebenfalls von Relevanz für die digitale Vertriebsstrategie eines Unternehmens sind die Eigenschaften des Kundensegments. Denn der Erfolg und Misserfolg digitaler Vertriebskanäle ist abhängig von der Nachfrage. Generell können verschiedene Faktoren einen Einfluss auf die Internetnutzung und damit auf das E-Commerce-Nutzungsverhalten der landwirtschaftlichen Kundschaft haben. Die Literatur deutet hier oftmals auf soziodemografische Faktoren wie das Alter und die Ausbildung der Betriebsleiterin, des Betriebsleiters hin. Das Alter korreliert dabei negativ mit der Nutzung. Das bedeutet, dass ältere LandwirtInnen Computer, das Internet und damit digitale oder internetbasierte Einkaufsmöglichkeiten weniger nutzen als jüngere (Ackermann et al., 2018; Batte, 2006; Mishra et al., 2009; Rosskopf und Wagner, 2006). Die Relevanz dieses Faktors wird durch den Altersdurchschnitt der KundInnen verdeutlicht. Aktuell sind 34\% der deutschen LandwirtInnen insgesamt sowie fast 40\% der Betriebsinhabenden 55 Jahre und älter. Damit sind sie deutlich älter als der Durchschnitt der Bevölkerung anderer deutscher Erwerbssegmente (Pascher et al., 2018). Ergebnisse von Vennemann und Theuvsen (2004) zeigten weiterhin einen Einfluss des Alters auf das Interesse an Online-Informationen zu Futtermitteln. In ihrer Studie recherchierten ausschließlich TeilnehmerInnen, die jünger als 40 Jahre waren, Futtermittel online. Neuere Studien zum Online-Einkaufsverhalten von LandwirtInnen konnten hingegen keinen Einfluss des Alters auf die Nutzungsabsicht nachweisen (Ackermann et al., 2018; Schulze Schwering und Spiller, 2018). Hinsichtlich der Bildung zeigt sich, dass die E-Commerce-Nutzung mit steigendem Bildungsniveau des Betriebsleitenden zunimmt (Ackermann et al., 2018; Batte und Ernst, 2007; Batte, 2006; Mishra et al., 2009; Park und Mishra, 2003). Laut Mishra et al. (2009) sollten sich Onlineangebote daher vor allem an junge LandwirtInnen mit einem Hochschulabschluss richten.

Landwirtschaftliche Betriebsmittel werden noch immer größtenteils über den Landhandel bezogen (Ackermann et al., 2018; Gartzke, 2016; Schulze Schwering und Spiller, 2018). Als Gründe gegen den Kauf von Futtermitteln im Internet nannten die Teilnehmenden einer Studie 
von Vennemann und Theuvsen (2004) unter anderem erschwerte Preisverhandlungen und fehlende persönliche Beratung. Letzteres bestätigten auch neuere Ergebnisse von Gartzke (2016), wonach das Vertrauen in den Handel vor Ort und die persönliche Beratung die Nutzung von E-Commerce negativ beeinflussen. Fecke et al. (2018b) fanden heraus, dass bezogen auf den Einkauf von Pflanzenschutzmitteln eine gute persönliche "Vor-Ort-Beratung" im Landhandel die Wechselbereitschaft hin zum Onlineshop verringert. Die häufig sehr loyalen, engen und emotional geprägten Beziehungen gehen mit viel persönlichem Kontakt und hohem Vertrauen einher (Gartzke, 2016; Gollisch und Theuvsen, 2015; Schulze Schwering und Spiller, 2018). Diese Bindung geht so weit, dass KundInnen auch bei höheren Preisen eher bereit sind ihre Betriebsmittel vor Ort zu kaufen (Batte und Ernst, 2007). Andere Studien deuten jedoch darauf hin, dass die Stärke der Landwirt-Händler-Beziehung im Zeitverlauf vermutlich abnehmen wird (Gollisch und Theuvsen, 2015; Schulze Schwering und Spiller, 2019).

Die Bedeutung des Vertrauens stellen Batte und Ernst (2007) heraus, in deren Befragung mehr als $77 \%$ der Teilnehmenden angaben, eher bei einem Händler online einzukaufen, den sie bereits kennen und dem sie vertrauen. Das Preisgeben von Daten im Internet an einen anonymen Geschäftspartner wird von LandwirtInnen hingegen als riskant eingestuft (Voss, 2008). Dabei spielen Gefühle wie Misstrauen, aber auch Bedenken über Sicherheit und Privatsphäre eine Rolle. Sie wirken hemmend auf die Nutzung von E-Commerce-Angeboten (Gartzke, 2016; Henderson et al., 2006; Schulze Schwering und Spiller, 2018).

Als weitere Gründe gegen den Einkauf von Betriebsmitteln im Internet nannten LandwirtInnen Zeitnachteile gegenüber telefonischen Bestellungen und umständliche Bestellvorgänge (Pohl et al., 2002). Ackermann et al. (2018) zeigten hingegen auf, dass gerade Zeitvorteile ein Hauptmotiv für den Online-Einkauf von Betriebsmitteln sind. „Je wichtiger der Zeitfaktor bei der Beschaffung von Betriebsmitteln auf einen Probanden, desto häufiger werden E-Commerce-Strukturen genutzt. Die LandwirtInnen, bei denen vor allem Zeitvorteile wichtig sind, kaufen mehr online als jene, für die vorrangig Kostenvorteile zählen“" (Ackermann et al., 2018, S. 15). Entscheidend ist in diesem Kontext die Anwenderfreundlichkeit und dass der Kundschaft ein Mehrwert geboten wird (Voss, 2008; Weihofen, 2004). LandwirtInnen haben aufgrund ihrer hohen Arbeitsbelastung nur wenig Zeit und meist kein Interesse an der Auseinandersetzung mit komplizierten Anwendungen. Ansprechend wirken Onlineangebote für die/den LandwirtIn, wenn sie übersichtlich gestaltet und einfach anzuwenden sind. Informationen sollten gut verständlich sowie schnell, einfach und bequem auffindbar sein (Henderson et al., 2006; Weihofen, 2004). Bisher sind die LandwirtInnen laut Schulze 
Schwering und Spiller (2019) mit dem Angebot nur mäßig zufrieden. Die Gestaltung der Homepage, die meist nur zur Darstellung des Unternehmens für einen positiven, vertrauensbildenden Auftritt nach außen verwendet wird, ist ein entscheidender Aspekt. Sie bietet Kontaktmöglichkeiten, um das Vertrauen der KundInnen zu stärken und den Dialog zu fördern (Doluschitz, 2002; Vennemann und Theuvsen, 2004). Pohl et al. (2002) bezeichnen sie als "Onlinevisitenkarte".

Um den Online-Einkauf generell für KundInnen und Kunden attraktiv zu machen, können Anreize hilfreich sein. Dazu zählen unter anderem die Darstellung von Preisen, Lieferzeiten, die Produktpräsentation sowie der Kundenservice (Reibstein, 2002). Insbesondere günstigere Preise wirken auch bei LandwirtInnen als positiver Anreiz für den Online-Einkauf (Batte und Ernst, 2007; Clasen, 2005; Fecke et al., 2018a; Mishra et al., 2009). In einer Studie von Batte und Ernst (2007) zogen LandwirtInnen jedoch nur bei starken Preisvorteilen den Onlineshop dem lokalen Händler vor. Wie viel geringer der Preis sein musste, war dabei stark abhängig vom Kaufkontext, also z.B. wie dringend das Produkt benötigt wurde. Laut einer Studie von Fecke et al. (2018b) zum Online-Einkauf von Pflanzenschutzmitteln liegt der von LandwirtInnen geforderte jährliche Preisrabatt bei knapp 8,7\%, um vom bisherigen Anbieter zum Onlinehändler zu wechseln. Erweiterte Serviceangebote wie sofortige Verfügbarkeit und eine kurze Lieferzeit begünstigen den Online-Einkauf. Am Beispiel des Einkaufs von Pflanzenschutzmitteln konnte der negative Einfluss langer Lieferzeiten bestätigt werden (Batte und Ernst, 2007; Fecke et al., 2018b).

Insgesamt konnte in der Literatur eine Vielzahl verschiedener Einflussfaktoren auf die E-Commerce Entwicklung eines Unternehmens identifiziert werden. In der agrarökonomischen Forschung lag der Schwerpunkt bisher eher auf der ganzheitlichen Betrachtung des Betriebsmittelmarktes oder des Pflanzenschutzsektors. Studien, die sich explizit mit dem Ein- und Verkauf von Futtermitteln beschäftigen, liegen nicht vor. Da Futtermittel im Vergleich zu anderen Betriebsmitteln jedoch noch zögerlich über das Internet gehandelt werden und in Anbetracht der hohen Relevanz von Futtermitteln innerhalb der Vorleistungsindustrie stellt sich die Frage, welche Faktoren die digitale Entwicklung von Futtermittelunternehmen besonders beeinflussen. Worin sehen Hersteller die größten E-Commerce-Barrieren? Die vorliegende Studie soll einen Überblick über den digitalen Stand des Sektors ermöglichen und formuliert erste Handlungsempfehlungen für den E-Commerce bei Futtermitteln. 


\section{$4 \quad$ Material und Methoden}

\subsection{Internetrecherche}

Ziel der Untersuchung ist die Ermittlung des aktuellen Stands des Online-Vertriebs von Futtermitteln sowie die Identifikation von Barrieren, die diesem entgegenstehen. Im Rahmen dieser Arbeit wurden daher die Webseiten 40 deutscher- und niederländischer Misch- und Mineralfutterhersteller untersucht sowie Experteninterviews mit MitarbeiterInnen deutscher Futtermittelfirmen durchgeführt. Die Auswahl der interviewten Personen orientierte sich unter anderem an den Listen der Top-10 und Top 25- der deutschen Mischfutter herstellenden Unternehmen und dem DLG-Ranking der beliebtesten Futtermittelhersteller (Deter, 2015; Manager Magazin, 2011; Proplanta, 2010). Die untersuchten Unternehmenswebseiten repräsentieren je zur Hälfte Großbetriebe (mehr als 250 Mitarbeiter) und kleine und mittlere Unternehmen (KMU), wobei diese Einordnung nur anhand der Mitarbeiterzahlen getroffen wurde. Die EU-Empfehlung 2003/361 bezüglich der Abgrenzung von KMU sieht zusätzlich die Berücksichtigung des Jahresumsatzes oder der Jahresbilanzsumme vor (EU-Kommision, 2003). Diese Daten waren im Rahmen dieser Untersuchung allerdings nicht durchgängig zugänglich.

Die Internetauftritte der betrachteten Unternehmen wurden auf verschiedene Merkmale geprüft. Zum einen wurde die Gestaltung und die Funktionalität der Webseiten bewertet, wobei auch darauf geachtet wurde, ob die Webseiten für Smartphones responsive sind. Darüber hinaus wurde berücksichtigt, ob die jeweiligen Unternehmen über einen Kundenlogin verfügen und einen Newsletter-Service anbieten. In einem zweiten Schritt wurde die Produkt- und Preistransparenz betrachtet. Bewertet wurde, in welchem Umfang und in welcher Übersichtlichkeit die Produkte auf der Webseite vorgestellt und erläutert werden und ob Preisinformationen vorhanden sind. Abschließend wurde das Onlineshop-Angebot betrachtet. Dazu zählen zum einen die Verfügbarkeit von Onlineshops oder alternativen, digitalen Bestellmöglichkeiten (Bestell-Apps oder digitale Kundenportale) und zum anderen die Verfügbarkeit der Produkte bei anderen Onlineanbietern.

\subsection{Leitfadeninterviews}

Um den aktuellen Stand sowie die Einschätzungen und Erfahrungen der Branchen vertretende in Erfahrung zu bringen, wurden zusätzlich qualitative, leitfadengestützte Experteninterviews durchgeführt (Bogner et al., 2002). In Experteninterviews werden ExpertInnen aus einem 
bestimmten Fachgebiet befragt, welche stellvertretend für die Branche stehen können (Bogner et al., 2014, 2002). Durch den gemeinsamen institutionell-organisatorischen Kontext der ExpertInnen und die am Leitfaden orientierte Interviewführung wird die Vergleichbarkeit der generierten Daten sichergestellt (Meuser und Nagel, 2009). Das Experteninterview ermöglicht durch die Befragung ausgewählter Personen einen leichten Zugang in wenig erforschte Themengebiete (Flick, 2017; Lamnek und Krell, 2016). Der Interviewleitfaden wurde in Anlehnung an die vorgestellten drei Einflussfaktoren auf die digitale Entwicklung im Unternehmen und an den etablierten digitalen Reifegradmodellen erstellt (Berghaus und Back, 2016; Egeli, 2016). Der erste Teil befasst sich mit der Organisation des Vertriebs und der Wettbewerbssituation des Unternehmens, der zweite Teil umfasst neben allgemeinen Fragen zur Digitalisierung die Unterkategorien Bedeutung und Anwendung, Kundenakzeptanz, Performance Management, Sicherheit, Unternehmenskompetenzen und einen Ausblick auf zukünftige Entwicklungen in der Branche. Die Fragen wurden überwiegend offen formuliert, um möglichst umfangreiche Antworten zu generieren (Gläser und Laudel, 2010).

Es wurden Misch- und Mineralfuttermittelhersteller der in der Internetrecherche betrachteten Unternehmen kontaktiert. Bei der Auswahl wurde u.a. auf die Produktionsstärke im Bereich Futtermittel, Mitarbeiterzahl, Standort, Internetpräsenz und E-Commerce-Angebot geachtet, um die Branche möglichst im Ganzen darzustellen. Zudem wurden Personen gewählt, deren Expertenstatus sich dadurch begründet, dass sie über Wissen im Bereich Futtermittelvertrieb, Online-Vertrieb, Digitalisierung und dem Internetauftritt des Unternehmens verfügen. Die Interviews wurden zwischen Juli und August 2019 durchgeführt. Vier Interviews fanden bei den Unternehmen vor Ort statt, die übrigen Gespräche wurden am Telefon geführt. Die Interviews dauerten jeweils zwischen 30 und 85 Minuten und wurden zur Dokumentation und anschließenden Transkription aufgezeichnet. Im Anschluss wurden die Transkripte mit Hilfe des Programms MAXQDA Analytics Pro 2018 codiert und analysiert.

Nach der Transkription wurden die Interviews einer qualitativen Inhaltsanalyse nach Mayring unterzogen. Ziel dieser ist es, das Ausgangsmaterial so zu ordnen, kategorisieren und reduzieren, dass die wesentlichen Inhalte extrahiert werden können. Eine systematische, regel und theoriegeleitete Vorgehensweise ist üblich. Das Material wird dabei paraphrasiert, generalisiert und so weit reduziert, dass die verschiedenen Aussagen in ein Kategoriensystem eingeordnet werden können. Zur inhaltlichen Strukturierung der Themenkomplexe wurde das Gesagte zunächst in, durch den Interviewleitfaden vorgegebene, deduktive Kategorien eingeteilt (Mayring, 2015). Induktiv wurden von den Aussagen weitere Unterkategorien 
abgeleitet, welches eine umfangreiche Durchdringung des Datenmaterials sicherstellte (Mayring, 2015; Meuser und Nagel, 2009).

\section{$5 \quad$ Ergebnisse der Internetrecherche}

Die Internetrecherche zeigt, dass die Webseiten der Futtermittelhersteller große Unterschiede hinsichtlich Übersichtlichkeit und Benutzerfreundlichkeit aufweisen. Tabelle 2 gibt eine Übersicht über den Internetauftritt und das E-Commerce-Angebot der 10 wichtigsten Mischfutterhersteller. Tabelle 3 zeigt eine Übersicht der Internetauftritte weiterer ausgewählter Misch- und Mineralfutterhersteller. Der Großteil der Internetseiten ist bereits Smartphone responsive. Die betrachteten Unternehmen nutzen ihre Homepage überwiegend zur Darstellung des Unternehmens, Vorstellung ihrer Leistungen und Bereitstellung von Kontaktinformationen. Produkte, Einsatzbereiche und spezielle Fütterungskonzepte werden beschrieben, aber Produktdetails wie Inhaltstoffe und Zusammensetzung für die typischen Mengenprodukte sind seltener verfügbar. Zum Teil werden nur die Produktkategorien vorgestellt und auf eine genaue Auflistung der einzelnen Produkte wird verzichtet. Eine Preistransparenz ist in den meisten Fällen nicht vorhanden (Tabellen 2 und 3). Einige Unternehmen stellen Preis- und Produktinformationen nur nach persönlicher Anfrage und in Verbindung mit einer Produktberatung zur Verfügung.

Eine umfangreiche Produktübersicht gibt es bei den Top-Playern selten (Tabelle 2). Einen klassischen Onlineshop, in dem Produkte und Preise dargestellt werden, betreibt keiner der Top-Player. Als alternative digitale "Bestellsysteme" bieten einige dieser Unternehmen Online-Bestellformulare und Kontraktabrufsysteme in Kundenportalen oder Bestell-Apps an, deren Angebot aber häufig noch eingeschränkt ist. Drei der Top-Player bieten keine digitale Bestellmöglichkeit an.

Es zeitgt sich, dass die Produktübersicht bei den in Tabelle 3 aufgeführten Herstellern genauer ausfiel. Tendenziell zeigte sich, dass bei jenen Anbietern, die hauptsächlich Schüttgut anbieten, die Produktübersicht und der Einsatz digitaler Bezugsmöglichkeiten weniger umfangreich gestaltet war. Einen Kundenlogin und/oder Newsletter bieten 21 der untersuchten Unternehmen an. Während insgesamt gut ein Fünftel der Unternehmen einen klassischen Onlineshop führen, bieten sieben eine Bestell-App an und 10 Unternehmen stellen Alternativen wie ein Kundenportal oder ein Online-Bestellformular zur Verfügung. 
19 der betrachteten Unternehmen bieten keine digitalen Einkaufsmöglichkeiten an. Von den 21 Unternehmen, die digitale Bestellmöglichkeiten anbieten, sind 11 Großbetriebe und 10 zählen zu den KMUs. Während Großbetriebe eher Bestell-Apps oder Kundenportale ( $n=8)$ anbieten, sind Onlineshops vorwiegend bei den klein- und mittelständischen Unternehmen (n=6) zu finden, aber meist mit beschränktem Produktangebot. 15 der Unternehmen, die digitale Bestellmöglichkeiten anbieten, vermarkten zudem auch andere Produktgruppen.

Tabelle 2: Übersicht der Internetauftritte der Top-10 Mischfutterhersteller Deutschlands

\begin{tabular}{|c|c|c|c|c|c|c|c|c|c|c|c|}
\hline Unternehmen & 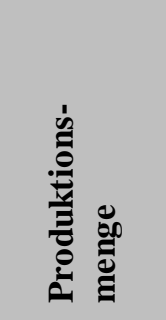 & 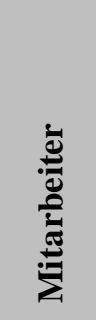 & 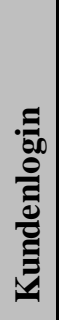 & 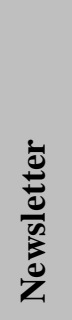 & 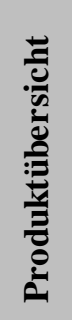 & 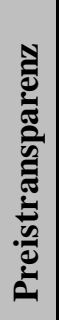 & $\frac{0}{\frac{2}{0}}$ & 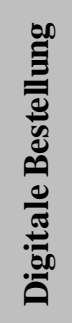 & 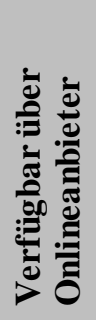 & 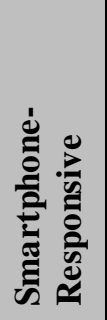 & : \\
\hline ForFarmers GmbH & 10 Mio. $t$ & 2700 & + & + & $(+)$ & - & - & $\mathrm{BF}$ & - & + & - \\
\hline Agravis Raiffeisen AG & 4,6 Mio. $\mathrm{t}$ & 6500 & + & + & $(+)$ & - & - & $\begin{array}{l}\mathrm{BA} \\
\mathrm{KP}\end{array}$ & - & + & + \\
\hline $\begin{array}{l}\text { Deutsche Tiernahrung } \\
\text { Cremer GmbH \& Co. } \\
\text { KG }\end{array}$ & 2,8 Mio.t & 700 & - & - & - & - & - & - & + & - & - \\
\hline $\begin{array}{l}\text { Hauptgenossenschaft } \\
\text { Nord AG }\end{array}$ & 1,9 Mio. $\mathrm{t}$ & 1400 & + & - & - & - & - & $\mathrm{KP}$ & + & + & + \\
\hline $\begin{array}{l}\text { Bröring Unternehmens- } \\
\text { gruppe }\end{array}$ & 1,6 Mio.t & 600 & + & - & $(+)$ & - & - & $\mathrm{BA}$ & - & + & $(+)$ \\
\hline $\begin{array}{l}\text { MEGA Tiernahrung } \\
\text { GmbH \& Co. KG }\end{array}$ & 1,2 Mio. $\mathrm{t}$ & 180 & - & - & - & - & - & - & - & + & - \\
\hline $\begin{array}{l}\text { Rothkötter } \\
\text { Unternehmensgruppe }\end{array}$ & 1 Mio. $\mathrm{t}$ & 3000 & + & - & - & - & - & $\begin{array}{l}\mathrm{BA} \\
\mathrm{KP}\end{array}$ & - & + & - \\
\hline ATR Landhandel & $800.000 \mathrm{t}$ & 800 & + & - & + & - & - & - & - & + & + \\
\hline GS Agri eG & $700.000 t$ & 380 & - & $(+)$ & - & - & - & $\mathrm{BA}$ & - & + & + \\
\hline $\begin{array}{l}\text { Fleming + Wedeln } \\
\text { GmbH und Co KG }\end{array}$ & $525.000 \mathrm{t}$ & 120 & - & - & - & - & - & $\begin{array}{l}\mathrm{BF} \\
\mathrm{BA}\end{array}$ & - & + & + \\
\hline
\end{tabular}

Quelle: Internetrecherche, eigene Darstellung, Stand März 2020, Legende: $+=$ vorhanden, - = nicht vorhanden,

$(+)=$ eingeschränkt vorhanden, $\mathrm{KP}=$ Kundenportal u.a. für Bestellungen, $\mathrm{BA}=\mathrm{Bestell}-\mathrm{APP}, \mathrm{BF}=$ digitales/online Bestellformular) 
Tabelle 3: Übersicht der Internetauftritte ausgewählter Misch- und Mineralfutterhersteller

\begin{tabular}{|c|c|c|c|c|c|c|c|c|c|c|}
\hline Unternehmen & 递 & 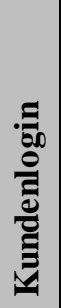 & 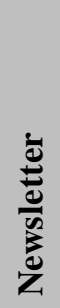 & 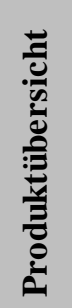 & 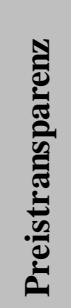 & 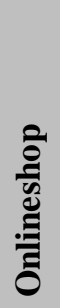 & 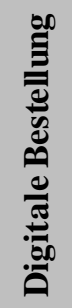 & 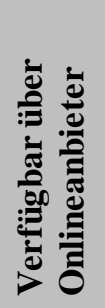 & 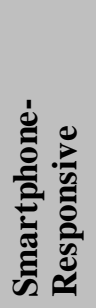 & \\
\hline agron $\mathrm{GmbH} \& \mathrm{Co} . \mathrm{KG}$ & Mittel & - & - & $(+)$ & - & - & - & - & + & + \\
\hline AHRHOFF GmbH & Klein & - & - & + & - & - & - & - & - & $(+)$ \\
\hline BayWa (Agrar) & Groß & + & + & + & + & + & - & + & + & + \\
\hline Bergophor & Groß & - & + & + & $(+)$ & + & - & + & + & + \\
\hline $\begin{array}{l}\text { BEWITAL } \\
\text { Unternehmensgruppe }\end{array}$ & Groß & - & + & ++ & $(+)$ & + & - & + & + & - \\
\hline $\begin{array}{l}\text { Blattin/PROFUMA } \\
\text { Spezialfutterwerke GmbH \& Co. } \\
\text { KG }\end{array}$ & Mittel & - & - & + & + & + & - & + & - & - \\
\hline DE HEUS Tierfutter & Groß & + & - & - & - & - & $\begin{array}{l}\mathrm{BA} \\
\mathrm{KP}\end{array}$ & - & + & - \\
\hline Denkavit Futtermittel GmbH & Mittel & - & - & + & - & - & - & - & + & - \\
\hline VILOFOSS Gruppe & Groß & - & - & + & - & - & - & + & + & + \\
\hline Diekgerdes Landhandel & Klein & - & - & - & - & - & - & - & + & + \\
\hline H. W. Schaumann GmbH & Mittel & - & - & + & - & - & - & - & + & + \\
\hline Hansa Landhandel & Mittel & + & + & $(+)$ & - & - & $\mathrm{KP}$ & - & + & + \\
\hline $\begin{array}{l}\text { HL HAMBURGER } \\
\text { LEISTUNGSFUTTER GmbH }\end{array}$ & Mittel & - & - & $(+)$ & - & - & - & + & - & - \\
\hline $\begin{array}{l}\text { HS-Kraftfutterwerk GmbH \& Co. } \\
\text { KG }\end{array}$ & Mittel & - & + & $(+)$ & - & - & $\mathrm{BF}$ & - & + & - \\
\hline Invaso $\mathrm{GmbH}$ & Mikro & + & + & ++ & + & + & - & + & + & $(+)$ \\
\hline Josera GmbH \& Co. KG & Groß & - & + & ++ & - & - & - & + & + & - \\
\hline LBD Damme e.G. & Mittel & + & - & $(+)$ & - & - & $\begin{array}{l}\mathrm{BA} \\
\mathrm{KP}\end{array}$ & - & + & + \\
\hline MaKiMa & Mikro & + & - & + & + & + & - & + & + & - \\
\hline Milkivit & Mittel & - & - & + & - & - & - & + & + & - \\
\hline Raiffeisen Waren GmbH & Groß & + & + & $(+)$ & - & - & - & - & + & + \\
\hline Rottmann Group GmbH & Klein & - & - & $(+)$ & - & - & - & - & + & + \\
\hline Royal Agrifirm Group & Groß & - & + & - & $(+)$ & - & - & - & + & - \\
\hline Salvana & Mittel & + & + & + & $(+)$ & + & - & $(+)$ & + & $(+)$ \\
\hline Sano & Groß & - & + & ++ & - & - & - & $(+)$ & + & - \\
\hline Schkade Landhandel GmbH & Klein & - & - & ++ & $(+)$ & + & - & + & + & + \\
\hline Trede und von Pein & Groß & - & - & - & - & - & - & - & + & + \\
\hline UNA HAKRA & Groß & - & - & + & - & - & $\mathrm{BF}$ & - & + & - \\
\hline Weissachmühle GmbH & Klein & - & - & - & - & - & - & + & - & - \\
\hline Wulfa Mast & Klein & - & - & $(+)$ & - & - & - & - & + & - \\
\hline $\begin{array}{l}\text { X. Scheule GmbH -Lexa } \\
\text { Tiernahrung }\end{array}$ & $\begin{array}{l}\text { Klein } \\
\text { Mittel } \\
\end{array}$ & + & + & + & $(+)$ & + & - & - & + & + \\
\hline
\end{tabular}

Quelle: Internetrecherche, eigene Darstellung, Stand März 2020, *angelehnt an die EU-Empfehlung 2003/361/EG, wobei hier nur die Mitarbeiterzahl betrachtet wurde, Legende: $+=$ vorhanden, $-=$ nicht vorhanden, $(+)=$ eingeschränkt vorhanden, $\mathrm{KP}=$ Kundenportal u.a. für Bestellungen, $\mathrm{BA}=$ Bestell-APP, $\mathrm{BF}=$ digitales/online Bestellformular 


\section{Ergebnisse der Experteninterviews}

\subsection{Stichprobenbeschreibung}

Die Stichprobe besteht aus acht ExpertInnen, die sieben deutsche Mischfutterhersteller repräsentieren. Details zur Person sind in Tabelle 4 einsehbar. Interviewt wurden VertreterInnen der Geschäftsführung, der Marketingleitung, des Produktmanagements oder Digitalisierungsbeauftragte. Die Interviews dauerten im Durchschnitt etwa eine Stunde. Zu den Befragten gehörten drei Männer und fünf Frauen mit einem Durchschnittsalter von 46,7 Jahren. Der älteste Befragte war 62 Jahre, die jüngste 27 Jahre alt. Die Betriebszugehörigkeit lag zwischen acht Monaten und 39 Jahren. Die Produktionsschwerpunkte der Unternehmen umfassen Mischfutter, Mineralfutter und Spezialprodukte. Drei der Unternehmen sind außerdem im Landhandel aktiv mit Sparten wie Düngemittel, Pflanzenschutz, Saatgut. Die befragten Unternehmen produzieren zwischen 10.000 und mehreren Mio. t Mischfutter jährlich und beschäftigen zwischen 45 und über 2.000 Mitarbeiter. Alle Unternehmen sind seit mehr als 45 Jahren etabliert; die ExpertInnen stehen daher für die Sichtweise des klassischen Futtermittelhandels.

Tabelle 4: Stichprobenbeschreibung

\begin{tabular}{|l|l|l|l|}
\hline Befragte(r) & Alter & Geschlecht & Interviewdauer \\
\hline 1 & 30 & W & 69 Minuten \\
\hline 2 & 60 & M & 36 Minuten \\
\hline 3 & 29 & M & 84 Minuten \\
\hline 4 & 31 & W & 66 Minuten \\
\hline 5 & 31 & W & 56 Minuten \\
\hline $6 \mathrm{a}$ & 57 & M & \multirow{2}{*}{ 2 Minuten } \\
\hline $6 \mathrm{~b}$ & 62 & W & 58 Minuten \\
\hline 7 & 27 & W & \\
\hline
\end{tabular}

\subsection{Vertriebsgestaltung und Relevanz der Digitalisierung}

Die Unternehmen bieten sowohl standardisierte Produkte als auch betriebsindividuelle Mischungen an, wovon letztere den Großteil ausmachen. Der Vertrieb ist in allen befragten Unternehmen ähnlich organisiert. Die von den Unternehmen eingesetzten Vertriebskanäle sind in Abbildung 1 dargestellt. Fast alle vertreiben ihre Produkte direkt über den Vertriebsinnenund außendienst an den Landwirt (Abbildung 1). Dabei erfolgt die Bestellung klassischerweise per Telefon, Fax und E-Mail sowie gelegentlich über WhatsApp. Die Zahlung erfolgt in der Regel auf Rechnung. Teilweise werden in sogenannten "Koppelgeschäften" auch Ernteerträge gegen Futtermittel eingetauscht. 


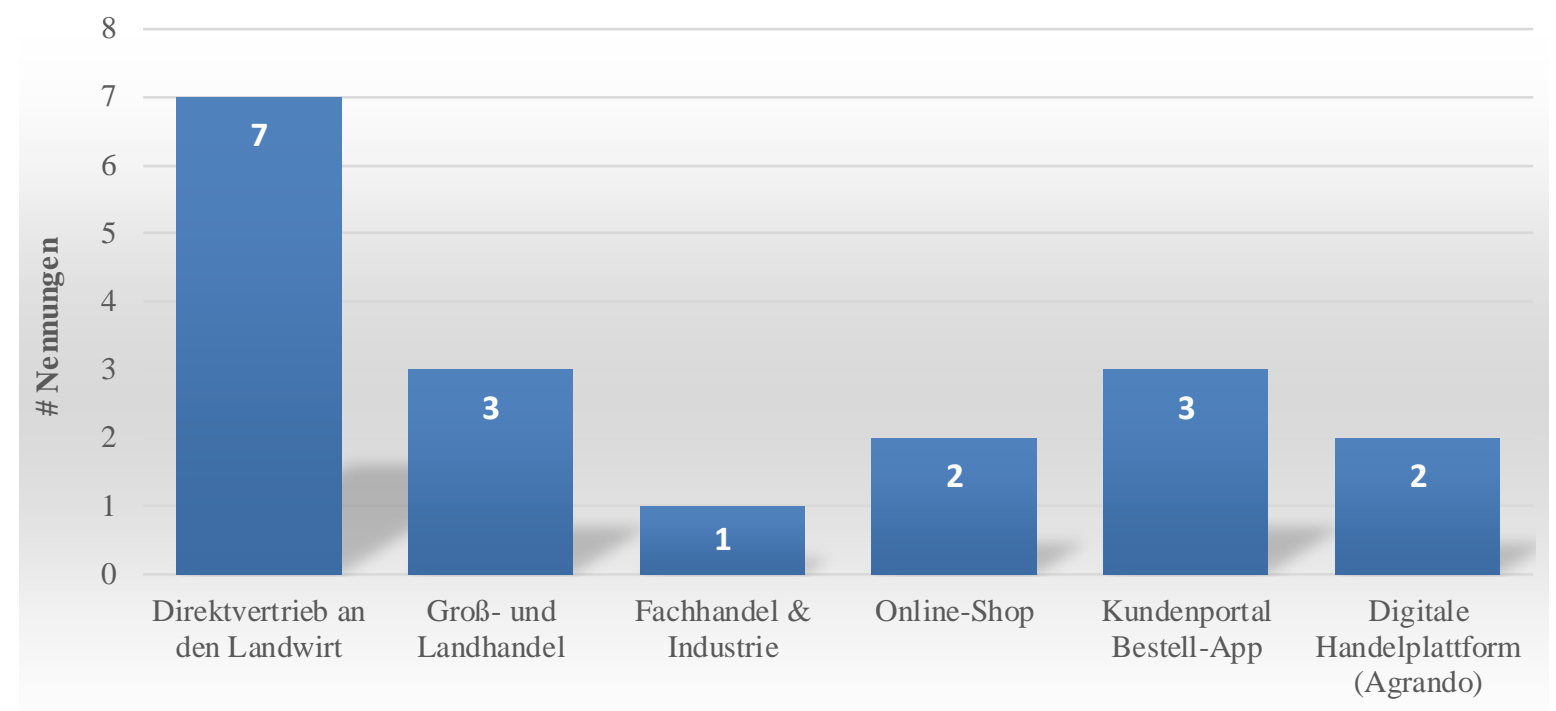

Abbildung 1: Genutzte Vertriebskanäle der befragten Unternehmen $(n=7)$

Quelle: Eigene Erhebung.

Zwei Unternehmen sind ausschließlich im Direktvertrieb tätig, während ein Unternehmen über Fachhandel und Industrie und drei Unternehmen indirekt über den Groß- und Landhandel verkaufen. Angebotene Bestellsysteme sind Bestell-Apps, Kundenportale und Onlineshops (Abbildung 1). Der Nutzung ist hier eine Registrierung beim Unternehmen vorgelagert. Kundenportale und Bestell-Apps werden von drei Unternehmen eingesetzt und dienen dazu, ausgehandelte Kontrakte online zu bestellen. Zusätzlich können darüber weitere Funktionen wie eine Kontraktübersicht und digitale Dokumente, z.B. Rechnungen, Lieferscheine, etc. abgerufen werden. Einen Onlineshop führen zwei Unternehmen seit zwei bzw. drei Jahren. In diesem wird nur ein Teil des Produktsortiments verkauft. Dazu zählen standardisierte Produkte wie Mineralfuttermittel, Milchaustauscher, Ergänzungs- und Spezialfuttermittel. Der Versand erfolgt mit Paketdiensten. Ein Unternehmen bietet die Produkte im Onlineshop über dem Händlerpreis an, um eine Konkurrenzsituation zu vermeiden. Digitale Bestellungen werden zum Teil nicht automatisch an das Warenwirtschaftssystem weitergeleitet, sondern zunächst manuell durch das Personal überprüft. Die Lieferzeiten bei Bestellungen über das Internet unterscheiden sich nicht von denen der telefonischen Bestellung. Zwei Unternehmen sind zusätzlich auf der digitalen Handelsplattform Agrando aktiv.

Insgesamt wurde der Wettbewerb von allen Befragten als sehr stark beschrieben und die Aktivitäten der Konkurrenz werden von den meisten genau beobachtet. Auch wenn es nur wenig neue Mitbewerberunternehmen gibt, ist der Markt auf Grund der Vielzahl von Anbietern sehr umkämpft und stark vom Preis getrieben, wodurch ein Verdrängungswettbewerb entsteht. 
„Es ist auf Deutsch "ein Käufermarkt".“(B2)

Um sich von der Konkurrenz abzusetzen, nutzen die herstellenden Unternehmen Alleinstellungsmerkmale wie Qualität, kundenindividuelle Mischungen, Spezialprodukte und Beratungen. Dies hat jedoch, wie ein Befragter anmerkte, nur wenig Erfolg.

„[...] die rühren alle in der gleichen Suppe.“ (B2)

Ihm zufolge sind sich die Produkte meist sehr ähnlich. Auch qualitative Unterschiede gibt es kaum, da ein gewisser Mindeststandard von der Kundschaft gefordert wird. Betriebsindividuelle Mischungen und Beratungen gehören zur Regel, wobei der Preis häufig das entscheidende Kriterium bleibt, denn auch die Händlertreue ist rückläufig. Futtermittel werden nicht mehr nur bei einem Händler eingekauft und auch feste Vertriebsgebiete gibt es nicht mehr.

„Der ganze Landhandel ist im Wechsel, das klassische Geschäft, dass man den Kunden hat, der einhundert Prozent seiner Betriebsmittel und das Futtermittel bei einem Landhändler kauft, die Zeiten sind ja schon lange vorbei.“(B1)

Die Kenntnisse über die Potenziale der Erschließung digitaler Vertriebswege sind zum Teil sehr gering. Ebenso gering beurteilen die meisten ExpertInnen den bisherigen Stand der Digitalisierung im Unternehmen und besonders im Vertrieb.

„[...] also ich würde sagen, dass alle Futtermittelfirmen noch in den Kinderschuhen stecken [...] im Bereich Digitalisierung.“(B5)

Es gibt jedoch Unterschiede. Größere Unternehmen und solche, die neben Futtermitteln noch andere Sortimente bedienen, waren in dieser Untersuchung meist stärker digitalisiert. Mit einer Ausnahme arbeiten alle Unternehmen kontinuierlich an einer Verbesserung der digitalen Entwicklung, denn allen ist die wachsende Bedeutung der Digitalisierung bewusst. Fünf Interviewte äußerten außerdem, dass eine digitale Transformation aufgrund von wirtschaftlichem Druck notwendig ist.

„Man kommt ja eigentlich an Digitalisierung nicht mehr vorbei.“(B5)

Für vier der Befragten haben digitale Technologien bereits eine hohe Bedeutung im Unternehmen, die anderen empfinden sie bislang als gering. Auf die Frage, wie lange sich die befragten Unternehmen schon mit der Thematik der Digitalisierung auseinandersetzen, merkten die Experten an, dass digitale Warenwirtschaftssysteme und Futterrationsberechnungs- 
programme schon seit Jahrzehnten eine Rolle spielen. Der E-Commerce beschäftigt sie besonders in den letzten fünf Jahren intensiver. Ihre Webseiten nutzen die befragten Unternehmen zur Darstellung des Unternehmens und des Leistungsangebots, als Informationsplattform für Aktuelles und Kontakte. Produkt- und Preisinformationen werden kaum präsentiert. Fast die Hälfte der Befragten sieht den Internetauftritt des Unternehmens allerdings als verbesserungswürdig an. Drei Unternehmen arbeiten an oder planen derzeit einen Umbau der Homepage und die Einführung eines Onlineshops oder Kundenportals.

Über Smartphone und Laptop verfügen inzwischen alle Außendienstmitarbeitende der befragten Unternehmen und öfter kommen auch Tablets im Kundenkontakt und zur Bestellaufnahme zum Einsatz. Es gibt auch AußendienstmitarbeiterInnen, die wenig digitale Anwendungen nutzen. Kundendaten werden von den Unternehmen zwar gesammelt, aber nur zwei nutzen diese systematisch in einem Customer-Relationship-Management-System(CRM). Die Qualität der Datenanalyse ist laut den Befragten abhängig von der Datenpflege durch die MitarbeiterInnen. Weiterbildungsangebote für digitale Technologien werden den MitarbeiterInnen vereinzelt angeboten. Werbung für die digitalen Angebote erfolgt z.T. über Rechnungen, Mailings, Newsletter, Fachmagazine, Facebook, Google AdWords und persönlich über den Außendienst. Hilfe bei der Nutzung der Kontraktabrufsysteme bieten Telefonhotlines, Nutzertutorials oder Übersichten in Papierform. Die Onlineshop-Systeme sind nach Ansicht der Befragten selbsterklärend. Feedback und Support werden größtenteils persönlich über den Außendienst oder am Telefon gegeben.

\subsection{Barrieren des Online-Vertriebs und digitaler Vertriebstools}

\subsubsection{Sektor- und Unternehmensspezifische Barrieren}

Drei der Interviewten sehen das Problem in den Strukturen der Unternehmen und damit in grundsätzlichen Herausforderungen des Change-Managements. Die Unternehmen arbeiten oftmals in über Jahrzehnten gewachsenen Systemen und sind sehr traditionell eingestellt. Veränderungen dauern lange und müssen schrittweise entwickelt werden.

„[...] oft ist es natürlich auch so, was ein gewachsenes System ist, kann man jetzt auch nicht von heute auf morgen mal eben umstricken. Also es ist ja auch immer ein langer Prozess.“(B5)

Ein Befragter wies auf den notwendigen Anstoß durch die Geschäftsführung hin, um die digitale Entwicklung zu fördern. Ein weiterer Aspekt, den sechs der Befragten erwähnten, sind die MitarbeiterInnen. In vielen Unternehmen liegt die Schwierigkeit bei der Einführung 
digitaler Neuerungen in der Akzeptanz der MitarbeiterInnen. Sie müssen vom Nutzen überzeugt werden und ein entsprechendes Change-Management ist notwendig. Drei ExpertInnenen hielten das Alter des Personals für relevant, vier konnten keinen bestimmten Einflussfaktor benennen und schlossen auf eine generelle Resistenz Veränderungen gegenüber.

„Menschen mögen einfach nicht so gerne Veränderungen, das ist nun mal einfach so. [...] Aber sobald alle Kolleginnen und Kollegen sich daran gewöhnt hatten oder haben, wäre es nicht mehr wegzudenken." (B1)

Problematisch sehen die ExpertInnen des Weiteren die durch den Onlinehandel entstehende Konkurrenzsituation mit den sonstigen Vertriebswegen. Dies betrifft vor allem den häufig auf Provisionsbasis arbeitenden Außendienst, kann aber auch für andere indirekte Vertriebswege eine Rolle spielen.

„Wenn ich einen zweiten Kanal aufbaue, klaue ich dem Fachberater ja Geschäft.“ (B6)

Auch der enge persönliche Kontakt und die Notwendigkeit der fachlichen Beratung schließen für den Großteil ein reines Onlinegeschäft aus. Das persönliche Gespräch spielt beim Verkauf von Futtermitteln in fast allen befragten Unternehmen noch immer eine sehr große Rolle und ist Aufgabe der Mitarbeiter.

„Also ich finde Digitalisierung gut in gewissem Maße oder Bereichen, aber trotzdem wird der persönliche Kontakt einfach immer das Wichtigste für uns bleiben.“(B5)

Eine weitere wichtige Barriere, die die ExpertInnen angesprochen haben, sind die Ressourcen im Unternehmen. Oft fehlt das Know-how im Unternehmen, insbesondere im Bereich IT. Drei Befragte nannten finanzielle Ressourcen und die Kosten des Onlineshops und digitaler Anwendungen als begrenzenden Faktor im Unternehmen. Dies ist einem Teilnehmenden zufolge vor allem in kleinen Unternehmen problematisch, da der Arbeitsaufwand und die Pflege eines Onlineshops enorm sind.

„Die Installation eines Onlineshops ist natürlich auch mit viel Arbeitsaufwand und Kosten im ersten Augenblick verbunden. Der Erfolg ist schwer kalkulierbar.“(B5)

Schwer ist laut der ExpertInnen auch die Auswahl der ,richtigen“ Anwendungen, die als langfristige Lösungen fungieren können. Mehreren erschien der Online-Vertrieb auf Grund der individuellen Bedingungen des Vertriebs von Futtermitteln als nicht zweckstiftend. Sie hielten eine Vereinfachung von anderen Prozessen durch digitale Technologien für sinnvoller. 
„[...] ein Futtermittelvertrieb, der läuft bei uns so individuell. [...] wir konzentrieren uns eher darauf, dass wir unsere Prozesse vereinfachen, allgemein im Unternehmen.“ (B3)

Auch die mit dem E-Commerce einhergehende Produkttransparenz war für viele Befragte ein Grund, der gegen die Einführung eines Onlineshops spricht. Zum einen, weil überwiegend kundenindividuelle Mischungen vertrieben werden, zum anderen aus Angst, dass Produkte von der Konkurrenz kopiert werden.

„Jeder zweite Landwirt hat eine eigene Mischung und das ist dann natürlich auch ein Stück weit nicht transparent bzw. nicht vergleichbar zu machen zu anderen Produkten von Mitbewerbern.“(B3)

Die meisten befragten Unternehmen stellen des Weiteren keine Preise online dar und sehen die Preistransparenz auf dem Onlinemarkt aufgrund des ohnehin schon starken Preiswettbewerbs als problematisch für den Sektor. Die Preise der Konkurrenz werden bereits jetzt stark beobachtet und wären online konstant einsehbar. Ein Experte wies im Zusammenhang mit der Transparenz darauf hin, dass diese für den Online-Vertrieb notwendig ist, da das Interesse neuer Kunden nur geweckt werden kann, wenn Leistungen und Produkte mit allen erforderlichen Merkmalen online präsentiert werden.

Weitere Barrieren, die immerhin fünf der Befragten erwähnten, sind die Logistik und die hohen Abnahmemengen. Mischfutter wird größtenteils als Schüttgut verkauft und große Mengen sind nicht für den Postversand geeignet. Eine funktionierende Logistik wird benötigt. Probleme betreffen dabei vor allem Auslastung und Zielort sowie die bei langen Transportwegen steigenden Lieferkosten.

„[...] Herausforderungen im Futtermittelbereich sehe ich vor allem in der Logistik. [...] größere Mengen, drei, vier Tonnen, dann fahre ich mit Silozügen und die muss ich ja auch vollkriegen. [...] eine Bestellung habe ich jetzt zum Beispiel an dem Tag [...] aus Norddeutschland und meine andere ist aus Süddeutschland [...] Und dann fahre ich immer nur Kleinstmengen und kriege die Lkws nicht voll, dann kann ich die Preise nicht halten.“(B3)

Auch die gesellschaftlicheEntwicklung im Bereich der Landwirtschaft und Tierhaltung, sowie neue Umweltauflagen, Tierschutzaktivitäten oder andere gesetzliche Novellierungen stellen weitere, zukünftige Risiken dar. Ebenso führen die abnehmende Zahl an Mischfutterherstellern, landwirtschaftlichen Betrieben und sinkende Tierbestände zu einer weiteren Konzentration des Marktes und verstärktem Wettbewerb. 


\subsubsection{Produktspezifische Barrieren}

Produktspezifische Barrieren sind laut der ExpertInnen vor allem die Art der Produkte, also ob standardisierte oder individuelle Futtermittel verkauft werden. Fast alle Befragten halten eine persönliche Beratung bei der Produktauswahl für notwendig und sehen deshalb geringe Chancen im Onlinehandel. Zum einen, weil kundenindividuelle Mischungen angeboten werden, die auf die Bedürfnisse der Betriebe abgestimmt sind. Zum anderen, weil die Produkte sehr erklärungsbedürftig sind und das Produktsortiment so umfangreich ist, dass die KundInnen mit der Auswahl überfordert sein könnten. Den Befragten ist es besonders wichtig, auf die individuellen Bedürfnisse der Kundschaft einzugehen.

„Wir arbeiten gerne mit betriebsindividuellen Lösungen. Weil in der Regel ist kein Betrieb wie der andere. Und es kann natürlich mal gut laufen mit dem gleichen Konzept, es kann aber auch völlig in die Hose gehen und deswegen setzten wir da eigentlich schon auf betriebsindividuelle Beratung." (B5)

Dies sind auch die Gründe, warum Produktdetails nicht online dargestellt werden. Auch die Darstellung von standardisierten Produkten wurde von einem Experten aufgrund des sehr großen Produktsortiments als zu aufwändig empfunden. Eine positive Entwicklung für den Online-Vertrieb sehen die Befragten vor allem für standardisierte Produkte wie bspw. Mineralfutter und Einzelfuttermittel, die anhand gewisser Parameter verglichen werden können und bei denen die Kundin, der Kunde „weiß, was ihn erwartet“. Weiterhin hielten sie nur Sackware und kleine Mengen als online vermarktungsfähig, da diese über Paketdienste versendet werden können.

Eine weitere Besonderheit des Futtermittelsektors liegt den ExpertInnen zufolge darin, dass die Preisbildung von einer Vielzahl von Faktoren abhängt. Sie variiert abhängig von Rohstoffpreisen und der Produktzusammensetzung bei individuellen Mischungen. Oft handelt es sich auch um Tagespreise, die immer wieder neu kalkuliert werden. Des Weiteren wird das Preisniveau von kundenspezifischen Faktoren bestimmt und unterscheidet sich häufig von Kunde zu Kunde, weshalb kein Festpreis gesetzt werden kann. $\mathrm{Zu}$ diesen Faktoren gehören Abnahmemenge, Frachtkosten, Dauer der Geschäftsbeziehung, Zahlungsfähigkeit, Verhandlungsposition der KundInnen etc.

„Preise können wir nicht veröffentlichen, weil wir das Problem haben, dass fast alle Kunden unterschiedliche Preise haben. Das wäre Selbstmord.“(B2) 


\subsubsection{Kundenspezifische Barrieren}

Den Befragten zufolge spielt der persönliche Kontakt und die Kundenbindung eine wichtige Rolle beim Futtermitteleinkauf. Der Know-how-Austausch und die gebotene Serviceleistung werden vom KundInnen geschätzt und können online in dieser Art und Weise nicht geboten werden. Im konventionellen Geschäft steht ihnen immer ein(e) AnsprechpartnerIn zur Verfügung, der vor allem bei Problemen Verantwortung übernehmen kann. Drei Interviewte hielten vor allem Vertrauen beim Kaufprozess für wichtig.

„Er hat einen Ansprechpartner. Er kann jederzeit anrufen, wenn irgendwas mit seiner Lieferung nicht passt, er kann, wenn es mal geldlich eng wird, mit ihm sprechen über irgendwelche Finanzierungsmodelle und, und, und.“ (B1)

Bedenken hinsichtlich der Sicherheits- und Privatsphäre schlossen die meisten Befragten als Grund gegen einen Onlineshop aus, da für alle die Vorgaben der Datenschutzverordnung gelten. Als Barriere nannten die Teilnehmenden hingegen die Unsicherheit der KundInnen bei Bestellungen über das Internet. Diese betraf auf der einen Seite die Unsicherheit über Inhaltsstoffe und Produktqualität bei anonymen Onlinehändlern. Sie halten Vorerfahrungen mit dem Unternehmen für notwendig.

„[...] da ist glaub ich auch jeder Landwirt [...] irgendwie vorsichtig dann irgendwas

[...] online zu bestellen, wenn er nicht genau weiß, was drinne ist, wenn das unbekannte Produkte sind.“(B1)

Auf der anderen Seite wurde eine Unsicherheit bezüglich der Zuverlässigkeit der Lieferung und der Verfügbarkeit der Produkte als problematisch für den Online-Vertrieb eingestuft.

,[...] im Futtermittelbereich sind die [...] Kunden skeptisch, weil da stehen ja auch ihre Tiere hinter. Also funktioniert das? Wird die Bestellung übermittelt? Kommt es an? [...] Wenn ich heute meinen Vertriebler anrufe, dann weiß ich, mit dem hat das schon zehn Jahre geklappt, das wird auch morgen noch klappen. Und dann ist da [...] die Hemmschwelle vielleicht so ein bisschen da.“ (B3)

„[...] bisher hat es funktioniert, warum soll ich irgendwo etwas verändern, weil ich mir unsicher bin [...] krieg ich die Ware wirklich beim ersten Mal? [...] weil da ja wirklich lebende Organismen dahinterstecken, die das Futter dann auch brauchen. [...] ich kann zwei Tage zu spät säen, aber wenn mein Schweinefutter zu spät kommt, meine Schweine kriegen zwei Tage kein Futter, dann ist es schon problematisch.“(B3)

Ein Befragter nannte auch die Anwenderfreundlichkeit als Einflussfaktor. Ist das System zu kompliziert, bleiben die KundInnen beim herkömmlichen Weg. 
„Und natürlich der Shop, dass ist das A und O. Der muss einfach sein [...]“(B3)

Auch die Zahlungsmöglichkeiten sind von Bedeutung, da der Produktwert bei großen Mengen steigt. Große Beträge einem anonymen Onlinehändler in Vorkasse zu zahlen, hielten die ExpertInnen für sehr risikoreich.

„[...] einiges an Volumen, was bewegt wird, und auch an Euro [...], da sind Kunden doch noch vorsichtig, mit unbekannten Marktteilnehmern Geschäfte zu machen.“(B1)

„[...], wenn ich bei Amazon klicke und sage ich will jetzt einen Strohhut haben, das ist ja ganz was anderes, das kann ich so machen. Aber ich kann nicht tausend Tonnen Futter online kaufen, weil doch die Information, die dahintersteckt, ein bisschen vielfältiger ist." (B2)

Generell glauben einige Befragte, dass jüngere KundInnen dem Onlinehandel aufgeschlossener gegenüberstehen. Zwei der ExpertInnen konnten jedoch keinen Zusammenhang zwischen der Nutzung der Onlineshops und Onlineportale und dem Alter oder der betrieblicher Faktoren feststellen.

„[...] älteren Kundschaft hätte ich jetzt [...] gesagt, sind [...] eher ihrem Landhändler vor Ort treu, weil sie auch Wert darauflegen, auf das Gespräch mit dem Vertriebsmitarbeiter und so ein bisschen immer noch das Geschäft Auge in Auge gemacht wird.“(B4)
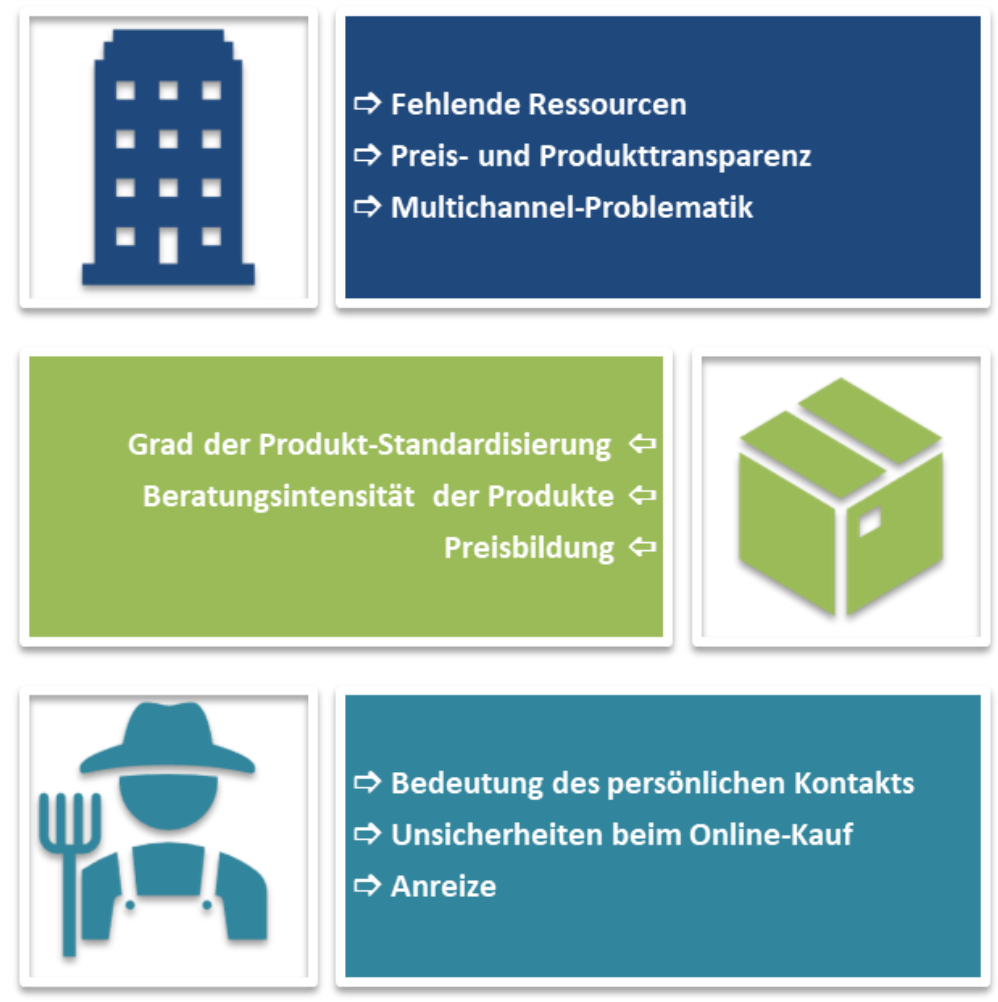

Abbildung 2: Übersicht der Hauptbarrieren des Onlinehandels im Futtermittelsektor Quelle: Eigene Darstellung 
Abbildung 2 fasst die Barrieren des Onlinehandels im Futtermittelsektor zusammen und listet die drei relevantesten unternehmens- und sektorspezifischsten sowie produkt- und kundenspezifischsten Barrieren auf. Fehlende Ressourcen im Unternehmen lassen sich als eine zentrale Barriere des Onlinehandels bestimmen. Dabei handelt es sich neben finanziellen Ressourcen auch um Humankapital, welches den digitalen Transformationsprozess zum einen technisch betreut und zum anderen aktiv in die Arbeitsprozesse integriert. Der Zuspruch für digitale Veränderungen durch MitarbeiterInnen und das Management fällt vielfach sehr gering aus. Zusätzlich fürchten Unternehmen den Wettbewerbsdruck der Branche durch die mit dem Online-Handel einhergehende Preis- und Produkttransparenz zusätzlich anzukurbeln. Auch die Multichannel-Strategie führt $\mathrm{zu}$ Problemen. So sehen HandelspartnerInnen oder Vertriebsmitarbeitende ihre Arbeit durch den Onlinehandel bedroht. Auf der Produktebene ist vor allem relevant, wie standardisiert bzw. individualisiert ein Produkt ist und welcher Beratungsbedarf hierfür besteht. Gerade bei großen Mengen oder Individualprodukten spielt der Preis eine entscheidende Rolle.

Der Wunsch der landwirtschaftlichen Kundschaft nach einem persönlichen Beratungs- oder Verkaufskontakt, die zum Teil noch vorherrschenden Unsicherheiten beim Online-Kauf und die zum Teil fehlenden Anreizsysteme im Internet zählen zu den Hemmfaktoren des OnlineFuttermittelhandels.

Insgesamt sehen die befragten Experten eine positive Entwicklung für die Digitalisierung des Sektors. Der persönliche Kontakt und die Beratung in der Agrarbranche werden laut den ExpertInnen aber nicht aufgegeben, könnten sich in Zukunft jedoch weiter verändern bzw. abnehmen. So wird mit einer verstärkten Kundennachfrage für digitale Optionen wie Shops und Portale gerechnet, wodurch die Digitalisierung des Vertriebs in den nächsten Jahren weiter an Bedeutung gewinnen wird. Um zukünftig wettbewerbsfähig zu bleiben, wird ein vermehrtes Aufkommen von Kontraktabrufsystemen und Onlineportalen erwartet.

„Es wird definitiv mehr Onlinesysteme geben und nur wer auch solche Systeme anbietet, kann zukünftig im Wettbewerb bestehen.“(B4) 


\section{Diskussion, Handlungsempfehlungen und Fazit}

In der vorliegenden Untersuchung wurden mit Hilfe einer Internetrecherche und Experteninterviews der Stand der Digitalisierung in Unternehmen des deutschen Futtermittelsektors sowie Barrieren des Online-Vertriebs untersucht.

Zunächst ist anzumerken, dass die Ergebnisse wegen des qualitativen Forschungscharakters nicht als repräsentativ einzustufen sind. Sie liefern aber aufgrund der Heterogenität der befragten Unternehmen einen breiten Einblick in den Futtermittelsektor und bieten Ansatzpunkte für die Gestaltung digitaler Vertriebsstrategien und für die weitere Forschung.

Der Stand der Digitalisierung in den sieben befragten Unternehmen des Futtermittelsektors weist große Unterschiede auf und ist bei den meisten Unternehmen noch nicht weit fortgeschritten. Dies betrifft vor allem den Vertrieb. Digitale Vertriebswege werden bisher nur selten angeboten. Ursachen hierfür sind den ExpertInnen zufolge die häufig traditionelle Struktur und eine geringe Adaptionsgeschwindigkeit der Unternehmen. Dies entspricht den Ergebnissen von Leroux et al. (2001), Herdon et al. (2006) und Hooker et al. (2001), welche die traditionellen Strukturen des landwirtschaftlichen Sektors und die konservative Einstellung der Branche für die zögerliche Übernahme der Technologie verantwortlich machen. Auch die von Elste (2016) angesprochene Akzeptanz der MitarbeiterInnen und deren Einfluss auf den digitalen Fortschritt, kann durch die ExpertInnen bestätigt werden. Die Digitalisierung verändert Arbeitsabläufe. Dies erzeugt bei den Beschäftigten häufig Unmut, was dazu führt, dass sie die Nutzung verweigern und so den Fortschritt blockieren (Dengler und Matthes, 2018). Es ist daher notwendig, sie vom Mehrwert digitaler Technologien zu überzeugen. Die Akzeptanz von VertriebsmitarbeiterInnen verstärkt sich, wenn sie der Überzeugung sind, mit Hilfe der neuen Technologien ihre eigene Leistung steigern zu können. Auch die Affinität $\mathrm{zu}$ digitalen Anwendungen und das notwendige Training spielen eine Rolle (Elste, 2016; Schillewaert et al., 2005). Ein entsprechendes Change-Management sowie die Aus- und Weiterbildung der MitarbeiterInnen können demnach helfen, ihre Akzeptanz zu steigern (Nds. MW, 2018; Schwartz, 2017). Diese Instrumente kommen jedoch bislang nur selten zum Einsatz. Ein Befragter bestätigte außerdem, dass auch der Anstoß durch die Geschäftsführung fehlt. Diese Faktoren verhindern die Digitalisierung des Vertriebs und die Einführung eines Onlineshops zwar langfristig nicht, können aber den Entwicklungsprozess stark verlangsamen. In dem durch den Außendienst und zum Teil auch durch den indirekten Vertrieb an den Handel geprägten Futtermittelsektor (Zimmermann, 2003) wirken beim Eintritt neuer digitaler 
Absatzwege sogenannte Kannibalisierungseffekte. AußendienstmitarbeiterInnen und der Landhandel fürchten durch digitale Kanäle wie Bestell-Apps oder Onlineshops ersetzt zu werden, wodurch ihre Akzeptanz von digitalen Lösungen sinkt (Böing, 2001). Hinzu kommt, dass der Außendienst meist auf Provisionsbasis arbeitet, wodurch Kannibalisierungseffekte direkte Verdiensteinbußen zur Folge haben können (Böing, 2001; Niehaus und Emrich, 2016). Dass sich diese MitarbeiterInnen gegen einen Onlineshop aussprechen, scheint berechtigt. Die mögliche Entlastung wird dabei jedoch außer Acht gelassen. So würde bspw. ein Onlinebestellsystem KundInnen, die bereits wissen, welches Produkt sie kaufen möchten, und AbnehmerInnen von kleinen Mengen die Möglichkeit bieten, diese direkt zu erwerben (Voss, 2008). Außen- und Innendienst könnten so entlastet werden. Die freiwerdenden Kapazitäten könnten genutzt werden, um sich z.B. auf Key-Account-Kunden oder die Neukundenakquise zu konzentrieren (Biesel und Hame, 2018).

In einer solchen Struktur sollte das Entlohnungssystem des Außendienstes überdacht werden und von einem provisionsbasierten auf ein festes Gehalt umgestellt werden. Alternativ würde sich auch ein Provisionsanteil an Onlinebestellungen durch Stammkunden aus dem Vertriebsgebiet der jeweiligen MitarbeiterInnen anbieten. Hierfür ist es allerdings notwendig, den Kanalmix durchlässig zu gestalten bzw. den Omnichannel-Ansatz zu implementieren (Verhoef et al., 2015). Die verschiedenen Vertriebskanäle verschmelzen demnach miteinander und agieren gemeinsam im Sinne der Kundschaft. Das heißt, Angebote, Leistungen und vor allem Preise müssen über alle Vertriebskanäle einheitlich angeboten werden (Niehaus und Emrich, 2016; Schulze Schwering und Spiller, 2018). Die Kundschaft soll ,aus einer Hand über mehrere Kanäle“ bedient werden. Dazu müssen Kundendaten aus allen Vertriebswegen zentralisiert und für alle Mitarbeiter zugänglich gemacht werden (Schulze Schwering und Spiller, 2018). Hier bestehen bei den befragten Unternehmen Schwierigkeiten, da Kundendaten zwar gesammelt, aber nur von wenigen effektiv genutzt werden. Auch Voss (2008) stellte fest, dass die landwirtschaftliche Vorleistungsindustrie aufgrund mangelnder personeller und finanzieller Ressourcen, IT-Kenntnissen und fehlender Strategien zur Implementierung, CRMSysteme nur selten erfolgreich nutzt.

Die beschriebene Konkurrenzsituation mit einem Onlineshop betrifft auch den Handel (Akridge, 2003). Eins der befragten Unternehmen reagiert darauf, indem es die online angebotenen Produkte preislich über denen des Handels ansetzt. Dies erscheint als eine gute Möglichkeit, die Konkurrenz zu minimieren, stellt aber das Vorhandensein des eigenen Shops in Frage. Eine sinnvollere Möglichkeit ist auch hier eine kanalübergreifende Preisstrategie, 
wodurch KundInnen Ihre Geschäftspartner unabhängig vom Preis wählen können (Niehaus und Emrich, 2016). Vertriebspartner durch einen Onlineshop auszuschalten, empfiehlt sich nicht, da eine Mehrkanalstrategie dabei hilft, verschiedene Kundensegmente mit unterschiedlichen Bedürfnissen zu erreichen und Absatzzahlen zu steigern (Voss, 2008). Zudem gilt der Preis als ein wesentlicher Anreiz für Internetkäufe (Batte und Ernst, 2007; Fecke et al., 2018a, 2018b).

Die persönliche Beratung und der enge Kontakt mit der landwirtschaftlichen Kundschaft wird von den ExpertInnen für das Unternehmen selbst, die zu vertreibenden Produkte und auch für die KundInnen als notwendig erachtet. Das Unternehmen nutzt sie, um den KundInnen einen Mehrwert zu bieten und in Zeiten des verstärkten Preiswettbewerbs durch besondere Betreuung langfristige Geschäftsbeziehungen $\mathrm{zu}$ fördern und der rückläufigen Kundenbindung entgegenzuwirken (DVT, 2018). Zudem erfordern die stark individualisierten Produkte sowie die zusätzlichen ganzheitlichen Betreuungskonzepte, die neben der Fütterung auch Aspekte wie Hygiene, Lüftung oder Herdenmanagement enthalten, einen intensiven persönlichen Kontakt. Damit wird die von Leroux et al. (2001) festgestellte hohe Bedeutung des engen persönlichen Kontakts in landwirtschaftlichen Geschäftsbeziehungen bestätigt. Solche Beziehungen über das Internet aufzubauen, halten sie, ebenso wie Ivanic et al. (2001) und Henderson et al. (2006), für schwierig, weshalb einige Studien empfehlen, vor allem standardisierte Produkte über Onlinekanäle zu vermarkten (Batte und Ernst, 2007; Doluschitz, 2002; Schulze Schwering und Spiller, 2018). Autoren wie Hosoi (2000) argumentieren hingegen, dass digitale Technologien die Kommunikation mit den KundInnen sogar erleichtern. Dafür spricht z.B. auch, dass durch das Internet viel mehr Kontaktpunkte mit der Kundschaft entstehen, die ihn leichter erreichbar machen und auch das strategische Sammeln von Daten vereinfachen (Elste, 2016; Große Holtforth, 2017; Lässig et al., 2015; Weihofen, 2004). Diese könnten die Unternehmen noch stärker und strategischer nutzen, indem sie bspw. ihre Homepage, soziale Medien und andere Foren gezielter zur Kundenakquise, Steigerung des Bekanntheitsgrades und Kontaktaufnahme einsetzen (Hooker et al., 2001).

Die Beratung könnte auch in Form von Onlineberatungen über Chats oder Videokonferenzen erfolgen. Diese könnten ebenfalls für die Durchführung der im Sektor üblichen Preisverhandlungen genutzt werden. Live Chats werden bereits von einigen Anbietern angeboten (ag.supply, agrar2b). Eine andere Möglichkeit, die in Zukunft relevant werden könnte, umfasst das Robotic Process Automation (RPA). Implementiert wird es durch einen Software-Roboter, der die menschliche Arbeit nachahmt (Asatiani und Penttinen, 2016; Monga, 2015). Ein Beispiel ist ein Robo-Advisor, bei dem mit Hilfe eines Algorithmus nach 
der Eingabe bestimmter Kriterien individuelle Empfehlungen oder Angebote erstellt werden können (Brenner und Meyll, 2020). Dies wird bereits im Finanzsektor verwendet, um die Buchhaltung oder Kunden bei der Auswahl zu unterstützen und zu beraten (Brenner und Meyll, 2020; Jung et al., 2018; Monga, 2015).

Aus der Perspektive der Kundschaft, schafft der persönliche Kontakt Vertrauen und Sicherheit, was mit der Anonymität des Onlinehandels nur unter größeren Anstrengungen geschaffen werden kann (Mueller, 2001). Dies betrifft auch die erwähnte Unsicherheit der KundInnen über die Zuverlässigkeit der Lieferung. Daher ist es umso wichtiger, dass die Unternehmen digital Vertrauen schaffen. Dazu können Qualitätszertifizierungen, aber auch Produktgarantien oder Systeme zur Rückverfolgbarkeit genutzt werden (Deiters et al., 2011). Als Gütesiegel bietet sich bspw. der neue Zertifizierungsstandard "DLG Trusted AgriTrade" an, der speziell für den Online-Vertrieb von Betriebsmitteln entwickelt wurde (DLG Test Service GmbH, 2019). Sicherheit beim Online-Futtermittelkauf kann auch das spezielle "DLG-Futtermittel-Zertifikat" bieten, welches gerade im Rahmen eines Pilotprojekts auf der Handelsplattform Agrando getestet wird (Lutilsky, 2020). LandwirtInnen können hier nun gezielt nach DLG zertifizierten Futtermitteln suchen. Es bleibt jedoch abzuwarten, inwieweit ein solches Siegel den Absatz ankurbeln kann. Einer Studie zufolge ist das Vertrauen der LandwirtInnen in ein Gütesiegel wie das der DLG größer als in ein staatliches Gütesiegel und wirkt sich entsprechend positiv auf den Online-Einkauf aus (Fecke et al., 2018b). Die Autoren empfehlen Unternehmen daher die Implementierung eines Gütesiegels, um das Vertrauen der landwirtschaftlichen Kunden zu gewinnen.

Möglichkeiten, um die Sicherheit über den Bestellverlauf bereitzustellen, bieten z.B. Eingangsbestätigungen per E-Mail bei empfangener Bestellung, Kopplung der Bestellung an eine(n) feste(n) MitarbeiterIn und Versandinformationen wie Trackingsysteme für Pakete oder auch LKWs, um den KundInnen immer über den Status seiner Bestellung zu informieren, wie es bspw. auf Amazon üblich ist. Damit würde gleichzeitig das von den ExpertInnenen angesprochene Risiko des beim Futtermittelkauf oftmals entstehenden hohen Warenwertes und der online meist geforderten Vorauszahlung gesenkt werden. Insgesamt bleiben jedoch gerade die logistischen Herausforderungen, insbesondere für KMUs ohne angegliederte Spedition, eine zentrale Barriere des Online-Vertriebes.

Eine weitere große Barriere, die alle Befragten ansprachen, ist die Rolle der Preis- und Produkttransparenz. Für die Unternehmen steigern diese den ohnehin schon scharfen Wettbewerb, weshalb sie eine Transparenz größtenteils ablehnen. Für die Abwicklung von 
Futtermitteltransaktionen spielt neben den meist individuellen Produkten und Preisen auch die Zahlungsart und die Möglichkeit von Kopplungsgeschäften eine Rolle und bindet viele LandwirtInnen an den Handel vor Ort. Online könnte dies innerhalb von Kundenportalen ermöglicht werden, in dem bspw. Produkte und Preise nach bestimmten Kriterien automatisch vom System kundenindividuell berechnet werden. Dies ist mit Hilfe von ERP-Systemen (Enterprise-Resource-Planning) bereits möglich (Meier und Stormer, 2012), erfordert jedoch festgelegte Produkt- und Preiskriterien sowie umfangreiche Kundendaten. So könnten Produkte bspw. auch ohne Preis im Shop angeboten werden und eine automatische Gestaltung des Preises nach Auswertung kundenspezifischer Kriterien erfolgen. Gekoppelt an digitale Futterberechnungen oder Farmmanagement-Systeme könnten sich auch kundenindividuelle Produkte anbieten lassen. Damit wäre die Problematik transparenter Preise reduziert. Fraglich ist jedoch, ob der Nutzen die Implementierungskosten übersteigen wird. Ferner wird argumentiert, dass die große Produktvielfalt vieler Betriebsmittelfirmen online schwer darzustellen ist und zu einer Überforderung der KundInnen führt. Möglichkeiten zur Behebung dieses Problems bieten Einteilungen des Sortiments in Futterkategorien, Anwendungszweck etc., um den KundInnen die Auswahl zu erleichtern. Darüber hinaus bieten bereits einige Unternehmen sogenannte Produktfinder an. Hier können die KundInnen die entscheidenden Parameter ihrer gewünschten Produkte eingeben und erhalten eine Übersicht der für sie passenden Produkte. Solche Optionen kommen vereinzelt im Nutzierbereich zum Einsatz (BEWITALagri, Joseraagrar), gehören aber bspw. im Onlinemarkt für Pferde-/oder Heimtierfutter bereits zur Regel (vgl. marstall.de, futtershop24.com).

Zur Umsetzung dieser Maßnahmen sind vor allem finanzielle Mittel notwendig und verdeutlichen an dieser Stelle die Bedeutung einer der wichtigsten Barrieren für den OnlineVertrieb des Futtermittelsektors: Die Ressourcen. Diese wurden nicht nur von den Experten bestätigt, sondern sind bereits durch eine Vielzahl von Studien als große Herausforderung der Digitalisierung und deren Umsetzung belegt (Doluschitz und Pape, 2002; Doluschitz, 2002; Ehmke et al., 2001; Hooker et al., 2001; Meuser und Nagel, 2009; Nds. MW, 2018). Fehlendes Know-how und mangelnde finanzielle Ressourcen erschweren die Investition in einen Onlineshop oder andere digitale Vertriebstools. Dabei gibt es bereits Programme, wie das go-digital-Programm des Bundesministeriums für Wirtschaft und Energie, das kleine und mittlere Unternehmen bei der digitalen Transformation unterstützt (BMWi, 2020).

Eine Herausforderung, der sich Unternehmen im Rahmen von Investitionen in digitale Anwendungen letztlich stellen müssen, ist aus der Vielfalt der Möglichkeiten ein geeignetes 
System zu wählen, denn es gibt keine Musterlösung (Handschuh und Gebhardt, 2016; Niehaus und Emrich, 2016). Das Risiko einer Investition scheint daher für die meisten derzeit noch zu hoch. Mögliche erste Schritte wären, standardisierte Produkte über digitale Agrarhandelsplattformen anzubieten, diese stellen eine günstige Alternative zum eigenen Onlineshop dar und helfen die Nachfrageentwicklung einzuschätzen. Für individualisierte Produkte scheinen Kontraktabrufsysteme in Onlineportalen bzw. Apps geeigneter zu sein. So können die Vertriebsstrukturen schrittweise digitalisiert und gleichzeitig schon die Vorteile der automatisierten Bestellung unabhängig von Geschäftszeiten genutzt werden (Clasen, 2018). Gerade in Zeiten der aktuellen Corona-Krise, in der soziale Kontakte auf ein notwendiges Minimum reduziert werden müssen, sind Unternehmen aufgefordert, zunehmend digital zu arbeiten. Plötzlich müssen viele Prozesse digital über Homeoffice, Videokonferenzen und Webinare ablaufen. Die Corona-Krise kann daher auch als Chance gesehen werden, um bisher digital-zurückhaltende Unternehmen in den Zukunftsmodus zu puschen. Die gestiegene Bereitschaft der MitarbeiterInnen und KundInnen zu Change-Management-Prozessen könnte für zukünftige digitale Neuerungen genutzt werden. Außendienstbesprechungen oder auch Kundenberatungen könnten auch in Zukunft zu einem gewissen Anteil online durchgeführt werden und $\mathrm{zu}$ einem festen Bestandteil der Vertriebsstrategie gemacht werden, um so langfristig zur Arbeitsoptimierung beizutragen (Agrobrain, 2020).

Literatur und ExpertInnen weisen darauf hin, dass sich digitale Investitionen meist nur langsam rentieren (Heinemann, 2018), weil die Nutzung digitaler Dienste bisher sehr gering ausfällt. Neben Werbung und der Verbesserung der Anwenderfreundlichkeit kann auch die durch den Generationenwechsel auf den Betrieben prognostizierte gesteigerte digitale Aktivität der landwirtschaftlichen KundInnen zu einem Umdenken und somit zu einer intensiveren Nutzung digitaler Vertriebskanäle führen.

Insgesamt wird die Futtermittelbranche, angesichts der zu erwartenden steigenden Nachfrage nach digitalen Angeboten und einer zunehmenden Veränderungsbereitschaft aller Akteure, ihre digitalen Bemühungen ausweiten müssen. Dabei ist es wichtig rechtzeitig zu reagieren, um wettbewerbsfähig zu bleiben, denn einen wirtschaftlichen Druck verspüren die Unternehmen des Sektors den Experten zufolge bereits jetzt (Köllinger, 2004). Für die Ausarbeitung weiterer Handlungsempfehlungen empfiehlt sich eine vertiefende quantitative Untersuchung auf der Grundlage der vorliegenden Ergebnisse. 


\section{Literatur}

Ackermann, S., Adams, I., Gindele, N. und Doluschitz, R. (2018). Die Nutzung von E-Commerce bei der Beschaffung landwirtschaftlicher Betriebsmittel. Landtechnik 73(1): 10-19. doi: 10.15150/LT.2018.3177

AgrarOnline GmbH (2020). myAGRAR Onlineshop. https://www.myagrar.de/. (27.03.2020).

Agrobrain (2020). Corona - Virus und Digitalisierungsbeschleuniger? Agrobrain. https://www.agrobrain.de/news/academy/corona-virus-und-digitalisierungsbeschleuniger. (27.03.2020).

Akridge, J.T. (2003). E-business in the agricultural input industries. Review of Agricultural Economics 25(1): 3-13. doi: $10.2307 / 1349859$

Asatiani, A. und Penttinen, E. (2016). Turning robotic process automation into commercial successCase OpusCapita. Journal of Information Technology Teaching Cases 6(2): 67-74. doi: $10.1057 /$ jittc. 2016.5

Bandow, G. und Holzmüller, N. (2010). „Das ist gar kein Modell!“. Unterschiedliche Modelle und Modellierungen in Betriebswirtschaftslehre und Ingenieurwissenschaften. Gabler Verlag, Wiesbaden. doi: 10.1007/978-3-8349-8484-5

Batte, M. T. (2006). Shopping at the Farm Office: What Is the Future of Farm E-commerce? Journal of the American Society of Farm Managers and Rural Appraisers 2006(387-2016-22853): 100105. doi: 10.22004/ag.econ.190698

Batte, M. T. und Ernst, S. C. (2007). Net gains from 'net purchases? Farmers' preferences for online and local input purchases. Agricultural and Resource Economics Review 36(1): 84-94. doi: $10.1017 /$ S1068280500009461

Berghaus, S. und Back, A. (2016). Stages in Digital Business Transformation: Results of an Empirical Maturity Study. Proceedings of the Tenth Mediterranean Conference on Information Systems (MCIS). Paphos, Cyprus, 1-17.

Biesel, H.H. und Hame, H. (2018). Vertrieb und Marketing in der digitalen Welt. So schaffen Unternehmen die Business Transformation in der Praxis. Springer Fachmedien, Wiesbaden. doi: 10.1007/978-3-658-17532-0

BLE (2018). Bericht zur Markt- und Versorgungslage Futtermittel 2018. Bundesanstalt für Landwirtschaft und Ernährung (BLE). https://bit.ly/3mjweIz. (25.03.2020).

BMEL (2020). Landwirtschaftliche Gesamtrechnung: Vorleistungen für den Bereich Landwirtschaft. Bundesministerium für Ernährung und Landwirtschaft. https://www.bmelstatistik.de/fileadmin/daten/SGT-3130600-0000.xlsx. (17.02.2020).

BMEL (2018). Struktur der Mischfutterhersteller 2018. Bundesministerium für Ernährung und Landwirtschaft. Bundesministerium für Ernährung und Landwirtschaft. https://www.bmelstatistik.de/fileadmin/daten/SBB-0100000-2018.PDF. (27.02.2020).

BMWi (2020). Förderprogramm go-digital. Digitalisieren Sie Ihr Unternehmen jetzt! Bundesministerium für Wirtschaft und Energie (BMWi). https://bit.ly/2VYZHMo. (27.03.2020).

Bogner, A., Littig, B. und Menz, W. (2014). Interviews mit Experten. Eine praxisorientierte Einführung. Qualitative Sozialforschung. VS Verlag für Sozialwissenschaften, Wiesbaden. doi: 10.1007/978-3-531-19416-5

Bogner, A., Littig, B. und Menz, W. (2002). Das Experteninterview. Theorie, Methode, Anwendung. VS Verlag für Sozialwissenschaften, Wiesbaden. doi: 10.1007/978-3-322-93270-9 
Böing, C. (2012). Erfolgsfaktoren Im Business-to-Consumer-E-Commerce. Unternehmensführung und Marketing, Gabler Verlag, Wiesbaden. doi: 10.1007/978-3-322-96453-3

Bongardt, K. (2018). Onlineshop will gekonnt sein. In: Pionke, S. (Hrsg.) Fitness-check Agrarhandel. agrarzeitung, p. 11.

Brenner, L. und Meyll, T. (2020). Robo-advisors: A substitute for human financial advice? Journal of Behavioral and Experimental Finance 25(2020): 100275. doi: 10.1016/j.jbef.2020.100275

Clasen, M. (2018). Die Rolle Digitaler Marktplätze in einer vollständig selbstgesteuerten Landwirtschaft. In: Ruckelshausen, A., Meyer-Aurich, A., Borchard, K., Hofacker, C., Loy, J.P., Schwerdtfeger, R., Sundermeier, H.-H. F. und Theuvsen, B. (Hrsg.) 38. GIL-Jahrestagung in Kiel, Digitale Marktplätze und Plattformen. Lecture Notes in Informatics (LNI). Gesellschaft für Informatik e.V., Bonn, 17-22.

Clasen, M. (2005). Erfolgsfaktoren digitaler Marktplätze in der Agrar- und Ernährungsindustrie. Dissertation. Deutscher Universitätsverlag, Wiesbaden.

Clasen, M., Horz, S. und Karpenstein, D. (2013). Erfolgsfaktoren elektronischer Marktplätze in der Agrar-und Ernährungswirtschaft-Die ersten 10 Jahre. In: Clasen, M., Kersebaum, K. C., MeyerAurich, A., Theuvsen, B. (Hrsg.) 33. GIL-Jahrestagung in Potsdam, Massendatenmanagement in der Agrar- und Ernährungswirtschaft Erhebung - Verarbeitung - Nutzung. Lecture Notes in Informatics (LNI). Gesellschaft für Informatik e.V, Bonn, 47-50.

Clasen, M., Müller, Rolf, A. E. und Abdul Madjied (2003). Digitale Marktplätze in der LandwirtschaftTotal virtuell? Zeitschrift für Agrarinformatik 1(3): 8-15.

Deiters, J., Fritz, M. und Schiefer, G. (2011). Vertrauen und E-Commerce in deutschen Supply Networks der Agrar- und Ernährungswirtschaft. In: Clasen, M., Schätzel, O. und Theuvsen, B. (Hrsg.) 31. GIL-Jahrestagung in Oppenheim, Qualität und Effizienz durch informationsgestuitzte Landwirtschaft, Fokus: Moderne Weinwirtschaft. Lecture Notes in Informatics (LNI). Gesellschaft für Informatik e.V., Bonn, 57-60.

Dengler, K. und Matthes, B. (2018). Substituierbarkeitspotenziale von Berufen: Wenige Berufsbilder halten mit der Digitalisierung Schritt. IBA-Kurzbericht. Institut für Arbeits und Berufsforschung, Nürnberg. http://doku.iab.de/kurzber/2018/kb0418.pdf. (29.10.2019).

Deter, A. (2015). DLG-Ranking der beliebtesten Futtermittelhersteller. top agrar online. https://www.topagrar.com/management-und-politik/news/dlg-ranking-der-beliebtestenfuttermittelhersteller-9411950.html. (01.03.2021).

DLG Test Service GmbH (2019). DLG Trusted AgriTrade. Vertrauen im Onlinehandel mit landwirtschaftlichen Betriebsmitteln. https://bit.ly/3g7t19M. (20.10.2019).

Doluschitz, R. (2002). Electronic Business in der Agrar und Ernährungswirtschaft Ernüchterung und Konsolidierung lösen die anfängliche Euphorie ab. German Journal of Agricultural Economics 51(2): 97-98. doi: 10.22004/ag.econ.98114

Doluschitz, R., Emmel, M., Kaiser, F., Pape, J. und Roth, M. (2004). E-Business in der Agrar-und Ernährungswirtschaft. AgriMedia GmbH, Bergen/Dumme.

Doluschitz, R. und Pape, J. (2002). E-Business in der Agrarwirtschaft zwischen Euphorie und Resignation. Zeitschrift für Agrarinformatik 10(1): 13-20.

DVT (2019). Futter Fakten - Die Futtermittelbranche. https://bit.ly/3g2m3Eg. (29.01.2020).

DVT (2018). DVT-Jahresbericht 2017/2018. Wir machen Tiernahrung. Deutscher Verband Tiernahrung e. V. (DVT). https://bit.ly/37J1k3B. (29.01.2020).

Egeli, M. (2016). Erfolgsfaktoren von Mobile Business. Ein Reifegradmodell zur digitalen Transformation von Unternehmen durch Mobile IT. BestMasters. Springer Vieweg, Wiesbaden. doi: $10.1007 / 978-3-658-12771-8$ 
Ehmke, C., Ernst, S., Hopkins, J. und Tweeten, L. (2001). The Market for E-commerce Services in Agriculture. Select Paper for Agricultural and Applied Economics Association (AAEA) Annual Meetings, Chicago, Illinois 1-16.

Elste, R. (2016). Paradigmenwechsel im Vertrieb - Konsequenzen neuer Technologien für das Kundenmanagement. In: Binckebanck, L. und Elste, R. (Hrsg.) Digitalisierung im Vertrieb: Strategien zum Einsatz neuer Technologien in Vertriebsorganisationen. Springer Fachmedien, Wiesbaden, 3-27. doi: 10.1007/978-3-658-05054-2_1

EU-Kommision (2003). Empfehlung der Kommission vom 6. Mai 2003 betreffend die Definition der Kleinstunternehmen sowie der kleinen und mittleren (Bekannt gegeben unter Aktenzeichen K (2003) 1422). http://data.europa.eu/eli/reco/2003/361/oj. (20.02.2020).

Fecke, W., Danne, M. und Mußhoff, O. (2018a). Digitalisierung in der deutschen Landwirtschaft: Ein Experiment zum Online-Einkauf von Pflanzenschutzmitteln. In: Ruckelshausen, A., MeyerAurich, A., Borchard, K., Hofacker, C., Loy, J.-P., Schwerdtfeger, R., Sundermeier, H.-H. F. und Theuvsen, B. (Hrsg.) 38. GIL-Jahrestagung in Kiel, Digitale Marktplätze und Plattformen. Lecture Notes in Informatics (LNI). Gesellschaft für Informatik e.V., Bonn, 71-74.

Fecke, W., Danne, M. und Mußhoff, O. (2018b). E-commerce in agriculture: The case of crop protection product purchases in a discrete choice experiment. (DARE) Diskussionsbeitrag No. 1803. Georg-August-Universität Göttingen, Göttingen.

Fitzgerald, M., Kruschwitz, N., Bonnet, D. und Welch, M. (2014). Embracing digital technology: A new strategic imperative. MIT sloan management review 55(2): 1-12.

Flick, U. (2017). Qualitative Sozialforschung. Eine Einführung. Rowohlts Enzyklopädie 55694. Rowohlt Taschenbuch, Reinbek bei Hamburg. doi: 10.1007/s11577-003-0074-9

Gartzke, S. (2016). Kleffmann Group Global New Media Tracker - Our international Study. In: Farwick, C. (Hrsg.) Kleffmann Group. Agri Experts Around the World. Newsletter, 18-21.

Gläser, J. und Laudel, G. (2010). Experteninterviews und qualitative Inhaltsanalyse als Instrumente rekonstruierender Untersuchungen. VS Verlag für Sozialwissen schaften, Springer, Wiesbaden.

Gollisch, S. und Theuvsen, L. (2015). Risikomanagement im Landhandel: Charakteristika, Herausforderungen, Implikationen. Berichte über Landwirtschaft Zeitschrift für Agrarpolitik und Landwirtschaft 93(1): 1-17. doi: 10.12767/buel.v93i1.72

Große Holtforth, D. (2017). Schlü sselfaktoren im E-Commerce. Innovationen, Skaleneffekte, Daten und Kundenzentrierung. Springer Gabler, Wiesbaden. doi: 10.1007/978-3-658-16434-8

Handschuh, M. und Gebhardt, C. (2016). Wie die Digitalisierung den B2B-Vertrieb verändert. Sales Management Review 25(1): 44-55. doi: 10.1007/s35141-016-0018-4

Heinemann, G. (2018). Der neue Online-Handel. Geschäftsmodelle, Geschäftssysteme und Benchmarks im E-Commerce. Springer Gabler, Wiesbaden. doi: 10.1007/978-3-658-20354-2

Henderson, J., Dooley, F. und Akridge, J. (2004). Internet and E-Commerce Adoption by Agricultural Input Firms. Review of Agricultural Economics 26(4): 505-520. doi: 10.2307/3700794

Henderson, J. R., Akridge, J. T. und Dooley, F. J. (2006). Internet and e-commerce use by agribusiness firms: 2004. Journal of Agribusiness 24(1): 17-39. doi: 10.22004/ag.econ.57697

Henderson, J. R., Dooley, F. J. und Akridge, J. T. (2000). Adoption of E-Commerce strategies for agribusiness firms. Selected Paper at the American Agricultural Economics Association Annual Meeting. doi: 10.22004/ag.econ.21771

Herdon, M., Zimányi, K. und Péntek, Á. (2006). e-Factors in e-Agribusiness. Information Systems in Agriculture and Forestry XII. European Conference. Czech University of Agriculture, Prague.

Hooker, N.H., Heilig, J. und Ernst, S. (2001). What is unique about e-agribusiness? Proceedings of the 2001 International Agribusiness Management Association World Food and Agribusiness Forum, Sydney. 
Hosoi, K. (2000). Advanced B 2 B procurement on the Internet. Fujitsu scientific and technical journal 36(2): 226-231.

Huchtemann, J.-P. und Theuvsen, L. (2018). Startups im Agribusiness - Marktplätze als Geschäftsmodell und deren Anwendung in der deutschen Landwirtschaft. In: Ruckelshausen, A., Meyer-Aurich, A., Borchard, K., Hofacker, C., Loy, J.-P., Schwerdtfeger, R., Sundermeier, H.-H. F. und Theuvsen, B. (Hrsg.) 38. GIL-Jahrestagung in Kiel, Digitale Marktplätze und Plattformen. Lecture Notes in Informatics (LNI). Gesellschaft für Informatik e.V., Bonn, 119122.

IFH Köln (2019). B2B-E-Commerce wächst auf 1.300 Milliarden Euro Umsatz. Pressemitteilungen der IFH Köln. https://www.ibusiness.de/aktuell/db/906907grollmann.html. (30.06.2019).

Ivanic, R., Akridge, J., Dooley, F., Ehmke, C. und Wall, S. (2001). E-commerce strategies among agricultural input firms. Staff Paper No. 01-9. Purde University, West Lafayette.

Jung, D., Dorner, V., Weinhardt, C. und Pusmaz, H. (2018). Designing a robo-advisor for risk-averse, low-budget consumers. Electronic Markets 28(3): 367-380. doi: 10.1007/s12525-017-0279-9

Keisidou, E., Sarigiannidis, L. und Maditinos, D. (2011). Consumer characteristics and their effect on accepting online shopping, in the context of different product types. International Journal of Business Science \& Applied Management 6(2): 31-51.

Koch, J. (2019). Digitalisierung im Agrarhandel: Diese Angebote gibt es. agrarheute. https://bit.ly/3g5vtib. (01.03.2021).

Köllinger, P. (2004). E-Business in europäischen Unternehmen: wachsende Kluft zwischen Pionieren und Nachzüglern. DIW Wochenbericht 71. Deutsches Institut für Wirtschaftsforschung (DIW), Berlin.

Lamnek, S. und Krell, C. (2016). Qualitative Sozialforschung. Mit Online-Materialien. Psychologie Verlagsunion, Beltz, Weinheim, Basel.

Lässig, R., Leutiger, P., Fey, A., Hentschel, S., Tornier, S. und Hirt, F. (2015). Die digitale Zukunft desB2B-Vertriebs. Warum Industriegüterunternehmen sich auf veränderte Anforderungen ihrer Kunden einstellen müssen. Roland Berger $\mathrm{GmbH}$, München. https://bit.ly/3m6hdtw. (20.03.2020).

Leroux, N., Wortman Jr, M. S. und Mathias, E. D. (2001). Dominant factors impacting the development of business-to-business (B2B) e-commerce in agriculture. The International Food and Agribusiness Management Review 4(2): 205-218. doi: 10.22004/ag.econ.34473

Lutilsky, K. (2020). DLG, Agrando und Bergophor sind Pilotpartner. https://agrando.com/dede/magazin/dlg-agrando-bergophor?utm_source=facebook\&utm_medium=referral. (01.03.2021).

Manager Magazin (2011). Mischfutterhersteller: Die Top Ten in Deutschland. manager magazin. https://www.manager-magazin.de/fotostrecke/fotostrecke-63297.html. (27.03.2020).

Mayring, P. (2015). Qualitative Inhaltsanalyse. Grundlagen und Techniken. Beltz, Weinheim.

Meier, A. und Stormer, H. (2012). eBusiness \& eCommerce. Management der digitalen Wertschöpfungskette. Springer Verlag, Berlin, Heidelberg. doi: 10.1007/978-3-642-29802-8

Meuser, M. und Nagel, U. (2009). Das Experteninterview - konzeptionelle Grundlagen und methodische Anlage. In: Pickel, S., Pickel, G., Lauth, H.-J. und Jahn, D. (Hrsg.) Methoden der vergleichenden Politik- und Sozialwissenschaft: Neue Entwicklungen und Anwendungen. VS Verlag für Sozialwissenschaften, Wiesbaden, 465-479. doi: 10.1007/978-3-531-91826-6_23

Mishra, A. K., Williams, R. P. und Detre, J. D. (2009). Internet Access and Internet Purchasing Patterns of Farm Households. Agricultural and Resource Economics Review 38(2): 240-257. doi: $10.1017 /$ S1068280500003233 
Monga, V. (2015). The new bookkeeper is a robot. Wall Street Journal. https://www.wsj.com/articles/the-new-bookkeeper-is-a-robot-1430776272. (20.03.2020).

Mueller, R. A. E. (2001). E-commerce and entrepreneurship in agricultural markets. American Journal of Agricultural Economics 83(5): 1243-1249. doi: 10.1111/0002-9092.00274

Nds. MW (2018). Die Strategie Niedersachsens zur digitalen Transformation. Masterplan Digitalisierung. Niedersächsisches Ministerium für Wirtschaft Arbeit Verkehr und Digitalisierung, Hannover. https://bit.ly/3g3xf3g. (01.04.2020).

Niehaus, A. und Emrich, K. (2016). Ansätze und Erfolgsfaktoren für die Digitalisierung von Vertriebsstrategien. In: Binckebanck, L. und Elste, R. (Hrsg.) Digitalisierung im Vertrieb: Strategien zum Einsatz neuer Technologien in Vertriebsorganisationen. Springer Gabler, Wiesbaden, 47-63. doi: 10.1007/978-3-658-05054-2_3

Pape, J. und Doluschitz, R. (2001). DV-Ausstattung und Internetnutzung in Unternehmen der landwirtschaftlichen Primärproduktion-ausgewählte Ergebnisse empirischer Untersuchungen in Mecklenburg-Vorpommern, Sachsen und Baden-Württemberg. In: Kögl, H., Spilke, J. und Brinker, U. (Hrsg.) 22. GIL-Jahrestagung in Rostock, Information und Kommunikation im Dienst der ländlichen Entwicklung Methoden - Anwendungen - Probleme. Berichte der Gesellschaft für Informatik in der Land-, Forst- und Ernährungswirtschaft, vol. 22, Bonn, 105108.

Park, T. und Mishra, A. (2003). Internet usage by farmers: Evidence from a national survey. Paper for presentation at the 2003 AAEA annual meeting, Montreal, Canada.

Pascher, P., Hemmerling, U. und Naß, S. (2018). Situationsbericht 2018/19 Trends und Fakten zur Landwirtschaft. Deutscher Bauernverband e.V., Berlin.

Pohl, A., Litfin, T. und Weber, A. (2002). Marktauftritt Internet - Strategische Herausforderung und Umsetzung im Marketing-Mix. In: Weiber, R. (Hrsg.) Handbuch Electronic Business: Informationstechnologien - Electronic Commerce - Geschäftsprozesse. Gabler Verlag, Wiesbaden, 645-671. doi: 10.1007/978-3-322-96349-9_26

Porter, M., E. (2001). Strategy and the Internet. Harvard Business Review 79(3): 62-78.

Proplanta (2010). Top 25 der deutschen Mischfutterhersteller. Mit Abstand wichtigster Absatzmarkt für die deutschen Mischfutterhersteller ist und bleibt die Schweinehaltung.proplanta.de. https://www.proplanta.de/agrar-nachrichten/agrarwirtschaft/top-25-der-deutschenmischfutterhersteller_article1272612624.html.(20.03.2020).

Reibstein, D. J. (2002). What attracts customers to online stores, and what keeps them coming back? Journal of the academy of Marketing Science 30(4): 465-473. doi: 10.1177/009207002236918

Rosskopf, K. und Wagner, P. (2006). Vom Daten-zum Wissensmanagement: Wofür verwenden Landwirte einen Computer? In: Wenkel, K.-O. und Wagner, P. (Hrsg.) 26. GIL Jahrestagung in Potsdam, Land- und Ernährungswirtschaft im Wandel: Aufgaben und Herausforderungen für die Agrar- und Umweltinformatik. Berichte der Gesellschaft für Informatik in der Land-, Forstund Ernährungswirtschaft, Bonn, 225-228.

Schillewaert, N., Ahearne, M. J., Frambach, R. T. und Moenaert, R. K. (2005). The adoption of information technology in the sales force. Industrial marketing management 34(4): 323-336. doi: 10.1016/j.indmarman.2004.09.013

Schulze Schwering, D. und Spiller, A. (2019). Zukunftsperspektiven von Online-Shops in der landwirtschaftlichen Vorleistungsindustrie - eine Analyse aus der Perspektive von Landwirten. In: Meyer-Aurich, A., Gandorfer, M., Barta, N., Gronauer, A., Kantelhardt, J. und Floto, H. (Hrsg.) 39. GIL-Jahrestagung in Wien, Digitalisierung für landwirtschaftliche Betriebe in kleinstrukturierten Regionen - ein Widerspruch in sich? Lecture Notes in Informatics (LNI). Gesellschaft für Informatik e.V, Bonn, 227-232. 
Schulze Schwering, D. und Spiller, A. (2018). Das Online-Einkaufsverhalten von Landwirten im Bereich landwirtschaftlicher Betriebsmittel. (DARE) Diskussionsbeitrag No. 1805. GeorgAugust-Universität, Göttingen.

Schwartz, M. (2017). E-Commerce steckt im Mittelstand noch in den Kinderschuhen. KfW Research Fokus Wirtschaft. https://bit.ly/3jZQ1cY. (20.03.2020).

Strzębicki, D. (2015). The development of electronic commerce in agribusiness-The polish example. Procedia economics and finance 23(2015): 1314-1320. doi: 10.1016/S2212-5671(15)00573-0

Vennemann, H. und Theuvsen, L. (2004). Landwirte im Internet: Erwartungen und Nutzungsverhalten. In: Schiefer, G., Wagner, P., Morgenstern, M. und Rickert, U. (Hrsg.) 25. GIL Jahrestagung in Bonn, Integration und Datensicherheit - Anforderungen, Konflikte und Perspektiven. Berichte der Gesellschaft für Informatik in der Land-, Forst- und Ernährungswirtschaft, Bonn, 241-244.

Verhoef, P. C., Kannan, P. K. und Inman, J. J. (2015). From multi-channel retailing to omni-channel retailing: introduction to the special issue on multi-channel retailing. Journal of retailing 91(2): 174-181. doi: 10.1016/j.jretai.2015.02.005

Voss, J. (2008). Customer-Relationship-Management im Agribusiness. Sierke, Göttingen.

Weihofen, C. (2004). Potenziale des Internet für das elektronische Kundenbeziehungsmanagement (eCRM) am Beispiel der Raiffeisen-Warengenossenschaften. Dissertation. Rheinische Friedrich-Wilhelms-Universität, Bonn.

Wheatley, W.P., Buhr, B.L. und Dipietre, D. (2001). E-Commerce in Agriculture Development, Strategy and Market Implications. Staff paper. University of Minnesota.

Wittmann, G. and Listl, C. (2017). Online-Kaufverhalten im B2B-E-Commerce 2017. Ergebnisse einer Expertenbefragung von ibi research an der Universität Regensburg, Creditreform und SIX Payment Services. ibi research an der Universität Regensburg GmbH, Regensburg.

Zanker, C. (2018). Branchenanalyse Logistik: Der Logistiksektor zwischen Globalisierung, Industrie 4.0 und Online-Handel. Study der Hans-Böckler-Stiftung, Düsseldorf.

Zeng, Y., Jia, F., Wan, L. und Guo, H. (2017). E-commerce in agri-food sector: a systematic literature review. International Food and Agribusiness Management Review 20(4): 439-459. doi: 10.22004/AG.ECON.264235

Zimmermann, M. (2003). Das Kaufverhalten von Landwirten im Bereich landwirtschaftlicher Investitionsgüter. Cuvillier Verlag, Göttingen. 
Chapter II - Sales Management in Agribusiness

II.1 Die Wahrnehmung des Außendienstes in der landwirtschaftlichen Vorleistungsindustrie - Eine empirische Studie aus Sicht deutscher LandwirtInnen

Authors: Jan-Philipp Huchtemann, Dorothee Schulze Schwering \& Achim Spiller

This article was published in similar form in Austrian Journal of Agricultural Economics and Rural Studies, 2019 28(18): 137-142.

Doi: 10.15203/OEGA_28.18 


\title{
II.1 Die Wahrnehmung des Außendienstes in der landwirtschaftlichen Vorleistungsindustrie - Eine empirische Studie aus Sicht deutscher LandwirtInnen
}

\section{Zusammenfassung}

Die zunehmende Angleichung von Produkten und Produktportfolios im Agribusiness macht eine Differenzierung zu Wettbewerbern deutlich schwieriger. Ein starker Außendienst kann daher ein wichtiger Faktor zur Differenzierung sein, insbesondere in den Bereichen Servicequalität sowie Kundenbindung und -orientierung. Bislang ist jedoch wenig über die Wahrnehmung und die Bewertung der Fähigkeiten des Außendienstes aus der Perspektive deutscher LandwirtInnen bekannt. Die Ergebnisse der vorliegenden Online-Befragung zeigen, dass vor allem die Persönlichkeit und die Sozialkompetenz von Außendienstmitarbeitenden deren Außenwahrnehmung bestimmen. Für Unternehmen der Vorleistungsindustrie bedeutet dies, dass bei der Einstellung neuer und Schulung bestehender MitarbeiterInnen ein Fokus auf die Identifizierung und Förderung der persönlichen Stärken von Beschäftigten im Außendienst gelegt werden sollte.

Schlagworte: LandwirtInnenbefragung, Außendienst, Landwirtschaft, Erfolgsdeterminanten, Regressionsanalyse

\begin{abstract}
Increasing alignment of products and product portfolios in the agribusiness impede the differentiation from competitors. A strong sales force can therefore be an important factor for differentiation, especially regarding service quality, customer loyalty and orientation. So far, little is known about the perception and evaluation of the sales force from the perspective of farmers. Results of this online survey show that mainly the personality and the social competence of the sales force determines the external perception. For companies, this means that when hiring new employees or training existing ones, a stronger focus should be placed on identifying and promoting personal strengths of the sales force.
\end{abstract}

Keywords: Farmer survey, sales force, agriculture, determinants of success, regression analysis 


\section{$1 \quad$ Einleitung}

Die Agritechnica 2017 war mit 2.802 Ausstellenden und rund 458.000 BesucherInnen aus 128 Ländern die größte Leitmesse für moderne Agrartechnik weltweit (Agritechnica, 2017). Die ausstellenden Unternehmen präsentierten mit ihren Außendienstteams ihre aktuellen Produkte und neuesten Innovationen. Bei der Betrachtung der Produkte fällt auf, dass sich nicht nur die einzelnen Produkte der Landtechnikhersteller mit Full-Liner Strategie annähern, sondern auch die Produktportfolios (Hartl, 2017; Keudell, 2016). Eine Differenzierung über die Produkte wird zusehends schwerer. In Anbetracht dieser Tatsache stellen ein hochwertiger Außendienst und eine gute Servicequalität potenzielle Differenzierungsmerkmale zu Wettbewerbern dar. Dies unterstreicht, in Kombination mit einer zunehmenden Bereitstellung von Ressourcen für Teams im Außendienst, die herausragende Stellung des Außendienstes im Agribusiness. Der Bundesverband des Berufsverbandes Agrar, Ernährung, Umwelt e. V. (VDL) konstatiert dazu, dass über 30\% der Fach- und Führungskräfte mit agrarwissenschaftlichem Ausbildungshintergrund von Unternehmen im Außendienst eingesetzt werden, die Nachfrage nach Außendienstmitarbeitenden konstant hoch ist und die Besetzung der offenen Stellen zunehmend schwieriger wird (VDL, 2014). Das Tätigkeitsspektrum im Außendienst ist stark durch den persönlichen Verkauf, insbesondere durch den Verkaufsbesuch bei den KundInnen geprägt. Dabei spielen die Wahrnehmung und die Fähigkeiten des Außendienstes eine entscheidende Rolle für den wirtschaftlichen Erfolg des Unternehmens (Dannenberg und Zupancic, 2008; Maas, 2012)

Bislang ist wenig darüber bekannt, wie LandwirtInnen in Deutschland den Außendienst der Vorleistungsindustrie bewerten, bestimmte Fähigkeiten der AußendienstmitarbeiterInnen wahrnehmen und welche Einflussfaktoren das Image des Außendiensts beeinflussen. Basierend auf den Daten einer Online-Befragung von 238 LandwirtInnen in Deutschland soll diese Forschungslücke in dem vorliegenden Beitrag mittels einer Faktoren- und Regressionsanalyse geschlossen werden. Damit trägt diese Studie zum einen dazu bei, Erkenntnisse über das Ansehen des Außendienstes zu erhalten und zum anderen dienen diese Ergebnisse als Grundlage für Handlungsempfehlungen für das Außendienstmanagement. 


\section{Der Außendienst und seine Erfolgsdeterminanten}

Der Außendienst beschreibt einen bestimmten Tätigkeitsbereich in der Vertriebsorganisation eines Unternehmens, in dem die MitarbeiterInnen in engem Kundenkontakt stehen und hauptsächlich Aufgaben des persönlichen Verkaufs erfüllen (Fredebeul-Krein, 2012). Der persönliche Kontakt mit der Kundschaft nimmt den größten Teil des Aufgabenspektrums von MitarbeiterInnen im Außendienst ein (Behle und vom Hofe, 2006; Fredebeul-Krein, 2012). Dieser enge wechselseitige Dialog zwischen Unternehmen und ihrer Kundschaft ermöglicht eine zeitnahe Reaktion auf Probleme und Bedürfnisse der KundInnen (Fredebeul-Krein, 2012). Bei den Produkten und Dienstleistungen der landwirtschaftlichen Vorleistungsindustrie handelt es sich häufig um komplexe Produkte, die auf den landwirtschaftlichen Betrieben sehr individuell angepasst eingesetzt werden (Rüther und Maier, 2007). Daher setzen Unternehmen Außendienstmitarbeitende verstärkt mit einer Beratungsfunktion ein (Rüther, 2007; Rüther und Maier, 2007). Für eine erfolgreiche Arbeit im Außendienst sollten MitarbeiterInnen über bestimmte Kompetenzen verfügen. Die Bestimmung von Erfolgsfaktoren von AußendienstmitarbeiterInnen ist Untersuchungsgegenstand vieler wissenschaftlicher Beiträge (Churchill et al., 1985; Homburg et al., 2012). Neben der Persönlichkeit stellen die Fachkompetenz und die Sozialkompetenz in der wissenschaftlichen Betrachtung zentrale Merkmale dar, die erfolgreiche AußendienstmitarbeiterInnen vereinen sollten (Churchill et al., 1985; Homburg et al., 2012). In die Persönlichkeit von Außendienstmitarbeitenden fließen Faktoren wie Kontaktfreudigkeit, Selbstbewusstsein sowie Empathie und Optimismus ein. Die Sozialkompetenz beinhaltet die verbale und nonverbale Kommunikationsfähigkeit, ein gewisses Maß an Teamfähigkeit sowie Freundlichkeit und Flexibilität. Zur Fachkompetenz lassen sich das Wissen um Produkte, Märkte und der eigenen Kundschaft zuordnen sowie der persönliche Verkaufsstil und die Selbstorganisation (Homburg et al., 2012).

\section{Material und Methoden}

Das Ansehen und die Zufriedenheit mit dem Außendienst der landwirtschaftlichen Vorleistungsindustrie war im November 2017 Gegenstand einer deutschlandweiten Online- Befragung von LandwirtInnen. Insgesamt haben 283 LandwirtInnen den Fragebogen vollständig ausgefüllt. Nach einer Bereinigung der Stichprobe, unter anderem um Befragte, die innerhalb der letzten 12 Monate keinen Besuch vom Außendienst empfingen, verblieb für die statistische Auswertung ein Datensatz von 238 auswertbaren Befragungen. Für die statistische Auswertung wurde das Programm IBM SPSS Statistics 25 verwendet. 
Geprüft werden sollte, welchen Einfluss die drei, in der Literatur definierten Erfolgsdeterminanten des Verkaufspersonals - Sozial- und Fachkompetenz sowie Persönlichkeit auf die Bewertung des Außendienstes haben. Abgefragt wurden die Statements mithilfe einer fünfstufigen Likert-Skala von 1=,,trifft zu“ bis 5=,,trifft nicht zu“. Zur Überprüfung der Erfolgsdeterminanten wurde zunächst eine Verdichtung der Statements in Form einer Faktorenanalyse mittels Hauptkomponentenanalyse und Varimax-Rotation (Tab. 2) vorgenommen. Eine explorative Faktorenanalyse wurde für das Ansehen des Außendienstes durchgeführt und bestand sowohl aus der Abfrage des allgemeinen Ansehens sowie des Ansehens der jeweiligen Vorleistungsbereiche wie etwa Futtermittel, Düngemittel etc. (Tab.3). Die Statements zur Wahrnehmung und zum Ansehen des Außendienstes wurden in Form von Schulnoten 1 (sehr gut) bis 6 (ungenügend) abgefragt. Die Reliabilität der ermittelten Faktoren wurde mit Hilfe von Cronbach's Alpha (CA) untersucht (Hair et al., 2009). Im Anschluss wurde mit einer linearen Regression ein Modell, das die Einflussfaktoren auf die Wahrnehmung des Außendienstes durch die Befragten abbildet, geschätzt. Neben den soziodemografischen und betrieblichen Angaben wurden, die zuvor durch die Faktorenanalyse identifizierten, Erfolgsdeterminanten als unabhängige Variable in die Schätzung einbezogen (Bühl, 2014).

\section{$4 \quad$ Ergebnisse}

Das mittels Schneeballsystems generierte convenience Sample ist nicht repräsentativ für die deutsche Landwirtschaft und besteht zu 91,2\% aus konventionell wirtschaftenden Betrieben, wovon mehr als 90\% im Haupterwerb geführt werden. Mit 41,6\% sind Betriebe aus Norddeutschland am häufigsten vertreten. Die Verteilung der landwirtschaftlichen Betriebe aus über das Bundesgebiet weicht von der Verteilung der Agrarstrukturerhebung ab (Hemmerling et al., 2017). Knapp die Hälfte der befragten Betriebe $(49,6 \%)$ bewirtschaftet zwischen 100-500 Hektar, 18,9\% bewirtschaften sogar mehr als 500 Hektar. Damit weisen die Teilnehmenden dieser Stichprobe eine, im Vergleich zum bundesweiten Durchschnitt von etwa 60,5 Hektar, überdurchschnittliche Betriebsgröße auf (Hemmerling et al., 2017). 
Tabelle 1: Stichprobenbeschreibung

\begin{tabular}{|c|c|c|c|}
\hline Merkmal & & Ausprägung & \\
\hline Geschlecht & Männlich: 87,0\% & Weiblich: $13,0 \%$ & \\
\hline Alter & $\leq 34$ Jahre: $45,5 \%$ & 35-54 Jahre: $37,7 \%$ & $\geq 55$ Jahre: $16,8 \%$ \\
\hline Bildung & Hochschulabschluss: $48,7 \%$ & Mittlere Reife: $24,4 \%$ & Sonstige: $2,1 \%$ \\
\hline & Abitur: $20,6 \%$ & Hauptschulabschluss: $4,2 \%$ & \\
\hline Betriebsgröße & $\leq 24$ ha: $10,9 \%$ & $20-49$ ha: $5,5 \%$ & $50-99$ ha: $24,4 \%$ \\
\hline & 100-199 ha: $26,5 \%$ & $200-500$ ha: $23,1 \%$ & $>500$ ha: $18,9 \%$ \\
\hline Erwerbsform & Haupterwerb: 93,3\% & Nebenerwerb: 6,7\% & \\
\hline Betriebsform & Konventionell: $91,2 \%$ & Ökologisch: 5,9\% & Sonstige/Umstellung: $2,9 \%$ \\
\hline Bewirtschaftung & Ackerbau: $26,5 \%$ & Viehhaltung: $41,1 \%$ & Sonderkulturen: $2,6 \%$ \\
\hline & Mischbetrieb: $29,8 \%$ & & \\
\hline Lage & Norden: $41,6 \%$ & Osten: $10,9 \%$ & \\
\hline & Süden: $19,3 \%$ & Westen: $28,2 \%$ & \\
\hline & Alte Bundesländer: $82,4 \%$ & Neue Bundesländer: 17,6\% & \\
\hline Zukunfts- & Wachstum: $46,6 \%$ & Status quo: $32,4 \%$ & Schrumpfung: $0,4 \%$ \\
\hline perspektive & Umstrukturierung: 19,3\% & Betriebsaufgabe: $1,3 \%$ & \\
\hline Stichprobengröße $=2$ & & & \\
\hline
\end{tabular}

Tabelle 1 beschreibt die Stichprobe. Die Teilnehmerinnen (13\%) und Teilnehmer (87\%) sind zu 45,5\% jünger als 35 Jahre. Die Altersstruktur der Befragten liegt unter dem bundesweiten Altersdurchschnitt von LandwirtInnen, bei der nur 25\% der BetriebsinhaberInnen jünger als 45 Jahre sind (Hemmerling et al., 2017). Sie sind zudem besser ausgebildet, da 48,7\% von ihnen einen (Fach-) Hochschulabschluss vorweisen können. In der Grundgesamtheit ist diese Studienquote mit 12\% vergleichbar gering (Hemmerling et al., 2017). 41,1\% der Teilnehmenden halten Nutztiere (Bundesdurchschnitt 41\%) und 26,5\% sind reine Ackerbaubetriebe (Bundesdurchschnitt 30\%), (Hemmerling et al., 2017).

Die sowohl in Tabelle 2 als auch in Tabelle 3 dargestellten Gütekriterien der Faktorenanalyse entsprechen den in der Literatur beschriebenen allgemeinen Anforderungen (Backhaus et al., 2016; Bühl, 2014), wodurch die Ergebnisse der Faktorenanalyse für eine anschließende Regressionsanalyse verwendet werden können. Einen Überblick über die identifizierten Faktoren und die kennzeichnenden Items geben Tabelle 2 und Tabelle 3. 
Tabelle 2: Erfolgsfaktoren für AußendienstmitarbeiterInnen im Agribusiness

Faktoren/Statements ${ }^{\mathrm{a}}$

Faktorladung

Sozialkompetenz (Cronbach's Alpha = 0,86)

\begin{tabular}{lc}
\hline Ist kritikfähig. & 0,778 \\
Passt sein Verhalten der Gesprächssituation an. & 0,769 \\
Betreibt aktives Zuhören im Verkaufsgespräch. & 0,746 \\
Schafft eine angenehme Gesprächsatmosphäre. & 0,743 \\
Lässt mich aussprechen. & 0,712 \\
Stimmt sich mit seinen Kollegen im Innendienst gut ab. & 0,524 \\
\hline
\end{tabular}

Persönlichkeit (Cronbach's Alpha =0,820)

Der Verkäufer geht von selbst auf mich zu.

0,747

0,683

Ist sich sicher, meinen Anforderungen gerecht zu werden.

0,674

Bringt eigene Ideen und Vorschläge aktiv in unser Gespräch ein.

0,667

Er fühlt sich in der Zusammenarbeit mit mir wohl.

0,633

Er verarbeitet meine negativen Produkterfahrungen schnell.

0,540

Er verliert auch in schwierigen Situationen nicht den Mut.

Fachkompetenz (Cronbach's Alpha = 0,803)

\begin{tabular}{lc}
\hline Kennt die Preismargen seiner Produkte. & 0,739 \\
Ist vertraut mit den Produkten der Konkurrenz. & 0,721 \\
Kennt die Aktivitäten des Wettbewerbs. & 0,676 \\
Kennt das gesamt Produktportfolio des Unternehmens, sowie die Merkmale und & 0,632 \\
Leistungsfähigkeit der Produkte. & 0,622 \\
Kennt die Kosten und Nutzen des Produktes. & 0,556 \\
Hat ein realistisches Bild von der Marktposition des eigenen Unternehmens. & \\
\hline
\end{tabular}

a 5er Likert-Skala:1=,,trifft zu“ bis 5=,,trifft nicht zu“, KMO=0,918; Erklärte Gesamtvarianz= 55,469\%

Quelle: Eigene Erhebung.

Tabelle 3: Faktor Wahrnehmung des Außendienstes

\begin{tabular}{lc}
\hline \multicolumn{1}{c}{ Item $^{\text {a }}$} & Faktorladung \\
\hline Allgemeine Beurteilung des Ansehens des Außendienstes im Agribusiness & 0,796 \\
Mittelwert über die Beurteilung des Ansehens je nach Sparte & 0,769 \\
\hline${ }^{a}$ 6er Likert-Skala: 1=,,sehr gut“ bis 6=,,ungenügend“; KMO=0,5; Erklärte Gesamtvarianz=66,163\%; Cronbach’s Alpha $=0,474$ \\
\hline Quelle: Eigene Erhebung.
\end{tabular}

Die Faktoranalyse bestätigt, dass sich Außendienstmitarbeitende seitens ihrer Kundschaft durch drei Determinanten bewerten lassen. Ein Mittelwertvergleich der identifizierten Erfolgsfaktoren zeigt, dass die Befragten das allgemeine Ansehen des Außendienstes der landwirtschaftlichen Vorleistungsindustrie mit einer Durchschnittsnote (in Schulnoten) von 3,0, welches einer befriedigenden Leistung entspricht, bewerten. Aufgegliedert in die Kompetenzbereiche zeigt sich, dass die Fachkompetenz von den Befragten mit einem Mittelwert von 1,88 etwas besser bewertet, wird als die Sozialkompetenz $(1,94)$ und die 
Persönlichkeit (2,0). Insgesamt verdeutlicht der Mittelwertvergleich, dass LandwirtInnen Außendienstmitarbeitenden gute Leistungen in den drei Bereichen Persönlichkeit, Sozialkompetenz und Fachkompetenz zusprechen.

Um zu bestimmen, ob und welchen Einfluss die drei Determinanten und ausgewählte soziodemografische Faktoren wie Alter und Bildung auf die Wahrnehmung des Außendienstes und das Ansehen des Außendienstes (Abhängige Variable) haben, wird im Folgenden eine Regressionsanalyse durchgeführt (Tabelle 4).

Tabelle 4: Regressionsanalyse zur Wahrnehmung des Außendienstes

\begin{tabular}{lcccc}
\hline Unabhängige Variablen & Effektgröße & Standardfehler & T-Wert & Signifikanz \\
\hline Persönlichkeit Außendienst & 0,266 & 0,061 & 4,396 & 0,000 \\
Sozialkompetenz Außendienst & 0,262 & 0,061 & 4,333 & 0,000 \\
Fachkompetenz Außendienst & 0,141 & 0,061 & 2,327 & 0,021 \\
Bildungsabschluss LandwirtIn & $-0,054$ & 0,066 & $-0,886$ & 0,377 \\
Alter LandwitIn & $-0,035$ & 0,046 & $-0,561$ & 0,575 \\
\hline Abh. Variable: Wahrnehmung des Außendienstes; Korr. R²: 0,$147 ;$ F: $8,354^{* * * *}$ & & \\
\hline
\end{tabular}

Quelle: Eigene Erhebung.

Die Ergebnisse weisen darauf hin, dass alle Erfolgsdeterminanten einen Beitrag zur Erklärung der Außenwahrnehmung des Außendienstes bei LandwirtInnen leisten. Die Regressionsanalyse zeigt, dass die oben genannten fünf unabhängigen Variablen insgesamt ca. 15\% (Korr. R2: 0,147) der Varianz der Wahrnehmung des Außendienstes durch die Befragten erklären (Tabelle 4). Das Gesamtmodell ist signifikant (F-Wert: 8,354***), die Irrtumswahrscheinlichkeit für den ermittelten Zusammenhang zwischen den unabhängigen Variablen und der abhängigen Variablen beträgt $\leq 0,1 \%$. Mittels der standardisierten Beta-Koeffizienten (Effektgröße) können die Einflussfaktoren verglichen werden.

Gemessen an der Effektgröße hat die Persönlichkeit den größten positiven Einfluss auf die Wahrnehmung. Je höher die Mittelwerte in der Dimension Persönlichkeit der AußendienstmitarbeiterInnen, desto besser nehmen die Befragten deren Gesamtleistung wahr. Einen ähnlich starken Einfluss hat die Sozialkompetenz. Die Fachkompetenz hat hingegen einen geringeren positiven Einfluss auf die Außenwahrnehmung. Das heißt, mit steigender Fachkompetenz steigt auch das Ansehen der Außendienstmitarbeitenden. Jedoch steigt das Ansehen der Außendienstmitarbeitenden stärker, wenn sich die Persönlichkeit und die Sozialkompetenz der Außendienstmitarbeitenden verbessern. 
Keinen signifikanten Einfluss auf die Beurteilung haben das Alter und das Bildungsniveau der LandwirtInnen. Demnach ist die Außenwahrnehmung des Außendienstes unabhängig vom Alter und Bildungsgrad der LandwirtInnen.

Die Regressionsanalyse weist darauf hin, dass die Persönlichkeit und die Sozialkompetenz die Beurteilung des Außendienstes durch die Befragten am stärksten beeinflussen und die Fachkompetenz des Außendienstes einen geringeren Einfluss hat. Zudem zeigen die Ergebnisse, dass die Fachkompetenz, obwohl sie im Vergleich zu den verbleibenden zwei Erfolgsdeterminanten etwas besser bewertet wird, nicht den bedeutendsten Einfluss auf die Bewertung des Ansehens des Außendienstes hat.

\section{$5 \quad$ Diskussion und Schlussfolgerung}

Die Ergebnisse des vorliegenden Beitrags liefern erste Erkenntnisse über die Wahrnehmung des Außendienstes sowie die Bewertung von Erfolgsdeterminanten im Außendienst aus der Sicht deutscher LandwirtInnen. Die Regressionsanalyse zeigt, dass LandwirtInnen AußendienstmitarbeiterInnen unabhängig von ihrem Bildungsgrad und Alter wahrnehmen und bewerten. Dies liegt vermutlich an der Alters- und Bildungsstruktur der Stichprobe. Rüther (2007) fand heraus, dass bezogen auf die Fachberatung, bildungsstarke LandwirtInnen zufriedener mit der Fachberatung sind. Obwohl die Ergebnisse nicht signifikant sind, könnte das Vorzeichen der Effektstärke darauf hinweisen, dass in dieser Stichprobe tendenziell bildungsstärkere LandwirtInnen kritischer sind bei der Beurteilung des Außendienstes als bildungsschwächere LandwirtInnen. Um diesen Effekt zu bestätigen, bedarf es allerdings genauerer Untersuchungen.

Zahlreiche wissenschaftliche Beiträge bestätigen die Fachkompetenz der MitarbeiterInnen als wichtigen Erfolgsfaktor (Churchill et al., 1985; Johnston und Marshall, 2009; Randall und Randall, 1990; Walker et al., 1977; Weitz et al., 1986). Laut Rüther (2007) wird die Qualitätswahrnehmung der LandwirtInnen in Bezug auf die Fachberatung durch drei Qualitätsdimensionen bestimmt, die fachliche und methodische Beratungskompetenz, die persönlichen Beratereigenschaften und die Erreichbarkeit und der Preis der Beratung. Bezugnehmend auf die Fachberatung stellt die erste Qualitätsdimension, also die fachliche Kompetenz der Beratenden den wichtigsten Faktor dar (Rüther, 2007; Rüther und Maier, 2007). 
Im Gegensatz dazu zeigen die Ergebnisse der vorliegenden Studie, dass eben nicht die Fachkompetenz den größten Einfluss hat, sondern die Persönlichkeit eines Außendienstmitarbeitenden, ebenso wie dessen Sozialkompetenz. Das heißt, dass LandwirtInnen zwar die fachlichen Kompetenzen der Außendienstmitarbeitenden durchaus als gut einschätzen, diese jedoch nicht als Hauptfaktor in die Gesamtbeurteilung einfließen. Erfolgsentscheidend ist vielmehr eine gute Persönlichkeit der AußendienstmitarbeiterInnen gekoppelt mit guten sozialen Kompetenzen. Diese Ergebnisse finden sich ebenfalls in den vorliegenden wissenschaftlichen Beiträgen. So gilt die Persönlichkeit als die wichtigste Erfolgskomponente, deren Leistungspotentiale oft noch nicht ausgeschöpft sind (Menthe und Sieg, 2013). Hervorzuheben ist auch, dass laut Homburg et al. (2012) eine positive Korrelation zwischen einer positiv ausgeprägten Persönlichkeit, hier insbesondere Empathie, und dem Verkaufsabschluss besteht. Werden die Ergebnisse der vorliegenden Studie auf die Aussage von Homburg et al. (2012) übertragen, so werden Außendienstmitarbeitende mit einer höheren Ausprägung der Persönlichkeit besser bewertet als jene mit einer weniger ausgeprägten Persönlichkeit.

In der Praxis zeigt sich jedoch häufig das skizzierte Bild der alles überragenden Fachkompetenz. Hier überzeugen Außendienstmitarbeitende oft mit hervorragendem Produktund Anwendungswissen, wobei ihre verkäuferische Kommunikation deutliche Schwächen aufweist (Menthe und Sieg, 2013). Die beschriebene Angleichung der Produkte und Dienstleistungen der Unternehmen im Agribusiness setzt meist voraus, dass die fachliche Kompetenz zu einem wichtigen Verkaufsargument, insbesondere für komplexe Produkte, wird (Bänsch, 2013; Homburg et al., 2012). Zusätzlich setzen Unternehmen der Vorleistungsindustrie zusehends Fach- und SpezialberaterInnen zur Unterstützung des Außendienstes ein. Aufgrund dieser Tatsache rückt die Fachkompetenz nochmals deutlich in den Fokus bei der Bewertung eines / einer AußendienstmitarbeiterIn. Dementsprechend liegt der Schwerpunkt in der Ausbildung (landwirtschaftliche Ausbildung, Hochschule und Universität) von Nachwuchskräften im Vertrieb auf der Vermittlung fachlicher Kompetenz. Der in dieser Studie bereits sehr gute Mittelwert der Fachkompetenz bestätigt eine gute fachliche Kompetenz der Außendienstmitarbeitenden. 
In Anbetracht der Ergebnisse des vorliegenden Beitrags ergibt sich für Unternehmen der landwirtschaftlichen Vorleistungsindustrie jedoch die Handlungsempfehlung, MitarbeiterInnen für den Außendienst nicht ausschließlich nach fachlichen Kompetenzen einzustellen, sondern auch der Persönlichkeit eine erhöhte Aufmerksamkeit zu widmen. Homburg et al. (2012) stellen hierzu fest, dass die Fachkompetenz durch Weiterbildungsmaßnahmen deutlich leichter weiterzuentwickeln ist, als die Persönlichkeit und die Sozialkompetenz. Daher sollten sich Unternehmen bei der Schulung ihrer bestehenden und künftigen MitarbeiterInnen nicht nur auf die Vermittlung von Fachwissen fokussieren, sondern deutlich mehr Ressourcen dafür investieren, die Stärken der Persönlichkeit und die sozialen Kompetenzen von Außendienstmitarbeitenden zu identifizieren und gezielt zu fördern. 


\section{Literatur}

Agritechnica (2017). Daten und Fakten. Das war die Agritechnica 2017. Rückblick. https://bit.ly/2VT6SWz. (15.09.18).

Backhaus, K., Erichson, B., Plinke, W. und Weiber, R. (2016). Multivariate Analysemethoden. Eine anwendungsorientierte Einführung. Springer Gabler, Berlin, Heidelberg. doi: 10.1007/978-3$662-46076-4$

Bänsch, A. (2013). Verkaufspsychologie und Verkaufstechnik. Oldenbourg Wissenschaftsverlag, München.

Behle, C. und vom Hofe, R. (2006). Handbuch Außendienst: Kundengewinnung und Kundenbindung; Gebietsmanagement und Key-Account-Management; Verkaufspsychologie und Preisgespräche. mi-Fachverlag, Landsberg am Lech.

Bühl, A. (2014). SPSS 22. Einführung in die moderne Datenanalyse. Pearson, Hallbergmoos.

Churchill, G.A., Ford, N.M., Hartley, S.W. und Walker, O.C. (1985). The Determinants of Salesperson Performance: A Meta-Analysis. Journal of marketing research 22(2): 103-118. doi: $10.2307 / 3151357$

Dannenberg, H. und Zupancic, D. (2008). Spitzenleistungen im Vertrieb. Optimierungen im Vertriebsund Kundenmanagement. Mit Handlungsempfehlungen. Gabler, Wiesbaden. doi: 10.1007/9783-8349-8769-3

Fredebeul-Krein, T. (2012). Koordinierter Einsatz von Direktmarketing und Verkaufsaußendienst im B2B-Kontext. Kundenmanagement \& Electronic Commerce. Springer Gabler Verlag, Wiesbaden. doi: 10.1007/978-3-8349-3940-1

Hair, J.F., Black, W.C., Babin, B.J. und Anderson, R.E. (2009). Multivariate data analysis. Pearson Prentice Hall, Upper Saddle River.

Hartl, U. (2017). Branchenanalyse Landtechnik: Entwicklungstrendsund Herausforderungen. Working Paper Forschungsförderung No. 052. Hans-Böckler-Stiftung, Düsseldorf.

Hemmerling, U., Pascher, P. und Naß, S. (2017). Situationsbericht 2017/18. Trends und Fakten zur Landwirtschaft. Deutscher Bauernverband e.V, Berlin.

Homburg, C., Schäfer, H. und Schneider, J. (2012). Sales excellence. Vertriebsmanagement mit System. Springer Gabler, Wiesbaden.

Johnston, M.W. und Marshall, G.W. (2009). Churchill-Ford-Walker's sales force management. McGraw-Hill/Irwin, Boston.

Keudell, R. von (2016). Vertrauen als wichtiges Asset in Zeiten der Volatilität und Globalisierung von Märkten. In: Keuper, F., Sommerlatte, T. (Hrsg.) Vertrauensbasierte Führung: Devise und Forschung. Springer Gabler, Berlin, Heidelberg, 27-36.

Maas, M. (2012). Praxiswissen Vertrieb. Berufseinstieg, Tagesgeschäft und Erfolgsstrategien. Gabler Verlag, Wiesbaden. doi: 10.1007/978-3-8349-7090-9

Menthe, T. und Sieg, M. (2013). Kundennutzen: die Anwendung im Verkaufsgespräch. So verhandeln Sie wert- und nutzenorientiert. Springer Gabler, Wiesbaden. doi: 10.1007/978-3-8349-3621-9

Randall, E.J. und Randall, C. H. (1990). Review of salesperson selection techniques and criteria: A managerial approach. International Journal of Research in Marketing 7(2-3): 81-95. doi: $10.1016 / 0167-8116$

Rüther, C. (2007). Untersuchungen zur Qualitätsbestimmung landwirtschaftlicher Fachberatung aus Kundenperspektive. Dissertation. Der Andere Verlag, Tönning, Lübeck, Marburg. 
Rüther, C. und Maier, P. (2007). Wie beurteilen LandwirtInnen Beratungsleistungen? Qualität landwirtschaftlicher Fachberatung. Fachzeitschrift B\&B Agrar 60(2): 54-56.

VDL (2014). Fach- und Führungskräftebedarf in der Agrarbranche Befragungen und Analysen im Agrarbereich 2013/2014. Berufsverband Agrar, Ernährung, Umwelt e.V., Berlin.

Walker Jr, O.C., Churchill Jr, G.A. und Ford, N. M. (1977). Motivation and performance in industrial selling: Present knowledge and needed research. Journal of marketing research 14(2): 156-168. doi: $10.2307 / 3150465$

Weitz, B.A., Sujan, H. und Sujan, M. (1986). Knowledge, Motivation, and Adaptive Behavior: A Framework for Improving Selling Effectiveness. Journal of Marketing 50(4): 174-191. doi: $10.2307 / 1251294$ 


\section{II.2 Identifizierung von Verkäufertypen in der landwirtschaftlichen Vorleistungsindustrie aus Sicht der landwirtschaftlichen KundInnen}

Authors: Dorothee Schulze Schwering, Jan-Philipp Huchtemann, Philipp Welter, Eike Nordmeyer, Achim Spiller \& Dominic Lemken

This article was published in similar form in German Journal of Agricultural Econonics (2020) 69 (3), $200-218$.

Doi:10.30430/69.2020.3.200-218 


\title{
II.2 Identifizierung von Verkäufertypen in der landwirtschaftlichen Vorleistungsindustrie aus Sicht der landwirtschaftlichen KundInnen
}

\begin{abstract}
Personal selling has become even more important as companies are moving towards serviceund solution-oriented businesses with a strong customer focus. Today, the performance measurement of sales perosnnel goes far beyond quantitative performance indicators und increasingly focuses personal characteristics und competencies of sales persons. While personal sales have already been scientifically investigated in many economic sectors, agricultural economic research is lacking in systematic analysis of behavioural patterns und competencies of salespersons. A survey of 238 agricultural entrepreneurs investigates how they perceive the sales force of the agricultural input industry und how they evaluate their competencies. The results show that three types of salespersons could be identified on the basis of the professional und social competence as well as the sales-oriented personality. $43 \%$ of the evaluated sales representatives of this study can be described as "sales talents" with good characteristics of the three success factors. $30 \%$ of sales representatives can be distinguished by their high level of professional competence, while $27 \%$ of sales representatives show weaknesses in all three success factors. Overall, it can be seen that professional competence varies more between the identified salesperson types than social competence und personality.
\end{abstract}

Key Words: Sales force; agricultural input industry; success factors; cluster analysis 


\section{Zusammenfassung}

In einer Zeit, in der sich Unternehmen zunehmend zu dienstleistungs- und lösungsorientierten Unternehmen mit starker Kundenfokussierung entwickeln, ist der persönliche Verkauf noch entscheidender geworden. Dabei geht die Leistungsmessung von VertriebsmitarbeiterInnen heute weit über quantitative Vertriebskennzahlen hinaus und ist zunehmend auf persönliche Eigenschaften und Kompetenzen des Vertriebspersonals ausgerichtet. Während der persönliche Verkauf in vielen Wirtschaftsbereichen bereits wissenschaftlich untersucht worden ist, mangelt es der agrarökonomischen Forschung an systematischen Analysen zu den Verhaltensmustern und Kompetenzen von Vertriebsmitarbeitenden. In einer Befragung von 238 landwirtschaftlichen Unternehmen wird untersucht, wie diese den Außendienst der landwirtschaftlichen Vorleistungsindustrie wahrnehmen und dessen Eigenschaften sowie Kompetenzen bewerten. Die Ergebnisse zeigen, dass anhand der in der vorliegenden wissenschaftlichen Literatur erkannten Erfolgsfaktoren Fach- und Sozialkompetenz sowie der Persönlichkeit von Außendienstmitarbeitern drei Verkäufertypen identifiziert werden konnten. Rund 43\% der bewerteten AußendienstmitarbeiterInnen dieser Studie lassen sich als "Verkaufstalente" mit guten Ausprägungen der drei Erfolgsfaktoren bezeichnen. 30\% der Außendienstmitarbeitenden zeichnen sich durch ihre hohe Fachkompetenz aus, während 27\% Schwächen in allen drei Erfolgsfaktoren aufweisen. Insgesamt zeigt sich, dass die Fachkompetenz zwischen den identifizierten Verkäufertypen stärker variiert als die Sozialkompetenz und die Persönlichkeit.

Schlüsselwörter: Außendienst; landwirtschaftliche Vorleistungsindustrie; Erfolgsfaktoren; Clusteranalyse 


\section{$1 \quad$ Einleitung}

Der persönliche Verkauf nimmt in vielen Unternehmen eine zentrale Funktion ein. In einer Zeit, in der sich Unternehmen zunehmend zu stärker dienstleistungsorientierten Anbietern entwickeln (Hohenschwert, 2012), ist die Rolle des Verkauspersonals noch wichtiger geworden (Abeysekera und Wickramasinghe, 2013). So hat sich der persönliche Verkauf von einer engeren Vertriebsfunktion zu einer stärkeren beratungs- und wertschöpfungsorientierten Funktion entwickelt (Terho et al., 2015; Zhang und Glynn, 2015). Zudem hat der Außendienst vielfach Einfluss auf zentrale betriebswirtschaftliche Größen wie den Unternehmenserfolg, die Kundenzufriedenheit (Baldauf und Cravens, 2002; Behrman und Perreault, 1982; Fritz, 1993; Homburg und Stock, 2004) und die Unternehmensreputation (Agnihothri et al., 2002; Ou et al., 2012). Nicht verwunderlich ist daher ein hoher Einsatz eines unternehmenseigenen Außendienstes, der von Unternehmen mit direktem Vertrieb zu etwa 68\% eingesetzt wird und damit über dem Einsatz von unternehmenseigenen Filialen, Internet, Katalogen oder dem Telefonverkauf liegt (Huckemann und Schmitz, 2016; Scholl, 2003). Insgesamt planen rund 46\% der deutschen Unternehmen, ihre personellen Kapazitäten im Vertrieb in den nächsten Jahren zu erhöhen (Schmitz und Wieseke, 2015).

Von großer Relevanz ist der Außendienst auch für die Unternehmen der landwirtschaftlichen Vorleistungsindustrie. Voss (2008) verweist in diesem Zusammenhang darauf, dass regelmäßige Kundenbesuche durch AußendienstmitarbeiterInnen in der landwirtschaftlichen Vorleistungsindustrie das meistgenutzte Marketinginstrument mit der höchsten Erfolgseinschätzung sind. In Agrarunternehmen bekleiden rund 32\% der Mitarbeiter eine Position im Vertrieb, wobei ein steigender Bedarf an VertriebsmitarbeiterInnen prognostiziert wird (VDL, 2014). Dabei müssen sich Vertriebsmitarbeitende unter anderem mit komplexer werdenden Vertriebssituationen auseinandersetzen, ihre Kunden in wettbewerbsintensiven Umgebungen überzeugen, Kundenvertrauen aufbauen und die gesteckten vertrieblichen Ziele des Unternehmens erreichen (Ahearne und Rapp, 2010; Franklin und Marshall, 2019; Herjanto und Franklin, 2019; Metze und Igl, 2012).

Angesichts der Bedeutung der persönlichen Leistung von Verkäufern ist die Messung der Vertriebsleistung bzw. der Außendienstqualität ein wichtiges Thema (Fritz, 1993; Zallocco et al., 2009). Dabei kann die Vertriebsleistung einerseits anhand von quantitativen Kennzahlen (insbesondere Verkaufszahlen, Umsatz) und andererseits von qualitativen Indikatoren (Persönlichkeit, Produkt- und Kundenwissen, Verkaufsfähigkeiten) gesteuert werden 
(Behrman und Perreault, 1982; Hohenschwert, 2012; Jackson et al., 1983). Gerade mit der zunehmenden Bedeutung einer kundenorientierten Vertriebsausrichtung und komplexer werdenden Verkaufssituationen blicken Unternehmen bei der Messung und Bewertung der individuellen Verkaufsleistung über Kennzahlen wie Absatzzahlen und Umsatz hinaus (Zallocco et al., 2009). Einige wissenschaftliche Untersuchungen plädieren für eine Anpassung der Vertriebsleistungskennzahlen (Ingram et al., 2005; Zallocco et al., 2009). Eine Möglichkeit ist die Wahrnehmung des eigenen Außendienstes durch die Kundschaft einzubeziehen, also die Zufriedenheit der KundInnen mit der Betreuung durch den Außendienst als eine Kennzahl zu nutzen.

Trotz der Praxisrelevanz existieren in der agrarökonomischen Forschung nur wenige Untersuchungen zu den vertriebsrelevanten Persönlichkeitsmerkmalen, Fähigkeiten und Verhaltensweisen von Vertriebsmitarbeitenden. Vergleichbare Literatur bezieht sich auf die Bewertung und Analyse der landwirtschaftlichen Fachberatung (Maier, 2013; Rüther und Maier, 2007), diese ist jedoch nicht direkt auf die anders gelagerten Aufgaben des Vertriebs übertragbar. Es gibt demnach wenige Erkenntnisse darüber, wie AußendienstmitarbeiterInnen von LandwirtInnen wahrgenommen werden. Der vorliegende Beitrag greift diese Fragestellung auf und analysiert mittels einer Clusteranalyse, welche Verkäufertypen sich im Agribusiness auf Basis des Verhaltens im Kundenkontakt identifizieren lassen. Die Identifizierung von Verkäufertypen trägt dazu bei, das Verhalten von VerkäuferInnen im Kundenkontakt, die Beziehung zur Kundschaft und das Verkaufsfeld, in dem sich der Vertriebsmitarbeitende befindet, besser zu verstehen. Segmentiert wird anhand der in der Literatur identifizierten Erfolgsfaktoren von Verkäufern, nämlich Sozial- und Fachkompetenz sowie Vertriebsorientierung der Persönlichkeit. Die Analyse erfolgt auf der Grundlage einer empirischen Untersuchung bei 238 landwirtschaftlichen Unternehmen. Zusätzlich liefert diese Betrachtung Ansatzpunkte für die Qualifikation von Vertriebsmitarbeitern mit direktem Kundenkontakt.

Im Weiteren werden zunächst die Vertriebsstrukturen der landwirtschaftlichen Vorleistungsindustrie (Kapitel 2) und die in der Literatur diskutierten Kompetenzen und Erfolgsfaktoren von Vertriebsmitarbeitern (Kapitel 3) vorgestellt. Die Kapitel 4 und 5 stellen Methodik, Stichprobe und Ergebnisse der empirischen Untersuchung vor. In Kapitel 6 folgt die Diskussion der Forschungsergebnisse. Abschließend werden ein Fazit gezogen und Handlungsempfehlungen formuliert. 


\section{Vertriebsstrukturen in der landwirtschaftlichen Vorleistungsindustrie}

Unternehmen der Vorleistungsindustrie stellen landwirtschaftlichen Betrieben Investitionsgüter (z.B. Landmaschinen) und Betriebsmittel (bspw. Düngemittel, Pflanzenschutz, Genetik) zur Produktion agrarischer Erzeugnisse bereit (Koester, 2016; Plinke, 1991). Zur Vorleistungswirtschaft werden in diesem Beitrag die Teilbranchen Saatgut, Gebäude- und Maschineninstandhaltung, Düngemittel, Pflanzen-schutz, Futtermittel, Landtechnik, Energie und Tiergenetik sowie der private und genossenschaftliche Landhandel gefasst. Der Produktionswert der vorgelagerten Wirtschaftsbereiche lag, 2017 bei 47,2 Mrd. Euro, wovon 55\% auf landwirtschaftliche Betriebsmittel und 45\% auf den Agrarhandel und Dienstleister zurückzuführen sind (Pascher et al., 2018). Der Absatz der Vorleistungswirtschaft ist in den letzten Jahren unabhängig von der Anzahl landwirtschaftlicher Betriebe relativ konstant geblieben und somit nicht vom Strukturwandel betroffen (BMEL, 2019; Hemmerling et al., 2017, 2016; Pascher et al., 2018). Dennoch zeigt sich, dass sich die Ansprüche landwirtschaftlicher Betriebe gegenüber Unternehmen der Vorleistungsindustrie im Zuge der Digitalisierung und des Strukturwandels verändert haben. Landwirtschaftliche Kunden, die im Strukturwandel fortbestehen, professionalisieren und spezialisieren sich zunehmend und verfügen über größere Beschaffungsvolumina (Pionke, 2018).

Die Herstellung landwirtschaftlicher Produktionsmittel ist unterschiedlich organisiert (Voss, 2008). Während mittelständisch geprägte Unternehmen vielfach den Markt für Spezialund Nischenprodukte besetzen, dominieren wenige (globale) Unternehmen den Markt für forschungs- und entwicklungsintensive Produkte wie Saatgut, Pflanzenschutzmittel oder auch großer Feldtechnik (Voss, 2008). Der Absatz der Produkte der Vorleistungsindustrie erfolgt größtenteils über zwischengeschaltete Handelsstufen, welche traditionell durch den privaten oder genossenschaftlichen Land- bzw. Agrarhandel organisiert sind. Dementsprechend ist das deutsche Agribusiness seit langer Zeit durch indirekte Absatzwege gekennzeichnet (Gollisch und Theuvsen, 2015; Strecker et al., 2010).

Die Digitalisierung von Verkaufsprozessen (e-commerce) animiert Herstellerunternehmen der Vorleistungsindustrie dazu, ihre Produkte direkt an ihre landwirtschaftlichen Kundschaft zu vertreiben, z.B. durch einen eigenen Online-Shop oder über einen Marktplatz (Huchtemann und Theuvsen, 2018). Die Produkte und Dienstleistungen der landwirtschaftlichen Vorleistungsindustrie sind häufig komplex und erfordern eine auf die KundInnen zugeschnittene und individuelle Anpassung (Rüther und Maier, 2007). So setzen Hersteller 
verstärkt AußendienstmitarbeiterInnen mit einer Beratungsfunktion ein (Rüther und Maier, 2007). Aber auch der Landhandel und Genossenschaften binden einen Außendienst zur allgemeinen Produkt- und Anwendungsberatung ein. Wie die Abbildung 1 verdeutlicht, wird der Außendienst als persönlicher Kontaktpunkt zum landwirtschaftlichen Kunden eingesetzt.

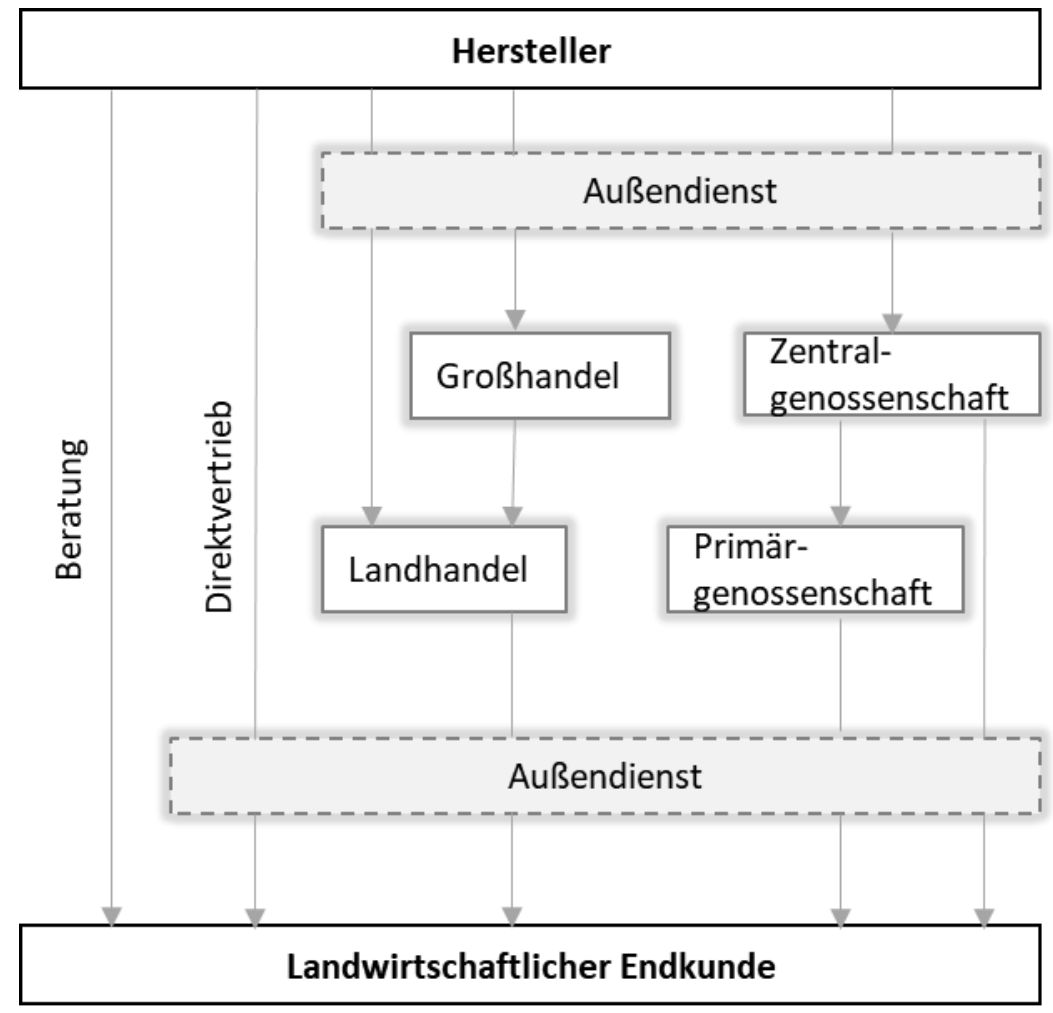

Abbildung 1: Vertriebsstrukturen der landwirtschaftlichen Vorleistungsindustrie Quelle: Eigene Darstellung in Anlehnung an Voss (2008)

Dabei ist der Außendienst des Handels vom Außendienst der Herstellerunternehmen zu unterscheiden. Letztere haben z.T. im Rahmen eines Direktvertriebs Verkaufsfunktionen, z.T. aber auch nur eine Beratungsfunktion, wenn ein Betriebsmittel herrstellendes Unternehmen über den Handel vertreibt, aber Beratung der LandwirtInnen durch den eigenen Außendienst anbietet. Eine weitere Funktion des Herstelleraußendienstes ist der Vertrieb an den Groß- und Einzelhandel. Dieser Bereich des Vertriebs wird in der vorliegenden Studie nicht erfasst, da nur LandwirtInnen als KundInnen befragt wurden (vgl. Kapitel 5).

AußendienstmitarbeiterInnen der landwirtschaftlichen Vorleistungsindustrie stehen etwa 15-23\% ihrer Arbeitszeit im direkten Kundenkontakt (Friedemann, 2010; Harris und Pike, 1996). Relevant ist der persönliche Verkauf durch den Außendienst vor allem deswegen, weil er als absatzfördernd für ein Unternehmen und als wichtig in Bezug auf die Bildung von Kundenpräferenzen und das Image des Unternehmens beim KundInnen gilt (Kotler und Bliemel, 1999; Kraft und Bosch, 2015). Im Durchschnitt berichten unzufriedene KundInnen 
etwa zwanzig anderen Menschen von ihren negativen Erfahrungen (Agnihothri et al., 2002; Ou et al., 2012). Ein guter persönlicher Kontakt kann dagegen zu Kundenzufriedenheit und bindung führen (Boles et al., 2000; Liu und Leach, 2001). Thiel (2017) verdeutlicht, dass KundInnen mit besonders starker Bindung zum Unternehmen dazu neigen, Anbieterleistungen in größerem Umfang zu beanspruchen, Konkurrenzprodukte abzulehnen und den Anbieter weiterzuempfehlen. Da in der landwirtschaftlichen Vorleistungsindustrie der direkte Kontakt zur Kundschaft meist über den Außendienst stattfindet (Abb. 1), fungiert dieser als Repräsentant des Unternehmens, dessen Reputation auf das gesamte Unternehmen zurückstrahlt.

\section{Kompetenzen und Erfolgsfaktoren von Vertriebsmitarbeitern}

Hinsichtlich des persönlichen Verkaufs liegt die Aufmerksamkeit der Wissenschaft und Praxis auf der Messung der Vertriebsleistung. Dabei geht es um das Verständnis, wie die Effizienz und die Effektivität des persönlichen Verkaufs gemessen und optimiert werden können (Friend et al., 2014; Singh und Koshy, 2010). Zurückzuführen ist die Fokussierung auf die Messung der Vertriebsleistung auf den bedeutsamen Beitrag von VertriebsmitarbeiterInnen zum Unternehmenserfolg (Baldauf und Cravens, 2002; Fritz, 1993), zur Unternehmensreputation (Agnihothri et al., 2002; Ou et al., 2012) und zur Kundenzufriedenheit (Abeysekera und Wickramasinghe, 2013; Goff et al., 1997).

Die Erfolgs- bzw. Leistungsmessung kann dabei sowohl quantitativ als auch qualitativ stattfinden. In der Praxis verbreitet ist die quantitative Leistungsmessung anhand der zentralen Leistungsindikatoren Umsatz und Neukundenrate (Behrman und Perreault, 1982). Unternehmen steuern und bewerten ihren Vertrieb anhand von durchschnittlich acht Kennzahlen, wovon etwa fünf zur wirksamen Entscheidungsfindung dienen (Huckemann und Schmitz, 2016). Zu den fünf meistgenutzten Vertriebskennzahlen zählen: Umsatz pro Produktgruppe, Umsatz pro Vertriebsmitarbeiter, Vertriebskosten in Relation zum Umsatz, Deckungsbeitrag pro Produktgruppe und die Anzahl neuer KundInnen (Huckemann und Schmitz, 2016). Diese Kenngrößen sind einfach zu erheben, gut vergleichbar und reliabel.

Doch gerade in der Wissenschaft liegt der Fokus zunehmend auf einer Leistungsmessung, welche über diese traditionellen Leistungsindikatoren hinausgeht. Die klassischen quantitativen Vertriebskennzahlen erscheinen zwar als objektiv, vernachlässigen aber die Tatsache, dass unterschiedliche Verkäuferleistungen auch auf Faktoren zurückzuführen sind, die außerhalb der Kontrolle des Verkaufspersonals liegen, wie z. B. unterschiedliche Kundenpotenziale in 
verschiedenen Verkaufsgebieten, abweichende Konkurrenzsituationen (Behrman und Perreault, 1982). Hinzu kommt, dass die Beziehung des Vertriebspersonals zur Kundschaft, deren Anstrengungen zur Repräsentation des Unternehmens bei den KundInnen sowie die Schaffung eines langfristigen Kundenmehrwertes keine Beachtung finden.

Insbesondere der wertorientierte Verkauf zählt zu den wichtigsten Treibern der Verkäuferleistung in B2B-Märkten (Hummels, 2009; Terho et al., 2012; Töytäri und Rajala, 2015). Der wertorientierte Verkauf beschreibt die konsequente Orientierung auf die Schaffung von Problemlösungen für die KundInnen an Stelle des Verkaufs von durch Anbieterunternehmen definierten Produktvorteilen (Hummels, 2009). Da der Verkauf auf langfristige Kundenbeziehungen fokussiert sein sollte, die klassischen Kennzahlen aber vornehmlich den kurzfristigen Absatzerfolg messen, besteht zunehmend die Notwendigkeit für Unternehmen, über die traditionellen (Ergebnis-) Kennzahlen der Vertriebsleistung hinauszugehen und auch verhaltensbezogene, eher langfristige Effekte messende Kennzahlen (z.B. verkäuferbezogene Kundenzufriedenheit, Grad der Kundeninteraktion, Teamwork) sowie Mitarbeiterkompetenzen (z.B. kommunikative und fachliche Kompetenzen) in die Leistungsmessung $\mathrm{zu}$ integrieren (Zallocco et al., 2009). Die Ermittlung von verhaltensbezogenen Kennzahlen und Mitarbeiterkompetenzen bilden zudem eine Grundlage für die Weiterentwicklung des Vertriebspersonals, bspw. durch Verkaufstrainings, Mentoringprogramme und Coachings (Zallocco et al., 2009). Johnston und Marshall (2013) erklären, dass die Leistung der VerkäuferInnen eine Funktion ist, die sowohl von den persönlichen Eigenschaften der VerkäuferInnen als auch von unternehmensbezogenen Faktoren abhängt.

Die Bestimmung und Messung von persönlichkeitsbezogenen Erfolgsfaktoren von VertriebsmitarbeiterInnen ist ein relativ häufiger Untersuchungsgegenstand der Vertriebsforschung (Hennig-Thurau und Thurau, 1999; Herjanto und Franklin, 2019; Spiro und Weitz, 1990; Verbeke et al., 2011; Zahn, 1997). Zu den wichtigsten Determinanten auf der persönlichen Ebene von VerkäuferInnen zählen laut Churchill et al. (1985) deren Eignung, Persönlichkeit, Qualifikationslevel, Rollenwahrnehmung und Motivation. Hinzu kommen organisatorische bzw. umweltbezogene Aspekte. Verbeke et al. (2011) sowie Herjanto und Franklin (2019) kamen nach der Überprüfung von rund 250 zwischen 1982 und 2017 veröffentlichten Beiträgen zu der Erkenntnis, dass alle sechs von Churchill et al. (1985) postulierten Determinanten der Verkäuferleistung auch heute noch nicht an Gültigkeit verloren haben. 
Homburg et al. (2016) nehmen die auf den Mitarbeiter bezogenen Faktoren von Churchill et al. (1985) Eignung, Persönlichkeit, Qualifikationslevel, Rollenwahrnehmung und Motivation auf und verdichten diese zu den drei Faktoren (1) vertriebsorientierte Persönlichkeit sowie (2) Fach- und (3) Sozialkompetenz. Sie unterscheiden pro Erfolgsfaktor vier bzw. sechs Determinanten, die die Ausprägung des jeweiligen Faktors bestimmen. Eine praxisorientierte Untersuchung bei 181 B2B-Anbietern und 302 Kunden, durchgeführt von Infoteam und dem F.A.Z-Institut, bestätigt in ähnlicher Form die Bedeutung dieser drei Schlüsselkompetenzen von Außendienstmitarbeitern. Demnach bilden die Professionalität (52\%), die Fachkompetenz (39\%) und die Sozialkompetenz (29\%) die bedeutendsten Kompetenzen von Außendienstmitarbeitenden (Mühlberger, 2010). Die drei genannten Schlüsselkompetenzen umfassen nicht immer identische, aber doch sehr ähnliche Einflussfaktoren (Churchill et al., 1985; Crosby et al., 1990; Verbeke, 1994; Yang und Wu, 2014). Im Folgenden werden diese Erfolgsfaktoren detaillierter vorgestellt.

Homburg et al. (2016) fassen Kontaktfreudigkeit, Selbstbewusstsein, Optimismus und Empathie als vertriebsorientierte Persönlichkeitseigenschaften von erfolgreichen VertriebsmitarbeiterInnen zusammen. Diese Eigenschaften spielen eine zentrale Rolle in der Bewältigung von Frustration und schwierigen Verkaufssituationen, mit denen VertriebsmitarbeiterInnen im unmittelbaren Kundenkontakt des operativen Vertriebs konfrontiert werden (Friedemann, 2010; Homburg et al., 2016; Homburg und Giering, 2001). Weitere Studien führen einen positiven Effekt der Persönlichkeitsmerkmale Kontaktfreude, Selbstkontrolle, Durchsetzungsvermögen, Offenheit und Anpassungsfähigkeit auf die Verkaufsleistung an (Rothmann und Coetzer, 2003; Verbeke, 1994). Rich (1999) untersuchte die Auswirkungen von Optimismus auf den Verkaufserfolg und fand heraus, dass optimistische VerkäuferInnen produktiver sind und sich intensiver im Unternehmen einbringen. Eine Konsumentenbefragung mit 484 Teilnehmenden zeigt einen positiven Einfluss von Empathie im Verkauf und verweist diesbezüglich auf eine höhere Wahrscheinlichkeit eines Verkaufsabschlusses (Pilling und Eroglu, 1994).

Aufgrund der Heterogenität der KundInnen benötigen AußendienstmitarbeiterInnen eine hohe Sozialkompetenz. Bestandteil der Sozialkompetenz sind verbale und nonverbale kommunikative Fähigkeiten, die helfen, sich auf die jeweiligen KundInnen einzustellen. Zusätzlich ist Teamfähigkeit von Bedeutung. Piercy et al. (1999) können hohe positive Korrelationen zwischen der Vertriebsleistung und verschiedenen Komponenten des Verkäuferverhaltens, wie beispielsweise adaptives Verkaufen, also die Anpassung des 
Verkaufenden an die Verkaufssituation, Teamfähigkeit und Verkaufspräsentation nach weisen. Die Bedeutung der Kommunikation innerhalb von Verkaufsinteraktionen und die Auswirkung unterschiedlicher Kommunikationspraktiken auf die Verkaufsleistung wird von weiteren Studien bestätigt (Boorom et al., 1998; Dion und Notarantonio, 1992). Homburg et al. (2016) fassen ein hohes $\mathrm{Maß}$ an Freundlichkeit und Flexibilität zu einer guten vertriebsorientierten Sozialkompetenz zusammen. Dion und Notarantonio (1992) zeigen, dass ein auf die Kundin / den Kunden zugeschnittener und freundlicher Kommunikationsstil des Verkaufspersonals zu besseren Verkaufsergebnissen führt.

Die Fachkompetenz bildet den dritten Erfolgsfaktor von Vertriebsmitarbeitenden. Dabei lassen sich die Einflussfaktoren so zusammenfassen, dass die MitarbeiterInnen wissen müssen, welches Produkt (Produktwissen) für welche KundInnen (Kundenwissen) und welchen Geschäftsbereich der KundInnen (Markt- und Geschäftswissen) relevant ist. Crosby et al. (1990) stellten fest, dass Produkt und Marktkenntnisse des Verkaufspersonals häufig ein wichtiges Kriterium für die Zufriedenheit der KundInnen darstellen und einen positiven Einfluss auf die Verkaufseffektivität haben. Yang und Wu (2014) konnten eine Beziehung zwischen der fachlichen Kompetenz und dem Vertrauen der KundInnen identifizieren. Sie vergleichen in ihrer Studie die Effekte der Sozialkompetenz und der Fachkompetenz und zeigen, dass der direkte Effekt der Sozialkompetenz auf die Vertriebsleistung höher ist als die Auswirkung der Fachkompetenz. Metze und Igl (2012) konstatieren, dass das Aufgabenspektrum von Außendienstmitarbeitenden im Agribusiness heute deutlich komplexer ist und Fertigkeiten und Kenntnisse aus interdisziplinären Bereichen erforderlich sind. Dementsprechend ergeben bereichsspezifische Fachkompetenzen, fächerübergreifende und außerfachliche Kompetenzen eine gute Kombination für MitarbeiterInnen im Außendienst (Metze und Igl, 2012).

Laut Kotler et al. (2007) lässt sich der Verkaufserfolg unter anderem auf Unterschiede im Verkaufsstil von Verkäufern zurückführen. Daher wurden in früheren Studien bereits Ansätze zur Identifizierung verschiedener Verkäufertypen entwickelt, um das Verkäuferverhalten sowie dessen Beziehung zur Kundschaft besser zu verstehen (Haas, 2002; Homburg et al., 2016; Homburg und Müller, 2009; Tomczak et al., 1998). In einem managementorientierten Ansatz stellen Homburg et al. (2016) vier verschiedene Verkäufertypen vor. Gebildet werden diese auf der Grundlage der drei beschriebenen Erfolgsfaktoren, welche sie zuvor in verschiedenen Branchen (IT, Chemie, Industriegüter) geprüft haben. Die Verkäufertypen werden als der „Vielwisser“, der „Socializer“, die „Verkaufsniete“ und der „Allrounder“ benannt. 
Das Idealbild ist der Allrounder, der durch eine hohe Fach- und Sozialkompetenz überzeugt. Bei ihm sind alle Erfolgsfaktoren stark ausgeprägt und er hat die besten Voraussetzungen für eine erfolgreiche Karriere im Vertrieb (Homburg et al., 2016). Es ist anzumerken, dass Homburg et al. (2016) die Faktoren Sozialkompetenz und vertriebsorientierte Persönlichkeit zusammenfassen, da ihrer Auffassung nach die Persönlichkeitseigenschaften einer Mitarbeiterin / eines Mitarbeiters die Sozialkompetenz bedingen und beide miteinander verknüpft sind (Homburg et al., 2016; Lang, 2009).

Die in der Literatur vorgestellten Ansätze zur Typologisierung von VerkäuferInnen wurden wissenschaftlich bisher nicht geprüft. Zudem zeigt die Literaturübersicht, dass bisher keine wissenschaftlichen Erkenntnisse darüber vorliegen, wie AußendienstmitarbeiterInnen der landwirtschaftlichen Vorleistungsindustrie von ihrer landwirtschaftlichen Kundschaft wahrgenommen und bewertet werden. Durch die Übertragung der skizzierten Zusammenhänge der Literatur auf das Vertriebsmanagement in der landwirtschaftlichen Vorleistungsindustrie sollen folgende Forschungsfragen in diesem Beitrag untersucht werden: Wie werden AußendienstmitarbeiterInnen in der landwirtschaftlichen Vorleistungsindustrie von ihren KundInnen hinsichtlich der Fach- und Sozialkompetenz und ihrer vertriebsorientierten Persönlichkeitseigenschaften bewertet? Können anhand der drei Erfolgsfaktoren unterschiedliche Verkäufertypen identifiziert werden und lässt sich damit der aus der Literatur abgeleitete managementorientierte Ansatz von Homburg et al. (2016) für das Agribusiness bestätigen?

\section{$4 \quad$ Material und Methoden}

\subsection{Studiendesign}

Die beschriebene Bewertung der Außendienstleistung, welche über die quantitativen Leistungsindikatoren hinausgeht, kann durch Fachleute, wie z. B. die Vertriebsleitung, durch KundInnen oder durch eine Selbstbewertung vorgenommen werden (Behrman und Perreault, 1982). Studien zeigen, dass bei einer Verkäuferbefragung (Saxe und Weitz, 1982) eine signifikant höhere Punktzahl/Leistung erzielt wird als bei einer Kundenbefragung (Michaels und Day, 1985). Grund dafür könnte sein, dass eine Selbstbewertung immer ein gewisses Risiko der Verzerrung birgt (Behrman und Perreault, 1982; Brown et al., 1991; Michaels und Day, 1985). Eine Beurteilung der Vertriebsleistung durch die Vertriebsleitung vernachlässigt hingegen Dinge, die außerhalb des Sichtfeldes der Vertriebsführung ablaufen. Bei der Bewertung durch die KundInnen wird das Verkaufspersonal hinsichtlich der Leistungsaspekte 
beurteilt, die sich auf die Einstellung der KundInnen und deren Kaufabsicht auswirken. Dadurch ist auch eine Quantifizierung der Wahrnehmung der AußendienstmitarbeiterInnen bei der Kundschaft möglich.

Im Rahmen der zunehmend diskutierten Kundenorientierung von Verkäufer Innen bietet sich mithin eine Beurteilung der AußendienstmitarbeiterInnen anhand einer Kundenbefragung an. Brown et al. (1991) raten dabei davon ab, Verkaufende ohne Bezug zu einer bestimmten Branche oder Verkaufssituation $\mathrm{zu}$ befragen und empfehlen, KundInnen um die Verkäuferbeurteilung einer gezielten Verkaufssituation oder einer bestimmten Branche zu bitten. Deshalb wurden in dieser Studie LandwirtInnen befragt, welche innerhalb der letzten 12 Monate von einem Außendienstmitarbeitenden auf ihrem Betrieb besucht wurden. Durchgeführt wurde die Onlinebefragung im November und Dezember 2017. Es wurde ein standardisierter Fragebogen erstellt und die ProbandInnen wurden mittels Schneeballsystems (persönliche Kontakte, soziale Medien und Verbände) angesprochen. Insgesamt besteht der Datensatz aus Angaben von 278 ProbandInnen. Dieser wurde für weitere Analysen auf seine Datenqualität geprüft und bereinigt. Hierzu wurden Teilnehmende, die innerhalb der letzten 12 Monate keinen Besuch vom Außendienst hatten $(n=35)$, sowie Teilnehmende, welche ein inkonsistentes, zu schnelles oder stereotypes Antwortverhalten aufwiesen $(n=5)$, aus dem Datensatz herausgenommen. Ein zu schnelles Antwortverhalten wurde anhand der Gesamtbearbeitungszeit ( $<6$ Minuten) und der Reaktionszeit pro Item ( $<2$ Sekunden), (Schnipke und Scrams, 1997) bestimmt. Für weitere Analysen verbleibt nach Datenbereinigung damit ein Datensatz mit Angaben von 238 LandwirtInnen.

Ziel der Erhebung und Gegenstand des vorliegenden Beitrages ist die Identifikation von Verkäufertypen. Grundlage ist die Wahrnehmung der AußendienstmitarbeiterInnen durch die befragten landwirtschaftlichen Unternehmen. Der Fragebogen gliedert sich in drei Themenbereiche. Im ersten Teil wurde das generelle Ansehen des Außendienstes sowohl branchenunabhängig („Bitte beurteilen Sie das Image (Ansehen) des Außendienstes im Agribusiness anhand von Schulnoten") als auch nach einzelnen Teilbranchen des Agribusiness („Beurteilen Sie bitte den Außendienst der verschiedenen Bereiche (z.B. Futtermittel, Düngemittel) in Schulnoten“) abgefragt. Darüber hinaus wurden allgemeine Aspekte wie Besuchshäufigkeit und -dauer erfragt. Im zweiten Teil erfolgte die Abfrage der für die Beantwortung der $\mathrm{zu}$ untersuchenden Forschungsfragen relevanten Eigenschaften der AußendienstmitarbeiterInnen. Die LandwirtInnen beurteilten die Eigenschaften der Mitarbeiterin, des Mitarbeiters, welche(r) sie zuletzt auf ihrem Betrieb besucht hat. 
Es wurde sich an den von Homburg et al. (2016) vorgeschlagenen Statements zur Ermittlung der vertriebsorientierten Persönlichkeit sowie der Sozial- und Fachkompetenz der AußendienstmitarbeiterInnen orientiert. Der Grad der Zustimmung wurde mit Hilfe von fünfstufigen Likert-Skalen von 1=,,trifft zu“ über 3=,,eils/teils“ bis 5=“trifft nicht zu“ ermittelt. Eine hohe Zustimmungsrate kann als eine positive bzw. starke Kompetenzausprägung verstanden werden. Das bedeutet, stimmen LandwirtInnen den Statements in hohem Maße zu, ist davon auszugehen, dass in ihrer Wahrnehmung der/die AußendienstmitarbeiterIn eine positive/starke Ausprägung der jeweiligen Kompetenz aufweist. Im letzten Abschnitt der Befragung erfolgte die Ermittlung von betriebsstrukturellen sowie soziodemografischen Daten.

\subsection{Datenanalyse}

Die Datenanalyse erfolgte unter Verwendung quantitativer Analysemethoden mit der Statistiksoftware IBM SPSS 24. Zunächst wurde eine deskriptive statistische Auswertung durchgeführt, um die demografischen Merkmale der Stichprobe zu beschreiben. Ziel der Analyse ist es, mittels einer Clusteranalyse, welche $\mathrm{zu}$ den multivariaten Analysemethoden zählt, die Datenpunkte zu möglichst homogenen Gruppen zusammenzufassen. Hierfür müssen zu Beginn der Analyse die Variablen, anhand derer die Cluster gebildet werden sollen, ausgewählt werden (Backhaus et al., 2016).

Da die drei Erfolgsfaktoren im Fragebogen mit mehreren Items erfasst wurden, erfolgte zunächst eine Verdichtung der Statements über eine konfirmatorische Faktorenanalyse (Hauptkomponentenanalyse) mit Varimax-Rotation. Die Ausgangsdaten wurden vor Beginn der Faktorenanalyse mittels variablenspezifischen Measure of sampling adequacy (MSA), Kaiser-Meyer-Olkin-Kriterium (KMO) und Bartlett-Test auf ihre Eignung für die Faktorenanalyse geprüft. Der Bartlett-Test auf Sphärizität prüft, ob Korrelationen zwischen den Variablen vorliegen. Eine Faktoranalyse kann dann fortgeführt werden, wenn die Korrelationsmatrix der beobachteten Variablen in der Grundgesamtheit ungleich der Einheitsmatrix ist (Backhaus et al., 2016). Um zu prüfen, ob ein nennenswerter Zusammenhang zwischen den Variablen besteht und die Daten somit für eine Faktorenanalyse geeignet sind, werden der KMO-Wert und die MSA-Werte herangezogen. Der KMO-Wert und der MSA-Wert sind sehr ähnlich. Während die MSA-Werte sich auf einzelne Variablen bezieht, kann der KMO-Wert als eine Verallgemeinerung der MSA-Werte für alle Variablen verstanden werden. Größere Werte sprechen für eine starke Zusammengehörigkeit der Variablen. Gemäß Kaiser und Rice (1974) werden Werte von <0,5 als ungeeignet zur Faktorenanalyse anges ehen. 
Als weitere Gütekriterien werden die Indikatorreliabilität (Faktorladung) und die erklärte Gesamtvarianz herangezogen. Guadagnoli und Velicer (1988) geben Bedingungen für die Interpretierbarkeit von Faktoren an. Zum einen kann ein Faktor interpretiert werden, wenn auf diesen Faktor wenigstens vier Variablen mit einer Ladung größer als 0,6 entfallen, und zum anderen kann eine Interpretation erfolgen, wenn mehr als zehn Variablen eine Ladung größer als 0,4 aufweisen. In der Literatur liegt kein exakter Grenzwert für die erklärte Gesamtvarianz vor, aller-dings werden Werte zwischen $50 \%$ und $60 \%$ verbreitet akzeptiert (Hair et al., 2009; Watson, 2017).

Die extrahierten Faktoren dienen dann als Grundlage für die Clusteranalyse (Backhaus et al., 2016), um homogene Untergruppen basierend auf den identifizierten Erfolgsfaktoren zu erhalten. Im Rahmen der Faktoranalyse wurden die Erfolgsfaktoren z-standardisiert, sodass die Faktorwerte in standardisierter Form vorliegen und einen Mittelwert von 0 sowie eine Standardabweichung von 1 aufweisen (Backhaus et al., 2016). Faktorwerte über (unter) 0 zeigen eine überdurchschnittliche (unterdurchschnittliche) Faktorausprägung für eine Untergruppe an.

Die Clusteranalyse erfolgt mehrstufig: Mittels Single-Linkage-Clustering werden zunächst Ausreißer identifiziert, welche in weiteren Berechnungen nicht berücksichtigt werden. Anschließend werden mit der hierarchischen Clusteranalyse mittels des bewährten Ward-Verfahrens und der quadrierten euklidischen Distanz die verschiedenen Möglichkeiten der Cluster-anzahl identifiziert. Die Festlegung der Clusteranzahl erfolgt nach einem systematischen Vergleich der Clustermöglichkeiten anhand des Dendrogramms sowie der Agglomerationstabelle mittels Elbow-Kriteriums. Die festgelegte Clusteranzahl wurde zusätzlich auf ihre inhaltliche Interpretierbarkeit überprüft. Die Cluster-Zentroide werden dann als Ausgangspunkt für eine endgültige Partitionierungs-Cluster-Methode (K-Means) verwendet, was die Homogenität der Gruppen verbessert (Backhaus et al., 2016; Milligan und Hirtle, 2013). Die Klassifikationsgenauigkeit der Analyse wird abschließend mittels Diskriminanzanalyse bewertet (Morrison, 1969). Zur Beurteilung der Heterogenität der identifizierten Cluster können die F-Werte und die Signifikanzen der Ergebnisse herangezogen werden. 


\section{$5 \quad$ Ergebnisse der empirischen Studie}

\subsection{Stichprobenbeschreibung}

Die Stichprobe beinhaltet Angaben von 238 landwirtschaftlichen Unternehmen. Mit 70,4\% sind die BetriebsleiterInnen in dieser Stichprobe dominierend. $21 \%$ sind mitarbeitende Familienmitglieder, und weniger als $10 \%$ der BefragungsteilnehmerInnen stehen in einem Anstellungsverhältnis. Das Geschlechterverhältnis entspricht mit einem Anteil von 87\% männlichen und 13\% weiblichen ProbandInnen weitgehend der Grundgesamtheit von Betriebsleitern in Deutschland (Statista, 2011). 83\% der ProbandInnen sind unter 55 Jahren, wodurch sie im Vergleich zur Grundgesamtheit, mit 40\% der Betriebsleiter Innen über 55 Jahre, deutlich jünger sind (BMEL, 2016; Hemmerling et al., 2016). 48,7\% der Teilnehmenden haben einen Hochschulabschluss. Unter den BetriebsleiterInnen in der deutschen Landwirtschaft haben dagegen weniger als 8\% einen Hochschulabschluss (BMEL, 2016). Damit sind die Teilnehmenden jünger und weisen im Durchschnitt einen deutlich höheren Bildungsabschluss auf als der Durchschnitt der BetriebsleiterInnen im landwirtschaftlichen Sektor in Deutschland. Knapp 42\% der TeilnehmerInnen bewirtschaften einen Betrieb in Norddeutschland, gefolgt von Westdeutschland (28\%), Süddeutschland (19\%) und Ostdeutschland (11\%). 93\% der Betriebe werden im Haupterwerb und 91\% konventionell bewirtschaftet. Dabei bewirtschaften gut 50\% der Befragten zwischen 50 und 200 Hektar. Knapp 19\% sind Großbetriebe mit einer Bewirtschaftung von mehr als 500 Hektar. Im deutschen Durchschnitt sind Haupterwerbsbetriebe etwa 60 Hektar groß (Hemmerling et al., 2017). Der Betriebsschwerpunkt liegt für 26,5\% auf der Sparte Ackerbau/Marktfruchtbau, 41\% sind viehhaltende Betriebe, knapp 30\% bezeichnen sich als Mischbetriebe und 2,5\% bauen Gemüse oder Sonderkulturen an. 2016 lag der Anteil viehloser landwirtschaftlicher Betriebe in Deutschland bei rund 32,8\% und rund 67\% aller Betriebe hielten Vieh (Pascher et al., 2018).

\subsection{Beschreibung der Außendienstbesuche}

Tabelle 1 gibt einen Überblick über die Häufigkeit und Dauer der Außendienstbesuche auf den Betrieben der StudienteilnehmerInnen. Innerhalb der letzten 12 Monate wurden $60 \%$ der Befragten ein bis mehrmals im Monat von einer(m) Außendienstmitarbeiter-/in besucht. $16 \%$ der Teilnehmenden wurden sogar mindestens einmal in der Woche besucht, während $24 \%$ weniger als einmal im Monat besucht wurden. Dabei verbringen die Mitarbeitenden im Außendienst im Durchschnitt, 20 bis 45 Minuten auf den Betrieben. Während 44,5\% der 
Befragten mit der Besuchshäufigkeit zufrieden sind, empfinden 40,5\% die Besuche als zu oft und $15 \%$ als zu selten stattfindend.

Tabelle 1: Besuchshäufigkeit und Besuchsdauer

\begin{tabular}{ll|lc}
\hline \multicolumn{1}{c}{ Besuchshäufigkeit } & \multicolumn{2}{c}{ Durchschnittliche Besuchsdauer } \\
\hline (1) Mehrmals die Woche & $7 \%$ & (1) < 20 min & $34 \%$ \\
(2) Einmal in der Woche & $9 \%$ & (2) $20-45 \mathrm{~min}$. & $56 \%$ \\
(3) Mehrmals im Monat & $30 \%$ & (3) $46-90 \mathrm{~min}$. & $9 \%$ \\
(4) Einmal im Monat & $30 \%$ & (4) $>90 \mathrm{~min}$. & $1 \%$ \\
(5) Seltener & $24 \%$ & & \multirow{2}{*}{$15 \%$ eher zu selten. } \\
\hline Die Besuche erfolgen für: & \multicolumn{3}{c}{ 44,5\% genau im } \\
\hline \multicolumn{3}{c}{ richtigen Rhythmus. } \\
\hline
\end{tabular}

Quelle: Eigene Erhebung ( $\mathrm{n}=238$ ) () geben die Skalierung an.

Die LandwirtInnen wurden gebeten, die Kompetenzen des/der Außendienstmitarbeiter-/in zu bewerten, der/die sie zuletzt, aber mindestens innerhalb der letzten 12 Monate, auf ihrem Betrieb besucht hat. Es wurden Außendienstmitarbeitende der Futtermittelindustrie (30\%), Agrartechnik (25\%), Saatgut (18\%), Agrarhandel (10\%) und Sonstige (17\%) bewertet. 95\% de s bewerteten Außendienstpersonals war männlich. Insgesamt wird der Außendienst mit einer durchschnittlichen Schulnote von 2,7 von den LandwirtInnen als befriedigend bewertet.

\subsection{Faktorenanalyse}

Die Ergebnisse der konfirmatorischen Faktorenanalyse sind in Tabelle 2 dargestellt. Es wurde eine konfirmatorische Faktorenanalyse gewählt, da es zu überprüfen galt, ob die drei in der Literatur identifizierten Fähigkeiten von VerkäuferInnen auch im landwirtschaftlichen Außendienst von den LandwirtInnen wahrgenommen werden. Es konnten drei Faktoren mit insgesamt 18 Items und einem Eigenwert größer eins gebildet werden. Die geeigneten Statements werden mit einem KMO-Wert von 0,918 als erstaunlich (Kaiser und Rice, 1974) bezeichnet und übertreffen den Grenzwert mit 55,5 \% erklärter Gesamtvarianz. Die interne Konsistenz der Faktoren wurde mittels Cronbachs Alpha $(\mathrm{C} \alpha)$ geprüft, wobei alle Faktoren ein $\mathrm{C} \alpha$ von über 0,8 aufweisen und daher als reliabel akzeptiert werden können. Die gebildeten Faktoren bestätigen die drei durch Homburg et al. (2016) eingeführten Erfolgsfaktoren von AußendienstmitarbeiterInnen.

Der erste Faktor beschreibt die Dimension Sozialkompetenz (Homburg et al., 2016). Der Faktor gibt an, wie kompetent die VerkäuferInnen im Umgang mit ihrer Kundschaft sind und wie sie Verkaufsgespräche gestalten. Die sechs auf den zweiten Faktor ladenden Items beschreiben die 
Fachkompetenz. Diese umfasst sowohl gute Kenntnisse über eigene Produkte und KundInnen als auch über den Markt und die Aktivitäten des Wettbewerbs. In Anlehnung an Homburg et al. (2016) kann der dritte Faktor als vertriebsorientierte Persönlichkeit bezeichnet werden. Die Items, die auf diesen Faktor laden, beschreiben die für die Vertriebsarbeit begünstigenden Charaktereigenschaften des Verkaufspersonals, wie z.B. Kontaktfreudigkeit, Selbstbewusstsein und gute Problemlösungskompetenz.

Tabelle 2: Faktorenanalyse

\begin{tabular}{|c|c|c|c|}
\hline Faktoren/Statements & Ladung & Mittelwert & $\begin{array}{l}\text { Standard- } \\
\text { abweichung }\end{array}$ \\
\hline \multicolumn{4}{|l|}{ Sozialkompetenz $($ Cronbach's Alpha $=0,86)$} \\
\hline Ist kritikfähig. & 0,778 & 2,12 & 0,849 \\
\hline Passt sein Verhalten der Gesprächssituation an. & 0,769 & 1,90 & 0,805 \\
\hline Betreibt aktives Zuhören im Verkaufsgespräch. & 0,746 & 1,92 & 0,858 \\
\hline Schafft eine angenehme Gesprächsatmosphäre. & 0,743 & 1,92 & 0,820 \\
\hline Lässt mich aussprechen. & 0,712 & 1,64 & 0,819 \\
\hline Stimmt sich mit seinen Kollegen im Innendienst gut ab. & 0,524 & 2,21 & 0,883 \\
\hline \multicolumn{4}{|l|}{ Vertriebsorientierte Persönlichkeit $($ Cronbach's Alpha $=0,820)$} \\
\hline Der Verkäufer geht von selbst auf mich zu. & 0,747 & 1,89 & 0,946 \\
\hline Ist sich sicher, meinen Anforderungen gerecht zu werden. & 0,683 & 1,95 & 0,796 \\
\hline $\begin{array}{l}\text { Bringt eigene Ideen und Vorschläge aktiv in unser } \\
\text { Gespräch ein. }\end{array}$ & 0,674 & 1,92 & 0,943 \\
\hline Er fühlt sich in der Zusammenarbeit mit mir wohl. & 0,667 & 2,02 & 0,862 \\
\hline $\begin{array}{l}\text { Er verarbeitet meine negativen Produkterfahrungen } \\
\text { schnell. }\end{array}$ & 0,633 & 2,31 & 0,961 \\
\hline Er verliert auch in schwierigen Situationen nicht den Mut. & 0,540 & 2,00 & 0,869 \\
\hline \multicolumn{4}{|l|}{ Fachkompetenz (Cronbach's Alpha $=0,803$ ) } \\
\hline Kennt die Preismargen seiner Produkte. & 0,739 & 1,88 & 0,936 \\
\hline Ist vertraut mit den Produkten der Konkurrenz. & 0,721 & 2,16 & 0,900 \\
\hline Kennt die Aktivitäten des Wettbewerbs. & 0,676 & 1,88 & 0,829 \\
\hline $\begin{array}{l}\text { Kennt das gesamt Produktportfolio des Unternehmens, } \\
\text { sowie die Merkmale und Leistungsfähigkeit der Produkte. }\end{array}$ & 0,632 & 1,77 & 0,816 \\
\hline Kennt die Kosten und Nutzen des Produktes. & 0,622 & 1,76 & 0,788 \\
\hline $\begin{array}{l}\text { Hat ein realistisches Bild von der Marktposition des } \\
\text { eigenen Unternehmens. }\end{array}$ & 0,556 & 1,84 & 0,847 \\
\hline \multicolumn{4}{|c|}{ Mittelwerte auf einer Skala: $1=$, ,Trifft zu“ bis 5=,,Trifft nicht zu“; KMO=0,918; Erklärte Gesamtvarianz $=55,469 \% ; \mathrm{n}=238$} \\
\hline
\end{tabular}


Insgesamt wird aus der Tabelle 2 ersichtlich, dass die Items auf einer fünfstufigen Likert-Skala von 1=,,trifft zu“ bis 2=,,trifft nicht zu“"Mittelwerte von 1,64 bis 2,31 aufweisen. Dies bedeutet, dass den drei Faktoren grundsätzlich eher zugestimmt wird, was einer positiven Ausprägung der Eigenschaften entspricht. Anhand der Mittelwerte zeigt sich auch, dass die Fachkompetenz im Mittel die höchste Zustimmung erfährt. Hier überzeugen AußendienstmitarbeiterInnen mit der Kenntnis über sowohl Kosten und Nutzen als auch über die Merkmale und Leistungsfähigkeit der Produkte. Den Items der Sozialkompetenz wird mit Mittelwerten zwischen 1,64 bis 2,21 eher zugestimmt. Als besondere Stärke der Außendienstmitarbeitenden wird die Fähigkeit gesehen, den/die Kunden-/in aussprechen zu lassen. Der Faktor vertriebsorientierte Persönlichkeit erhält eine geringere Zustimmungsrate als die beiden anderen Faktoren. Hier weicht der Mittelwert des Items „Er verarbeitet meine negativen Produkterfahrungen schnell “ am stärksten negativ ab. Die stärkste Zustimmung erhält hier die Eigenschaft der AußendienstmitarbeiterInnen, von selbst auf den Kunden zuzugehen.

\subsection{Clusteranalyse}

Tabelle 3 gibt einen Überblick über die Charakteristika der Cluster und Gütekriterien der Clusteranalyse. Mittels Single-Linkage-Clustering konnten 5 Ausreißer identifiziert werden, welche in weiteren Berechnungen nicht berïcksichtigt werden (neues $n=233$ ).

Tabelle 3: Ergebnisse der Clusteranalyse

\begin{tabular}{llcccr}
\hline $\begin{array}{l}\text { Clusterbildende } \\
\text { Merkmale }\end{array}$ & & $\begin{array}{c}\text { Cluster I } \\
\text { Das } \\
\text { "Vertriebstalent" }\end{array}$ & $\begin{array}{c}\text { Cluster II } \\
\text { Der } \\
\text { "Fachspezialist" }\end{array}$ & $\begin{array}{c}\text { Cluster III } \\
\text { Der } \\
\text { "Erträgliche" }\end{array}$ & $\begin{array}{c}\text { *F- } \\
\text { Wert }\end{array}$ \\
\hline Clustergröße (n) & 100 & 71 & 62 & \\
\multicolumn{2}{l}{ Anteil am Gesamtsample (\%) } & $42,9 \%$ & $30,5 \%$ & $26,6 \%$ & \\
\hline \multirow{2}{*}{ Fachkompetenz } & FMW & 0,08 & 0,80 & $-1,10$ & 142,7 \\
& SD & 0,66 & 0,59 & 0,69 & \\
\hline Vertriebsorientierte & FMW & 0,67 & $-0,42^{\text {III }}$ & $-0,34^{\mathrm{II}}$ & 73,94 \\
Persönlichkeit & SD & 0,48 & 0,68 & 0,82 & \\
\hline \multirow{2}{*}{ Sozialkompetenz } & FMW & 0,44 & $-0,21^{\mathrm{III}}$ & $-0,49 \mathrm{II}$ & 27,51 \\
& SD & 0,60 & 0,92 & 0,92 & \\
\hline
\end{tabular}

FMW=Mittelwert des Faktors auf einer Skala von $<0$ unterdurchschnittlich, 0 durchschnittlich, $>0$ überdurchschnittlich; $\mathrm{SD}=$ Standardabweichung; * ANOVA, höchst signifikant $(\mathrm{p}<0.001)$; II Nach dem Post-Hoc Test nach Scheffé unterscheidet

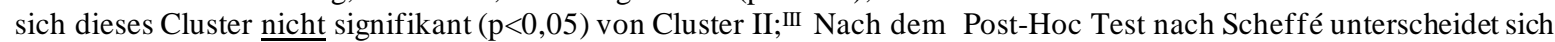
dieses Cluster nicht signifikant $(\mathrm{p}<0,05)$ von Cluster III. $(\mathrm{n}=233)$

Quelle: Eigene Erhebung.

Mit den drei gebildeten Faktoren als clusterbildende Variablen wurden dann eine hierarchische Clusteranalyse (Ward-Verfahren) sowie darauf aufbauend eine Partitionierungs-Clusteranalyse 
(K-Means) durchgeführt. Die Diskriminanzanalyse ergab eine gute Klassifikationsgenauigkeit der Cluster von 97,4\% (Morrison, 1969). Die Standardabweichungen innerhalb der Cluster sind geringer als die allgemeinen Standardabweichungen, was auf die Homogenität der Cluster hindeutet. Die Ergebnisse des F-Tests sind signifikant, was darauf hinweist, dass die Werte zwischen den Clustern heterogen sind und somit die Clusteranalyse zusammenfassend als erfolgreich bewertet werden kann (Tabelle 3). Der Faktor Fachkompetenz trennt die Cluster am stärksten $(\mathrm{F}-\mathrm{Wert}=142,698)$, gefolgt von dem Faktor vertriebsorientierte Persönlichkeit (F-Wert=73,94). Zur Überprüfung der Signifikanz zwischen den Clustern wurden Post-hoc-Tests durchgeführt. Tabelle 3 veranschaulicht, dass sich in der vorliegenden Studie alle Cluster im Bereich der Fachkompetenz signifikant voneinander unterscheiden. Hinsichtlich der Sozialkompetenz und der vertriebsorientierten Persönlichkeit unterscheiden sich Cluster II und III nicht signifikant voneinander.

Tabelle 4: Mittelwerte der 7 wichtigsten clusterbildenden Statements

\begin{tabular}{|c|c|c|c|c|c|c|c|}
\hline $\begin{array}{l}\text { Clusterbildende } \\
\text { Statements }\end{array}$ & & Gesamt & $\begin{array}{c}\text { Cluster I } \\
\text { Das } \\
\text { "Vertriehstalent" }\end{array}$ & $\begin{array}{c}\text { Cluster II } \\
\text { Der } \\
\text { "Fachsnezialist" }\end{array}$ & $\begin{array}{c}\text { Cluster III } \\
\text { Der } \\
\text { "Erträgliche" }\end{array}$ & $\begin{array}{c}* \mathbf{F}- \\
\text { Wert }\end{array}$ & $\beta$ \\
\hline \multirow{2}{*}{$\begin{array}{l}\text { Der Verkäufer geht von } \\
\text { selbst auf mich zu. (P) }\end{array}$} & MW & 1,85 & 1,32 & $2,23^{\mathrm{III}}$ & $2,27^{\mathrm{II}}$ & \multirow{2}{*}{42,75} & \multirow{2}{*}{0,24} \\
\hline & SD & 0,89 & 0,60 & 0,88 & 0,88 & & \\
\hline \multirow{2}{*}{$\begin{array}{l}\text { Kennt die Preismargen } \\
\text { seiner Produkte. }(\mathrm{F})\end{array}$} & MW & 1,87 & $1,59^{\mathrm{II}}$ & $1,42^{\mathrm{I}}$ & 2,82 & \multirow{2}{*}{80,01} & \multirow{2}{*}{0,24} \\
\hline & $\mathrm{SD}$ & 0,91 & 0,65 & 0,55 & 0,90 & & \\
\hline \multirow{2}{*}{$\begin{array}{l}\text { Ist sich sicher, meinen } \\
\text { Anforderungen gerecht } \\
\text { zu werden. (P) }\end{array}$} & MW & 1,91 & 1,59 & 1,93 & 2,42 & \multirow[b]{2}{*}{30,32} & \multirow[b]{2}{*}{0,23} \\
\hline & SD & 0,74 & 0,59 & 0,59 & 0,82 & & \\
\hline \multirow{2}{*}{$\begin{array}{l}\text { Schafft eine angenehme } \\
\text { Gesprächsatmosphäre. } \\
\text { (S) }\end{array}$} & MW & 1,92 & 1,48 & 1,99 & 2,55 & \multirow[b]{2}{*}{47,32} & \multirow[b]{2}{*}{0,19} \\
\hline & SD & 0,81 & 0,56 & 0,82 & 0,69 & & \\
\hline \multirow{2}{*}{ Ist kritikfähig. (S) } & MW & 2,11 & 1,68 & 2,24 & 2,66 & \multirow{2}{*}{38,00} & \multirow{2}{*}{0,16} \\
\hline & SD & 0,82 & 0,71 & 0,78 & 0,63 & & \\
\hline \multirow{2}{*}{$\begin{array}{l}\text { Er verliert auch in } \\
\text { schwierigen Situationen } \\
\text { nicht den Mut. (P) }\end{array}$} & MW & 1,96 & 1,52 & $2,23^{\mathrm{III}}$ & $2,37^{\mathrm{II}}$ & \multirow[b]{2}{*}{34,58} & \multirow[b]{2}{*}{0,13} \\
\hline & SD & 0,81 & 0,58 & 0,83 & 0,75 & & \\
\hline \multirow{2}{*}{$\begin{array}{l}\text { Ist vertraut mit den } \\
\text { Produkten der } \\
\text { Konkurrenz. (F) }\end{array}$} & MW & 2,16 & $1,94^{\mathrm{II}}$ & $1,82^{\mathrm{I}}$ & 2,90 & \multirow[b]{2}{*}{40,82} & \multirow[b]{2}{*}{0,10} \\
\hline & $\mathrm{SD}$ & 0,88 & 0,77 & 0,74 & 0,76 & & \\
\hline
\end{tabular}

$\mathrm{SD}=$ Standardabweichung, MW= Mittelwert Likert-Skala: 1=,trifft zu“ bis 5=,trifft nicht zu“; * ANOVA, höchst signifikant (p<0.001); I,II,III Der Post-Hoc-Test nach Scheffé besagt, dass sich dieses Cluster, bezogen auf das jeweilige Statement, nicht signifikant $(p<0,05)$ von Cluster I (II, III) unterscheidet. P, F und S zeigen die Zugehörigkeit zu den Faktoren: P - Persönlichkeit; F - Fachkompetenz und S - Sozialkompetenz an. ( $\mathrm{n}=233)$

Quelle: Eigene Erhebung.

Tabelle 4 zeigt die sieben wichtigsten clusterbildenden Statements. Die Wichtigkeit der Statements (Tabelle 4) wurde anhand des mittleren Diskriminanzkoeffizienten $(\beta)$ ermittelt. Dieser gibt die diskriminatorische Bedeutung einer Merkmalsvariablen bezüglich aller 
Diskriminanzfunktionen an, indem die mit dem Eigenwert gewichteten absoluten Werte der Koeffizienten einer Merkmalsvariablen addiert werden (Backhaus et al., 2016). Allgemein zeigen die angegebenen Mittelwerte für die Gesamtstichprobe, dass LandwirtInnen den Außendienst in allen drei Bereichen positiv wahrnehmen, da die Werte aller dargestellten Statements unterhalb des mittleren Wertes (3) liegen und damit positiv ausgeprägt sind. Dennoch lassen sich Unterschiede zwischen den Clustern feststellen.

\section{Cluster I - Das "Vertriebstalent"}

43\% ( $\mathrm{n}=100)$ und damit der größte Anteil der Außendienstmitarbeiter Innen zeichnet sich durch eine gute Bewertung aller drei Erfolgsfaktoren aus, da die Mittelwerte aller Faktoren im positiven Bereich liegen (Tabelle 3). Der Faktor vertriebsorientierte Persönlichkeit hat mit 0,67 die stärkste Ausprägung, während die Fachkompetenz mit einem Mittelwert von 0,08 eher als durchschnittlich einzustufen ist. Außendienstmitarbeiter Innen dieses Clusters wird zudem eine gute Sozialkompetenz zugesprochen. Die Übersicht der wichtigsten clusterbildenden Statements (Tabelle 4) verdeutlicht zusätzlich, dass Cluster I im Vergleich zu den anderen beiden Verkäufertypen über nahezu alle Variablen hinweg gut bewertet wird und keine wesentlichen Defizite aufweist. Der Mittelwert bei der Kritikfähigkeit zeigt an, dass diese AußendienstmitarbeiterInnen kritikfähiger sind $(1,68)$ als VerkäuferInnen des zweiten $(2,24)$ und dritten $(2,66)$ Typs. Die Fachkompetenz dieser Verkäufergruppe ist nur leicht überdurchschnittlich und nähert sich eher einer, im Vergleich zu den anderen VerkäuferInnen, durchschnittlichen Ausprägung an. So haben Verkaufende dieses Clusters beispielsweise weniger Kenntnisse über die Preismargen der eigenen Produkte als Verkaufende der zweiten Gruppe (Tabelle 4). Im Vergleich zu den anderen Verkäufertypen geht der erste Verkäufertyp jedoch selbstständiger auf die Kunden zu und schafft eine angenehmere Gesprächsatmosphäre. Zudem überzeugt er im Vergleich zu den anderen Clustern stärker mit Selbstsicherheit, Kritikfähigkeit und dem Umgang mit schwierigen Situationen. Unter Berücksichtigung dieser Charakterisierungsmerkmale kann man VertriebsmitarbeiterInnen des ersten Clusters vereinfachend als "Vertriebstalente" bezeichnen.

\section{Cluster II - Der "Fachspezialist"}

Der mit $31 \%(n=71)$ am zweithäufigsten vertretene Verkäufertyp wird von Cluster II beschrieben. AußendienstmitarbeiterInnen des zweiten Clusters zeichnen sich durch eine überdurchschnittliche Ausprägung der Fachkompetenz und eine unterdurchschnittliche Ausprägung der vertriebsorientierten Persönlichkeit aus. Beispielsweise wissen sie sehr gut über Preismargen ihrer Produkte $(1,42)$ und über Produkte der Konkurrenz $(1,82)$ Bescheid, 
und das signifikant besser als die AußendienstmitarbeiterInnen des Clusters drei (Tabelle 4). Hinsichtlich der für die Vertriebsarbeit begünstigenden Persönlichkeitseigenschaften und der Sozialkompetenz unterscheidet sich dieses Cluster nicht signifikant vom dritten Cluster. Verkaufenden dieser Gruppe fällt es, im Vergleich zum ersten Cluster, schwerer selbstständig auf die KundInnen zuzugehen $(2,23)$ und sich in schwierigen Situationen zurechtzufinden $(2,23)$. Bei der Betrachtung der Einzelstatements fällt zudem auf, dass dieser Verkäufertyp selbstsicherer und kritikfähiger ist als die VerkäuferInnen des dritten Clusters (Tabelle 4). Die Sozialkompetenz und vertriebsorientierte Persönlichkeit dieser Gruppe sind als durchschnittlich einzustufen, während ihre Fachkompetenz im Vergleich zu den anderen Clustern überdurchschnittlich ausgeprägt ist. Insgesamt lässt sich diese Verkäufergruppe vereinfacht mit dem Begriff "Fachspezialisten" umschreiben.

\section{Cluster III - Der "Erträgliche"}

Das dritte Cluster wird von rund $27 \%$ der AußendienstmitarbeiterInnen im Agribusiness repräsentiert. Die Faktorwerte der dem Cluster III zugehörigen AußendienstmitarbeiterInnen sind durch jeweils unterdurchschnittliche Ausprägungen bezüglich aller Clustervariablen gekennzeichnet. Die Fachkompetenz sowie die vertriebsorientierte Sozialkompetenz und Persönlichkeit des dritten Clusters werden signifikant schlechter bewertet als die von Cluster I. Besonders schwach ausgeprägt ist die Fachkompetenz dieser Verkäufergruppe (Tabelle 3 und 4). Hier werden die AußendienstmitarbeiterInnen dieses Clusters nur noch mit teils/teils bewertet, die Bewertung liegt bei den Einzelstatements um rund einen Skalenwert schlechter als bei den anderen beiden Gruppen. Auch über die Statements zu den Persönlichkeitseigenschaften und insbesondere zur Sozialkompetenz hinweg lässt sich eine schlechtere Bewertung erkennen. Die Statements „Ist kritikfähig“ und „Schafft eine angenehme Gesprächsatmosphäre" (Sozialkompetenz) sowie das Statement des Faktors vertriebsorientierte Persönlichkeit „Ist sich sicher meinen Anforderungen gerecht zu werden “ werden, im Vergleich zu den anderen Verkäufertypen, signifikant schwächer bewertet. Durch die eher schwache Ausprägung der drei Erfolgsfaktoren lässt sich diese Gruppe von AußendienstmitarbeiterInnen als die "Erträglichen" bezeichnen.

Abbildung 2 visualisiert die Ausprägung der Fach- und Sozialkompetenz sowie der vertriebsorientierten Persönlichkeit für die drei identifizierten Cluster. Dargestellt sind die standardisierten Mittelwerte der Faktoren (s. Tabelle 3). Die Grafik zeigt, dass "Erträgliche" im Vergleich zu den anderen beiden Verkäufertypen vor allem bei der Fachkompetenz abfallen, 
während "Fachspezialisten" diesbezüglich besonders herausstechen. Das "Vertriebstalent" überzeugt hingegen vor allem durch seine Persönlichkeit und Sozialkompetenz.

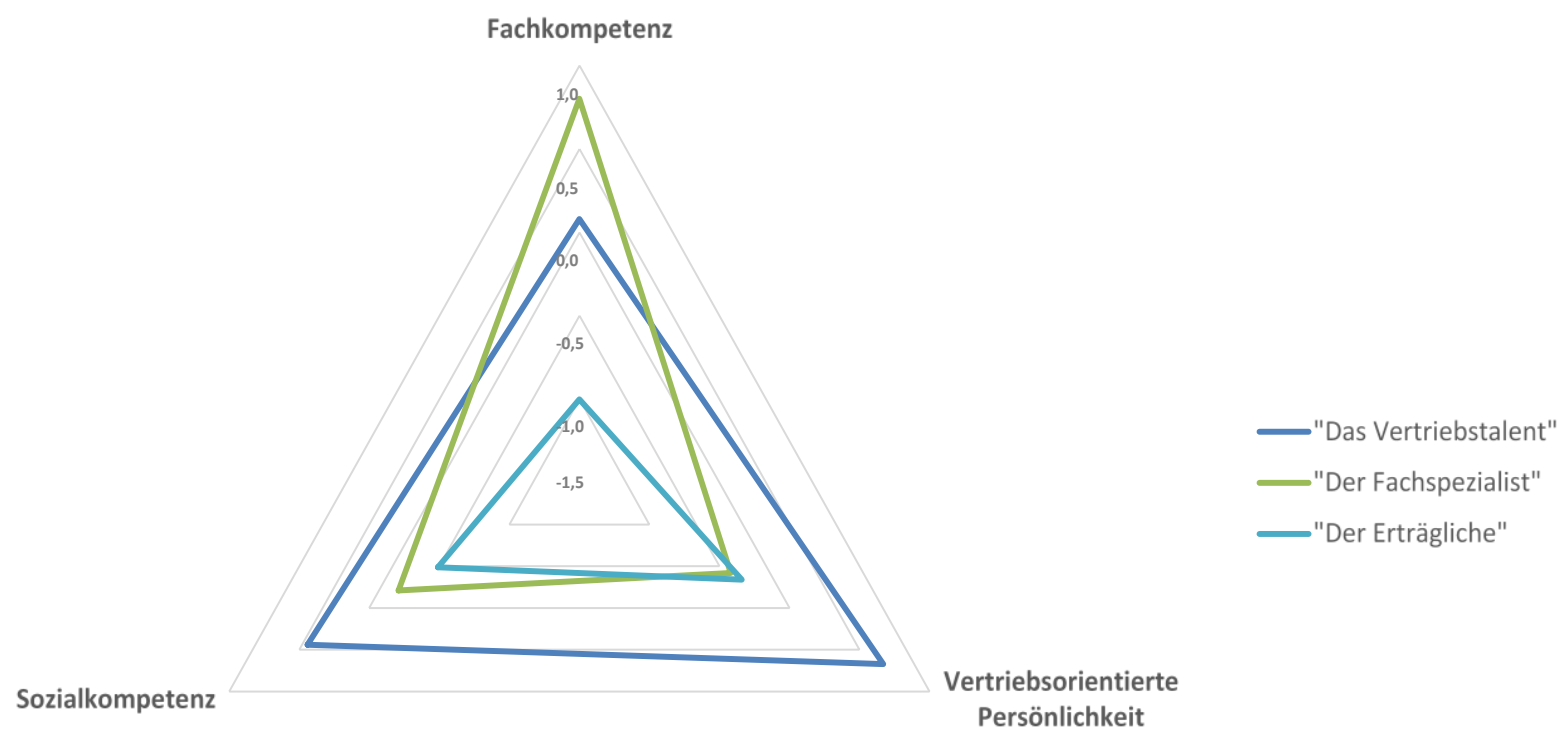

Abbildung 2: Ausprägung der drei Erfolgsfaktoren je Cluster

Quelle: Eigene Erhebung. *Standardisierte Mittelwerte der drei Erfolgsfaktoren; Ausprägung <0 (unterdurchschnittlich), 0 (durchschnittlich), >0 (überdurchschnittlich)

Die Analyse der clusterbeschreibenden demografischen und betrieblichen Merkmale der Stichprobe und der Cluster hat nur ein signifikantes Ergebnis hervorgebracht. Lediglich hinsichtlich der landwirtschaftlichen Bildung weisen die Cluster signifikante Unterschiede auf $\left(\mathrm{F}-\mathrm{Wert}=2,98^{* *}\right.$; Chi-Quadrat $\left.\mathrm{x}^{2}=21^{*}\right) .32 \%$ der LandwirtInnen, die den Verkäufertyp des ersten Clusters beschreiben, haben einen Universitätsabschluss, während in den anderen Clustern mehr als 50\% der LandwirtInnen einen Universitätsabschluss aufweisen. Mit 35\% Landwirtschaftsmeister/staatl. geprüfter Landwirt und 51\% Hochschulabsolventen verfügen LandwirtInnen, die die von ihnen bewerteten AußendienstmitarbeiterInnen dem zweiten Cluster zuordnen, über das höchste Bildungsniveau. Keine signifikanten Unterschiede gibt es hinsichtlich der betrieblichen (Betriebsgröße und -schwerpunkt) und demografischen (Alter und Herkunft) Merkmale.

Die Bewertung der AußendienstmitarbeiterInnen erfolgt unabhängig von der Besuchshäufigkeit und Besuchsdauer. Das bedeutet, die Bewertung des Außendienstes basiert auf der Grundlage einer gleichen Besuchshäufigkeit und -dauer. So werden die hinter den Clustern stehenden LandwirtInnen durchschnittlich mindestens einmal im Monat (MW>3,5) von AußendienstmitarbeiterInnen für maximal 20 bis 45 Minuten $(M W \approx 2)$ besucht (Tabelle 1). 


\section{Diskussion, Schlussfolgerungen und Limitationen}

Der vorliegende Beitrag bekräftigt die in der Literatur etablierten Erfolgsfaktoren der vertriebsorientierten Persönlichkeit sowie der Fach- und Sozialkompetenz von Außendienstmitarbeitern und identifiziert anhand dieser Faktoren drei Verkäufertypen, die in diesem Beitrag etwas zugespitzt als "Vertriebstalente", "Fachspezialisten" und "Erträgliche" bezeichnet werden.

Die Betrachtung der Clusterergebnisse zeigt, dass für die Agrarwirtschaft nicht, wie von Homburg et al. (2016) dargestellt, vier, sondern lediglich drei Cluster identifiziert werden konnten. Zudem können die Cluster nicht, wie im theoretischen Rahmen illustriert, in einer Matrix angeordnet werden, sondern liegen statistisch relativ nah zusammen. Das erste Cluster bewegt sich auf Grund der sehr positiven Ausprägung aller drei Erfolgsdimensionen in dem von Homburg et al. (2016) bezeichneten Quadranten des Allrounders. Das zweite Cluster weist ähnlich wie der nach Homburg et al. (2016) beschriebene "Vielwisser" eine ausgeprägte Fachkompetenz auf, hat jedoch im Vergleich zum "Vielwisser" eine weniger schwache Sozialkompetenz. Das dritte Cluster erhält im Vergleich zu den anderen beiden Clustern zwar eine stark unterdurchschnittliche Bewertung bei der Fachkompetenz, kann aber unter Berücksichtigung der allesamt immer noch leicht positiven Mittelwerte nicht als die durch Homburg et al. (2016) vorgestellte "Verkaufsniete" bezeichnet werden. Die Beobachtungen legen nahe, dass sich die Verkaufstypen des "Socializers" und der "Verkaufsniete" in dieser Studie nicht nachweisen lassen. Begründet werden kann dies dadurch, dass mittels der Faktorenanalyse drei klar voneinander abgrenzbare Erfolgsfaktoren identifiziert werden konnten. Ein Zusammenlegen der Sozialkompetenz und der Persönlichkeitsdimension, wie dies Homburg et al. (2016) tun, erwies sich daher als nicht sinnvoll. Weiterhin lassen die Ergebnisse eine unsichere Beurteilung der AußendienstmitarbeiterInnen durch die LandwirtInnen vermuten. Schließlich kann auch vermutet werden, dass Homburg et al. (2016) in ihrer Darstellung aus didaktischen oder Marketingüberlegungen heraus die Darstellung zugespitzt haben.

Von den drei identifizierten Faktoren besitzt der Faktor Fachkompetenz die höchste Trennkraft. Die beschriebene Ausprägung des Faktors und die Analyse zeigen, dass die Fachkompetenz unter den Clustern stärker variiert als die anderen beiden Faktoren. Zahlreiche Untersuchungen bestätigen die Fachkompetenz der Mitarbeiter als Erfolgsfaktor (Churchill et al., 1985; Johnston und Marshall, 2013; Randall und Randall, 1990; Walker et al., 1977; Weitz et al., 1986). 
In Bezug auf die Fachkompetenz bei AußendienstmitarbeiterInnen führen Untersuchungen entsprechend an, dass in der Vergangenheit der Weiterbildungsfokus auf der Weiterentwicklung der Fachkompetenz lag (Binckebanck, 2006; Boland et al., 2005). Die Ergebnisse des VDL-Berufsverbands bestätigen die Orientierung von Unternehmen des Agribusiness auf die Fachkompetenzen (VDL, 2014). Gerade durch diese intensive Förderung könnte davon ausgegangen werden, dass unter den Außendienstmitarbeitenden ein gleiches Niveau der Fachkompetenz vorherrscht. Die Ergebnisse zeigen aber, dass die Fachkompetenz die höchste Varianz zwischen den Clustern besitzt. Ein möglicher Grund könnte auf der einen Seite die subjektive Einschätzung durch die landwirtschaftlichen Unternehmer sein, welche die Fachkompetenz in Abhängigkeit ihrer eigenen Kompetenzen unterschiedlich einschätzen. Auf der anderen Seite könnten trotz Schulungen unterschiedliche Niveaus der Fachkompetenz von Außendienstmitarbeitenden existieren, was für eine weitere Optimierung der Schulungskonzepte sprechen würde. Homburg et al. (2016) betonen, dass Fachkompetenzen durch Weiterbildungsmaßnahmen leichter weiterzuentwickeln sind als die beiden anderen Erfolgsfaktoren.

Da die vertriebsorientierte Persönlichkeit und die Sozialkompetenz nur unter größeren Anstrengungen weiterzuentwickeln sind, sollten Unternehmen auf die Persönlichkeit und die Sozialkompetenz von potenziellen VertriebsmitarbeiterInnen bereits im Einstellungsverfahren achten. Studienergebnisse lassen darauf schließen, dass sich das Persönlichkeitsprofil eines Erwachsenen im Laufe der Zeit kaum ändern wird (Costa und McCrae, 1994; McCrae und Costa, 1994; Montag, 2016). Die entscheidende Prägung der Persönlichkeit findet in der Kindheit und im Jugendalter statt und lässt mit zunehmendem Alter nur wenige Veränderungen zu (Costa und McCrae, 1994). Diese Veränderungen der Persönlichkeit können innerhalb eines gewissen Maßes durch Erfahrungen und die Umwelt beeinflusst werden (Montag, 2016; Watson, 1957; Wunderer und Dick, 2002). Die Stabilitätsannahme legt jedoch nahe, dass die vertriebsorientierte Persönlichkeit der Mitarbeiter durch die Unternehmen nur begrenzt, beeinflussbar ist und damit ein stärkerer Fokus im Einstellungsverfahren auf diese Merkmale bei Bewerbern gelegt werden sollte.

Auch die Sozialkompetenz ist nur mittelfristig und begrenzt entwickelbar. Die Förderung der Sozialkompetenz kann laut Wunderer und Dick (2002) an drei Ebenen ansetzen, an der einzelnen Person, dem Team und der Organisation. Die Förderung und Weiterentwicklung auf der Team- und Organisationsebene erfolgen beispielsweise über die Gestaltung der Unternehmenskultur und Strategie sowie über die Prioritätensetzung der Unternehmensleitung. 
Auf der Ebene der einzelnen Person können nur sehr begrenzt Maßnahmen ergriffen werden. Stabile Persönlichkeitsmerkmale der einzelnen MitarbeiterInnen und mangelnde Entwicklungsbereitschaft gelten als schwer beeinflussbare Barrieren der Sozialkompetenzförderung (Wunderer und Dick, 2002). Ansatzpunkt ist hier die Gestaltung einer qualitativen Personalstruktur. Im Rekruitingprozess sozialkompetenter Mitarbeiter Innen sollte daher neben den Persönlichkeitsmerkmalen auch auf deren Sozialkompetenz geachtet werden, beispielweise in Stellenausschreibungen, bei Auswahlgesprächen oder Assessment Centern (Wunderer und Dick, 2002).

Der vorliegende Beitrag ist Teil einer Untersuchung zum Image des Außendienstes im Agribusiness in Deutschland. Auch für diese Fragestellung liefern die Ergebnisse neue Hinweise. Wenn die Befragten 43\% der Vertriebs- und AußendienstmitarbeiterInnen durchgängig als gut (als "Vertriebstalent") einschätzen, deutet dies darauf hin, dass das Image dieser MitarbeiterInnen bei ihrer Kundschaft positiv ist. Rund 27\% der Außendienstmitarbeiter werden allerdings in allen drei Erfolgsfaktoren schwächer bewertet. Diese Außendienstmitarbeitenden scheinen mit den komplexer werdenden Vertriebssituationen, wie sie durch Metze und Igl (2012) sowie von Ahearne und Rapp (2010) beschrieben wurden, eher überfordert zu sein. Die Ergebnisse belegen, dass AußendienstmitarbeiterInnen des dritten Clusters mit Kritik schlechter umgehen können als die AußendienstmitarbeiterInnen der anderen beiden Cluster. Für Unternehmen stellt sich an dieser Stelle die Frage, wie gerade die vertriebsorientierte Persönlichkeit und Sozialkompetenz im Einstellungsverfahren geprüft werden können, und inwieweit sich diese Mitarbeitergruppe fördern lässt.

Hieraus ergibt sich die zweite Handlungsempfehlung für das strategische Vertriebsmanagement. Da MitarbeiterInnen mit Kundenkontakt Unternehmensrepräsentanten sind, sollte angestrebt werden, die Vertriebs- und AußendienstmitarbeiterInnen gezielt zu fördern, um das Image der MitarbeiterInnen und des Unternehmens weiter zu verbessern. Zur Imageverbesserung sollte den AußendienstmitarbeiterInnen ein serviceorientiertes und partnerschaftliches Denken und Handeln sowie ein kundenorientiertes Handeln vermittelt werden (Kittinger, 2010; Stock und Hoyer, 2005). Die Sozialkompetenz kann in gewissem Maße durch Team- und Organisationsstrukturen verbessert werden. Während die dem Sozialverhalten zugrundeliegenden Werte und Motive nicht wesentlich beeinflusst werden können, bieten sich gezielte Ansatzpunkte für die Förderung sozialer Fertigkeiten, z.B. durch Schulungen/Coachings zu Präsentationstechniken und Rhetoriktrainings (Wunderer und Dick, 2002). Dabei erweist sich die Mitarbeiterförderung hinsichtlich der vorhandenen, 
gut ausgeprägten vertriebsorientierten Persönlichkeits- und Sozialkompetenzen im Vergleich zur Behebung größerer persönlicher Defizite, als erfolgreicher (Schuler und Barthelme, 1995; Wunderer und Dick, 2002).

In der allgemeinen Bewertung wurde der Außendienst mit einer Schulnote von 2,7 als befriedigend bewertet. Die Bewertung der einzelnen Verkaufssituation bzw. der einzelnen AußendienstmitarbeiterInnen fiel hingegen im Schnitt etwas positiver aus (43\% Vertriebstalente). Es könnte daher vermutet werden, dass gerade negative Erfahrungen prägender für die Gesamtbeurteilung sind (Agnihothri et al., 2002; Fitzsimmons und Fitzsimmons, 2001; Mittal et al., 1998). Zudem sollte berücksichtigt werden, dass auch die Umstände der Außendienstbesuche Einfluss auf die Bewertung haben. Immerhin empfinden mehr als die Hälfte (55,5 \%) der Befragten, dass die Außendienstbesuche nicht im richtigen Rhythmus stattfinden, was sich negativ auf die Gesamtbeurteilung ausgewirkt haben könnte. Unternehmen und Außendienstmitarbeitende sollten daher zusätzlich darauf achten, wie oft und wann ihre KundInnen besucht werden. Eine vorherige Terminabsprache bietet den LandwirtInnen die Chance zur Vorbereitung, wodurch Zeitdruck und Missmut aufseiten der Kundschaft vermieden werden können.

Der vorliegende Beitrag liefert eine erste Bewertung von AußendienstmitarbeiterInnen im Agribusiness aus der Perspektive der KundInnen. Es konnten drei Verkäufertypen im deutschen Agribusiness identifiziert werden. Bei der Interpretation der Ergebnisse sollten jedoch die Limitationen berücksichtigt werden. Die Repräsentativität der verwendeten Stichprobe ist ein erster hemmender Faktor. Die teilnehmenden LandwirtInnen sind jünger, besser ausgebildet und haben größere Betriebe als der Durchschnitt in Deutschland. Dies kann die Interpretation der Ergebnisse einschränken, denn laut Rüther (2007) sind bildungsstarke LandwirtInnen mit der landwirtschaftlichen Fachberatung zufriedener. In der vorliegenden Studie deutet sich ein gegenteiliger Zusammenhang an, denn die LandwirtInnen, die den von ihnen bewerteten Außendienstmitarbeiter dem Cluster I zuordnen, verfügen über einen geringeren Ausbildungsstand.

Obwohl die Mittelwerte für die untersuchten Erfolgsfaktoren bei den meisten Variablen zwischen den Clustern differenzieren, zeigt sich, dass die Mittelwerte sich in einem ähnlichen Skalenbereich bewegen. Sowohl in der Betrachtung der Einzelstatements als auch in der Betrachtung "Gesamtbeurteilung" liegen die Mittelwerte unterhalb des Skalenmittels von drei und sind damit positiv geprägt. Dies könnte auf einen Positiv-Bias ähnlich wie in Kundenzufriedenheitsanalysen zurückzuführen sein. Die Kundenzufriedenheitsforschung 
bestätigt, dass Zufriedenheitsanalysen meist eine natürliche Schiefe aufweisen, wobei die Mehrheit der StudienteilnehmerInnen positive Bewertungen vornehmen (Diener, 1984; Peterson und Wilson, 1992). Laut Peterson und Wilson (1992) können Kundenzufriedenheitsanalysen damit den Hawthorne-Effekt widerspiegeln. Dieser beschreibt den verzerrenden Effekt einer Untersuchung, der besagt, dass Teilnehmer einer Befragung positiv beeinflusst sind, eben weil sie als ProbandInnen ausgewählt wurden Kleist (2006). Außerdem ist zu vermuten, dass bei der Einschätzung der Kompetenzen Irradiationseffekte wirken, d.h. wird ein-/e Mitarbeiter-/in in einem wichtigen Erfolgsfaktor als stark bzw. schwach eingeschätzt, so werden auch die weiteren Erfolgsfaktoren als stark bzw. schwach eingeschätzt. Bei der Interpretation sollte daher berücksichtigt werden, dass bereits Werte nahe des Mittelwertes möglicherweise Zeichen für eine schwächere Kompetenzausprägung sind. Zukünftige Studien könnten möglicherweise stärker ausdifferenzierte Skalen verwenden.

Auch die Methodik (Online-Befragung) weist Grenzen auf, da nur diejenigen LandwirtInnen erreicht wurden, die bereits online aktiv sind. Die vorliegende Untersuchung kann daher als eine Vor-Studie interpretiert werden, da die Ergebnisse erste nützliche Informationen für landwirtschaftliche Vorleistungsunternehmen mit Außendienstteams liefern. Sie kann dafür sensibilisieren, dass Unternehmen ihre AußendienstmitarbeiterInnen hinsichtlich der Kompetenzbereiche Fachwissen und Sozialkompetenz fördern sollten. Zudem wird deutlich, dass nicht alle AußendienstmitarbeiterInnen eine vertriebsorientierte Persönlichkeit aufweisen, ein Defizit, das sich durch Schulungen nur sehr begrenzt beseitigen lässt. 


\section{Literatur}

Abeysekera, N. und Wickramasinghe, A. (2013). Relationship marketing and customer orientation of sales people: learning from banks. International Journal of Financial Services Management 6(1): 79-91. doi: 10.1504/IJFSM.2013.052893

Agnihothri, S., Sivasubramaniam, N. und Simmons, D. (2002). Leveraging technology to improve field service. International Journal of Service Industry Management 13(1): 47-68. doi: $10.1108 / 09564230210421155$

Ahearne, M. und Rapp, A. (2010). The role of technology at the interface between salespeople and consumers. Journal of Personal Selling \& Sales Management 30(2): 111-120. doi: 10.2753/PSS0885-3134300202

Backhaus, K., Erichson, B., Plinke, W. und Weiber, R. (2016). Multivariate Analysemethoden. Eine anwendungsorientierte Einführung. Springer Gabler, Berlin, Heidelberg. doi: 10.1007/978-3-662-46076-4

Baldauf, A. und Cravens, D. W. (2002). The effect of moderators on the salesperson behavior performance and salesperson outcome performance and sales organization effectiveness relationships. European Journal of Marketing 36(11/12): 1367-1388. doi: $10.1108 / 03090560210445227$

Behrman, D.N. und Perreault, W. D. (1982). Measuring the performance of industrial salespersons. Journal of Business Research 10(3): 355-370. doi: 10.1016/0148-2963(82)90039-X

Binckebanck, L. (2006). Interaktive Markenführung. Der persönliche Verkauf als Instrument des Markenmanagements im B2B-Geschäft. Applied Marketing Science /Angewandte Marketingforschung. Deutscher Universitäts-Verlag, Wiesbaden. doi: 10.1007/3-8350-5701-4

BMEL (2019). BMEL-Statistik: Landwirtschaftliche Gesamtrechnung 2019. Bundesministerium für Ernährung und Landwirtschaft. https://www.bmel-statistik.de/fileadmin/daten/SGB-01000202019.pdf. (28.01.2020).

BMEL (2016). Tabellen zur Landwirtschaft: Landwirtschaftliche Berufsbildung der Betriebsleiter in landwirtschaftlichen Betrieben. Bundesministerium für Ernährung und Landwirtschaft. https://www.bmel-statistik.de/fileadmin/daten/SJT-3040320-2016.xlsx. (28.01.2020).

Boland, H., Thomas, A. und Ehlers, K. (2005). Expertise zur Beratung landwirtschaftlicher Unternehmen in Deutschland: eine Analyse unter Berücksichtigung der Anforderungen der Verordnung (EG) Nr. 1782/2003 zu Cross Compliance. BMVEL Bundesministerium für Verbraucherschutz, Ernährung und Landwirtschaft; Justus-Liebig-Universität Gießen, Bonn/Gießen.

Boles, J. S., Johnson, J. T. und Barksdale, H. C. (2000). How Salespeople Build Quality Relationships. Journal of Business Research 48(1): 75-81. doi: 10.1016/S0148-2963(98)00078-2

Boorom, M. L., Goolsby, J. R. und Ramsey, R. P. (1998). Relational communication traits and their effect on adaptiveness and sales performance. Journal of the Academy of Marketing Science 26(1): 16-30. doi: 10.1177/0092070398261003

Brown, G., Widing, R. E. und Coulter, R. L. (1991). Customer evaluation of retail salespeople utilizing the SOCO scale: A replication, extension, and application. Journal of the Academy of Marketing Science 19(4): 347-351. doi: 10.1007/bf02726510

Churchill, G. A., Ford, N. M., Hartley, S. W. und Walker Jr, O. C. (1985). The determinants of salesperson performance: A meta-analysis. Journal of marketing research 22(2): 103-118. doi: $10.1177 / 002224378502200201$ 
Costa, P. T. und McCrae, R. R. (1994.). Set like plaster? Evidence for the stability of adult personality. In: Heatherton, T.F. (ed) Can personality change? 1st ed. American Psychological Association, Washington, 21-40.

Crosby, L.A., Evans, K. R. und Cowles, D. (1990). Relationship quality in services selling: an interpersonal influence perspective. Journal of marketing 54(3): 68-81. doi: $10.1177 / 002224299005400306$

Diener, E. (1984). Subjective well-being. Psychological Bulletin 95(3): 542-575. doi: 10.1037/0033-2909.95.3.542

Dion, P.A. und Notarantonio, E. M. (1992). Salesperson communication style: The neglected dimension in sales performance // Salesperson Communication Style: The Neglected Dimension in Sales Performance. The Journal of Business Communication (1973) 29(1): 63-77. doi: $10.1177 / 002194369202900104$

Fitzsimmons, J.A. und Fitzsimmons, M.J. (2001). Service management. Operations, strategy, and information technology. McGraw-Hill, New York.

Franklin, D. und Marshall, R. (2019). Adding co-creation as an antecedent condition leading to trust in business-to-business relationships. Industrial Marketing Management 77: 170-181. doi: 10.1016/j.indmarman.2018.10.002

Friedemann, J.C. (2010). 200 Tipps für Verkäufer im Aussendienst. Selbstorganisation Akquisitionsstrategien - Verkaufsgesprächstechnik. Gabler Verlag, Wiesbaden. doi: 10.1007/978-3-8349-8879-9

Friend, S.B., Curasi, C. F., Boles, J. S. und Bellenger, D. N. (2014). Why are you really losing sales opportunities? A buyers' perspective on the determinants of key account sales failures. Industrial Marketing Management 43(7): 1124-1135. doi: 10.1016/j.indmarman.2014.06.002

Fritz, W. (1993). Produktqualität, Marktanteil und Unternehmenserfolg: Ergebnisse der PIMSForschung und ihre empirische Relevanz für die westdeutsche Industrie, 93/03. Arbeitspapier/Technische Universität Braunschweig, Institut für Marketing, Braunschweig.

Goff, B.G., Boles, J. S., Bellenger, D. N. und Stojack, C. (1997). The influence of salesperson selling behaviors on customer satisfaction with products. Journal of retailing 73(2): 171-183. doi: 10.1016/S0022-4359(97)90002-6

Gollisch, S. and Theuvsen, L. (2015). Risikomanagement im Landhandel: Charakteristika, Herausforderungen, Implikationen. Berichte über Landwirtschaft - Zeitschrift für Agrarpolitik und Landwirtschaft 93(1): 1-16. doi: 10.12767/buel.v93i1.72

Guadagnoli, E. und Velicer, W. F. (1988). Relation of sample size to the stability of component patterns. Psychological Bulletin 103(2): 265. doi: 10.1037/0033-2909.103.2.265

Haas, A. (2002). Erfolgsstrategien im Verkauf: eine verkäuferbasierte Analyse im Finanzdienstleistungsbereich. Arbeitsparpier Nr. 100. In: Diller, H. (Hrsg.): Arbeitspapiere des Lehrstuhls für Marketing der Universität Erlangen-Nürnberg, Nürnberg.

Hair, J.F., Black, W.C., Babin, B.J. und Anderson, R.E. (2009). Multivariate data analysis. Pearson Prentice Hall, Upper Saddle River.

Harris, K. und Pike, J. (1996). Issues concerning adoption and use of sales force automation in the agricultural input supply sector. Agribusiness: An International Journal 12(4): 317-326. doi: 10.1002/(SICI)1520-6297(199607/08)12:4<317:AID-AGR2>3.0.CO;2-1

Hemmerling, U., Pascher, P. und Naß, S. (2017). Situationsbericht 2017/18. Trends und Fakten zur Landwirtschaft. Deutscher Bauernverband e.V, Berlin.

Hemmerling, U., Pascher, P. und S. Naß (2016). Situationsbericht 2016/17: Trends und Fakten zur Landwirtschaft. Deutscher Bauernverband, Berlin. 
Hennig-Thurau, T. und Thurau, C. (1999). Sozialkompetenz als vernachlässigter Untersuchungsgegenstand des (Dienstleistungs-) Marketing: Einsatzmöglichkeiten und Konzeptualisierung. Marketing: Zeitschrift für Forschung und Praxis 21(4): 297-311.

Herjanto, H. und Franklin, D. (2019). Investigating salesperson performance factors: A systematic review of the literature on the characteristics of effective salespersons. Australasian Marketing Journal (AMJ) 27(2): 104-112. doi: 10.1016/j.ausmj.2018.12.001

Hohenschwert, L. (2012). Salespeople's value creation roles in customer interaction: An empirical study. Journal of Customer Behaviour 11(2): 145-166. doi: $10.1362 / 147539212 X 13420906144679$

Homburg, C. und Giering, A. (2001). Personal characteristics as moderators of the relationship between customer satisfaction and loyalty - an empirical analysis. Psychology \& Marketing 18(1): 43-66. doi: 10.1002/1520-6793(200101)18:1<43:AID-MAR3>3.0.CO;2-I

Homburg, C. und Müller, M. (2009). Effektives Verhalten von Verkäufern im Kundenkontakt-Status Quo und Erfolgsfaktoren. Management Know-how M118.

Homburg, C., Schäfer, H. und Schneider, J. (2016). Sales Excellence. Vertriebsmanagement mit System. Springer Gabler, Wiesbaden.

Homburg, C. und Stock, R. M. (2004). The link between salespeople's job satisfaction and customer satisfaction in a business-to-business context: A dyadic analysis. Journal of the Academy of Marketing Science 32(2): 144-158. doi: 10.1177/0092070303261415

Huchtemann, J.-P. and Theuvsen, L. (2018.). Startups im Agribusiness - Marktplätze als Geschäftsmodell und deren Anwendung in der deutschen Landwirtschaft. In: Ruckelshausen, A., Meyer-Aurich, A., Borchard, K., H., C., Loy, J.-P., Schwerdtfeger, R., Sundermeier, H.-H., Floto, H. and Theuvsen, B. (eds.). 38. GIL-Jahrestagung in Kiel, Germany, Digitale Marktplätze und Plattformen. Gesellschaft für Informatik e.V., Bonn 119-122.

Huckemann, M. und Schmitz, C. (2016). Key Performance Indicators (KPI)-Steuerung und Messung von Leistung im Vertrieb. Institut für Marketing, Universität St. Gallen.

Hummels, H. (2009). Anmerkungen zum wertorientierten Verkauf komplexer Güter. Fachartikel, 387. WiWi-Media AG, Hamburg. https://bit.ly/3k18hmr. (04.12.2019).

Ingram, T.N., LaForge, R. W., Locander, W. B., MacKenzie, S. B. und Podsakoff, P. M. (2005). New directions in sales leadership research. Journal of Personal Selling \& Sales Management 25(2): 137-154. doi: 10.1080/08853134.2005.10749055

Jackson, D.W., Keith, J. E. und Schlacter, J. L. (1983). Evaluation of selling performance: A study of current practices. Journal of Personal Selling \& Sales Management 3(2): 42-51.

Johnston, M.W. und Marshall, G.W. (2013). Sales force management. Routledge, New York.

Kaiser, H.F. und Rice, J. (1974). Little jiffy, mark IV. Educational and psychological measurement 34(1): 111-117.

Kittinger, A. (2010). Serviceorientierung und partnerschaftliches Handeln im B2B-Vertrieb. Gabler Verlag, Wiesbaden. doi: 10.1007/978-3-8349-6090-0

Kleist, P. (2006). Vier Effekte, Phänomene und Paradoxe in der Medizin. Swiss Medical Forum 6(46): $1023-1027$.

Koester, U. (2016). Grundzüge der landwirtschaftlichen Marktlehre. Lernbücher für Wirtschaft und Recht. Franz Vahlen, München.

Kotler, P. und Bliemel, F. (1999). Marketing-Management. Analyse, Planung, Umsetzung und Steuerung. Schaeffer-Poeschel, Stuttgart.

Kotler, P., Bliemel, F. und Keller, K.L. (2007). Marketing-Management. Strategien für wertschaffendes Handeln. Pearson Deutschland GmbH, München. 
Kraft, M. und Bosch, C. (2015). Vertriebssteuerung. In: Backhaus, K., Voeth, M. (Hrsg.) Handbuch Business-to-Business-Marketing. Grundlagen, Geschäftsmodelle, Instrumente des Industriegütermarketing. Springer Fachmedien Wiesbaden; Imprint: Springer Gabler, Wiesbaden, 623-648.

Lang, D. (2009). Soziale Kompetenz und Persönlichkeit: Zusammenhänge zwischen sozialer Kompetenz und den Big Five der Persönlichkeit bei jungen Erwachsenen. Psychologie 61. Empirische Pädagogik e.V., Landau.

Liu, A.H. und Leach, M. P. (2001). Developing loyal customers with a value-adding sales force: Examining customer satisfaction and the perceived credibility of consultative salespeople. Journal of Personal Selling \& Sales Management 21(2): doi: 147-156. 10.1080/08853134.2001.10754265

Maier, P. (2013). Entwicklung der landwirtschaftlichen Be-ratung in der Bundesrepublik Deutschland unter dem Aspekt der Beratungsqualität. Problemy Nauk Sto-sowanych 1(1): 189-196.

McCrae, R.R. und Costa, P. T. (1994). The stability of personality: Observations and evaluations. Current directions in psychological science 3(6): 173-175. doi: 10.1111/1467-8721.ep10770693

Metze, S. und Igl, G. (2012). Anforderungen an die Kompetenzen des höher qualifizierten Personals im Agribusiness unter den Bedingungen zunehmender Vertikalisierung. Rhombos-Verlag, Berlin.

Michaels, R.E. und Day, R. L. (1985). Measuring customer orientation of salespeople: a replication with industrial buyers. Journal of marketing research 22(4): 443-446. doi: $10.1177 / 002224378502200409$

Milligan, G.W. und Hirtle, S. C. (2013). Clustering and Classification Methods. In: Weiner et al. (Hrsg.) Handbook of psychology. Clinical psychology. Wiley, Hoboken, N.J., 165-186. doi: 10.1002/0471264385.wei0207 [Titel anhand dieser DOI in Citavi-Projekt übernehmen]

Mittal, V., Ross, W. T. und Baldasare, P. M. (1998). The Asymmetric Impact of Negative and Positive Attribute-Level Performance on Overall Satisfaction and Repurchase Intentions. Journal of marketing 62(1): 33-47. doi: 10.1177/002224299806200104

Montag, C. (2016). Persönlichkeit - Auf der Suche nach unserer Individualität. Springer Verlag, Berlin, Heidelberg. doi: 10.1007/978-3-662-48895-9

Morrison, D.G. (1969). On the interpretation of discriminant analysis. Journal of marketing research 6(2): 156-163. doi: 10.1177/002224376900600203

Mühlberger, A. (2010). Motiviert, Kompetent, Qualifiziert. Sales Excellence 2010(10): 8-11.

Ou, W.-M., Shih, C.-M., Chen, C.-Y. und Tseng, C.-W. (2012). Effects of ethical sales behaviour, expertise, corporate reputation, and performance on relationship quality and loyalty. The Service Industries Journal 32(5): 773-787. doi: 10.1080/02642069.2010.531268

Pascher, P., Hemmerling, U. und S. Naß (2018). Situationsbericht 2018/19 Trends und Fakten zur Landwirtschaft. Deutscher Bauernverband e.V., Berlin.

Peterson, R.A. und Wilson, W. R. (1992). Measuring Customer Satisfaction: Fact and Artifact. Journal of the Academy of Marketing Science 20(1): 61-71. doi: 10.1007/BF02723476

Piercy, N.F., Cravens, D. W. und Morgan, N. A. (1999). Relationships between Sales Management Control, Territory Design, Salesforce Performance and Sales Organization Effectiveness. British Journal of Management 10(2): 95-111. doi: 10.1111/1467-8551.00113

Pilling, B.K. und Eroglu, S. (1994). An Empirical Examination of the Impact of Salesperson Empathy and Professionalism and Merchandise Salability on Retail Buyers' Evaluations. Journal of Personal Selling \& Sales Management 14(1): 45-58. 
Pionke, S. (2018). Fitness-check agrarhandel Unbequeme Sandwich-Position. agrarzeitung. https://www.agrarzeitung.de/news/media/4/Fitness-Check-Agrarhandel-37180.pdf. (05.06.2019)

Plinke, W. (1991). Investitionsgütermarketing. Marketing: Zeitschrift für Forschung und Praxis 13(3): $172-177$.

Randall, E.J. und Randall, C. H. (1990). Review of salesperson selection techniques and criteria: A managerial approach. International Journal of Research in Marketing 7(2-3): 81-95. doi: 10.1016/0167-8116(90)90013-D

Rich, G.A. (1999). Salesperson Optimism: Can Sales Managers Enhance it and so What if They Do? Journal of Marketing Theory and Practice 7(1): 53-63. doi: 10.1080/10696679.1999.11501819

Rothmann, S. und Coetzer, E. P. (2003). The big five personality dimensions and job performance. SA Journal of Industrial Psychology 29(1): 68-74. doi: 10.4102/sajip.v29i1.88

Rüther, C. (2007). Untersuchungen zur Qualitätsbestimmung landwirtschaftlicher Fachberatung aus Kundenperspektive. Disseration. Der Andere Verlag, Tönning, Lübeck, Marburg.

Rüther, C. und Maier, P. (2007). Wie beurteilen LandwirtInnen Beratungsleistungen? Qualität landwirtschaftlicher Fachberatung. Fachzeitschrift B\&B Agrar 60(2): 54-56.

Saxe, R. und Weitz, B. A. (1982). The SOCO Scale: A Measure of the Customer Orientation of Salespeople. Journal of marketing research 19(3): 343-351. doi: 10.1177/002224378201900307

Schmitz, C. und Wieseke, J. (2015). Herausforderungen und Potenziale im Vertrieb. Marketing Review St. Gallen 32(6): 12-21. doi: 10.1007/s11621-015-0596-3

Schnipke, D.L. und Scrams, D. J. (1997). Modeling Item Response Times with a Two-State Mixture Model: A New Method of Measuring Speededness. Journal of Educational Measurement 34(3): 213-232. doi: 10.1111/j.1745-3984.1997.tb00516.x

Scholl, M. (2003). Multi Channel Management. Gestaltung, Steuerung und Erfolg von Multi Channel Vertriebssystemen. Dissertation. Universität Mannheim.

Schuler, H. und Barthelme, D. (1995). Soziale Kompetenz als berufliche Anforderung. In: Seyfried, B. (ed) Berichte zur beruflichen Bildung, 179. Bertelsmann, Bielefeld, 77-116.

Singh, R. und Koshy, A. (2010). Determinants of B2B salespersons' performance and effectiveness: a review and synthesis of literature. Journal of Business \& Industrial Marketing. doi: $10.1108 / 08858621011077763$

Spiro, R.L. und Weitz, B. A. (1990). Adaptive Selling: Conceptualization, Measurement, and Nomological Validity. Journal of marketing research 27(1): 61-69. doi: $10.1177 / 002224379002700106$

Statista (2011). Entwicklung der Anzahl der Betriebsleiter in der Landwirtschaft in Deutschland nach Geschlecht von 1990 bis 2007. https://bit.ly/3g6q5LM. (30.11.19).

Stock, R.M. und Hoyer, W. D. (2005). An Attitude-Behavior Model of Salespeople's Customer Orientation. Journal of the Academy of Marketing Science 33(4): 536-552. doi: $10.1177 / 0092070305276368$

Strecker, O., Strecker, O.A., Elles, A., Weschke, H.-D., Kliebisch, C. und Enneking, U. (2010). Marketing für Lebensmittel und Agrarprodukte. DLG-Verlag, Frankfurt am Main.

Terho, H., Eggert, A., Haas, A. und Ulaga, W. (2015). How sales strategy translates into performance: The role of salesperson customer orientation and value-based selling. Industrial Marketing Management 45(2015): 12-21. doi: 10.1016/j.indmarman.2015.02.017

Terho, H., Haas, A., Eggert, A. und Ulaga, W. (2012). 'It's almost like taking the sales out of selling'Towards a conceptualization of value-based selling in business markets. Industrial Marketing Management 41(1): 174-185. doi: 10.1016/j.indmarman.2011.11.011 
Thiel, J. (2017). Anforderungen an Marketingkonzepte für Großtraktoren unter Berücksichtigung des Wandels landwirtschaftlicher Rahmenbedingungen. Dissertation. Uni-versität Hohenheim.

Tomczak, T., Reinecke, S., Karg, M. und Mühlmeyer, J. (1998). Best Practice in Marketing-Empirische Erfolgsstudie zum aufgabenorientierten Ansatz. Fachbericht für Marketing. Thexis, St. Gallen.

Töytäri, P. und Rajala, R. (2015). Value-based selling: An organizational capability perspective. Industrial Marketing Management 45(2015): 101-112. doi: 10.1016/j.indmarman.2015.02.009

VDL (2014). Fach- und Führungskräftebedarf in der Agrarbranche Befragungen und Analysen im Agrarbereich 2013/2014. Berufsverband Agrar, Ernährung, Umwelt e.V., Berlin.

Verbeke, W. (1994). Personality characteristics that predict effective performance of sales people. Scandinavian Journal of Management 10(1): 49-57. doi: 10.1016/0956-5221(94)90036-1

Verbeke, W., Dietz, B. und Verwaal, E. (2011). Drivers of sales performance: a contemporary metaanalysis. Have salespeople become knowledge brokers? Journal of the Academy of Marketing Science 39(3): 407-428. doi: 10.1007/s11747-010-0211-8

Voss, J. (2008). Customer-Relationship-Management im Agribusiness. Universität Göttingen, Dissertation. Sierke, Göttingen.

Walker, O.C., Churchill, G. A. und Ford, N. M. (1977). Motivation and Performance in Industrial Selling: Present Knowledge and Needed Research. Journal of marketing research 14(2): 156168. doi: $10.1177 / 002224377701400203$

Watson, J.B. (1957). Behaviorism. Transaction Publishers, New Brunswick/New Jersey.

Watson, J.C. (2017). Establishing Evidence for Internal Structure Using Exploratory Factor Analysis. Measurement and Evaluation in Counseling and Development 50(4): 232-238. doi: $10.1080 / 07481756.2017 .1336931$

Weitz, B.A., Sujan, H. und Sujan, M. (1986). Knowledge, Motivation, and Adaptive Behavior: A Framework for Improving Selling Effectiveness. Journal of marketing 50(4): 174-191. doi: $10.1177 / 002224298605000404$

Wunderer, R. und Dick, P. (2002). Sozialkompetenz-eine mitunternehmerische Schlüsselkompetenz. Die Unternehmung 56(6): 361-391.

Yang, D.-J. und Wu, M. J. (2014). Does customer trust play a mediating role between salesperson competence and performance? International Journal of Management, Economics and Social Sciences 3(2): 100-121.

Zahn, E. (1997). Vertrieb und Verkauf 2000-Zahlen, Fakten, Trends. Verlag Norbert Müller, München.

Zallocco, R., Pullins, E. B. und Mallin, M. L. (2009). A re-examination of B2B sales performance. Journal of Business \& Industrial Marketing 24/8(2009): 598-610.

Zhang, A.L. und Glynn, M. S. (2015). Towards a Framework of a Salesperson's Resource Facilitation and Interaction. Australasian Marketing Journal (AMJ) 23(2): 124-131. doi: 10.1016/j.ausmj.2015.04.007 


\section{II.3 Einflussfaktoren auf die Attraktivität einer Tätigkeit im Vertrieb bei Studierenden der Agrarwissenschaften}

Authors: Dorothee Schulze Schwering \& Jan-Philipp Huchtemann

This article was published in similar form in: Berichte über Landwirtschaft: Zeitschrift für Agrarpolitik und Landwirtschaft, (2020) 98 (1).

Doi: 10.12767/buel.v98i1.262 


\title{
II.3 Einflussfaktoren auf die Attraktivität einer Tätigkeit im Vertrieb bei Studierenden der Agrarwissenschaften
}

\begin{abstract}
The persistent shortage of specialist and managerial talent is increasingly making itself felt in German agribusiness. In particular in sales, which are the central point of contact with customers, enterprises find it increasingly difficult to fill their vacancies with qualified personnel. In general, in the public mind a post in sales is frequently associated with the somewhat negative image of "going cap-in-hand". Against this backdrop, the question arises as to the attitude of students of agricultural sciences towards sales in agriculture and their motivation to work in this field. A survey among 299 students of agricultural sciences in Germany examines, by means of regression analysis, the question which determinants affect the attractiveness of a position in sales. The results show that the attractiveness of a position in sales first and foremost depends on how the students perceive career options in sales. Moreover, the attitude towards sales and students' past experience, both in theory and in practice, have a significant impact on the career preferences of students of agricultural sciences. The sales activity's "hard sell image" proves to be a barrier to the recruiting of motivated specialists for sales. The survey thereby contributes to explaining the shortage of specialist and managerial talent in agribusiness and draws attention to the relevance of the job's-image for students' occupational choices.
\end{abstract}




\section{Zusammenfassung}

Der anhaltende Fach- und Führungskräftemangel wird zunehmend im deutschen Agribusiness spürbar. Insbesondere im Vertrieb, dem zentralen Berührungspunkt mit der Kundschaft, haben Unternehmen verstärkt Probleme, die offenen Positionen mit geeigneten Fachkräften zu besetzen. Allgemein ist eine Position im Vertrieb in der öffentlichen Wahrnehmung häufig mit dem Bild des klassischen "Klinkenputzers" eher negativ behaftet. Vor diesem Hintergrund stellt sich die Frage nach der Einstellung von Studierenden der Agrarwissenschaften zum landwirtschaftlichen Vertrieb und ihrer Motivation, eine Tätigkeit in diesem Bereich aufzunehmen. Anhand einer Umfrage unter 299 Studierenden der Agrarwissenschaften in Deutschland wird mittels einer Regressionsanalyse die Frage untersucht, welche Determinanten die Attraktivität einer Position im Vertrieb beeinflussen. Die Ergebnisse zeigen, dass die Attraktivität einer Position im Vertrieb vor allem von den von Studierenden empfundenen Karriereoptionen im Vertrieb abhängig ist. Zudem haben die Einstellung zum Vertrieb und die bisherigen Erfahrungen der Studierenden, sowohl praktisch als auch theoretisch, einen erheblichen Einfluss auf die Berufspräferenzen der Studierenden der Agrarwissenschaften. Das "Hard-Selling-Image" der Vertriebstätigkeit erweist sich als Barriere bei der Gewinnung motivierter Fachkräfte im Vertrieb. Die Studie liefert damit einen Beitrag zur Erklärung des Fachkräftemangels im Agribusiness und verweist auf die Relevanz des Job-Images für das Berufswahlverhalten von Studierenden. 


\section{$1 \quad$ Einleitung}

Der Vertrieb nimmt branchenübergreifend in vielen Unternehmen eine zentrale Funktion ein und wird häufig als "Speerspitze" des Unternehmens bezeichnet (de Jager und Bayat, 2009; Puspitasari und Harjanti, 2017). Dies ist unter anderem darin begründet, dass der Vertrieb einen unmittelbaren Einfluss auf den Unternehmenserfolg hat (Behrman und Perreault, 1982; Fritz, 1993). Durch einen leistungsstarken Vertrieb können zudem Kundenbeziehungen verbessert und Wettbewerbsvorteile generiert werden (Goff et al., 1997; Homburg und Stock, 2004; Homburg und Giering, 2001). Aufgrund der intensiven Interaktionen mit den KundInnen ist das Vertriebspersonal zentral für den Vertriebserfolg.

Die Suche nach qualifizierten MitarbeiterInnen fällt Unternehmen des Agribusiness zunehmend schwerer. Rund 69\% der Unternehmen bewerten die gegenwärtige Suche nach Fachkräften bereits als problematisch (VDL, 2014). Eine konstant hohe Nachfrage nach qualifizierten Fachkräften besteht aktuell im Bereich des landwirtschaftlichen Vertriebs (Schwerdtfeger, 2015a; VDL, 2014). Vorliegende praxisorientierte Studien geben an, dass über $70 \%$ der befragten Unternehmen des Agribusiness die Suche nach Fach- und Führungskräften für den Vertrieb als schwierig ansehen (VDL, 2014). Die Unbeliebtheit des Vertriebs bei Hochschulabsolvierende und mangelnde Kompetenzen gelten für den Fachkräftemangel im Vertrieb als wesentliche Gründe, obwohl der Vertrieb zahlreiche Einstiegsmöglichkeiten und eine attraktive Vergütung bietet (VDL, 2014). Schmitz und Wieseke (2015) führen als Gründe für den Fachkräftemangel im Vertrieb das allgemein schlechte Ansehen, die steigenden Anforderungen an die VertriebsmitarbeiterInnen sowie Lücken im Bildungssystem an. In der vorliegenden Literatur wird die Vorbereitung der Studierenden durch das agrarwissenschaftliche Hochschulstudium weniger betrachtet, ebenso findet die generelle Einstellung der Studierenden zum Vertrieb landwirtschaftlicher Produkte und Dienstleistungen wenig Betrachtung (Briedis et al., 2011).

Der vorliegende Beitrag widmet sich den Einflussfaktoren auf die Attraktivität einer Position im landwirtschaftlichen Vertrieb aus Sicht von 299 Studierenden der Agrarwissenschaften. Er basiert auf den Ergebnissen einer Onlinebefragung zum Thema Vertrieb im agrarwissenschaftlichen Hochschulstudium. Die Erhebung wurde im November 2018 durchgeführt. Die Zielsetzung der Arbeit liegt darin, herauszufinden, welche Faktoren die Attraktivität einer Vertriebsposition für Studierende der Agrarwissenschaften beeinflussen. Die Ermittlung von Faktoren, die Hochschulabsolvierende dazu veranlassen, eine Position im 
Vertrieb anzunehmen, soll helfen die Rekrutierungskosten zu senken und die Chancen zu verbessern, VertriebsmitarbeiterInnen auszuwählen, die ihren Berufsstart mit einer positiven Einstellung zum Vertrieb beginnen (Crawford und Lumpkin, 1983).

An die Einleitung schließt sich die Vorstellung relevanter theoretischer Grundlagen an (Kapitel 2). In Kapitel 3 wird die im Rahmen der Untersuchung angewandte Methodik vorgestellt. Im vierten Kapitel werden die Ergebnisse zu den Einflussfaktoren auf die Attraktivität einer Position im Vertrieb von Studierenden der Agrarwissenschaften vorgestellt. Zum Abschluss werden die Ergebnisse bewertet und ein Ausblick auf mögliche zukünftige Forschungsfragen gegeben.

\section{Theoretischer Hintergrund}

\subsection{Die Rolle des Vertriebs im Unternehmen}

Im Zusammenhang mit dem Absatz von Produkten und Dienstleistungen existieren verschiedene Begriffsdefinitionen. In dem vorliegenden Artikel werden die Ausführungen von Albers und Krafft (2013) zur Definition des Begriffs zugrunde gelegt. Diese definieren den Vertrieb als „das Verkaufen von Produkten und Leistungen durch eigene Mitarbeiter, Dritte oder unpersönliche Kanäle wie Direct Mailings, das Internet oder Telefon“ (Albers und Krafft, 2013:2). Unterschieden wird zwischen dem Vertrieb zwischen Unternehmen und privaten Konsumenten (B2C) und dem Vertrieb zwischen mindestens zwei Unternehmen (B2B).

Der Vertrieb stellt eine wichtige betriebliche Funktion in fast allen Unternehmen dar. Dem persönlichen Verkauf kommt aufgrund der zunehmenden Bedeutung einer kundenorientierten Vertriebsausrichtung und komplexer werdenden Verkaufssituationen trotz der Entwicklungen im Onlineabsatz weiterhin eine wichtige Rolle zu (Zallocco et al., 2009). Um die Bedeutung des Vertriebs für das Unternehmen zu unterstreichen, wird er in diesem Zusammenhang häufig als Schnittstelle bzw. Bindeglied zur Kundschaft bezeichnet (Albers und Krafft, 2013; Puspitasari und Harjanti, 2017; Schmitz und Wieseke, 2015). Vor allem für mittelständische Unternehmen des Agribusiness, die ihre Produkte und Dienstleistungen an landwirtschaftliche KundInnen (B2B-Vertrieb) absetzen, ist der Vertrieb von zentraler Bedeutung (Albers und Krafft, 2013; Voss, 2008). Laut Briedis et al. (2011) hat der Vertrieb für den Geschäftserfolg im Vergleich zu anderen Unternehmensbereichen mit $61 \%$ die größte Bedeutung. Lux (2010) stellt in diesem Zusammenhang fest, dass 89\% der befragten Vorstände 
sowie die Vertriebs-, und Geschäftsleitung den Bereich Vertrieb wichtiger einschätzen als die Produktion, das Marketing und die Forschung und Entwicklung (Lux, 2010).

\subsection{Der Vertrieb und seine Position in der Gesellschaft}

In Deutschland sind knapp 10\% der sozialversicherungspflichtig Beschäftigten in Einkaufs-, Vertriebs-, Handels- und Verkaufsberufen tätig (Schmitz und Wieseke, 2015; Statista, 2015). Positionen im Vertrieb weisen einen hohen Anteil an männlichen Mitarbeitern auf. Nur etwa 10-15\% Frauen bewerben sich auf offene Stellen im Vertrieb (Böttcher, 2012), wenngleich die persönlichen Eigenschaften von Frauen oft als vorteilhaft für die Vertriebsarbeit eingeschätzt werden (Böttcher, 2012; Croson und Gneezy, 2009b; Zimmermann, 2014). Ebenso treten tendenziell mehr Bachelor- als Masterabsolvierende eine Position im Vertrieb an (KonegenGrenier, 2011; Konegen-Grenier und Koppel, 2009; Schwerdtfeger, 2015b). Insgesamt planen rund 46\% der deutschen Unternehmen, ihre Vertriebsabteilung bis 2020 um etwa 30\% zu vergrößern (Schmitz und Wieseke, 2015). Besonders für Berufseinsteigende kann der Vertrieb ein spannendes und abwechslungsreiches Berufsfeld darstellen. Positionen im Vertrieb bieten für junge Berufseinsteigende lukrative Verdienstmöglichkeiten und stellen aufgrund des erlangten Markt- und Kundenwissens häufig eine gute Basis für den Aufstieg in höhere Positionen in Unternehmen dar (Winkelmann, 2012).

Als Hauptgrund für den bestehenden Fach- und Führungskräftemangel im Vertrieb gilt vor allem das schlechte Image des Berufsbildes (Schmitz und Wieseke, 2015; Zimmermann, 2014). Der Ruf des Vertriebs in der öffentlichen Wahrnehmung ist eher negativ. Eine im Jahr 2015 durchgeführte Öffentlichkeitsbefragung zum Thema Vertrieb zeigt auf, dass die Meinung, der Job von Vertriebsmitarbeitenden sei in erster Linie das "Klinkenputzen" und "Andrehen von Produkten", weiterhin sehr verbreitet ist (Schmitz und Wieseke, 2015). Vertriebsmitarbeitende werden als unehrlich und eigennützig eingeschätzt und ihr Job wird als unattraktiv eingestuft. Obwohl 76\% der VertriebsmitarbeiterInnen gerne in ihrem Beruf arbeiten, bewerten 67\% der Bevölkerung das Berufsfeld Vertrieb als unattraktiv (Schmitz und Wieseke, 2015).

Auch bei Studierenden ist diese negative Sichtweise auf die Vertriebstätigkeit stark verankert (Crawford und Lumpkin, 1983). Die wahrgenommene Attraktivität einer Vertriebsposition bzw. das Image des Vertriebs wird dabei sowohl von der persönlichen Vertriebserfahrung der Studierenden als auch vom beruflichen Hintergrund ihrer Eltern beeinflusst (Crawford und Lumpkin, 1983). Neben Bedenken bezüglich eines hohen Arbeitsdrucks und langer Arbeitszeiten wirkt sich bei Frauen auch ein im Vergleich zu Männern stärkeres 
Sicherheitsbedürfnis aus. Variable Gehälter und Arbeitszeiten wirken daher negativ (Zimmermann, 2014). Diese empfundene Unsicherheit des Vertriebsberufs wird von Studenten geteilt (Crawford und Lumpkin, 1983). Auch die Work-Life-Balance ist zu einem entscheidenden Faktor bei der Berufswahl geworden (Ehrhart et al., 2012).

Geprägt wird die Wahrnehmung des Vertriebs ebenfalls durch bestimmte Verkaufsansätze der Verkäufer. Machen KundInnen in Verkaufssituationen schlechte Erfahrungen, so übertragen sie diese auf den Vertriebsmitarbeitenden (Nachtwei, 2014). Solche, durch Negativerfahrungen entstehende Vorurteile sind das Ergebnis von unmoralischem und meist proaktivem Verhalten einiger VertriebsmitarbeiterInnen (Nerdinger, 2001). In der Forschung zu Vertriebskonzepten werden Hard- und Soft-Selling unterschieden (Okazaki et al., 2010). Während es sich beim Hard-Selling-Ansatz um einen direkten, oft aggressiveren Verkaufsansatz mit dem Ziel schneller Abschlüsse handelt, wodurch er bei Nachwuchskräften auf Bedenken stößt, ist der Soft-Selling-Ansatz eher indirekter und geht mehr auf die KundInnen ein, wodurch er durch Nachwuchskräfte positiver wahrgenommen wird (Guenzi, 2003; Okazaki et al., 2010; Zboja et al., 2016).

Zukünftig könnten die beschriebenen Bedenken der Nachwuchskräfte gegenüber dem Hard-Selling jedoch an Relevanz verlieren. Bedingt dadurch, dass das Arbeitsumfeld von Vertriebsmitarbeitenden zunehmend komplexer und wettbewerbsintensiver wird, verändern sich ebenfalls die gewählten Verkaufsansätze (Schmitz und Ganesan, 2014). Die Komplexität nimmt sowohl auf der Kundenseite durchzunehmende Nachfrage nach kundenindividuellen Lösungen, als auch auf Unternehmensseite im Hinblick auf die interne Organisation zu (Schmitz und Ganesan, 2014). Um weiterhin wettbewerbsfähig zu bleiben, ist eine kundenorientierte Vertriebsausrichtung und damit ein Übergang von harten (Hard-Selling) zu weichen Verkaufsansätzen (Smart/Soft Selling) erforderlich (Ferreira, 2017; Guenzi, 2003).

Die stärkere strategische und kundenorientierte Ausrichtung des Vertriebs zeigt sich in höheren Kompetenz- und Anforderungsprofilen (Schmitz und Wieseke, 2015). Neu eingestellte VertriebsmitarbeiterInnen verfügen oft über große Defizite. Ein Grund kann der Mangel an Modulen mit vertrieblicher Ausrichtung an den Hochschulen sein (Schmitz und Wieseke, 2015). Im Studium wird der Vertrieb meist nur als Teilbereich des Marketing-Mixes behandelt, die Forschung zu vertrieblichen Fragestellungen ist im Vergleich zu anderen Themen des Marketings geringer. Dies führt dazu, dass der Vertrieb ein typischer "Quereinsteiger-Bereich" ist, indem die MitarbeiterInnen eine divergierende und eher geringe universitäre Vorbildung aufweisen (Schmitz und Wieseke, 2015). Insgesamt wird von 69\% der 
Unternehmen beklagt, dass die Hochschulen Vertriebsthemen nicht ausreichend behandeln, während die Nachfrage nach Hochschulabsolvierenden mit Vertriebskenntnissen weiter steigt (Schmitz und Wieseke, 2015). Aufgrund der neuen Herausforderungen, mit denen sich der persönliche Verkauf konfrontiert sieht, ist davon auszugehen, dass Vertriebsmitarbeitende zukünftig ein breiteres Kompetenzportfolio benötigen (Schmitz und Wieseke, 2015). Laut Crawford und Lumpkin (1983) mangelt es Studierenden an Informationen zur Bedeutung des Vertriebs für die Wirtschaft. Hinzu kommen Mängel bei betriebswirtschaftlichen Grundkenntnissen und der Kommunikation mit KundInnen (Schmitz und Wieseke, 2015).

\subsection{Der Vertrieb im deutschen Agribusiness}

Unter dem Begriff Agribusiness werden alle der Landwirtschaft vor- und nachgelagerten Wertschöpfungsstufen zusammengefasst (Janze et al., 2018). In den vergangenen Jahren hat sich das deutsche Agribusiness positiv entwickelt, vor allem die Exportquote konnte gesteigert werden, und die Zahl der Beschäftigten stieg an (Janze et al., 2018; Statista, 2018). Pascher et al. (2018) konstatieren in Bezug auf den landwirtschaftlichen Arbeitsmarkt, dass etwa 150.000 junge Erwachsene mit abgeschlossener Ausbildung oder Studium jährlich in einem Beruf im Agribusiness beginnen (Pascher et al., 2018). Rund 11\% der Erwerbstätigen in Deutschland arbeiten in den 750.000 Unternehmen des Sektors. Insgesamt erwirtschaftet das Agribusiness 8\% der gesamtwirtschaftlichen Wertschöpfung in Deutschland und stellt etwa jeden zehnten Ausbildungsplatz (VDL, 2018). Der Vertrieb gilt als wichtiges berufliches Tätigkeitsfeld im Agribusiness (VDL, 2018).

\subsection{Herausforderungen des Vertriebs im Agribusiness}

Die vertrieblichen Aktivitäten in der Landwirtschaft lassen sich wie folgt beschreiben: Unternehmen der Vorleistungsindustrie setzen ihre Produkte und Dienstleistungen (Saatgut, Pflanzenschutzmittel, Landtechnik) an landwirtschaftliche Betriebe der Tier- und Pflanzenproduktion sowie der Bioenergieerzeugung ab. Zwar erfolgt der Absatz der Produkte klassischerweise über verschiedene Handelsstufen (indirekter Vertrieb), jedoch stellen die herstellenden Unternehmen ein erhebliches Vertriebsbudget für Service und Beratung bereit (Strecker et al., 2010). Die Beratung und der Service rund um das Produktportfolio sichern einen engen Kontakt zur landwirtschaftlichen Kundschaft und erfolgen durch einen personalintensiven Außendienst (Barnard et al., 2016; Maier, 2013; Voss, 2008). Für Unternehmen der landwirtschaftlichen Vorleistungsindustrie gilt „regelmäßiger Kundenbesuch durch Außendienstmitarbeiter" mit 78,3\% als der am häufigsten verwendeten 
Kommunikationsweg (Voss, 2008). Daraus resultiert eine konstante Nachfrage an Fach- und Führungskräften im Bereich des Vertriebs (Schwerdtfeger, 2015a).

Das Agribusiness in Deutschland steht einigen Herausforderungen gegenüber, die ebenfalls direkten Einfluss auf die strategische Ausrichtung der vertrieblichen Aktivitäten in den Unternehmen haben. Neben dem allgemein schlechten Ruf dieses Berufsfeldes werden die speziellen Herausforderungen für den Vertrieb im Agribusiness im Folgenden kurz skizziert.

In den vergangenen Jahrzehnten setzen verstärkt strukturelle Veränderungen in der deutschen Landwirtschaft ein, die immer mehr zu einer Änderung der Marktbedingungen führen (Balmann und Schaft, 2008; Hemmerling et al., 2016; Voss, 2008). Da die Anzahl der Betriebe kontinuierlich abnimmt und der Flächen- und Produktionsumfang relativ konstant bleibt, steigt die Größe der bestehenden landwirtschaftlichen Unternehmen stetig. Dies führt dazu, dass einzelne landwirtschaftliche Betriebe ihr Budget für den Einkauf von Betriebsmitteln erhöhen und für Lieferunternehmen wichtiger werden (Voss, 2008). Dieser Wandel wirkt sich auf alle Teilnehmende der Wertschöpfungskette aus, welche sich den neuen Gegebenheiten anpassen müssen. So sind Unternehmen der landwirtschaftlichen Vorleistungsindustrie bestrebt, ihre Marketing- und Vertriebsprozesse neu zu gestalten und konsequenter an verschiedene Zielgruppen anzupassen (Voss, 2008).

Neben dem Strukturwandel in der Landwirtschaft wird auch die digitale Transformation den Vertrieb vor Herausforderungen stellen und Veränderungen herbeiführen. In diesem Zusammenhang gilt häufig der Einsatz neuer Technologien wie digitale Marktplätze, Big Data, Augmented Reality oder künstliche Intelligenz als Treiber für Veränderungen im Vertrieb (Wallmüller, 2017). Exemplarisch lässt sich hierzu aufführen, dass die Möglichkeit, Informationen und Produkte über das Internet $\mathrm{zu}$ beziehen, die Rolle der Vertriebsmitarbeitenden, welche früher für die Bereitstellung produktspezifischer Informationen zuständig waren, verändert hat (Storbacka et al., 2009). Unternehmen der Vorleistungsindustrie digitalisieren zunehmend ihre Marketing- und Vertriebsaktivitäten.

Der wachsende Fach- und Führungskräftemangel stellt für Unternehmen des Agribusiness in Deutschland ebenfalls eine Herausforderung dar. Laut Prognosen wird der Bedarf an Fachkräften in der Agrarbranche in den nächsten zehn Jahren um etwa $10 \%$ steigen (VDL, 2018). Die Vermarktung von komplexen Produkten der Vorleistungsindustrie und die daran geknüpften kundenbindenden Dienstleistungen stellen eine anspruchsvolle Aufgabe dar, welche bestimmte persönliche und fachliche Fähigkeiten von VertriebsmitarbeiterInnen fordern (Schmitz und Wieseke, 2015). Der hohe Anspruch zeigt sich in dem Bildungsniveau 
der VertriebsmanagerInnen, da 65\% von ihnen ein Studium absolviert haben (Seidenglanz et al., 2016). Diese Tendenz zeigt sich ebenfalls im Agribusiness.

Für 19\% der Fachhochschulabsolvierenden und 16\% der Universitätsabsolvierenden in agrarwissenschaftlichen Studiengängen liegt der erste Einsatzbereich nach dem Studium im Vertrieb des Agribusiness (VDL, 2018). Bereits heute haben Unternehmen Schwierigkeiten, gut ausgebildete VertriebsmitarbeiterInnen zu gewinnen, welche den steigenden Anforderungen des Marktes gerecht werden (VDL, 2014). Eine Umfrage des VDL Berufsverband Agrar, Ernährung, Umwelt e.V. (VDL) macht deutlich, dass im Agribusiness gegenwärtig und zukünftig Arbeitskräfte für den Unternehmensbereich Vertrieb gesucht werden. Unternehmen des Agribusiness bewerten mit $78 \%$ besonders die Suche nach Fachkräften im Bereich Vertrieb als schwierig. Noch schwieriger gestaltet sich die Suche nach Führungskräften für den Bereich Vertriebsaußendienst (86\%), (VDL, 2014). Schwerdtfeger (2015a) konstatiert dazu, dass im Agribusiness neben dem Vertrieb die Bereiche Informationstechnologie und die Produktion besonders vom Fachkräftemangel betroffen sind.

Der Vertrieb im deutschen Agribusiness befindet sich damit insgesamt in einem Spannungsfeld aus landwirtschaftlichem Strukturwandel, zunehmender digitaler Transformation der Landwirtschaft, dem Fach- und Führungskräftemangel sowie einer eher negativen Wahrnehmung in der Öffentlichkeit. Vor diesem Hintergrund stellt sich die Frage, welche Faktoren darauf Einfluss haben, ob Studierende der Agrarwissenschaften, also potenzielle VertriebsmitarbeiterInnen, sich zukünftig vorstellen können, im Vertrieb zu arbeiten. Der vorliegende Beitrag liefert einen Beitrag zur Erklärung der Fachkräftelücke im Agribusiness und verweist auf die Relevanz von Job-Images für das Berufswahlverhalten von Studierenden. $\mathrm{Zu}$ beiden Fragen liegen bisher nur wenige Forschungsarbeiten vor.

$\mathrm{Zu}$ den untersuchten Einflussfaktoren zählen neben der Einstellung auch die Berührungspunkte und Erfahrungen mit dem Vertrieb sowie studienbezogene Daten wie Studienform und Studienschwerpunkt. Der vorliegende Beitrag leistet damit einen Beitrag zum Themengebiet Personalwirtschaft und Hochschulausbildung, welcher bisher wenig untersucht wurde (von Davier und Theuvsen, 2010). 


\section{$3 \quad$ Material und Methoden}

Um die Einstellung von Studierenden der Agrarwissenschaften zum Thema Vertrieb zu ermitteln, wurde ein Fragebogen mit einstellungsbasierten Fragen als auch Fragen zur Erfahrung mit dem Vertrieb in einem webbasierten Format durchgeführt. Das mittels Schneeballsystems generierte Convenience-Sample aus 299 Datensätzen wurde über ProfessorInnen und DozentInnen, persönliche Kontakte sowie in den sozialen Medien generiert. Die Studie wurde im November 2018 in Deutschland durchgeführt. An der Umfrage nahmen insgesamt 299 Studierende verschiedener Hochschulen teil. Es handelt sich bei der Stichprobe um eine nicht repräsentative Auswahl. Abgefragt wurden die verschiedenen Statements mithilfe einer fünfstufigen Likert-Skala von 1=,trifft zu“ bis 5=,trifft nicht zu“. Mit der Option, Mehrfachnennungen abzugeben, wurden die Studierenden einleitend nach ihren Berührungspunkten mit dem Vertrieb gefragt. Als Berührungspunkte konnten beispielsweise Praktika, Beruf oder Vertriebsmodule im Studium angegeben werden. So konnte eine Skala für die Variable Berührungspunkte mit dem Vertrieb von 1 (keine Berührungspunkte) bis 5 (min. 4 Berührungspunkte) gebildet werden. Die Variable des landwirtschaftlichen Hintergrundes reicht von 1 (keinen Hintergrund) bis 4 (starker Hintergrund, über die Eltern hinaus). Die Bewertung der Vertriebsinhalte, welche im Studium vermittelt werden, erfolgte im Schulnotensystem von sehr gut (1) bis ungenügend (6). Zur Bestimmung der präferierten JobCharakteristika wurden typische Charakteristika einer Vertriebstätigkeit (Homeoffice, Reisen, flexible Arbeitszeiten etc.) den typischen Charakteristika einer Innendiensttätigkeit (fester Arbeitsplatz, geregelte Arbeitszeiten etc.) gegenübergestellt, wobei die Skalierung von 1 (pro Vertriebsaußendienst) über 3 (neutral) bis 5 (pro Innendienst) erfolgt.

Die statistische Auswertung erfolgte mithilfe des Programms IBM SPSS Statistics 25. Anschließend an eine deskriptive Stichprobenbeschreibung wurde, zur Überprüfung der bestehenden Images, eine Verdichtung von Items in Form einer Faktorenanalyse mittels Hauptkomponentenanalyse und Varimax-Rotation (Tabelle 1) vorgenommen. Die Reliabilität der ermittelten Faktoren wurde mit Hilfe von Cronbach's Alpha (CA) untersucht (Hair et al., 2009). Im Anschluss wurde mit einer linearen Regression ein Modell, das die Einflussfaktoren auf die Attraktivität einer Vertriebsposition aus Sicht von Agrarstudierenden abbildet, geschätzt. Eine Regressionsanalyse dient dazu, kausale Beziehungen zwischen der Attraktivität einer Vertriebsposition und anderen relevanten Variablen aufzuzeigen. Neben den soziodemografischen Angaben wurden, die zuvor durch die Faktorenanalyse identifizierten, Einstellungsdimensionen als unabhängige Variable in die Schätzung einbezogen (Bühl, 2016). 


\section{$4 \quad$ Ergebnisse}

\subsection{Stichprobenbeschreibung}

Das Sample weist eine ausgeglichene Geschlechterverteilung auf. Bei einer Altersspanne von 18-34 Jahren beträgt das Durchschnittsalter 23,3 Jahre. Die Teilnehmenden teilen sich auf in 42,5\% Masterstudierende und 57,5\% Bachelorstudierende, wovon sich etwa 39\% für und 35\% gegen ein zukünftiges Masterstudium aussprechen. 26\% der Bachelorstudierenden sind hingegen unentschlossen, ob sie ein Masterstudium im Anschluss an den Bachelor aufnehmen sollen. Die Studierenden verteilen sich zu 65,5\% auf Universitäten, 29,1\% auf Fachhochschulen (FH) und 5,4\% machen keine genaue Angabe dazu. Die Mehrheit der Studierenden (43,5\%) wählt in ihrem Studium eine Vertiefung im Wirtschaftsbereich. Knapp 20\% spezialisieren sich auf den Bereich Pflanze und rund 16\% auf den Tierbereich. Nahezu 90\% der Probanden geben an, landwirtschaftliche Berufserfahrung zu haben. Einen familiären landwirtschaftlichen Hintergrund haben $76,4 \%$.

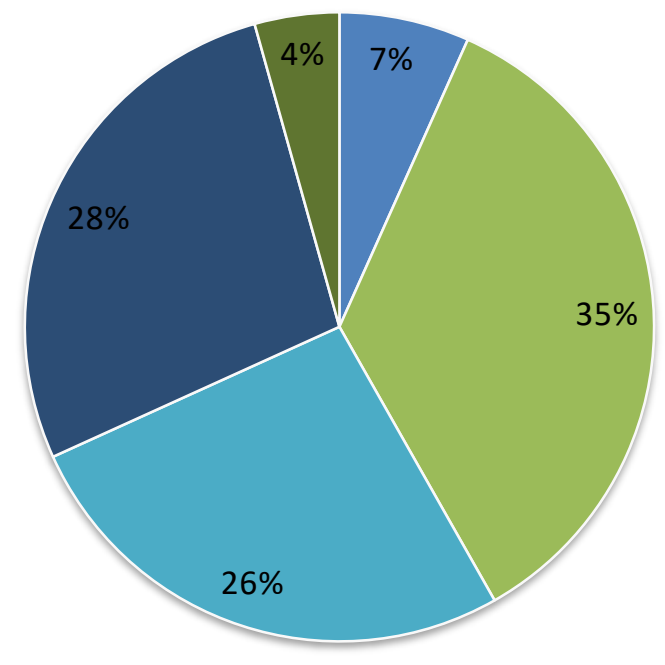

- Ja, auf jeden Fall

- Ja, wahrscheinlich schon

- Vielleicht/ weiß nicht

- Nein, eher nicht

- Nein, auf keinen Fall

Abbildung 1: Anteil der Studierenden, die sich vorstellen können, nach dem Studium im Vertrieb zu arbeiten $(\mathrm{N}=299)$

Quelle: Eigene Erhebung.

Rund 56\% geben an, keine Berührungspunkte mit dem Vertrieb zu haben. Insgesamt können sich weniger als die Hälfte der Agrarwissenschaftsstudierenden (42\%) vorstellen, nach dem Studium im Vertrieb zu arbeiten, während sich $32 \%$ nicht vorstellen können, im Vertrieb zu arbeiten (Abb. 1). 
Abbildung 2 verdeutlicht, dass die Vorbereitung auf eine Position im Vertrieb durch das Hochschulstudium als eher schlecht angesehen wird. Rund $28 \%$ der befragten AgrarstudentInnen fühlen sich mangelhaft bis ungenügend auf eine Tätigkeit im Vertrieb vorbereitet.

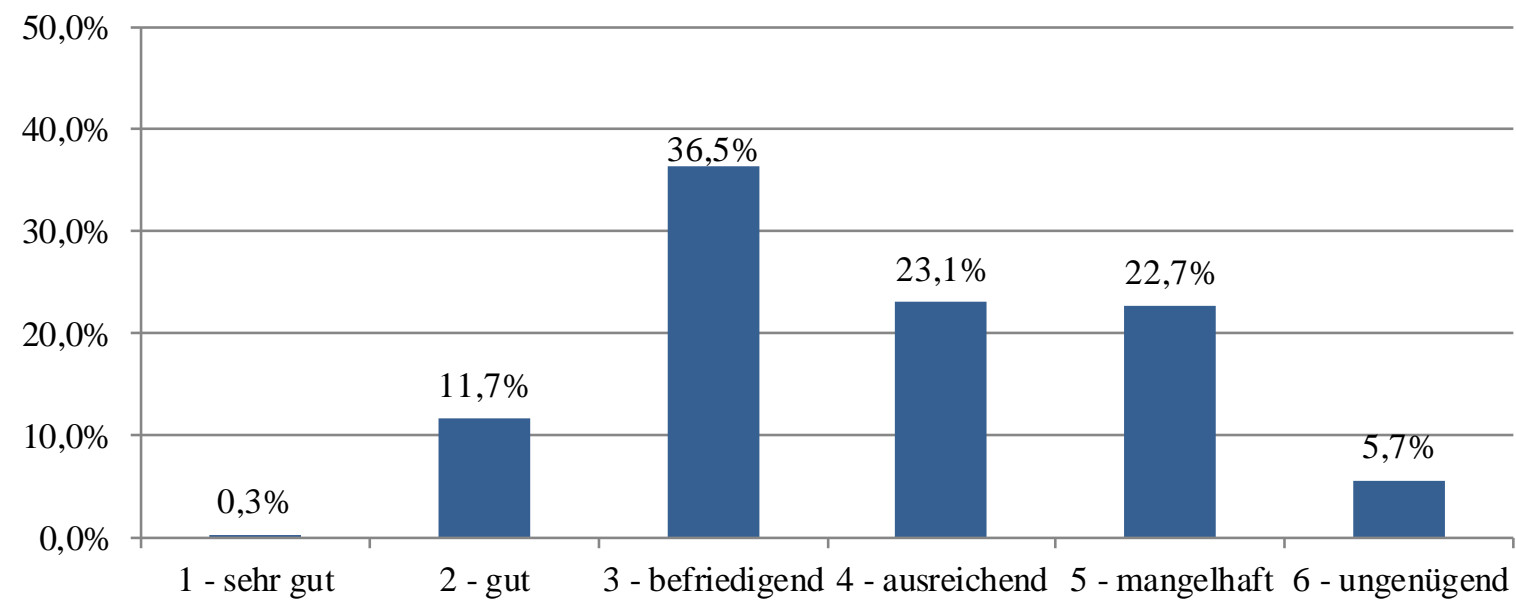

Abbildung 2: Bewertung der Vorbereitung auf den Vertrieb durch das Studium (N=299)

Quelle: eigene Erhebung.

\subsection{Einflussfaktoren auf die Attraktivität einer Vertriebsposition}

Im Rahmen der Befragung wurden die Studierenden zu ihrer Einstellung zum Vertrieb befragt. Mit Hilfe einer 5-stufigen Likert-Skala von 1=,,trifft zu“ bis 5=,,trifft nicht zu“ konnten die Teilnehmenden ihre Einstellung zum Vertrieb angeben. Mittels der Faktoranalyse wurden diese Statements dann zu zwei Faktoren verdichtet. Einen Überblick über die identifizierten Faktoren und die kennzeichnenden Items der Faktoren gibt Tabelle 1. Die in Tabelle 1 dargestellten Gütekriterien der Faktorenanalyse entsprechen den in der Literatur beschriebenen allgemeinen Anforderungen (Backhaus et al., 2016; Bühl, 2016), wodurch das Ergebnis der Faktorenanalyse für eine anschließende Regressionsanalyse verwendet werden kann.

Um zu bestimmen, was Einfluss auf die Attraktivität einer Vertriebsposition für AgrarstudentInnen hat, wird im Folgenden eine Regressionsanalyse durchgeführt (Tabelle 2). Abhängige Variable ist das Item „Können Sie sich vorstellen, nach dem Studium im Vertrieb zu arbeiten?" mit der Skalierung von 1=,Ja, auf jeden Fall“" über 3=,,vielleicht" bis 5=,,nein, auf keinen Fall“. In das Modell wurden neben den zwei Faktoren zur Einstellung gegenüber dem Vertrieb auch soziodemografische Daten (Geschlecht, familiärer Hintergrund), studienbezogene Daten und Vertriebserfahrung aufgenommen. 
Das Modell hat mit einem $R^{2}=0,378$ (korrigiertes $R^{2}=0,332$ ) eine relativ hohe Anpassungsgüte (Cohen, 1992). Die 10 Prädiktoren erklären 33,2\% der Streuung der Attraktivität einer Anstellung im Vertrieb. Mittels der standardisierten Beta-Koeffizienten (Effektgröße) können die Einflussfaktoren verglichen werden.

Tabelle 1: Faktoren zur Einstellung der Studierenden zum Vertrieb

\begin{tabular}{lcc}
\hline \multicolumn{1}{c}{ Faktoren/Statements $^{\mathbf{a}}$} & Faktorladung & Mittelwert \\
\hline Hard-Selling-Image des Vertriebs (Cronbach's Alpha = 0,759) & & \\
\hline Es geht nur ums Verkaufen und die Abschlüsse. & 0,791 & 2,72 \\
Vertriebsarbeit ist das klassische Klinkenputzen. & 0,759 & 2,95 \\
Die meisten Verkäufer sind nur am Abschluss interessiert. & 0,748 & 2,51 \\
Ein typischer Vertriebsmitarbeiter ist eigennützig. & 0,691 & 2,87 \\
\hline Karriereoptionen und Nützlichkeit des Vertriebs (Cronbach's Alpha = 0,550) & \\
\hline Ein Einstieg im Vertrieb öffnet die Türen für die weitere Karriere. & 0,765 & 2,21 \\
Mit einer Position im Vertrieb lässt sich schnell viel Geld verdienen. & 0,648 & 2,78 \\
Ein Vertriebsmitarbeiter hilft seinen Kunden beim Erfolg ihres & 0,619 & 2,28 \\
Unternehmens. & & \\
Die Vertriebsarbeit ist abwechslungsreich und vielschichtig. & 0,526 & 2,46 \\
\hline
\end{tabular}

a5er Likert-Skala: 1=,,trifft zu“ bis 5=,,trifft nicht zu“, KMO=0,752; Erklärte Gesamtvarianz= 52,170\%

Quelle: Eigene Erhebung.

Tabelle 2: Determinanten der Vertriebsattraktivität aus Sicht von Studierenden

\begin{tabular}{|c|c|c|c|}
\hline Unabhängige Variablen & $\begin{array}{c}\text { Effektgröße } \\
\text { (Beta) }\end{array}$ & T-Wert & Signifikanz \\
\hline $\begin{array}{l}\text { Karriereoptionen und Nützlichkeit des } \\
\text { Vertriebs }\end{array}$ & 0,323 & 4,704 & 0,000 \\
\hline Hard-Selling-Image des Vertriebs & $-0,267$ & $-3,975$ & 0,000 \\
\hline Berührungspunkte mit dem Vertrieb & $-0,207$ & $-2,65$ & 0,009 \\
\hline Präferierte Job-Charakteristika & 0,203 & 2,8 & 0,006 \\
\hline Studienabschnitt ${ }^{\mathrm{c}}$ & 0,143 & 1,904 & 0,059 \\
\hline Qualität der Vorlesungsinhalte & $-0,140$ & $-1,863$ & 0,064 \\
\hline Landw. familiärer Hintergrund & $-0,119$ & $-1,757$ & 0,081 \\
\hline Geschlecht ${ }^{b}$ & $-0,060$ & $-0,827$ & 0,409 \\
\hline Studienschwerpunkt Nutzpflanze ${ }^{d}$ & 0,051 & 0,637 & 0,525 \\
\hline Studienschwerpunkt Nutztier ${ }^{\mathrm{d}}$ & 0,040 & 0,484 & 0,629 \\
\hline Studienschwerpunkt Wirtschaft ${ }^{d}$ & 0,026 & 0,285 & 0,776 \\
\hline
\end{tabular}


Gemessen an der Effektgröße $(\beta)$ haben die Karriereoptionen und die Nützlichkeit des Vertriebs den größten Einfluss auf die Attraktivität einer Vertriebsposition. Je nützlicher der Vertrieb den Studierenden also erscheint, desto vorstellbarer ist es für sie, im Vertrieb zu arbeiten. Während das Hard-Selling-Image des Vertriebs dazu führt, dass sich weniger Studierende vorstellen können, nach dem Studium im Vertrieb zu arbeiten. Gehen die Studierenden also davon aus, dass die Vertriebsarbeit klassisches "Klinkenputzen" bedeutet, so können sie sich nicht vorstellen, im Vertrieb zu arbeiten. Wird der Vertrieb jedoch als Karrieresprungbrett und abwechslungsreich erachtet, wirkt sich dies positiv aus. Wobei sich das positive Image stärker auswirkt $(\beta=0,323)$ als das negative Hard-Selling-Image $(\beta=-0,267)$.

Einen ebenfalls starken Einfluss hat die Anzahl der Berührungspunkte mit dem Vertrieb. Je öfter Studierende mit Themen des Vertriebs in Kontakt gekommen sind, bspw. über Praktika und Vorlesungen im Studium, umso denkbarer ist für sie eine Anstellung im Vertrieb. Hinsichtlich des Studiums wirkt sich die Qualität der Vorlesungsinhalte $(\beta=-0,140)$ in Bezug auf das Thema Vertrieb leicht negativ aus, das heißt, auch mit schlechten Inhalten der Studiengänge zum Thema Vertrieb kann sich ein Student vorstellen, im Vertrieb zu arbeiten.

Einen geringen Einfluss hat auch der Studienabschnitt. Studierende im Bachelor sind eher bereit, eine Vertriebsposition anzunehmen. Die Vertiefung im Studium, also der Studienschwerpunkt, hat hingegen keinen signifikanten Einfluss. Das Interesse an einer Vertriebstätig ist unabhängig davon, ob Studierende schwerpunktmäßig Nutztier- oder Nutzpflanzenwissenschaften bzw. Agrarwissenschaften mit ökonomischem Schwerpunkt studieren. Sind für Studierende eher die typischen Charakteristika einer Vertriebsposition (flexible Arbeitszeiten, Geschäftsreisen, Leistungszulagen, Verkaufsdruck) interessant, dann können sie sich auch eher vorstellen, dort zu arbeiten.

Einen schwach signifikanten Einfluss hat der landwirtschaftliche familiäre Hintergrund, mit einer steigender Attraktivität der Vertriebsposition bei starkem familiärem landwirtschaftlichem Hintergrund. Das Geschlecht hat keinen signifikanten Einfluss. 


\section{Diskussion und Ausblick}

Die Ergebnisse machen deutlich, dass die Vertriebsarbeit bei vielen Studierenden nur ein mäßiges Image genießt. Dies ist wenig überraschend und spiegelt die Wahrnehmung der Bevölkerung wider (Schmitz und Wieseke, 2015).

Das Image des Vertriebs bei Studierenden, sowohl negativ als auch positiv, hat einen sehr starken Einfluss darauf, ob sie sich eine Position im Vertrieb vorstellen können oder nicht. Besonders positiv wirkt sich der Faktor Karriereoptionen und Nützlichkeit aus. Je stärker die Studierenden also davon ausgehen, dass der Vertrieb ihre Karrierechancen erhöht und Nutzen stiftet, desto attraktiver ist für sie auch eine Position im Vertrieb.

Das negativ behaftete Hard-Selling-Image wirkt hingegen als hemmender Faktor der Attraktivität einer Vertriebsposition. Der VDL sieht das schlechte Image des Vertriebs als Hauptgrund für den dortigen Fachkräftemangel (VDL, 2014). Viele negative Bewertungen gehen auf harte Verkaufsmethoden zurück, welche nicht primär am Kundennutzen orientiert sind, sondern an der Maximierung des (kurzfristigen) Gewinns der anbietenden Unternehmen. Es ist allerdings zu beobachten, dass im Vertriebsmanagement im B2B-Bereich die Kundschaft und deren langfristige Zufriedenheit in den Vordergrund der Vertriebsziele gerückt wird (Albers und Krafft, 2013; Voss, 2008). Im Vergleich zur vormals existierenden Hard-SellingAusrichtung liegt der Fokus der MitarbeiterInnen nicht mehr nur auf dem Verkaufsabschluss, sondern auf einer intensiven Betreuung der KundInnen, deren Probleme rechtzeitig erkannt und gelöst werden müssen (Albers und Krafft, 2013; Backhaus et al., 2011; Voss, 2008). Eine solche strategische Kundenorientierung könnte langfristig einen erheblichen Einfluss auf das generelle Image des persönlichen Verkaufs nehmen (Kittinger, 2010) und sollte zukünftig deutlich stärker kommuniziert werden, um das Berufsfeld für Studierende der Agrarwissenschaften attraktiver zu machen. Dies kann sowohl über Einblicke in die praktische Vertriebsarbeit bspw. in Form von Praktika geschehen als auch über eine stärkere Präsenz auf Jobmessen und Berufsinformationstagen an Hochschulen, bei denen über die Vertriebstätigkeit informiert wird. Ebenso können Vorlesungen zum Thema Vertrieb an den Hochschulen einen gewissen Beitrag leisten, um ein realistisches Bild von Vertriebstätigkeiten zu vermitteln. Zum einen, weil sie über die zunehmende Kundenorientierung des Vertriebs informieren, und zum anderen, weil sie erste theoretische Berührungspunkte schaffen. Es zeigt sich, dass die Besetzung von offenen Positionen im Vertrieb durch Studierende der Agrarwissenschaften dadurch positiv beeinflusst 
wird, wie oft die Studierenden mit dem Thema Vertrieb bereits in Kontakt gekommen sind, bspw. über Module mit vertrieblichen Inhalten in ihrem Hochschulstudium.

Ferner wird deutlich, dass je höher die Übereinstimmung der Vertriebs-Charakteristika mit den von Studierenden präferierten Job-Charakteristika (Flexibilität, Reisen, Festgehalt etc.) ist, desto höher ist die Bereitschaft im Vertrieb zu arbeiten. Es gilt also in zukünftigen Studien genauer zu untersuchen, was sich Studierende der Agrarwissenschaften in ihrem zukünftigen Beruf wünschen. Der vorliegende Beitrag lässt vermuten, dass Studierende vermehrt auf die Vereinbarkeit von Familie und Beruf, z.B. durch flexible Arbeitszeiten, Wert legen. In der vorliegenden Literatur zeigt sich, dass das Thema Work-Life-Balance für die Generation Y bei der Wahl der beruflichen Tätigkeit eine wichtige Rolle spielt (Ehrhart et al., 2012). Das heißt, Unternehmen könnten die Vertriebstätigkeit interessanter machen, wenn sie in Stellenanzeigen die Flexibilität der Arbeitszeit für die Arbeitnehmer herausstellen.

Hinsichtlich des Studiums zeigen die Ergebnisse, dass die gewählten Inhalte bzw. die Qualität der Vorlesungsinhalte einen schwachen negativen, aber signifikanten Einfluss auf die Wahl einer Vertriebsposition für Studierende haben. Das heißt, dass bereits durch eine einfache und oberflächliche Behandlung von Vertriebsthemen, wie durch Schmitz und Wieseke (2015) dargelegt wurde, ein positiver Effekt erzielt werden kann. Ein möglicher Grund für die mangelhaften Inhalte könnte auf eine schwache curriculare Verankerung von Modulen mit vertrieblichen Themenschwerpunkten an den Hochschulen hindeuten. Diese geringe Ausrichtung der Hochschulen auf den Vertrieb könnte daher ein möglicher Grund für den Mangel an potenziellen Vertriebsmitarbeitern sein (Schmitz und Wieseke, 2015). So sind mehr als $67 \%$ der Unternehmen der Auffassung, dass sich die Hochschulen zu wenig mit dem Thema Vertrieb beschäftigen (Schmitz und Wieseke, 2015). Laut der vorliegenden Ergebnisse wäre es denkbar, dass mit einem Ausbau Angebots von Vertriebsmodulen mit entsprechender Qualität die Attraktivität einer Position im Vertrieb für Studierende der Agrarwissenschaften deutlich gesteigert werden könnte.

Während dem gewählten Studienschwerpunkt keine signifikante Bedeutung auf die Wahl einer Position im Vertrieb zugesprochen werden kann, zeigt sich ein leichter, aber signifikanter Einfluss des Studienabschnitts. So können sich Bachelorstudierende eher vorstellen, im Vertrieb zu arbeiten, wobei der Effekt als eher schwach zu bewerten ist. Da nur rund 39\% der Bachelorstudierenden nach ihrem Bachelorstudium ein Masterstudium anstreben, lässt sich vermuten, dass die Bachelorstudierenden dieser Stichprobe praxisorientiert sind und schnell in das Berufsleben einsteigen möchten, z.B. über eine Tätigkeit im Vertrieb. Darüber hinaus 
deutet das Ergebnis darauf hin, dass Masterstudierende sich in anderen Tätigkeitsfeldern sehen. Diese Annahme stimmt mit den Erkenntnissen von Konegen-Grenier und Koppel (2009) überein. Demnach sehen Unternehmen die Haupteinsatzfelder für Masterabsolvierende in der Forschung sowie in der Entwicklung und Konstruktion und weniger im Vertrieb. Die Studie belegt zudem, dass AbsolventInnen mit Bachelorabschluss im Bereich Vertrieb, Marketing und Kundenakquise mit 22,8\% häufiger angestellt sind als AbsolventInnen mit Masterabschluss mit $6 \%$. Gleichzeitig geben aber rund 62\% der Unternehmen an, dass sowohl Bachelor- als auch Masterstudierende in diesem Arbeitsfeld einsetzbar sind (Konegen-Grenier und Koppel, 2009; Schwerdtfeger, 2015b). Ein genereller Ausbau an Modulen mit vertrieblichen Inhalten in Bachelor- und Masterstudiengängen könnte helfen, das Interesse an vertrieblichen Inhalten der Studierenden zu wecken und auch MasterabsolventInnen für eine Position im Vertrieb stärker zu motivieren. Die bisher als Grund für den Fachkräftemangel im Vertrieb angeführten mangelhaften Kompetenzen der Bewerbenden ließen sich durch ein längeres Studium, in Form eines Masterstudiums mit zusätzlicher Integration von Vertriebsmodulen reduzieren. Zudem sind Bewerbende mit Masterabschluss tendenziell älter und teilweise reifer, während es den Bachelorabsolvierende gelegentlich an Reife und Orientierung fehle (Petersdorff-campen, 2014). Das deutlich flexiblere und auf Selbstorganisation ausgerichtete Masterstudium könnte sich daher vorteilhaft auswirken.

Laut Crawford und Lumpkin sind Hochschulabsolvierende dem Vertrieb als Karriereweg gegenüber eher abgeneigt. Insbesondere diejenigen, die keine Erfahrungen mit der Vertriebsarbeit gesammelt haben oder nicht durch ihr Elternhaus in Kontakt zu diesem Berufsfeld stehen, sind von einer Vertriebstätigkeit wenig überzeugt (Crawford und Lumpkin, 1983). Auch der vorliegende Beitrag belegt, dass praktische Vertriebserfahrung und der familiäre Hintergrund einen Einfluss auf die Attraktivität einer Position im Vertrieb haben. Vorstellbar ist, dass sich gerade Studierende mit landwirtschaftlichem Hintergrund den direkten Kundenkontakt mit den landwirtschaftlichen BetriebsleiterInnen eher zutrauen als andere. Wobei laut Crawford und Lumpkin (1983) nicht der Effekt der tatsächlichen Vertriebserfahrung des Studenten signifikant ist, sondern vielmehr die Tatsache, ob einer oder beide Elternteile mit dem Vertrieb in Kontakt getreten sind. In der vorliegenden Studie zeigt sich jedoch, dass der Effekt der Berührungspunkte mit dem Vertrieb größer ist als der Effekt des familiären landwirtschaftlichen Hintergrundes. Begründet werden könnte dies damit, dass nicht explizit erfragt wurde, ob die Eltern im Vertrieb arbeiten oder gearbeitet haben. Zudem umfasst die Variable Berührungspunkte nicht nur die praktische Vertriebserfahrung, sondern ebenfalls 
andere Kontaktpunkte wie das Studium. Vertriebsorganisationen sollten daher jene Personen suchen, die bereits Berührungspunkte mit dem Vertrieb vorweisen und deren Eltern landwirtschaftliche oder vertriebliche Erfahrungen haben. Diese Studierenden bewerten alle Aspekte des persönlichen Verkaufs positiver und es bedarf weniger Überzeugungskraft, sie für eine Position im Vertrieb zu motivieren. Dafür sollten Rekrutierungsverfahren so angepasst werden, dass diese Eigenschaften der BewerberInnen vor und während des Rekrutierungsprozesses identifiziert werden können (Crawford und Lumpkin, 1983).

Eine berufliche Tätigkeit im Vertrieb gilt als sogenannte typische Männerdomäne, in der Frauen deutlich unterrepräsentiert sind (Stober und Meuwis, 1998). Zimmermann (2014) hält diesbezüglich fest, dass berufliche Tätigkeiten im Vertrieb für Frauen als wenig attraktiv gelten. Eine branchenübergreifende Analyse zeigt, dass nur etwa 10\% der Beschäftigten im Vertrieb weiblichen Geschlechts sind (Seidenglanz et al., 2016). Im vorliegenden Beitrag konnte dagegen kein signifikanter Einfluss des Geschlechts auf die Attraktivität einer Tätigkeit im Vertrieb im deutschen Agribusiness identifiziert werden. Da es laut Schmitz und Wieseke (2015) vielen Vertriebsmitarbeitenden an der Fähigkeit mangelt, KundInnen erfolgreich zu analysieren und zu binden, spielt bei der Wahl des Außendienstpersonals die Existenz sozialer Kompetenzen eine wichtige Rolle. Zahlreiche Studien haben ergeben, dass Frauen häufiger einen Beruf präferieren, in dem sie die Möglichkeit erhalten, anderen zu helfen. Im Vergleich zum männlichen Geschlecht legen sie mehr Wert auf zwischenmenschliche Beziehungen und können sich besser auf die/den KundenIn fokussieren (Bartol, 1976; Busch und Bush, 1978; Croson und Gneezy, 2009a; Konrad et al., 2000; Storbacka et al., 2009). Die Ergebnisse der vorliegenden Studie zeigen, dass Studentinnen ein ähnliches Interesse an einem Vertriebsjob haben wie Studenten, woraus sich schließen ließe, dass Unternehmen mit Personalproblemen gezielt auch Frauen ansprechen sollten.

Der vorliegende Beitrag zu den Einflussfaktoren auf die Attraktivität einer Vertriebsposition für Studierende der Agrarwissenschaften bietet verschiedene Anknüpfungspunkte für weitere Forschungsarbeiten. Nachdem in der vorliegenden Untersuchung die Erwartungen an den landwirtschaftlichen Vertrieb von Studierenden der Agrarwissenschaften betrachtet wurden, wäre es interessant, die Berufsanforderungen der Unternehmen des deutschen Agribusiness zu erheben und mit der Perspektive der Studierenden abzugleichen. 


\section{Literatur}

Albers, S. and Krafft, M. (2013). Vertriebsmanagement. Organisation, Planung, Controlling, Support. Springer Gabler, Wiesbaden. doi: 10.1007/978-3-8349-3663-9

Backhaus, K., Budt, M. und Neun, H. (2011). Strategisches Vertriebsmanagement. In: Homburg, C. und Wieseke, J. (Hrsg.) Handbuch Vertriebsmanagement. Strategie - Führung Informationsmanagement - CRM. Gabler Verlag, Wiesbaden, doi: 35-55. 10.1007/978-3-83496733-6_2

Backhaus, K., Erichson, B., Plinke, W. und Weiber, R. (2016). Multivariate Analysemethoden. Eine anwendungsorientierte Einführung. Springer Gabler, Berlin, Heidelberg. doi: 10.1007/978-3-662-46076-4

Balmann, A. und Schaft, F. (2008). Zukünftige ökonomische Herausforderungen der Agrarproduktion: Strukturwandel vor dem Hintergrund sich ändernder Märkte, Politiken und Technologien. Archiv Tierzucht $=$ Archives Animal Breeding 51(Sonderheft): 13-24.

Barnard, F.L., Akridge, J.T., Dooley, F.J., Foltz, J.C. und Yeager, E.A. (2016). Agribusiness management. Routledge, London.

Bartol, K.M. (1976). Relationship of sex and professional training area to job orientation. Journal of Applied Psychology 61(3): 368-370. doi: 10.1037/0021-9010.61.3.368

Behrman, D.N. und Perreault, W. D. (1982). Measuring the performance of industrial salespersons. Journal of Business Research 10(3): 355-370. doi: 10.1016/0148-2963(82)90039-X

Böttcher, G. (2012). Warum Frauen dem Vertrieb gut tun. springerprofessional.de. https://www.springerprofessional.de/vertriebsmanagement/warum-frauen-dem-vertrieb-guttun/6604180. (20.07.19).

Briedis, K., Heine, C., Konegen-Grenier, C. und Schröder, A.-K. (2011). Mit dem Bachelor in den Beruf. Arbeitsmarktbefähigung und -akzeptanz von Bachelorstudierenden und -absolventen. Stifterverband für die Deutsche Wissenschaft. Essen.

Bühl, A. (2016). SPSS 23. Einführung in die moderne Datenanalyse. Pearson, Hallbergmoos.

Busch, P. und Bush, R. F. (1978). Women Contrasted to Men in the Industrial Salesforce: Job Satisfaction, Values, Role Clarity, Performance, and Propensity to Leave. Journal of marketing research 15(3): 438-448. doi: 10.1177/002224377801500314

Cohen, J. (1992). Statistical power analysis current directions. Psychol Science 1(3): 98-101.

Crawford, J.C. und Lumpkin, J. R. (1983). The choice of selling as a career. Industrial Marketing Management 12(4): 257-261. doi: 10.1016/S0019-8501(83)80005-4

Croson, R. und Gneezy, U. (2009a). Gender Differences in Preferences. Journal of Economic literature 47(2): 448-474. doi: 10.1257/jel.47.2.448

Croson, R. und Gneezy, U. (2009b). Gender Differences in Preferences. Journal of Economic literature 47(2): 448-474. doi: 10.1257/jel.47.2.448

de-Jager, P. und Bayat, M. S. (2009). Training Salespeople At Tertiary Level. Journal of Business and Management Dynamics 3(1): 18-25.

Ehrhart, K.H., Mayer, D. M. und Ziegert, J. C. (2012). Web-based recruitment in the Millennial generation: Work-life balance, website usability, and organizational attraction. European Journal of Work and Organizational Psychology 21(6): 850-874. doi: 10.1080/1359432X.2011.598652

Ferreira, T.S. (2017). Motivational factors in sales team management and their influence on individual performance. Tourism \& Management Studies 13(1): 60-65. doi: 10.18089/tms.2017.13108 
Fritz, W. (1993). Produktqualität, Marktanteil und Unternehmenserfolg: Ergebnisse der PIMSForschung und ihre empirische Relevanz für die westdeutsche Industrie, 93/03. Arbeitspapier/Technische Universität Braunschweig, Institut für Marketing, Braunschweig.

Goff, B.G., Boles, J. S., Bellenger, D. N. und Stojack, C. (1997). The influence of salesperson selling behaviors on customer satisfaction with products. Journal of retailing 73(2): 171-183. doi: 10.1016/S0022-4359(97)90002-6

Guenzi, P. (2003). Antecedents and consequences of a firm's selling orientation. European Journal of Marketing 37(5/6): 706-727. doi: 10.1108/03090560310465116

Hair, J.F., Black, W.C., Babin, B.J. und Anderson, R.E. (2009). Multivariate data analysis. Prentice Hall, New Jersey.

Hemmerling, U., Pascher, P. und S. Naß (2016). Situationsbericht 2016/17: Trends und Fakten zur Landwirtschaft. Deutscher Bauernverband, Berlin.

Homburg, C. und Giering, A. (2001). Personal characteristics as moderators of the relationship between customer satisfaction and loyalty — an empirical analysis. Psychology \& Marketing 18(1): 4366. doi: 10.1002/1520-6793(200101)18:1<43:AID-MAR3>3.0.CO;2-I

Homburg, C. und Stock, R. M. (2004). The link between salespeople's job satisfaction and customer satisfaction in a business-to-business context: A dyadic analysis. Journal of the Academy of Marketing Science 32(2): 144-158. doi: 10.1177/0092070303261415

Janze, C., Theuvsen, L., Schmidt, C. und J. Meyer (2018). Konjunkturbarometer Agribusiness in Deutschland 2018. Ersnst \& Young GmbH Wirtschaftsprüfungsgesellschaft.

Kittinger, A. (2010). Serviceorientierung und partnerschaftliches Handeln im B2B-Vertrieb. Gabler Verlag, Wiesbaden. doi: 10.1007/978-3-8349-6090-0

Konegen-Grenier, C. (2011). Bachelor und Master auf dem Arbeitsmarkt: Ergebnisse aus zwei Unternehmen sbefragungen. Wirtschaftsdienst 91(1): 20-26. doi: 10.1007/s10273-011-1179-9

Konegen-Grenier, C. und Koppel, O. (2009). Akzeptanz und Karrierechancen von Ingenieuren mit Bachelor- oder Masterabschluss. IW-Trends -Vierteljahresschrift zur empirischen Wirtschaftsforschung 36(4): 65-78. doi: 10.2373/1864-810X.09-04-05

Konrad, A.M., Ritchie Jr, J. E., Lieb, P. und Corrigall, E. (2000). Sex differences and similarities in job attribute preferences: a meta-analysis. Psychological Bulletin 126(4): 593-641. doi: 10.1037/0033-2909.126.4.593

Lux, K. (2010). Vertrieb als Erfolgsfaktor für Unternehmen. Unternehmenswelt. https://www.unternehmenswelt.de/news/unternehmertum/vertrieb-als-erfolgsfaktor-fuerunternehmen.(10.01.19).

Maier, P. (2013). Entwicklung der landwirtschaftlichen Be-ratung in der Bundesrepublik Deutschland unter dem Aspekt der Beratungsqualität. Problemy Nauk Stosowanych 1(1): 189-196.

Nachtwei, J. (2014). Egozentrisch und erfolgreich. Vertriebsmanager 9-10:68-73.

Nerdinger, F.W. (2001). Psychologie des persönlichen Verkaufs. Lehr- und Handbücher der Psychologie. Oldenbourg, München.

Okazaki, S., Mueller, B. und Taylor, C. R. (2010). Measuring Soft-Sell Versus Hard-Sell Advertising Appeals. Journal of Advertising 39(2): 5-20. doi: 10.2753/JOA0091-3367390201

Pascher, P., Hemmerling, U. und S. Naß (2018). Situationsbericht 2018/19 Trends und Fakten zur Landwirtschaft. Deutscher Bauernverband e.V., Berlin.

Petersdorff-campen, W. von (2014). Hilfe, die Grünschnäbel kommen. Frankfurter Allgemeine Zeitung. https://www.faz.net/aktuell/wirtschaft/wirtschaftspolitik/sind-die-bachelor-absolventen-reiffuer-den-beruf-13054798.html. (20.07.19). 
Puspitasari, E. und Harjanti, W. (2017). Meaningful Experience Of Motivation To Power Seller With Orientation On Consumer Satisfaction For Identification Of Employee Benefits In The Textile Sales In South Surabaya. International Journal Of Entrepreneurship And Business Development 1(1): 1-22. doi: 10.29138/ijebd.v1i1.341

Schmitz, C. und Ganesan, S. (2014). Managing Customer and Organizational Complexity in Sales Organizations. Journal of marketing 78(6): 59-77. doi: 10.1509/jm.12.0296

Schmitz, C. und Wieseke, J. (2015). Herausforderungen und Potenziale im Vertrieb. Marketing Review St. Gallen 32(6): 12-21. doi: 10.1007/s11621-015-0596-3

Schwerdtfeger, C. (2015a). Agrarbranche leidet unter Fachkräftemangel - neue Studie der Dr. Schwerdtfeger Agri HR Consult belegt den Trend. https://www.personalschwerdtfeger.de/agrarbranche-leidet-unter-fachkraeftemangel-neue-studie-der-drschwerdtfeger-agri-hr-consult-belegt-den-trend/. (20.01.19).

Schwerdtfeger, C. (2015b). Vom Arbeitstier zum Goldesel?! Voraussetzungen, Chancen und Gehälter im Agribusiness. Young Farmers Day - Agritechnica 2015. Dr. Schwerdtfeger AgriHRConsult, Hannover.

Seidenglanz, R., Nachtwei, J. und Fischer, A. (2016). Profession Vertriebsmanagement, Strukturen, Karrierewege und Herausforderungen der Führungsfunktion Vertriebsmanagement in Deutschland. Bundesverband der Vertriebsmanager e.V. (BdVM), Berlin.

Statista (2018). Anzahl der Studierenden der Agrarwissenschaft/Landwirtschaft in Deutschland vom Wintersemester 1998/99 bis 2017/18. https://bit.ly/2UkeZuS. (20.01.20).

Statista (2015). Anzahl der Beschäftigten in Einkaufs-, Vertriebs-, Handels- und Verkaufsberufen in Deutschland in den Jahren 1999 bis 2014. https://bit.ly/3jZyDVW. (20.07.19).

Stober, D. und Meuwis, K. (1998). Frauen im Vertrieb. Sozialwissenschaften und Berufspraxis 21(2): 141-149.

Storbacka, K., Ryals, L., Davies, I. A. und Nenonen, S. (2009). The changing role of sales: viewing sales as a strategic, cross-functional process. European Journal of Marketing 43(7/8): 890-906. doi: 10.1108/03090560910961443

Strecker, O., Strecker, O.A., Elles, A., Weschke, H.-D., Kliebisch, C. und Enneking, U. (2010). Marketing für Lebensmittel und Agrarprodukte. DLG-Verlag, Frankfurt a. Main.

VDL (2018). Bachelor und Master - Was kommt nach dem Studienabschluss? Absolventenbefragung im Agrarbereich 2018, VDL - Berufsverband Agrar, Ernährung, Umwelt (Hrsg.), Berlin.

VDL (2014). Fach- und Führungskräftebedarf in der Agrarbranche Befragungen und Analysen im Agrarbereich 2013/2014. Berufsverband Agrar, Ernährung, Umwelt e.V. (Hrsg.), Berlin.

vonDavier, J.Z. von und Theuvsen, L. (2010). Landwirtschaftliches Personalmanagement. Mitarbeiter gewinnen, führen und motivieren. DLG-Verlag, Frankfurt am Main.

Voss, J. (2008). Customer-Relationship-Management im Agribusiness. Universität Göttingen, Dissertation. Sierke, Göttingen.

Wallmüller, E. (2017). Praxiswissen Digitale Transformation. Den Wandel verstehen, Lösungen entwickeln, Wertschöpfung steigern. Carl Hanser Verlag GmbH \& Co. KG, München.

Winkelmann, P. (2012). Vertriebskonzeption und Vertriebssteuerung: die Instrumente des integrierten Kundenmanagements - (CRM). Franz Vahlen, München.

Zallocco, R., Pullins, E. B. und Mallin, M. L. (2009). A re-examination of B2B sales performance. Journal of Business \& Industrial Marketing 24/8(2009): 598-610. doi: 10.1108/08858620910999466 
Zboja, J.J., Clark, R. A. und Haytko, D. L. (2016). An offer you can't refuse: consumer perceptions of sales pressure. Journal of the Academy of Marketing Science 44(6): 806-821. doi: 10.1007/s11747-015-0468-z

Zimmermann, G. (2014). Frauen im Versicherungsvertrieb. Was sagen die Privatkunden dazu? Forschung am ivwKöln. Technische Hochschule Köln - Institut für Versicherungswesen. https://bit.ly/2VYHPBR. (20.12.19). 


\section{Chapter III - Excursus: Seed Industry Reputation}

\section{III.1 Ever New Topics Damage the Reputation - The Public and the Publicized Issues of the Seed Industry}

Authors: Dorohee Schulze Schwering, Christine Heins \& Dominic Lemken

The article is in similar form under review at Agrobiotechnology Management \& Economics (AgBioForum). 


\title{
III.1 Ever New Topics Damage the Reputation - The Public and the Publicized Issues of the Seed Industry
}

\begin{abstract}
The interplay of media, NGOs, and public opinion has generated consumer interest for the seed industry. The seed industry's reputation has been under pressure due to disputes on intellectual property rights, genetically modified organisms, market concentration (MC), privatization concern, biodiversity concerns, and the bee colony collapse disorder (BCCD). Public opinion has also managed to influence regulatory frameworks regarding these topics of concern (ToCs). Against this background, public interest in ToCs, its attitude towards ToCs, and the seed sector's reputation were evaluated among a sample of 753 consumers. The average interest in the ToCs was moderate, except for high public interest in BCCD. The results of partial least square models indicate the correlation of ToCs with reputation. The attitude towards MC and innovation and productivity (IP) stands out as strongly linked to reputation. While IP is known to managers, seed firms should improve the communication of mergers, highlighting potential social benefits.
\end{abstract}

Keywords: corporate social responsibility (CSR), genetically modified crops, reputation, partial least square (PLS), seed industry 


\section{$1 \quad$ Introduction}

In today's fast-moving world with increasingly uncertain and complex business environments, companies are forced to look beyond short-term financials. To predict sustainable business success, non-financial indicators need to be incorporated into companies' strategic goals. One of the most significant non-financial indicators is corporate reputation (Vig et al., 2017). Reputation serves as a company's intangible asset, can be an important predictor of a company's financial performance, and provides a competitive advantage (Hildebrandt et al., 2010; Vig et al., 2017). From a managerial point of view, reputation signifies potential barriers to market entry (Schwaiger and Raithel, 2014), and it is rated as one of the highest general business risks (Vig et al., 2017). Managing reputation and developing sustainable innovation policies is getting priority for the company management.

Besides the level of the individual company, the reputation of a sector also serves as an important strategic resource (Isaak et al., 2020). A loss of sector reputation, i.e., due to critical events, has direct consequences for an industry's performance even if buyer groups feel more positive about the sector than the public. The public perception matters through the "social license to operate", i.e., stricter political regulations and prohibitions, negative peer pressure on buyer groups, and increasing costs for attracting labor (Albersmeier and Spiller, 2010). Corporate social responsibility (CSR) is of growing relevance for companies and their customers and has an important impact on reputation (Gistri et al., 2019). Especially in the seed industry, the CSR commitment of companies is closely monitored.

But why has the seed sector's reputation been under pressure? Since the emergence of the dispute surrounding genetic modification (GM), the public has begun to take an interest in the seed sector (Schurmann, 2004). The public opinion on the sector and GM has been under pressure from NGOs and the media (Farre et al., 2011), leading to stricter regulations. In contrast to the assumption among stakeholders that public interest in the sector is limited to GM, a variety of other topics have made it to the mass media spotlight. Lately, mergers have accelerated an ongoing concentration of seed breeding firms (Howard, 2015): the merger of Bayer and Monsanto (2016-2018), the merger of DuPont-Pioneer and Dow (2015), and the merger of ChemChina and Syngenta (2016), (Bonny, 2017; Pray et al., 2005). All merging partners were already among the largest firms in the agrochemical and seed industry. The media further reported on seed patents that extend the rights reserved under the traditional plant variety protection. Further, disputes arose from the handling of the expiration of intellectual property 
rights if the seed variety was still of interest to growers, e.g., the potato variety "Linda" in Germany (Godt, 2016). Additionally, issues affecting the environment, such as decreasing biodiversity or the more frequently observed colony collapse disorder of bees, have been linked to companies involved in seed breeding. The public concern for bees has led to a revision of the regulations on the insecticide group neonicotinoids. The media can repeatedly report on new developments surrounding these topics of concern (ToCs) so that the general public has developed an opinion on the seed sector.

Against this background, this study investigated ToCs and the relationship with the sector's reputation. The questions raised were: (1) Which topics of concern (ToCs) are of interest to the public? (2) How do topics of concern (ToCs) correlate with the reputation of the seed sector? (3) Is the attitude towards a topic of concern (ToC) linked to socio-demographic variables? The first question identifies the relevance of a ToC, which is not necessarily of interest to a broader audience beyond standard agricultural stakeholders. The second question evaluates the impact the ToC had on reputation so that the industry's issue management can prioritize ToCs. The third question can help to identify critical consumer groups to encourage a discourse with such consumers. The questions were answered by surveying a consumer sample in Germany. A partial least square (PLS) analysis was applied to cope with the measurement challenges involved. The PLS model identified the link between attitude towards ToCs and the reputational rating of the seed sector. Finally, managerial implications for the seed sector are discussed.

\section{Conceptual Design}

\subsection{How to Measure Reputation}

We evaluated reputation before the ToC so that repeating the notions of a $\mathrm{ToC}$ did not trigger consumers to feel differently about the industry than they usually do. Before measuring reputation, it should be noted that there is no unchallenged definition of reputation (Hildebrandt et al., 2010). A common definition of corporate reputation is "a stakeholder's overall evaluation of a company over time" (Gotsi and Wilson, 2001, p. 29). The characteristic or ability can vary between scholars. What does not vary is that reputation consists of how stakeholders perceive a firm's ability. Studies have shown the media's influence on a firm's or even a sector's reputation (Schwaiger and Raithel, 2014). "Media reputation, defined as the overall evaluation of a firm presented in the media", is a strategic resource and has an impact on performance (Deephouse, 2000, p. 1091). To measure a firm's reputation, different approaches have been developed in the last decades and are already being used in business practice. Two widely 
recognized ones are the AMAC (America's most admired companies) released by the Fortune Magazine and the Global RepTrak® Pulse (Hautzinger, 2009; Schwaiger and Raithel, 2014). The main differences between the models are their measurement indicators. AMAC mostly refers to indicators such as innovation, quality of products, and people management (Hautzinger, 2009). Global RepTrak® $1^{1}$, on the other hand, is based on the RepTrak® Pulse, which measures esteem, trust, feeling, and admiration, and seven more dimensions, among them innovation, governance, and performance. Building on these prominent measurements, Hautzinger (2009) developed an approach to measure the business sector's reputation. His approach focuses on the following dimensions: environmental awareness, social commitment, quality of the products, credibility, high-quality standards, display in the media, the reputation of market-leading firms, the danger of products, and no scandals (Hautzinger, 2009).

This study of the seed sector's reputation is based on Hautzinger's (2009) approach. The suitability of this approach for the agri-food industry has recently been confirmed by measuring the reputation of the horticultural sector (Isaak et al., 2020). However, the importance of model adaptation and indicator specification was mentioned. With a multi-stage pre-test, Hautzinger (2009) ensured that the construct was assigned indicators that matched the content. In the present study, the dimension integrity was omitted because a pretest revealed diverse understandings of the concept. Three concepts by Fombrun et al. (2000) were added because they were not covered by Hautzinger (2009): reputation as an employer, financial position, and trust. In line with Hautzinger's approach, a formative model of reputation was estimated, i.e., the dimensions make up the reputation instead of a reflective model, where the dimensions are a consequence of reputation.

\subsection{Topics of Concern to the Seed Sector's Reputation}

Topics of concern (ToCs) were identified by a print media scan. Studies have shown that people often talk about news they have received from traditional media sources, as these are considered more trustworthy and credible (Schultz et al., 2011; Utz et al., 2013). Second-highest effect scores were found for newspapers when organizational reputation was used as a dependent variable (Schultz et al., 2011). Controversial statements from the media were selected to evaluate the attitude towards a ToC. The attitude is based on consumers' agreement with a statement. The operationalized statements and the media outlet with the analogous text are

\footnotetext{
${ }^{1}$ RepTrak ${ }^{\circledR}$ is a measuring method for reputation and states how the public sees the best-known companies in the world. More than 50 countries and over 7.000 companies have been included (Reputation Institute, 2017).
} 
summarized in Appendix 3. The print media scan was conducted with Nexis, a database with more than 300 German-language newspapers and magazines (Nexis, 2017). The considered publishers were general mass media outlets, not specialized agricultural press. The topics were market concentration (MC), genetic engineering (GM), intellectual property rights (IPR), biodiversity concerns $(\mathrm{BC})$, bee colony collapse disorder (BCCD), privatization concerns (PC), and innovation and productivity (IP), to include a positive counterpart.

The topics are briefly introduced:

MC: Concerns over mergers have been raised several times during mergers of Limagrain, Syngenta, Monsanto, and others (Pray et al., 2005), but society's perspective on these mergers and how they affect the industry reputation is still unclear. Opponents express the risk of market power and ownership in intellectual property rights over food supply and farmers, while proponents stress the increasing innovation potential of larger firms (Maisashvili et al., 2016; Pray et al., 2005). The global concentration ratio of the four largest companies in the seed and biotechnology sector has increased sharply in recent years, with values up to 59\%, depending on the calculation method (Deconinck, 2020).

IPR: The role and effect of intellectual property rights, like patents, that grant the exclusive legal right to commercialize and license a new technology, are often discussed (Maisashvili et al., 2016). Lesser (1998) claims that IPR are a barrier to market entry, trigger vertical integration of downstream industries, create financial resources which boost downstream mergers and acquisitions, and they significantly influence the structure of the sector. Critics also argue that patents could be misused or narrow the genetic diversity (Godt, 2016). Generally, cases of disputes around seed property rights occur frequently, e.g., the German potato variety "Linda", the broccoli case, or the tomato case (Prifti, 2016; Stirner et al., 2017).

GM: Since the 1990s NGOs have opposed the usage of GM technology in agribusinesses in Europe (Graff, Gregory, D. et al., 2009; Schurmann, 2004). Opponents of GM have concerns not only about food safety, allergenicity, toxicity, changes in the nutritional quality of food, and labeling of GM food, but also about the environment, i.e., gene transfer to wild plants or the possible creation of new toxins and viruses (Bonny, 2014; Islam et al., 2020). Schwägerl (2005) describes the overall success of the anti-GMO activists as one of the biggest marketing successes, which emphasizes the role of public opinion. The topic repeatedly appeared in the media, e.g., the cultivation of $\mathrm{Bt}$ corn was allowed and prohibited multiple times (Voss et al., 2009). Opinions on GM are well-researched, although the effect on reputation is not clarified. 
BC: The public assigns seed firms a responsible role in issues surrounding biodiversity losses or negativities of monocultures of proprietary seeds (Bonny, 2014; Mulvany, 2021). Biodiversity losses refer to pollinator biodiversity, which opponents associate with monocropping and the use of insecticides, as well as genetic diversity of seed varieties, which is affected by the business strategies of seed firms.

BCCD: Negatively connotated buzz words, such as the death of bees, are floating through the media (Kulhanek et al., 2017). In discussion are the chemical treatments of seeds (Rundlöf et al., 2015), but seed firms are primarily placed alongside BCCD due to their agrochemical products. Especially the term "seed coating", i.e., coating with the bee-unfriendly insecticide neonicotinoid (Watson and Stallins, 2016), which is often used in public discussion, inevitably involves the seed industry. Independent of the true impact of breeders on BCCD, the topic may influence how people see the seed industry..

PC: Privatization indicates people's opinion that the state/government should either promote seed breeding or that it should be left to private actors. Plant genetic resources have become predominantly private. At the same time, private firms have transformed into large and integrated enterprises, which lead to a high market concentration and a monopolistic market structure (Maisashvili et al., 2016). This is particularly a subject debated about in China and developing countries, where research and development where long left to the state (Hu et al., 2011). NGOs seize this topic mostly to criticize large companies like Monsanto (Peschard and Randeria, 2020).

IP: While all topics mentioned above are negatively connotated, a topic focusing on the advantages of the seed industry and its development over the last years was also pushed in the media cycle. The topic deals with innovation in breeding and its utility to society (higher productivity to cope with hunger, etc.). The level of R\&D activities in the industry has increased over the years (Kalaitzandonakes et al., 2018; Pray et al., 2005). Opportunities for seed technology advocates include developing the shelf life of fruit and vegetables, or enhancing food quality and health benefits of food (Islam et al., 2020). People may value IP advances to the benefit of the industry's reputation. 


\section{$3 \quad$ Material and Methods}

\subsection{Analytical Method}

A partial least square structural equation model (PLS-SEM) was used as an analysis tool for this study. A PLS-SEM was chosen for its ability to allow for a formative and a reflective measurement model (Hair et al., 2020; Hair et al., 2017), i.e., reputation is measured by indicators that cause the concept reputation (formative), while ToCs are evaluated by attitudinal indicators that are an outcome of how someone perceives the topic (reflective), (Hair et al., 2020). The PLS approach to measure a latent variable is based on multiple indicators, which reduces the measurement error in reflecting reputation and the attitude towards ToCs. A PLS SEM can measure latent concepts and simultaneously estimates the structural and subsequent structural relationship between latent variables (Fornell, 1987; Hair et al., 2017). In the result section, the measurement model, i.e., how well the indicators represent the latent concepts, and the structural model, i.e., the relationship between ToCs and reputation, will be explained.

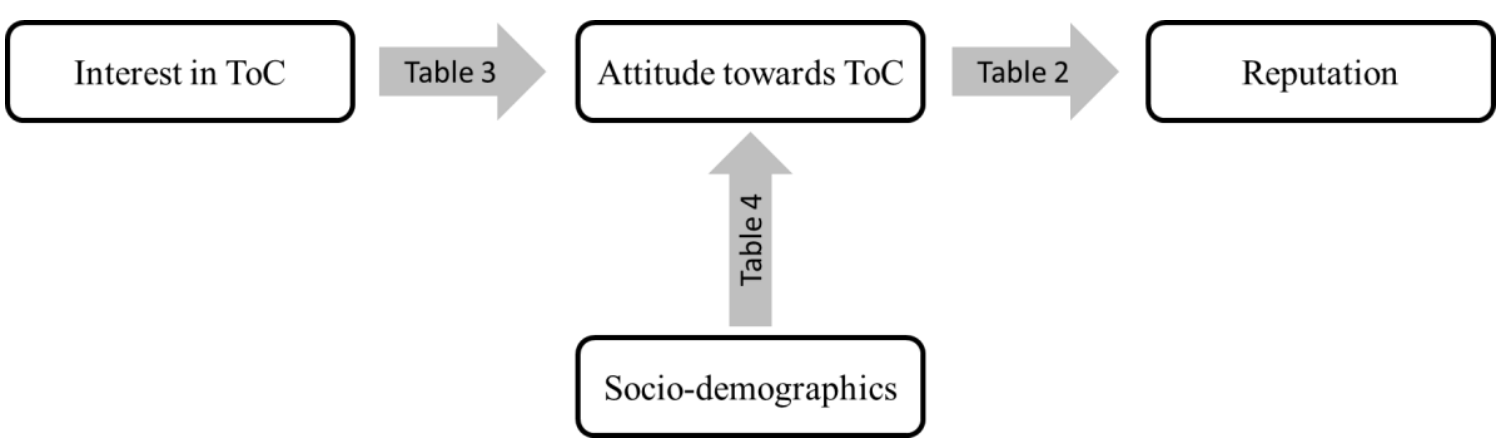

Figure 1: Structural model to measure ToC relation ship with reputation

Source: Own elaboration. Note. ToCs in each model are market concentration (MC), genetic engineering (GM), intellectual property rights (IPR), biodiversity concerns (BC), bee colony collapse disorder (BCCD), privatization concerns (PC), and innovation and productivity (IP).

Originally, the interest in and attitude towards multiple ToCs and the influence on reputation were to be estimated in one model, but multicollinearity concerns arose. Latent variables could not be discriminated against. For example, the bivariate correlations between the interest in ToCs were generally high (Spearman $r=0.5-0.8$, one exception). The multicollinearity issue reversed the relationship between ToC and reputation to a significant degree. Seven separate models for each ToC were built (Fig. 1). The socio-demographic variables of age, gender, formal education, household income, size of residence community, size of origin community, and contact with farm life intentionally explained attitude towards a ToC, which subsequently influenced the seed sector's reputation (Fig. 1). 
In line with the research question, the emphasis was given to how the attitude towards a ToC related to reputation. To compare the effect sizes across the different ToC models for reputation, we used a test proposed by Henseler et al. (2009). Since PLS is free of distributional assumption for the underlying variables, many tests from covariate-based regression analysis are not suitable. The proposed test utilizes the bootstrapped sample repetitions to determine the conditional probability that a coefficient is larger than a coefficient from a different PLS estimation. Consider the following probability function:

$$
\text { (1) } P\left(b_{1}<b_{2} \mid \beta_{1} \geq \beta_{2}\right)=1-\sum_{i, j} \frac{\Phi\left(2 * b \emptyset_{1}-b_{1, j}-2 * b \emptyset_{2}-b_{2, i}\right.}{j^{2}} \text {, }
$$

where $b$ represents the PLS coefficient, $b \varnothing$ the average coefficient measured over the bootstrapped samples, and $\beta$ the true population parameters. $\mathrm{J}$ and $\mathrm{i}$ denote the bootstrapped samples of each model. $\Phi$ indicates a binary function so that there is an outcome of 0 or 1 for each bootstrapped sample. The approach is comparable to the Mann-Whitney-Wilcoxon test which is applied to the bootstrap-values while the original parameter values are corrected (Henseler et al., 2009). The test reflects the probability of a coefficient from model 1 to be significantly higher or lower than the coefficient from model 2 . The test was repeated between each of the seven models and displayed in a matrix that indicates significant differences (Appendix A2).

\subsection{Sampling}

An online survey was conducted in May 2017. To obtain good data quality, strict quality checks were performed. First, control questions were asked to check whether the participants had read the questions thoroughly. Participants who did not follow the instruction of the control question were automatically excluded from the study. Second, streamlining ensured that participants took a minimum of time to complete a set of questions (Lemken et al., 2019). Streamlining monitors how participants progress through the blocks of questions to exclude participants who respond too quickly and/or systematically. The eliminates the need to monitor the total time spent on the survey. A total number of 753 valid observations were surveyed. The survey started with sociodemographic questions. Next, participants were asked to judge the seed sector's reputation before the statements on ToCs. The statements were evaluated on a Likert scale from one to five, expressing participants' disagreement or agreement, respectively (Brosius et al., 2016).

The order of all statements and the dimensions of reputation were randomized to prevent order effects, as recommended (Brosius et al., 2016). The interest in ToCs was evaluated on a 
ten-level single-item scale. Smart PLS 3 was used for the PLS-SEMs. Stata 13 was applied for data management and other statistical tasks.

The convenience sample approximated the German population. The groups with low income, low educational level, and older people were slightly overrepresented in this study (Fig. 2). Regarding reputation, the respondents rated the seed sector as relatively neutral. The dimensions financing and quality of products were perceived as relatively positive, while the risk of products and free of scandals dimensions received a relatively negative average rating (Appendix A1).

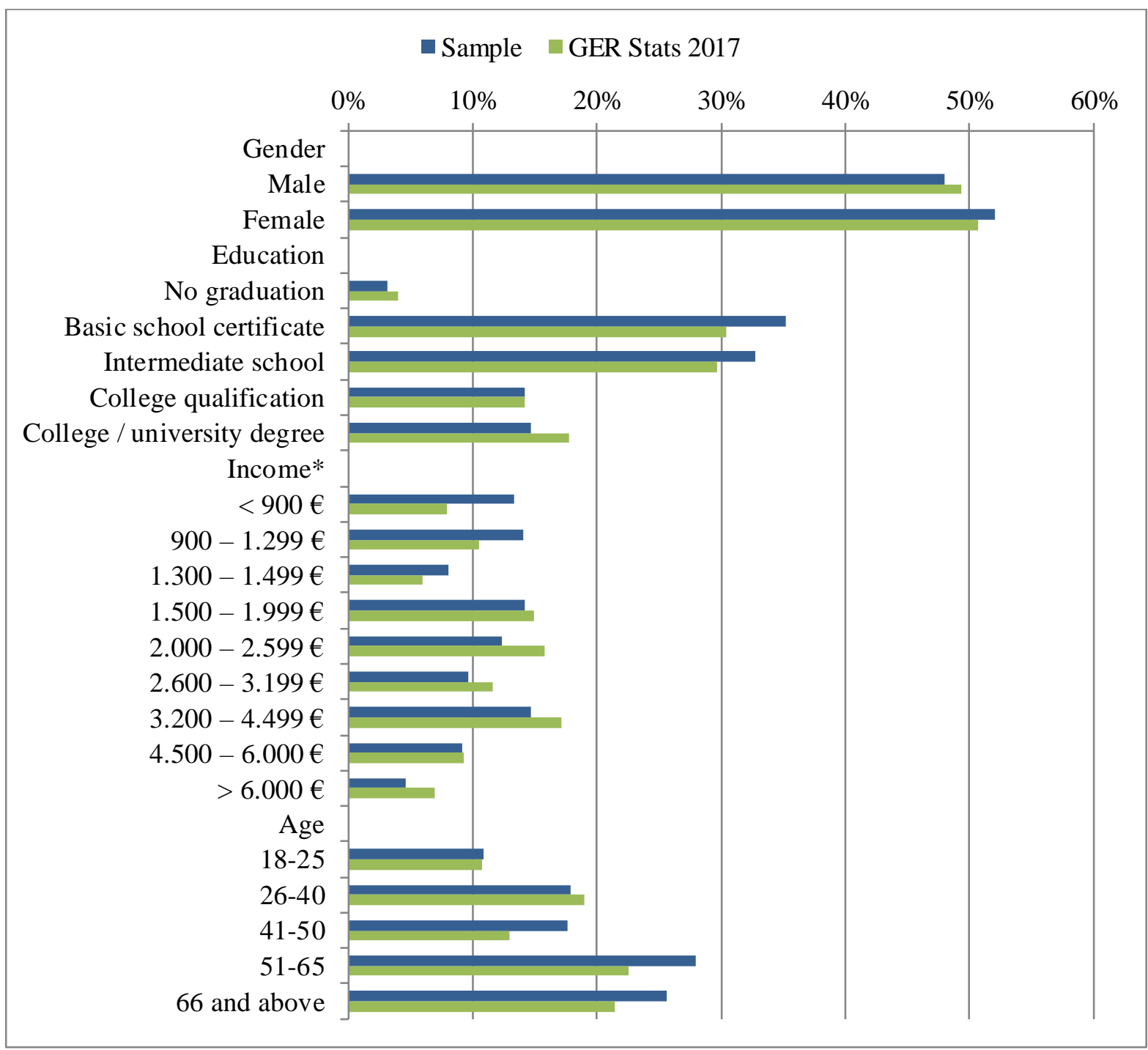

Figure 2: Sample characteristics

Source: Own elaboration. Note. GER Stats 2017 are based on data from the German Federal Statistical Office (Statistisches Bundesamt, 2020, 2019) *Data of 2019 by Statista (2020). 


\section{$4 \quad$ Results}

\subsection{The Interest in Topics of Concern}

Most ToCs were of medium or lesser interest to the public (Fig. 3). The standard deviation for each $\mathrm{ToC}$ was at least 2.3. A share of consumers stated a moderate interest in the topics. An exception was the bee topic, which stood out with relatively high interest among a large share of consumers. Graphically illustrated, the mean interest scores ranked the ToCs in the following order (Fig. 3).

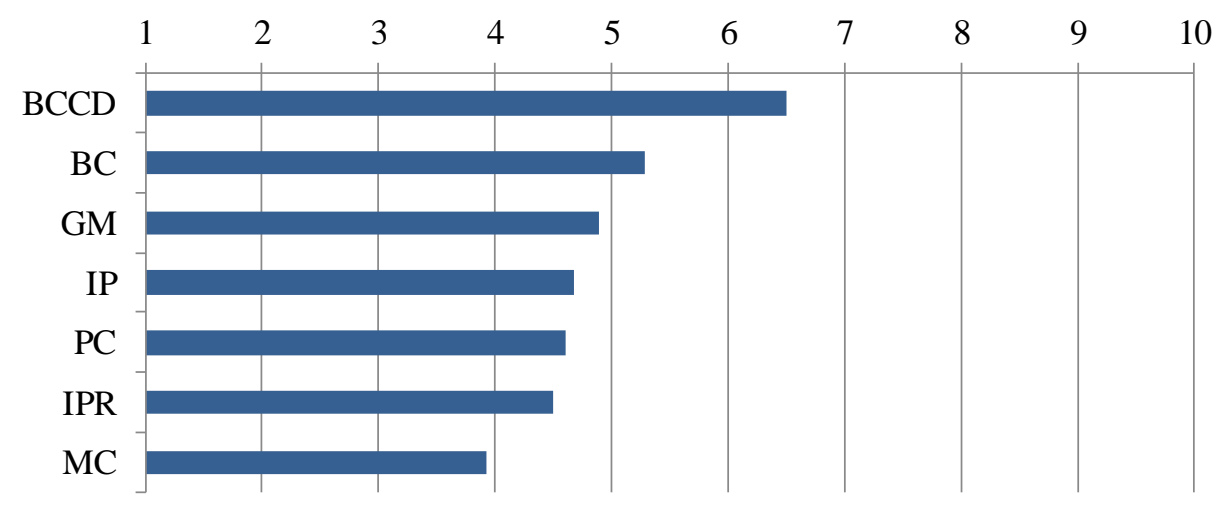

Figure 3: Interest in topics of concern

Source: Own elaboration. Note. Market concentration (MC), genetic engineering (GM), intellectual property rights (IPR), biodiversity concerns (BC), bee colony collapse disorder (BCCD), privatization concerns (PC), and innovation and productivity (IP) interest in ToCs was measured: $1=$ very low interest, 5 to $6=$ medium interest, $10=$ very high interest. A t-test indicated that all means were significantly different from each other ( $\mathrm{p}<0.05)$, except PC and IP.

\subsection{PLS-SEM measurement model}

Before analyzing the structural relationships, the quality of the measurement model of PLS-SEM needed to be established. Measurement error can occur through reliability or validity issues of indicators to measure a concept. Starting with the reflective measurements of the attitude towards topics of concern (ToCs), we assessed construct reliability (via DijkstraHenseler's rho and Cronbach's alpha), convergence validity (via average variance extracted, AVE), and discriminant validity (via heterotrait-monotrait ratio of correlations, HTMT). The assessment of reflective concepts was in line with a recent recommendation from PLS experts (Henseler et al., 2016) and is shown in Table 1. For the HTMT, one can apply cutoff scores below 0.90 (HTMT < 0.9). The convergence validity is assured if the AVE is higher than 0.5. A few latent variables were just below the AVE threshold. We refrained from dropping items or latent variables, as the construct reliability was established. A few items were dropped due to factor loading or insufficient construct reliability (Table 1). The formative measurement 
of reputation was assessed by multicollinearity among indicators and significance of indicators via bootstrapping (Hair et al., 2020; Helm, 2005). The convergent validity was assumed drawing on reputation theory. Multicollinearity is present if the variance inflation factor is larger than 5, which was the case for sustainability and environmental consciousness, as well as for trust and credibility. After dropping the latter dimensions, no model variance inflation factor (VIF) was higher than four (Hair et al., 2017). The bootstrapped p-value of the outer weights of the formative indicators is preferred to be significant, although cannot be dropped if theoretically supported, as they contribute to reputation. Indicators were held constant across the models.

\subsection{The structural PLS-SEM}

The structural relationships were estimated for each ToC(Figure 1). The results are summarized in three tables. PLS-SEM computes standardized coefficients for structural relationships with potential values from -1 to +1 . The effect size is often interpreted with $f 2$ values $(>0.02$ weak effect $<0.15$, $>0.15$ moderate effect $<0.35$, strong effect $>0.35)$, (Cohen, 1988; Hair et al., 2020; Hair et al., 2017), although the normative rating may overestimate the effect sizes typically found in reputation research.

Table 1: Reflective measurement of the attitude towards topics of concern

\begin{tabular}{|c|c|c|c|c|c|c|}
\hline \multirow{2}{*}{$\begin{array}{l}\text { Attitude } \\
\text { towards }\end{array}$} & \multicolumn{3}{|c|}{ Construct reliability } & \multirow{2}{*}{$\begin{array}{c}\text { Convergence } \\
\text { validity } \\
\text { AVE }\end{array}$} & \multirow{2}{*}{$\begin{array}{c}\text { Discriminant } \\
\text { validity } \\
\text { HTMT }\end{array}$} & \multirow[t]{2}{*}{$\begin{array}{l}\text { Dropped } \\
\text { items }\end{array}$} \\
\hline & Factor Loadings & DHR & $\mathrm{Ca}$ & & & \\
\hline GM & $\begin{array}{l}\text { GM1: } 0.813 \text { GM3: } \\
0.926\end{array}$ & 0.869 & 0.859 & 0.759 & $<0.3$ & GM2 \\
\hline MC & $\begin{array}{l}\text { MC1: } 0.727 \\
\text { MC2: } 0.545 \\
\text { MC3: } 0.625 \\
\text { MC4: } 0.706\end{array}$ & 0.757 & 0.754 & 0.429 & $<0.3$ & N.A. \\
\hline BC & $\mathrm{BC} 2$ & N.A. & N.A. & N.A. & $<0.3$ & $\mathrm{BC} 1 \& \mathrm{BC} 3$ \\
\hline BCCD & BCCD1 & N.A. & N.A. & N.A. & $<0.3$ & BCCD2 \\
\hline IPR & $\begin{array}{l}\text { IPR 2: } 0.717 \\
\text { IPR 3: } 0.777\end{array}$ & 0.719 & 0.716 & 0.559 & $<0.5$ & IPR1 \\
\hline PC & $\begin{array}{l}\text { PC1: } 0.682 \\
\text { PC2: } 0.868 \\
\text { PC3: } 0.472\end{array}$ & 0.774 & 0.720 & 0.481 & $<0.3$ & N.A. \\
\hline IP & $\begin{array}{l}\text { IP1: } 0.771 \\
\text { IP2: } 0.601 \\
\text { IP3: } 0.693\end{array}$ & 0.741 & 0.732 & 0.479 & $<0.3$ & N.A: \\
\hline
\end{tabular}

Source: Own elaboration. Note. AVE = average variance extracted; DHR = Dijkstra-Henseler-Rho; C $\alpha=$ Cronbach's alpha; HTMT = heterotrait-monotrait ratio; $\mathrm{BC}=$ biodiversity concern; IPR = intellectual property rights; $\mathrm{GM}=$ genetical engineering; $\mathrm{IP}=$ innovation and productivity; $\mathrm{MC}=$ market concentration $; \mathrm{PC}=$ privatization concern, $\mathrm{BCCD}=$ bee colony collapse disorder 
For the reader, we included the traditionally used regression coefficient R2, which estimates how much of the variance of reputation is explained by the attitude towards the ToC (bilateral relationship). The significance of the structural relationships was validated with a bootstrapping procedure of 753 repetitions in consideration of the sample size. Reputation dimensions were graded from 1 to 5, with 1 symbolizing a very good reputation. Generally, the better the attitude towards a ToC, the better the reputational rating, and vice versa. Four topics with a moderate or strong relationship on reputation emerged ( $\mathrm{f}^{2}$ value $\left.>0.15\right)$ : MC, IPR, BCCD, IP (Table 2).

Table 2: Explanatory power of "attitude towards topic of concern" on reputation

\begin{tabular}{llccccc}
\hline $\begin{array}{l}\text { Attitude } \\
\text { towards }\end{array}$ & \multicolumn{1}{c}{ Scaling } & Coef & Std & p-value & $\mathbf{f}^{2}$ value & $\mathbf{R}^{\mathbf{2}}$ \\
\hline GM & $\rightarrow$ negative & 0.280 & 0.043 & 0.000 & 0.085 & 0.077 \\
MC & attitude & 0.605 & 0.033 & 0.000 & 0.578 & 0.366 \\
IPR & towards ToC & 0.365 & 0.037 & 0.000 & 0.154 & 0.134 \\
BC & & 0.202 & 0.128 & 0.117 & 0.042 & 0.041 \\
PC & & 0.277 & 0.049 & 0.000 & 0.083 & 0.077 \\
BCCD & & 0.437 & 0.035 & 0.000 & 0.237 & 0.191 \\
IP & & 0.515 & 0.043 & 0.000 & 0.361 & 0.261 \\
\hline
\end{tabular}

Source: Own elaboration. Note. $\mathrm{BC}=$ biodiversity concern; IPR = intellectual property rights; $\mathrm{GM}=$ genetical engineering; $\mathrm{IP}=$ innovation and productivity; $\mathrm{MC}=$ market concentration; $\mathrm{PC}=$ privatization concern; $\mathrm{BCCD}=$ bee colony collapse disorder. ${ }^{* *} \mathrm{p} \leq 0.05$ (significant); $* * * \mathrm{p} \leq 0.01$ (highly significant), reputation was measured as $1=$ very good reputation to $5=$ very bad reputation; Coef $=$ coefficient; std $=$ standard deviation.

The attitude towards GM revealed only a weak relationship with reputation. Given the high interest in BCCD and how the attitude towards BCCD influenced reputation, the relevance of this ToC for the industry is evident. The proposed test by Henseler et al. (2009) indicates whether the attitude towards a ToC has a significantly different effect size than the attitude towards a different ToC. The p-values of the test statistic are displayed in a way so that a value over 0.95 indicates the ToC in the row is significantly higher than the ToC in the column, and a value under 0.05 indicates an opposite significant difference (Appendix A2).

Based on the significant differences, we ranked the strength of the relationship in the following order: MC > IP > BCCD, IPR > GM, PC, BC. Some of the differences were only established at the 10\%-significance level. MC and IP represent attitudes highly relevant for how the reputation of the seed sector was perceived. Looking into the relationship of interest in and attitude towards ToCs, both variables were significantly linked (Table 3). Nevertheless, the interest in a ToC was not overly decisive for the attitude. The analysis consistently revealed significant but weak relationships (based on the f2 value), except for IPR. 
The socio-demographic variables age, gender (Gen), income (Inc), formal education (Edu), size of origin community (SoO), size of current community (SoC), and contact to farmers ( $\mathrm{CtF}$ ) were partially linked to the attitude towards a ToC (Table 4). For readability, only the PLS variable coefficients (b) and significance levels are displayed (Table 4).

Table 3: Explanatory power of interest in topic of concern on attitude towards topic of concern

\begin{tabular}{llllll} 
Interest in & Scaling & Coef & Std & p-value & $\mathbf{f}^{2}$ value \\
\hline GM & $\rightarrow$ higher & 0.118 & 0.038 & 0.002 & 0.015 \\
MC & interest in & 0.259 & 0.044 & 0.000 & 0.070 \\
IPR & ToC & 0.460 & 0.038 & 0.000 & 0.251 \\
BC & & 0.221 & 0.038 & 0.038 & 0.049 \\
PC & & 0.149 & 0.048 & 0.002 & 0.022 \\
BCCD & & 0.288 & 0.034 & 0.000 & 0.087 \\
IP & & -0.111 & 0.051 & 0.032 & 0.012 \\
\hline
\end{tabular}

Source: Own elaboration. Note. $\mathrm{BC}=$ biodiversity concern; IPR = intellectual property rights; $\mathrm{GM}$ = genetical engineering; IP $=$ innovation and productivity; $\mathrm{MC}=$ market concentration; $\mathrm{PC}=$ privatization concern; ${ }^{* *} \mathrm{p} \leq 0.05$ (significant); ${ }^{* * *} \mathrm{p} \leq 0.01$ (highly significant); Coef = coefficient; std = standard deviation. Interest in ToC was measured as $1=$ very low interest, 5 to $6=$ medium interest, $10=$ very high interest; scaling of ToC: higher value equals negative attitude

Table 4: Relationship between socio-demographics and attitude towards topics of concern

\begin{tabular}{|c|c|c|c|c|c|c|c|c|}
\hline & Coding & GM & MC & IPR & BC & PC & BCCD & IP \\
\hline Gen & -> Female & $\begin{array}{c}0.187 \\
* * *\end{array}$ & -0.029 & -0.059 & -0.009 & 0.023 & -0.045 & $\begin{array}{c}0.120 \\
* * *\end{array}$ \\
\hline SoO & -> Urban & -0.028 & 0.021 & 0.056 & 0.027 & -0.035 & -0.045 & -0.005 \\
\hline SoC & -> Urban & -0.010 & 0.020 & 0.030 & -0.020 & 0.083 & 0.015 & -0.029 \\
\hline $\mathrm{CtF}$ & -> No contact & $\begin{array}{c}0.085 \\
* *\end{array}$ & -0.012 & -0.002 & 0.039 & -0.001 & -0.045 & 0.003 \\
\hline Age & -> Young & $\begin{array}{c}-0.215 \\
* * *\end{array}$ & $\begin{array}{c}-0.138 \\
* * *\end{array}$ & -0.025 & $\begin{array}{c}0.098 \\
* * *\end{array}$ & 0.027 & 0.005 & $\begin{array}{c}-0.092 \\
* *\end{array}$ \\
\hline Edu & $\begin{array}{l}\text {-> more } \\
\text { education }\end{array}$ & $\begin{array}{c}-0.202 \\
* * *\end{array}$ & 0.071 & -0.057 & -0.017 & 0.093 & $0.073 *$ & -0.009 \\
\hline Inc & ->High income & -0.046 & -0.068 & 0.019 & -0.032 & -0.081 & -0.012 & $\begin{array}{c}-0.129 \\
* * *\end{array}$ \\
\hline
\end{tabular}

Source: Own elaboration. Note. $\mathrm{Gen}=\mathrm{Gender} ; \mathrm{SoO}=$ size of origin community; $\mathrm{SoC}=$ size of current community; $\mathrm{CtF}=\mathrm{contact}$ to farmers; Inc = income; Edu = formal education; $\mathrm{BC}=$ biodiversity concern; IPR = intellectual property rights; $\mathrm{GM}=$ genetical engineering; $\mathrm{IP}=$ innovation and productivity; $\mathrm{MC}=$ market concentration; $\mathrm{PC}=$ privatization concern; * $\mathrm{p} \leq 0.1$ (low significance), $* * \mathrm{p} \leq 0.05$ (significant), *** $\mathrm{p} \leq 0.01$ (highly significant); scaling of ToC: higher value equals negative attitude.

\section{Discussion}

\subsection{Topics of Concern and Reputation}

In the past, experts have stressed the importance of public relation activities concerning GM and depicted it as inevitable for the seed industry (Heyder and Theuvsen, 2012; Merten, 2001). This study revealed how the industry faces several topics strongly linked with reputation ratings. The high level of correlation between the ToCs indicates that the ToCs are not 
independent of each other, but it can be assumed that they will gradually become a part of a worldview that decisively explains the reputation. When judging the seed industry's reputation, attitudes towards structural developments in the industry, such as market concentration (MC) and innovation and productivity (IP), are decisive for an individual's opinion. A large share of variance in reputation is explained just by these attitudes. Table 2 shows that MC and IP are the key drivers of reputation, and other ToCs, including GM, follow depending on the view on MC and IP. One could assume that MC is a manifestation of the fact that many people distrust the seed sector. Therefore, industry structures are a major critique of the industry. It has to be clarified whether these objections are caused by a "David versus Goliath" or "underdog effect" (Paharia et al., 2010), where the public supports the underdog, i.e., smaller enterprises. It may be a preference for a family-owned business, which we know the public favors for farm businesses. It may also be partially rooted in a critique of the economic system concerning food supply.

Environmental topics are also of concern to the public, but the industry is not accused of all of them. This study found no evidence that the attitudes towards biodiversity issues (BC) are related to the seed sector's reputation. The benevolent perception of the seed market structures indicates an increasing acceptance of how the industry develops. However, BCCD matters to the reputation and presents an issue that the public assigns to the actors in the seed market. The bee colony collapse disorder (BCCD) attracted high public interest, significantly more than genetic modification (GM), despite GMs broad coverage in the mass media (Lemken, 2017). The interest in bees and beekeeping has experienced a completely new upswing in recent years, triggered, among other things, by an increasing dialogue about bee mortality and correlated biodiversity losses (Stripf, 2019). BCCD possesses a widespread impact on our environment, controversy surrounding whose fault it is, and the media's negative framing with keywords such as "the death of bees" make it highly relevant to a broader audience. This study already implies that the seed sector will have to deal with a multiple-issue complex, as opponents hold more than one topic against it. The danger is that different issues can create a worldview of the harmfulness of an entire industry.

In terms of future trends, younger respondents had a more positive attitude towards GM, MC, and IP. The less critical view on GM is confirmed by Hampel (2004) and Popek and Halagarda (2017). Studies have shown that older people and women are less inclined to accept GM food products (Gaskell et al., 2006), and Popek and Halagarda (2017) suspect that this is because younger people's knowledge about GM is more up to date. In contrast, younger people cared 
more about biodiversity losses and felt that the seed firms share a responsibility to preserve it. In line, Pribis et al. (2010) found that younger people are more likely to consider moral and ecological aspects in their diet than older people. Regarding gender, women are more skeptical of GM (Gaskell et al., 2006; Hampel, 2004; Moerbeek and Casimir, 2005). Women in other studies tended to worry more about the environment than men (Rhead et al., 2018; Zelezny et al., 2000), which could not be confirmed here. Rather, women stood out as less receptive to innovation and productivity messages.

Education leads to a more open-minded view on GM technology (Hampel, 2004; Traill et al., 2005) and more concern for the environment (Rhead et al., 2018). Both findings are reflected in this study. While in this study formal education led to a more positive attitude on GM, Huang and Peng (2015) found a higher risk perception of GM with increasing educational level. Generally, it is expected that educated people have a greater knowledge of GMOs (López Montesinos et al., 2016), but it might depend on someone's personality traits if the information is reflected to be positive or negative. On the other hand, the educational level promotes people's attention to environmental issues (Rhead et al., 2018), which could suggest that more highly educated participants are more concerned about the environment. This would incorporate the need for consumer education and the provision of information. Only a few investigations have explicitly addressed income. Moerbeek and Casimir (2005) found that the higher a person's income, the more he or she saw the benefits of biotechnology. Furthermore, low income was found to correlate with a little interest in environmental topics (Straughan and Roberts, 1999). These income relationships were not confirmed here, as we rather observed that more income went hand in hand with a more positive attitude towards innovation and productivity advances of the industry.

The characteristics contact to farmers, size of origin, and current community were hardly relevant to consumer attitudes. In agricultural topics, such as animal welfare, some relationships are hypothesized. For example, participants who do not personally know any farmers are not satisfied with the farm life of animals as it is today (Helme, 2010; Vanhonacker and Verbeke, 2014). Often ambiguous findings are presented on these characteristics. The IMA report of 2017 (Kantar Emnid and IMA, 2017) found that a rural population tends to be of a benevolent opinion concerning agriculture in general. The characteristics cannot be used to pinpoint groups of interest to issue management. 


\subsection{Managerial Implications}

A lot of firms, including agribusinesses, have, intentionally or not, excluded the public as a stakeholder of their business model and left the field to the NGOs. Due to the "poor image of the seed industry in the minds of the general public" (Bonny, 2017, p. 14), the seed industry must accept the public as a major stakeholder, even if a consumer is not a direct customer. Public perception matters because of the environmentally linked "social license to operate" (Murphy-Gregory, 2018) or the increasing demand and awareness for company-specific CSR strategies, which can both also influence buyer decisions. This makes the public increasingly relevant as a stakeholder and for reputation building. A bad reputation of a few firms can affect the whole sector, as exemplified by the latest financial crisis when a few banks damaged the reputation of many (Piwinger, 2014). The agricultural sector is characterized by its up- and downstream businesses, so a scandal might easily diffuse through the value chain and affect the whole sector (Heyder and Theuvsen, 2012). It is therefore advisable to actively involve the public and, in certain cases, to cooperate with NGOs. It is also advisable to take up topics in the media before the NGOs do so. To this end, the present study offers a prioritization of the current ToCs. Seed companies should take these ToCs into account. They might be able to design new products to specifically ease the ToCs, which hold substantial reputation value.

Positive news on the ToCs will need to better accommodate the interest's tangible to the public. Innovations and breeding novelties are often noticed by the public. Environmentally friendlier varieties in terms of chemical input needs will be of interest to consumers, as indicated by public reservations on pesticide use (Marette et al., 2012). This contrasts with a business model where new varieties allow for extended pesticide use. Novel varieties to counter climate change can be positive marketing frames to be recognized by consumers. Based on the slight increase of environmental awareness in the German public (BMUB, 2017), such environmental arguments are of increasing relevance to public perceptions. Especially women and lower-income groups are not convinced that the current form of innovation and productivity justifies a positive attitude and, subsequently, a better reputation. Therefore, we propose a target group-specific issue management.

The negative reputation of a competitor may also present an opportunity for firms to develop an advantage in issue management (Zyglidopoulos, 2003). A progressive firm can highlight its issue management to a ToC, e.g., efforts on bee nursing or highlighting the small-scale, family-owned, or local business style, if not already highlighted. The issue management should be integrated into a general (CSR) strategy. Heyder and Theuvsen (2012) have shown for the 
agricultural sector how CSR communications positively influence a firm's reputation. In terms of content, for seed firms, the CSR strategies should primarily focus on BCCD, IP, and MC. Currently, opponents can strengthen a negative media view with a bouquet of news on ToCs.

MC and IP have proven to be key drivers of the reputation of the seed sector. Therefore, the main task for companies' reputation management is to better communicate merger strategies to explain why they need to grow, and how society can benefit from the merge. Market concentration is seen with increasing suspicion. However, Deconinck (2020) was not able to find systemic evidence of harmful effects on prices or innovation, as is often feared, and he showed that due to divestments, recent mergers have not led to a significant increase in market concentration. Nevertheless, future merging activities should consider the reputation loss that comes with it and address how they can, nevertheless, ease ToCs. Further, firms can stress how the revenues of the whole seed market are several times smaller than those of a downstream processor, such as Nestlé. Market concentration in the seed industry grants less financial power than consumers typically believe.

Consumer concern over bees may pressure retailers to restrict agrochemical use of farmers if the chemical can be linked to BCCD. The seed sector would have to deal with the consequences. At present, it is not clear which strategy would have the most positive impact on the reputation of the sector. One possibility for seed companies would be to distance themselves from the chemical companies, but this is often not possible, as agrochemical and seed companies are sometimes vertically integrated. Seed firms could also start a joint campaign about bees, but the question arises whether they would then move more into the "polluter pays" role. Regarding MC and IP, Schimmelpfennig et al. (2004) showed that reduced competition in the market is associated with reduced R\&D. Accordingly, maintaining competition in biotech innovation markets and the related better-valued R\&D can contribute to improving the reputation. Krueger (2001) set up a four-stage strategy plan to improve public acceptance of biotech foods, including 1) introducing listening sessions to better understand public concerns and to gather feedback for improvements, 2) engaging credible messengers through scientific public relations efforts for an objective discourse on the risks and benefits of biotechnology, 3) communication of benefits to different stakeholders, and 4) building critical coalitions, i.e., initiatives like the council for biotechnology information (launched by leading biotechnology companies) and improving public awareness. 


\subsection{Limitations}

A future evaluation of the seed sector's reputation can account for the heterogeneity of seed firms. The majority of seed firms are small and medium enterprises (SME), (Bonny, 2017). Bigger players, such as Limagrain or KWS, are focused on seed sales, other big players have substantially higher overall revenues, such as Bayer-Monsanto, Dow-Dupont, or ChemChinaSyngenta, due to their involvement in other industries, e.g., their revenues from agrochemical products (Bonny, 2017). The reputation will differ between these types of firms, although we expect consumers to think only of a few big players during the evaluation. To back this up, Monsanto was known to circa $36 \%$ of our sample, while KWS was known to less than $4 \%$, so that Monsanto will likely contribute more to the industry's reputation, and Monsanto's reputation is continuously among the worst of all companies according to the United States public (harris poll, 2015). 


\section{References}

Albersmeier, F. and Spiller, A. (2010). Die Reputation der Fleischwirtschaft: eine Kausalanalyse. German Journal of Agricultural Economics 59(4): 258-270. doi: 10.22004/ag.econ.146102

BMUB (2017). Umweltbewusstsein in Deutschland 2016. Ergebnisse einer repräsentativen Bevölkerungsumfrage. Bundesministerium für Umwelt, Naturschutz, Bau und Reaktorsicherheit (BMUB). https://bit.ly/3k9gOp5. (02.09.20).

Bonny, S. (2017). Corporate Concentration and Technological Change in the Global Seed Industry. Sustainability 9(9): 1632. doi: 10.3390/su9091632

Bonny, S. (2014). Taking stock of the genetically modified seed sector worldwide: market, stakeholders, and prices. Food Security 6(4): 525-540. doi: 10.1007/s12571-014-0357-1

Brosius, H.-B., Haas, A. und Koschel, F. (2016). Methoden der empirischen Kommunikationsforschung. Eine Einführung. Studienbücher zur Kommunikations- und Medien wissenschaft. VS Verlag für Sozialwissenschaften, Wiesbaden.

Cohen, J. (1988). Statistical power analysis for the behavioral sciences. Erlbaum, Hillsdale.

Deconinck, K. (2020). Concentration in Seed and Biotech Markets: Extent, Causes, and Impacts. Annu. Rev. Resour. Econ. 12(1): 129-147. doi: 10.1146/annurev-resource-102319-100751

Deephouse, D. L. (2000). Media Reputation as a Strategic Resource: An Integration of Mass Communication and Resource-Based Theories. Journal of Management 26(6): 1091-1112. doi: $10.1177 / 014920630002600602$

Farre, G., Twyman, R. M., Zhu, C., Capell, T. and Christou, P. (2011). Nutritionally enhanced crops and food security: scientific achievements versus political expediency. Current opinion in biotechnology 22(2): 245-251. doi: 10.1016/j.copbio.2010.11.002

Fombrun, C. J., Gardberg, N. A. and Sever, J. M. (2000). The Reputation QuotientSM: A multistakeholder measure of corporate reputation. Journal of Brand Management 7(4): 241-255. doi: $10.1057 / \mathrm{bm} .2000 .10$

Fornell, C. (1987). A Second Generation of Multivariate Analysis: Classification of Methods and Implications for Marketing Research Review of Marketing. In: Houston Michael J. (ed). American Marketing Association, Chicago, 407-450.

Gaskell, G., Allansdottir, A., Allum, N., Corchero, C., Fischler, C., Hampel, J., Jackson, J., Kronberger, N., Mejlgaard, N. and Revuelta, G. (2006). Europeans and biotechnology in 2005: patterns and trends. Final report on Eurobarometer 64(3): 1-87.

Gistri, G., Corciolani, M. and Pace, S. (2019). Does the perception of incongruence hurt more? Customers' responses to CSR crises affecting the main reputation dimension of a company. Journal of Marketing Management 35(7-8): 605-633. doi: 10.1080/0267257X.2019.1580761

Godt, C. (2016). Geistiges Eigentumsrecht als Instrument zum Erhalt biologischer Vielfalt? Saat gut als Sonderfall Biopatente Saatgut als Ware und als öffentliches Gut. In: Brandl, B. and Schleissing, S. (eds.). Nomos, Baden-Baden, 19-54. doi: 10.5771/9783845275246-18

Gotsi, M. and Wilson, A. M. (2001). Corporate reputation: seeking a definition. Corporate Communications An International Journal 6(1): 24-30. doi: 10.1108/13563280110381189

Graff, G. D., Hochman, G. and Zilberman, D. (2009). The Political Economy of Agricultural Biotechnology Policies. AgBioForum 12(1): 34-46.

Hair, J. F., Howard, M. C. and Nitzl, C. (2020). Assessing measurement model quality in PLS-SEM using confirmatory composite analysis. Journal of Business Research 109 101-110. doi: 10.1016/j.jbusres.2019.11.069 
Hair, J. F., Hult, G. T., Ringle, C. M., Sarstedt, M., Richter, N. F. and Hauff, S. (2017). Partial Least Squares Strukturgleichungsmodellierung: Eine anwendungsorientierte Einführung. Franz Vahlen Verlag, München.

Hampel, J. (2004). Die Akzeptanz gentechnisch veränderter Lebensmittel in Europa. Stuttgarter Beiträge zur Risiko- und Nachhaltigkeitsforschung 3. doi: 10.18419/opus-5481

harris poll (2015). Harris Poll Annual Reputation Quotient Summary Report. https://skift.com/wpcontent/uploads/2015/02/2015-RQ-Media-Release-Report_020415.pdf. (26.04.20).

Hautzinger, H. (2009). Der Ruf von Branchen. Eine empirische Untersuchung zur Messung, Wechselwirkung und Handlungsrelevanz des Branchenreputation. Dissertation. Gabler, Wiesbaden.

Helm, S. (2005). Designing a Formative Measure for Corporate Reputation. Corporate Reputation Review 8(2): 95-109. doi: 10.1057/palgrave.crr.1540242

Helme, S. (2010). Images sind Kommunikation: empirische Untersuchung und Modellbildung zum Image der Landwirtschaft in Deutschland. Jahrbuch der Österreichischen Gesellschaft für Agrarökonomie 19(1): 51-60.

Henseler, J., Hubona, G. and Ray, P. A. (2016). Using PLS path modeling in new technology research: updated guidelines. Industrial Management \& Data Systems 116(1): 2-20. doi: 10.1108/IMDS-09-2015-0382

Henseler, J., Ringle, C. M. and Sinkovics, R. R. (2009). The use of partial least squares path modeling in international marketing. In: Sinkovics, R.R. and Ghauri, P.N. (eds.) New Challenges to International Marketing (Advances in International Marketing Vol. 20), Emerald Group Publishing Limited, Bingley, 277-319. doi: 10.1108/S1474-7979(2009)0000020014

Heyder, M. and Theuvsen, L. (2012). Determinants and Effects of Corporate Social Responsibility in German Agribusiness: A PLS Model. Agribusiness 28(4): 400-420. doi: 10.1002/agr.21305

Hildebrandt, L., Kreis, H. and Schwalbach, J. (2010). Unternehmensreputation und der FortuneReputationsindex - Eine Analyse der Stabilität und Struktur. Marketing: ZFP: journal of research and management 32(4): 203-217.

Howard, P. H. (2015). Intellectual Property and Consolidation in the Seed Industry. Crop Science 55(6): 2489-2495. doi: 10.2135/cropsci2014.09.0669

Hu, R., Liang, Q., Pray, C., Huang, J. and Jin, Y. (2011). Privatization, Public R\&D Policy, and Private R\&D Investment in China's Agriculture. Journal of Agricultural and Resource Economics 36(2): 416-432. doi: 10.22004/ag.econ.117213

Huang, J. and Peng, B. (2015). Consumers' perceptions on GM food safety in urban China. Journal of Integrative Agriculture 14(11): 2391-2400. doi: 10.1016/S2095-3119(15)61125-X

Isaak, M., Brenneke, I. and Lentz, W. (2020). Conception and evaluation of a structural equation model to measure the reputation of German horticulture. International Food and Agribusiness Management Review 24(2): 337-354. doi: 10.22434/IFAMR2020.0009

Islam, R., Parvin, A., Billah, M. M., Islam, M., Imaran, M. A. S., Sarker, R. K., Uddin, E., Alam, M. S. and Abedin, M. Z. (2020). Assessment of the Effects of Genetically Modified (GM) Foods: A Brief Study on Health and Environmental Concerns. Journal of Materials and Environmental Science 11(10): 1676-1688.

Kalaitzandonakes, N., Carayannis, E. G., Grigoroudis, E. and Rozakis, S. (2018). From Agriscience to Agribusiness. Theories, Policies and Practices in Technology Transfer and Commercialization. Innovation, Technology, and Knowledge Management. Springer International Publishing, Cham. 
Kantar Emnid and IMA (2017). Das Image der deutschen Landwirtschaft. Ergebnisbericht. Kantar Emnid and information.medien.agrar e.V. (i.m.a) https://media.repro-mayr.de/79/668279.pdf. (26.04.20).

Krueger, R.W. (2001). The Public Debate On Agrobiotechnology: A Biotech Company's Perspective. AgBioForum 4(3\&4): 209-220.

Kulhanek, K., Steinhauer, N., Rennich, K., Caron, D. M., Sagili, R. R., Pettis, J. S., Ellis, J. D., Wilson, M. E., Wilkes, J. T., Tarpy, D. R., Rose, R., Lee, K., Rangel, J. and van Engelsdorp, D. (2017). A national survey of managed honey bee 2015-2016 annual colony losses in the USA. Journal of Apicultural Research 56(4): 328-340. doi: 10.1080/00218839.2017.1344496

Lemken, D. (2017). Issue's media linkages: GMO sets the stage for intellectual property rights and market concentration. AgBioForum 20(2): 148-155.

Lemken, D., Spiller, A. and Schulze-Ehlers, B. (2019). More room for legume - Consumer acceptance of meat substitution with classic, processed and meat-resembling legume products. Appetite 143 104412. doi: 10.1016/j.appet.2019.104412

Lesser, W. (1998). Intellectual Property Rights and Concentration in Agricultural Biotechnology. AgBioForum 1(2): 56-61.

López Montesinos, O.A., Pérez, E. F., Fuentes, E. E. S., Luna-Espinoza, I. and Cuevas, F. A. (2016). Perceptions and attitudes of the Mexican urban population towards genetically modified organisms. British Food Journal 118(12): 2873-2892. doi: 10.1108/BFJ-06-2016-0247

Maisashvili, A., Bryant, H., Raulston, J. M., Knapek, G., Outlaw, J. and Richardson, J. (2016). Seed prices, proposed mergers and acquisitions among biotech firms. Choices 31(4): 1-11. doi: 10.22004/ag.econ.246985

Marette, S., Messéan, A. and Millet, G. (2012). Consumers' willingness to pay for eco-friendly apples under different labels: Evidences from a lab experiment. Food Policy 37(2): 151-161. doi: 10.1016/j.foodpol.2011.12.001

Merten, K. (2001.). Die Berichterstattung über Gentechnik in Presse und Fernsehen - eine Inhaltsanalyse. Gentechnik in der Öffentlichkeit: Wahrnehmung und Bewertung einer umstrittenen Technologie. In: Hampel, J. and Renn, O. (eds.). Campus Verlag, Frankfurt/New York, 317-339.

Moerbeek, H. and Casimir, G. (2005). Gender differences in consumers' acceptance of genetically modified foods. International Journal of Consumer Studies 29(4): 308-318. doi: 10.1111/j.1470-6431.2005.00441.x

Mulvany, P. (2021). Sustaining agricultural biodiversity and heterogeneous seeds Rethinking Food and Agriculture. In: Kassam, A. und Kassam, L. (eds.). New ways forward. Woodhead Publishing, 285-321.

Murphy-Gregory, H. (2018). Governance via persuasion: environmental NGOs and the social licence to operate. Environmental Politics 27(2): 320-340. doi: 10.1080/09644016.2017.1373429

Nexis (2017). LexisNexis - Internationale \& verlässliche Informationsquellen bei LexisNexis. https://www.lexisnexis.de/unternehmen/quellen. (26.04.17).

Paharia, N., Keinan, A., Avery, J. and Schor, J. B. (2010). The Underdog Effect: The Marketing of Disadvantage and Determination through Brand Biography. Journal of Consumer Research 37(5): 775-790. doi: 10.1086/656219

Peschard, K. and Randeria, S. (2020). Taking Monsanto to court: legal activism around intellectual property in Brazil and India. The Journal of Peasant Studies 47(4): 792-819. doi: $10.1080 / 03066150.2020 .1753184$ 
Piwinger, M. (2014). Das Reputationsrisiko: Herausforderungen und Bedeutung für die Unternehmensführung Handbuch Unternehmenskommunikation. In: Zerfaß, A. and Piwinger, M. (eds.). Springer Fachmedien Wiesbaden, Germany, 307-327.

Popek, S. and Halagarda, M. (2017). Genetically modified foods: Consumer awareness, opinions and attitudes in selected EU countries. International Journal of Consumer Stu dies 41(3): 325-332. doi: $10.1111 /$ ijcs. 12345

Pray, C.E., Oehmke, J. F. and Naseem, A. (2005). Innovation and dynamic efficiency in plant biotechnology: An introduction to the researchable issues. AgBioForum 8(2\&3): 52-63.

Pribis, P., Pencak, R. C. and Grajales, T. (2010). Beliefs and attitudes toward vegetarian lifestyle across generations. Nutrients 2(5): 523-531. doi: 10.3390/nu 2050523

Prifti, V. (2016). Die Rolle des öffentlichen Interesses an Pflanzenpatenten: Eine europäische Perspektive Biopatente Saatgut als Ware und als öffentliches Gut. In: Brandl, B. and Schleissing, S. (eds.). Nomos, Baden-Baden, 55-74.

Rhead, R., Elliot, M. and Upham, P. (2018). Using latent class analysis to produce a typology of environmental concern in the UK. Social science research 74 210-222. doi: 10.1016/j.ssresearch.2018.06.001

Rundlöf, M., Andersson, G. K. S., Bommarco, R., Fries, I., Hederström, V., Herbertsson, L., Jonsson, O., Klatt, B. K., Pedersen, T. R., Yourstone, J. and Smith, H. G. (2015). Seed coating with a neonicotinoid insecticide negatively affects wild bees. Nature 521(7550): 77-80. doi: 10.1038 /nature14420

Schimmelpfennig, D.E., Pray, C. E. and Brennan, M. F. (2004). The impact of seed industry concentration on innovation: a study of US biotech market leaders. Agricultural Economics 30(2): 157-167.

Schultz, F., Utz, S. and Göritz, A. (2011). Is the medium the message? Perceptions of and reactions to crisis communication via twitter, blogs and traditional media. Public Relations Review 37(1): 20-27. doi: 10.1016/j.pubrev.2010.12.001

Schurmann, R. (2004). Fighting "Frankenfoods": Industry Opportunity Structures and the Efficacy of the Anti-Biotech Movement in Western Europe. Social Problems 51(2): 243-268. doi: $10.1525 / \mathrm{sp} .2004 .51 .2 .243$

Schwägerl, C. (2005). Der Panikkonzern. Weltwoche. https://www.weltwoche.ch/ausgaben/200524/aktuell/der-panikkonzern-die-weltwoche-ausgabe-242005.html. (17.05.17).

Schwaiger, M. and Raithel, S. (2014). Reputation und Unternehmenserfolg. Management Review Quarterly 64(4): 225-259. doi: 10.1007/s11301-014-0106-8

Statista (2020). Privathaushalte in Deutschland nach monatlichem Haushaltsnettoeinkommen 2019. https://bit.ly/3lsRVlc. (02.11.20).

Statistisches Bundesamt (2020). Bevölkerung im Alter von 15 Jahren und mehr nach allgemeinen und beruflichen Bildungsabschlüssen nach Jahren. https://bit.ly/2UJRqvb. (02.11.20).

Statistisches Bundesamt (2019). Bevölkerung und Erwerbstätigkeit Bevölkerungsfortschreibung auf Grundlage des Zensus 20112017 Fachserie 1(1.3):

Stirner, B., Aebischer, G. and Hansmann, R. (2017). Ist der Patentausschluss von «im Wesentlichen biologische(n) Verfahren» und daraus resultierenden Erzeugnissen geklärt? https://www.siconline.ch/fileadmin/user_upload/Sic-Online/2017/documents/611.pdf. (15.02.21).

Straughan, R.D. and Roberts, J. A. (1999). Environmental segmentation alternatives: a look at green consumer behavior in the new millennium. Journal of Consumer Marketing 16(6): 558-575. doi: 10.1108/07363769910297506

Stripf, R. (2019). Imkerei-ein neuer Boom? Honig für das Volk: Geschichte der Imkerei in Deutschland. In: Stripf, R. (ed). Ferdinand Schöningh, 302-308. 
Traill, W.B., Jaeger, S. R., Yee, W. M. S., Valli, C., House, L. O., Lusk, J. L., Moore, M. and Morrow Jr, J. L. (2005). Categories of GM risk-benefit perceptions and their antecedents. AgBioForum 7(4): 176-186.

Utz, S., Schultz, F. and Glocka, S. (2013). Crisis communication online: How medium, crisis type and emotions affected public reactions in the Fukushima Daiichi nuclear disaster. Public Relations Review 39(1): 40-46. doi: 10.1016/j.pubrev.2012.09.010

Vanhonacker, F. and Verbeke, W. (2014). Public and Consumer Policies for Higher Welfare Food Products: Challenges and Opportunities. Journal of Agricultural and Environmental Ethics 27(1): 153-171. doi: 10.1007/s10806-013-9479-2

Vig, S., Dumičić, K. and Klopotan, I. (2017). The Impact of Reputation on Corporate Financial Performance: Median Regression Approach. Business Systems Research Journal 8(2): 40-58. doi: 10.1515/bsrj-2017-0015

Voss, J., Spiller, A. and Enneking, U. (2009). Zur Akzeptanz von gentechnisch verändertem Saatgut in der deutschen Landwirtschaft. German Journal of Agricultural Economics 58(3): 155-167. doi: 10.22004/ag.econ.134179

Watson, K. and Stallins, J. A. (2016). Honey Bees and Colony Collapse Disorder: A Pluralistic Reframing. Geography Compass 10(5): 222-236. doi: 10.1111/gec3.12266

Zelezny, L.C., Chua, P. and Aldrich, C. (2000). Elaborating on gender differences in environmentalismstatistical data included. Journal of Social Issues 56(3): 443-445.

Zyglidopoulos, S.C. (2003). The Issue Life-Cycle: Implications for Reputation for Social Performance and Organizational Legitimacy. Corporate Reputation Review 6(1): 70-81. doi: 10.1057/palgrave.crr.1540191 


\section{Appendix}

Appendix 1: The dimensions of reputation

\begin{tabular}{lcc}
\hline Reputation dimension & $\varnothing$ & Std \\
\hline Financing & 2.66 & 0.84 \\
Quality of products & 2.76 & 0.93 \\
Employer & 2.93 & 0.85 \\
Trust & 2.99 & 1.01 \\
Sustainability & 3.07 & 1.01 \\
Credibility & 3.08 & 0.97 \\
Image of industry leaders & 3.08 & 0.98 \\
Environmental awareness & 3.12 & 1.06 \\
Social commitment & 3.13 & 0.91 \\
Media image & 3.18 & 0.91 \\
Free of scandals & 3.21 & 0.99 \\
Risk of products & 3.21 & 0.96 \\
\hline
\end{tabular}

Source: Own elaboration. Note. Grading 1 = very good reputation, $2=\operatorname{good}$ reputation, $3=$ medium reputation $4=$ bad reputation, 5 = very bad reputation.

Appendix 2: The probability that the effect size on reputation differs between two topics of concern

\begin{tabular}{lccccccc}
\hline $\begin{array}{c}\text { ToC on } \\
\text { reputation }\end{array}$ & BCCD & GM & IP & IPR & MC & PC & BC \\
\hline BCCD & $\mathrm{X}$ & 0.999 & 0.086 & 0.869 & 0.000 & 0.995 & 1.000 \\
GM & & $\mathrm{X}$ & 0.003 & 0.054 & 0.000 & 0.454 & 0.902 \\
IP & & & $\mathrm{X}$ & 0.991 & 0.042 & 0.996 & 0.997 \\
IPR & & & & $\mathrm{X}$ & 0.000 & 0.918 & 0.999 \\
MC & & & & & $\mathrm{X}$ & 1.000 & 1.000 \\
PC & & & & & & $\mathrm{X}$ & 0.911 \\
BC & & & & & & & $\mathrm{X}$ \\
\hline
\end{tabular}

Source: Own elaboration. Note. $\mathrm{BC}=$ biodiversity concern; IPR = intellectual property rights; $\mathrm{GM}=$ genetical engineering; $\mathrm{IP}=$ innovation and productivity; $\mathrm{MC}=$ market concentration; $\mathrm{PC}=$ privatization concern; $\mathrm{BCCD}=$ bee colony collapse disorder. The $\mathrm{p}$-values of the test statistic are displayed in a way so that a value over 0.95 indicates that the ToC in the row is significantly higher than the ToC in the column, and a value below 0.05 indicates an opposite significant difference. 
Appendix 3: Statements and media sources

\begin{tabular}{|c|c|c|c|}
\hline Abbrev. & Translated statement & $\begin{array}{l}\text { Operationalized statement } \\
\text { (in German language) }\end{array}$ & $\begin{array}{l}\text { Content } \\
\text { abstracted from }\end{array}$ \\
\hline MC 1 & $\begin{array}{l}\text { The merger of Bayer and Monsanto } \\
\text { is like a wedding in hell. }\end{array}$ & $\begin{array}{l}\text { Die Fusion von Bayer und Monsanto } \\
\text { ist wie eine Hochzeit in der Hölle. }\end{array}$ & $\begin{array}{l}\text { Der Tagesspiegel, } \\
16.09 .16\end{array}$ \\
\hline MC 2 & $\begin{array}{l}\text { Mergers in the seed industry mean } \\
\text { the end of rural farming. }\end{array}$ & $\begin{array}{l}\text { Fusionen in der Saatgutbranche } \\
\text { bedeuten das Aus für die bäuerliche } \\
\text { Landwirtschaft. }\end{array}$ & $\begin{array}{l}\text { Kölner Express, } \\
12.10 .16\end{array}$ \\
\hline MC 3 & $\begin{array}{l}\text { Politics have to tell the cartel office } \\
\text { to forbid the Monsanto merger. }\end{array}$ & $\begin{array}{l}\text { Die Politik muss dafür sorgen, dass } \\
\text { das Kartellamt Fusionen verbietet. }\end{array}$ & $\begin{array}{l}\text { Nordwest-Zeitung, } \\
16.09 .16\end{array}$ \\
\hline MC 4 & $\begin{array}{l}\text { The Monsanto merger will lead to } \\
\text { less hunger in the world. (reversed) }\end{array}$ & $\begin{array}{l}\text { Durch Fusionen wird sich der Hunger } \\
\text { in der Welt verringern. (invers) }\end{array}$ & $\begin{array}{l}\text { Hamburger } \\
\text { Morgenpost, } \\
15.09 .16 \\
\end{array}$ \\
\hline GM 1 & $\begin{array}{l}\text { The usage of genetic engineering has } \\
\text { to be forbidden by politics. }\end{array}$ & $\begin{array}{l}\text { Der Einsatz von Gentechnik muss von } \\
\text { der Politik verboten werden. }\end{array}$ & $\begin{array}{l}\text { Allgemeine } \\
\text { Zeitung, 17.06.16 }\end{array}$ \\
\hline GM 2 & $\begin{array}{l}\text { Genetic engineering speeds up plant } \\
\text { breeding. }\end{array}$ & $\begin{array}{l}\text { Gentechnik beschleunigt die } \\
\text { Pflanzenzüchtung. }\end{array}$ & $\begin{array}{l}\text { Tagesspiegel, } \\
16.09 .16\end{array}$ \\
\hline GM3 & $\begin{array}{l}\text { Genetic engineering is the work of } \\
\text { the devil. (reversed) }\end{array}$ & $\begin{array}{l}\text { Gentechnik ist ein Teufelswerk. } \\
\text { (invers) }\end{array}$ & $\begin{array}{l}\text { Tagesspiegel, } \\
16.09 .16\end{array}$ \\
\hline EC 1 & $\begin{array}{l}\text { We need a system change - away } \\
\text { from monoculture. }\end{array}$ & $\begin{array}{l}\text { Wir brauchen einen Systemwechsel- } \\
\text { weg von der Monokultur. }\end{array}$ & $\begin{array}{l}\text { Lebensmittel- } \\
\text { zeitung, 16.09.16 }\end{array}$ \\
\hline EC 2 & $\begin{array}{l}\text { Seed breeding companies are } \\
\text { responsible for the preservation of } \\
\text { biodiversity (reversed) }\end{array}$ & $\begin{array}{l}\text { Saatgutunternehmen tragen eine } \\
\text { Verantwortung für den Erhalt der } \\
\text { Artenvielfalt. (invers) }\end{array}$ & $\begin{array}{l}\text { Ernährungsdienst, } \\
23.09 .16 \\
\text { Zeit, } 19.01 .17\end{array}$ \\
\hline EC 3 & $\begin{array}{l}\text { Big companies stand for diversity } \\
\text { rather than monoculture. }\end{array}$ & $\begin{array}{l}\text { Großkonzerne stehen für Vielfalt statt } \\
\text { Monokultur. (invers) }\end{array}$ & $\begin{array}{l}\text { Welt online, } \\
15.10 .16\end{array}$ \\
\hline BCCD 1 & $\begin{array}{l}\text { Seed breeding companies are not to } \\
\text { blame concerning the death of bees. } \\
\text { (reversed) }\end{array}$ & $\begin{array}{l}\text { Saatgutunternehmen haben keine } \\
\text { Mitschuld am Bienensterben. (invers) }\end{array}$ & $\begin{array}{l}\text { Rheinische Post } \\
\text { Düsseldorf, } \\
\text { 15.09.16 } \\
\text { Lebensmittel- } \\
\text { zeitung, 16.09.16 }\end{array}$ \\
\hline BCCD 2 & $\begin{array}{l}\text { Bees are better off in the city } \\
\text { because they don't find any } \\
\text { chemically treated seeds. }\end{array}$ & $\begin{array}{l}\text { Bienen geht es in der Stadt besser, } \\
\text { weil sie kein chemisch behandeltes } \\
\text { Saatgut vorfinden. }\end{array}$ & $\begin{array}{l}\text { Lebensmittel- } \\
\text { zeitung } 16.09 .16\end{array}$ \\
\hline IPR 1 & $\begin{array}{l}\text { There should be patents on seeds. } \\
\text { (reversed) }\end{array}$ & Es soll Patente auf Saatgut geben. & $\begin{array}{l}\text { Südwest Presse, } \\
20.09 .16\end{array}$ \\
\hline IPR 2 & $\begin{array}{l}\text { Patents give the companies a lot of } \\
\text { power over nature and humans. }\end{array}$ & $\begin{array}{l}\text { Patente geben Unternehmen viel } \\
\text { Macht über Natur und Mensch. }\end{array}$ & Stern, 02.06.16 \\
\hline IPR 3 & $\begin{array}{l}\text { With patents, companies ensure } \\
\text { control over the world's food } \\
\text { supplies. }\end{array}$ & $\begin{array}{l}\text { Mit Patenten sichern sich } \\
\text { Unternehmen die Kontrolle über die } \\
\text { Welternährung. }\end{array}$ & TAZ, 08.12.16 \\
\hline PC 1 & $\begin{array}{l}\text { Politics should not leave the seed } \\
\text { research to private businesses. }\end{array}$ & $\begin{array}{l}\text { Die Politik darf die Saatgut-Forschung } \\
\text { nicht der Privatwirtschaft überlassen. }\end{array}$ & $\begin{array}{l}\text { Hamburger } \\
\text { Abendblatt Online, } \\
21.10 .16\end{array}$ \\
\hline PC 2 & $\begin{array}{l}\text { The state should not leave the seed } \\
\text { research to private businesses. }\end{array}$ & $\begin{array}{l}\text { Die Lebensmittelversorgung sollte } \\
\text { nicht in privater Hand liegen. }\end{array}$ & $\begin{array}{l}\text { dpa-AFX ProFeed, } \\
04.12 .2016\end{array}$ \\
\hline IP 1 & $\begin{array}{l}\text { Innovations in plant breeding help } \\
\text { the plants to become more resistant. }\end{array}$ & $\begin{array}{l}\text { Innovationen in der Saatgutzucht } \\
\text { machen die Pflanzen } \\
\text { widerstandsfähiger. }\end{array}$ & $\begin{array}{l}\text { Nordwest-Zeitung, } \\
01.02 .17\end{array}$ \\
\hline IP 2 & $\begin{array}{l}\text { Newly bred seed s produce food with } \\
\text { better processing qualities. }\end{array}$ & $\begin{array}{l}\text { Neu gezüchtetes Saatgut hat bessere } \\
\text { Verarbeitungsqualitäten. }\end{array}$ & $\begin{array}{l}\text { Ernährungsdienst, } \\
03.02 .17\end{array}$ \\
\hline IP 3 & $\begin{array}{l}\text { Varieties with high yields are } \\
\text { necessary in order to feed humans in } \\
\text { the future. }\end{array}$ & $\begin{array}{l}\text { Sorten mit hohem Ernteertrag sind } \\
\text { notwendig, um zukünftig mehr } \\
\text { Menschen zu ernähren. }\end{array}$ & TAZ, 29.11.16 \\
\hline
\end{tabular}

Source: Own elaboration. 


\section{General Discussion, Implications, and Outlook}

This dissertation aims to provide comprehensive insights into aspects of the research areas of e-commerce and sales management in agribusiness. To date, this field of research has received little attention. A particular focus of this dissertation is to better understand the online purchasing behavior and e-commerce expectations of farmers. Based on the results, this work offers initial implications to optimize both personal and digital sales of agricultural inputs for farmers as buyers and for companies of the agricultural input industry as suppliers. Thus, the results can support the adjustment and development of digital business models within the agricultural input industry as an important part of the agribusiness.

\section{General Discussion and Summary}

\section{E-Commerce in Agribusiness}

Article I.1. The first study consisted of an online survey among 371 farmers with at least some experience in online purchasing. The results prove that the internet, as a prerequisite for digital applications, has arrived on farms and that farmers are familiar with computers, smartphones, and several internet applications (Ackermann et al., 2018; Michels et al., 2020, 2019a). Compared to results in the early 2000s (Stricker et al., 2001), there is a positive trend of e-commerce user rates.

However, compared to the e-commerce usage of other B2B sectors, such as the craft sector, the share of e-commerce in agricultural purchasing is relatively low and indicates untapped potential (Fröhlich, 2018; Kobinger and Wittmann, 2019; Wittmann and Listl, 2017). Other studies also found that farmers are generally interested in e-commerce, but on average and across all farm inputs, e-commerce is only rarely used, and less than half of the farmers surveyed are satisfied with online offers. Furthermore, the results confirm the findings of Ackermann et al. (2018) and Gartzke (2016) that the purchase of operating resources via the internet is strongly product-dependent and that regular use of e-commerce is limited to only specific farm inputs (e.g., spare parts, everyday materials). Product-related characteristics such as awareness level, need for explanation, degree of standardization, or product prices are strong influencing factors here. Individual products that have to be adapted and adjusted to the conditions of the respective farms, and which are often associated with a high financial outlay (e.g., animal feed, crop protection), are therefore purchased online particularly rarely or not at all (Ackermann et al., 2018; Ardrey et al., 2020; Gartzke, 2016). According to Clasen and 
Mueller (2006), individualized, complex, and new products are less suitable for agricultural online sales (cf. I.6). This could be attributed to the higher product involvement for such products (Deges, 2020). According to Hill et al. (2013), farmers include more sources of information in the decision-making process when purchasing high-involvement products (i.e., expensive, novel, or risky products). For purchasing farm inputs, farmers primarily rely on stationary retailers with their much-appreciated personal advisory services (Fecke et al., 2018c; Schulze, 2012).

The relationship to stationary retailers and online distrust can be identified as the main e-commerce barriers. The main drivers of online trade are perceived benefits, i.e., convenience, simplicity, time and cost savings, work facilitation, or online shopping enjoyment. The existence of these e-commerce drivers and barriers has also basically been confirmed by previous agricultural studies (Ackermann et al., 2018; Briggeman and Whitacre, 2010; Fecke et al., 2018b; Gartzke, 2016). In terms of effect sizes, it appears that the effect of perception of benefits associated with e-commerce has a stronger impact than distrust and relationship with local merchants. This is also confirmed in article I.2, where perceived benefits strongly shape attitudes and thus usage intentions. The results show that e-commerce usage is almost independent of sociodemographic and farmographic data. While this could be due to the non-representative sample, Ackermann et al. (2018) also showed that e-commerce usage is relatively independent of these factors. Whether the mentioned influences persist or shift over time should be the subject of further scientific investigations.

All in all, these results prove untapped potential of e-commerce in agriculture, as many farmers have already gained experience with operational or private online purchasing (Gartzke, 2016) but have not intensified their business use due to the reasons mentioned above.

Article I.2 The importance of the attitude towards an innovation is understood as a significant partial aspect in the adaptation of this innovation and is considered as an important predictor of behavior or intention to behave (Hamada, 2019; Six and Eckes, 1996). As article I.1 has already pointed out, online shopping behavior is determined by many factors and suggests user groups with different characteristics. In order to gain a deeper understanding of farmers' attitudes and thus their behavior toward e-commerce, the second study involved a farmer segmentation based on the tripartite model of attitudes (ABC model). Based on an online survey of 371 farmers with at least some e-commerce experience, four clusters were identified: business professionals, loyal offliners, online fans, and online hesitants. 
The online fans, who are very positive and open-minded about e-commerce, and the online hesitants, who have a rather negative attitude toward it and show hardly any intention to use it, emerge as segments that contrast each other. It is interesting that online fans feel more pressure to use e-commerce to stay competitive. This can also be seen in other B2B areas, where emotional variables other than enjoyment emerge to work stronger for e-commerce usage, e.g., competitive pressure, emotional ties between trading partners, or strength of business relationships (Pandey and Mookerjee, 2018; Thakur and AlSaleh, 2020). The online hesitators show high levels of online stress and frustration as well as low competence in dealing with e-commerce. This could be due to their higher age, lower level of education, large proportion of southern German farms and hence smaller farm structures (Gandorfer et al., 2017; Reichardt et al., 2009). Particularly exciting is the cluster of young loyal offliners who perceive the advantages as well as online enjoyment but are very attached to local retailing and therefore least willing to shop online. Their connectedness to local agricultural retailers might be explained by their lower business experience, higher uncertainties, or continuing longstanding business contacts, making stationary retail a kind of "shelter" for them (Feng et al., 2011). The segment of business professionals focusses on the benefits and is second most likely to use e-commerce but has the least online enjoyment. The surprisingly weaker competence assessment of business professionals could be a reason for the low level of online enjoyment, as a lack of e-commerce competencies inhibits the perception of online conveniences (Abdeldayem, 2010). The high educational level of this group as well as the farm sizes and region suggest a professionalized farmer that is considered to be more digitally affine (Reichardt et al., 2009) and, similar to B2B, apparently acts out of rational economic interest (Pandey and Mookerjee, 2018; Rèklaitis and Pilelienè, 2019).

The results further suggest that prior online shopping experience and the self-perception of online competence moderate the attitude formation and hence e-commerce usage, which is in line with the literature (Abdeldayem, 2010; Fecke et al., 2018b). The segmentation proves the dominance of the cognitive perception of online shopping benefits, as these are perceived more strongly by farmers than, for example, affective perceptions (e.g., online shopping enjoyment), (cf. I.1), and contribute more strongly to a positive attitude formation among farmers. In addition, article 1 showed that perceived benefits exert the greatest overall influence on usage behavior and intention. This might be attributed to high involvement products, i.e., the majority of agricultural inputs that require a more cognitive, informational level of the buyers instead of their emotional, fun level (Dens and Pelsmacker, 2010). This study also showed that although 
age differs among the different e-commerce attitude groups, the results of other studies suggesting that younger farmers are inherently more open to e-commerce (Briggeman and Whitacre, 2010; Taragola and van Lierde, 2010) could not be confirmed.

Thus, the results of the second article illustrate that there are different groups of farmers with different attitudes towards e-commerce who consequently require individualized communication strategies and product features when shopping online. Future agricultural e-commerce studies should scientifically investigate the socio-demographic and farmographic as well as the emotional and technical competence variables of the farmers in more detail.

Article I.3 One of the factors relevant to the success of an innovation, such as e-commerce, is the customer's perception and assessment of the innovation (Tomczak et al., 2016). The third article therefore dealt with the assessment of the future viability of agricultural e-commerce from the farmer's perspective $(\mathrm{N}=371)$ and examined the factors influencing this assessment. The evaluation of the future potential of agricultural e-commerce is negatively influenced by farmers' mistrust of online retailing, by the importance of personal advice, and by their loyalty to a retailer. The close contact with the retailer showed no influence on the evaluation of the e-commerce potential, which could support a paradigm shift of the farmers (Gollisch and Theuvsen, 2015). On the other hand, if farmers already shop online more frequently (i.e., have higher online experience) and plan to engage in online shopping in the future, the potential of e-commerce is rated higher (cf. I.1, I.2). The extent to which e-commerce will establish itself in the farm input trade in the future seems to be causing more reticence, with $15 \%$ assuming that stationary retail could be replaced by online business and $21 \%$ describing the farmer of tomorrow as an online shopper. Overall, it can be concluded from this study that although farmers predict a future role for e-commerce, it should not be underestimated that personal trade relationships are very strong and formative.

Article I.4 The described results already outline the complex and heterogeneous purchasing process for agricultural inputs, especially considering digital distribution channels. According to Borchers et al. (2012), primarily behavioral marketing strategies for farm inputs should be developed instead of product-related strategies. But they also suggest that even if the majority of farmers engage in a certain purchasing behavior regardless of the product, a significant number change their purchasing behavior depending on the product. The results (cf. I.1) speak for a more product-dependent e-commerce behavior. Furthermore, there is a heterogeneous acceptance of digital applications on farms (Hess et al., 2015; Munz and Doluschitz, 2021). 
Against this background, it is always important to look at different buyer segments and productspecific attributes of e-commerce adoption.

As e-commerce is mostly product-dependent and the agricultural purchasing process still very much tied to traditional, personal patterns, article 1.4 looks at agricultural information and purchasing behavior for crop protection products. These are rarely purchased online (cf. I.1), while the online supply of crop protection products starts to grow (Bickert, 2020). To gain a deeper understanding of agricultural buying behavior, a buyer segmentation was carried out based on six established factors that farmers use in the decision-making process for an input supplier: convenience/location, customer service/information, personal factors, price and product performance, and after-sales service (Alexander et al., 2005; Borchers et al., 2012; Gloy and Akridge, 1999). A survey of 590 German farmers serves as the data basis.

The five generated segments were then compared with regard to the use of digital sales channels. Equated with the segments presented in article I.2, this segmentation also reveals one segment - independent buyer - that is particularly open to online retailing and digital information channels and thus less tied to stationary retail. In terms of their sociodemographic data, the segments seem to be similar, especially in terms of their younger age and higher educational level. Another parallel between this study and study I.2 is that this study also identified a segment that is averse to online retailing. Like the online hesitators from article I.2, the service comfortables do not perceive any advantages of e-commerce, even if they use the internet for information purposes. However, the segment of service comfortables is characterized by a high degree of retailer and service orientation. Both segments (online hesitators I.2; service comfortables I.4) are older, show a lower educational level, and tend to be from southern Germany, which might explain the low e-commerce acceptance (Ackermann et al., 2018; Gandorfer et al., 2017; Taragola and van Lierde, 2010). The remaining three segments also show some digital information behavior, but at over $80 \%$, they all reject e-commerce as a shopping channel. This can be explained by the lack of perception of e-commerce benefits and the strong rejection of e-commerce due to a lack of personal contacts. This suggests that these segments all place high value on local retail and the convenience that comes with it. None of them place price or brand at the forefront of decision making.

Nevertheless, based on a lack of significant differences between clusters, the results of article I.4 showed that this segmentation approach is not a good predictor for explaining digital information and procurement behavior. To derive segment-specific digital marketing strategies, a scientific follow-up study is recommended that focuses on segmenting digital information and 
purchasing behavior. Finally, it can be concluded from this study that although a large number of farmers would like to be informed digitally when purchasing crop protection products, e.g., via smartphone apps, the purchase is preferably made in a stationary location in conjunction with a personal contact.

Article I.5 Against the background that the articles I.1 - I.4 have shown that the generation of benefits (above all, cost and time advantages) is a main driver and mistrust a main obstacle of agricultural e-commerce, the question arises as to what farmers expect from an e-commerce website and based on which parameters they determine this. Therefore, in article I.5, a qualitative approach - the method of thinking aloud - was used to investigate what farmers expect from an e-commerce website. In the process, eight farmers were observed purchasing plant protection and corn seed online. The 5-C model of customer satisfaction (confidence, choice, charge, convenience, and care) according to Hammerschmidt et al. (2016) served as the model basis.

As estimated, farmers primarily expect to be able to gain measurable advantages when using 'e-commerce. Accordingly, these advantages can be generated by a clear, simple, but meaningful store design in combination with illustrations using photos. In this respect, smartphone apps indicate potential, as farmers associate them with faster, leaner, and simplified processes. However, stationary retail serves as a benchmark for e-commerce with regard to all 5 Cs. According to this, farmers seem to have a "mental map" based on the stationary conditions before they enter the online store (Groeppel-Klein and Bartmann, 2007; Niklas, 2014), which implies a habitualized pattern of behavior (Foscht et al., 2017). For example, farmers expect at least the same product selection and product arrangement in the online store as in the offline store, the same product sorting or filtering online as offline, the likewise last non-negotiable product price, personal contact options, and invoice payment. If the online store deviates too much from this mental map, this results in, for example, a loss of trust for the e-commerce provider or, in the worst case, in the cancellation of the purchase (Niklas, 2014). That means that if well-functioning trade relationships already exist, hard or measurable advantages are needed to achieve a willingness to switch from offline to online, e.g., price reductions (Fecke et al., 2018b). The strong position of stationary retail described above can also be traced back to long-established and consolidated business relationships (Gollisch and Theuvsen, 2015; Schulze, 2012) or to the cross-industry trend of greater service orientation (Vidickiene and Gedminaite-Raudone, 2018), in this case in the form of personal service (Fecke et al., 2018c). 
In the end, it becomes clear again that some farmers ultimately lack the "mental e-readiness" to move away from established, often face-to-face, purchasing channels to digital channels, supporting findings in chapter I.2 and I.4.

Article I.6 According to Binckebanck and Elste (2016), the success of digital distribution systems always depends on two factors, firstly on the digital readiness of customers and secondly on the digital maturity of the offering companies. After the previous articles have taken a closer look at e-commerce behavior of farmers, the last article in this chapter is devoted to the aspect of digital maturity of agricultural input suppliers. Using a qualitative research approach and taking the feed sector as an example, with feed being one of the least purchased products online, the barriers to e-commerce from a supplier perspective were investigated. For this purpose, seven representatives of the feed sector were interviewed.

The results show that feed distribution has so far been little digitized and that there are major differences in the user-friendliness of the individual websites. Digital distribution channels are rarely offered, leaving experts to describe the sector's digital distribution as "in its infancy". This can be attributed to company- and sector-specific factors as well as product- and customerspecific factors. At the sector and company level, traditional, highly personal structures are the main obstacle to digital transformation. However, companies also lack financial, technological, and human resources to digitize their processes. In this context, for example, the compatibility of the systems (online ordering and ERP systems) and the commitment of the employees and managers turn out to be barriers, which is in line with the results of other studies (Claycomb et al., 2005; Merhar et al., 2019). Due to the complexity of the products, the sales force keeps an essential role in the company, but it sees this role as being jeopardized by digital offerings and is therefore often hostile toward digital innovations (Paschen et al., 2020).

The product level can probably be identified as a decisive factor that is particular to this industry. At this level, the highly individualized, consultation-intensive product features and the associated difficulty of price transparency hinder digital commerce. Passing on prices for customized products would require product and price transparency, thus increasing competition and the fear of product copying. The more difficult logistics for bulk goods also harms online trade. On the customer's side, the farmer's side in this case, the experts see the great relevance of personal contacts, online distrust, and a lack of online incentives as barriers to online trade for animal feed. According to Gabriel et al. (2021), the uncertainties felt by farmers with regard to data management (i.e., data sovereignty and data security), which serve as a digital technology barrier, have increased in recent years. The findings of this chapter confirm that 
online mistrust is one key inhibiting factor in agricultural e-commerce (Briggeman and Whitacre, 2010; Gartzke, 2016). However, experts believe that the new technical possibilities will make this less of a problem in the future.

Overall, the results demonstrate that most companies of the sector are feeling competitive pressure to expand their digital efforts, particularly towards digital distribution. It was finally also suggested that, due to the high degree of individualization of feed and the enormous importance of personal contact points, no purely online business for feed products will be possible.

The change in perspective highlights that product characteristics, the relevance of personal contacts, and online mistrust are major barriers to online retailing from both the farmer's and the company's perspective. This indicates that companies are already on the right track to recognizing and satisfying the needs of their customers. However, while "mental e-readiness" still shows apparent weaknesses on both sides, digital readiness or digital maturity in the companies seems to be lagging more strongly in most feed companies. 


\section{Key Findings Chapter I - E-Commerce in Agribusiness:}

Farmers' perspective

- Agricultural e-commerce shows significant untapped potential

- E-commerce is used only rarely and is strongly product-dependent

- Farmers' attitudes and behaviors towards e-commerce are very heterogeneous

- While technical readiness is mostly given, digital competence is partly missing

- Some farmers lack "mental readiness" for digital sales channels

- Next to rational behavior patterns, e-commerce is increasingly influenced by emotional stimuli (e.g., personal relationships, competitive pressure, online enjoyment)

- Perception of benefits is a main driver in farmers' use of e-commerce, but varies widely among them

- Online mistrust can be highlighted as a key barrier, but might lose importance in the future

- Website quality can determine the level of online confidence and perception of online benefits

- Based on the local store, farmers create a kind of "mental map" before entering the online store, with deviations resulting in negative effects

$\Rightarrow$ Outstanding, local retail with personal contacts holds a manifested position in the purchase of agricultural products and serves as an e-commerce benchmark

\section{Suppliers' perspective}

- Customized and explanatory product features are perceived as a main barrier to digital sales

- Degree of product customization determines ability of online price and product transparency

- Long-established, often traditional sector structures lead to protracted change processes

- Companies struggle with employee (e.g., sales force) commitment for digital sales transformation

- Lack of financial and human capital (IT know-how) limits implementation of digital solutions

- Farmers' high demand for personal contact, their online mistrust, and the lack of online incentives are perceived as factors inhibiting e-commerce

$\Rightarrow$ Pure online business will not be possible due to the necessity of personal customer contact 


\section{Sales Management in Agribusiness}

Article II.1 A common result of the first chapter is the outstanding importance of personal contacts between the buyer and seller in the trade of agricultural inputs. A typical personal contact point for the industry, which is increasingly threatened by structural change and digital transformation, is the agricultural sales force. Since little evidence has been available on the perception and evaluation of the agricultural sales force, this was examined in the first article of this chapter based on a survey of 238 farmers. The results show that, in general, the sales force of the agricultural input industry is rated with only a satisfactory performance. It is, above all, the personality and the social competence of a sales representative that determine the sales force's external perception. Other studies also indicate personality as the most important component for success, whose performance potential is often not yet fully exploited (Menthe and Sieg, 2013) and whose degree has a decisive influence on closing sales (Homburg et al., 2016). In addition, the results show that although professional competence is rated somewhat better than personality and social competence, it does not have the most significant influence on sales force evaluations by farmers and thus contradicts other research findings (Churchill et al., 1985; Johnston and Marshall, 2009; Rüther and Maier, 2007). Based on these results, it can be proven that there is a need for action to make the agricultural sales force even more customer-centric and thus to support the company's success.

Article II.2 The second article in this chapter takes up the three determinants of sales force success identified in article II.1. Based on a survey among 238 farmers, a cluster analysis was conducted to examine which types of sales personnel can be identified in agribusiness based on their behavior within the customer contact. The identification of sales personnel types helps to better understand the behavior of the sales force in the customer contact, their relationship wi th the customer, and the sales field in which the sales force is located. Within 12 months, $60 \%$ of the surveyed farmers were visited between once and several times a month, with $16 \%$ being visited at least once a week. On average, the sales force spends 20 to 45 minutes with its customers. While about $45 \%$ of farmers are satisfied with the frequency of visits, about $56 \%$ are less satisfied. Based on the success factors of sales representatives named in the scientific literature, i.e., professional and social competence as well as personality (Churchill et al., 1985; Homburg et al., 2016), three salesperson types could be identified. Accordingly, only about $43 \%$ of the evaluated sales representatives can be described as so-called "sales talents", with a solid proficiency in all three success factors. Less than one third of the sales representatives are characterized by their high professional competence, while the remaining sales representatives 
show deficits in all three success factors. Although there is a strong focus by firms on the training of professional competence (Boland et al., 2005; VDL, 2014), this differs most across clusters. This could be attributed, on the one hand, to the subjective assessment by farmers, who assess professional competence differently depending on their own competencies, and, on the other hand, to the different levels of professional competence, despite clusters. This, in turn, would be an argument for further optimization of the training concepts.

However, the results underline that the sales representatives with a correspondingly lower level of professional competence, but a stronger sales-oriented personality and a higher social competence are more convincing to the customer than the purely professional sales representatives, which supports the suggestions of article II.1.

Article II.3 As articles II.1 and II.2 have shown, the sales force's professional competence is only one component of a successful employee because it is, above all, personal and social skills that round off the image of a good sales representative in the eyes of the customer. However, the industry is increasingly facing the problem of a shortage of skilled workers (Schmitz and Wieseke, 2015; VDL, 2018). Recruiting suitable personnel with the right attitude, especially for sales, is difficult because in many areas sales still has a bad image and, in addition, digitization brings new challenges (Schmitz and Wieseke, 2015). Against this background, the third article of this chapter investigated influencing factors on the attractiveness of a sales job for agricultural students. A survey of 299 German students of agricultural sciences served as the data basis. First, the results clarify that about two-fifths of the students can imagine working in a sales position after graduation. Nearly one-third of students rate the sales training provided by their agricultural science degree as poor to inadequate. This seems unsurprising when the topic of sales is often only partly addressed in the context of marketing lectures (Löhr, 2010).

The attractiveness of a sales position depends primarily on what career opportunities in sales students expect. However, the negatively tainted "hard-selling image" of sales is proving to be a barrier in attracting motivated specialists in sales. The rather poor image of the distribution business is also particularly evident in the insurance and pharmaceutical sectors (Führer et al., 2007; Wüsthof, 2017). About $56 \%$ of students have had no contact points with sales topics so far, but the results indicate that the number of touch points (e.g., internships) can contribute positively to the attractiveness of a sales job. All in all, the results reveal that there is still a need for action, both at the vocational school or university and on the company side, to motivate agricultural students to take a position in sales. 
The degree to which companies' job requirements match students' expectations could provide further evidence for optimizing recruiting and should be studied scientifically.

\section{Key Findings Chapter II - Sales Management in Agribusiness}

- The performance of the agricultural field service is only satisfactory

- Expertise alone is not enough to make a good impression on the farmer

- The farmer's perception of the sales force is based more on the personnel's personality than on its expertise

- Agricultural sales representatives lack customer centricity

- A position in sales is only moderately popular among agricultural students

- Career options are most likely to attract agricultural students to sales position

- Negative hard-selling image of sales is a deterrent to students

- Only a few students have had contact with sales, but this has a positive effect on the attractiveness of the sales position

- University education for sales shows significant weaknesses 


\section{Excursus: Reputation of the seed industry}

The interplay of media, nongovernmental organizations, and public opinion has sparked consumer interest not only in agriculture itself but also in the seed industry (Schurmann, 2004). Due to topics of public interest like intellectual property rights, genetically modified organisms, market concentration, privatization concerns, biodiversity concerns, and the bee colony collapse, especially the seed industry's reputation has been under pressure (Bonny, 2017; Maisashvili et al., 2016; Pray et al., 2005; Schurmann, 2004). This is because public opinion is increasingly succeeding in influencing the legal framework for these topics. However, as reputation is an important predictor of a company's financial performance and competitive advantage (Vig et al., 2017), strategic reputation management and the development of a sustainable innovation policy is highly relevant for companies. This mainly concerns the implementation in the sales and marketing departments of the companies, which are supposed to ensure the marketing of the seed products to wholesalers and agricultural customers. The question is which of these topics of concerns (ToCs) is most harmful to the seed industry and on whose communication the companies' issue management should primarily focus.

Therefore, this excursus paper first examined public interest in and attitudes toward the mentioned topics of interest, and then explored their influence on the reputation of the seed sector. Most ToCs were of medium or lesser interest to the public, except for the bee colony collapse, which stood out with relatively high interest among a large share of consumers. The results of partial least square models indicate that market concentration (MC) and innovation $\&$ productivity (IP) are key drivers of the reputation of the seed sector with the public. Therefore, industry structures are a major critique of the industry. Also, the bee colony collapse disorder attracted high public interest, and matters more strongly to the seed industry's reputation than the issue of genetic modifications. In this study, younger respondents had a more positive attitude towards most of the mentioned topics of concern, which is basically in line with other research findings (Popek and Halagarda, 2017). In addition, the educational level promotes people's attention to environmental issues (Rhead et al., 2018), which would incorporate the need for consumer education and the proper provision of information. Due to the poor public image of the seed industry, the industry needs to accept the public as an important stakeholder. Public perception is crucial because of the environmental "social license to operate" or the increasing demand and awareness of company-specific corporate social responsibility strategies, both of which can also influence customers', e.g., farmers', purchasing decisions. As the agricultural sector is characterized by its up- and downstream businesses, bad 
reputations or scandals might easily diffuse through the value chain and affect the whole sector (Heyder and Theuvsen, 2012). It is therefore advisable to actively involve the public and NGOs in the industry's issue management. All in all, a strategic reputation management must be established to better communicate, in the first instance, merger strategies to explain reasons to grow and how the society benefits from the merge. Secondly, maintaining competition in biotech innovation will keep up public perception of innovation and productivity (Schimmelpfennig, 2004). The results indicate that the seed industry will have to deal with a multiple-issue complex to keep up a good reputation and sustainable sales.

Furthermore, the results show that agricultural input companies, and thus also their sales and marketing departments, are influenced by a variety of factors. In addition to the digital transformation and the structural change in agriculture, the predominantly negative or critical attitude of society towards topics such as structural change in agriculture, animal husbandry, and the use of fertilizers (Zander et al., 2013) is exerting additional pressure on the already strained input sector. This must be counteracted not only with targeted sales management, in particular by constantly optimizing customer centricity, but also by taking the public issues of concern seriously and addressing them thematically.

\section{Key Findings Chapter III - Seed Industry Reputation}

- Seed industry reputation is strongly influenced by public perception of market concentration and perception of innovation \& productivity

- Bee colony collapse disorder is known to the public

- Younger people tend to be more positive towards industry's topics of concern

- The seed industry has to deal with a multiple-issue complex which requires a strategic reputation management with two issues on the first agenda:

○ Communication of merger strategies

- Maintaining industry competition to keep a good level of innovation from public's perspective

- Neglecting reputation management could have consequences along the entire value chain 


\section{Implications and Outlook}

As the practice and the results of this dissertation show, the challenges associated with online retail for farm inputs exist on the part of all players in the agricultural input industry and seem impossible to solve in some cases. However, examples from other sectors, e.g., Mister Spex or DocMorris, have already successfully demonstrated that many of these challenges can be resolved. After all, eyeglasses and pharmaceuticals were not considered tradable online for a long time (Caspar, 2016; Fallgatter and Brink, 2008). Therefore, this work offers implications for future fields of action on a practical and scientific level to better meet the described challenges of (online) trade of agricultural inputs. Implications are presented below and supplemented by a general outlook.

Improving online experience: Although farmers show a basic willingness to engage in e-commerce, they are so far only moderately satisfied with online purchasing and use it rather product-specifically (cf. I.1). One priority should therefore be to optimize information management in order to improve the online experience and to reduce uncertainties, e.g., regarding product suitability or data security issues. It must be ensured that, besides the user-friendliness of the websites (e.g., less clicks to completion), information (especially comparative product attributes) is available in a clear, comprehensible, correct, and up-to-date manner. A strategic information management is also crucial to increase farmers' awareness or perception of online benefits, as these are key drivers of e-commerce. Nevertheless, information management should go hand in hand with communication management. The results show that farmers have certain expectations in terms of customer integration. For example, they expect to be able to select different communication channels depending on the purpose, but always on the premise of the fastest availability (cf. I.5). In the future, 24/7 availability for queries or inquiries will become crucial, especially regarding customer expectations of a constantly shortening response time. It can thus be assumed that the "instant \& everywhere mentality" that is widespread in B2C will also be transferred to farmers, especially under the premise of urgencies in, e.g., the harvest season (Ardrey et al., 2020; Zagel et al., 2015). In this context, smartphone apps in particular show great potential (Michels et al., 2020). They are already used by around $40 \%$ of farmers for online purchasing (cf. I.1) and are associated with simplicity, flexibility, and speed (cf. I.5). Accordingly, smartphone integration (i.e., via website responsiveness or apps) can help make information, communication, and purchasing processes more user-friendly and customer-centric for farmers. 
In the future, voice commerce, the purchase via voice assistants, could also provide faster and more convenient access to products. Here, further research is needed to assess which factors farmers appreciate when using the smartphone especially for information and purchasing purposes.

In the context of the online experience, it is also worth mentioning the rapidly growing role of Amazon Business. With Amazon Business, the private customer experience is now being transferred to $\mathrm{B} 2 \mathrm{~B}$, providing buyers with a simple, convenient, and familiar way of procurement. It can be assumed that the trend in $\mathrm{B} 2 \mathrm{~B}$ e-commerce is moving further and further in the direction of a marketplace model such as Amazon Business (Kobinger and Wittmann, 2019).

Multichannel management: This dissertation has clearly demonstrated that farmers, on average, show only a moderate "mental readiness" to actively integrate e-commerce as a purchasing channel for agricultural inputs, as they still feel closely connected to local retail structures and personal consultations. However, online business should be seen as a necessary complement to offline services, as there are already some online-savvy agricultural shoppers. A digital multichannel strategy can also contribute to a better customer experience, in addition to other benefits (e.g., resource savings), (Kollmann, 2020). Nevertheless, as personal touch points remain important, both online and offline retailers must ensure that personal contacts are available to farmers. This could also consolidate the unique selling proposition of stationary retailers because they are already personally on site and enjoy the customers' trust. With the help of a strategic marketing and sales management, this unique selling proposition could be established as a competitive advantage over pure online businesses. Nevertheless, the online channels should complement companies' offline channels in order to best serve the various customer needs by using a "bricks and clicks" approach to follow an offline-online development (Kollmann, 2020).

The "brick and click" concept also seems to increasingly emerge from an online-offline development where large online retailers such as Amazon (Go), Zalando, and MisterSpex progressively enter the offline business by opening local stores, local showrooms, or by cooperating with stationary retailers (Heinemann, 2015; Kollmann, 2020). If even the big players are now doing a kind of "backflip", will pure online business models have a resounding effect in agribusiness at all, or will pure online retailing ever happen in the already very personal agri-input trade at all? 
An exciting approach in this context is the new "Agrando Widget" of the start-up Agrando, with the feed manufacturer Bewital agri as an innovation partner. The eye-catching widget is placed on the manufacturer's website and, when clicked, leads directly to Agrando's online product catalogue, where BEWITAL agri products can be requested directly from regional retailers. This digital trade innovation creates a seamless process chain from the manufacturer via regional retailers to the farmer, thus providing a smart digital sales support (Lutilsky, 2020).

As article I.6 has stressed, multichannel management is a key challenge for man y companies in the agricultural input industry. However, in the course of future competitiveness, its necessity is undisputed. In combination with strategic communication management, a special focus should be placed on channel transparency. Article I.5 has shown that farmers expect companies to be as similar as possible in their offline and online presence. This requires cross-departmental collaboration within the companies and should be supported by, among others, customer relationship management systems (CRM). Finally, the goal and probably also the prime discipline is the omnichannel approach, in which, to put it simply, the customer does not even notice which channel he is using to interact with the company, because the channels are perfectly coordinated with each other (Binckebanck and Elste, 2016). However, that is a huge challenge for input companies due to the fact that omnichannel distribution needs a perfect coordination between different business segments and often a digital transformation in the whole company. To tackle this challenge, there is a need for further research to provide support and guidance for the implementation process of new digital distribution channels and tools.

Digital training: There is also a need for action with regard to the digital and mental e-readiness of farmers, which would improve the perception of the online experience. As indicated in this dissertation, other studies also confirm that farmers are digitally equipped but often lack the competence and skills to use new technologies (Gandorfer et al., 2017). Furthermore, there often is an undefinable fear of contact with new or specialized technologies. This is especially true for less educated farmers (Fecke et al., 2018b; Michels et al., 2020; Reichardt et al., 2009). It has also been indicated that farmers' digital readiness influences the willingness to engage in e-commerce (Ardrey et al., 2020). Therefore, vocational schools and universities as well as companies and retailers of agricultural inputs should offer various digital training systems, including training on e-commerce (Fecke et al., 2018a; Gandorfer et al., 2017; Goller et al., 2021). The willingness to pay for such digital training already seems to be given, as it can help farmers to generate benefits (Michels et al., 2019b). 
Agricultural paradigm shift: Another exciting aspect is the paradigm shift of farmers, which may cause further challenges and should therefore be closely monitored. According to this, the reasons for choosing a stationary retailer as a business partner have changed within a few decades, from more emotional aspects, such as a long-standing business relationship and kind services, to more rational aspects such as price and location advantages (Gollisch and Theuvsen, 2015). Even though the emotional attachment to one local retailer seems to have lost intensity (i.e., a loss of loyalty), there is still a high importance of service and customer orientation in agricultural input trade (Gollisch and Theuvsen, 2015; Schulze, 2012). The importance of service and customer centricity is also reflected in this study. Accordingly, as other studies also show, location advantages combined with emotional reasons are more likely to be considered the main barrier to e-commerce (Ackermann et al., 2018; Gartzke, 2016). At this point, it remains to be seen how this paradigm shift will continue to develop and whether it will also lead to a "loss of personal services" in favor of digital commerce. In order to determine whether this paradigm shift continues or develops in other directions, it is recommended to scientifically investigate the relationship network and loyalty structures between farmers and their input traders. It also remains to be seen whether there will be a second structural change in agriculture. While this is currently characterized by the principle of "grow or give way", the current diversification strategies within primary agriculture suggest that this may be reversed, from today's primarily "mono-farms" to more multifunctional farms in the future (Höllinger et al., 2020). This would lead to changes of farmers' requirements and of the role of the sales force but would strengthen rather than weaken its right to exist.

Strengthening the sales force: On the supplier side, the strengthening of sector structures within a simultaneous digital transformation process is challenging. Even if improving online experience is important, personal sales should not be disregarded. As the results indicated, there is still considerable potential for improvement, especially regarding the sales force. This needs to evolve to strengthen the potential unique selling proposition of local retail versus online retail. Articles II.1 and II.2 revealed that, without neglecting social and professional competence, it is personality that shapes a farmer's perception of the sales force. However, since professional competence is much easier to develop through further training measures than personality and social competence (Homburg et al., 2016), companies should not only focus on imparting professional knowledge when training their sales force. They should also identify and specifically promote the strengths and weaknesses of the personality and social competences of sales representatives. The lamented shortage of skilled workers could be 
counteracted by addressing the subject of sales in agricultural university studies and by efforts on the part of companies to reduce the "hard-selling image" of sales activities. Internships or temporary jobs in sales would provide first sales contacts to potential graduates, which supports the formation of better sales images.

Artificial intelligence (AI) will release further potential in the future, increasingly influencing not only agriculture itself but also the input industry. Accordingly, the platforms and start-ups that are increasingly springing up as part of the platform economy will be able to ensure that many processes are fully automated (Clasen, 2018). In the future, platforms including AI systems can solve the problems of price and product transparency mentioned by the experts (cf. I.6) and thus the problem of online product suitability, for example, by automatically calculating an individual product and price based on farm data. It is also conceivable that AI will optimize machines and farm management information systems to such an extent that farmers will soon no longer have to make purchases themselves (Clasen, 2018). At this point, however, there is still a need for research, especially with regard to the question of how far or when farmers are willing to hand over such processes. AI systems can also contribute to improved information and communication management. Transforming vast amounts of data into information using AI provides sales with better knowledge and can significantly change the traditional human-centric sales process (Paschen et al., 2020). AI, machine learning, or robotics could even make face-to-face sales redundant in the future, replacing sales and marketing professionals (Siau and Yang, 2017). How the agricultural trade and the advisory structures will change in the course of this remains exciting and should also be scientifically investigated.

Covid-19 effect: Finally, the most topical question is about the Covid-19 effect. The global coronavirus crisis, which has been ongoing since early 2020s, has significantly increased the importance of digitization and has ensured that many companies across industries are currently experiencing a digitization boost. The digitization measures range from the use of new hardware and software, through the implementation of digital meetings, to home offices and digital recruiting (Berg, 2020). Within this period, also B2C and B2B e-commerce have experienced a real boom (Guthrie et al., 2021; IFH, 2020). The views on the Covid-19 effect within the agricultural trade seem to diverge somewhat among the industry players. On the one hand, some state that the effect is marginal, while others, on the other hand, report increasing online sales and a change in farmers' online behavior. The data collection of the present study was already finished within the first months of the pandemic, so that the results unfortunately do not allow 
any conclusion on the effects of the coronavirus crisis on the agricultural online purchasing behavior. Initial results suggest that the coronavirus pandemic has led to significantly more online purchases of farm inputs and that attitudes towards online trade have improved overall (Ardrey et al., 2020). Future research should therefore investigate the effect of the coronavirus pandemic on the business models of agribusiness companies and on agricultural online purchasing behavior. It also needs to be examined whether the indicated effect will persist in the long term and thus accelerate the process of "mental e-commerce readiness". In the medium term, however, personal customer service seems to remain crucial for the agricultural input trade.

In conclusion, the topic of e-commerce and sales management in agribusiness, especially within the input industry, remains a highly exciting topic for both research and the entire agricultural sector, in which much will happen in the coming years. If we believe the forecasts according to Deloitte (2012), the "bang" induced by digital disruption could follow in a few years and lead to major changes in the industry structures. However, it remains to be seen in which form and intensity this "bang" will take place. In the context of the dynamics of digital trade and agricultural structural change, there are still some open questions which provide room for further research.

Agribusiness is already undergoing a digital transformation, and companies in this sector have to carefully examine and adapt to the needs of their customers to persist in the digital today and tomorrow. 


\section{References}

Abdeldayem, M.M. (2010). A study of customer satisfaction with online shopping: evidence from the UAE. International Journal of Advanced Media and Communication 4(3): 235-257. doi: 10.1504/IJAMC.2010.034659

Ackermann, S., Adams, I., Gindele, N. and Doluschitz, R. (2018). The role of e-commerce in the purchase of agricultural input materials. Landtechnik 73(1): 10-19. doi: 10.15150/1t.2018.3177

Alexander, C.E., Wilson, C. A. and Foley, D. H. (2005). Agricultural Input Market Segments: Who Is Buying What? Journal of Agribusiness 23(345-2016-15124): 113-132. doi: 10.22004/ag.econ.59673

Ardrey, J., Denis, N., Magnin, C. and Revellat, J. (2020). Unlocking the online retail opportunity with European farmers. McKinsey \& Company. https://mck.co/2Rt1EhS. (07.03.2021).

Berg, A. (2020). Digitalisierung der Wirtschaft - Auswirkungen der Corona-Pandemie. Bitkom. https://www.bitkom.org/sites/default/files/2020-11/bitkom-charts-digitalisierung-derwirtschaft-16-11-2020_final.pdf. (08.08.2021).

Bickert, C. (2020). Online trading Agriculture 4.0 - or only hot air? Beiträge DLG Wintertagung 2020. https://www.dlg.org/en/agriculture/topics/dlg-agrifuture-magazine/knowledge-skills/onlinetrading-agriculture-40-or-only-hot-air. (30.06.21).

Binckebanck, L. and Elste, R. (2016). Digitalisierung im Vertrieb. Strategien zum Einsatz neuer Technologien in Vertriebsorganisationen. Springer Gabler, Wiesbaden. doi: 10.1007/978-3658-05054-2

Boland, H., Thomas, A. and Ehlers, K. (2005). Expertise zur Beratung landwirtschaftlicher Unternehmen in Deutschland: eine Analyse unter Berücksichtigung der Anforderungen der Verordnung (EG) Nr. 1782/2003 zu Cross Compliance. BMVEL Bundesministerium für Verbraucherschutz, Ernährung und Landwirtschaft; Justus-Liebig-Universität Gießen, Bonn/Gießen.

Bonny, S. (2017). Corporate Concentration and Technological Change in the Global Seed Industry. Sustainability 9(9): 1632. doi: 10.3390/su9091632

Borchers, B., Roucan-Kane, M., Alexander, C. E., Boehlje, M., Downey, W. S. and Gray, A. W. (2012). How Large Commercial Producers Choose Input Suppliers: Expendable Products from Seed to Animal Health. International Food and Agribusiness Management Review 15(2) 1-20. doi: 10.22004/ag.econ.127281

Briggeman, B.C. and Whitacre, B. E. (2010). Farming and the internet: Reasons for non-use. Agricultural and Resource Economics Review 39(3): 571-584. doi: $10.1017 / \mathrm{S} 1068280500007528$

Caspar, M. (2016). So kauft man Brillen heute - Die Erfolgsgeschichte von misterspex.de Digitale Transformation oder digitale Disruption im Handel. In: Heinemann, G., Gehrckens, H.M. und Wolters, U.J. (eds.). Digitale Transformation oder digitale Disruption im Handel. Vom Pointof-Sale zum Point-of-Decision im Digital Commerce. Springer Gabler, Wiesbaden, 153-168. doi: 10.1007/978-3-658-13504-1_7

Churchill, G.A., Ford, N. M., Hartley, S. W. and Walker Jr, O. C. (1985). The determinants of salesperson performance: A meta-analysis. Journal of marketing research 22(2): 103-118. doi: 10.1177/002224378502200201

Clasen, M. (2018). Die Rolle Digitaler Marktplätze in einer vollständig selbstgesteuerten Landwirtschaft. In: Ruckelshausen, A., Meyer-Aurich, A., Borchard, K., Hofacker, C., Loy, J.P., Schwerdtfeger, R., Sundermeier, H.-H. F. \& Theuvsen, B. (eds.). 38. GIL-Jahrestagung, Digitale Marktplätze und Plattformen in Kiel. Lecture Notes in Informatics. Gesellschaft für Informatik e.V, Bonn 17-22. doi: 10.25968/OPUS-1889 
Clasen, M. and Mueller, R. A. E. (2006). Success Factors of Agribusiness Digital Marketplaces. Electronic Markets 16(4): 349-360. doi: 10.1080/10196780600999809

Claycomb, C., Iyer, K. and Germain, R. (2005). Predicting the level of B2B e-commerce in industrial organizations. Industrial Marketing Management 34(3): 221-234. doi: 10.1016/j.indmarman.2004.01.009

Deges, F. (2020). Betriebstypen und Geschäftsmodelle im E-Commerce Grundlagen des E-Commerce. In: Deges, F. (eds.). Grundlagen des E-Commerce. Strategien, Modelle, Instrumente. Springer Fachmedien Wiesbaden; Imprint: Springer Gabler, Wiesbaden, 85-110. doi: 10.1007/978-3658-26320-1_5

Deloitte (2012). Digital disruption - Short fuse, big bang? Building the Lucky Country. Business imperatives for a prosperous Australia No. 2, Australia.

Dens, N. and Pelsmacker, de, P. (2010). Consumer response to different advertising appeals for new products: The moderating influence of branding strategy and product category involvement. Journal of Brand Management 18(1): 50-65. doi: 10.1057/bm.2010.22

Fallgatter, M.J. and Brink, S. (2008). Zum Einfluss der Legitimation auf die Entwicklung junger Unternehmen: Eine State of the Art-Betrachtung am Beispiel von DocMorris. Zeitschrift für Management 3(4): 303-320. doi: 10.1007/s12354-008-0046-0

Fecke, W., Danne, M. and O. Mußhoff (2018a). E-commerce in agriculture: The case of crop protection product purchases in a discrete choice experiment. (DARE) Diskussionsbeitrag Nr. 1803. Georg-August-Universität, Göttingen.

Fecke, W., Danne, M. and Musshoff, O. (2018b). E-commerce in agriculture-The case of crop protection product purchases in a discrete choice experiment. Computers and electronics in agriculture 151(2018): 126-135. doi: 10.1016/j.compag.2018.05.032

Fecke, W., Michels, M., Hobe, C.-F. von and Mußhoff, O. (2018c). Wie kommunizieren Landwirte in Zeiten der Digitalisierung? Berichte über Landwirtschaft - Zeitschrift für Agrarpolitik und Landwirtschaft 96(2): 1-17. doi: 10.12767/buel.v96i2.194

Feng, L., Nilsson, J., Ollila, P. and Karantininis, K. (2011). The human values behind farmers' loyalty to their cooperatives. 5th international conference on economics and management of networks, Limassol, Cyprus.

Foscht, T., Swoboda, B. and Schramm-Klein, H. (2017). Typen von Kaufentscheidungen. In: T. Foscht, B. Swoboda and H. Schramm-Klein (eds.): Käuferverhalten. Grundlagen - Perspektiven Anwendungen. Lehrbuch. Springer Gabler, Wiesbaden: 167-182. doi: 10.1007/978-3-83496726-8_10

Fröhlich, R. (2018). Jeder vierte Handwerker kauft online ein. Handwerksblatt. https://www.handwerksblatt.de/betriebsfuehrung/jeder-vierte-handwerker-kauft-online-ein. (10.08.21).

Führer, C., Köhler, A. and Naumann, J. (2007). Das Image der Versicherungsbranche unter angehenden Akademikern: Eine empirische Analyse. Reutlinger Diskussionsbeiträge zu Marketing \& Management. No. 2007-06. Hochschule Reutlingen, School of International Business, Reutlingen.

Gabriel, A., Gandorfer, M. and Spykman, O. (2021). Nutzung und Hemmnisse digitaler Technologien in der Landwirtschaft. Berichte über Landwirtschaft - Zeitschrift für Agrarpolitik und Landwirtschaft 99(1): 1-27. doi: 10.12767/buel.v99i1.328

Gandorfer, M., Schleicher, S., Heuser, S., Pfeiffer, J. and Demmel, M. (2017). Landwirtschaft 4.0Digitalisierung und ihre Herausforderungen. Ackerbau-technische Lösungen für die Zukunft Bayerische Landesanstalt für Landwirtschaft (LfL), Freising (9) 9-20. 
Gartzke, S. (2016.). Kleffmann Group Global New Media Tracker - Our international Study Kleffmann Group. In: Farwick, C. (Hrsg.). Kleffmann Group. Agri Experts Around the World. Newsletter, $18-21$.

Gloy, B.A. and Akridge, J. T. (1999). Segmenting the commercial producer marketplace for agricultural inputs. The International Food and Agribusiness Management Review 2(2): 145-163. doi: 10.1016/S1096-7508(00)00023-9

Goller, M., Caruso, C. and Harteis, C. (2021). Digitalisation in Agriculture: Knowledge and Learning Requirements of German Dairy Farmers. International Journal for Research in Vocational Education and Training 8(2): 208-223. doi: 10.13152/IJRVET.8.2.4

Gollisch, S. and Theuvsen, L. (2015). Risikomanagement im Landhandel: Charakteristika, Herausforderungen, Implikationen. Berichte über Landwirtschaft - Zeitschrift für Agrarpolitik und Landwirtschaft 93(1):. doi: 10.12767/buel.v93i1.72

Groeppel-Klein, A. and Bartmann, B. (2007). Anti-clockwise or clockwise? The impact of store layout on the process of orientation in a discount store. In: S. Borghini, M. A. McGrath and C. Otnes (eds.): E - European Advances in Consumer Research Vol. 8. Association for Consumer Research, Duluth, MN: 415-416.

Guthrie, C., Fosso-Wamba, S. and Arnaud, J. B. (2021). Online consumer resilience during a pandemic: An exploratory study of e-commerce behavior before, during and after a COVID-19 lockdown. $\begin{array}{llllll}\text { Journal of Retailing and Consumer Services } & 6102570 .\end{array}$ doi: $10.1016 /$ j.jretconser.2021.102570

Hamada, T. (2019). Determinants of decision-makers' attitudes toward Industry 4.0 adaptation. Social Sciences 8(5): 140. doi: 10.3390/socsci8050140

Hammerschmidt, M., Falk, T. and Weijters, B. (2016). Channels in the mirror: An alignable model for assessing customer satisfaction in concurrent channel systems. Journal of Service Research 19(1): 88-101. doi: 10.1177/1094670515589084

Heinemann, G. (2015). Der neue Online-Handel. Geschäftsmodell und Kanalexzellenz im Digital Commerce. Springer Gabler, Wiesbaden. doi: 10.1007/978-3-658-06786-1

Hess, S., Kiefer, F., Wack, K.-J., Magin, D. and Braun, S. (2015). Agrarwirtschaft meets Mobile UX Wie Apps zukünftig die Landwirtschaft unterstützen. In: Endmann, A., Fischer, H. and Krökel, M. (eds.). Mensch und Computer 2015 - Usability Professionals. De Gruyter Oldenbourg, Berlin: 203-212.

Heyder, M. and Theuvsen, L. (2012). Determinants and Effects of Corporate Social Responsibility in German Agribusiness: A PLS Model. Agribusiness 28(4): 400-420. doi: 10.1002/agr.21305

Hill, M., Kaine, G. and Ashburner, R. (2013). Where farmers' seek information when making purchasing decisions, implications for extension. Extension Farming Systems Journal 9(1): 43-51.

Höllinger, F., Eder, A. and Haring, S. A. (2020). Betriebliche Rahmenbedingungen und Perspektiven multifunktional-innovativer Landwirtschaft. Österreich $\mathrm{Z}$ Soziol 45(1): 69-89. doi: 10.1007/s11614-020-00391-3

Homburg, C., Schäfer, H. and Schneider, J. (2016). Sales Excellence. Vertriebsmanagement mit System. Springer Gabler, Wiesbaden.

IFH (2020). Nachhaltige Veränderungen der E-Commerce-Strategie im B2B-Bereich durch die Coronakrise. IFH Köln. https://www.ifhkoeln.de/nachhaltige-veraenderungen-der-ecommerce-strategie-im-b2b-bereich-durch-die-coronakrise/. (09.08.2021).

Johnston, M.W. and Marshall, G.W. (2009). Churchill-Ford-Walker's sales force management. McGraw-Hill/Irwin, Boston. 
Kobinger, C. and Wittmann, G. (2019). Marktplätze im B2B-E-Commerce in Deutschland 2019. Ergebnisse einer Expertenbefragung von ibi research an der Universität Regensburg. ibi research an der Universität Regensburg $\mathrm{GmbH}$, Regensburg.

Kollmann, T. (2020). Digital Marketing. Grundlagen der Absatzpolitik in der Digitalen Wirtschaft. W. Kohlhammer GmbH, Stuttgart.

Löhr, J. (2010). Gestatten: Verkäufer. Frankfurter Allgemeine Zeitung. https://www.faz.net/aktuell/karriere-hochschule/buero-co/aussendienst-und-vertrieb-gestattenverkaeufer-1943247.html. (10.08.2021).

Lutilsky, K. (2020). BEWITAL agri stärkt Außendienst mit Agrando. Agrando. https://agrando.com/dede/magazin/bewital-agri-agrando. (08.08.2021).

Maisashvili, A., Bryant, H., Raulston, J. M., Knapek, G., Outlaw, J. and Richardson, J. (2016). Seed prices, proposed mergers and acquisitions among biotech firms. Choices 31(4): 1-11. doi: 10.22004/ag.econ.246985

Menthe, T. and Sieg, M. (2013). Kundennutzen: die Anwendung im Verkaufsgespräch. So verhandeln Sie wert- und nutzenorientiert. Springer Gabler, Wiesbaden. doi: 10.1007/978-3-8349-3621-9

Merhar, L., Höllthaler, G. and Berger, C. (2019.). Digitale Assistenzsysteme für die Produktion: Von der Zielfindung bis zur Einbindung gemeinsam mit den Mitarbeitern Arbeit 4.0 im Mittelstand. In: Bosse, C.K. und Zink, K.J. (Hrsg.). Arbeit $4.0 \mathrm{im}$ Mittelstand. Chancen und Herausforderungen des digitalen Wandels für KMU. Springer Gabler Berlin Heidelberg, Berlin, Heidelberg, 279-302. doi: 10.1007/978-3-662-59474-2_17

Michels, M., Fecke, W., Feil, J.-H., Musshoff, O., Pigisch, J. and Krone, S. (2020). Smartphone adoption and use in agriculture: empirical evidence from Germany. Precision Agriculture 21(2): 403425. doi: 10.1007/s11119-019-09675-5

Michels, M., Fecke, W., Feil, J.-H., Musshoff, O., Pigisch, J. and Krone, S. (2019a). An empirical study of internet use intensity in German agriculture. German Journal of Agricultural Economics 68(1): $1-14$.

Michels, M., Fecke, W., Mußhoff, O., Heckmann, A. and Beneke, F. (2019b). Zur Zahlungsbereitschaft von Landwirten für Schulungen zur Digitalisierung. Berichte über Landwirtschaft - Zeitschrift für Agrarpolitik und Landwirtschaft 97(1): 1-18. doi: 10.12767/buel.v97i1.204

Munz, J. and Doluschitz, R. (2021). Status quo der Adoption digitaler Technologien im genossenschaftlichen Agrarhandel- Möglichkeiten einer digitalen Differenzierungsstrategie. Berichte über Landwirtschaft - Zeitschrift für Agrarpolitik und Landwirtschaft 99(2): 1-32. doi: 10.12767/buel.v99i2.335

Niklas, S. (2014). Mental Maps von Onlineshops-Kulturelle Unterschiede in der Informationsarchitektur. UP14-Vorträge. German UPA, Stuttgart.

Pandey, S.K. and Mookerjee, A. (2018). Assessing the role of emotions in B2B decision making: an exploratory study. Journal of Indian Business Research 10(2): 170-192. doi: 10.1108/JIBR-102017-0171

Paschen, J., Wilson, M. and Ferreira, J. J. (2020). Collaborative intelligence: How human and artificial intelligence create value along the B2B sales funnel. Business Horizons 63(3): 403-414. doi: 10.1016/j.bushor.2020.01.003

Popek, S. and Halagarda, M. (2017). Genetically modified foods: Consumer awareness, opinions and attitudes in selected EU countries. International Journal of Consumer Studies 41(3): 325-332. doi: $10.1111 /$ ijcs. 12345

Pray, C.E., Oehmke, J. F. and Naseem, A. (2005). Innovation and dynamic efficiency in plant biotechnology: An introduction to the researchable issues. AgBioForum 8(2\&3): 52-63. 
Reichardt, M., Jürgens, C., Klöble, U., Hüter, J. and Moser, K. (2009). Dissemination of precision farming in Germany: acceptance, adoption, obstacles, knowledge transfer and training activities. Precision Agric 10(6): 525-545. doi: 10.1007/s11119-009-9112-6

Rèklaitis, K. and Pilelienè, L. (2019). Principle Differences between B2B and B2C Marketing Communication Processes. Management of Organizations: Systematic Research 81(1): 73-86. doi: 10.1515/mosr-2019-0005

Rhead, R., Elliot, M. and Upham, P. (2018). Using latent class analysis to produce a typology of environmental concern in the UK. Social science research 74 210-222. doi: 10.1016/j.ssresearch.2018.06.001

Rüther, C. and Maier, P. (2007). Wie beurteilen LandwirtInnen Beratungsleistungen? Qualität landwirtschaftlicher Fachberatung. Fachzeitschrift B\&B Agrar 60(2): 54-56.

Schimmelpfennig, D. (2004). The impact of seed industry concentration on innovation: a study of US biotech market leaders. Agricultural Economics 30(2): 157-167. doi: 10.1016/j.agecon.2002.11.001

Schmitz, C. and Wieseke, J. (2015). Herausforderungen und Potenziale im Vertrieb. Marketing Review St. Gallen 32(6): 12-21. doi: 10.1007/s11621-015-0596-3

Schulze, B. (2012). Herausforderungen des Landhandels unter veränderten Marktbedingungen: Theoretische Überlegungen und empirische Evidenz. Annual Conference, Stuttgart. German Association of Agricultural Economists (GEWISOLA) 52(No. 133053). doi: 10.22004/ag.econ.133053

Schurmann, R. (2004). Fighting "Frankenfoods": Industry Opportunity Structures and the Efficacy of the Anti-Biotech Movement in Western Europe. Social Problems 51(2): 243-268. doi: $10.1525 /$ sp.2004.51.2.243

Siau, K. and Y. Yang (2017). Impact of artificial intelligence, robotics, and machine learning on sales and marketing. Twelve Annual Midwest Association for Information Systems Conference (MWAIS 2017): 18-19.

Six, B. and Eckes, T. (1996). Metaanalysen in der Einstellungs-Verhaltens-Forschung. Zeitschrift für Sozialpsychologie 27(1): 7-17. doi: 10.1016/j.bushor.2020.01.003

Stricker, S., Sundermeier, H. H. and Müller, R. A. (2001). Landwirte im Internet: Stand der Nutzung und Verwendungsabsichten. In: Kögl, H., Spilke, J. und Birkne, U. (eds.). Referate der 22. GILJahrestagung, Information und Kommunikation im Dienst der ländlichen Entwicklung, in Rostock. Gesellschaft für Informatik e.V, Bonn 138-142.

Taragola, N.M. and van Lierde, D. F. (2010). Factors affecting the Internet behaviour of horticultural growers in Flanders, Belgium. Computers and electronics in agriculture 70(2): 369-379. doi: 10.1016/j.compag.2009.09.004

Thakur, R. and AlSaleh, D. (2020). Drivers of managers' affect (emotion s) and corporate website usage: a comparative analysis between a developed and developing country. Journal of Business \& Industrial Marketing 36(6): 962-976. doi: 10.1108/JBIM-02-2020-0118

Tomczak, T., Vogt, D. and Frischeisen, J. (2016.). Wie Konsumenten Innovationen wahrnehmen Neuartigkeit und Sinnhaftigkeit als zentrale Determinanten Business Innovation: Das St. Galler Modell. In: Hoffmann, C.P., Lennerts, S., Schmitz, C., Stölzle, W. and Uebernickel, F. (eds.). Business Innovation: Das St. Galler Modell. Springer Fachmedien, Wiesbaden. 187-209. doi: 10.1007/978-3-658-07167-7_12

VDL (2018). Bachelor und Master - Was kommt nach dem Studienabschluss? Absolventenbefragung im Agrarbereich 2018. VDL- Berufsverband Agrar, Ernährung, Umwelt, Berlin. https://www.vdl.de/beruf-karriere/broschueren-film/.

VDL (2014). Fach- und Führungskräftebedarf in der Agrarbranche Befragungen und Analysen im Agrarbereich 2013/2014. Berufsverband Agrar, Ernährung, Umwelt e.V., Berlin. 
Vidickiene, D. and Gedminaite-Raudone, Z. (2018). Challenges for Agricultural Poilicy in the ServiceDriven Economic System. Economics of Agriculture 65(4): 1545-1555. doi: 10.5937/ekoPolj1804545V

Vig, S., Dumičić, K. and Klopotan, I. (2017). The Impact of Reputation on Corporate Financial Performance: Median Regression Approach. Business Systems Research Journal 8(2): 40-58. doi: $10.1515 / \mathrm{bsrj}-2017-0015$

Wittmann, G. and Listl, C. (2017). Online-Kaufverhalten im B2B-E-Commerce 2017. Ergebnisse einer Expertenbefragung von ibi research an der Universität Regensburg, Creditreform und SIX Payment Services. ibi research an der Universität Regensburg GmbH, Regensburg.

Wüsthof, A. (2017). "Als hätte ich meine Seele verkauft...". Die Zeit. https://www.zeit.de/2002/47/CMed-Pharma?utm_referrer=https\%3A\%2F\%2Fwww.google.com\%2F. (10.08.2021).

Zagel, C., Schopka, J., Piazza, A., Huber, S., Hofmann, J. and Bodendorf, F. (2015). Digital Company Eine Marktanalyse zur Verwendung sozialer Medien in der Bekleidungsindustrie. Arbeitspapier 03/2015. Lehrstuhl Wirtschaftsinformatik. Universität Erlangen-Nürnberg, Nürnberg.

Zander, K., Isermeyer, F., Bürgelt, D., Christoph-Schulz, I., Salamon, P. and Weible, D. (2013). Erwartungen der Gesellschaft an die Landwirtschaft. Abschlussbericht: Stiftung Westfälische Landschaft. Thünen-Institut, Stiftung Westfälische Landschaft, Braunschweig. 


\section{List of Publications}

\section{SCIENTIFIC JOURNAL ARTICLES}

Huchtemann, J. P., Schulze Schwering, D., \& Spiller, A. (2019). Die Wahrnehmung des Außendienstes in der landwirtschaftlichen Vorleistungsindustrie-Eine empirische Studie aus Sicht deutscher LandwirtInnen. In: Austrian Journal of Agricultural Economics and Rural Studies, 28 (18), 137-142.

Schulze Schwering, D. S., \& Huchtemann, J. P. (2020). Einflussfaktoren auf die Attraktivität einer Tätigkeit im Vertrieb bei Studierenden der Agrarwissenschaften. In: Berichte über Landwirtschaft-Zeitschrift für Agrarpolitik und Landwirtschaft, 98 (1), 1-19.

Schulze Schwering, D., Huchtemann, J. P., Welter, P., Nordmeyer, E., Spiller, A. \& Lemken, D. (2020). Identifizierung von Verkäufertypen in der landwirtschaftlichen Vorleistungsindustrie aus Sicht der landwirtschaftlichen Kunden. In: German Journal of Agricultural Economics 69 (3), 200-218.

Schulze Schwering, D. \& Kunz, W. (2020). Barrieren des Onlinehandels von Futtermitteln. In: Berichte über Landwirtschaft-Zeitschrift für Agrarpolitik und Landwirtschaft, 98(3), 1-36.

\section{REVIEWED CONFERENCE PAPERS}

Schulze Schwering, D., \& Spiller, A. (2019). Zukunftsperspektiven von Online-Shops in der landwirtschaftlichen Vorleistungsindustrie-eine Analyse aus der Perspektive von Landwirten. 39- GIL Jahrestagung. In: A. Meyer-Aurich et al.: Digitalisierung in kleinstrukturierten Regionen, Lecture Notes in Informatics (LNI), Gesellschaft für Informatik, Bonn 2019: 227-232.

Schulze Schwering, D., \& Lemken, D. (2020). Totally Digital? Adoption of Digital Farm Management Information Systems. 40. GIL-Jahrestagung, Digitalisierung für Mensch, Umwelt und Tier. In: M. Gandorfer et al.: Digitalisierung für Mensch, Umwelt und Tier, Lecture Notes in Informatics (LNI), Gesellschaft für Informatik, Bonn 2020: 295-300.

\section{DISCUSSION PAPER}

Schulze Schwering, D., \& Spiller, A. (2018). Das Online-Einkaufsverhalten von Landwirten im Bereich landwirtschaftlicher Betriebsmittel (No. 1805). Diskussionsbeitrag. Universität Göttingen. 


\section{CONTRIBUTIONS AT PRACTICE-ORIENTED JOURNALS}

Wienrich, N., Sonntag, W. I., Schulze Schwering, D. \& Severin, M. (2021). Nullnummer oder Nutzbringer? Bauernzeitung. 32/2021: 22-24.

CONFERENCE ATTENDANCE / PRESENTATIONS

18.- 19.02. 2019

17. -18.02 .2020$

23. -25.09 .2020$

22. + 29.01.2021\& 05.02.2021
39. GIL-Tagung vom 18.- 19. Februar 2019 in Wien; Thema: Digitalisierung für landwirtschaftliche Betriebe in kleinstrukturierten Regionen - ein Widerspruch in sich?

Vortrag: Zukunftsperspektiven von Online-Shops in der landwirtschaftlichen Vorleistungsindustrie-eine Analyse aus der Perspektive von Landwirten

40. GIL-Tagung vom 17. - 18.02.2020 in Weihenstephan; Thema: Digitalisierung für Mensch, Umwelt und Tier

Vortrag: Totally Digital? Adoption of Digital Farm Management Information Systems.

GEWISOLA-Jahrestagung vom 23. - 25.09.2020 in Halle (Saale); Thema: Herausforderungen für die ländliche Entwicklung - Wirtschafts- und sozialwissenschaftliche Perspektiven (Ohne Vortrag)

Georg-August-Universität Göttingen Online-Tagung zum Thema: Digitaler Vertrieb: Das neue „Must-have“ im Agribusiness?

Vortrag 1: Total digital? Akzeptanzhemmnisse von Farm Management Informationssystemen

Vortrag 2: Der Landwirt von Morgen. Ein offline- oder online-Käufer? 


\section{Authors'contributions}

Das Online-Einkaufsverhalten von LandwirtInnen im Bereich landwirtschaftlicher Betriebsmittel

Idea \& conceptualization: Dorothee Schulze Schwering, Achim Spiller

Literature research \& analysis: Dorothee Schulze Schwering

Data acquisition: Dorothee Schulze Schwering

Data analysis: $\quad$ Dorothee Schulze Schwering

Manuscript - original draft: $\quad$ Dorothee Schulze Schwering, Achim Spiller

\section{Agricultural E-Commerce: Attitude Segmentation of Farmers}

Idea \& conceptualization:

Dorothee Schulze Schwering, Sarah Kühl, Winnie Isabel Sonntag

Literature research \& analysis: $\quad$ Dorothee Schulze Schwering, Sarah Kühl

Data acquisition:

Dorothee Schulze Schwering

Data analysis:

Dorothee Schulze Schwering

Manuscript - original draft:

Dorothee Schulze Schwering, Sarah Kühl, Winnie Isabel Sonntag

\section{Zukunftsperspektiven von Online-Shops in der landwirtschaftlichen} Vorleistungsindustrie - eine Analyse aus der Perspektive von LandwirtInnen

Idea \& conceptualization:

Literature research \& analysis:

Data acquisition:

Data analysis:

Manuscript - original draft:

Manuscript: review \& editing:
Dorothee Schulze Schwering, Achim Spiller

Dorothee Schulze Schwering

Dorothee Schulze Schwering

Dorothee Schulze Schwering

Dorothee Schulze Schwering, Achim Spiller

Dorothee Schulze Schwering, Achim Spiller 
Crop Protection Market Segmentation: Relationship Between Buyer Segments and the Use of Digital Sales Channels

Idea \& conceptualization:

Anna Hollenbeck, Dorothee Schulze Schwering Achim Spiller

Literature research \& analysis: Dorothee Schulze Schwering, Anna Hollenbeck

Data acquisition:

Anna Hollenbeck

Data analysis:

Dorothee Schulze Schwering, Dominic Lemken

Manuscript - original draft:

Dorothee Schulze Schwering, Anna Hollenbeck, Saskia

Krone, Achim Spiller, Dominic Lemken

\section{Barrieren des Onlinehandels von Futtermitteln}

Idea \& conceptualization*:

Dorothee Schulze Schwering, Wiebke Kunz

Literature research \& analysis*:

Dorothee Schulze Schwering, Wiebke Kunz

Data acquisition:

Wiebke Kunz

Dataanalysis:

Wiebke Kunz, Dorothee Schulze Schwering

Manuscript - original draft:

Dorothee Schulze Schwering, Wiebke Kunz

* =The authors have contributed equally.

Agricultural input trade: Farmers' Expectations of an E-commerce-Website-Shopping Convenience is Key

Idea \& conceptualization:

Lena Pleus, Dorothee Schulze Schwering, Achim Spiller

Literature research \& analysis*:

Lena Pleus, Dorothee Schulze Schwering

Data acquisition:

Lena Pleus

Dataanalysis:

Lena Pleus

Manuscript - original draft:

Dorothee Schulze Schwering, Lena Pleus, Achim Spiller

* =The authors have contributed equally. 
Die Wahrnehmung des Außendienstes in der landwirtschaftlichen Vorleistungsindustrie - Eine empirische Studie aus Sicht deutscher LandwirtInnen

Idea \& conceptualization:

Literature research \& analysis*:

Data acquisition*:

Dataanalysis:

Manuscript - original draft:

Manuscript: review \& editing:

$*=$ The authors have contributed equally.
Jan-Philipp Huchtemann*, Dorothee Schulze Schwering* Achim Spiller

Dorothee Schulze Schwering, Jan-Philipp Huchtemann

Dorothee Schulze Schwering, Jan-Philipp Huchtemann

Dorothee Schulze Schwering

Jan-Philipp Huchtemann, Dorothee Schulze Schwering, Achim Spiller

Jan-Philipp Huchtemann, Dorothee Schulze Schwering, Achim Spiller

Identifizierung von Verkäufertypen in der landwirtschaftlichen Vorleistungsindustrie aus Sicht der landwirtschaftlichen KundInnen

Idea \& conceptualization:

Dorothee Schulze Schwering, Jan-Philipp Huchtemann, Philipp Welter, Eike Nordmeyer, Achim Spiller

Literature research \& analysis: Dorothee Schulze Schwering, Jan-Philipp Huchtemann

Data acquisition:

Dorothee Schulze Schwering, Jan-Philipp Huchtemann

Dataanalysis:

Dorothee Schulze Schwering, Dominic Lemken

Manuscript - original draft:

Dorothee Schulze Schwering, Jan-Philipp Huchtemann, Achim Spiller, Dominic Lemken

Manuscript: review \& editing: $\quad$ Dorothee Schulze Schwering, Jan-Philipp Huchtemann, Achim Spiller, Dominic Lemken

Einflussfaktoren auf die Attraktivität einer Tätigkeit im Vertrieb bei Studierenden der Agrarwissenschaften

Idea \& conceptualization*:

Dorothee Schulze Schwering, Jan-Philipp Huchtemann

Literature research \& analysis*:

Dorothee Schulze Schwering, Jan-Philipp Huchtemann

Data acquisition*:

Dorothee Schulze Schwering, Jan-Philipp Huchtemann

Dataanalysis:

Dorothee Schulze Schwering

Manuscript - original draft:

Dorothee Schulze Schwering, Jan-Philipp Huchtemann,

* =The authors have contributed equally. 
Ever New Topics Damage the Reputation - The Public and the Publicized Issues of the Seed Indutry

Idea \& conceptualization:

Dominic Lemken, Christine Heins, Dorothee Schulze Schwering

Literature research \& analysis*: Christine Heins, Dorothee Schulze Schwering

Data acquisition:

Christine Heins

Dataanalysis:

Dominic Lemken, Christine Heins

Manuscript - original draft:

Dorothee Schulze Schwering, Dominic Lemken, Christine Heins

* =The authors have contributed equally. 


\section{Formal declarations / Eidesstattliche Erklärung}

1. Hiermit erkläre ich, Dorothee Hedwig Schulze Schwering geb. am 05.07.1991 in Coesfeld, dass diese Arbeit weder in gleicher noch in ähnlicher Form bereits anderen Prüfungsbehörden vorgelegen hat. Weiter erkläre ich, dass ich mich an keiner anderen Hochschule um einen Doktorgrad beworben habe.

Göttingen, den August 2021

(Unterschrift Dorothee Hedwig Schulze Schwering)

2. Hiermit erkläre ich eidesstattlich, dass diese Dissertation selbständig und ohne unerlaubte Hilfe angefertigt wurde.

Göttingen, den August 2021

(Unterschrift Dorothee Hedwig Schulze Schwering) 


\title{
Acknowledgement / Danksagung
}

\author{
Tu zuerst das Notwendige, \\ dann das Mögliche, \\ und plötzlich schaffst du das Unmögliche.
}

- Franz von Assisi -

\section{Viele Personen haben auf unterschiedlichste Weise, im Großen wie im Kleinen, $\mathrm{zu}$ meiner Promotion beigetragen. \\ Ihnen allen gilt mein herzlichster Dank!}

Einigen möchte ich an dieser Stelle persönlich danken.

Ein ganz besonderer Dank geht an meinen Doktorvater, Prof. Dr. Achim Spiller, für das große Engagement, mit dem er meine Promotion unterstützt hat. Ich danke ihm für sein stets offenes Ohr, seine entgegengebrachte Wertschätzung und Zuversicht sowie für die vielen konstruktiven Gespräche und wertvollen Anregungen. Diese haben mich immer wieder aufs Neue inspiriert und motiviert.

Bedanken möchte ich mich auch bei Prof. Dr. Michael Clasen für die Übernahme der Zweitbetreuung und Prof. Dr. Bernhard Brümmer für die Komplettierung des Prüfungskomitees. Der gemeinsame Austausch war stets konstruktiv und überaus angenehm und hat damit gewinnbringend zu dieser Arbeit beigetragen.

Ein herzlicher Dank gilt auch der Konrad-Adenauer-Stiftung für die ideelle und finanzielle Förderung meiner Promotion. Der interdisziplinäre Austausch im Rahmen der KAS Seminare war sehr inspirierend und hat diese Arbeit bereichert.

Darüber hinaus möchte ich mich beim gesamten Team Spiller („Sportfreunde Spiller“) bedanken. Insbesondere danke ich Dr. Dominic Lemken, Dr. Winnie Isabel Sonntag und Dr. Sarah Kühl, die mich während meiner Promotionszeit so oft mit konstruktivem Feedback unterstützt und mit ihrem Zuspruch motiviert haben. Ein lieber Dank geht auch an Petra Geile, die mir so manchen Text korrekturgelesen hat.

Ein besonderer Dank gilt auch meinen Freunden, die das Wort „Paper“ wohl nicht mehr hören können. Sie waren immer für mich da, waren ziemlich geduldig und haben oft für die nötige Entschleunigung und Entspannung in stressigen Zeiten gesorgt.

Den größten Dank möchte ich an meine Eltern Mechthild und Alfons sowie an meine Geschwister richten, für ihre uneingeschränkte Unterstützung und ihre Geduld. Sie haben mir immer beigestanden und mich durch die Höhen und Tiefen meiner Promotionszeit begleitet. Vor allem haben Sie mir Rückhalt und Zuversicht in jeder Lebenslage gegeben und ganz besonders in den so turbulenten, letzten, anderthalb Jahren. Das Zitat von Franz von Assisi hat für uns als Familie eine besondere Bedeutung, so hat es uns schon durch viele Situation des Lebens begleitet und auf unterschiedlichste Weise nun auch durch meine Promotionszeit. Ich bin sehr dankbar, eine so wunderbare Familie zu haben. 